\title{
VALOR GENÉTICO DE POPULAÇÕES DE MILHO \\ PARA RESISTÊNCIA A DOENÇAS
}

\section{DARIO ROSA MESQUITA NETO}

Orientador: Prof. Dr. JOSÉ BRANCO DE MIRANDA FILHO

\begin{abstract}
Tese apresentada à Escola Superior de Agricultura "Luiz de Queiroz", Universidade de São Paulo, para obtenção do título de Doutor em Agronomia, Área de Concentração: Genética e Melhoramento de Plantas.
\end{abstract}

PIRACICABA

Estado de São Paulo - Brasil

Fevereiro - 2000 
ERRATA

\begin{tabular}{|c|c|c|}
\hline Pág (p). parágrafo (\&). linha (L) & Onde está & Substituir por \\
\hline p vii, $\$ 1$, L $8 \quad \ldots .$, & disponivel & utilizável \\
\hline p viii, $\$ 4, \quad$ L 3 & sendo que, em Rio Verde & onde \\
\hline Com excecão do $\S 2, \mathrm{p}$ xi & accesses & accessions \\
\hline $\mathrm{p} x \mathrm{x}, \S 1, \ldots \mathrm{L} 8$ & stalk lodging & root lodging \\
\hline $\mathrm{p} \mathrm{xi,} \$ 4, \quad$ L 3 & In Rio Verde grain & In this last place the grain \\
\hline $\mathrm{p} x \mathrm{xi}, \$ 4, \mathrm{~L} 6$ & the less yielding & the least yielding \\
\hline p 7, continuação do $\S$ da p 6, L 8 & $\begin{array}{l}5 \% \text { dos acessos foram selecionados e } \\
\text { trocados entre os países para, no terceiro } \\
\text { estágio, serem avaliados per se e em } \\
\text { cruzamento com um testador local adaptado } \\
\text { com duas repeticões em dois locais, }\end{array}$ & $\begin{array}{l}5 \% \text { dos acessos foram selecionados e, no } \\
\text { terceiro estágio, foram trocados entre os } \\
\text { paises e avaliados per se em dois locais com } \\
\text { duas repetições, e depois foram cruzados } \\
\text { com um testador local adabtado; }\end{array}$ \\
\hline p 18, continuacão do $\S$ da p 17, L 2 & milho (Zea mavs L.) em diferentes éoocas & milho em diferentes éoocas \\
\hline $\mathrm{p} 18, \S 2, \mathrm{~L} 3$ & $\begin{array}{l}\text { constataram que os efeitos de dominância } \\
\text { foram mais importantes que os aditivos no } \\
\text { controle... }\end{array}$ & $\begin{array}{l}\text { constataram que a variância dominante foi } \\
\text { mais importante que a aditiva no controle... }\end{array}$ \\
\hline $\mathrm{p} 18, \S 4, \mathrm{~L} 1$ & na cultura do milho, segundo são a... & na cultura do milho são a... \\
\hline p 20, $\$ 1$, L 3 & são produzidos aeciosporos na face... & são produzidos eciosporos na face... \\
\hline p $21, \S 2, \quad$ L 2 & menos necreose foliar & menos necrose foliar \\
\hline $\mathrm{p} 21, \S 2, \mathrm{~L} 3$ & herdabilidade e baixos número & herdabilidade e baixo número \\
\hline $\mathrm{p} 22, \S 2, \mathrm{~L} 1$ & Abedon et al. (1998) & Abedon e Tracv (1998) \\
\hline $\mathrm{p} 22, \S 5, \mathrm{~L} 6$ & Jugenhimer, 1976 & Jugenheimer, 1976 \\
\hline $\mathrm{p} 25, \quad \S 4, \mathrm{~L} 1$ & Pinho et al. (1998b) & Von Pinho et al. (1998b) \\
\hline $\mathrm{p} 26, \S 2, \mathrm{~L} 2$ & $\begin{array}{l}\text { levam, respectivamente, ao tombamento da } \\
\text { planta e à quebra do }\end{array}$ & levam à quebra do colmo \\
\hline $\mathrm{p} 27, \& 1, \quad \mathrm{~L} 19$ & Colletotrichum & Colletotrichum \\
\hline p $36, \$ 2$, L 11 & aditivos, inclusive, seu quadrado & aditivos, sendo que, seu quadrado \\
\hline p 41, Tabela 2, L 10 & $\begin{array}{llll} & Y_{.2} & Y_{.2} & Y .4 \\
\end{array}$ & $Y_{.1}, Y_{.2}, Y_{.2}, Y_{4}$, \\
\hline p 41, Tabela 2, L 11 & $Y_{11}, Y_{22}, Y_{33}, Y_{44}$ & $Y_{1,1}, Y_{2}^{\prime}, Y_{3,3}, Y_{4}, 4$ \\
\hline $\mathrm{p} 52, \$ 2, \quad \mathrm{~L} 2$ & nivel de $80 \%$ & nivel de $80 \%$ de probabilidade \\
\hline 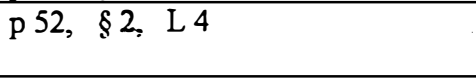 & $\begin{array}{l}\text { as médias dos materiais dos dialelos ou dos } \\
\text { "top-crosses" não foram }\end{array}$ & as médias não foram \\
\hline p 53, última linha & $\mathrm{e}_{\mathrm{jj}}$ & $\overline{\mathrm{e}}_{\mathrm{iij}}$ \\
\hline p 55, primeira linha & geral de combinação foram & $\begin{array}{l}\text { geral de combinação para produção de } \\
\text { grãos foram }\end{array}$ \\
\hline p 57, nrimeira linha & experimento 4 & experimento $\mathbf{3}$ \\
\hline p 58, $\$ 1$, L 3 & $\begin{array}{l}\text { vapiância não detectou signifícância das } \\
\text { fontes de variação do dialelo e nem do } \\
\text { "top-cross". }\end{array}$ & $\begin{array}{l}\text { variância acusou diferenças significativas } \\
\text { apenas entre os acessos do dialelo, e não } \\
\text { detectou significância das fontes de } \\
\text { variação do "top-cross". }\end{array}$ \\
\hline $\mathrm{p} 58, \S 2, \mathrm{~L} 3$ & $\begin{array}{l}\text { 2,00 a 5,25, e diferiram das testemunhas no } \\
\text { experimento } 4 \text { (Tabela 27), cujas médias } \\
\text { limitaram de } 3,7 \text { a } 6,9 .\end{array}$ & $\begin{array}{l}\text { 2,00 a 5,25; e no experimento } 4 \text { (Tabela } \\
27 \text { ), cujas médias limitaram de } 3,7 \text { a } 6,9 \text {, } \\
\text { em média o top-cross diferiu das } \\
\text { testemunhas. }\end{array}$ \\
\hline $\mathrm{p} 59, \S 4, \mathrm{~L} 1$ & ...era esperado, os híbridos & ...eта esperado, em média os híbridos \\
\hline $\mathrm{p} 61, \S 2, \mathrm{~L} 3$ & pior testernunha (T2) & $\begin{array}{l}\text { pior testemunha (T2) no experimento } 1 \text { e } \\
\text { ambas no experimento } 2 \text {; }\end{array}$ \\
\hline $\mathrm{p} 61, \S 2, \mathrm{~L} 5$ & $\begin{array}{l}\text { espiga maior, e diâmetro de espiga igual às } \\
\text { testemunhas }\end{array}$ & $\begin{array}{l}\text { espiga maior no experimento } 1 \text { e menor ou } \\
\text { igual no experimento } 2 \text {, e diâmetro de } \\
\text { espiga igual às testemunhas }\end{array}$ \\
\hline p 64, continuação do $\S$ da p 64 & 16s (CMS 28), que foi um dos & 16s (CMS 28), foi um dos que \\
\hline $\mathrm{p} 66, \quad \& 2, \mathrm{~L} 4$ & pois, os dialelos parciais & uma vez que os dialelos parciais \\
\hline p 67, $\$ 2, L 8$ & sendo que, os cruzamentos & sendo que, em média os cruzamentos \\
\hline p 67, $\$ 3, L 4$ & modo geral, os acessos & modo geral, alguns acessos \\
\hline $\mathrm{p} 68, \quad \S 2, \mathrm{~L} 1$ & De um modo geral, os híbridos & De um modo geral, os cruzamentos \\
\hline $\mathrm{p} 68, \S 3, \mathrm{~L} 4$ & que as testemunhas. & $\begin{array}{l}\text { que as testemunhas, exceto o } 19 \mathrm{~s}(2 \mathrm{C}) \text { que } \\
\text { foi superior à T2 }\end{array}$ \\
\hline
\end{tabular}




\begin{tabular}{|c|c|c|}
\hline $\mathrm{p} 68, \S 4, \mathrm{~L} \overline{2 \mathrm{e} 3}$ & $\begin{array}{l}\text { os cruzamentos foram significativamente } \\
\text { inferiores que uma ou outra das } \\
\text { testemunhas; ... a testemunha } \\
\text { apresentou ser mais produtiva que } T 2 \text {. }\end{array}$ & $\begin{array}{l}\text { os cruzamentos mostraram-se inferiores às } \\
\text { testemunhas; .... testemunha T1 foi mais } \\
\text { produtiva que T2. }\end{array}$ \\
\hline p 69, $\$ 4$, L 1 & $\begin{array}{l}\text { Nos "top-crosses" precoces, em Rio Verde } \\
\text { foi... }\end{array}$ & $\begin{array}{l}\text { Nos "top-crosses" precoces, apenas no } \\
\text { Anhembi foi... }\end{array}$ \\
\hline $\mathrm{p} 71, \S 2, \quad \mathrm{~L} 2$ & mostraram-se iguais à testemunha & mostrararn-se semelhantes à testemunha \\
\hline $\mathrm{p} 71, \$ 3, \mathrm{~L} 2$ & apresentar maior & apresentar, em média, maior \\
\hline $\mathrm{p} 71, \S 3, \mathrm{~L} 3$ & $\begin{array}{l}\text { testemunhas na Caterpillar e em Rio Verde, } \\
\text { mas }\end{array}$ & testemunhas, mas \\
\hline $\mathrm{p} \mathrm{71,} \$ 3, \mathrm{~L} 4$ & apresentaram-se iguais às testemunhas & $\begin{array}{lll}\begin{array}{l}\text { apresentaram-se } \\
\text { testemunhas }\end{array} & \text { semelhantes } \\
\end{array}$ \\
\hline $\mathrm{p} 71, \S 3, \mathrm{~L} 5$ & $\begin{array}{l}\text { os cruzamentos aparentemente tiveram } \\
\text { menos colmos quebrados e plantas } \\
\text { acamadas que a pior testemunha }\end{array}$ & $\begin{array}{l}\text { alguns cruzamentos, em relação à pior } \\
\text { testemunha (12), aparentemente tiveram } \\
\text { menos colmos quebrados e, na Catespillar, } \\
\text { menor porcentagem de plantas acamadas. }\end{array}$ \\
\hline p 72, continuação do $\S$ da p 71 & e de iqual tamanho às espigas & e de tamanho semelhante às espigas \\
\hline $\mathrm{p} 72, \S 1, \mathrm{~L} 6$ & $\begin{array}{l}\text { cruzamentos aparentemente tiveram menos } \\
\text { colmos }\end{array}$ & $\begin{array}{l}\text { cruzamentos tenderam a apresentar menos } \\
\text { colmos }\end{array}$ \\
\hline $\mathrm{p} 72, \S 3, \mathrm{~L} 1$ & $\begin{array}{l}\text { tropical e fenugem polysora, avaliadas } \\
\text { apenas na Caterpillar, os cruzamentos }\end{array}$ & tropical, os cruzamentos \\
\hline $\mathrm{p} 72, \S 3, \mathrm{~L} 4$ & (T2); para enfezamento & $\begin{array}{l}\text { (T2), mas para polysora, apresentaram } \\
\text { maior severidade que a pior testemunha; } \\
\text { para enfezamento }\end{array}$ \\
\hline p 72, $\$ 3$, L 8 & apresentaram menor & apresentaram maior \\
\hline $\mathrm{p} 72, \quad \& 3, \quad \mathrm{~L} 10$ & tamanho próximo ao das testemunhas . & Lamanho menor ao das testemunhas \\
\hline p 73, continuação do $\S$ da p 72 & comprimento e igual diâmetro & comprimento e menor diâmetro \\
\hline $\mathrm{p} \mathrm{73,} \& 2, \mathrm{~L} 1$ & nas anàlise & nas análises \\
\hline $\mathrm{p} 77, \S 1, \mathrm{~L} 6$ & permite fazer inferências & permitem fazer inferências \\
\hline $\mathrm{p} 81, \quad \S 3, \mathrm{~L} 4$ & $\begin{array}{l}\text { com o hibrido } \mathrm{H} 4 \text { no plantio de safrinha e } \\
\text { os hibridos } \mathrm{H} 2 \text { e } \mathrm{H3}\end{array}$ & com os híbridos $\mathbf{H 2}$ e $\mathbf{H 3}$ \\
\hline p 82, \& 2, L 6 & produção no plantio de safrinha & produção de grãos no plantio de safrinha \\
\hline p 83, $\$ 1$, penúltima linha & experimentos 1 e $2 \mathrm{C}$ & experimentos 2 e $2 \mathrm{C}$ \\
\hline p 84, $\$ 1, \quad$ L 2 & foi observado por também & foi observado também \\
\hline $\mathrm{p} 85, \quad \& 1, \mathrm{~L} 2$ & ambos foram não significantes & ambos foram não significativos \\
\hline p 86, $\$ 1, L 1$ & exceto 1R & Exceto para os acessos no experimento 1R \\
\hline $\mathrm{p} 87, \S 1, \mathrm{~L} 6$ & experimentos 3A, 3C e 3R e 27,4\%, & experimentos 3A. 3C e 3R, e $31,4 \%$ \\
\hline
\end{tabular}

\section{REFERÊNCIAS AUSENTES}

BRASL E. M, Variabilidade genética, heterose e efeitos de endogamia em populações de milho em cultivo normal e de safrinha. Goiânia, 1998. 213p. Tese (Doutorado) - Escola de Agronomia, Universidade Federal de Goiás.

TABA, S.. The fiture : needs and activities. In: TABA, S. The CIMMYT Maize Germplasm Bank Genetic Resouce Preservation, Regeneration, Maintenance, and Use Maize Program Special Report Mexico. D.F. 1994, p. 52-59. 
Dados Internacionais de Catalogação na Publicação (CIP) DIVISĀO DE BIBLIOTECA E DOCUMENTAÇĀO - Campus "Luiz de Queiroz"/USP

\author{
Mesquita Neto, Dario Rosa \\ Valor genético de populaçōes de milho para resistência a doenças / Dario Rosa \\ mesquita Neto. - Piracicaba, 2000. \\ $211 \mathrm{p}$. \\ Tese (doutorado) - Escola Superior de Agricultura Luiz de Queiroz, 2000. \\ Bibliografia. \\ 1. Germoplasma vegetal 2. Melhoramento genético vegetal 3. Milho 4. População de \\ planta 5. Resistência à doença I. Título
}

CDD 633.15

"Permitida a cópia total ou parcial deste documento, desde que citada a fonte - $\mathbf{O}$ autor" 
Aos meus pals,

Ozair e Zélia,

aos meus trmãos,

Eduardo e André.

e à Graziela

dedico 


\section{AGRADECIMENTOS}

A DEUS, ...

Ao Prof. Dr. José Branco de Miranda Filho, pela orientação dada, disposição e amizade

Aos funcionários do Departamento de Genética da ESALQ pela grande contribuição e convivio

Aos colegas pelo convívio, ajuda e amizade

À minha familia, pelo estímulo

$\grave{A} \quad$ todas as pessoas que direta ou indiretamente contribuiram para este trabalho, em especial, Graziela Angeli Piva

À FAPESP pelo auxílio financeiro 


\section{SUMÁRIO}

Página

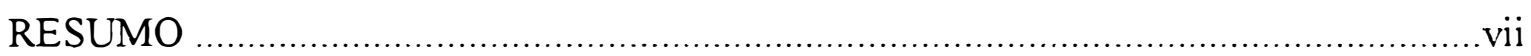

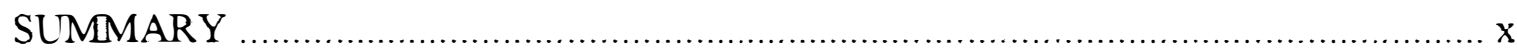

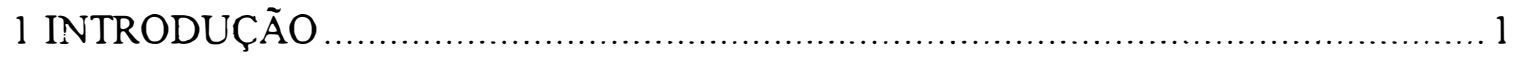

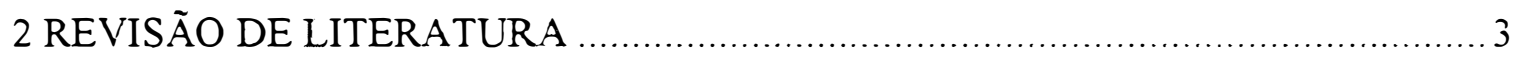

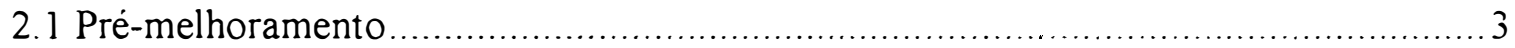

2.2 Considerações sobre doenças do milho ....................................................... 9

2.3 Considerações sobre o melhoramento para resistência ................................. 10

2.4 Algumas doenças importantes do milho no Brasil ................................... 12

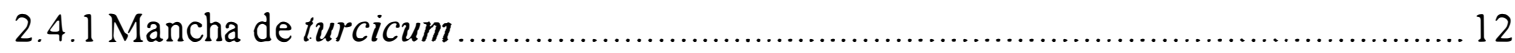

2.4.2 Mancha de Phaeosphaeria ........................................................ 16

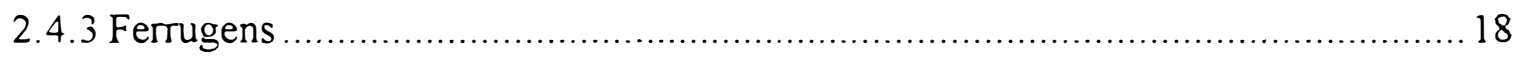

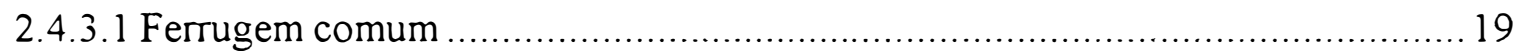

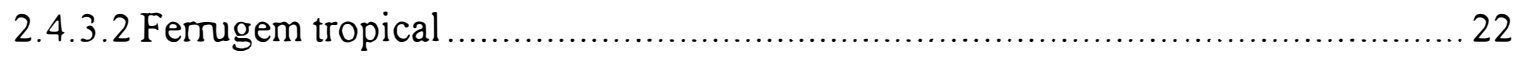

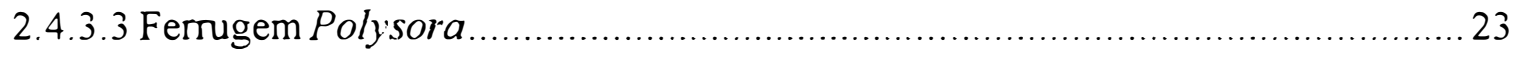

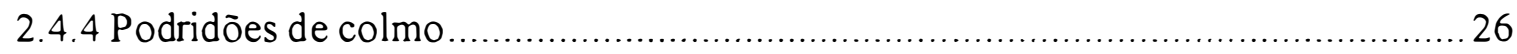

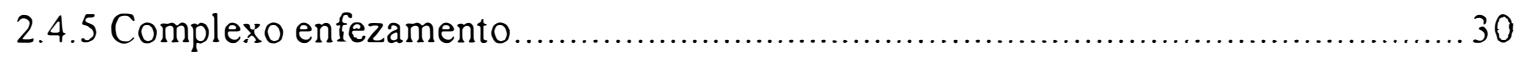

2.5 Valor genético de populações por meio de cruzamentos com testadores ................ 33

2.6 Predição de médias para a sintese de compostos.......................................... 37

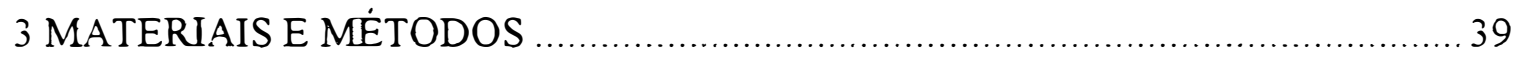

3.1 Escolha das populações para avaliação........................................................ 39

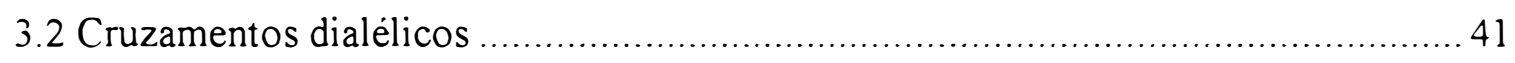

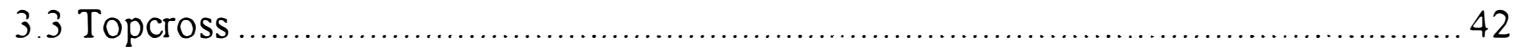

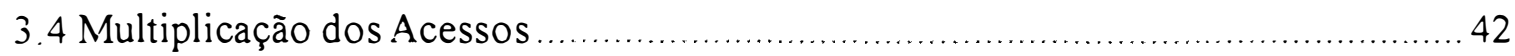

3.5 Obtenção dos Cruzamentos .................................................................... 42

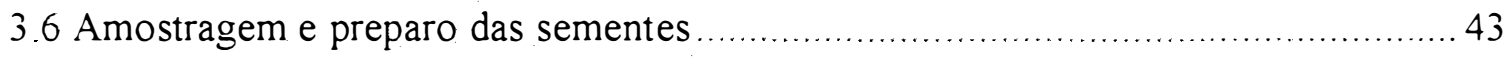

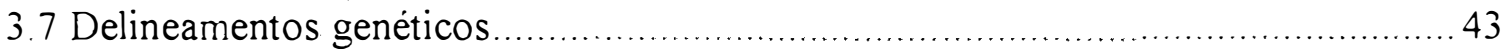

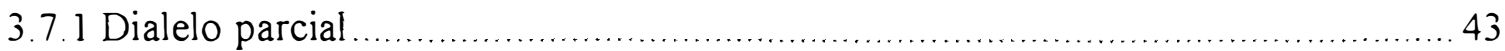

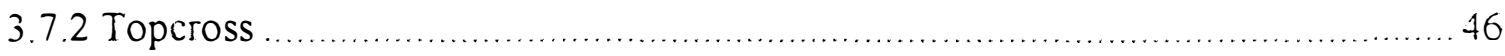




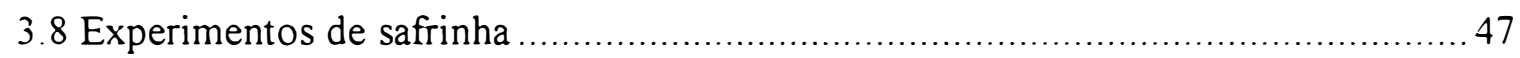

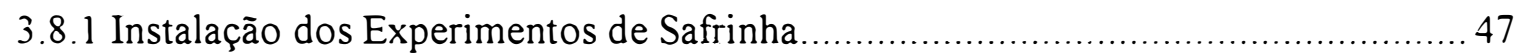

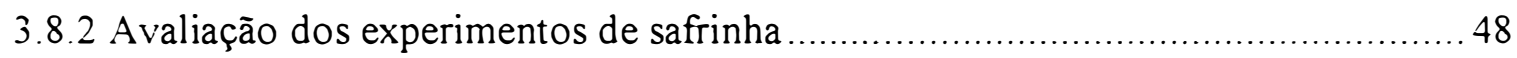

3.8.3 Análise dos dados dos experimentos de safrinha ........................................... 50

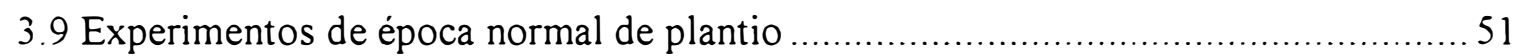

3.9.1 Instalação dos Experimentos de época normal .............................................. 51

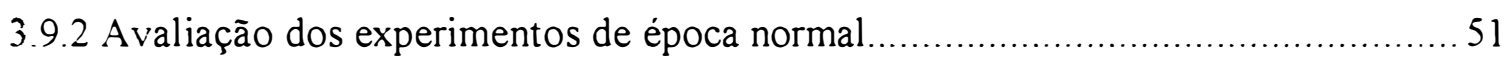

3.9.3 Análises individuais dos dados dos experimentos de época normal ...................52

3.9.4 Análise conjunta dos experimentos de época normal .......................................53

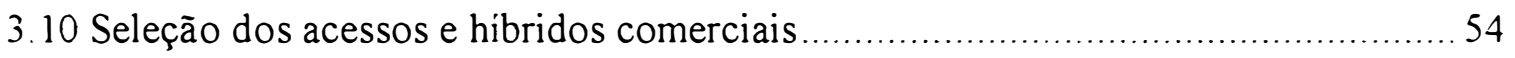

3.11 Predição de médias de compostos dos top-crosses ..........................................55

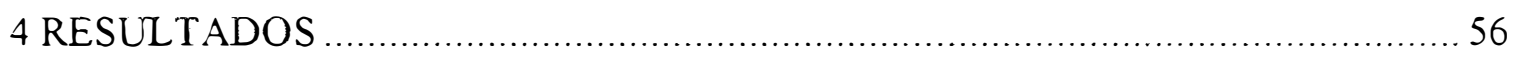

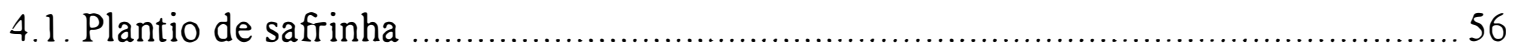

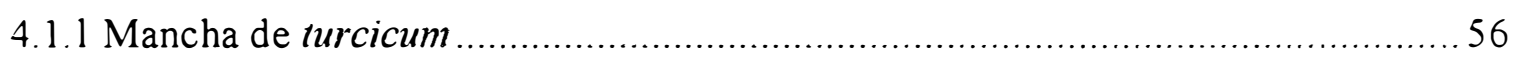

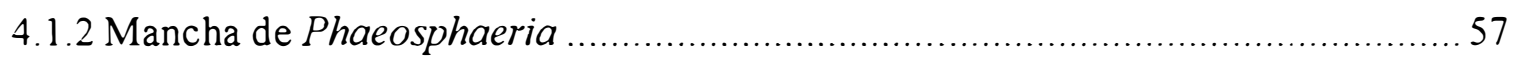

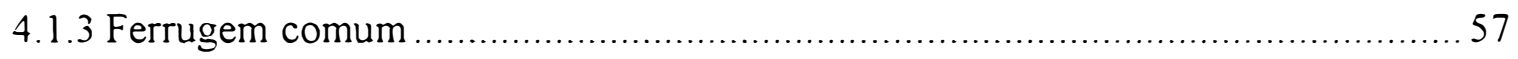

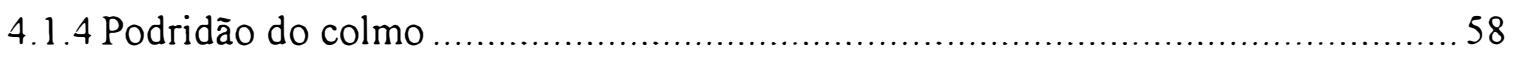

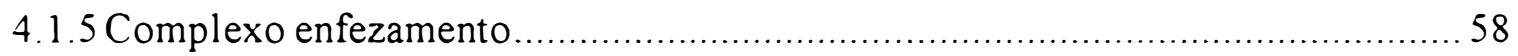

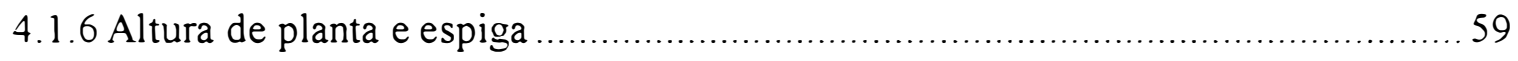

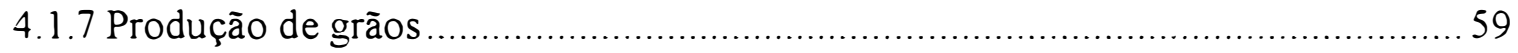

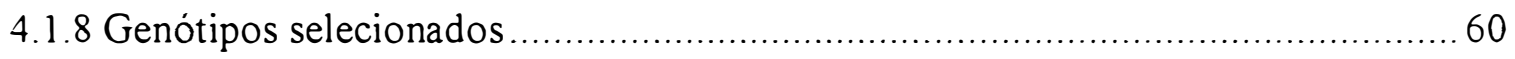

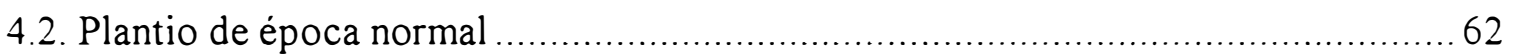

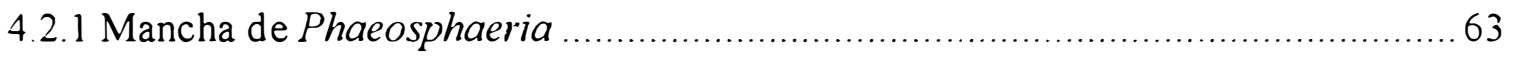

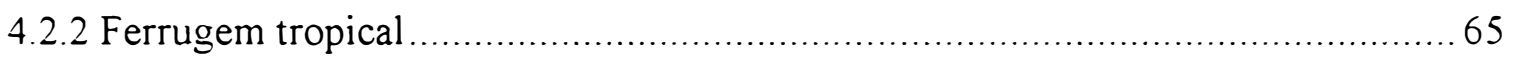

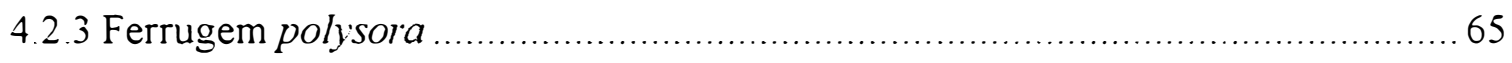

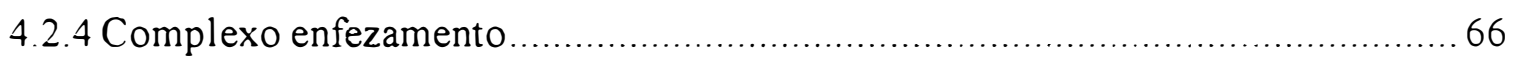

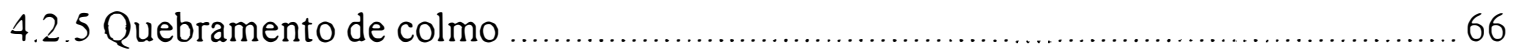

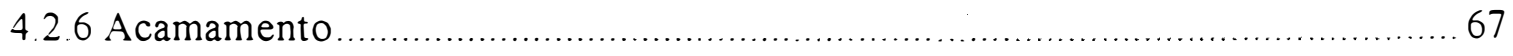

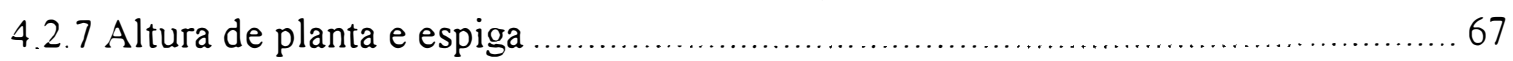

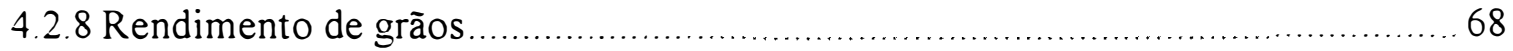

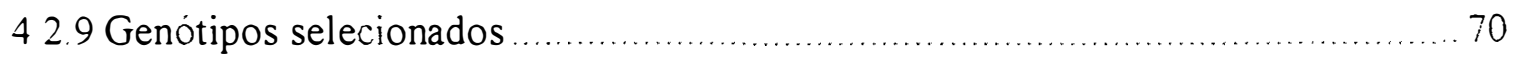


4.3 Predição de médias dos compostos......................................................... 73

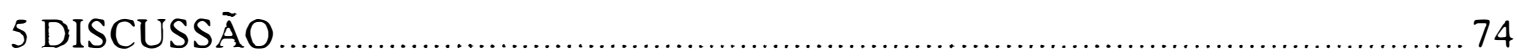

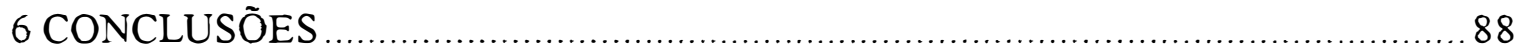

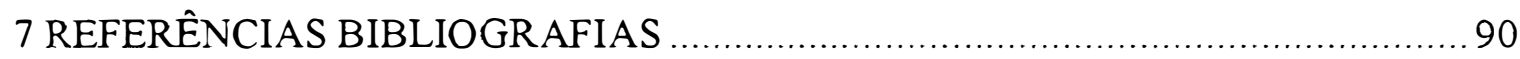

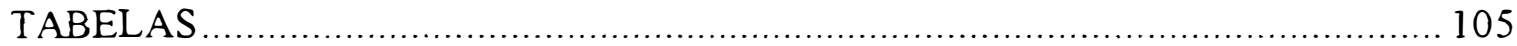




\title{
VALOR GENÉTICO DE POPULAÇÕES DE MILHO \\ PARA RESISTÊNCIA A DOENÇAS
}

\author{
Autor: DARIO ROSA MESQUITA NETO \\ Orientador: Prof. Dr. JOSÉ BRANCO DE MIRANDA FILHO
}

\section{RESUMO}

Os programas de melhoramento por determinadas razões concentram seus esforços em materiais adaptados e melhorados, vindo a incidir sobre uma base genética relativamente estreita, tornando os cultivares em uso corrente vulneráveis ao surgimento de novas pragas e novas raças de patógenos. Os bancos de germoplasma contêm materiais que podem contribuir para o aumento de resistência às doenças do milho, no entanto, mundialmente esses materiais têm sido pouco utilizados porque, normalmente, não reúnem características que atendam ao mercado. Em vista desses problemas, o pré-melhoramento constitui-se na alternativa mais promissora para tornar o germoplasma mais disponivel aos melhoristas.

Visando à uma melhor utilização de germoplasma, este trabalho teve como objetivos: a avaliação e o estudo do valor genético de acessos de milho quanto à performance per se e em cruzamento com testadores; e a seleção dos acessos de melhor capacidade geral de combinação, visando à formação de compostos com padrão agronômico desejável e alta concentração de alelos de resistência a doenças.

No ano agrícola de 1994/1995, o Núcleo de Apoio à Pesquisa em Milho (NAPMilho) avaliou 1273 acessos do Banco Ativo de Germoplasma de milho da Empresa Brasileira de Pesquisa Agropecuária (EMBRAPA) em 13 locais. Foram feitas avaliaçōes para rendimento de grãos e resistência ao complexo enfezamento, mancha de turcicum, 
mancha de Phaeosphaeria, ferrugem tropical e ferrugem polysora. Selecionaram-se os melhores acessos, resultando em dois grupos: o grupo $I$, formado de 28 acessos de ciclo precoce; e o grupo $I I$, constituido de 29 acessos de ciclo superprecoce.

No presente trabalho, os dois grupos de acessos foram avaliados em dialelos parciais utilizando como testadores a geração $F_{2}$ de quatro híbridos comerciais, e em topcross intragrupo, onde o testador foi a mistura de todos os acessos de cada grupo. Os tratamentos foram delineados em bloco completos casualizados em três locais e avaliados em condição de safrinha e de época normal de plantio para as doenças anteriormente avaliadas pelo NAP-milho e, também, para reação ao Puccinia sorghi e à podridão do colmo, acamamento, quebramento de colmo, rendimento e outros caracteres.

Para algumas doenças, houve os tipos de reação resistente, medianamente resistente e medianamente susceptível. Ferrugem comum, enfezamento e podridão do colmo foram as principais doenças da época de safrinha. As ferrugens tropical e polysora ocorreram apenas na época normal de plantio e não causaram muita severidade. A mancha de Phaeosphaeria foi a única doença que ocorreu em todos os experimentos nas duas época de plantio, sendo a principal doença no plantio de época normal.

Foram encontrados acessos com padrão de resistência satisfatório e rendimento considerável, sendo que, de um modo geral os acessos superprecoces apresentaram maior severidade das doenças e maior incidência de acamamento e de quebramento do colmo, mas foram semelhantes aos acessos precoces em produtividade.

No plantio de época normal, a produção de grãos foi maior na Caterpillar $(4,329$ $\mathrm{kg} /$ parcela) do que em Rio Verde $(3,276 \mathrm{~kg} /$ parcela $)$, e neste foi maior que no Anhembi $(2,799 \mathrm{~kg} /$ parcela $)$, sendo que, em Rio Verde o rendimento foi maior na época normal de plantio do que na condição de safrinha $(2,198 \mathrm{~kg} /$ parcela). No entanto, no plantio de safrinha, na ausência de doenças alguns acessos e muitos cruzamentos mostraram-se mais produtivos que a testemunha menos produtiva.

Foi detectada significância para a heterose média $(\bar{h})$ para reação à mancha de Phaeosphaeria e ao complexo enfezamento, porcentagem de plantas acamadas, altura de planta e altura de espiga e rendimento. Com exceção do complexo enfezamento, em que praticamente não houve incidência nos dialelos, para os demais caracteres maiores 
estimativas de heterose média foram obtidas no cruzamento com as gerações $F_{2}$ dos hibridos comerciais, indicando que os grupos de progenitores foram divergentes e que cruzamento com os híbridos comerciais resultou em melhor performance.

Dependendo dos parentais envolvidos nos cruzamentos, os efeitos de variedade $\left(v_{i}\right)$ foram mais importantes em alguns casos, e os efeitos de heterose de variedade $\left(h_{i}\right)$ em outros. Em ambos modelos estatístico-genéticos, independente da significância das fontes de variação progenitores (acessos e hibridos) e heterose dos progenitores, os efeitos de capacidade geral de combinação $\left(\mathrm{g}_{\mathrm{i}}\right)$ foram estimados e utilizados para seleção dos progenitores mais promissores, para posteriormente serem recombinados formando compostos que poderão ser utilizados em programas de melhoramento considerando a resistência a doenças. 


\title{
GENETIC VALUE OF MAIZE POPULATIONS \\ FOR RESISTANCE TO DISEASES
}

\author{
Author: DARIO ROSA MESQUITA NETO \\ Adviser: Prof. Dr. JOSÉ BRANCO DE MIRANDA FILHO
}

\section{SUMMARY}

Maize breeding programs in general concentrate efforts on adapted and improved germplasm, invariably resulting in a relatively narrow genetic base, exposing the currently used cultivars to vulnerability to old or new races of pests and diseases. The germplasm banks keep collections of accesses that can contribute to new sources of disease resistance in maize. However, all over the world new sources of germplasm have not been extensively used because they do not fulfill the market requirements in terms of acceptable agronomic traits. Under this circumstance the pre-breeding strategy turns to be a feasible alternative to prepare non conventional genetic materials for use in breeding programs.

Looking for an optimization of the germplasm use in breeding programs, this work followed the objectives: i) to evaluate and study the genetic value of maize accesses relative to the performance per se and in crosses with testers; ii) selection of the outstanding accesses, based on general combining ability, toward the synthesis of composites with acceptable pattern for agronomic traits and high concentration of alleles for disease resistance.

In the agricultural year of 1994/1995, the NAP-MILHO (Núcleo de Apoio à Pesquisa em Milho) Project was organized in a cooperative program involving public and private institutions. The project initiated with the evaluation of 1273 accesses from Germplasm Bank (CNPMS/EMBRAPA) in 13 locations over five states in Brazil. Traits evaluated comprised grain yield, resistance to corn stunt and leaf diseases including 
those caused by Exserohilum turcicum or northern leaf blight, Phaeosphaeria maydis or Phaeosphaeria leaf spot, Physopella zeae or tropical rost and Puccinia polysora or polysora rust. The best accesses for yield and disease resistance were selected and divided into two sets: Set I with 28 early accesses; and Set II with 29 extra-early accesses

The two sets of accesses were evaluated in two different mating schemes: A) intergroups partial diallel cross where the group of accesses were crossed with a group formed by $F_{2}$ generations of commercial hybrids; and B) intragroup top-cross, where the accesses were crossed the mixture of the whole set of accesses as tester in each set. Experiments followed the complete randomized block design in three locations and in two seasons (normal and off-season or "safrinha"). All the diseases previously considered in the NAP-Project were evaluated in the experiments, including also the reaction to Puccinia sorghi and stalk rot, stalk lodging, stalk breaking, grain yield and other traits.

For some diseases, there were the following types of reaction: resistant, moderately resistant and moderately susceptible. Common rust, corn stunt and stalk rot were the main diseases of the "safrinha" planting. The tropical and polysora rusts occurred only in the normal season at a moderate level of attack. The Phaeosphaeria leaf spot was the only disease that occurred in all the experiments in the two planting seasons, and was the main disease in the normal season.

Accesses with acceptable patterns for disease resistance and yield were found. In general, the extra-early accesses showed higher levels of severity for many diseases and also showed to be more susceptible to lodging and stalk breaking, but they were similar to the set of early accesses for yield.

In the normal season, the grain yield was higher in the area of Caterpillar $(4,329$ $\mathrm{kg} / \mathrm{plot})$ as compared to Rio Verde $(3,276 \mathrm{~kg} / \mathrm{plot})$, where yield was higher than in Anhembi $(2,799 \mathrm{~kg} / \mathrm{plot})$. In Rio Verde grain yield was higher in the normal planting season as compared to the off-season planting or "safrinha" $(2,198 \mathrm{~kg} / \mathrm{plot})$. However, in the absence of diseases in the "safrinha" planting some accesses and many crosses showed to be higher yielding than the less yielding check. 
It was found significant average heterosis $(\bar{h})$ for the following traits: reaction to the Phaeosphaeria leaf spot and the corn stunt, percentage of lodging, plant height, ear height and grain yield. Except for the corn stunt, that practically there was not incidence in the diallels, for the other traits larger estimates of average heterosis were obtained in the crosses with the $F_{2}$ generations of commercial hybrids, indicating that there was genetic divergence between the parent groups and that a better performance was observed in crosses between the accesses and commercial hybrids, as compared to crosses among the accesses themselves.

Depending on the parents involved in the crosses, the variety effects $\left(v_{i}\right)$ were more important in some cases, and the effects of variety heterosis $\left(h_{i}\right)$ in others. In both statistical-genetic models, independent of the level of significance for the variation among parents (accesses and hybrids) or for the variety heterosis effects, the effects of general combining ability $\left(\mathrm{g}_{\mathrm{i}}\right)$ were estimated and used for the selection of the most promising parents to be intercrossed for the synthesis of new composites to be used as base populations in recurrent selection programs. 


\section{INTRODUÇÃO}

O milho ( Zea mays L.) é uma espécie de grande importância econômica, sendo utilizado direta e indiretamente na alimentação humana. É cultivado em diversas regiōes do mundo, numa ampla faixa de latitude, se desenvolvendo em diferentes altitudes, estando sujeito a diversos fatores bióticos e abióticos; dentre os primeiros, as doenças têm tido muita importância.

O melhoramento de milho tem alcançado progressos satisfatórios; no entanto, a seleção era feita na ausência de populações de patógenos, resultando na erosão de genes de resistência. Assim, a cultura do milho, antes considerada rústica em relação a doenças, tornou-se vulnerável, e a partir da década de 80 , diferentes patógenos têm causado problemas nos cultivares utilizados no Brasil e no mundo.

O uso de cultivares resistentes tem sido o meio mais eficaz de controle das doenças do milho, contudo, a dificuldade em obter genótipos superiores e a competitividade do mercado levam os programas de melhoramento a concentrarem seus esforços em materiais adaptados, utilizando como fonte de genes materiais cuja base genética é relativamente estreita, apesar de o germoplasma de milho ser caracterizado por uma ampla variabilidade.

O pré-melhoramento é considerado a melhor estratégia para aumentar o uso de germoplasma sem prejudicar a performance dos materiais adaptados, uma vez que, fornece materiais fontes de genes para serem incluidos nos programas de melhoramento

O germoplasma pode ser melhorado por introgressão, retrocruzamento e a formação de novas populações bases. Tais populações normalmente são obtidas através da avaliação de acessos, seleção e recombinação de materiais promissores

No Brasil, pouco é conhecido a respeito dos diferentes materiais genéticos como fonte de resistência a doenças. Assim, para atender às necessidades dos programas de 
melhoramento, algumas instituições de pesquisa públicas e privadas se reuniram e implantaram o Núcleo de Apoio à Pesquisa em Milho (NAP-Milho), que está desenvolvendo um programa de pré-melhoramento com ênfase na resistência às doenças atualmente consideradas principais (mancha de turcicum, mancha de Phaeosphaeria, ferrugem polysora, ferrugem tropical e enfezamento). No primeiro estágio, foram avaliados cerca de 1413 materiais; no segundo estágio, os materiais mais promissores foram avaliados; e o terceiro estágio se refere à formação de populações base a partir dos materiais selecionados. O presente trabalho está contido no segundo estágio e tem como objetivos:

- Avaliação dos acessos, anteriormente selecionados, quanto à performance per se e em cruzamento com testadores;

- O estudo do valor genético dos acessos para uso per se ou em combinações híbridas;

- Seleção dos acessos de melhor capacidade geral de combinação, visando à formação de compostos com padrão agronômico desejável e alta concentração de alelos de resistência. 


\section{REVISÃO DE LITERATURA}

\subsection{Pré-melhoramento}

Introdução, intercâmbio, coleta, caracterização, avaliação, documentação e conservação de germoplasma são procedimentos fundamentais relacionados ao recursos genéticos para que a variabilidade genética seja mantida, assegurando assim, a utilização dos acessos. Além da conservação da diversidade e da variabilidade para uso atual e futuro, a ampliação da base genética de algumas culturas e uma melhor utilização do germoplasma disponivel têm se tomado um importante objetivo a nivel mundial.

O germoplasma de milho no Brasil é caracterizado por uma ampla variabilidade incluindo raças locais ou indigenas, populações adaptadas, germoplasma exótico e semiexótico, e as coleções de linhagens endogâmicas utilizadas nos programas de milho híbrido. Segundo Chang (1992), estima-se que os bancos de germoplasma no mundo mantêm cerca de 100.000 acessos de milho. Em 1994, o banco de germoplasma do Centro Internacional de Melhoramento de Milho e Trigo (CIMMYT) armazenava cerca de 11.000 acessos em suas coleções base e ativa, com expectativa de após duas décadas alcançar cerca de 30.000 a 35.000 acessos (Taba, 1994).

Apesar da variabilidade existente, uma melhor utilização dos acessos dos bancos de germoplasma ainda tem muito a contribuir para o melhoramento. De acordo com Nass et al. (1993), existe a nivel mundial uma baixa utilização de germoplasma. Muitos fatores são responsáveis por tal sub-utilização. Nass (1999), indica que os principais fatores são a falta de documentação e descrição adequadas; falta das informações desejadas pelo melhorista: acessos com adaptabilidade restrita; insuficiente número de melhoristas, principalmente em 
paises em desenvolvimento; e falta de avaliação das coleções. Regitano Neto (1998) relata que além da redução da média observada na introdução de germoplasma não adaptado em programas de melhoramento, a caracterização insuficiente de grande número de acessos nos bancos de germoplasma não estimula a utilização de materiais de comportamento desconhecido em determinadas localidades. Marshall (1989) enfatiza que a dificuldade em identificar genes úteis é o principal fator responsável pela baixa utilização de parentes selvagens, raças locais e exóticos disponiveis nos bancos de germoplasma.

Além da dificuldade em identificar genes úteis, a busca de genótipos superiores considerando rendimento, resistência e/ou tolerância a fatores bióticos e abióticos, e melhor qualidade nutricional requer tempo e é muito onerosa. Assim, os programas de melhoramento tendem a concentrar seus esforços em materiais adaptados e melhorados, vindo a incidir sobre uma base genética relativamente estreita, como tem ocorrido no melhoramento de milho. Nos Estados Unidos, por exemplo, o milho é a principal cultura, adiciona por ano mais que 16 bilhões de dólares à economia americana, e toda essa produção é obtida utilizando menos que $5 \%$ do germoplasma disponivel no mundo, sendo que, menos de $1 \%$ do milho comercial é de origem exótica (http://www. public.iastate.edu/ usda-gem/, 10/09/99). Esta situação se deve ao fato de que no setor privado existe uma competição para obtenção de cultivares que atendam ao mercado de uma maneira mais rápida. Sendo assim, são utilizadas linhagens elite como fonte de genes, evitando o uso de materiais exóticos, por terem menor adaptação. Além disso, híbridos comerciais têm sido muito utilizados para o desenvolvimento de novas populações base e linhagens. De acordo com Troyer (1990), linhagens elite de milho são consideradas a melhor fonte de germoplasma, uma vez que, cada linhagem contém uma combinação de características que satisfazem o mercado. Goodman (1990) relatou ser quase impossivel identificar um hibrido dentre os amplamente utilizados nos Estados Unidos, que não tenha um parentesco com as populações Reid Yellow Dent ou Lancaster Sure Crop, e além disso, cerca de 6 linhagens, C103, Mol7 e Oh43 (provenientes da população Lancaster) e A632, B37 e B73 (provenientes da população Reid Yellow Dent), e seus parentes mais próximos estão representadas em quase $70 \%$ dos hibridos comerciais norte americanos. 
O uso de uma base genética estreita toma os cultivares vulneráveis ao surgimento de novas pragas e novas raças de patógenos, podendo inviabilizar a cultura numa determinada região. Sendo assim, a vulnerabilidade genética deve ser levada em consideração nos programas de melhoramento. Além disso, existem fatos que mostraram as consequências do uso de uma base genética estreita, como, por exemplo, ocorreu com o milho na década de 70 devido ao uso de híbridos com o citoplasma T susceptivel a Helminthosporium maydis raça $\mathrm{T}$ nos Estados Unidos e em outros paises.

Os bancos de germoplasma tentam preservar o tanto quanto possivel a variabilidade a ser utilizada pelos melhoristas. Por outro lado, os programas de melhoramento não exploram eficientemente a variabilidade disponivel, contando quase que exclusivamente com sua coleção de trabalho. Evidentemente, há uma lacuna entre os recursos genéticos disponiveis e as atividades num programa de melhoramento. Assim, o pré-melhoramento constitui-se na alternativa mais promissora para uma conexão entre recursos genéticos e programas de melhoramento, tornando esses recursos disponiveis para os melhoristas (Nass, 1999). Este autor conceitua pré-melhoramento como todas as atividades designadas para identificar características e/ou genes desejáveis em materiais não adaptados ou adaptados que não tenham sido sujeito a algum processo de seleção e posterior incorporação nos materiais elite. E, além disso, este autor relata que caracteristicas úteis podem ser incorporadas em materiais adaptados por introgressão, retrocruzamento e a formação de novas populações base.

$\mathrm{Na}$ introgressão, a proporção de germoplasma exótico a ser incorporada em germoplasma adaptado é muito controvertida. Alguns autores relatam que os melhores semiexóticos são obtidos com $25 \%$ de germoplasma exótico, outros relatam $50 \%$, e outros relatam não haver diferenças entre $25 \%$ e $0 \%$ de exótico. Regitano Neto (1998) relata que a contribuição de materiais exóticos pouco adaptados na formação de compostos para melhoramento não deve ser superior a $50 \%$. A proporção mais adequada depende principalmente do comportamento dos exóticos nos cruzamentos e dos objetivos do programa de melhoramento, sendo que proporções elevadas de exóticos podem comprometer a utilização a curto prazo das populações semi-exóticas. 
O CIMMYT tem contribuido para melhorar a utilização de germoplasma através da sintese de novas populações e sua introdução nos programas de melhoramento. Vários pools gênicos têm sido estabelecidos de acordo com caracteristicas especificas como ciclo de maturação, cor do grão e tipo de endosperma (Salhuana, 1987). O pré-melhoramento conduzido pelo CIMMYT fornece aos programas de melhoramento um meio de ampliar a variabilidade do germoplasma melhorado bem como materiais com características especificas de interesse (Taba, 1994). Assim, os materiais resultantes do prémelhoramento terão mérito para serem incluidos nos programas de melhoramento, podendo ser utilizados para fornecer alelos para resistência a doenças e pragas, tolerância a diferentes tipos de estresse e caracteristicas de qualidade dos grãos, sem prejudicar o rendimento, e além disso, podem assistir na identificação de padrões heteróticos visando ao melhoramento de híbridos.

Salhuana (1987) destaca a importância na escolha do testador e sugere avaliação preliminar de germoplasma para os caracteres florescimento, altura de planta e de espiga, estande, plantas quebradas, plantas acamadas, prolificidade, tipo de endosperma, cor do grão e rendimento.

Smith \& Duvick (1989) relatam que os materiais resultantes de prémelhoramento, em comparação com os exóticos, são mais atrativos para os programas de empresas privadas. Todavia, uma cooperação entre instituições públicas e privadas pode ser muito útil ao melhoramento (Nass et al., 1993).

Programas de pré-melhoramento têm sido buscados por muitas instituições no mundo. Dentre eles podem-se citar o LAMP (Latin American Maize Project ), o GEM (Germplasm Enhancement of Maize ) e, também, o programa desenvolvido pelo NAP-milho (Núcleo de Apoio à Pesquisa em milho), sendo que, o primeiro talvez seja o mais conhecido.

O LAMP inclui 12 paises (Argentina, Bolivia, Brasil, Colômbia, Chile, Guatemala, México, Paraguai, Peru, Uruguai, Estados Unidos e Venezuela). Este projeto foi conduzido em cinco estágios durante um periodo de cinco anos. Foram avaliados 15000 acessos numa cooperação conjunta entre setores públicos e privados, havendo a descrição da adaptação ecológica e geográfica de acessos e raças, além do nivel de produção per se e em 
cruzamentos, e a determinação de novos grupos heteróticos entre materiais nativos e materiais exóticos (Salhuana, 1987), para identificar germoplasma que pudesse ser usado para melhorar a performance e ampliar a variabilidade genética de hibridos e variedades (Eberhart et al., 1995). O embasamento teórico do projeto e os métodos de seleção podem ser encontrados em Eberhart et al. (1995). No primeiro estágio, cada acesso selecionado em cada país foi avaliado com duas repetições em um só local; foram selecionados $20 \%$ dos acessos para serem avaliados no segundo estágio com duas repetições em dois locais; $5 \%$ dos acessos foram selecionados e trocados entre os paises para, no terceiro estágio, serem avaliados per se e em cruzamento com um testador local adaptado com duas repetições em dois locais; no quarto e no quinto estágio, foram conduzidos experimentos para testar a capacidade de combinação dos acessos com os testadores adaptados. Avaliações para resistência a doenças e tolerância a condições climáticas e de solo foram planejadas. Vários acessos selecionados apresentaram alto rendimento de grãos e características agronômicas importantes como baixa altura de espiga e precocidade.

O GEM (Germplasm Enhancement of Maize) é suportado pelo Congresso americano e mais de 50 organizações e individuos de instituições públicas e privadas. Tem como objetivo melhorar os 268 melhores acessos obtidos do LAMP para que sejam utilizados nos programas de melhoramento de milho nos Estados Unidos. Diferentemente dos outros projetos, o GEM propõe não introduzir novas raças de milho, mas, incorporar somente seus melhores e os mais úteis caracteres nas linhagens elite que já estão sendo utilizadas com sucesso nos Estados Unidos. Os acessos a serem avaliados são enviados a cada cooperado para ser cruzado com uma linhagem. Este cruzamento (50\% exótico) é enviado a outro cooperado para ser cruzado com sua linhagem, resultando num cruzamento que geneticamente tem $25 \%$ do acesso, $25 \%$ da linhagem do primeiro cooperado e $50 \%$ da linhagem do segundo cooperado. Cruzanentos superiores para rendimento, resistência a doenças, valor forrageiro e caracteres que contribuem para qualidade nutricional ou de processamento do grão, como conteúdo e qualidade de amido, proteína e óleo, são selecionados para autofecundação e desenvolvimento de linhagens, que serão enviadas para estação experimental em Ames no estado de lwoa para manutenção e distribuição (http://www public.iastate.edu/ usda-gem/, 10/09/99). 
No Brasil, em 1994, sob coordenação do Departamento de Genética da Escola Superior de Agricultura Luiz de Queiroz, instituições de pesquisa públicas e privadas se reuniram e implantaram o Núcleo de Apoio à Pesquisa em Milho (NAP-Milho). Devido à importância crescente das doenças do milho, este núcleo elaborou um projeto visando avaliar os materiais disponíveis em bancos de germoplasma, conduzindo estudos epidemiológicos e identificando marcadores moleculares relacionados à resistência e à tolerância às principais doenças do milho no Brasil, com o objetivo de fornecer fontes de resistência para os programas de melhoramento genético desenvolvidos no pais. No primeiro estágio, em 1995, 1273 acessos do Banco Ativo de Germoplasma de milho da Empresa Brasileira de Pesquisa Agropecuária (EMBRAPA) e 140 populações melhoradas oriundas dos programas de pesquisa de instituições públicas foram avaliadas em 13 locais no Brasil. As avaliações foram feitas para florescimento, produção de grãos e resistência ao complexo enfezamento e aos fungos Exserohilum turcicum, Puccinia polysora, Physopella zeae e Phaeosphaeria maydis. Num segundo estágio, os materiais mais promissores do primeiro estágio foram avaliados per se e em cruzamentos para produção, resistência a doenças e caracteres agronômicos em três subprojetos. No primeiro, Ferreira (1999) apresentou os resultados de avaliações feitas no ano de 1997 para doenças, principalmente ferrugem polysora, caracteres agronômicos e rendimento; além disso, obteve estimativas da variância aditiva num estudo de progênies de dez populações selecionadas no primeiro estágio. O segundo subprojeto se refere ao presente trabalho. No terceiro subprojeto, Basso (1999) apresentou os resultados das avaliações para produção de grãos e resistência ao complexo enfezamento de dez das 140 populações melhoradas e de 22 dos 1273 acessos do Banco Ativo de Germoplasma. O terceiro estágio inclui a recombinação dos materiais mais promissores para a formação de novas populações fonte de genes para resistência a doenças e com padrão agronômico aceitável. 


\subsection{Considerações sobre doenças do milho}

A algumas décadas passadas a cultura do milho era considerada rústica em relação a doenças. Atualmente, diferentes patógenos incluindo fungos, bactérias, virus, fitoplasma, espiroplasma e nematóides causam perdas bastante significativas, que podem estar associadas à redução da produtividade, da qualidade e do valor do grão, e ao aumento do custo de colheita. Todas as partes da planta, desde a raiz até o pendão, podem ser atacadas em vários estágios de desenvolvimento da cultura, desde plântula até fases próximas à maturação fisiológica. Balmer (1995) relata que os prejuizos causados pelos diferentes patógenos variam dentro de um gradiente que se estende desde aqueles de pouca importância econômica, causados por patógenos que ocorrem de forma esporádica, até aqueles causados por patógenos que causam sérios prejuizos econômicos; sendo que, desde que existam biótipos de patógenos virulentos, a importância das doenças está diretamente relacionada à susceptibilidade do germoplasma hospedeiro, à existência de condições ambientais favoráveis ao desenvolvimento das doenças, e à ocorrência de vetores eficientes, quando estes forem importantes na disseminação do patógeno ou na infecção do hospedeiro.

Pereira (1995) comenta que a importância das doenças do milho no Brasil podem ser divididas em três fases. A primeira foi caracterizada pelo descaso da pesquisa em relação a doenças. Na segunda, a partir de 1971, época em que o fungo Helminthosporium maydis dizimou os campos de milho portador do citoplasma $T$, iniciaram-se as preocupações de empresas privadas e universidades em obter materiais resistentes. A terceira fase iniciou-se no começo da década de 90, quando doenças foliares como ferrugem tropical, ferrugem polysora e mancha de Phaeosphaeria passaram a ocorrer com uma severidade bastante intensa, principalmente na região central do Brasil. Este autor, além disso, destaca as principais causas pelas quais as doenças do milho tornaram-se importantes em algumas regiões: a) surgimento de novas doenças em área cultivadas com milho, por exemplo a ferrugem tropical, Physopella zeae, que é uma doença recente na região Centro-Oeste, embora o fungo já

tenha sido observado no Espírito Santo há muitos anos atrás; b) produção mais tecnificada e aumento da área colhida mecanicamente, pois devido aos maiores 
investimentos feitos pelos produtores, perdas que antes consideradas pouco expressivas passaram a ter papel fundamental na rentabilidade da cultura como, por exemplo, perdas devidas às podridões de colmo e de espigas; c) perda de genes de resistência devido ao plantio de cultivares desenvolvidos em regiões em que os patógenos da região de cultivo não estão presentes como, por exemplo, tem ocorrido com a introdução de cultivares temperados em regiōes tropicais; d) o plantio contínuo de cultivares susceptíveis numa mesma área ou região, principalmente a partir dos chamados plantios de safrinha, vem contribuindo para aumento da concentração de inóculo, resultando em maior severidade das doenças e consequentemente maiores danos econômicos.

\subsection{Considerações sobre o melhoramento para resistência}

A obtenção e o uso de cultivares resistentes é o meio mais eficiente e econômico de controle às doenças na cultura do milho. Cultivares resistentes são obtidos através do uso de germoplasmas fontes de resistência e através de métodos apropriados de melhoramento, de tal modo que a resistência seja duradoura face à variabilidade dos patógenos.

A resistência do hospedeiro ao patógeno se manifesta na forma de barreiras mecânicas ou bioquimicas. As primeiras, também chamadas estruturais, são defesas fisicas que evitam ou restringem o desenvolvimento das doenças. As bioquimicas ou fisiológicas são as substâncias produzidas pelas reações bioquimicas que ocorrem na célula do hospedeiro e que são tóxicas ao patógeno ou criam condições adversas para o crescimento do mesmo no interior da planta (Pascholati e Leite, 1995; Balmer, 1995).

Os diferentes patógenos que atacam o milho representam entidades biológicas distintas que, quando o ambiente é favorável, interagem com a planta, induzindo, em cada sistema patógeno-hospedeiro, diferentes reações de susceptibilidade que caracterizam a doença (Balmer, 1995). Assim, segundo este autor, num programa de melhoramento para resistência, seja na avaliação de materiais comerciais, genéticos ou germoplasma, tornamse importantes a identificação dos patógenos e dos diferentes tipos de reação, o 
conhecimento dos fatores ambientais que favorecem a doença, e a identificação de locais que apresentam caracteristicas epidemiológicas distintas. Além disso, quantificar as doenças, identificar as fontes confiáveis de resistência, e conhecer a herança da resistência são de extrema importância. Amorim (1995) salienta que a quantificação de doenças é necessária tanto para medidas de controle, na determinação da eficiência de um fungicida ou na caracterização da resistência varietal, como para epidemiologia; sendo que, de nada adianta conhecer o patógeno de uma enfermidade se não for possivel quantificar os sintomas causados por ele.

Vanderplank (1963) propôs a classificação da resistência em vertical ou raçaespecifica e horizontal ou também chamada raça inespecifica. A primeira geralmente é monogênica e efetiva apenas contra algumas raças do patógeno, sendo, portanto, passivel de ser vencida; enquanto que, a resistência horizontal geralmente é poligênica e efetiva contra todas raças do patógeno, resultando numa redução do tamanho das lesões (Camargo e Bergamin Filho, 1995).

O melhorista de milho precisa conhecer a herança da resistência para poder combinar eficientemente os parentais e obter populações ou hibridos com resistência satisfatória. A resistência a doenças na cultura do milho envolve herança monogênica, poligênica e citoplasmática (Hooker, 1978). Tanto no caso de herança qualitativa como quantitativa, o conhecimento da ação gênica é importante. $\mathrm{Na}$ ação gênica aditiva, a seleção é facilitada porque um individuo ou grupo de individuos superiores quando selecionados produzirão uma descendência também superior. Na ação gênica dominante, a seleção de individuos superiores geralmente leva à produção de uma descendência inferior. Então, ocorrendo ação gênica dominante ou sobredominante, a atenção do melhorista deve ser voltada para a obtenção de hibridos (Ramalho et al., 1989).

O melhoramento de milho para resistência a doenças se procede de maneira semelhante ao melhoramento para rendimento, caracteres agronômicos ou caracteres morfológicos. Contudo, deve ser levada em consideração a variabilidade do patógeno, uma vez que deve-se buscar a obtenção de genótipos cuja resistência seja a mais durável possivel. E também, o melhoramento para resistência pode ser feito ao nivel de 
populações ou ao nivel linhagens. Em ambos casos, busca-se um padrão aceitável de tolerância às raças predominantes do patógeno.

O melhoramento ao nivel de populações busca aumentar a frequência de alelos favoráveis para produzir variedades melhoradas, ou aumentar a probabilidade de obtenção de linhagens superiores para a obtenção de híbridos resistentes. De um modo geral, a seleção recorrente tem sido aplicada no melhoramento de populações para resistência quantitativa.

O melhoramento de linhagens para resistência visa à obtenção de híbridos resistentes. Kovacs et al. (1994) afirmam que linhagens resistentes, ao contrário das susceptiveis, têm uma alta probabilidade de produzir hibridos resistentes. Jugenheimer (1976) relata que, em geral, a resistência de um hibrido a qualquer doença é proporcional ao número de linhagens resistentes que foram combinadas para formar o híbrido.

Os métodos normalmente utilizados para o melhoramento de linhagens são o retrocruzamento e o genealógico. O retrocruzamento pode ser usado para introduzir genes numa linhagem com boa capacidade geral de combinação para rendimento. $O$ método genealógico pode ser aplicado usando linhagens que se complementam para resistência resultando na obtenção de linhagens com boa resistência. Depois, a avaliação das linhagens é feita com base nas capacidades geral e especifica de combinação. A obtenção de híbridos pode ser feita também pelo cruzamento de linhagens complementares quanto à resistência a dois ou mais patógenos, o que corresponde ao piramidamento de genes (Camargo e Bergamin Filho, 1995).

\subsection{Algumas doenças importantes do milho no Brasil}

\subsubsection{Mancha de turcicum}

Causada pelo fungo Exserohilum turcicum (Pass.) Leonard and Suggs, previamente chamado Helminthosportum turcicum, esta doença tem sido economicamente importante em milho. Quando torna-se severa, perdas de rendimento de 
$30 \%$ ou mais podem ocorrer em híbridos susceptiveis, principalmente quando a infecção ocorre antes do florescimento (http://www.asgrow.com./gknowled/ScoutNoLB.html, 01/12/99). Nos Estados Unidos, tem sido a doença foliar mais prejudicial no norte do Corn Belt, mas sua severidade tem diminuido devido ao melhoramento para resistência (http://www. ag.iastate.edu/departments/plantpath/extension /foliagediseases /nlb.html, 01/12/99).

No Brasil, esse patógeno possui uma distribuição bastante generalizada, e pode causar danos bastante significativos em cultivares susceptiveis na região Sul e nas chapadas da região Centro-Oeste, principalmente nos plantios de setembro e de safrinha (Pereira, 1995).

As condições favoráveis ao desenvolvimento da doença são temperaturas moderadas $\left(18\right.$ a $20^{\circ} \mathrm{C}$ ), com o ótimo em $20^{\circ} \mathrm{C}$, e alta umidade, principalmente com presença de orvalho na superficie das folhas. Sob estas condições climáticas favoráveis, os esporos produzidos nas primeiras lesões são disseminados rapidamente pelo vento ou pela água da chuva (Fernandes \& Oliveira, 1997).

As lesões causadas por Exserohilum Iurcicum, para a reação de susceptibilidade, primeiramente surgem nas folhas inferiores, são necróticas, eliptico-alongadas, variando de 2,5 a $15 \mathrm{~cm}$ de comprimento (Balmer \& Pereira, 1987), de coloração palha, irregularmente distribuidas na superficie foliar, e que em casos severos coalescem (Fernandes \& Oliveira, 1997) e podem predispor as plantas a uma maior susceptibilidade aos agentes causadores de podridões de colmo (Balmer \& Pereira, 1987).

O uso de cultivares resistentes é o mais eficiente e econômico meio de controle da mancha de turcicum (Fernandes \& Oliveira, 1997). Pereira (1995) relatou que em 1995, $44 \%$ dos hibridos comercializados no Brasil eram resistentes, e $37 \%$ eram intermediários à mancha de turcicum.

Há no minimo duas formas de resistência, uma de natureza monogênica, que se manifesta na forma de lesões necróticas, circundadas por um halo amarelo, e com pouca ou nenhuma esporulação; e uma poligênica, caracterizada pela ocorrência de lesões foliares menores e em menor número, porém, mais numerosas nas folhas inferiores 
(Balmer \& Pereira, 1987; Fernandes \& Oliveira, 1997). A resistência qualitativa pode ser identificada no estágio de plântula, enquanto que a quantitativa é identificada com maior precisão no estágio de planta adulta (Hilu \& Hooker, 1963).

A resistência monogênica é determinada pelos genes $\mathrm{Ht}_{1}, \mathrm{Ht}_{2}, \mathrm{Ht}_{3} \mathrm{e} \mathrm{Ht}_{\mathrm{N}}$. Smith \& White (1988) citam que os três primeiros genes são independentes. O gene $\mathrm{Ht}_{3}$ foi transferido para o milho a partir de Tripsacum floridamum, $\mathrm{Ht}_{1}$ veio da linhagem $\mathrm{GE} 440$ e de uma população de milho pipoca, e Ht2 foi introduzido da linhagem australiana NN14 (Coe et al., 1977), citados por Ferreira (1999). O gene $\mathrm{Ht}_{\mathrm{N}}$, recentemente localizado no cromossomo 8L (Freymark et al., 1994), apresenta resistência dominante, não manifestada na forma de lesões cloróticas, mas que se expressa atrasando o aparecimento de lesões em plantas adultas, resultando em plantas livres de lesão até pouco depois da polinização (Gevers, 1975).

A resistência ao E. turcicum, determinada pelo gene $\mathrm{Ht}$, está associada com a maior produção de fitoalexinas. Os isolados com maior patogenicidade induzem à formação de fitoalexinas mais concentradas. As propriedades químicas da fitoalexina são determinadas pelo genótipo da planta e não pelo genótipo do patógeno (Lim et al., 1970)

Robbins e Warren (1993) num estudo de médias de gerações para determinar a herança da resistência à mancha de turcicum, cruzaram a linhagem H102 (altamente resistente) com seis linhagens, três susceptíveis, uma com resistência poligênica e duas outras contendo os genes $\mathrm{Ht}_{1}$ e $\mathrm{Ht}_{2}$. Os resultados obtidos sugeriram que a resistência da linhagem $\mathrm{H} 102$ pode ser controlada por um gene de efeito maior com contribuições de genes aditivos de efeito menor, fazendo da variedade Mayorbela, progenitora da $\mathrm{H} 102$, uma desejável fonte de resistência a Exserohilum turcicum. Calub et al. (1974) introduziram alelo $\mathrm{Ht}$ em linhagens com resistência quantitativa através de retrocruzamentos, observaram que as linhagens com os dois tipos de resistência apresentaram menor nivel de resistência que as linhagens contendo apenas resistência qualitativa, e concluíram que durante os ciclos de retrocruzamento, foram perdidos alguns alelos de resistência quantitativa. 
A resistência poligênica à mancha de turcicum, dependendo dos genótipos envolvidos no estudo da herança, é considerada aditiva por alguns autores, e dominante por outros. Jenkis et al. (1952) utilizaram cinco linhagens resistentes e três susceptiveis na análise de médias de gerações, e detectaram ação gênica dominante em sete dentre nove cruzamentos testados. Por outro lado, Hughes \& Hooker (1971), analisando médias de cruzamentos entre linhagens susceptiveis $x$ resistentes, verificaram que os efeitos gênicos aditivos contribuiram com 46,5 a $98,5 \%$ da variabilidade genética, enquanto que os efeitos de dominância contribuiram com 0,3 a $47 \%$; além disso, encontraram estimativas do coeficiente de herdabilidade no sentido amplo variando entre 40 a $70 \%$. Regitano Neto (1993), estudando progênies de IG e $S_{1}$ da população de milho pipoca Santa Rosa, relatou que a variância dominante foi maior que a variância aditiva, e que as estimativas de variância aditiva para progênies de IG foram quase duas vezes maiores que para progênies $S_{I}$. A herdabilidade estimada para a resistência utilizando essas progênies foram respectivamente 93,2 e $82,3 \%$.

Freymark et al. (1994), por meio de RFLP, fizeram o mapeamento de caracteres quantitativos para identificar o local e o efeito de QTL's em determinar os componentes da resposta de 150 linhagens de milho ao Exserohilum turcicum. Os componentes avaliados foram o número médio de lesões por folha, a porcentagem média de tecido foliar atacado e o tamanho médio das lesões. Constataram que número de lesões parece ser associado com QTL's no cromossomo 1S, $3 \mathrm{~L}$ e 5S; a severidade foi associada com QTL's nos cromossomos 7L e 8L; e o tamanho da lesão foi associado com QTL's sobre os cromossomos 7L e 5L. Muitos QTL's para os dois primeiros componentes envolveram ação gênica aditiva, dominância parcial ou sobredominância; enquanto que para o tamanho da lesão, ação gênica dominante com alelos recessivos pode estar envolvida no cromossomo $7 \mathrm{~L}$. A herdabilidade para esses caracteres foi estimada por Freymark et al. (1993); foram obtidos valores de 69,6; 62,8 e 31,9\%, respectivamente. para número de lesões, severidade da doença e tamanho de lesões.

O comprimento longo do periodo latente é uma importante característica componente de resistência parcial à mancha de turcicum. Carson (1995) estudou a 
herança do comprimento do periodo latente utilizando as gerações $F_{2}$ e retrocruzamentos da linhagem 69-1 (altamente resistente, longo periodo latente) e Mol7 (resistência intermediária) com a linhagem susceptivel A632. Análise de médias de gerações revelou que mais de $92 \%$ da variação entre médias foi explicada por ação gênica aditiva, e que os efeitos de dominância e epistáticos foram despreziveis. Além disso, esse autor inferiu que, possivelmente, o meio mais efetivo e rápido de selecionar para periodo latente aumentado seria com base na média de progênies, e essa seleção seria potencialmente mais efetiva que a seleção para severidade reduzida após a antese.

Ceballos et al. (1991) aplicaram quatro ciclos de seleção recorrente de progênies $S_{1}$ em oito populações subtropicais do CIMMYT para resistência poligênica à mancha de turcicum e à ferrugem comum. Relataram que o esquema de seleção recorrente utilizado foi eficiente em alcançar os objetivos, pois, houve um aumento muito rápido de resistência às duas doenças; relataram também que os resultados obtidos sugeriram altos valores de herdabilidade para a resistência poligênica à mancha de turcicum.

\subsubsection{Mancha de Phaeosphaeria}

A mancha de Phaeosphaeria é causada pelo fungo Phaeosphaeria maydis ( $P$. henning) Rane, Payak \& Renfro. Esta doença recentemente tem tido importância crescente para a cultura do milho (Carson, 1999), significativamente a partir dos anos 90 (Fernandes e Oliveira, 1997). Seu aparecimento se dava após a maturação fisiológica; atualmente, surge em plantas mais jovens, resultando em perdas de produtividade de grãos (Pereira, 1995) em torno de 60\% em cultivares susceptiveis (Fernandes e Oliveira, 1997).

As condições favoráveis ao desenvolvimento da doença são temperaturas moderadas a altas $\left(24\right.$ a $35^{\circ} \mathrm{C}$ ) (Agroceres, 1996). e essencialmente temperaturas noturnas em torno de $14^{\circ} \mathrm{C}$ e umidade relativa acima de $60 \%$ (Fernandes \& Oliveira, 1997). Sawazaki et al. (1997) concluiram que no estado de São Paulo, a umidade relativa é o fator preponderante para o desenvolvimento da doença. Silva (1997) relata que nas 
regiões com altitude acima de $700 \mathrm{~m}$, a ocorrência da mancha de Phaeosphaeria é devida à intensa formação de orvalho; e além destas condições, esta doença é favorecida também por adubação desequilibrada em que haja altas doses de nitrogênio.

O patógeno tem distribuição generalizada pelas áreas produtoras de milho. E sua severidade é maior nos plantios a partir de novembro (Pereira, 1995; Sawazaki et al., 1997), principalmente nos cultivos de safrinha (Pegoraro et al., 1998).

Inicialmente as lesões causadas por Phaeosphaeria são pequenas, cloróticas, tornando-se maiores, podendo alcançar até dois centimetros, arredondadas e alongadas, com coloração esbranquiçada e bordas escuras. Peritécios e picnídios, contendo esporos hialinos alongados ou arredondados, podem ser encontrados no centro das lesões (Balmer e Pereira, 1987). Em geral, os sintomas aparecem primeiro nas folhas inferiores, progredindo rapidamente em direção ao ápice da planta, e são mais severos após o florescimento masculino (Fernandes e Oliveira, 1997). Uma alta severidade confere à planta um aspecto de requeima bastante intenso, podendo causar a seca prematura das folhas e redução no ciclo da planta. E em função da susceptibilidade do cultivar e do ambiente favorável, os danos podem ser relevantes quando os sintomas se iniciam antes ou durante o florescimento (Fernandes e Oliveira, 1997; Agroceres, 1996).

Embora a utilização de cultivares resistentes seja o meio mais eficiente para o controle da mancha por Phaeosphaeria, atualmente a maioria dos cultivares comerciais de milho tem se mostrado susceptivel a esse patógeno. No entanto, fontes de resistência já foram identificadas (Fernandes e Oliveira, 1997).

Carson (1999), com o objetivo de avaliar a susceptibilidade do germoplasma em uso corrente nos Estados Unidos, avaliou 64 linhagens provenientes de empresas públicas e privadas e 80 hibridos comerciais. Os hibridos foram de um modo geral mais resistentes que as linhagens, sendo que, 54 hibridos apresentaram em torno de 1,5\% de área foliar atacada, e as linhagens relacionadas à linhagem $\mathrm{C} 103$ foram bastante resistentes.

Menten et al. (1996) avaliaram 9 hibridos de milho quanto à reação ao Phaeosphaeria maydis em Espirito Santo do Pinhal- SP, e verificaram que os hibridos AG 1043, AG 8430 e XL 380 foram moderadamente resistentes, sendo que, XL 380 e 
AG 1043 apresentaram maior rendimento. Brasil e Carvalho (1998) avaliaram treze hibridos de milho (Zea mays L.) em diferentes épocas de plantio, inclusive safrinha, quanto à resposta à infestação natural de Phaeosphaeria maydis em Goianésia-GO. Verificaram que a produtividade foi negativamente afetada pela doença, a severidade foi maior nos plantios mais tardios, e na época de maior severidade, foram considerados resistentes os hibridos AG-1043, AGX-7391, AGX-7393 e C-901.

Carson et al. (1996) relatam que a resistência à mancha de Phaeosphaeria na linhagem Mol 7 parece ser dominante incompleta e controlada por seis QTLs, com base em estudos de mapeamento usando linhagens derivadas do cruzamento entre B73 e Mol7.

Zocolli (1998) concluiu que os efeitos aditivos foram mais importantes para a reação à mancha de Phaeosphaeria. Ao contrário, Das et al. (1989) avaliaram 28 cruzamentos de um dialelo de oito variedades e constataram que os efeitos de dominância foram mais importantes que os aditivos no controle do caráter. Devido a isso, sugeriram a adoção da seleção recorrente para capacidade especifica de combinação para a obtenção de linhagens resistentes.

\subsubsection{Ferrugens}

Estas doenças são vulgarmente chamadas de ferrugem devido ao aspecto ferruginoso de suas pústulas, cujos agentes causais são fungos basidiomicetos pertencentes à ordem Uredinales. Esses fungos, representados por aproximadamente 5000 espécies ocorrendo em regiōes temperadas e tropicais, são parasitas obrigatórios, que com suas raças fisiológicas atacam várias culturas. Os sintomas manifestam-se predominantemente nas folhas, sendo que, as plantas atacadas têm sua atividade fotossintética reduzida devido à retirada de nutrientes pelos haustórios do fungo, à redução da área foliar e à queda de folhas (Bedendo, 1995).

As ferrugens que ocorrem na cultura do milho, segundo são a ferrugem comum, a ferrugem polysora e a ferrugem tropical (De Léon, 1994). 
A importância das ferrugens está intimamente relacionada com as condições climáticas e o genótipo do hospedeiro. Portanto, a incidência e a severidade podem variar de um ano para outro devido à seleção de novos biótipos do patógeno pelo hospedeiro, e devido às condições ambientais (Balmer \& Pereira, 1987).

\subsubsection{Ferrugem comum}

O agente causal da ferrugem comum é o fungo Puccinia sorghi Schw. Esta doença é bastante generalizada pelo mundo (De Léon, 1984). No Brasil, ela ocorre com maior severidade na região Sul devido às temperaturas mais amenas. Geralmente, o dano econômico à cultura não é muito significativo em virtude do bom nível de resistência apresentado pelos híbridos comercializados. Porém, dependendo da susceptibilidade do cultivar, a doença pode ocorrer resultando em perdas de rendimento em áreas cujas temperaturas são mais elevadas, como na região Centro-Oeste (Pereira, 1995). A esporulação do fungo é maior em temperaturas entre 17 a $25^{\circ} \mathrm{C}$ e elevada umidade relativa, sendo que, o desenvolvimento da doença é reduzido em temperaturas abaixo de $8^{\circ} \mathrm{C}$; e acima de $32^{\circ} \mathrm{C}$, quase não há esporulação (Headrick \& Pataky, 1986).

Apesar de a infeç̧ão geralmente aparecer em um periodo tardio, pode haver perdas severas na produtividade. Podem ocorrer em média perda de rendimento de até $50 \%$. Wallin (1951) estimou perda de $2 \%$ na região do "Corn Belt. Kim e Brewbaker (1977) relatam que as perdas podem chegar a $32 \%$ em regiões tropicais. O milho doce é mais suscetivel que o milho comum; Groth et al. (1983) estimaram perdas de $18 \%$ em Minnesota, e Pataky e Eastburn (1993) relataram perdas de 50\% em hibridos de milho doce altamente susceptiveis.

Os primeiros sintomas começam a aparecer quando as plantas se aproximam do florescimento. Ocorrem pústulas elipticas de coloração marron-canela espaçadas ou agrupadas localizadas nas duas faces da folha. As pústulas rompem a epiderme liberando os uredosporos, e à medida em que amadurecem tornam-se pretas (De Léon, 1994; Agroceres, 1996). 
A fase uninuclear do Puccinia sorghi Schw. não pode infectar o milho, mas possui como hospedeiros intermediários espécies de trevo do gênero Oxalis. Após a cariogamia, são produzidos aeciosporos na face inferior da folha dos trevos, cujos sintomas são pústulas alaranjadas. A partir daí o fungo pode infectar o milho (Smith e White, 1988).

O controle da ferrugem comum pode ser feito com fungicida quando a pressão da doença é moderada a severa, ou com o uso de cultivares resistentes (Pataky e Eastburn, 1993). Estes autores encontraram interação entre controle químico e resistência parcial, pois, com aplicação de fungicida a severidade da doença foi reduzida à metade no híbrido susceptivel, mas foi aumentada nos hibridos resistente, medianamente resistente $\mathrm{e}$ medianamente susceptivel.

A resistência à ferrugem comum pode ser do tipo especifica ou geral (Smith e White, 1988). Em 1995, 35\% dos hibridos comercializados no Brasil eram resistentes, e 55\% eram intermediários a esta doença (Pereira, 1995).

A resistência especifica é oligogênica, dominante e tida como uma reação de hipersensibilidade, resultando no desenvolvimento restrito de pústulas (Smith e White, 1988). Muitos locos que determinam a resistência à ferrugem comum têm sidos caracterizados e denominados Rp (Hooker, 1978). No cromossomo 10 estão os locos Rp1, Rp5 e Rp6; no cromossomo 3, Rp3; no cromossomo 4, Rp4 (Sanz-Alferez et al., 1995); e no cromossomo 6, Rp8 (Delaney et al., 1998). Segundo estes autores, o loco Rp8 exibe sobredominância, é o único em que somente os heterozigotos Rp8a Rp8b são resistentes enquanto os homozigotos são susceptiveis. O loco Rpl, o primeiro deles, é um bloco gênico que contém pelo menos 14 alelos (Hooker, 1969; Hu e Hulbert, 1996). Esse bloco gênico complexo exibe instabilidade, havendo permuta desigual entre sequências repetidas de DNA (Bennetzen et al., 1988), e alta taxa de recombinação intragênica (Hulbert, 1997), resultando em variabilidade e no aparecimento de novas formas de resistência especifica (Ritcher et al., 1995). Recombinações intragênicas têm sido identificadas conferindo resistência parcial também, podendo ser útil em controlar ferrugem de uma maneira durável (Hulbert, 1997). 
Groth et al. (1992) testaram a efetividade de 24 alelos de quatro locos Rp em linhagens quase isogênicas; somente os alelos Rpld e Rp3c foram totalmente efetivos, seguidos por quatro outros alelos Rple, Rplf, Rplg, e Rplk que mostraram traços de ferrugem em alguns experimentos.

A resistência não especifica ou geral se manifesta melhor na fase de planta adulta, conferindo menores número e tamanho de pústulas e menos necreose foliar. Ela está associada a valores altos de herdabilidade e baixos número de genes estimado (Smith e White, 1988). Valores de herdabilidade de $65 \%$ e $75 \%$ obtidos de variância entre familias $F_{2: 3}$ ao nivel de parcela foram encontrados por Holland et al. (1998).

O atraso no aparecimento das primeiras pústulas, influenciado pelo periodo latente e pela eficiência da infecção, é uma medida de resistência parcial à ferrugem comum (Gingera et al., 1995). Estes autores, trabalhando com 32 linhagens de milho doce, por meio da análise de média de gerações, encontraram controle genético aditivo para esse caráter na maioria dos cruzamentos. Efeitos gênicos dominantes foram encontrados em dois cruzamentos, e efeitos epistáticos significantes não foram encontrados em nenhum cruzamento. Além disso, não encontraram correlação entre o aparecimento das primeiras pústulas e a severidade da doença, o que indicou que a seleção para este caráter pode ser conduzida independentemente da severidade da doença.

Randle et al. (1984) encontraram altas estimativas de herdabilidade para resistência parcial, e relataram que em geral, os efeitos dominantes e aditivos tiveram grande importância na expressão do caráter, sendo que a dominância pode ocorrer no sentido da resistência ou da susceptibilidade, dependendo dos pais utilizados. Estes autores, após um ciclo de seleção recorrente utilizando progênies S1 e S2 obtiveram ganhos genéticos de 11 a 17\% para resistência à ferrugem comum.

Davis et al. (1990), trabalhando com introgressão de populações do México e do Peru em milho doce na Universidade de Minnesota, através de 10 ciclos de seleção recorrente utilizando progênies $S_{1}$, obtiveram ganhos significativos para resistência parcial à ferrugem comum. 
Gingera et al. (1994) verificaram a eficiência da seleção pelo método genealógico em três populações de milho doce até a geração $S_{3}$. Através da avaliação experimental das gerações em quatro ambientes, constataram que as linhagens $S_{3}$ de cada população desenvolveram 27,19 , e $49 \%$ menos severidade que a geração $S_{0}$.

Abedon et al. (1998) aplicaram três ciclos de seleção recorrente para resistência a ferrugem comum em três populações de milho doce, e verificaram que a porcentagem de área foliar infectada reduziu, em média, de 47 para $9 \%$ e de 22,5 para $9 \%$, respectivamente, após avaliação aos 40 e aos 21 dias após a polinização.

\subsubsection{Ferrugem tropical}

A ferrugem tropical é causada pelo fungo Physopella zeae (Mains) Cummins \& Ramachar. É a mais recente e preocupante das ferrugens; pois, o patógeno possui boa capacidade de disseminação, alta agressividade e grande capacidade de se adaptar em diversas condições ambientais (Pereira, 1995). Em nivel mundial, ocorre em algumas regiōes do continente americano, Índia e regiōes da África (Mc Gee, 1990). No Brasil, a ocorrência desta doença é maior na região Centro-Oeste (Pereira, 1995).

As condições favoráveis ao desenvolvimento do patógeno são altas temperaturas, numa ampla faixa em relação às outras doenças foliares $\left(22\right.$ a $35^{\circ} \mathrm{C}$ ), e umidade relativa média a muito baixa(Agroceres, 1996).

A ferrugem tropical se apresenta na forma de pequenas pústulas de formato arredondado a oval, agrupadas, de coloração amarela a castanha, ocorrendo na superficie superior da folha e recobertas pela epiderme foliar, podendo apresentar um bordo escuro de formato oval a alongado envolvendo um grupo de pústulas. Em condições de alta incidência pode ocorrer a coalescência dos grupos de pústulas e, consequentemente, a morte prematura das plantas (Agroceres, 1996; Balmer e Pereira, 1987; Jugenhimer, 1976). Assim como para a ferrugem polysora, não é conhecido nenhum hospedeiro alternativo do fungo (De Léon, 1984).

Von Pinho et al. (1998a) num estudo para quantificar os danos causados pelas ferrugens polysora e tropical em diferentes locais do Brasil, verificaram que a ferrugem 
tropical teve maior importância em reduzir a produção do milho. Houve um acréscimo de $0,40 \%$ no dano e uma redução de $26,3 \mathrm{Kg} /$ ha para cada aumento de uma unidade na AACPD (área abaixo da curva de progresso da doença); enquanto que para a ferrugem polysora, estes valores foram respectivamente $21,69 \mathrm{Kg} / \mathrm{ha} \mathrm{e} 0,26 \%$.

O uso de cultivares resistentes é o meio de controle mais viável. Em 1995, 11\% dos hibridos comercializados no Brasil eram resistentes, e 55\% eram intermediários à ferrugem tropical (Pereira, 1995). Foi verificado por Pinho et al. (1998a) que os híbridos C333, Z8392 e C909 foram os de melhor desempenho, evidenciando boa resistência.

Não há muitas informações sobre o controle genético da resistência a esta doença. Num estudo de médias de gerações de dois cruzamentos, Pinho et al. (1998b) encontraram predominância de efeitos genéticos aditivos, que atuaram no sentido de redução da severidade da doença. Além disso, houve predominância da variância genética aditiva, e o coeficiente de herdabilidade no sentido restrito considerando a média dos dois cruzamentos foi de 0,41. Lima et al. (1998) também encontraram que os efeitos aditivos foram os mais importantes e os responsáveis por significativa fonte de variação entre os cruzamentos contrastantes. Estes autores concluiram que os cruzamentos entre linhagens contrastantes tendem a apresentar valores próximos à média dos pais; mas desvios de dominância também podem ocorrer, tendendo, inclusive, para a susceptibilidade.

Lima et al. (1996) avaliaram 440 linhagens endogâmicas provenientes de diversas populações, encontraram ampla variabilidade, e concluiram que a seleção recorrente pode ser efetiva para se alcançar resistência a Physopella zeae.

\subsubsection{Ferrugem polysora}

Esta ferrugem é causada pelo fungo Puccimia polysora Underw. É uma doença altamente agressiva e destrutiva, podendo causar grandes perdas em cultivares que não apresentam bom nivel de resistência (Pereira, 1995). Um estudo de perdas no estado de Mississipi mostrou redução de rendimento superior a 45\% (Rodriguez-Ardon et al., 1980) 
As condições favoráveis ao desenvolvimento do patógeno são altas temperaturas $\left(27\right.$ a $35^{\circ} \mathrm{C}$ ) e umidade relativa (Agroceres, 1996). Sendo assim, a ocorrência desta doença tem maior importância na região Centro-Oeste, em todas as épocas de plantio, e no Paraná, nos plantios tardios (Pereira, 1995).

Os sintomas são similares aos da ferrugem comum. Mas, diferem em alguns aspectos: as pústulas são menores $(0,2$ a $2 \mathrm{~mm})$, usualmente circular ou oval, muito numerosas e distribuidas densamente sobre a superficie superior das folhas, e raramente sobre a superficie inferior (Smith e White, 1988); podem ocorrer no limbo, na bainha, nas brácteas das espigas e nos pendões quando a severidade é alta; os uredosporos são mais claros, apresentando uma coloração que varia do amarelo ao dourado (Balmer e Pereira, 1987 e Agroceres, 1996); quando as plantas aproximam da maturidade, as pústulas tornam-se marrom escuro; e não é conhecido nenhum hospedeiro alternativo do fungo (De Léon, 1984).

$\mathrm{O}$ uso de cultivares resistentes tem sido bastante efetivo no controle à ferrugem polysora. Em 1995, 40\% dos hibridos comercializados no Brasil eram resistentes, e 30\% eram intermediários a esta doença (Pereira, 1995).

Resistência especifica em milho tem sido identificada, e 11 genes foram encontrados e designados Rppl a Rppl1. O Rpp9 está no cromossomo 10, pode conter inúmeros alelos, e está ligado muito próximo ao Rpld, que confere resistência a algumas raças de $P$. sorghi (Scott et al., 1984).

Scott et al., (1984) relatam que genes de efeito dominante, parcialmente dominante e com ausência de dominância já foram identificados. Smith e White (1988) citam que muitas raças fisiológicas de P. polysora são conhecidas. Futrell et al.(1975), relataram que resistência à raça 9 de Puccinia polysora é devida à um único gene de efeito dominante.

Scott et al. (1984) com o objetivo de obter informações sobre o tipo de ação gênica e o número de genes envolvidos na resistência a Puccimia polysora, avaliaram progênies $F_{2}$ de cruzamentos entre genótipos resistentes e um testador susceptivel. Os resultados indicaram que a resistência pode ser devida a um ou dois genes com efeito de 
dominância completa ou parcial, e que tais genes estão no loco Rppg ou muito próximo e fortemente ligado a ele.

A utilização da resistência especifica é limitada, uma vez que existem raças do patógeno capazes de quebrá-la. Como alternativa, resistência geral ou não especifica recentemente tem sido encontrada, mas há pouca informação a seu respeito( Bailey et al. 1987). Estes autores conseguiram identificar genótipos de milho com resistência parcial à P. polysora usando como parâmetros de mensuração a área abaixo da curva de progresso da doença (AACPD) e a densidade de pústulas individuais.

Holland et al. (1998) investigaram a herança da resistência em duas populações $F_{2: 3}$ resultantes do cruzamento entre duas linhagens tropicais resistentes (1416-1 e 1497 2) e um hibrido susceptivel do Corn Belt. A herdabilidade estimada para resistência nas duas populações foi de 30 e $50 \%$ com base na regressão de $F_{2}$ para $F_{3}$, e de 65 e $75 \%$ com base na variância entre progênies $F_{2: 3}$ ao nivel de parcelas. Por análise de RFLP, detectaram que um loco, bnl3.04, foi associado com $82 \%$ da variação de resistência de campo entre as duas populações. Os locos umc26 e umc31, respectivamente, sobre os cromossomos 3 e 4 foram associados com resistência na população 1497-2 e cada um explicou $14 \%$ da variação fenotípica. Um modelo de múltiplos locos marcadores, incluindo os que estão nos cromossomos 3, 4 e 10 e suas interações epistáticas explicou $97 \%$ da variação fenotípica.

Barbosa et al. (1998), com o objetivo de estudar o modo de herança da resistência a $P$. Polysora, num estudo de médias de gerações a partir do cruzamento entre a linhagem mediamente resistente (Z95) e a linhagem altamente suscetivel (Z93), relataram que a variância fenotípica causada por efeitos aditivos, dominantes e desvios foi respectivamente de $61,0 \%, 37,0 \%$ e $3,4 \%$; a heterose calculada foi de -10 , a herdabilidade de $85,1 \%$ e o número estimado de fatores efetivos foi de 2,36 .

Num estudo de médias de gerações de dois cruzamentos, Pinho et al. (1998b) constataram que apesar dos efeitos aditivos terem sido superiores, houve também a presença de dominância, sendo que, ambos efeitos atuaram no sentido de redução da severidade do patógeno. Além disso, houve predominância da variância genética aditiva, 
e o coeficiente de herdabilidade no sentido restrito considerando a média dos dois cruzamentos foi de 0,82 .

\subsubsection{Podridões de colmo}

$\mathrm{Na}$ cultura do milho, as podridões podem ocorrer nas sementes a partir do plantio, nas raizes, no colmo e nas espigas antes e depois da colheita. Estão diretamente relacionadas a doenças foliares (pois, estas predispõem as plantas ao ataque de patógenos apodrecedores do colmo), nematóides (no caso de podridões por Fusarium) e a injúrias em raizes, colmo e grãos (pois, favorecem a entrada do patógeno).

As podridões de colmo têm efeito indireto no produto comercial, uma vez que levam, respectivamente, ao tombamento da planta e à quebra do colmo, resultando na perda da espiga, que apodrece no solo ou deixa de ser colhida, principalmente, se a colheita for mecanizada.

Os agentes causais de podridão do colmo são os fungos Diplodia maydis (Berk), Fusarium moniliforme (Gibberella fujikuroi) Sheld, Pythium aphanidermatum (Eds.) Fitz., Colletotrichum graminicola, Fusarium graminearum (Gibberella zeae), Macrophomina phaseoli (podridão preta do colmo), e Botryodiplodia theobromae, sendo que, os quatro primeiros são mais comuns (Balmer, 1980; Balmer \& Pereira, 1987). Além destes, a bactéria Erwinia carotovora também é agente causal de podridão de colmo.

Balmer (1980) relata que as condições favoráveis à doença são períodos secos no início da cultura seguidos por periodos chuvosos prolongados, logo após o florescimento feminino. Mas, segundo De Leon (1984), dependendo do agente causal, as condições favoráveis variam; pois, umidade baixa e temperaturas altas na época do florescimento favorecem a podridão preta do colmo e a podridão causada por Fusarium; umidade alta e temperaturas altas favorecem a podridão causada por Botryodiplodia e por Enwinia carotovora; e umidade alta e temperaturas baixas favorecem a podridão causada por Diplodia, segundo Balmer \& Pereira (1987), após periodo seco antes da polinização. A antracnose do colmo é favorecida por alta umidade e temperatura moderada (Balmer e 
Pereira, 1987). A ocorrência de antracnose do colmo e da folha não são necessariamente correlacionadas (http://w'ww.ag.iastate.edu/departments/plantpath/extension/stalkrots/asr. html, 16/09/99).

Os sintomas variam conforme o patógeno (De Leon, 1984): na podridão causada por Diplodia, os sintomas aparecem várias semanas após o embonecamento, sendo que, os entrenós inferiores passam de uma coloração verde normal para uma coloração palha a marrom claro, a medula se apresenta desintegrada e com cor alterada, e os feixes vasculares permanecem intactos, além disso, segundo (http://www.ag.iastate.edu /departments/plantpath/extension/stalkrots/dsr.html, 16/09/99), há o desenvolvimento de numerosos pontos pretos (picnídios) nos entrenós inferiores; na podridão causada por Fusarium moniliforme, os sintomas são muitos semelhantes aos causados por Diplodia, porém, quando se abrem os colmos de plantas infectadas, verifica-se que os vasos do floema têm uma coloração escura e que os tecidos do parênquima podem apresentar uma cor marrom; na podridão causada por Pythium aphanidermatum, os sintomas são semelhantes aos das demais podridões, porém, podem ser vistos antes do florescimento, em plantas jovens, uma vez que, este fungo é habitante do solo; na podridão causada por Eninia carotovora, as plantas apresentam cor escura, um apodrecimento aquoso na base do colmo e um cheiro repugnante, podendo morrer pouco antes do florescimento. $\mathrm{Na}$ podridão causada por Gibberella zeae, internamente os entrenós inferiores adquirem uma coloração rosada (http://www.ag.iastate. edu/departments/plantpath/extension/stalkrots /gsr.html, 16/09/99). Balmer \& Pereira (1987) relatam que na podridão causada por Colletotrichum, os sintomas surgem na casca logo após a polinização como lesões longitudinais estreitas, encharcadas, com uma coloração parda e avermelhada, que depois se torna castanho escura, podendo afetar o colmo inteiro.

Além do uso de cultivares resistentes, as podridões de colmo podem ser controladas pelo uso de uma adubação equilibrada, uma vez que, altos niveis de nitrogênio e baixos niveis de potássio favorecem a ocorrència da doença, Balmer (1980) Cloreto de potássio reduz a incidência de podridões do colmo e aumenta o rendimeno de grãos (Heckman, 1998). Anuar-ul-Haq \& Nasir (1994) selecionando diferentes cultivares 
de milho para resistência à podridão do colmo, constataram que a resistência foi positivamente correlacionada com o conteúdo de nitrogênio e negativamente com os conteúdos de açúcares e de fósforo no colmo.

Vários estudos relatam que a resistência a esta doença é herdada de maneira quantitativa, exceto no caso de Fusarium. A resistência a Diplodia envolve ação gênica aditiva, dominante e em alguns casos epistasia (Hooker, 1978). Num estudo da herança de resistência à podridão do colmo por antracnose, Weldekidan e Hawk (1993) avaliando nove linhagens de milho em cruzamento dialélico encontraram soma de quadrado para capacidade geral de combinação quatro a cinco vezes maior que a capacidade especifica de combinação, e concluiram que o efeito aditivo foi mais importante que os efeitos não aditivos. Carson e Hooker (1982) relatam que a resistência à podridão do colmo por antracnose (Colletotrichum graminicola) é governada por poucos genes. Pereira et al. (1989) concluíram que a herança da resistência a C. graminicola expressou diferentemente nos diferentes cruzamentos entre linhagens, os efeitos aditivos foram mais importantes em alguns cruzamentos, enquanto que em outros, os efeitos de dominância foram também importantes, sendo que, a direção da dominância não seguiu um padrão previsivel, mas variou de acordo com o background genético das linhagens parentais. A resistência à podridão do colmo causada por Colletotrichum graminicola foi controlada por um gene principal designado ASR numa linhagem, mas em outra foi controlada por muitos genes (Badu-Apraku, 1987).

A produção de fenóis é um mecanismo de resistência bioquimica a Colletotrichum graminicola. Badu-Apraku (1987), num estudo sobre herança e natureza da resistência a este patógeno, concluiram que a inibição fúngica foi correlacionada com o padrão de acúmulo de fenol em linhagens resistentes e susceptiveis. A resistência da casca é um mecanismo estrutural de resistência à podridão do colmo por Fusarium. Mesterhazy (1983) concluiu que podridão da espiga foi fortemente influenciada pela podridão do colmo e que boa resistência da casca corresponde à boa resistência do colmo, mas não necessariamente à resistência à podridão da espiga. 
Fontes de genes para resistência a podridão do colmo têm sido buscada em linhagens e em populações. Lambert (1996) relata que as linhagens PI592733, PI592734 e PI592735 têm valor potencial como fonte de alelos úteis de resistência a podridões do colmo para o melhoramento de linhagens derivadas das populações Stiff Stalk Synthetic e Lancaster. Weldekidan e Hawk (1993) estudando a herança da resistência à antracnose do colmo e à broca do colmo (Ostrinia mubialis), utilizaram nove linhagens e seus 36 hibridos simples. Constataram que as linhagens DE811ASR e RD6501 tiveram efeito negativo de capacidade geral de combinação altamente significativo, indicando que estas linhagens são boas fontes de germoplasma para resistência à antracnose do colmo e à broca do colmo.

De um modo geral, a seleção recorrente tem sido aplicada no melhoramento de populações para resistência quantitativa. Nyhus et al. (1989), trabalhando com dois sintéticos de milho para resistência à podridão do colmo causada por Diplodia maydis, verificaram que após quatro ciclos de seleção recorrente houve um aumento no nível de resistência, o acamamento foi reduzido de $16,3 \%$ para $2,9 \%$ em BSAA e de $23,4 \%$ a $6,3 \%$ em BSBB, mas houve redução da altura da planta e do comprimento da espiga, resultando, consequentemente, numa redução de $20 \%$ no rendimento. Porém, as mudanças correlacionadas em caracteres agronômicos e seleção recorrente para resistência a Diplodia maydis podem não ser similares entre diferentes materiais, podendo inclusive, a correlação ser não significante (Novoa e Russel, 1988).

O ganho genético e a resposta correlacionada dependem do método de seleção aplicado. Mostafa (1987) aplicou três ciclos de seleção recorrente simples e um ciclo de seleção recorrente baseada em progênies $S_{2}$ para resistência à podridão do colmo causada por Fusarium graminearum, e constatou que a seleção baseada em familias $\mathrm{S}_{2}$ foi mais efetiva para rendimento que a seleção recorrente simples, e que os dois métodos foram efetivos em melhorar para resistência.

Milles et al. (1981) relataram que a seleção de familia de meios-irmãos foi efetiva em aumentar a resistência à antracnose do colmo, mas não houve ganho para rendimento. 
Carson e Hooker (1982), num estudo feito com progênies de cinco cruzamentos envolvendo quatro linhagens resistentes e duas susceptiveis, com base nas estimativas de herdabilidade, na ação gênica aditiva e na frequência relativamente alta de famílias $F_{3}$ com resistência alta à antracnose do colmo, concluiram que a maneira mais efetiva de aumentar a resistência nas linhagens e nas populações é pelo método genealógico e pela seleção recorrente, respectivamente. Também, utilizando o método genealógico, Lambert (1996) desenvolveu as linhagens PI592733, PI592734 e PI592735, fontes de alelos úteis de resistência a podridões do colmo.

\subsubsection{Complexo enfezamento}

O enfezamento ou complexo enfezamento é uma doença que afeta toda a planta de forma sistêmica. Em casos extremos pode ocasionar perdas severas na produtividade, vindo a constituir um agravante para os produtores de milho do Brasil, Estados Unidos, México, Argentina e de outras áreas do Continente Americano. O enfezamento é possivelmente a doença mais importante para a produção de milho no sul dos Estados Unidos (Scott e Rosenkranz, 1974). No Brasil, segundo Pereira (1995), a partir de 1983, o enfezamento tem se tornado importante, principalmente quando materias desenvolvidos para plantio em época normal eram utilizados nos plantios de safrinha.

O complexo enfezamento é constituído por duas doenças: corn stunt ou enfezamento pálido (Balmer \& Pereira, 1987), que é causado por Corn Stunt Spiroplasma (CSS) (Spiroplasma kunkelii) (Davis, 1973); e Mesa Central corn stunt ou enfezamento vermelho (Balmer \& Pereira, 1987), que é causado por Maize Bushy Stunt Phytoplasma (MBS) (Harrison et al., 1996). Espiroplasmas podem ser definidos como procariotos destituidos de parede celular, que apresentam forma espiralada, mobilidade e dimensões em torno de $250 \mathrm{~nm}$ de diâmetro e $15 \mu \mathrm{m}$ de comprimento, e podem ser cultivados "in vitro" (Balmer \& Pereira, 1987; Smith e White, 1988). Enquanto que os fitoplasmas também são procariotos desprovidos de parede celular (www abs sdstate.edu 
/plantsci/ext/path/HortCrops/Lect_4a.html, 25/11/99) e não podem ser cultivados em meios artificiais (Gamez,1983).

A transmissão do enfezamento é feita pela cigarrinha Dalbulus maidis (Balmer, 1987). Associação entre alta densidade de $D$. maidis e alta incidência de enfezamento amarelo e de enfezamento vermelho foi encontrada por Oliveira et al. (1998) no Brasil Central. Maior densidade populacional do vetor ocorre no final do verão e no outono, em milho de plantio tardio ou de safrinha. A saliva injetada nas plântulas contém toxina, que reduz o crescimento da planta e provoca estrias amareladas nas folhas, contudo, Gassen (1996), citado por Basso (1999), relata que estes danos não justificam a adoção de medidas de controle do vetor. Moya-Raygoza \& Nault (1998) encontraram taxa de transmissão mais alta a 20 e $25^{\circ} \mathrm{C}$ e taxas mais baixas a 15 e $30{ }^{\circ} \mathrm{C}$. Urbina (1991) relata que o desenvolvimento do vetor é favorecido por baixas precipitações, temperatura alta e baixa umidade relativa.

Segundo Harrison et al. (1996), a faixa de temperatura na qual os agentes causais do complexo enfezamento podem se desenvolver é muito ampla; sendo que, o CSS é mais encontrado em condições de temperaturas mais elevadas que as requeridas pelo MBS (Gordon et al., 1985). Contudo, a ocorrência da doença é maior em plantios tardios, época em que se tem maior população do vetor no campo (Agroceres, 1996).

Plantas com enfezamento pálido apresentam como sintomas iniciais uma clorose marginal das folhas, podendo em seguida apresentar avermelhamento das folhas inferiores. Áreas cloróticas podem com o tempo coalescer, dando origem a faixas cloróticas que se estendem em direção ao ápice da folha. As plantas infectadas, em relação às sadias, são menores; apresentam maior número de espigas, porém menores; e podem apresentar perfilhamento (Balmer \& Pereira, 1987). O enfezamento vermelho confere sintomas semelhantes ao enfezamento pálido, a diferença é que sintoma inicial há uma clorose menos acentuada, e as plantas tornam-se menores e as folhas mais velhas adquirem uma coloração vermelha mais intensa (Agroceres, 1996; Smith e White, 1988).

O uso de inseticida como estratégia de controle não impede a picada de prova e a consequente injeção de saliva contendo os patogenos. Portanto, o uso de cultivares 
resistentes está sendo a medida mais eficaz de controle. Em 1995, Pereira (1995) relatou que no Brasil, resistência ao enfezamento era encontrada em $54 \%$ dos híbridos, sendo que $11 \%$ destes tinham comportamento intermediário.

Brewbaker et al. (1991) relatam que as fontes de resistência para o complexo enfezamento são encontradas com maior frequência nas regiōes em que estas doenças prevalecem. Estes autores, avaliando 113 linhagens de diversas origens, encontraram alta resistência em materiais do CIMMYT provenientes de germoplasma Tuxpeño e Cubano. Houve boa resistência também nos materiais EMBRAPA 345 (Brasil), ICA L223 (Colômbia), KU 1414 (Tailândia), Tzi (Nigéria) e W64 (USA). Foi observado que no germoplasma de origem tropical as linhagens não apresentaram um padrão de resistência muito definido, mas as linhagens com germoplasma de origem temperada apresentaram moderada a alta susceptibilidade. Narro-León e Miranda Filho (1998), com base nas médias preditas, selecionaram dez populações e 25 acessos com bom padrão de resistência, e verificaram que os materiais mais promissores para a sintese de populações de milho com resistência a doenças viróticas e ao complexo enfezamento foram as populações CMS-454, Iapar-51 e BR-106; os acessos precoces CMS-458, República Dominicana-300 e CMS-24; os acessos intermediários PE-001, SE-032 e BA-032; e os acessos tardios Cateto Colômbia VIII, SE-030, BA-187 e MG-099.

O estudo da herança ao complexo enfezamento tem tido pouco avanço No entanto, em função de sua distribuição contínua, pode ser inferido que a expressão da resistência é controlada por muitos genes (Scott e Rosenkranz, 1977). Basso (1999) concluiu que os efeitos gênicos não aditivos são de menor importância na manifestação da resistência ao enfezamento, e relatou que alguns autores também têm encontrado predominância de efeitos aditivos.

Os métodos de melhoramento utilizados para resistência ao enfezamento têm sido o retrocruzamento, para desenvolver formas resistentes de linhagens elite susceptiveis, e a seleção recorrente utilizando progênies endogâmicas ( $\mathrm{S} 1$ ou S2), o que minimiza o efeito encobridor do hibrido na manifestação dos sintomas da doença (Findley et al., 1981), citados por Basso ( 1999) 


\subsection{Valor genético de populações por meio de cruzamentos com testadores}

Nos programas de melhoramento, antes de se obterem híbridos ou populações como produtos finais, normalmente seus progenitores são avaliados contra testadores em cruzamentos do tipo top-cross ou em cruzamentos dialélicos, obtendo informações sobre o valor genético dos genitores e o comportamento dos materiais em cruzamentos. Após esta etapa, são feitas predições dos híbridos ou compostos a serem formados, reduzindo o número de materiais a serem avaliados em experimentos caros, com maior número de repetições e em vários locais.

Top-cross se refere ao cruzamento de linhagens ou variedades com um testador de base genética ampla ou estreita, para avaliar as linhagens ou as variedades quanto à capacidade de combinação. Este tipo de cruzamento foi proposto por Davis (1927) para avaliação preliminar de linhagens $S_{2}$ em cruzamento com uma variedade, para predizer quais linhagens seriam levadas adiante num programa de desenvolvimento de hibridos.

O cruzamento top-cross é mais fácil de ser executado em relação ao cruzamento dialélico devido ao menor número de cruzamentos a serem realizados. Sotchenko (1971) avaliou a capacidade de combinação de linhagens de milho utilizando top-cross e dialelos, verificou que os dois esquemas de cruzamento deram resultados semelhantes, e concluiu que na presença de um testador adequado, o uso de topcross é mais aconselhável em razão de sua maior praticidade.

Moreira Júnior (1995) relata que as primeiras modificações no uso de top-cross começaram com os trabalhos teóricos que serviram de base para o desenvolvimento dos cruzamentos dialélicos.

Um dialelo se refere, em termos gerais, a todos os cruzamentos possiveis entre um grupos de genitores, cuja análise pode incluir os progenitores, os $F_{1}$ 's, os cruzamentos recíprocos e outras gerações relacionadas (Cruz \& Regazzi, 1994).

A partir dos conceitos de capacidade geral (CGC) e capacidade especifica de combinação (CEC) introduzidos por Sprague \& Tatum (1942), os cruzamentos dialélicos têm sido bastante utilizados no melhoramento de plantas. A capacidade geral de 
combinação, associada com a ação gênica aditiva, foi conceituada por esses autores como sendo o desempenho médio de uma linhagem ou uma variedade em combinações hibridas. A capacidade especifica de combinação, associada aos efeitos gênicos não aditivos, foi conceituada como o desvio que um cruzamento especifico apresenta em relação à CGC dos seus parentais.

Em espécies alógamas, normalmente os progenitores no dialelo são os próprios genótipos de inferência; evidentemente, o modelo é fixo. Portanto, neste caso, não é recomendável o uso de cruzamentos dialélicos com a finalidade de fornecer estimativas dos componentes de variância. Contudo, os dialelos são frequentemente usados para fornecer informações sobre a herança de um determinado caráter, como também, auxiliar na escolha de progenitores com base nas estimativas de seus valores genéticos.

Dentre os métodos de análise dialélica, os mais utilizados em alógamas são o de Griffing (1956), o de Gardner e Eberhart (1966) e os parciais fatoriais.

Griffing (1956), para estimar os efeitos e as somas de quadrado das capacidades geral e especifica de combinação, apresentou análises dialélicas para modelo fixo e modelo aleatório, em quatros métodos estabelecidos de acordo com os tratamentos envolvidos: o método 1 envolve os pais, os $F_{1}$ 's e os reciprocos; método 2, pais e $F_{1}$ 's; método 3, $F_{1}$ 's e reciprocos; e método 4 , somente os $F_{1}$ 's.

Gardner \& Eberhart (1966) propuseram um modelo fixo aplicável a progenitores em equilibrio de Hardy-Weinberg, que não contem os efeitos das capacidades geral e especifica de combinação, mas a informação genética é obtida com base nos efeitos de variedade e com base no detalhamento da heterose em heterose média, heterose de variedade e heterose especifica, utilizando quatro métodos estabelecidos de acordo com hipóteses em torno da heterose.

Enquanto esses primeiros dialelos se referem aos cruzamentos entre progenitores de um mesmo conjunto, os dialelos parciais fatoriais se referem aos cruzamentos entre dois conjuntos distintos de parentais, sendo que, de acordo com Cruz \& Regazzi (1994), as inferências são feitas para cada grupo. Os dialelos parciais foram inicialmente propostos por Kemptorne e Curnow em 1961, para ampliar a inclusão de progenitores 
num dialelo (Hallauer \& Miranda Filho, 1981). Tais dialelos podem fornecer os efeitos de capacidade de combinação ou os efeitos de variedade e de heterose, dependendo se eles são analisados a partir do dialelo de Griffing ou de Gardner e Eberhart.

Miranda Filho \& Geraldi (1984) apresentaram um modelo para dialelos parciais adaptado a partir do método quatro de Gardner e Eberhart de 1966. Dois grupos distintos de progenitores e os $F_{1}$ 's constituem o material a ser avaliado, cuja análise fornece informações sobre o potencial per se dos progenitores e da heterose manifestada em seus hibridos. Neste modelo, o número de cruzamentos a serem avaliados é reduzido em relação aos dialelos completos, tornando possivel avaliar um maior número de materiais em uma menor área, ou avaliar um menor número de tratamentos com maior precisão experimental. Posteriormente, Geraldi \& Miranda Filho (1988) apresentaram uma adaptação dos modelos de Sprague e Tatum de 1942 e de Griffing de 1956 a dialelos parciais. Por comparação destes dialelos parciais com o modelo de Miranda Filho e Geraldi, estes autores concluíram que a relação $g_{i}=\frac{1}{2} v_{i}+h_{i}$, estabelecida por Gardner \& Eberhart (1966) para dialelos completos, também é válida para os dialelos parciais; sendo que, $g_{i}, v_{i}$ e $h_{i}$ são, respectivamente, o efeito de capacidade geral de combinação, o efeito de variedade e o efeito de heterose de variedade.

Os dialelos baseados no modelo de Griffing, sejam eles completos ou parciais, contém no modelo a capacidade geral e a capacidade especifica de combinação. Neste caso, segundo Cruz \& Regazzi (1994), a magnitude do quadrado médio da CGC e do quadrado médio da CEC evidenciam, respectivamente, a importância de efeitos aditivos e não aditivos no controle do caráter, sendo que, os efeitos da CGC $\left(\mathrm{g}_{\mathrm{i}}\right)$ proporcionam informações sobre a concentração de alelos predominantemente aditivos, indicando progenitores a serem utilizados em programas de melhoramento intrapopulacional; enquanto que os efeitos da CEC $\left(s_{i j}\right)$ evidenciam a importância dos genes que exibem efeitos não aditivos.

Os dialelos baseados no modelo de Gardner e Eberhart, sejam eles completos ou parciais, não contém no modelo a capacidade geral e a capacidade especifica de combinação, mas contém como medida de valor genético dos progenitores o efeito de 
variedade $\left(v_{i}\right)$ e o efeito de heterose de variedade $\left(h_{i}\right)$. Segundo Cruz \& Regazzi (1994), o primeiro evidencia o potencial dos progenitores para melhoramento per se; e o segundo evidencia os progenitores de maior potencial para uso em combinações hibridas mais heteróticas.

Os $v_{i}$ 's não necessariamente evidenciam a importância de efeitos aditivos, pois, em se tratando de variedades de polinização livre, as diferenças entre elas, desconsiderando epistasia, podem ser devidas aos efeitos aditivos e aos efeitos de dominância.

Para os dialelos idealizados a partir do modelo de Gardner e Eberhart, o efeito de capacidade geral de combinação $\left(g_{i}\right)$ pode ser construído pela relação anteriormente mencionada. Neste caso, igualmente à CGC do dialelo de Griffing, os g 's são interpretados como a capacidade que um progenitor tem de se combinar bem com os outros progenitores do grupo; porém, sendo devida aos efeitos de variedades $\left(\mathrm{v}_{\mathrm{i}}\right)$ e aos efeitos de heterose de variedade $\left(h_{i}\right)$. Logo, os $g_{i}$ 's não são associados apenas aos efeitos aditivos, sendo que, nos casos em que o efeito de variedade não é favorável, uma melhor capacidade geral de combinação pode ser devida ao efeito de heterose, e quando este for desfavorável, um melhor $g_{i}$ pode ser devido ao efeito de variedade. Por outro lado, as estimativas da heterose especifica $\left(s_{i j}\right)$ do modelo de Miranda Filho e Geraldi evidenciam a importância dos efeitos não aditivos, inclusive, seu quadrado médio equivale ao quadrado médio da CEC do modelo de Griffing adaptado a dialelos parciais incluindo apenas os cruzamentos.

Embora a CEC pelo método 2 de Griffing de 1956 e a heterose pelo método de Gardner e Eberhart de 1966 se referem à mesma fonte de variação, a heterose é mais informativa, uma vez que é dividida em heterose média, heterose de variedade e heterose específica (Geraldi \& Miranda Filho, 1988). Além disso, estes dois autores enfatizam que o método 2 de Griffing adaptado a dialelo parcial inclui a CEC dentro dois pais, o que não faz sentido do ponto de vista prático.

Oliveira et al. (1987) apresentaram os procedimentos de análise conjunta de cruzamentos dialélicos parciais adaptando o modelo de Miranda Filho e Geraldi de 1984 
a vários ambientes. $\mathrm{Na}$ análise conjunta, além das fontes de variação obtidas nas análises individuais, estes autores apresentaram o desdobramento das interações entre os tratamentos (progenitores e cruzamentos) e os ambientes.

\subsection{Predição de médias para a síntese de compostos}

Composto é uma população resultante do cruzamento entre variedades. Os compostos têm sido amplamente utilizados como população base, pois é esperado que eles tenham muita variabilidade, proporcional à divergência entre as variedades recombinadas (Hallauer \& Miranda Filho, 1981). Além disso, os compostos reúnem uma combinação de caracteristicas agronômicas favoráveis.

A predição de médias é de grande importância nos programas de melhoramento, pois direciona a sintese somente dos melhores cruzamentos preditos (Moreira Júnior, 1995). No caso de predição para a sintese de compostos, o número de compostos possiveis aumenta exponencialmente em função do número de variedades. Vencovsky \& Miranda Filho (1972) mostraram que o número de compostos possiveis a partir de $\mathbf{n}$ variedades com participação equitativa é dado por $\mathrm{Nc}=2^{\mathrm{n}}-(\mathbf{n}+1)$, o que se toma inexequivel à medida em que $\mathbf{n}$ aumenta.

Wright (1922) foi um dos pioneiros em predição de médias, fornecendo as bases teóricas que levaram às fórmulas de predição de sintéticos de linhagens e compostos de variedades. A partir daí, vários outros métodos de predição surgiram. Jenkins (1934) propôs quatro métodos para a predição de hibridos duplos. Eberhart et al. (1967) mostraram que a média de compostos de $k$ variedades pode ser predita por $Y_{k}=H-(H-V) / k$, onde $V$ é a média das variedades e $\mathrm{H}$ é a média dos hibridos entre as mesmas.

Moreira Júnior (1994) cita que alguns autores propuseram métodos de predição de médias a partir da análise de variância de tabelas dialélicas. Miranda Filho \& Chaves (1991) apresentaram uma fórmula de predição de compostos de variedades a partir da predição proposta por Eberhart e outros em 1967, juntamente com o modelo completo de Gardner e Eberhart de 1966, e sugeriram os indices $I_{j}=w_{1} v_{j}+w_{2} h_{j}$ ou $I_{j}^{\prime}=(2 / k) I_{j}$ para uma seleção 
preliminar entre variedades parentais para a formação de compostos. Estes autores mostraram que aumentando-se $\mathrm{k}$ (o tamanho do composto), $\mathrm{I}_{\mathrm{j}}$ tende ao efeito da capacidade geral de combinação. Chaves \& Miranda Filho (1997), com base na predição proposta por Eberhart e outros em 1967, e com base no modelo 3 de Gardner de 1967, apresentaram um método para a análise do valor genético de variedades e para a predição de compostos de variedades a partir de top-cross intragrupo ao invés de cruzamentos dialélicos; ou seja, os cruzamentos dialélicos entre as variedades parentais são substituidos pelo cruzamento de tais variedades com uma mistura de polén proveniente das mesmas. 


\section{MATERIAIS E MÉTODOS}

\subsection{Escolha das populações para avaliação}

No ano agrícola de 1994/1995, o Núcleo de Apoio à Pesquisa em Milho (NAPMilho) avaliou 1273 acessos do Banco Ativo de Germoplasma de milho da Empresa Brasileira de Pesquisa Agropecuária (EMBRAPA) em 13 locais incluindo os estados de Goiás, Mato Grosso, Minas Gerais, Paraná e São Paulo. Foram feitas avaliações para florescimento, rendimento de grãos e resistência a Corn stunt, Exserohilum turcicum, Phaeosphaeria maydis, Physopella zeae e Puccinia polysora.

O NAP-Milho classificou os acessos levando em consideração a distribuição das doenças nesses locais e a produção de grãos em gramas por parcela. Partindo desta classificação, foram selecionados os melhores acessos, resultando em dois grupos: o grupo I, formado de 28 acessos de ciclo precoce; e o grupo II, constituido de 29 acessos de ciclo superprecoce (Tabela 1). Acesso precoce foi aquele cujo florescimento masculino (50\% das plantas), ocorreu de 61 a 66 dias após a emergência; enquanto que, no superprecoce ocorreu de 55 a 60 dias. Os dois grupos de acessos foram avaliados em dois esquemas de cruzamento, dialelo parcial e top-cross intragrupo. 
Tabela 1. Acessos dos grupos I e II provenientes da EMBRAPA de milho e sorgo.

\begin{tabular}{|c|c|c|c|}
\hline & Grupo I & & Grupo II \\
\hline 1 & $\mathrm{BA}-166$ & $1 \mathrm{~s}$ & Matahambre x Guapira \\
\hline 2 & Composto Jaiba III & $2 s$ & CMS 470 \\
\hline 3 & $\mathrm{SE}-025$ & $3 s$ & CMS 471 \\
\hline 4 & $S E-030$ & $4 s$ & CMS 463 \\
\hline 5 & Composto Jaiba I & $5 s$ & $\mathrm{BA}-042$ \\
\hline 6 & $P E-011$ & $6 s$ & $I-75-6$ \\
\hline 8 & $B A-035$ & $7 \mathrm{~s}$ & Composto Manaus \\
\hline 9 & $\mathrm{RN}-003$ & $8 s$ & CNPH -1 \\
\hline 10 & $B A-032$ & $9 s$ & CMS 466 \\
\hline 11 & $S E-032$ & $10 \mathrm{~s}$ & CMS 21 \\
\hline 12 & $P B-003$ & $11 \mathrm{~s}$ & BR $105 \mathrm{~V}$ \\
\hline 13 & $B A-159$ & $12 \mathrm{~s}$ & CMS 05 \\
\hline 14 & $B A-158$ & $13 \mathrm{~s}$ & CMS 14 \\
\hline 15 & $\mathrm{RN}-001$ & $14 \mathrm{~s}$ & Composto Planta Baixa \\
\hline 16 & $\mathrm{BA}-191$ & $15 \mathrm{~s}$ & BR $105 \mathrm{MI}$ \\
\hline 17 & $\mathrm{BA}-176$ & $16 s$ & CMS 28 \\
\hline 18 & $A L-001$ & $17 \mathrm{~s}$ & CMS 451 \\
\hline 19 & $P E-001$ & $18 s$ & CMS 457 \\
\hline 20 & $B A-094$ & $19 \mathrm{~s}$ & $S E-033$ \\
\hline 21 & $S E-036$ & $20 \mathrm{~s}$ & Brasil 2294 \\
\hline 22 & $B A-165$ & $21 \mathrm{~s}$ & Mezcla Tropical Blanco \\
\hline 23 & $W P-32$ & $22 \mathrm{~s}$ & $\mathrm{AL}-009$ \\
\hline 24 & Puebla Grupo 27 & $23 \mathrm{~s}$ & Blanco Cristalino \\
\hline 25 & San Luis Potosi 127 & $24 s$ & CMS +54 \\
\hline 26 & $P R-053$ & $25 \mathrm{~s}$ & San Luis Potosi 118 \\
\hline 27 & Vera Cruz 212 & $26 \mathrm{~s}$ & PortoRico 5 \\
\hline 29 & $M G-076$ & $27 \mathrm{~s}$ & $\mathrm{MS}-010$ \\
\hline \multirow[t]{2}{*}{30} & $\mathrm{MS}-054$ & $28 \mathrm{~s}$ & CUBA 142 \\
\hline & & $30 \mathrm{~s}$ & CMS 50 \\
\hline
\end{tabular}




\subsection{Cruzamentos dialélicos}

As populações precoces e superprecoces foram avaliadas em cruzamentos com a geração $F_{2}$ de quatro hỉbridos comerciais com padrão aceitável de resistência a doenças foliares:

- H1 e H2: Geração $F_{2}$ de dois híbridos comerciais não identificados provenientes da Sementes Pioneer;

- H3: Geração $F_{2}$ de híbrido comercial não identificado proveniente da Sementes Agroceres, atualmente Monsanto;

- H4: Geração $F_{2}$ do híbrido comercial G 85 da Ciba Sementes, atualmente Novartis.

O esquema de cruzamento utilizado foi o dialelo parcial proposto por Miranda Filho e Geraldi (1984), o qual se identifica com a tabela dialélica intergrupos (Tabela 2).

Tabela 2- Tabela dialélica para análise de cruzamentos intergrupos.

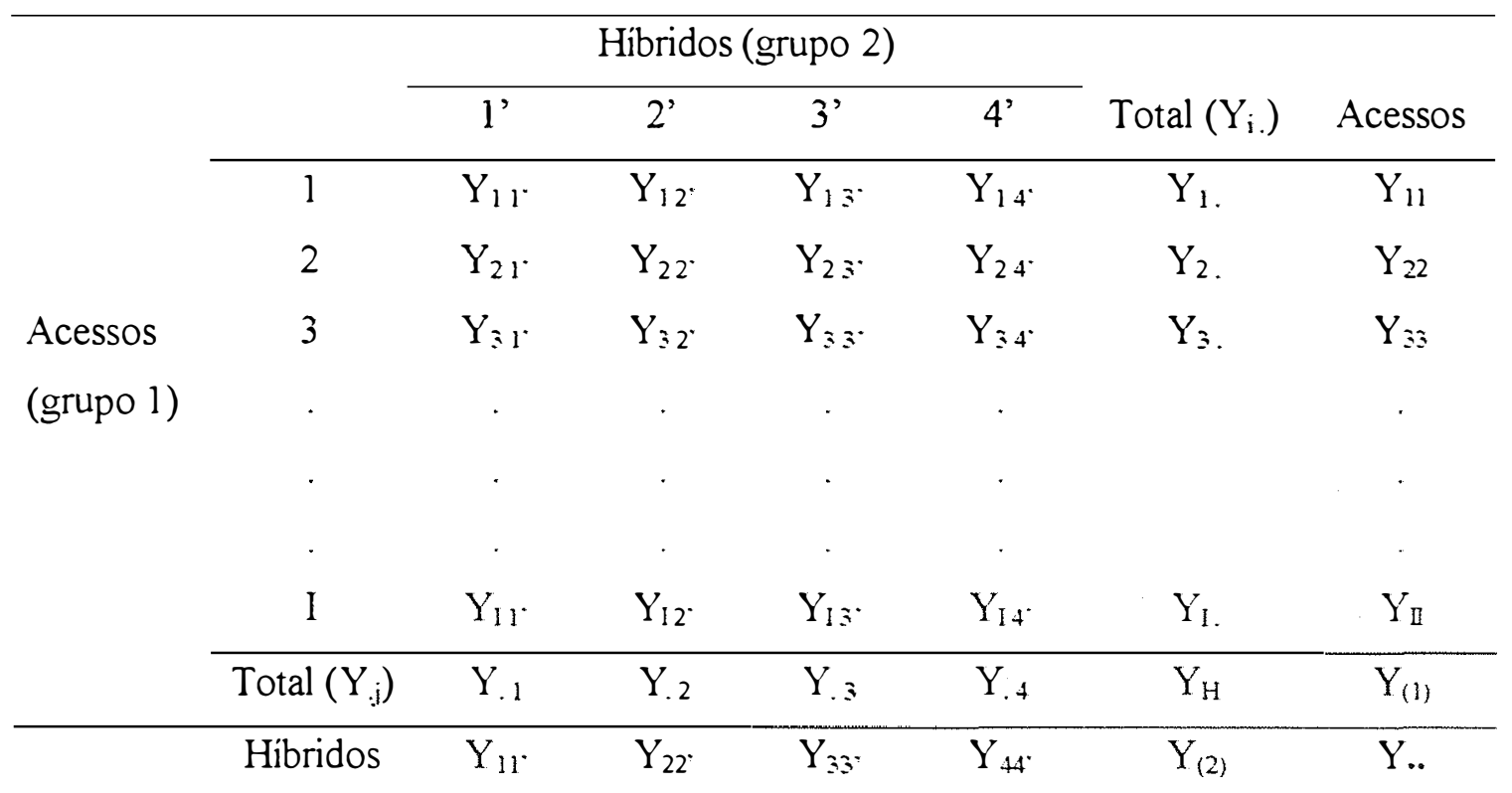

Deste modo, para o grupo $I$, foram obtidos $I \times J=112$ cruzamentos que, somados às $I$ $=28$ populações e aos $\mathrm{J}=4$ hibridos comerciais, totalizam $\mathrm{I}+\mathrm{J}+\mathrm{I} \times \mathrm{J}=144$ tratamentos. Da mesma forma, para o grupo $I I, \mathrm{I}=29$ e J $=4$, houve uma total de 149 tratamentos. 


\section{3 "Top-cross"}

As populações foram avaliadas também em cruzamento "top-cross" intragrupo. Neste esquema, foi utilizado como testador uma mistura de todas populações selecionadas em cada grupo, conforme a metodologia de Chaves e Miranda Filho (1997). Deste modo, para o grupo $I$, foram obtidos $\mathrm{I}=28$ topcrosses, os quais somados às $\mathrm{I}=28$ populações, totalizam $2 \mathrm{I}=56$ tratamentos. Da mesma forma, para o grupo $I I$, as I $=29$ populações e os seus topcrosses totalizaram 58 tratamentos.

\subsection{Multiplicação dos Acessos}

Em abril de 1996, na Escola Superior de Agricultura "Luiz de Queiroz," foi feito o plantio para multiplicação dos acessos e para a obtenção da geração $F_{2}$ dos híbridos comerciais. Cada acesso e cada hibrido foram representados por uma amostra de 100 sementes, que foram plantadas em duas linhas de $10 \mathrm{~m}$. Em cada material, toda espiga foi polinizada por uma mistura de pólen do mesmo, obtendo-se, assim, os acessos multiplicados e a geração $F_{2}$ dos hibridos comerciais.

\subsection{Obtenção dos Cruzamentos}

O plantio dos lotes de cruzamento iniciou-se em 26/08/96 e se estendeu até 16/09/96 devido à diferença de ciclo entre os hibridos e as populações precoces e superprecoces. Os cruzamentos foram feitos durante todo o mês de dezembro/96, de acordo com os esquemas anteriormente propostos. Foram feitos cruzamentos manuais dirigidos das 57 populações selecionadas com os quatro híbridos comerciais e com o respectivo testador precoce e superprecoce.

Devido às chuvas e à não sincronização perfeita no florescimento dos materiais a serem cruzados, alguns cruzamentos resultaram em quantidades muito pequenas de sementes, não podendo ser avaliados. Sendo assim, foi feita uma avaliação em época de safrinha utilizando menor número de tratamentos. E na mesma época, na Estação 
Experimental Anhembi foram feitos mais cruzamentos a fim de serem obtidas sementes de todos os tratamentos em quantidade suficiente para avaliação em época normal de plantio.

\subsection{Amostragem e preparo das sementes}

Foi feita uma amostragem para a quantidade de semente necessária para instalar os experimentos. A amostragem é feita de tal forma que toda espiga colhida de um material (acessos, hibridos comerciais, cruzamentos ou testadores) contribua com uma quantidade aproximada de semente para constituir um tratamento. Sendo assim, cada tratamento foi representativo do correspondente material a ser avaliado. Depois da amostragem, as sementes foram preparadas para a instalação dos experimentos, catalogadas e, depois, as sementes remanescentes foram armazenadas em caixas de madeira na câmara fria e seca.

\subsection{Delineamentos genéticos}

\subsubsection{Dialelo parcial}

As médias de tratamentos foram utilizadas para construir a tabela dialélica (Tabela 3 ). O modelo para análise do dialelo parcial proposto por Miranda Filho e Geraldi (1984) é:

$Y_{\eta !}=\mu+\alpha d+\frac{1}{2}\left(v_{1}+v_{\jmath}\right)+\theta\left(\bar{h}+h_{1}+h_{1}+s_{i j}\right)+\bar{e}_{i l} ;$ onde:

- $Y_{\mathrm{ij}}$ é a média do cruzamento entre o acesso i e o hibrido $j$, para $\alpha=0$ e $\theta=1$;

- $Y_{\text {ii }}$ é a média do acesso i, para $\alpha=1$ e $\theta=0$;

- $Y_{. j}$ é a média do acesso $\mathrm{j}$, para $\alpha=-1$ e $\theta=0$

- $\mu$ é a média entre a média dos dois grupos parentais;

- $d$ é uma medida da diferença entre as médias dos dois grupos parentais;

- $v_{i}$ e $v_{j}$ são, respectivamente, o efeito do i-ésimo acesso e do j-ésimo hibrido;

- $\bar{h}$ é a heterose média de todos os cruzamentos; 
- $h_{i}$ e $h_{j}$ são, respectivamente, os efeitos de heterose atribuidos ao i-ésimo acesso e ao j-ésimo híbrido;

- $\mathrm{s}_{\mathrm{ij}}$ é a heterose especifica do cruzamento i $\mathrm{x}$ j;

- $\mathrm{e}_{\mathrm{ij}}$ é o erro experimental associado às medias observadas.

Nas Tabelas 3 e 4, respectivamente, são dadas as fórmulas para estimação dos efeitos e para realização da análise da variância.

Tabela 3. Fórmulas para estimação dos efeitos e das respectivas variâncias para cruzamentos dialélicos parciais segundo o modelo de Miranda Filho e Geraldi (1984).

Parâmetro Estimador Variâncias

Média dos parentais $\quad \hat{\mu}=\frac{1}{2}\left(\bar{V}_{p}+\bar{V}_{\mathfrak{t}}\right)$

$$
\begin{array}{lll}
\text { Média dos parentais } & \hat{\mu}=\frac{1}{2}\left(\overline{\mathrm{V}}_{\mathrm{p}}+\overline{\mathrm{V}}_{\mathrm{t}}\right) & \operatorname{var}(\hat{\mu})=\frac{\mathrm{I}+\mathrm{J}}{4 \mathrm{IJ}} \hat{\sigma}^{2} \\
\text { Contraste entre grupos } & \hat{\mathrm{d}}=\frac{1}{2}\left(\overline{\mathrm{V}}_{\mathrm{p}}-\overline{\mathrm{V}}_{\mathrm{t}}\right) & \operatorname{var}(\hat{\mathrm{d}})=\frac{\mathrm{I}+\mathrm{J}}{4 \mathrm{IJ}} \hat{\sigma}^{2} \\
\text { Efeito de populações } & \hat{\mathrm{v}}_{\mathrm{i}}=\mathrm{V}_{\mathrm{i}}-\overline{\mathrm{V}}_{\mathrm{p}} & \operatorname{var}\left(\hat{\mathrm{v}}_{\mathrm{i}}\right)=\frac{\mathrm{I}-\mathrm{l}}{\mathrm{I}} \hat{\sigma}^{2} \\
\text { Efeito de testadores } & \hat{\mathrm{v}}_{\mathrm{j}}=\mathrm{V}_{\mathrm{j}}-\overline{\mathrm{V}}_{\mathrm{t}} & \operatorname{var}\left(\hat{\mathrm{v}}_{\mathrm{j}}\right)=\frac{\mathrm{J}-\mathrm{I}}{\mathrm{J}} \hat{\sigma}^{2} \\
\text { Heterose média } & \overline{\mathrm{h}}=\overline{\mathrm{H}}-\hat{\mu} & \operatorname{var}(\overline{\mathrm{h}})=\frac{4+\mathrm{I}+\mathrm{J}}{4 \mathrm{IJ}} \hat{\sigma}^{2} \\
\text { Het. de populações } & \hat{\mathrm{h}}_{\mathrm{i}}=\overline{\mathrm{H}}_{\mathrm{i}} \cdot-\overline{\mathrm{H}}+\frac{1}{2}\left(\overline{\mathrm{V}}_{\mathrm{p}}-\mathrm{V}_{\mathrm{i}}\right) & \operatorname{var}\left(\hat{\mathrm{h}}_{\mathrm{i}}\right)=\frac{(\mathrm{I}-1)(4+\mathrm{J})}{4 \mathrm{IJ}} \hat{\sigma}^{2} \\
\text { Het. de testadores } & \hat{\mathrm{h}}_{\mathrm{j}}=\overline{\mathrm{H}}_{\mathrm{j}} \cdot-\overline{\mathrm{H}}+\frac{1}{2}\left(\overline{\mathrm{V}}_{\mathrm{t}}-\mathrm{V}_{\mathrm{j}}\right) & \operatorname{var}\left(\hat{\mathrm{h}}_{\mathrm{j}}\right)=\frac{(\mathrm{J}-1)(4+\mathrm{I})}{4 \mathrm{IJ}} \hat{\sigma}^{2} \\
\text { Het. especifica } & \hat{\mathrm{s}}_{\mathrm{ij}}=\mathrm{H}_{\mathrm{ij}}+\overline{\mathrm{H}}-\overline{\mathrm{H}}_{\mathrm{i}} \cdot-\overline{\mathrm{H}}_{\cdot j} & \operatorname{var}\left(\hat{\mathrm{s}}_{\mathrm{ij}}\right)=\frac{(\mathrm{I}-1)(\mathrm{J}-\mathrm{I})}{\mathrm{IJ}} \hat{\sigma}^{2}
\end{array}
$$$$
\text { Efeito de populações } \quad \hat{v}_{i}=V_{i}-\bar{V}_{p}
$$$$
\text { Efeito de testadores }
$$$$
\hat{v}_{j}=V_{j}-\bar{v}_{t}
$$

Heterose média

$$
\overline{\mathrm{h}}=\overline{\mathrm{H}}-\hat{\mu}
$$

Het. de populações

$$
\hat{\mathrm{h}}_{\mathrm{i}}=\overline{\mathrm{H}}_{\mathrm{i}} \cdot-\overline{\mathrm{H}}+\frac{1}{2}\left(\overline{\mathrm{V}_{\mathrm{p}}}-\mathrm{V}_{\mathrm{i}}\right)
$$

Het. de testadores

$$
\hat{\mathrm{h}}_{\mathrm{j}}=\overline{\mathrm{H}}_{\mathrm{j}} \cdot-\overline{\mathrm{H}}+\frac{1}{2}\left(\overline{\mathrm{V}}_{\mathrm{t}}-\mathrm{V}_{\mathrm{j}}\right)
$$

Het. especifica

$$
\hat{\mathrm{s}}_{\mathrm{ij}}=\mathrm{H}_{\mathrm{ij}}+\overline{\mathrm{H}}-\overline{\mathrm{H}}_{\mathrm{i}} \cdot-\overline{\mathrm{H}}_{\cdot \mathrm{j}}
$$

$V_{1}$ e $V_{1}$ : médias de cada população ou testador: $V_{p}$ e $V_{1}$ : média do grupo de populações e de testadores: $\mathrm{H}$ : média de todos os hibridos: $\mathrm{H}_{1}$ e $\mathrm{H}_{\mathrm{j}}$ : médias marginais de híbridos da população $\mathrm{i}$ ou do testador $\mathrm{j}: \mathrm{H}_{4}$ : média do hibrido ixj. 
Tabela 4. Esquema da análise da variância para cruzamentos dialélicos parciais segundo o modelo de Miranda Filho e Geraldi (1984).

Fonte

G.L.

Somas de quadrados

\begin{tabular}{|c|c|c|}
\hline Tratamentos & $(I+J+I \times J)-1$ & $\sum_{i} \mathrm{~V}_{1}^{2}+\sum_{j} \mathrm{~V}^{2}{ }_{j}+\sum_{i j} \mathrm{H}^{2}{ }_{i j}-\frac{\mathrm{G}^{2}}{\mathrm{I}+\mathrm{J}+\mathrm{IJ}}$ \\
\hline Populaçōes & I-1 & $\frac{4}{4+\mathrm{I}} \sum_{i}\left[\mathrm{~V}_{\mathrm{i}}-\overline{\mathrm{V}}_{\mathrm{p}}+\frac{1}{2}\left(\mathrm{H}_{\mathrm{i}} \cdot-\mathrm{IH}\right)\right]^{2}$ \\
\hline Testadores & $J-1$ & $\frac{4}{4+\mathrm{J}} \sum_{\mathrm{j}}\left[\mathrm{V}_{\mathrm{j}}-\overline{\mathrm{V}}_{\mathrm{t}}+\frac{1}{2}\left(\mathrm{H}_{\mathrm{j}}-\mathrm{J} \overline{\mathrm{H}}\right)\right]^{2}$ \\
\hline Pop. vs Test. & 1 & $\frac{\mathrm{IJ}}{(\mathrm{I}+\mathrm{J})(4+\mathrm{I}+\mathrm{J})}\left[(\mathrm{I}+2) \overline{\mathrm{V}}_{\mathrm{p}}+(\mathrm{J}+1) \overline{\mathrm{V}}_{\mathrm{t}}+(\mathrm{J}-\mathrm{I}) \overline{\mathrm{H}}\right]$ \\
\hline Heteroses & $\mathrm{I} \times \mathrm{J}$ & -- \\
\hline Het. média & 1 & $\frac{\mathrm{I}+\mathrm{J}}{4+\mathrm{I}+\mathrm{J}}\left[\overline{\mathrm{V}}_{\mathrm{p}}+\overline{\mathrm{V}}_{\mathrm{t}}-2 \overline{\mathrm{H}}\right]^{2}$ \\
\hline Het.população & $\mathrm{I}-1$ & $\frac{\mathrm{J}}{4+\mathrm{J}} \sum_{\mathrm{i}}\left[\mathrm{V}_{\mathrm{i}}-\overline{\mathrm{V}}_{\mathrm{p}}-2\left(\overline{\mathrm{H}}_{1}-\overline{\mathrm{H}}\right)\right]^{2}$ \\
\hline Het.testador & $\mathrm{J}-1$ & $\frac{\mathrm{I}}{4+\mathrm{I}} \sum_{j}\left[\mathrm{~V}_{\mathrm{j}}-\overline{\mathrm{V}}_{\mathrm{t}}-2\left(\overline{\mathrm{H}}_{\mathrm{j}}-\overline{\mathrm{H}}\right)\right]^{2}$ \\
\hline Het.especifica & $(\mathrm{I}-1)(\mathrm{J}-1)$ & $\sum_{i j} H_{i j}^{2}-\sum_{J}^{1} \sum_{i} H_{i}^{2} \cdot-\sum_{I}^{1} \sum_{j} H^{2} \cdot+\frac{1}{I J} H^{2}$. \\
\hline
\end{tabular}




\subsection{2 "Top-cross"}

Neste esquema de análise, foram utilizadas as médias das populações e dos respectivos "topcrosses" para análise genética segundo a metodologia de Chaves e Miranda Filho (1997), com base no Modelo 3 de Gardner (1967):

$$
\mathrm{Y}_{j j^{\prime}}=\mu+\frac{1}{2}\left(\mathrm{v}_{3}+\mathrm{v}_{\mathrm{j}^{\prime}}\right)+\theta\left(\overline{\mathrm{h}}+\mathrm{h}_{\mathrm{j}}+\mathrm{h}_{\mathrm{j}^{\prime}}\right)+\overline{\mathrm{e}}_{\mathrm{j}^{\prime}}
$$

As fórmulas para estimação dos componentes de médias e das respectivas variâncias são apresentadas na Tabela 5. E as fórmulas para realização da análise da variância são apresentas na Tabela 6 .

Tabela 5. Fórmulas para estimação dos efeitos e das respectivas variâncias para topcrosses segundo o modelo de Chaves e Miranda Filho (1997).

$\begin{array}{llc}\text { Parâmetro } & \text { Estimador } & \text { Variância } \\ \text { Média de populações } & \hat{\mu}=\bar{V}=\frac{1}{n} V & \frac{1}{n} \sigma^{2} \\ \text { Efeito de população } & \hat{v}_{j}=V_{j}-\bar{V} & \frac{n-1}{n} \sigma^{2} \\ \text { Heterose média } & \bar{h}=\frac{n}{n-2}[\bar{T}-\bar{V}] & \frac{2 n}{(n-1)^{2}} \sigma^{2} \\ \text { Het.população } & \hat{h}_{j}=\frac{n}{n-2}\left[\left(T_{j}-\bar{T}\right)-\frac{1}{2}\left(V_{j}-\bar{V}\right)\right] & \frac{5 n(n-1)}{4(n-2)^{2}} \sigma^{2}\end{array}$

$V_{3} . T_{1}$ : média de cada acesso e do respectivo topcross: $\bar{V}$ e $\bar{T}$ : médias dos respectivos grupos. 
Tabela 6. Esquema da análise da variância para cruzamentos "top-crosses" segundo o modelo de Chaves e Miranda Filho (1997).

Fonte

G.L.

Somas de quadrados

$\begin{array}{lcc}\text { Tratamentos } & 2 \mathrm{I}-1 & \sum_{j} \mathrm{~V}_{j}^{2}+\sum_{j} \mathrm{~T}_{j}^{2}-\frac{(\mathrm{V}+\mathrm{T})^{2}}{2 \mathrm{n}} \\ \text { Populações } & \mathrm{I}-1 & \frac{1}{5} \sum_{j}\left[2\left(\mathrm{~V}_{j}-\overline{\mathrm{V}}\right)+\left(\mathrm{T}_{j}-\overline{\mathrm{T}}\right)\right]^{2} \\ \text { Heterose média } & 1 & \frac{1}{2 \mathrm{n}}(\mathrm{V} \cdot-\mathrm{T})^{2} \\ \text { Het. população } & \mathrm{I}-1 & \frac{1}{5} \sum_{j}\left[\left(\mathrm{~V}_{j}-\overline{\mathrm{V}}\right)-2\left(\mathrm{~T}_{j}-\overline{\mathrm{T}}\right)\right]^{2}\end{array}$

$V_{j}$ e $T_{j}$ : média de cada população e do respectivo "topcross": $V$ e $T$ : médias dos respectivos grupos.

\subsection{Experimentos de safrinha}

\subsubsection{Instalação dos Experimentos de Safrinha}

Em Abril/97, na Estação Experimental Anhembi, foram instalados quatro experimentos, utilizando delineamento em blocos completos casualizados com duas repetições e duas testemunhas, uma considerada resistente a doenças foliares (hibrido AG 7393) e outra considerada susceptivel (hibrido DINA 170); identificadas, respectivamente, por $\mathrm{T} 1$ e T2. Tanto nos experimentos de safrinha como nos experimentos de época normal, a cada dez parcelas, foi intercalada uma parcela de uma ou outra destas testemunhas; cada parcela foi constituída de duas linhas de $4 \mathrm{~m}$ espaçadas de $90 \mathrm{~cm}$, contendo, após o desbaste, 5 plantas por metro; e como bordadura, em todos os experimentos foi utilizado o hibrido G85. Os experimentos de safrinha foram 
identificados como $1,2,3$ e 4. Seus tratamentos, além das testemunhas, foram os seguintes:

- Experimento 1 teve como tratamentos os acessos precoces, as gerações $F_{2}$ dos quatro hibridos comerciais, e os cruzamentos entre estes dois grupos de progenitores.

- Experimento 2 envolveu os acessos superprecoces, as gerações $F_{2}$ dos quatro híbridos comerciais, e os cruzamentos entre estes dois grupos de progenitores.

- Experimento 3 envolveu os acessos precoces e os seus cruzamentos com o testador precoce (mistura destes acessos).

- Experimento 4 envolveu os acessos superprecoces e os seus cruzamentos com o testador superprecoce (mistura destes acessos).

\subsubsection{Avaliação dos experimentos de safrinha}

Não foi possivel fazer avaliação para resistência a ferrugem polysora e resistência a ferrugem tropical, tendo em vista que essas doenças não ocorreram. Mas, pôde-se avaliar para resistência à mancha de turcicum, mancha de Phaeosphaeria, ferrugem comum, complexo enfezamento e à podridão de colmo.

A resistência às doenças foi avaliada em todas as plantas de todas as parcelas. Para o complexo enfezamento, a avaliação consistiu em registrar a porcentagem de plantas com sintomas, mesmo tendo pouca infecção; e para a podridão do colmo, também consistiu em quantificar a incidência, não importando em investigar o agente causal. Para as doenças foliares, a avaliação foi feita utilizando a escala diagramática da Sementes Agroceres, segundo a qual são atribuidas notas de 1 a 9 , correspondendo às plantas altamente resistentes até as altamente susceptiveis: 


\begin{tabular}{lccccccccc}
\hline \multicolumn{1}{c}{ Patógeno } & $\mathbf{1}$ & $\mathbf{2}$ & $\mathbf{3}$ & $\mathbf{4}$ & $\mathbf{5}$ & $\mathbf{6}$ & $\mathbf{7}$ & $\mathbf{8}$ & $\mathbf{9}$ \\
\hline Puccinia sorghi & $\mathrm{AR}$ & $\mathrm{R}$ & $\mathrm{R}$ & $\mathrm{R}$ & $\mathrm{MR}$ & $\mathrm{MR} / \mathrm{MS}$ & $\mathrm{MS}$ & $\mathrm{S}$ & $\mathrm{AS}$ \\
Puccinia polysora & $\mathrm{AR}$ & $\mathrm{R}$ & $\mathrm{R}$ & $\mathrm{MR}$ & $\mathrm{MR} / \mathrm{MS}$ & $\mathrm{MS}$ & $\mathrm{S}$ & $\mathrm{S}$ & $\mathrm{AS}$ \\
Physopella zeae & $\mathrm{AR}$ & $\mathrm{R}$ & $\mathrm{R}$ & $\mathrm{MR}$ & $\mathrm{MR} / \mathrm{MS}$ & $\mathrm{MS}$ & $\mathrm{S}$ & $\mathrm{S}$ & $\mathrm{AS}$ \\
Exserohilum turcicum & $\mathrm{AR}$ & $\mathrm{R}$ & $\mathrm{R}$ & $\mathrm{MR}$ & $\mathrm{MS}$ & $\mathrm{MS} / \mathrm{S}$ & $\mathrm{S}$ & $\mathrm{S}$ & $\mathrm{AS}$ \\
Phaeosphaeria maydis & $\mathrm{AR}$ & $\mathrm{R}$ & $\mathrm{R}$ & $\mathrm{MR}$ & $\mathrm{MR} / \mathrm{MS}$ & $\mathrm{MS}$ & $\mathrm{S}$ & $\mathrm{S}$ & $\mathrm{AS}$ \\
\hline
\end{tabular}

Nos materiais precoces, as avaliações para doenças foliares e o complexo enfezamento foram feitas ao redor de 25 dias após o florescimento masculino, e nos materiais superprecoces, ao redor de 20 dias. Para podridão do colmo, as avaliações foram feitas após a maturação fisiológica dos grãos. No experimento 2 , não foi possivel fazer avaliação para podridão do colmo, devido à quantidade de chuva e ventos fortes, que acamaram muitas plantas impossibilitando tal avaliação.

Foram feitas avaliações também para os caracteres florescimento masculino (50\% das plantas com pendões expostos) e feminino ( $50 \%$ das plantas com espigas emitindo estilete), altura da planta (AP) em $\mathrm{cm}$, altura da espiga ( $\mathrm{AE}$ ) em $\mathrm{cm}$ e, durante a colheita, número de plantas por parcela. Além disso, após a colheita, o material foi secado ao sol e manuseado num galpão, onde foi feita avaliação para comprimento de espiga (CE) em $\mathrm{cm}$, diâmetro de espiga $(\mathrm{DE})$ em $\mathrm{cm}$ e peso dos grãos por parcela $(\mathrm{PG}) \mathrm{em} \mathrm{kg}$. Após a secagem ao sol, a umidade dos grãos tomada a partir de 25 amostras ficou em torno de $12,5 \%$, variando de 12 a $13 \%$, o que dispensou a correção do peso dos grãos para uma umidade fixa de 12 ou $13 \%$.

Tanto nos experimentos de safrinha como nos experimentos de época normal, os dados de porcentagem foram transformados para arc seno $\sqrt{\frac{x}{100}+0,5}$ conforme sugerido por Demétrio (1978). Além disso, o peso dos grãos foi corrigido para o estande inicial de 40 plantas por parcela através do método de covariância entre produção e número de plantas por parcela, conforme sugerido por Miranda Filho em Vencovsky \& Barriga (1992): 


$$
\hat{Y_{i j}}=Y_{i j}-b\left(X_{i j}-N\right), \text { sendo } b=\frac{S P_{E_{x Y}}}{S Q_{E_{X}}} ; \text { onde, }
$$

$\hat{Y}_{i j}$ é o peso de grãos por parcela ajustado;

$Y_{i j}$ é o peso de grãos observado por parcela;

$b$ é o coeficiente de regressão linear entre o peso de grãos observado por parcela e o número de plantas observado por parcela;

$X_{i j}$ é o número de plantas observado por parcela;

$N$ é o número inicial de plantas por parcela;

$S P_{E_{\lambda J}}$ é a soma de produto entre $X_{i j}$ e $Y_{i j}$ para o erro experimental;

$S Q_{E_{X}}$ é a soma de quadrado de $X_{i j}$ para o erro experimental.

\subsubsection{Análise dos dados dos experimentos de safrinha}

Nos experimentos 1 e 2, devido à quantidade demasiada de cruzamentos ausentes, foram feitas as análises estatísticas utilizando os dados de cruzamento das populações com a geração $\mathrm{F}_{2}$ de apenas dois dos hibridos comerciais parentais, $\mathrm{H} 3$ e H4.

Nos experimentos de safrinha assim como dos experimentos de época normal, as análises de variância e as análises dos "top-crosses" foram feitas no programa EXCEL, onde foram montadas todas as fórmulas necessárias; e, as análises dos dialelos parciais foram feitas nos programas GENES, (Universidade Federal de Viçosa) e MAPGEN (Universidade Federal de Lavras). A fonte de variação de tratamentos foi desdobrada em materiais do NAP (dialelo ou topcross), testemunhas e NAP versos testemunhas. A fonte de variação devida ao dialelo ou ao topcross foi desdobrada conforme os modelos propostos por Miranda Filho e Geraldi (1984), e Chaves e Miranda Filho (1997). 


\subsection{Experimentos de época normal de plantio}

\subsubsection{Instalação dos Experimentos de época normal}

Os mesmos tipos de experimentos da época de safrinha foram instalados em dezembro/97 em três locais. Em Rio Verde-GO foram instalados os experimentos identificados como 1R, 2R, 3R e 4R; na estação Anhembi (Piracicaba-SP), os experimentos 1A, 2A, 3A e 4A; e na estação Caterpillar (Piracicaba-SP) os experimentos 1C, 2C, 3C e 4C. Em todos os experimentos foram utilizados delineamentos em blocos completos casualizados com quatro repetições e novamente as testemunhas T1 e T2. Além de, a cada dez parcelas, ter sido intercalada uma ou outra testemunha, em cada repetição uma parcela de cada testemunha foi distribuída aleatoriamente junto com os tratamentos.

\subsubsection{Avaliação dos experimentos de época normal}

No experimento $\mathbf{2 C}$, devido a uma erosão provocada por chuvas muito fortes uma semana após a emergência das plântulas, duas repetições foram perdidas, restando apenas duas repetições.

A avaliação para doenças foliares foi feita com base no aspecto geral de cada parcela, atribuindo uma nota mediante a mesma escala diagramática utilizada nos experimentos de safrinha. Para o complexo enfezamento, também foi quantificada a incidência de plantas com sintomas, mesmo tendo pouca infecção. Na Tabela 7, encontram-se os caracteres avaliados e analisados, e os locais em que foram avaliados.

Nos experimentos contendo acessos precoces as avaliações para doenças foram feitas ao redor de 25 dias após o florescimento, e, naqueles envolvendo os acessos superprecoces, ao redor de 20 dias. Para acamamento e quebramento do colmo, as avaliações foram feitas após a maturação fisiológica dos grãos. 
Tabela 7. Caracteres avaliados e analisados, e os respectivos locais.

\begin{tabular}{|c|c|c|c|c|c|c|c|c|c|c|c|c|}
\hline \multirow[b]{2}{*}{ Caracteres } & \multicolumn{4}{|c|}{ Anhembi } & \multicolumn{4}{|c|}{ Caterpillar } & \multicolumn{4}{|c|}{ Rio Verde } \\
\hline & $\overline{1 A}$ & $2 \mathbf{A}$ & $3 \mathbf{A}$ & $4 \mathrm{~A}$ & $\overline{1 C 2}$ & $2 \mathrm{C}$ & $3 \mathrm{C}$ & $4 \mathrm{C}$ & $\overline{1 R}$ & $2 \mathbf{R}$ & $3 \mathbf{R}$ & $4 R$ \\
\hline Número de plantas da parcela & $x$ & $\mathrm{x}$ & $x$ & $x$ & $x$ & $x$ & $x$ & $x$ & $x$ & $x$ & $x$ & $x$ \\
\hline Reação ao Phaeosphaeria maydis - PHAE & $x$ & $x$ & $x$ & $x$ & $x$ & $x$ & $x$ & $x$ & $x$ & $x$ & $x$ & $x$ \\
\hline Reação ao Physopella zeae - PHYSO & & & & & $x$ & $x$ & $x$ & $x$ & & & & \\
\hline Reação ao Puccinia polysora - POLY & & & & & & & $x$ & $x$ & & & & \\
\hline Reação ao complexo enfezamento - ENFE & & & & & & & & & $x$ & $x$ & $x$ & $x$ \\
\hline Porcentagem de colmos quebrados - QUEB & & & & & $x$ & $x$ & $x$ & $x$ & & & & \\
\hline Porcentagem de plantas acamadas - ACAM & & & & & $\mathrm{x}$ & $x$ & $x$ & $\mathrm{x}$ & $x$ & $x$ & $x$ & $\mathrm{x}$ \\
\hline Altura da planta em cm - AP & $x$ & $x$ & $x$ & $\mathrm{x}$ & $x$ & $x$ & $\mathrm{x}$ & $x$ & $\mathrm{x}$ & $x$ & $x$ & $\mathrm{x}$ \\
\hline Altura da espiga em $\mathrm{cm}-\mathrm{AE}$ & $x$ & $x$ & $x$ & $x$ & $x$ & $x$ & $x$ & $x$ & $x$ & $\mathrm{x}$ & $\mathrm{x}$ & $\mathrm{x}$ \\
\hline Comprimento de espiga em $\mathrm{cm}-\mathrm{CE}$ & $x$ & $x$ & $\mathrm{x}$ & $x$ & $x$ & $x$ & $x$ & $x$ & & & & \\
\hline Diâmetro de espiga em $\mathrm{cm}-\mathrm{DE}$ & $x$ & $x$ & $x$ & $x$ & $x$ & $x$ & $x$ & $x$ & & & & \\
\hline Peso de grãos em kg por parcela - PG & $x$ & $x$ & $x$ & $x$ & $x$ & $x$ & $x$ & $x$ & $x$ & $x$ & $\mathrm{x}$ & $x$ \\
\hline
\end{tabular}

\subsubsection{Análises individuais dos dados dos experimentos de época normal}

Foram feitas as análises estatísticas individuais dos quatro experimentos nos três locais. Devido ao fato de os experimentos serem muito grandes, o menor com 58 e o maior com 151 tratamentos por repetição, foi suposta a possibilidade de heterogeneidade ambiental dentro das repetições. Então, foi feita uma análise prévia com base nas observações das testemunhas para verificar a significância de tal heterogeneidade. Dividiu-se cada repetição em estratos contendo pelo menos uma parcela de cada testemunha.

A análise prévia teve como fontes de variação repetição, estratos (ou blocos) dentro de repetições, testemunha e residuo. $\mathrm{O}$ teste $\mathrm{F}$ ao nivel de $80 \%$ detectou significância do quadrado médio de estrato dentro de repetição para altura de planta nos experimentos $1 \mathrm{~A}$, 2A, $1 \mathrm{C}$ e 2R, no entanto as médias dos materiais dos dialelos ou dos "top-crosses" não foram ajustadas com base nas médias das testemunhas, uma vez que, os dados de altura foram tomados de uma planta de cada fileira, estando sujeito a erro. 


\subsubsection{Análise conjunta dos experimentos de época normal}

Pela comparação dos quadrados médios dos resíduos, conforme Pimentel Gomez (1990), houve possibilidade de fazer as análises conjuntas dos experimentos de época normal de plantio nos três locais apenas para altura da planta, altura da espiga, mancha de Phaeosphaeria e peso de grãos por parcela. No entanto, fez-se análise conjunta somente para os dois últimos caracteres.

As análises conjuntas dos dialelos intergrupos foram feitas utilizando o programa MAPGEN (Universidade Federal de Lavras), de acordo com a metodologia proposta por Oliveira et al. (1987), cujo modelo para análise de cruzamentos parciais repetidos em vários ambientes é:

$$
Y_{i j j^{\prime}}=\mu+\alpha d+l_{i}+\frac{1}{2}\left(v_{j}+v_{j^{\prime}}\right)+\theta\left(\bar{h}+h_{j}+h_{j^{\prime}}+s_{i j}\right)+\alpha l d_{i}+\frac{1}{2}\left(l v_{i j}+l v_{i j}\right)+\theta\left(l \bar{h}_{i}+l h_{i j}+l h_{i j^{\prime}}+1 s_{i j^{\prime}}\right)+\bar{e}_{i j j^{\prime}}
$$

- Yijo é a média do cruzamento do acesso j com o hibrido j' no local i, para $\alpha=0$ e $\theta=1$;

- $Y_{i \mathfrak{i j}}$ é a média do acesso j, para $\alpha=1$ e $\theta=0$;

- $Y_{\mathrm{ij} j \mathrm{j}}$ é a média do acessoj', para $\alpha=-1$ e $\theta=0$

- $\mu$ é a média entre a média dos dois grupos parentais;

- d é uma medida da diferença entre as médias dos dois grupos parentais;

- 1, é o efeito do i-ésimo ambiente;

- $v_{j}$ e $v_{j}$ são, respectivamente, o efeito do j-ésimo acesso e do j'-ésimo híbrido;

- $\overline{\mathrm{h}}$ é a heterose média de todos os cruzamentos;

- $h_{j}$ e $h_{j}$ são, respectivamente, os efeitos de heterose atribuidos ao j-ésimo acesso e ao j'-ésimo hibrido;

- $\mathrm{S}_{\mathrm{j} j}$ é a heterose especifica no cruzamento $\mathrm{j}$ j j ;

- $\mathrm{e}_{\mathrm{i}, \mathrm{j}}$ é o erro experimental associado às medias observadas. 
As análises conjuntas dos topcrosses foram feitas seguindo os procedimentos adotados por Vencovsky e Barriga (1992). O modelo para análise de cruzamentos parciais repetidos em vários ambientes é:

$Y_{i j j^{\prime}}=\mu+1_{j}+\frac{1}{2}\left(v_{j}+v_{j}\right)+\theta\left(\bar{h}+h_{j}+h_{j}\right)+\frac{1}{2}\left(l v_{i j}+l v_{i j}\right)+\theta\left(1 \bar{h}_{i}+l h_{i j}+l h_{i j}\right)+\bar{e}_{i j j} ;$ onde, $l_{1}$ é o efeito do i-ésimo ambiente.

\subsection{Seleção dos acessos e hibridos comerciais}

Os acessos e os hibridos comerciais que nas duas épocas de plantio apresentaram capacidade geral de combinação mais favorável foram selecionados para a formação de compostos.

No dialelo intergrupo, a capacidade geral de combinação segundo Geraldi e Miranda Filho (1988), é estimada por $g_{1}=\frac{1}{2} v_{i}+h_{1}$; onde, $v_{1}$ é o efeito dos parentais e $h_{i}$ é o efeito de heterose dos parentais ( $\mathrm{i}$ para os acessos, e j para os hibridos comerciais).

No "top-cross", com base na metodologia de Chaves e Miranda Filho (1997), foi deduzida uma expressão que estima a capacidade geral de combinação como sendo:

$$
g_{1}=\frac{n}{n-2}\left(T_{i}-\bar{T}\right)-\frac{1}{n-2}\left(V_{i}-\bar{V}\right) ; \text { onde, } n \text { é o número de acessos ou }
$$

variedades parentais, $T_{i}$ é a média de cada cruzamento entre uma variedade e o testador, $\overline{\mathrm{T}}$ é a média de todos os cruzamentos, $\mathrm{V}_{\mathrm{i}}$ é a média de cada variedade, e $\overline{\mathrm{V}}$ é a média de todas as variedades. Contudo, esta expressão é equivalente à utilizada no dialelo intergrupo.

A partir das capacidades gerais de combinação, os materiais foram selecionados para os caracteres de sanidade e principalmente produção de grãos. Assim, os acessos ou hibridos que apresentaram bom desempenho para os caracteres de sanidade, mas não apresentaram boa capacidade geral de combinação para produção foram eliminados; e 
materiais que apresentaram semelhantes efeitos de capacidade geral de combinação foram discriminados com base nos $g_{i}$ 's para as doenças. No plantio de época normal, devido à interação significativa entre as fontes de variação do dialelo ou do "top-cross" e os ambientes, foram selecionados os genótipos que tiveram melhor adaptação para os três locais, portanto, materiais que deixaram a desejar para rendimento em um dos locais foram eliminados.

\subsection{Predição de médias de compostos dos topcrosses}

O número de possíveis compostos a partir de $n$ variedades com participação equitativa segundo Vencovsky e Miranda Filho (1972) é $\mathrm{Nc}=\left[2^{\mathrm{n}}-(\mathrm{n}+1)\right]$, onde n, no presente estudo, é o número de acessos, o que toma impraticável a manipulação dos dados de predição. Por esta razão, primeiramente, os materiais foram selecionados com base na capacidade geral de combinação, de modo que fossem preditas as médias dos compostos formados pelos materiais que apresentaram capacidade de combinação $\left(\mathrm{g}_{\mathrm{i}}\right)$ mais favorável.

Segundo Chaves e Miranda Filho (1997), a partir de um esquema de cruzamento topcross, a média para um caráter quantitativo de um composto formado por $\mathbf{k}$ variedades é predita por:

$$
Y_{k}=\frac{n-2 k}{k^{2}(n-2)} \sum V_{i}+\frac{2 n(k-1)}{k^{2}(n-2)} \sum T_{i}+\frac{n(k-1)}{k(n-1)(n-2)} \bar{V}-\frac{n^{2}(k-1)}{k(n-1)(n-2)} \bar{T} ; \quad \text { onde, }
$$

n é o número total de variedades, e $\mathrm{k}$ é o tamanho do composto; sendo que os demais elementos já foram definidos anteriormente.

Com base nessa expressão, foi feita a predição para peso de grãos por parcela dos possiveis compostos formados pelas populações selecionadas com base na capacidade geral de combinação. 


\section{RESULTADOS}

\subsection{Plantio de safrinha}

Para os experimentos 1, 2,3 e 4, as médias, as análises de variância (Anava) e os efeitos genéticos estão contidos nas Tabelas 8 a 31 do seguinte modo:

\begin{tabular}{lcccc} 
& Exp. 1 & Exp. 2 & Exp. 3 & Exp.4 \\
\cline { 2 - 5 } & \multicolumn{4}{c}{ Tabelas } \\
\hline Médias dos tratamentos & 9 & 14 & 20 & 26 \\
Anava dos caracteres de sanidade & 15 & 21 & 27 \\
Anava dos caracteres agronômicos e de produção & 10 & 16 & 22 & 28 \\
Efeito de variedade $\left(\mathrm{v}_{\mathrm{i}}\right)$ & 11 & 17 & 23 & 29 \\
Efeito de heterose de variedade $\left(\mathrm{h}_{\mathrm{i}}\right)$ & 12 & 18 & 24 & 30 \\
Efeito de capacidade geral de combinação $\left(\mathrm{g}_{\mathrm{i}}\right)$ & 13 & 19 & 25 & 31 \\
\hline
\end{tabular}

\subsubsection{Mancha de turcicum}

Ocorreu pouca severidade de mancha de turcicum nos dialelos em relação aos "top-crosses". No experimento 1 , não foi detectada diferença significativa entre os tratamentos. No experimento 2 , houve um pouco mais de severidade e houve diferença significativa entre os acessos, no entanto, essas diferenças não foram suficientes para alocá-los em tipos diferentes de reação, uma vez que as médias se concentraram nos limites de 2,0 a 3,5.

Nos "top-crosses", os acessos tiveram comportamento similar nos experimentos 3 e 4. As médias dos tratamentos limitaram-se de 2,92 a 5,00 e de 2,75 a 5,22 , respectivamente (Tabelas 20 e 26). As diferenças significativas entre os tratamentos foram devidas às diferenças entre os acessos e entre as testemunhas (Tabelas 21 e 27), 
sendo que, no experimento 4 houve significância para a fonte de variação "top-cross" versus testemunhas. Nos dois experimentos, T1 foi classificada como resistente e T2 como medianamente resistente; e os acessos que apresentaram menor severidade de mancha de turcicum foram o 8 (nota 3 ) e os superprecoces 6 s e 16 s (nota 3,00 ).

\subsubsection{Mancha de Phaeosphaeria}

Nos experimentos 1,2 e 3 , as diferenças significativas observadas entre os tratamentos estão dentro de um mesmo tipo de reação, resistente neste caso; sendo que, as médias limitaram-se de 1,75 a 3,38. Nos dialelos, a severidade máxima observada foi 2,50 ( acesso 4) e 3,38 (acesso 6s). Não foi possível detectar diferenças significativas entre as testemunhas em nenhum experimento de safrinha.

No experimento 3 , as diferenças significativas entre os tratamentos foram devidas às diferenças entre os acessos, e entre os materiais do "top-cross" e as testemunhas (Tabela 21). O acesso 2 (nota 2,94) foi o que apresentou maior severidade, enquanto o 23 apresentou o efeito de variedade mais negativo.

No experimento 4, entre os acessos houve apenas reação do tipo resistência, e entre os seus cruzamentos houve os tipos de reação resistente e medianamente resistente. As médias dos tratamentos limitaram-se de 1,72 a 3,55 (Tabela 26), no entanto, foi detectada significância somente para a fonte de variação "top-cross" versus testemunha

\subsubsection{Ferrugem comum}

Nos dialelos foram observados os tipos de reação resistente e medianamente resistente, enquanto que, nos "top-crosses" foram encontrados materiais resistentes até medianamente susceptiveis. Em todos os experimentos não foi detectada significància de heterose, e a testemunha $\mathrm{Tl}$, significativamente, apresentou menor severidade que $\mathrm{T} 2$. $\mathrm{O}$ coeficiente de variação obtido em cada experimento foi, respectivamente, 19,57\%. $31,39 \%, 13,20 \%$ e $14,75 \%$. 
Nos experimentos envolvendo acessos precoces, apesar de as médias dos tratamentos se limitarem de 3,00 a 5,75 no experimento 1 , e de 3,3 a 6,5 no experimento 3, a análise de variância não detectou significância das fontes de variação do dialelo e nem do "top-cross".

Nos experimentos envolvendo acessos superprecoces, os acessos diferiram entre si, diferiram dos hibridos no experimento 2 (Tabela 15), cujas médias se limitaram de 2,00 a 5,25 , e diferiram das testemunhas no experimento 4 (Tabela 27), cujas médias limitaram de 3,7 a 6,9 .

\subsubsection{Podridão do colmo}

A ocorrência de plantas com podridão de colmo foi maior nos "top-crosses" do que no dialelo parcial precoce, cuja incidência limitou de zero a 2,67\%, sendo que, apenas três acessos e um cruzamento tiveram plantas com sintomas (Tabela 8). Em todos os experimentos, as testemunhas e os híbridos comerciais não apresentaram sintomas.

Nos "top-crosses", muitos tratamentos tiveram plantas com podridão do colmo, a incidência limitou de zero a $10,36 \%$ no experimento 3 , e de zero a $17,1 \%$ no experimento 4 (Tabelas 20 e 26). Houve diferenças significativas entre os acessos, sendo que, apesar de não ter sido detectada significância para a heterose média, houve significância para a heterose dos acessos precoces (Tabelas 2 I e 27).

\subsubsection{Complexo enfezamento}

Em todos os experimentos, principalmente no 3 e no 4 , houve incidência considerável de plantas com sintomas do complexo enfezamento. Os respectivos coeficientes de variação foram $19,8 \%, 18,0 \%, 20,3 \%$ e $7,0 \%$.

Nos dialelos, embora a incidência de plantas com enfezamento limitou de zero a $29,54 \%$ no experimento 1 , e de zero a $15,98 \%$ no experimentos 2 , a análise de variância 
conseguiu detectar diferença significativa apenas entre os grupos de parentais do experimento 1 (Tabela 9).

Nos "top-crosses", a incidencia de plantas com enfezamento limitou de 3 a 54\% no experimento 3 , e de zero a $25,4 \%$ no experimento 4 (Tabelas 20 e 26). Foi detectada significância para a heterose média, sendo sua estimativa e porcentagem em relação à média dos pais, obtidas com os dados não transformados, respectivamente, iguais a $4,580(-25,3 \%)$ e $-2,886$ (- 23,7\%) (dados não apresentados); sendo que, no experimento 4 , os acessos se diferiram entre si, mas não se diferiram quanto à manifestação da heterose.

Dentre os acessos, o precoce 27 e o superprecoce 25 s tenderam a apresentar um dos mais favoráveis efeitos de capacidade geral de combinação, tanto nos dialelos como nos "top-crosses".

\subsubsection{Altura de planta e espiga}

Para o caráter altura de planta, houve muita variação, principalmente entre os acessos superprecoces. Houve diferença significativa entre os acessos e significância para a heterose média em todos os experimentos de safrinha. No entanto, apenas no experimento 4 não houve diferenças entre os acessos quanto à manifestação da heterose. A média dos acessos precoces $(221,5 \mathrm{~cm})$ foi significativamente maior que a média dos hibridos $(169,7 \mathrm{~cm})$. Além disso, de um modo geral, os acessos precoces e seus cruzamentos apresentaram maior altura de planta e de espiga que os acessos superprecoces, no entanto, alguns acessos superprecoces se apresentaram tão altos e com maior altura de espiga quanto os precoces.

\subsection{Produção de grãos}

Como era esperado, os hibridos foram mais produtivos que os acessos. Em todos os experimentos, os acessos se diferiram quanto à produtividade, e a heterose média foi significativa, contudo, os progenitores (acessos e hibridos) não se diferiram quanto à 
manifestação da heterose. No entanto, no experimento 1, foi detectada significância para a heterose especifica (Tabela 10).

Nos experimentos 1 e 2 o peso dos grãos por parcela foi major que nos experimentos 3 e 4; respectivamente, as médias dos acessos foram 2,80, 2,87, 0,90 e $0,85 \mathrm{~kg} /$ parcela. Nos dialelos parciais as testemunhas não se diferiram quanto ao rendimento; mas, nos "top-crosses", a testemunha T1 foi significativamente mais produtiva que a testemunha T2 (Tabelas 20 e 26). Em todos os experimentos, a média das testemunhas diferiu da média do dialelo ou do "top-cross", sendo que, alguns acessos e muitos cruzamentos, principalmente nos experimentos 1 e 2 , tenderam a ser mais produtivos que a testemunha e o hibrido comercial menos produtivos (Tabelas 8 e 14).

Em cada experimento, a heterose média estimada igual a 0,$711 ; 0,958 ; 0,145 \mathrm{e}$ $0,188 \mathrm{~kg} /$ parcela correspondeu a 23,$7 ; 33,8 ; 16,1$ e 22,1\% da média dos progenitores. Os acessos que tenderam a apresentar os maiores efeitos de capacidade geral de combinação $\left(\mathrm{g}_{\mathrm{i}}\right)$ foram 13, 1, 20, 11, 30 e H4 no dialelo precoce; 12s, 17s, 10s e H3 no dialelo superprecoce; 12 , e 10 no "top-cross" precoce; e 30 s, 19s e 13 s no "top-cross" superprecoce.

\subsubsection{Genótipos selecionados}

Para cada experimento, com base na capacidade geral de combinação, os progenitores foram classificados simultaneamente para os caracteres de sanidade e, principalmente, rendimento. Nos dialelos, essa classificação indicou os acessos e o hibrido que tenderam a apresentar os efeitos de capacidade geral de combinação $\left(\mathrm{g}_{\mathrm{i}}\right)$ mais favoráveis, para serem recombinados visando à formação de um composto; enquanto que, nos "top-crosses", a classificação indicou os acessos que tenderam a apresentar os efeitos $g_{i}$ 's mais favoráveis, para a predição de compostos. Assim, em cada experimento, os melhores materiais foram os seguintes: 
- Experimento 1, os acessos 13 (BA-159), 1 (BA-166), 11 (SE-032), 30 (MS054), 21 (SE-036) e o hibrido H4 (G 85);

- Experimento 2, os acessos 25s (San Luis Potosi 118), 10s (CMS 21), 12s (CMS 05) e 19s (SE-033), e o hibrido H3;

- Experimento 3, os acessos 10 (BA-032), 12 (PB-003) e 27 (Vera Cruz 212);

- Experimento 4, os acessos 21s (Mezcla Tropical Blanco), 13s (CMS 14) e 30s (CMS 50).

Os cruzamentos dos acessos selecionados para a sintese de populações com padrão agronômico desejável e alta concentração de alelos de resistência mostraram-se superiores a uma ou outra testemunha para alguns caracteres de sanidade, agronômicos e rendimento.

Nos experimentos 1 e 2, para o rendimento de grãos, os cruzamentos dos acessos selecionados mostraram-se superiores às testemunhas; para reação à ferrugem comum, aparentemente mostraram-se iguais ou superiores à pior testemunha (T2); e para os caracteres agronômicos, tenderam a apresentar altura de planta e altura de espiga menores ou iguais às da testemunha mais alta (T2), comprimento de espiga maior, e diâmetro de espiga igual às testemunhas (Tabelas 8 e 14).

No experimento 3, para rendimento de grãos, os cruzamentos dos acessos selecionados mostraram-se iguais ou superiores à testemunha menos produtiva (T2); para reação a doenças, aparentemente mostraram-se iguais ou superiores a uma ou outra testemunha; para os caracteres agronômicos, tenderam a apresentar altura de planta e de espiga maiores ou iguais às da testemunha mais alta (T2), comprimento de espiga maior, e diâmetro de espiga menor que T2 (Tabela 20).

No experimento 4, para rendimento de grãos, os cruzamentos dos acessos selecionados mostraram-se iguais ou superiores à testemunha menos produtiva (T2); para reação a doenças, exceto o complexo enfezamento, aparentemente mostraram-se iguais ou superiores à pior testemunha (T2); para os caracteres agronômicos, tenderam a 
apresentar altura de planta e de espiga menores que a testemunha mais alta (T2), comprimento e diâmetro de espiga menor que Tl (Tabela 26).

\subsection{Plantio de época normal}

Para todos experimentos em cada local, as médias, as análises de variância (Anava) resumidas e os efeitos genéticos estão contidos nas Tabelas 32 a 98 do seguinte modo:

\begin{tabular}{|c|c|c|c|c|}
\hline \multirow[b]{2}{*}{ Anhembi } & $1 \mathrm{~A}$ & $2 \mathrm{~A}$ & $3 \mathrm{~A}$ & $4 A$ \\
\hline & \multicolumn{4}{|c|}{ Tabelas } \\
\hline Médias dos tratamentos & 32 & 49 & 66 & 83 \\
\hline Análises de variância & 33 & 50 & 67 & 84 \\
\hline Efeito de variedade $\left(v_{i}\right)$ & 34 & 51 & 68 & 85 \\
\hline Efeito de heterose de variedade $\left(h_{i}\right)$ & 35 & 52 & 69 & 86 \\
\hline Efeito de capacidade geral de combinação $\left(\mathrm{g}_{\mathrm{I}}\right)$ & 36 & 53 & 70 & 87 \\
\hline & $1 \mathrm{C}$ & $2 \mathrm{C}$ & $3 \mathrm{C}$ & $4 \mathrm{C}$ \\
\hline Caterpillar & \multicolumn{4}{|c|}{ Tabelas } \\
\hline Médias dos tratamentos & 37 & 54 & 71 & 88 \\
\hline Anava de PHAE, PHYSO, POLY, QUEB e ACAM & 38 & 55 & 72 & 89 \\
\hline Anava para $\mathrm{AP}, \mathrm{AE}, \mathrm{CE}, \mathrm{DE}$ e $\mathrm{PG}$ & 39 & 56 & 73 & 90 \\
\hline Efeito de variedade $\left(v_{1}\right)$ & 40 & 57 & 74 & 91 \\
\hline Efeito de heterose de variedade $\left(h_{3}\right)$ & 41 & 58 & 75 & 92 \\
\hline Efeito de capacidade geral de combinação $\left(\mathrm{g}_{\mathrm{l}}\right)$ & 42 & 59 & 76 & 93 \\
\hline & $1 \mathrm{R}$ & $2 \mathrm{R}$ & $3 R$ & $4 \mathrm{R}$ \\
\hline Rio Verde & \multicolumn{4}{|c|}{ Tabelas } \\
\hline Médias dos tratamentos & 43 & 60 & 77 & 94 \\
\hline Análise de variância & 44 & 61 & 78 & 95 \\
\hline Efeito de variedade $\left(v_{1}\right)$ & 45 & 62 & 79 & 96 \\
\hline Efeito de heterose de variedade $\left(h_{i}\right)$ & 46 & 63 & 80 & 97 \\
\hline Efeito de capacidade geral de combinação $\left(\mathrm{g}_{\mathrm{i}}\right)$ & 47 & 64 & 81 & 98 \\
\hline
\end{tabular}




\subsubsection{Mancha de Phaeosphaeria}

Considerando os três locais, as notas médias de severidade limitaram-se de 1,81 no experimento $1 \mathbf{R}$ a 6,31 no experimento $4 \mathbf{C}$. Os coeficientes de variação limitaram-se de 6,8 a $28,4 \%$. De um modo geral a testemunha $\mathrm{Tl}$ recebeu menores notas de severidade de mancha de phaeosphaeria do que a testemunha T2, como era esperado. Em todos os experimentos, as testemunhas foram em média, significativamente, mais resistentes que os materiais do dialelo.

Nos dialelos precoces (1A, 1C e $\mathbf{1 R}$ ), com exceção do experimento $\mathbf{1 A}$, nos demais houve significância para os acessos, hibridos, heterose e heterose média, sendo que a estimativa de heterose média igual a - 0,450 na Caterpillar e - 0,296 em Rio Verde correspondeu, respectivamente, a $-11,9 \%$ e $-9,0 \%$ da média dos pais.

A análise conjunta dos dialelos precoces não detectou diferenças significativas entre os locais (Tabela 48). Também, não foi detectado comportamento diferencial dos materiais do dialelo de um ambiente para outro. No entanto, houve interação entre os locais e os efeitos de variedade $\left(\mathrm{v}_{\mathrm{i}}\right)$ dos acessos e dos hibridos, o que possivelmente resulta no comportamento diferencial dos acessos quanto à capacidade geral de combinação de um local para o outro. Apesar da interação, na Caterpillar e em Rio Verde houve uma certa concordância entre os materiais quanto ao comportamento, pois, os acessos 24, 25 e 27 e o híbrido $\mathbf{H 3}$ tenderam a apresentar os efeitos de capacidade geral de combinação $\left(\mathrm{g}_{\mathrm{i}}\right)$ mais negativos nestes dois locais (Tabelas 36, 42 e 47).

Nos dialelos superprecoces (2A, $2 \mathrm{C}$ e $\mathbf{2 R}$ ), houve significância para os acessos, hibridos e heterose. Porém, não houve diferença entre os acessos quanto à manifestação da heterose. Somente na Caterpillar e em Rio Verde houve significância para a heterose média (Tabelas 55 e 61 ), sendo que sua estimativa em severidade e em porcentagem em relação à média dos pais foi igual a- $0,671(-17 \%)$ no experimento $2 \mathrm{C}$, e - 0,252 ($6,3 \%$ ) no experimento $2 \mathrm{R}$.

A análise conjunta dos dialelos superprecoces detectou diferenças significativas entre os locais (Tabela 65). A nota média de severidade do dialelo parcial superprecoce no Anhembi, na Caterpillar e em Rio Verde foi, respectivamente, 4,85, 3,27 e 3,63. A 
significância da interação indicou que houve comportamento diferencial dos materiais do dialelo de um ambiente para outro. No entanto, não houve comportamento diferencial da heterose dos progenitores entre os ambientes. A interação significativa indicou que $o$ ordenamento dos acessos não se manteve de um local para o outro. Contudo, houve alguma concordância entre os materiais, uma vez que, o acesso $25 \mathrm{~s}$ e o híbrido H3 tenderam a mostrar os efeitos de capacidade geral de combinação $\left(\mathrm{g}_{\mathrm{i}}\right)$ mais favoráveis nos três locais (Tabelas 53, 59 e 64). Além disso, o acesso 16s (CMS 28), que foi um dos apresentaram melhor capacidade geral de combinação no Anhembi e em Rio Verde. Este acesso, foi destaque também na avaliação feita por Zocolli (1998), mostrando um menor nivel de infestação de mancha de phaeosphaeria.

Nos "top-crosses" precoces (3A, $\mathbf{3} \mathbf{C}$ e $\mathbf{3 R}$ ), com exceção do experimento $\mathbf{3 A}$, houve significância para os acessos. Em todos os locais, não foi detectada significância para a heterose média. No entanto na Caterpillar, os acessos se diferiram quanto à manifestação da heterose (Tabela 72).

A análise conjunta dos "top-crosses" precoces indicou que em Rio Verde a severidade da mancha de phaeosphaeria foi significativamente menor que nos outros locais (Tabela 82). A nota média de severidade no Anhembi, na Caterpillar e em Rio Verde foi, respectivamente, 4,70, 4,55 e 2,68. Apesar de ter sido detectado comportamento diferencial dos acessos quanto ao seu valor per se de um local para o outro, o acesso $\mathbf{2 4}$ foi um dos que apresentou efeito de variedade $\left(v_{i}\right)$ mais favorável, na Caterpillar e em Rio Verde (Tabelas 74 e 79).

Nos "top-crosses" superprecoces (4A, 4C e 4R), em todos os locais os acessos se diferiram quanto ao seu valor per se, mas não se diferiram quanto à manifestação da heterose. Somente na Caterpillar, foi detectada significância para a heterose média (Tabela 89), sendo que sua estimativa foi igual a 0,250 ( $5 \%$ da média dos pais)

A análise conjunta dos "top-crosses" superprecoces revelou que houve diferenças significativas entre os locais (Tabela 99). A nota média de severidade no Anhembi, na Caterpillar e em Rio Verde foi, respectivamente, 4,96, 4,97 e 4,00. Houve interação significativa entre os acessos e os locais, indicando que o ordenamento dos acessos quanto ao seu valor per se não se manteve de um local para o outro. Contudo, o acesso 
25s foi um dos que apresentou maior potencial para melhoramento intrapopulacional nos três locais (Tabelas 85, 91 e 96) e o melhor $g_{i}$ na Caterpillar e em Rio Verde.

\subsubsection{Ferrugem tropical}

Em todos os experimentos, ocorreram os tipos de reação resistente e medianamente resistente, sendo que, as notas médias de severidade limitaram-se de 3,0 a 4,5. Com exceção do experimento 2C, nos demais experimentos os acessos não se diferiram quanto ao seu valor per se. As testemunhas foram significativamente diferentes, sendo que, T1 apresentou-se como resistente, e T2 como medianamente resistente.

Nos dois dialelos, o híbrido $\mathbf{H} \mathbf{2}$ significativamente apresentou maior severidade que os demais. No experimento $\mathbf{1 C}$, as diferenças significativas entre os tratamentos foram distribuidas entre os híbridos e as testemunhas. No experimento $2 \mathrm{C}$, foi detectada diferenças entre os grupos parentais, sendo que, em média os hibridos apresentaram menos severidade que os acessos superprecoces; além disso, a significância da heterose foi devida à heterose especifica, indicando a existência de cruzamentos especificos superiores e inferiores ao que seria esperado com base na capacidade geral de combinação dos seus progenitores (Tabela 55).

No experimento $3 \mathrm{C}$, a diferença entre os tratamentos foi distribuida entre as testemunhas e entre os materiais do top-cross e as testemunhas. Enquanto que no experimento $\mathbf{4 C}$, a diferença entre os tratamentos foi devida apenas às testemunhas.

\subsubsection{Ferrugem poly:sora}

Esta doença ocorreu apenas nos experimentos 3C e 4C. Todos os materiais foram considerados resistentes, as médias limitaram-se de 2,0 a 3,4 (Tabelas 71 e 88). No entanto, houve diferenças significativas entre os tratamentos, as quais foram distribuidas entre as testemunhas, e entre as testemunhas e os materiais do top-cross. A testemunha Tl apresentou menor severidade da doença do que a testemunha T2. 


\subsubsection{Complexo enfezamento}

A incidência máxima observada de plantas com sintomas nos experimentos $\mathbf{1} \mathbf{R}$, 2R, 3R e 4R foi, respectivamente, 7,34\%, 3,45\%, 1,41\% e 2,08\%. Em todos os experimentos, não houve diferenças significativas entre os acessos quanto à incidência observada. Também, as testemunhas tiveram o mesmo comportamento. Apesar das baixas porcentagens de incidência e da falta de significância, os efeitos genéticos foram estimados.

\subsubsection{Quebramento de colmo}

Em todos os experimentos na Caterpillar, houve porcentagens razoáveis de plantas com colmos quebrados, principalmente, nos dialelos parciais, 0 que possivelmente pode ter sido devido às diferentes condições em que os experimentos foram submetidos; pois, os dialelos parciais foram plantados relativamente longe dos top-crosses. A incidência máxima observada de plantas com colmo quebrado nos experimentos 1C, 2C, 3C e 4C foi, respectivamente, 22,04\%, 50,00\%, $11,17 \%$ e 22,85\%. Em todos os experimentos, foi detectada diferença significativa entre os progenitores, contudo não foi detectada manifestação da heterose. Nos dialelos, houve diferença significativa entre os grupos de progenitores, sendo que, os hibridos comerciais apresentaram menos colmos quebrados que os acessos e os cruzamentos (Tabelas 38 e 55). Dentre os hibridos, H2 e $\mathbf{H 4}$ não apresentaram colmos quebrados, no entanto, no cruzamento com os acessos precoces, o hibrido $\mathrm{H} 3$ apresentou melhor performance. 


\subsubsection{Acamamento}

As avaliações da quantidade de plantas acamadas foram feitas na Caterpillar e em Rio Verde. A incidência máxima observada nos experimentos da Caterpillar se limitou de 2,78\% a 47,40\%; sendo que, pelo mesmo motivo atribuido à porcentagem de colmos quebrados, a porcentagem de plantas acamadas foi maior nos dialelos que nos "top-crosses", a incidência máxima nos experimentos $3 \mathrm{C}$ e $4 \mathrm{C}$ foi igual a $3,22 \%$ e $2,78 \%$, respectivamente. Em Rio Verde, a incidência máxima observada nos experimentos se limitou de $14,43 \%$ a $29,47 \%$.

Nos dois locais, houve diferenças significativas entre os acessos e entre os híbridos nos dialelos, e entre os acessos nos top-crosses, exceto no experimento $4 \mathrm{C}$. De um modo geral, os materiais dos dialelos e dos "top-crosses" acamaram mais que as testemunhas, sendo que, nos experimentos em que houve diferenças entre as testemunhas, $\mathbf{T}_{\mathbf{2}}$ apresentou maior acamamento que $\mathbf{T}_{\mathbf{1}}$, o que possivelmente foi devido à sua maior altura. Nos dialelos, os acessos se diferiram quanto à manifestação da heterose, exceto no experimento $2 \mathrm{C}$; e somente nos experimentos $1 \mathrm{C}, 2 \mathrm{C}$ e $2 \mathrm{R}$ houve significância para a heterose média (Tabelas 38, 55 e 61), sendo que, os cruzamentos foram significativamente mais resistente que os progenitores.

\subsubsection{Altura de planta e espiga}

Para altura de planta, houve muita variação entre os acessos, principalmente entre os acessos superprecoces, exceto nos dialelos da Caterpillar. Na maioria dos dialelos parciais, os híbridos se diferiram quanto à sua altura, exceto no experimento $2 \mathbf{R}$, e de um modo geral, os acessos se apresentaram significativamente mais altos que os hibridos utilizados como progenitores, exceto, no experimento 2C (Tabela 56). Nos "top-crosses" envolvendo os acessos precoces não foi detectada significância para a heterose média. Assim como ocorreu no plantio de safrinha, de um modo geral os acessos precoces e seus cruzamentos apresentaram maior altura de planta e de espiga que os acessos 
superprecoces, sendo que, alguns acessos superprecoces se apresentaram tão altos e com maior altura de espiga quanto os precoces.

Os acessos precoces 5, 10 e 11 e os superprecoces $1 \mathrm{~s}$, $2 \mathrm{~s}$ e $4 \mathrm{~s}$ foram um dos que tenderam a apresentar os melhores efeitos de capacidade geral de combinação $\left(\mathrm{g}_{\mathrm{i}}\right)$, no sentido de, simultaneamente, reduzir a altura de planta e de espiga.

\subsubsection{Produção de grãos}

De um modo geral, os hibridos foram mais produtivos que os acessos, principalmente na Caterpillar (Tabelas 37, 54, 71 e 88). Em todos os experimentos houve significância para os acessos e para a heterose média, positiva, indicando, respectivamente, que pelo menos um dos acessos diferiu dos demais e que a média dos cruzamentos foi superior à média dos pais.

Em todos os dialelos parciais houve significância para a heterose è, em quase todos, para a heterose especifica. Além disso, alguns acessos apresentaram ser mais produtivos que a geração $F_{2}$ dos hibridos comerciais. Contudo, nenhum acesso mostrouse mais produtivo que as testemunhas.

Nos "top-crosses", apesar da alta magnitude relativa do quadrado médio da heterose média, os cruzamentos foram significativamente inferiores que uma ou outra das testemunhas; e, na maioria dos experimentos, a testemunha $\mathrm{Tl}$ apresentou ser mais produtiva que $\mathrm{T} 2$.

Nos dialelos precoces, nas análises individuais dos três locais não foram detectadas diferenças entre os híbridos quanto à manifestação da heterose. Mas, os acessos se diferiram quanto à sua heterose no Anhembi e em Rio Verde (Tabelas 33 e 44). Em cada um dos três locais, a heterose média estimada, respectivamente, igual a 0,$766 ; 1,368$ e $1,063 \mathrm{~kg} /$ parcela correspondeu a 36,$3 ; 35,3$ e 43,2\% da média dos progenitores. Os materiais que tenderam a apresentar $\mathrm{g}_{\mathrm{i}}$ 's mais favoráveis foram $27,3 \mathrm{e}$ H2 no Anhembi; 23, 15 e H2 na Caterpillar; e 23, 27 e H3 em Rio Verde (Tabelas 36, 42 e 47 , respectivamente). 
A análise conjunta dos dialelos precoces detectou diferenças significativas entre os locais (Tabela 48). A média de produção nos experimentos $\mathbf{1 A}, \mathbf{C}$ e $\mathbf{1 R}$ foi 2,898, 5,074 e $3,430 \mathrm{~kg} /$ parcela, respectivamente. A significância da interação indicou que houve comportamento diferencial dos materiais do dialelo de um ambiente para outro. No entanto, para os efeitos de heterose dos acessos e dos híbridos não foi detectado comportamento diferencial ao longo dos ambientes.

Nos dialelos superprecoces, apenas na Caterpillar, não foi detectada diferença entre os acessos quanto à manifestação da heterose. Em cada um dos três locais, a heterose média estimada, respectivamente, igual a 0,826;1,057 e $1,031 \mathrm{~kg} /$ parcela correspondeu a 36,$7 ; 26,2$ e $37,6 \%$ da média dos progenitores. Os materiais que tenderam a apresentar $\mathrm{g}_{\mathrm{i}}$ 's mais favoráveis foram $30 \mathrm{~s}, 16 \mathrm{~s}$, $25 \mathrm{~s}$ e $\mathrm{H3}$ no Anhembi; $21 \mathrm{~s}$, 11s, 12s, 22s e H2 na Caterpillar; e 22s, 30s, 12s, 20s e H3 em Rio Verde (Tabelas 53, 59 e 64).

Para os dialelos superprecoces também, a análise conjunta detectou diferenças significativas entre os locais (Tabela 65). A média de produção nos experimentos $2 \mathrm{~A}$, 2C e $\mathbf{2 R}$ foi, respectivamente, 3,080, 4,929 e 3,704 Kg/parcela. Foi detectada interação significativa entre os materiais do dialelo e os locais. No entanto, não foi detectado comportamento diferencial da heterose entre os ambientes. Apesar da interação, o acesso $22 \mathrm{~s}$ em todos os três locais foi um dos que apresentaram efeito de heterose de variedade $\left(\mathrm{v}_{\mathrm{i}}\right)$ mais favorável (Tabelas 51, 57 e 62).

Nos "top-crosses" precoces, em Rio Verde foi detectada diferença entre os acessos quanto à manifestação da heterose. Em cada um dos três locais, a heterose média estimada, respectivamente, igual a 0,140;0,434 e 0,356 kg/parcela correspondeu a 6,0; 11,8 e $14,1 \%$ da média dos progenitores. Os acessos que tenderam a apresentar $\mathrm{g}_{\mathrm{i}}$ 's mais favoráveis foram 23, 11 e 25 no Anhembi; 20, 12 e 16 na Caterpillar; e 23, 22 e 21 em Rio Verde (Tabela 70, 76 e 81)

A análise conjunta dos "top-crosses" precoces revelou que a produtividade na Caterpillar foi significativamente superior à dos demais locais (Tabela 82). A média de produção no experimentos 3A, 3C e 3R foi, respectivamente, 2,608, 4,024 e 2,840 $\mathrm{kg} /$ parcela. Foi detectada interação para os acessos e para a heterose média. Apesar da 
interação, o acesso 6 foi um dos melhores para melhoramento per se no Anhembi e em Rio Verde (Tabelas 68 e 79).

Nos "top-crosses" superprecoces, assim como ocorreu com os acessos precoces, apenas em Rio Verde não houve diferença entre os acessos quanto à manifestação da heterose. Em cada um dos três locais, a heterose média estimada, respectivamente, igual a 0,$270 ; 0,516$ e $0,527 \mathrm{~kg} /$ parcela correspondeu a 12,$0 ; 15,3$ e $19,7 \%$ da média dos progenitores. Os acessos que tenderam a apresentar $g_{i}$ 's mais favoráveis foram $21 \mathrm{~s}, 30 \mathrm{~s}$ e 25s no Anhembi; 30s, 22s e 17s na Caterpillar; e 30s, 19s e 22s em Rio Verde (Tabelas $87,93$ e 98$)$.

A análise conjunta dos "top-crosses" superprecoces revelou que houve diferenças significativas entre os locais (Tabela 99). A média de produção nos experimentos $\mathbf{4 A}$, 4C e $\mathbf{4 R}$ foi, respectivamente, $2,611,3,789$ e 3,130 Kg/parcela. A interação significativa entre os acessos e os locais indicou que os acessos que apresentaram efeito de variedade mais favorável não se mantiveram de um local para o outro. Contudo, não foi detectada interação entre a heterose dos acessos e os locais, permitindo que os acessos 30 s e $22 \mathrm{~s}$ se mantivessem de um local para o outro, como sendo um dos que apresentaram $h_{i}$ e $g_{i}$ mais favoráveis.

\subsubsection{Genótipos selecionados}

Quando a interação é significativa e predominantemente do tipo complexa, normalmente faz-se a seleção buscando os materiais de melhor adaptação nos ambientes envolvidos (Vencovsky \& Barriga, 1992); por outro lado, quando não houver significância da interação ou quando ela for significativa e do tipo simples, a seleção dos materiais de melhor adaptação equivale à seleção com base nas médias dos genótipos sobre todos os ambientes em questão.

Embora o ordenamento dos genótipos não se manteve de um local para o outro, puderam ser selecionados os materiais que tiveram melhor adaptação para os três locais. Assim, em cada tipo de experimento (dialelo precoce, dialelo superprecoce, "top-cross" precoce e "top-cross" superprecoce), os progenitores foram classificados 
simultaneamente para os caracteres de sanidade e, principalmente, produção de grãos, com base na capacidade geral de combinação, buscando os genótipos que tiveram melhor adaptação para os três locais. Nos dialelos, essa classificação indicou os acessos e o híbrido que tenderam a apresentar os efeitos de capacidade geral de combinação $\left(g_{i}\right)$ mais favoráveis, para serem recombinados visando à formação de composto; enquanto que, nos "top-crosses", a classificação indicou os acessos que tenderam a apresentar os efeitos $g_{i}$ 's mais favoráveis, para a predição de compostos. Assim, em cada tipo de experimento, os melhores materiais foram os seguintes:

- Experimentos 1A, 1C e 1R, os progenitores 23 (WP - 32), 3 (SE - 025), 17 (BA - 176) e H3.

- Experimentos 2A, 2C e 2R, os progenitores 22s (AL - 009), 16s (CMS 28), 20s (Brasil 2294) e H3.

- Experimentos 3A, 3C e 3R, os acessos 20 (BA - 094) e 23 (WP - 32).

- Experimentos 4A, 4C e 4R, os acessos 30s (CMS 50), 21s (Mezcla Tropical Blanco) e 22s (AL - 009).

Os cruzamentos dos acessos selecionados mostraram-se superiores a uma ou outra testemunha para alguns caracteres de sanidade, agronômicos e rendimento.

Nos dialelos, para o caráter produção de grãos, tais cruzamentos mostraram-se iguais à testemunha menos produtiva (T2) na Caterpillar, mas foram inferiores às testemunhas no Anhembi e em Rio Verde.

Nos dialelos precoces, para reação a doenças, os cruzamentos dos acessos selecionados tenderam a apresentar maior severidade de mancha de Phaeosphaeria que as testemunhas na Caterpillar e em Rio Verde, mas, para ferrugem tropical, avaliada apenas na Caterpillar, apresentaram-se iguais às testemunhas. Para caracteres agronômicos, os cruzamentos aparentemente tiveram menos colmos quebrados e plantas acamadas que a pior testemunha (T2); aparentemente apresentaram menor altura de 
planta e maior altura de espiga que a testemunha mais alta (T2); e tenderam a apresentar espigas de menor comprimento e diâmetro que as testemunhas no Anhembi, e de igual tamanho às espigas das testemunhas na Caterpillar (Tabelas 32, 37 e 47).

Nos dialelos superprecoces, para reação a doenças, os cruzamentos dos acessos selecionados tenderam a apresentar maior severidade de mancha de phaeosphaeria que as testemunhas, no entanto, no Anhembi, onde apresentaram maior severidade, foram classificados como medianamente resistente; para ferrugem tropical, avaliada apenas na Caterpillar, apresentaram-se iguais às testemunhas. Para caracteres agronômicos, os cruzamentos aparentemente tiveram menos colmos quebrados que a pior testemunha (T2), exceto, o cruzamento do acessos 20s; apresentaram mais resistentes ao acamamento que a testemunha T2 na Caterpillar, e menos resistentes que ambas testemunhas em Rio Verde; aparentemente apresentaram menor altura de planta e de espiga que a testemunha mais alta (T2); e tenderam a apresentar espigas de tamanho próximo ao das testemunhas (Tabelas 49, 54 e 60).

Nos "top-crosses", para rendimento de grãos, os cruzamentos dos acessos selecionados mostraram-se inferiores às testemunhas. Para mancha de Phaeosphaeria, estes cruzamentos tenderam a apresentar maior severidade que as testemunhas, no entanto, no Anhembi e na Caterpillar, onde apresentaram maior severidade, foram classificados como resistente ou medianamente resistente.

Nos "top-crosses" precoces, para ferrugem tropical e ferrugem polysora, avaliadas apenas na Caterpillar, os cruzamentos dos acessos selecionados foram resistentes ou medianamente resistentes e tenderam a apresentar menos severidade que a pior testemunha (T2); para enfezamento, não houve plantas com sintomas. Para caracteres agronômicos, um cruzamento aparentemente teve menos colmos quebrados que a pior testemunha (T2), enquanto o outro cruzamento apresentou maior porcentagem de colmos quebrados que T2; não apresentaram plantas acamadas na Caterpillar, e em Rio Verde tenderam a ser iguais às testemunhas; aparentemente apresentaram menor altura de planta e de espiga que a testemunha mais alta (T2); aparentemente apresentaram espigas de tamanho próximo ao das testemunhas no Anhembi, e maior 
comprimento e igual diâmetro que as espigas das testemunhas na Caterpillar (Tabelas 66,71 e 77).

Nos "top-crosses" superprecoces, para ferrugem tropical, avaliada apenas na Caterpillar, os cruzamentos dos acessos selecionados foram resistentes e tenderam a apresentar menos severidade que a pior testemunha (T2), exceto o cruzamento do acesso 30s; para ferrugem polysora, tenderam a apresentar mais severidade que a pior testemunha (T2); para enfezamento, não houve plantas com sintomas. Para caracteres agronômicos, os cruzamentos aparentemente apresentaram menor porcentagem de colmos quebrados que a pior testemunha (T2); não apresentaram plantas acamadas na Caterpillar, mas em Rio Verde, tenderam a ser mais susceptiveis ao acamamento que as testemunhas; aparentemente apresentaram menor altura de planta e de espiga que a testemunha mais alta (T2); aparentemente apresentaram espigas de igual comprimento e menor diâmetro que as das testemunhas no Anhembi, e maior comprimento e menor diâmetro que as espigas das testemunhas na Caterpillar (Tabelas 83, 88 e 94).

\subsection{Predição de médias dos compostos}

$\mathrm{Na}$ época de safrinha, tanto para os acessos precoces 10,12 e 27 como para os superprecoces $21 \mathrm{~s}, 13 \mathrm{~s}$ e $30 \mathrm{~s}$, a predição de rendimento dos possiveis compostos revelou que houve uma tendência de a recombinação dos três acessos selecionados resultar no melhor composto (Tabela 100).

$\mathrm{Na}$ época de plantio normal, para os experimentos $3 \mathrm{~A}, 3 \mathrm{C}$ e $3 \mathrm{R}$ o único composto possivel, formado pelos acessos 20 e 23 , apresentou maior média predita na Caterpillar; enquanto que para os experimentos $4 \mathrm{~A}, 4 \mathrm{C}$ e $4 \mathrm{R}$, dentre os quatro compostos possiveis, o composto formado pelos acessos $30 \mathrm{~s}$, $21 \mathrm{~s}$ e $22 \mathrm{~s}$, apresentou a segunda maior média predita no Anhembi e a maior média predita na Caterpillar e em Rio Verde (Tabela 100). 


\section{DISCUSSĀO}

Na estação experimental Anhembi, no plantio de safrinha, os experimentos 1 e 2 foram instalados numa área relativamente nova, enquanto que os experimentos 3 e 4 foram instalados numa área que a mais tempo vem sendo ocupada com milho de diferentes origens, durante o ano inteiro, alternando plantio de lotes de cruzamento e plantio de experimentos para fins de melhoramento, sendo, portanto, um lugar apropriado para a avaliação para resistência a diferentes doenças, tanto da época de safrinha como de plantio normal. Então, quando são comparados os mesmos materiais plantados nas duas áreas, as menores notas de severidade de mancha de turcicum e mancha de Phaeosphaeria nos experimentos 1 e 2 e as menores porcentagens de incidência de plantas com podridão do colmo no experimento 1 podem ser devidas a escape ao patógeno ou a uma baixa concentração de inóculo, o que não permite fazer inferências seguras quanto ao valor genético dos acessos para resistência a essas três doenças nos experimentos 1 e $\mathbf{2}$.

Em alguns casos, nas análise de variância dos caracteres de sanidade ocorreram diferenças significativas; no entanto, essas diferenças não foram suficientes para alocar os tratamentos em tipos diferentes de reação, conforme a escala diagramática utilizada para avaliar a severidade; ou em outros casos, os tratamentos foram alocados em diferentes tipos de reação e $O$ teste $F$ não acusou significância. Esta discordância é bastante frequente, pois o teste $\mathrm{F}$ acusa a probabilidade de que as diferenças observadas sejam devidas ao acaso, enquanto que, as escalas diagramáticas, segundo Amorim (1995), estão associadas ao limite máximo da doença e às limitações da acuidade visual humana. Além disso, a classificação das plantas quanto à reação a doenças depende de cada doença em particular. 
Apesar da seleção praticada com base na avaliação feita pelo NAP-milho no ano agrícola 1995/1996, para algumas doenças houve os tipos de reação resistente, medianamente resistente e medianamente susceptivel. O nivel de severidade observado pode ter sido devido às seguintes causas: a referida avaliação ocorreu numa época que não era a mais propícia para o desenvolvimento de algumas doenças, como mancha de turcicum, ferrugem comum e o complexo enfezamento; interações dos acessos com os ambientes; ou a concentração de inóculo foi baixa não permitindo uma discriminação eficiente. Além disso, as avaliações do NAP-milho foram feitas em parcelas relativamente pequenas $\left(6 \mathrm{~m}^{2}\right)$ com uma repetição, não representando adequadamente a variabilidade genética dentro dos acessos.

A ocorrência de mancha de turcicum no Anhembi, na época de safrinha e a não ocorrência na época de plantio normal, está de acordo com a literatura, haja visto que as condições de temperatura e umidade neste local para o desenvolvimento da doença foram semelhantes às descritas por Fernandes \& Oliveira (1997).

A mancha de Phaeosphaeria foi a única doença que ocorreu em todos os experimentos, tanto no plantio de safrinha, como no plantio da época normal. Em todos eles houve uma tendência de os acessos superprecoces apresentarem maior severidade que os precoces. Na estação experimental Anhembi, foi observada menor severidade no plantio de safrinha do que no plantio de época normal, onde houve temperaturas moderadas a altas, estando de acordo com Silva (1997); no entanto, Pegoraro et al. (1998) relataram que maior severidade ocorre principalmente nos cultivos de safrinha.

A maior severidade observada de ferrugem comum do que das outras doenças foliares na época de safrinha, possivelmente, foi devida ao fato de a seleção entre os 1273 acessos do CNPMS não ter sido feita com base em avaliações para resistência a esta doença. Além disso, as maiores notas atribuidas aos materiais dos "top-crosses" em relação aos dialelos, possivelmente foram devidas às condições da área experimental, anteriormente descritas. Os cruzamentos apresentaram em média menor severidade que os acessos, indicando que o cruzamento com os híbridos resultou em melhor nivel de resistência. 
$\mathrm{Na}$ Caterpillar, por comparação com as parcelas vizinhas de outros experimentos, pôde-se afirmar que as ferrugens tropical e polysora ocorreram. Foram encontrados materiais resistentes e medianamente resistentes à primeira, e materiais resistentes à segunda, isto indicou que a seleção entre os 1273 acessos foi efetiva para estas doenças. A significância da heterose específica para ferrugem tropical no dialelo superprecoce indicou que houve cruzamentos em que um híbrido ou outro proporcionou menor severidade.

A incidência de podridão de colmo observada, principalmente nos experimentos 3 e 4, possivelmente foi devida às mesmas causas atribuídas à severidade encontrada para a ferrugem comum. No presente estudo, devido à quantidade de avaliações a serem feitas, não houve o interesse em identificar os agentes causais, mas, possivelmente estiveram presentes Diplodia maydis, Fusarium moniliforme e/ou Colletotrichum graminicola, uma vez que, frequentemente ocorrem no estado de São Paulo.

Tendo em vista a importância que têm tido as podridões de colmo do milho, a avaliação feita no plantio de safrinha, principalmente por ter sido numa área em que estima-se ter uma alta concentração de inóculo, contribuiu para a identificação de acessos fontes de resistência. Assim, os acessos precoces 20, 22 e 27 e os superprecoces $11 \mathrm{~s}, 13 \mathrm{~s}$ e $30 \mathrm{~s}$ tenderam a ser os melhores para uso em cruzamentos (Tabelas 25 e 31 , respectivamente). Pode-se notar que nos cruzamentos de cada um com os demais do grupo, não foi encontrada nenhuma planta com sintoma, e além disso, o rendimento de grãos foi razoável, sendo que, o cruzamento do acesso 27 (Tabela 20) teve rendimento igual ao da testemunha menos produtiva $\left(T_{2}\right)$, e o cruzamento do acesso 30 s (Tabela 26) foi igual à testemunha mais produtiva $\left(T_{1}\right)$.

A porcentagem de plantas com sintomas do complexo enfezamento em Rio Verde foi muito menor que a porcentagem encontrada nos experimentos de safrinha, isto era previsto, pois, de acordo com Pereira (1995), a ocorrência da doença é maior no plantio desta última época. Contudo, Basso (1999) relata que em áreas de plantio contínuo de milho podem ser registradas grandes perdas na produtividade em decorrència dos efeitos desta doença. No entanto, esse fato não ocorreu no presente 
estudo, uma vez que, no plantio de época normal no Anhembi, seguido ao plantio de safrinha, não foram encontradas plantas com sintomas.

Apesar das baixas porcentagens de incidência do complexo enfezamento no plantio de época normal, em Rio Verde, foram encontradas plantas com sintomas bastante severos, o que sugere baixa população do vetor na área experimental, escape de muitas plantas e resistência, haja visto que a avaliação de safrinha revelou a presença de resistência. Logo, os dados obtidos da avaliação para enfezamento em Rio Verde não permite fazer inferências genéticas seguras a partir da análise de variância e dos efeitos genéticos.

Embora na testemunha $T 1$ houve maior incidência que na $T 2$, a severidade do enfezamento nas plantas infectadas foi muito baixa, foi observado apenas um ligeiro encurtamento dos entrenós terminais das plantas, sem afetar a coloração das folhas e, visualmente, a quantidade e o tamanho das espigas. Isto reforça a idéia de que a reação dos genótipos é melhor caracterizada, segundo Basso (1999), levando em consideração a severidade e a incidência.

Normalmente, a altura da planta é associada positivamente com o rendimento, mas também, apresenta associação positiva com o acamamento e com o quebramento do colmo, podendo ter efeito negativo no rendimento. De um modo geral, nas duas épocas de plantio, os acessos avaliados apresentaram-se significativamente mais altos que a geração $\mathrm{F}_{2}$ dos híbridos comerciais utilizados nos dialelos, o que vem a ser uma característica agronômica desfavorável dos acessos, uma vez que, existe uma preferência para o uso de materiais de menor porte. No entanto, Moreira Júnior (1995) relata que cultivares mais altos podem ser usados para silagem ou em sistemas de produção em que não há um bom controle de plantas daninhas.

Nos dialelos precoces, os cruzamentos apresentaram em média menor altura de planta que os acessos, indicando que os hibridos, principalmente o $\mathrm{H} 3$ no plantio de safrinha e o $\mathbf{H 1}$ no plantio de época normal, contribuiram para a redução da altura de planta nos cruzamentos com os acessos precoces.

Brasil (1998), num estudo de progênies, relatou que devido a uma maior competição por luz, as plantas cresceram mais no plantio de safrinha em comparação 
com o plantio de época normal. Esse fato não foi observado no presente estudo, pois, possivelmente devido às doenças, as plantas de safrinha apresentaram menor altura.

A produção de grãos foi o caráter mais visado na seleção dos materiais para a sintese de populações. Os coeficientes de variação se limitaram de 14,03 a $20,38 \%$ no plantio de safrinha, e de 11,89 a 16,21\% na época normal de plantio, sendo considerados médios, conforme a classificação dos coeficientes de variação para a cultura do milho proposta por Scapim et al. (1995).

No plantio de safrinha, provavelmente devido à maior severidade das doenças, o peso dos grãos por parcela nos experimentos 1 e 2 foi maior que nos experimentos 3 e 4 ; as médias dos acessos foram respectivamente $2,80,2,87,0,90$ e $0,85 \mathrm{~kg}$.

No plantio de época normal, considerando a média geral dos quatro tipos de experimentos em cada local, o peso de grãos expresso em $\mathrm{kg}$ por parcela foi maior na Caterpillar $(4,329)$ do que em Rio Verde $(3,276)$, e neste foi maior que no Anhembi $(2,799)$; sendo que, neste último local, a produtividade foi maior na época normal de plantio do que na condição de safrinha $(2,198 \mathrm{~kg} /$ parcela). No entanto, nos dialelos, com exceção da Caterpillar, no plantio de safrinha houve maior produtividade dos pais e dos cruzamentos do que no plantio de época normal. Menor produtividade no plantio de safrinha em comparação à época normal foi encontrada por Brasil (1998) em dois anos de avaliação.

Nos dialelos de safrinha, as testemunhas não se diferiram quanto à produção de grãos; mas, nos "top-crosses", em que houve maior severidade das doenças, como era previsto maior nivel de resistência para a testemunha T1, esta foi significativamente mais produtiva que a testemunha T2 (Tabelas 20 e 26). Em todos os experimentos, a média das testemunhas diferiu da média do dialelo ou do "top-cross"; sendo que, alguns acessos e muitos cruzamentos, principalmente nos experimentos 1 e 2 , tenderam a ser superior à testemunha e ao hibrido comercial menos produtivos (Tabelas 8 e 14). Boa performance de alguns materiais foi observada também no plantio de época normal na Caterpillar e em Rio Verde, onde alguns cruzamentos se apresentaram tão produtivos quanto as testemunhas. Isto mostra que em condições de safrinha na ausência de doenças, e no plantio normal, alguns dos acessos avaliados podem apresentar maior 
potencial para uso per se ou podem, em cruzamentos, gerar híbridos mais produtivos que alguns materiais comerciais.

Os modelos estatístico-genéticos utilizados no presente trabalho, Miranda Filho \& Geraldi (1984) e Chaves \& Miranda Filho (1997), fornecem informações sobre o potencial genético dos progenitores quanto ao seu valor per se $\left(\mathrm{v}_{\mathrm{i}}\right)$ e em cruzamentos com base no estudo da heterose. O primeiro modelo permite o detalhamento da heterose $\left(h_{i j}\right)$ em heterose média $(\bar{h})$, heterose de variedade $\left(h_{i}\right.$ e $\left.h_{j}\right)$ e heterose especifica $\left(s_{i j}\right)$, enquanto que, o segundo fornece a heterose média e a heterose de variedade. Neste último, os autores não incluem a heterose específica por ela não ser estimável pelo modelo; mas consideram que isto não deve causar transtornos nos resultados, uma vez que a heterose especifica parece ser a fonte menos importante de variação em dialelos de variedades, e além disso, tem se mostrado ser não significante na análise de variância de muitos estudos. Bellucci (1994) relata que a perda de informações pelo uso do modelo reduzido não é tão importante quando o interesse é apenas em conhecer o potencial das variedades, mas, torna-se importante quando o interesse é a obtenção de hibridos intervarietais ou híbridos de linhagens provenientes destas variedades.

No presente trabalho, em 61 análises de dialelos parciais, foi detectada significância para a heterose especifica em 18 análises; sendo que, em cinco destas (uma para resistência à mancha de Phaeosphaeria, uma para altura de espiga, uma para comprimento de espiga, duas para diâmetro de espiga e duas para produção de grãos) a magnitude do quadrado médio da heterose especifica foi maior que a magnitude do quadrado médio da heterose dos acessos. Contudo, em nenhuma análise, os efeitos $s_{i j}$ foram estimados, porque o objetivo não foi identificar cruzamentos especificos para a obtenção de híbridos.

As estimativas de heterose média $(\bar{h})$ e dos efeitos de variedade $\left(v_{i}\right)$, heterose de variedade $\left(h_{i}\right)$ e de capacidade geral de combinação $\left(g_{i}\right)$ mais favoráveis podem ser positivas ou negativas, dependendo do caráter e do objetivo da seleção. Estimativas negativas são mais favoráveis quando indicam, por exemplo, menor nota de severidade ou menor porcentagem de incidência de uma doença, plantas de menor altura e mais baixa inserção de espiga, etc.; enquanto que, estimativas positivas são mais favoráveis 
quando indicam plantas de maiores valores de rendimento e dos componentes de rendimento.

A significância da heterose média $(\bar{h})$ e a da heterose de variedade $\left(h_{i}\right.$ ou $\left.h_{j}\right)$ indicam, respectivamente, que a média dos cruzamentos é diferente da média dos pais, e que os parentais de um ou de outro grupo de progenitores diferem entre si quanto à manifestação da heterose. A significância de $v_{i}$ ou $h_{i}$ implica em diferenças entre os efeitos de capacidade geral de combinação $\left(\mathrm{g}_{\mathrm{i}}\right)$. Nos casos em que a heterose média $(\overline{\mathrm{h}})$ não difere de zero e a heterose de variedade $\left(h_{i}\right)$ e/ou a heterose especifica acusam significância, segundo Vencovsky \& Barriga (1992), pode-se inferir que ocorre dominância não unidirecional, e que a heterose é positiva em alguns cruzamentos e igualmente negativa em outros. Este fato foi observado para mancha de Phaeosphaeria nos experimentos 1 e $3 C$, ferrugem tropical (2C), podridão de colmo (3), acamamento (1R), altura de planta (3R), altura de espiga (4A) e diâmetro de espiga (1).

No presente estudo foi detectada significância da $\overline{\mathrm{h}}$ para alguns caracteres em alguns experimentos.

Para a mancha de Phaeosphaeria, as estimativas negativas da heterose média nos dialelos parciais e as estimativas positivas nos "top-crosses" superprecoces indicaram que o cruzamento com os hibridos resultou em melhor nivel de resistência. Zoccoli (1998) também encontrou estimativas positivas e negativas para a reação à esta doença. Ferreira (1999), em avaliação de top-crosses intragrupo obteve somente estimativas negativas.

Para o complexo enfezamento, na época de safrinha foi estimada maior heterose média no "top-cross" precoce que no superprecoce, ambas negativas, indicando que a incidência média de enfezamento nos cruzamentos ( $13,7 \%$ no experimento 3 e $9,4 \%$ no experimento 4) foi significativamente menor que a incidência média nos acessos $(18,1 \%$ e $12,2 \%$, respectivamente). Com os dados não transformados, as estimativas expressas em porcentagem da média dos pais foram iguais a $-25,3 \%$ no experimento 3 e $-23,7 \%$ no experimento 4. Este valores estão próximos aos encontrados por Basso (1999) na 
análise de dialelos parciais e de "top-crosses" a partir dos dados obtidos da avaliação de incidência e severidade.

Para a porcentagem de plantas acamadas, as estimativas de heterose média foram negativas, evidenciando heterose favorável. Na Caterpillar e em Rio Verde foi detectada significância para a heterose média apenas nos dialelos, indicando que o cruzamento com os híbridos resultou em menor incidência de plantas acamadas. Na Caterpillar, com os dados não transformados, as estimativas expressas em porcentagem da média dos pais (aproximadamente - 40\%) foram maiores que a obtida em Rio Verde no dialelo superprecoce $(-18 \%)$.

Para altura da planta, na maioria dos experimentos houve significância para a heterose média. As estimativas variaram de 7,9 a $15,5 \mathrm{~cm}$ nos dialelos e de 1,8 a $3,1 \mathrm{~cm}$ nos "top-crosses", com exceção do experimento 4 , em que $\vec{h}$ foi igual a $7,5 \mathrm{~cm}$. Nos top-crosses estas estimativas estão abaixo das encontradas por Basso (1999) e Ferreira (1999), que também avaliaram "top-cross" intragrupo e encontraram respectivamente, $\overline{\mathrm{h}}$ igual a 9,6 e $6,1 \mathrm{~cm}$.

Para a produção de grãos, considerando as duas épocas de plantio, as estimativas de heterose média foram maiores nos dialelos em comparação com os "top-crosses", isto mostra que o cruzamento com os híbridos melhora a adaptação dos acessos. Principalmente, o cruzamento com o híbrido $\mathbf{H} 4$ no plantio de safrinha e os híbridos $\mathbf{H 2}$ e H3 no plantio de época normal.

Com exceção dos dialelos do plantio de safrinha, foi observado que a heterose média para esse caráter foi maior nos dialelos precoces que nos superprecoces, e que a divergência entre os grupos de progenitores (acessos e hibridos), medida pelo componente "d" do modelo da análise dialélica, foi maior nos dialelos precoces. Além disso, nas duas épocas de plantio observou-se que a heterose média foi maior nos topcrosses superprecoces em relação aos precoces, e que a variabilidade genética entre os acessos superprecoces apresentou maior magnitude que a variabilidade genética entre os acessos precoces. Estas observaçōes estão de acordo com Falconer (1960), em que a heterose é diretamente proporcional à diferença de frequências alélicas entre os progenitores. 
As estimativas de heterose média expressas em porcentagem da média dos pais se limitaram de 23,7 a 43,2\% nos dialelos, e de 6,0 a 22,1\% nos "top-crosses". Estes valores se assemelham aos obtidos por Basso (1999), que encontrou valores de 17 a $46 \%$ em dialelos parciais de populações exótica versus adaptadas, e valores de 9,4 a 16,6\% nos "top-crosses".

No esquema de cruzamento "top-cross", a média das estimativas de heterose média em porcentagem da produção média dos pais foi maior no plantio de safrinha $(19,1 \%)$ que no plantio de época normal $(13,1 \%)$; enquanto que no dialelo parcial ocorreu o contrário, a média das estimativas foi igual a $28,8 \%$ na safrinha e $35,9 \%$ na época normal. Brasil (1998), num estudo de cruzamento de variedades, também encontrou maiores estimativas de heterose média de produção no plantio de safrinha $(25,2 \%$ e $20,3 \%)$ em comparação com o plantio em época normal $(10,3 \%$ e $18,7 \%)$ e relatou que a tendência de maiores valores para a heterose nos ensaios de safrinha sugere que a condição hibrida é mais adequada aos estresses ambientais. No presente estudo, essa inferência é válida para os "top-crosses", onde os acessos, como anteriormente mencionado, produziram muito pouco e apresentaram maior severidade das doenças. Nos dialelos, foi utilizado um menor número de progenitores no plantio de safrinha em relação à época normal, o que não permite fazer inferência segura na comparação entre as estimativas da heterose média das duas épocas.

A média de todos os valores de heterose média obtidos para a produção nos "topcrosses" (14,6\%) está próxima ao valor médio de $19,5 \%$ observado por Hallauer \& Miranda Filho (1981) em 1394 cruzamentos intervarietais obtidos por diversos autores, onde as estimativas se limitaram de $-3,6 \%$ a $50,3 \%$. No entanto, as estimativas de heterose média relativamente elevadas obtidas nos cruzamentos entre os acessos e os hibridos, possivelmente são devidas ao fato de terem sido utilizadas as gerações $F_{2}$ dos hibridos, que devido ao intercruzamento, expressam depressão endogâmica reduzindo a média dos pais. Assim, o excesso de heterose em relação à heterose dos cruzamentos intervarietais parece ser devido à recuperação do vigor perdido pelas gerações $F_{2}$; pois, Miranda Filho (1999) relata que parte da heterose é meramente a recuperação do vigor perdido quando um ou ambos os pais expressam depressão endogâmica. 
Para caracteres poligênicos, as gerações $F_{2}$ estão em equilibrio de HardyWeinberg para locos individuais e o coeficiente de endogamia é $\mathrm{F}=0$ tomando a própria geração $F_{2}$ como população de referência. Entretanto, uma geração $F_{2}$ de hibridos comerciais pode ser considerada como uma população de tamanho reduzido, resultante de cruzamentos de duas, três ou quatro linhagens nos hibridos simples, triplos e duplos, respectivamente. Consequentemente, devido ao tamanho reduzido, pode haver uma grande proporção de locos fixados em frequências alélicas 0 ou 1 , sendo a depressão endogâmica um fenômeno inevitável (Miranda Filho, 1999). Assim, tem-se, normalmente, uma considerável redução da média de produção quando se passa da geração $F_{1}$ de hibridos comerciais para a $F_{2}$. Tais perdas têm sido variáveis, dependendo dos materiais em estudo, Basso (1999) encontrou perdas de 18 a 69\%, Bellucci (1994) encontrou uma redução média de $28,1 \%$, e cita que reduções da mesma magnitude foram encontradas por outros autores. No presente estudo, não foi possivel estimar tais perdas, uma vez que as gerações $F_{1}$ não foram utilizadas; no entanto, com exceção dos experimentos 2 e $2 \mathrm{C}$, nos demais as gerações $\mathrm{F}_{2}$ dos hibridos comerciais apresentaram em média, significativamente, menor produção de grãos que os acessos.

$\mathrm{Na}$ análise dialélica, a menor magnitude do quadrado médio dos progenitores (acessos e hibridos) em relação ao quadrado médio da heterose dos progenitores revela a maior importância do segundo. E, além disso, quando simultaneamente ocorre significância para ambas fontes de variação, pode-se inferir que os efeitos não aditivos tiveram maior contribuição para a variabilidade, uma vez que a heterose é função de efeitos não aditivos em nivel interpopulacional. Mas, por outro lado, quando o quadrado médio dos progenitores apresenta maior magnitude que o quadrado médio da heterose dos progenitores, não se pode afirmar que os efeitos aditivos foram mais importantes em contribuir para a variabilidade; pois, as diferenças entre variedades de polinização livre, medidas pelos $v_{i}$ 's, incluem efeitos aditivos e não aditivos intrapopulacionais.

No presente estudo, dependendo dos parentais envolvidos nos cruzamentos, os efeitos de variedade foram mais importantes em alguns casos, e os efeitos de heterose de variedade em outros. 
Para mancha de turcicum, porcentagem de colmos quebrados, porcentagem de plantas acamadas, altura de planta e altura de espiga, como foi observado por também por Ferreira (1999), em todos ou em quase todos experimentos os efeitos de variedades contribuiram mais para a variabilidade do que os efeitos de heterose de variedade.

Para a mancha de Phaeosphaeria, no experimento 4 houve equivalência entre o quadrado médio dos acessos e o quadrado médio da heterose dos acessos, enquanto que, nos demais experimentos foi observado predominância do quadrado médio dos progenitores. Assim, na maioria dos experimentos, as variedades se diferiram mais pelo seu valor per se do que pela heterose dos seus cruzamentos. Nos experimentos $1,1 \mathrm{C}$ 2C (Tabelas 9, 38 e 55) a significância da heterose específica indicou que os efeitos não aditivos foram importantes em contribuir para a variabilidade; no entanto, o presente estudo não permite identificar os efeitos aditivos e não aditivos. A importância destes últimos foi observada por Das et al. (1989). Estes autores em um dialelo de nove variedades encontraram maior variabilidade associada aos efeitos da CEC $(0,138)$ em relação à $\operatorname{CGC}(0,017)$.

Para a ferrugem comum, nos experimentos 1, 2 e 4 (Tabelas 9, 15 e 27), o quadrado médio dos acessos apresentou maior magnitude que o quadrado médio da heterose dos acessos, enquanto que, no experimento $\mathbf{3}$, foi observado o contrário, mesmo não tendo sido detectada diferença entre os acessos (Tabela 21). Para os híbridos comerciais, quando cruzados com acessos precoces, houve maior magnitude do quadrado médio dos híbridos; enquanto que, no cruzamento com os acessos superprecoces, houve maior magnitude do quadrado médio da heterose dos híbridos. Portanto, estas observaçōes associadas à não significância da heterose média em todos os experimentos indicam que os efeitos não aditivos parecem ser de menor importância na herança da reação à ferrugem comum, estando em concordância com o trabalho de Gingera et al. (1995), em que num estudo de média de gerações, estes autores encontraram efeito de dominância, no entanto, efeito aditivo ocorreu na maioria dos cruzamentos.

Para a ferrugem tropical, de um modo geral os efeitos de variedade dos progenitores tiveram maior importância que os efeitos de heterose dos progenitores. 
Porém, nos experimentos $\mathbf{2 C}$ e $\mathbf{3 C}$, o quadrado médio dos acessos não diferiu muito do quadrado médio da heterose dos acessos; além disso, no experimento $\mathbf{2 C}$, a significância da heterose, evidenciando a possibilidade de exploração de combinações hibridas, foi devida à heterose específica, indicando que os efeitos não aditivos tiveram importância para a variabilidade da reação à ferrugem tropical (Tabela 55). No entanto, Lima et al. (1998), através de um estudo de médias de gerações, relataram que efeitos de dominância foram menos expressivos.

Para a ferrugem polysora, os quadrados médios dos acessos e da heterose dos acessos apresentaram magnitude semelhante, e ambos foram não significantes (Tabelas 72 e 89). Ferreira (1999) utilizou análise de "top-cross" intragrupo também, mas, diferentemente, encontrou que os efeitos de variedade foram preponderantes para a variação na severidade. Alguns trabalhos sobre a herança da reação ao Puccinia polysora (Barbosa et al., 1998; Pinho et al., 1998b) mostram que os efeitos de dominância foram importantes, porém, menos que os efeitos aditivos.

Para podridão do colmo, considerando apenas os "top-crosses", houve maior importância dos efeitos de variedade. Os efeitos de heterose de variedade em relação aos efeitos de variedade foram menos importantes para os acessos superprecoces do que para os acessos precoces (Tabelas 27 e 21). Possivelmente, isto tenha contribuido para a diferença entre os acessos precoces quanto à manifestação da heterose, portanto, os efeitos não aditivos foram importantes em contribuir para a variabilidade. A ação gênica predominante na resistência à podridão do colmo varia com os genótipos utilizados nos cruzamentos e com o patógeno. Cosmin et al. (1988) relataram que a resistência ao Fusarium foi controlada por genes dominantes. Segundo (Hooker, 1978), a resistência ao Diplodia envolve ação gênica aditiva, dominante e em alguns casos epistasia. Pereira et al. (1989) concluiram que a importância dos efeitos aditivos ou de dominância para a resistência à antracnose do colmo variou com os cruzamentos, sendo que Uthaiwan (1985) encontrou maior contribuição do efeito aditivo.

Para o complexo enfezamento, na época de safrinha, tanto nos dialelos parciais como nos "top-crosses", os efeitos de variedade dos acessos, quanto à sua magnitude, foram mais importantes que os efeitos de heterose de variedade. Nos experimentos 3 e 4 , 
a importância dos $v_{i}^{\prime}$ 's em comparação com os $h_{i}$ 's foi maior para os acessos superprecoces do que para os acessos precoces. Assim, pode-se se inferir que no esquema de cruzamento "top-cross", os efeitos não aditivos foram menos importantes para os acessos superprecoces, o que resultou na menor estimativa de heterose média no experimento 4. Para os hibridos, quando cruzados com acessos precoces, os efeitos de heterose de variedade foram mais importantes; enquanto que, no cruzamento com os acessos superprecoces, houve maior importância dos efeitos de variedade nos hibridos. Estas observações concordam em parte com o trabalho realizado por Basso (1999), onde foi encontrada maior magnitude para o quadrado médio dos progenitores do que para o quadrado médio da heterose dos progenitores.

Para a produção de grãos, em quase todos os experimentos, exceto $\mathbf{1 R}$, o quadrado médio dos progenitores apresentou maior magnitude que o quadrado médio da heterose dos progenitores, indicando a maior importância dos efeitos de variedade. No entanto, no plantio de safrinha, no dialelo parcial superprecoce (experimento 2 ) houve indicativo de maior importância dos efeitos de heterose de variedade para os híbridos. Nos "top-crosses", os efeitos de variedade em relação aos efeitos de heterose de variedade foram mais importantes para os acessos superprecoces, indicando que os efeitos não aditivos foram menos importantes para estes acessos do que para os precoces. Contudo, a heterose média foi maior nos "top-crosses" superprecoces em relação aos precoces. Como a variabilidade genética entre os acessos superprecoces apresentou maior magnitude que a variabilidade genética entre os acessos precoces, pode-se inferir que as maiores estimativas de heterose média nos "top-crosses" superprecoces podem ter ser sido devidas muito mais à divergência entre estes acessos do que aos efeitos de dominância.

Um composto de variedades tem sido definido como uma população obtida pelo intercruzamento e recombinação de duas ou mais variedades de polinização livre (Miranda Filho \& Chaves, 1991) com o objetivo de reter alta variabilidade genética para que eles possam ser utilizados como populações base em programas de seleção recorrente (Miranda Filho \& Vencovsky, 1984) 
Hallauer \& Miranda Filho (1981) relatam que a produção do composto é esperada ser maior que a média de produção das variedades parentais. No presente trabalho, na estimação das médias de cada composto houve um ganho genético em relação à média de todos os cruzamentos antes da seleção. O ganho estimado do melhor composto na época de safrinha foi igual a $49 \%$ e $48,4 \%$ nos experimentos 3 e 4 ; e na época de plantio normal, 19,3\%, 5,7\% e $17,0 \%$ nos experimentos $3 \mathrm{~A}, 3 \mathrm{C}$ e $3 \mathrm{R}$, e $27,4 \%$, $25,4 \%$ e $23,7 \%$ nos experimentos 4 A, 4 C e 4 R. Estes valores estão em concordância com os obtidos por Basso (1999), que também utilizou a predição proposta por Chaves \& Miranda Filho (1997) e estimou ganhos de 9,1 a 37,7\%.

No presente estudo pode-se inferir que os menores ganhos estimados para os compostos precoces em relação aos superprecoces indicam que a divergência entre os acessos 20 e 23 foi menor que a divergência entre os acessos 30s, 21s e 22s. Além disso, as maiores estimativas de ganho com os dados de safrinha podem ter sido devidas ao fato de a condição híbrida, conforme inferiu Brasil (1998), ser mais adequada aos estresses ambientais. 


\section{CONCLUSÕES}

1) A seleção feita com base na avaliação dos 1273 acessos realizada pelo grupo NAP-Milho foi mais efetiva para as ferrugens tropical e polysora. Além disso, essa seleção com base em avaliação apenas na época normal de plantio possivelmente não incluiu genótipos que poderiam apresentar melhor nivel de resistência à ferrugem comum e ao complexo enfezamento;

2) A mancha de Phaeosphaeria foi a doença de maior abrangência, ocorreu em todos os locais e nas duas épocas de plantio, sendo a principal doença no plantio de época normal; enquanto que na época de safrinha, ferrugem comum, podridão do colmo e enfezamento foram as principais doenças;

3) Na ausência de doenças, os acessos avaliados podem ser mais produtivos na época de safrinha do que na época normal de plantio, sendo possivel, em condição de safrinha, selecionar acessos tão produtivos quanto os híbridos comerciais utilizados como testemunhas;

4) Os dois modelos de análise genética utilizados foram eficientes para o estudo do valor genético. O "top-cross" permitiu identificar os acessos de maior potencial para a formação de compostos de variedade a serem usados como populações base. O dialelo parcial permitiu a observação de que alguns dos acessos avaliados apresentam potencial para serem usados em cruzamentos, resultando em hibridos mais produtivos que alguns materiais comerciais; permitiu também a identificação dos acessos de maior potencial para introgressões com os hibridos comerciais, sendo, portanto, um modelo mais adequado ao estudo do valor genético para dar subsidio à introgressão e à seleção recorrente recíproca. 
5) $\mathrm{O}$ cruzamento com as gerações $\mathrm{F}_{2}$ dos híbridos comerciais contribuiu para maior produção de grãos, menor altura de planta e de espiga e maior nivel de resistência à mancha de Phaeosphaeria, ’a ferrugem comum e ao acamamento;

6) As estimativas de heterose média negativas para enfezamento e acamamento, e positivas para a produção de grãos indicaram a possibilidade de obtenção de compostos de variedades apresentando ganhos genéticos satisfatórios. Os efeitos não aditivos foram mais importantes para estes caracteres que para os demais, sendo que a sua importância varia conforme os progenitores e as condições ambientais;

7) O acesso CMS 50, tanto para o plantio de saffinha como de época normal, foi um dos que apresentaram melhor performance, principalmente para produção. 


\section{REFERÊNCIAS BIBLIOGRAFLAS}

ABEDON, B.G.; TRACY, W.F. Direct and indirect effects of full-sib recurrent selection for resistance to common rust (Puccinia sorghi Schw.) in three sweet corn populations. Crop science, v.38, n.1, p.56-61, Jan-Feb 1998.

AGROCERES. Guia de Sanidade. 2ed. São Paulo: Sementes Agoceres S/A, 1996. 72p.

AMORIM, L. Avaliação de Doenças. In: FILHO, A. B.; KIMATI, H. \& AMORIM, L. Manual de Fitopatologia. São Paulo: Ceres, 1995. Capp. 32, p. 647-671: Avaliação de Doenças

ANUAR-UL-HAQ \& NASIR, M. A. Screening of Different Maize Cultivars for Resistance against Stalk Rot. Pakistan Journal of Phytopathology., v.6, n. 1, p.31 $-34,1994$.

BADU-APRAKU, B. The Inheritance and Nature of Resistance to Anthracnose Leaf Blight and Stalk Rot of Corn. Dissertation-Abstracts, B. Sc. and Engineering. 1987. $144 p$

BAILEY, B.A.; SCHUH, W.; FREDERICKSEN, R.A.; et al. Identification of show rusting resistance to Puccinia polysora Underw. in inbreds and single crosses. Plant Disease. v.71, p. 518-521, 1987.

BALMER, E. Doenças do Milho In: GALli F. Manual de Fitopatologia . 3ed, São Paulo: Agronômica Ceres, 1980. cap. 27, 371-379. 
BALMER, E. ; PEREIRA, O. A. P. Doenças do Milho. In: PATERNIANI, E. \& VIÉGAS, G. P. Melhoramento e Produção do Milho. Campinas: Fundação Cargill, 1987. Cap. 14, p. 597-634.

BALMER, E. Considerações fitopatológicas no melhoramento do milho visando resistência a patógenos. In: ENCONTRO SOBRE TEMAS DE GENÉTICA E MELhORAMENTO, 12., Piracicaba, 1995. Anais. Piracicaba: Departamento de Genética/ ESALQ, 1995. p. 1-10.

BARBOSA M. P. M.; SILVA H. P.; CAMARGO L. E. A. Avaliação Quantitativa de Resistência a Puccinia polysora Underw. em Milho( Zea mays L). In: CONGRESSO NACIONAL DE MILHO E SORGO, 22., Recife, 1998. Globalização e segurança alimentar; resumos. Recife: ABMS / EMBRAPA / IPA, 1998. p. 24.

BASSO, C. M. Síntese de Compostos de Milho (Zea mays L.) com Resistência ao Complexo de Enfezamento. Piracicaba, 1999. 122p. Tese (Doutorado) - Escola Superior de Agricultura "Luiz de Queiroz", Universidade de São Paulo.

BEDENDO, I.P. Ferrugens. In: BERGAMIN FILHO, A.; KIMATI, H.; AMORIN, L. Manual de Fitopatologia. São Paulo: Agronômica Ceres, 1995.cap. 48, 872-880: Ferrugens.

BELLUCCI, A A. Avaliação de populações derivadas de hibridos de milho (Zea mays L.) em ceuzamentos nos esquemas dialélico e "top-cross". Piracicaba, 1994. 133p. Dissertação (Mestrado) - Escola Superior de Agricultura "Luiz de Queiroz", Universidade de São Paulo.

BENNETZEN, J.L.; QUIN, M.; INGELS, S.; ELLINGBOE, A.H. Allelic-specific and mutator-associated instability at the Rpl disease-resistance locus of maize. Nature, v.332, p.369-70, 1988. 
BRASIL E. M.; CARVALHO Y. Comportamento de Hibridos de Milho em Relação a Phaeosphaeria Maydis em Diferentes Épocas de Plantio Pesquisa Agropecuária Brasileira, v.33, n.12, p. 1977-1981, Dez. 1998.

BREWBAKER, J, L.; ROBERTSON, D. C. Rsistance of tropical maize inbreds to maijor virus and virus-lika disease. Maydica, v.36, p.257-265, 1991

CAlub, A. G.; DUnN, G. .M.; ROUTLEy, D. G.; COUTURE, R.. M. Genetic and environmental effects or production of inibition compounds in corn resistant to Helminthosporium turcicum. Crop Science, Madison, v. 14, p.359-61, 1974.

CAMARGO, L. E. A.; BERGAMIN FILHO, A. Controle genético. In: BERGAMIN F ${ }^{O}$, A.; KIMATI, H. E AMORIN, L. Manual de fitopatologia.. São Paulo: Agronômica Ceres, 1995.capp.37, p.729-760: Controle genético

CARSON, M. L. Inheritance of Latent Period Length in Maize Infected with Exserohilum turcicum. Plant Disease, v.79, n.6, p.581-585, Jun 1995.

CARSON, M. L. \& HOOKER, A. L. Reciprocal Translocation Testcross Analysis of Genes for Anthracnose Stalk Rot Resistance in a Corn Inbred Line. Phytopathology, v.72, n.2, p.175-177, 1982.

CARSON, M. L., STUBER, C. W.; SENIOR, M. L. Identification of Quantitative Trait Loci (QTLs) for Resistance to two Foliar Diseases in a Mapping Population of Recombinant Inbred (RI) Lines of Maize. Abstract. Phytopathology, v. 86: 59, 1996.

CARSON, M.L. Vulnerability of U. S. Maize Germplasm to Phaeosphaeria Leaf Spot. Plant Disease, v. 83, n. 5, p.462-464. 1999.

CEBALLOS, H.; DEUTSCH, J.A; GUTIERREZ, H. Recurrent selection for resistance to Exserobilum turcicum in eight subtropical maize populations. Crop Science, v.31, n. 4, p.964-971, 1991 
CHANG, T.T.. Availability of plant germplasm for use in crop improvement. In: H.T. Stalker; J.P. Murphy . Plant Breeding in the 1990s. Redwood Press Ltd.,, Melksham, p.17-35,1992.

CHAVES, L. J. \& MIRANDA FILHO, J. B. Predicting variety composite means without diallel crossing. Brazilian Journal of Genetics, v.20, n.3, p.501-506. 1997.

COE JUNIOR, E.H.; NEUFFER, M.G.; HOISINGTON, D.A. The genetics of corn. In: SPRAGUE, G.F.; DUDLEY, J.W. (Ed.) Corn and corn improvement. Madison: ASA/CSSA/SSSA, 1977. Cap. 3, p.81-258.

COSMIN, O.; CRAICIU, D.; SARCA, T.; BICA, N.;CIOCAZANU, I. \& RESTEA, T. The Inheritance of Resistance to Stalk Lodging and Ear Rot, caused by Fusarium graminearum Schw. and Fusarium moniliform Sheld. in Maize and its Importance for Breeding Programmes. Abstracts. Probleme de Genetica Teoretica si Aplicata, v.20, n.2, p.75 - 107. 1988.

CRUZ, C. D. \& REGAZZI, A. J. Modelos Biométricos Aplicados ao Melhoramento Genético. Viçosa:UFV,Impr.Univ., 1994. 390p.

DAS, S.N.; SINHAMAHAPATRA, S.P.; BASAK, S.L. Inheritance of resistance to phaeosphaeria leaf spot of maize. Annals of Agricultural Research, v.10, n.2, p. 182-4, 1989.

DAVIS, D.W.; ENGELKES, C.A.; GROTH, J.V. Erosion of resistance to common leaf rust in exotic-derived maize during selection for other traits. Phytopathology, v.80, p.339-342, 1990.

DAVIS, R. E. Occurrence of a spiroplasma in corn stunt plants in Mexico. Plant Disease Report, Sain Paul. V.57, pp.333-337, 1973. 
DAVIS, R.L . Report of the plant breeder. Rep. Puerto Rico Agric. Exp. Stn, p.14-15, 1927

DE LÉON, C. Maize Disease, a guide for field identification. México: Centro Internacional de Mejoramento de Maíz y Trigo (CIMMYT), 1984. 114p.

DE LÉON, C. Moléstias do Milho - guia para sua identificação no campo. 2.ed. Campinas: Fundação Cargill.. 1994. 119p.

DELANEY,-D. E.; WEBB,-C. A.; HULBERT,-S. H. Molecular-plant-microbeinteractions MPMI USA, v. 11, n.3, p. 242-245, Mar 1998

DEMÉTRIO, C. G. B. Transformações de dados: efeito sobre a anállise de variância. Piracicaba, 1978. 113p. Tese (Doutorado) - Escola Superior de Agricultura "Luiz de Queiroz", Universidade de São Paulo.

EBERHART, S.A., W. SALHUANA, R. SEVILlA, AND S. TABA.. Principles for tropical maize breeding. Maydica, v. 40, p. 339-355, 1995.

FALCONER, D. S. Introduction to Quantitative Genetics. New York, The Ronald Press, $1960,365 p$.

FERnandes, F. T.; Oliveira, E. Principais Doenças na Cultura do Milho. Sete Lagoas: EMBRAPA-CNPMS, Circular Técnica, 26, 1997. 80p.

FERREIRA, J. M. Análise genética e sintese de populações visando resistência à ferrugem (Puccinia poly:sora Underw.) em milho (Zea mays L.). Piracicaba, 1999. 230p. Tese (Doutorado) - Escola Superior de Agricultura "Luiz de Queiroz", Universidade de São Paulo.

FREYMARK, P.J.; LEE, M.: MARTINSON, C.A. et al. Molecular marker-facilited investigation of host-plant response to Exserohilum turcicum in maize (Zea ma\}s L.): components of resistance. Theoretical and Applied Genetics, v.88, p.305$313,1994$. 
FREYMARK, P.J.; LEE, M.; WOODMAN, W.L. et al. Quantitative and qualitative trait loci affecting host-plant response to Exserohilum turcicum in maize (Zea mays L.). Theoretical and Applied Genetics, v.87, p.537-544, 1993.

FUTRELL, M.C.; HOOKER, A.L.; SCOTT, G.E. Resistance in maize to corn rust, controlled by a single dominant gene. Crop Science, v. 15, p.597-599, 1975.

GAMEZ, R. Maize "rayado fino" disease: the virus-host-vector interactions in neotropical enviroments. In: Proceedings of the International Maize Virus Disease Colloquium and Workshop. Ohio. E. U. Gordon Ed.: Knoke, Nault and Ritter, 1983, p. 62-68.

GARDNER, C.O. Simplified methods for estimating constants and computing sums of squares for a diallel cross analysis. Fitotecnia Latino Americana.v.4, p.1-12, 1967.

GARDNER, C.O.; EBERHART, S.A. Analysis and interpretation of the variety cross diallel and related populations. Biometrics, v.22, p.439-452, 1966.

GERALDI, I.O.; MIRANDA FILHO, J.B. Adapted models for the analysis of combining ability of varieties in partial diallel crosses. Revista Brasileira Genética, v. 11, p.419$430,1988$.

GEVERS, H.O. A new major gene for resistance to Helminthosporium turcicum leaf blight of maize. Plant Disease Reporter, v. 59, p.296-299, 1975.

GINGERA, G.R.; DAVIS, D.W. Identification and inheritance of delayed first pustule appearance to common leaf rust in sweet corn. Journal of American Society Horticultural Science, v. 120, n.4, p.667-672, 1995.

GINGERA, G.R.; DAVIS, D.W.; GROTH, J.V. Pedigree selection for improved partial resistance to common leaf rust in sweet corn. Crop Science, v.34, n.3, p.615-620, may-jun 1994. 
GOODMAN, M.M.. Genetic and germplasm stocks worth conserving. Journal of Heredity v. 81, p. $11-16,1990$.

GORDON, D. T.; NAULT, R.; GORDON, N. H.; HADY, S. E. Serological deteccion of corn stunt espiroplasma and maize "rayado finino" virus in fieeld collected Dalbulus sp. From Mexico. Annual Review of Phypathology, v.23, p.391-426, 1985.

GRIFFING, B. Concept of general and specific combining ability in relation to diallel crossing systems. Australian Journal Biology Science, v.9, p.463-493, 1956.

GROTH, J.V.; DAVIS, D.W.; ZEYEN, R.J.; MOGEN, B.D. Ranking of partial resistance to common rust (Puccinia sorghi Schw) in sweet corn (zea mays) hybrids. Crop Protection, v.2, p.219-23, 1983.

GROTH, J.V.; PATAKY, J.K.; GINGERA, G.R. Virulence in eastern North American populations of Puccinia sorghi to Rp resistance genes in corn. Plant Disease, v.76, p.1140-1144, 1992.

HALlAUER, A. R. \& MIRANDA FILHO, J. B. Quantitative Genetics in Maize Breeding. Iowa State: Univ. press. 1981. 468p.

HARRISON NA, RICHARDSON PA, TSAI JH. PCR Assay for detection of the phytoplasma associated with maize bushy stunt disease. Plant Disease, v.80, n.3, p. 263-269, Mar 1996.

HEADRICK, J.M.; PATAKY, J.K. Effects of night temperature and mist period on infection of sweet corn by Puccinia sorghi. Plant Disease, v. 70, p.950-953, 1986.

HECKMAN, J. R. Corn stalk rot suppression and grain yield response to chloride. Journal of Plant Nutrition, v.21, n.1, p. 149-155, 1998

HILU, H.M.; HOOKER, A.L. Monogenic chlorotic lesion resistance to H. turcicum. in corn seedlings. Phytopathology, v.53, p.909-912, 1963. 
HOLLAND JB, UHR DV, JEFFERS D, GOODMAN MM. Inheritance of resistance to southern corn rust in tropical by corn-belt maize populations. Theoretical and Applied Genetics, v.96, n.2. p.232-241, Feb 1998.

HOOKER, A. L. Genetics of Disease Resistance in Maize. In: WALDEN, D. B. John Wiley \& Sons Maize Breeding \& Genetics. New York, 1978. 794p.

HOOKER, A.L. Widely based resistance to rust in corn. In: BROWNING, J.A. (Ed.) Disease consequences of intensive and extensive culture of field crops. Iowa Agric. Home Econ. Exp. Stn. Spec. Rep., 1969 n.64, p.28-34.

HU, G.S.; HULBERT, S. Construction of "compound" rust resistance genes in maize. Euphytica, v.87, p.45-51, 1996.

HUGHES, G.R.; HOOKER, A.L. Gene action conditioning resistance to northern leaf blight in maize. Crop Science, v.11, p.180-184, 1971.

HULBERT, S. H. Structure and evolution of the rpl complex conferring rust resistance in maize. Annual Review of Phytopathology, v.35, p. 293-310. 1997

JENKINS, M.T.; ROBERT, A.L.; FINDLEY JÚNIOR, W.R. Inheritance of resistance to Helminthosporium turcicum leaf blight in populations of $F_{3}$ progenie. Agronomy Journal, Madison, v.44, p.438-42, 1952.

JUGENHEIMER, R. W. Corn: Improvement, Seed Production, and Uses. New York: Wiley-Interscience, 1976.670p.

KEMPTHORNE,O.; CURNOW,R.N. The partial diallel cross. Biometrics, v.17, p.229$250,1961$.

KIM, S.K.; BREWBAKER, J.L. Inheritance of general resistance in maize to Puccimia sorghi Schw. Crop Science, v. 17, p.456-461, 1977. 
KOVACS, K.; KOVACS, G. \& MESTERHAZY, A. Expression of Resistance to Fusarial Ear Blight in Corn Inbreds and their Hybrids. Maydica, v.39, n.3, p.187190, 1994.

LAMBERT, R. J. Registration of R228, R229, and R230 parental lines of maize. CropScience, v. 36, n. 3, p. 827,1996

LIM, S.M.; HOOKER, A.L.; PAXTON, D.J. Isolation of phytoalexins from corn with monogenic resistance to Helminthosporium urcicum. Phytopathology, v.60, p.1071-1074, 1970.

LIMA, M.; MIRANDA FILHO, J.B.; DUDIENAS, C.; SORDI, G. D. Herança da resistência à ferrugem tropical causada por Physopella Zeae em milho. In: CONGRESSO NACIONAL DE MLHO E SORGO, 22., Recife, 1998. Globalização e segurança alimentar; resumos. Recife: ABMS / EMBRAPA / IPA, 1998. p. 39.

LIMA, M; PATERNIANI, M.E.A.G.Z; DUDIENAS, C. et al. Avaliação da resistência à ferrugem tropical em linhagens de milho. Bragantia, v.55, n.2, p.269-273, 1996.

MARSHALL, D.R.. Limitations to the use of germplasm collections. In: A.D.H. BROWN; O.H. FRANKEL; D.R. MARSHALL; J.T. WILLIAMS eds. The Use of Plant Genetic Resources. Cambridge University Press, London., 1989. p. 105-120.

MC GEE, D.C. Maize disease: a reference source for seed technologists. 2.ed. St Paul: Press: American Phytopathological Society, 1990. 150p.

MENTEN, J.O.M.; PARADELA, A.L.; MARTINS, L.M.D.; ARANTES, S.R.A Reação de genótipos de milho a Phaeosphaeria maydis e efeitos na produtividade. Ecossistema, v.21, p.72-74. 1996. 
MESTERHAZY, A. Relationship between Resistance to Stalk Rot and Ear Rot of Corn influenced by Rind Resistance, Premature Death and the Rate of Drying of the Ear. Abstracts. Maydica, v.28, n.4, p.425-437, 1983.

MILES, J. W.; DUDLEY, J. W.; WHITE, D. G. \& LAMBERT, R. J. Response to Selection for Resistance to Four Diseases in Two Corn Populations. Crop Science, v.21, n.6, p.980-983, 1981.

MIRANDA FILHO, J. B. \& GERALDI, I. O. An adapted for the analysis of partial diallel crosses. Brazilian Journal of Genetics, v.7, p.677-688, 1984.

MIRANDA FILHO, J.B. Inbreeding Depression and Heterosis. In: COORS, J. G.; PANDEY, S. The Genetics and Exploration of Heterosis in Crops.Madison: ASA, 1999. cap. 7, p. 69-80: Inbreeding Depression and Heterosis.

MIRANDA FILHO, J.B.; CHAVES, L.J. Procedures for selecting composites based on prediction methods. Theoretical and Applied Genetics, v.81, p.265-271, 1991.

MIRANDA FILHO, J.B.; VENCOVSKY, R. Analysis of diallel crosses among open pollinated varieties of maize (Zea mays L.). Maydica, v.29, p.217-234, 1984.

MOREIRA JÚNIOR, W. N. Compnentes de heterose a partir de testadores reciprocos intergrupos em linhagens de milho (Zea mays L.). Goiânia, 1995. 114p. Dissertação (Mestrado) - Escola de Agronomia/ Universidade Federal de Goiás.

MOSTAFA, M. A. M. Selection for Resistance to Corn Stalk Rot Caused by Gibberella zeae and Correlated Effects on Agronomic Traits. DissertationAbstracts, B.Sc. and Engineering. 1987. 80p

MOYA-RAYGOZA G, NAULT L R Transmission biology of maize bushy stunt phytoplasma by the corn leafhopper (Homoptera : Cicadellidae). Annals of the Entomological Society of America, v.91, n. 5, p.668-676, Sep 1998 
NARRO-LEÓN, T.P.; MIRANDA FILHO, J.B. Síntese de populações de milho com resistência a doenças viróticas e complexo "com stunt". In: CONGRESSO NACIONAL DE MILHO E SORGO, 22., Recife, 1998. Globalização e segurança alimentar; resumos. Recife: ABMS / EMBRAPA / IPA, 1998. p. 37.

NASS, L.L. Pré-melhoramento em milho (Zea may's L.). In: MARIANTE, A.S.; BUSTAMANTE, P.G. (eds) SIMPÓSIO DE RECURSOS GENÉTICOS PARA AMÉRICA LATINA E CARIBE - SIRGEALC, 2., 1999, Brasilia. Anais. Brasilia: Embrapa Recursos Genéticos e Biotecnologia, 1999. CD-ROM. 4p.

NASS, L.L.; I.J. PELLICANO; VALOIS, A.C.C. Utilization of genetic resources for maize and soybean breeding in Brazil. Brazilian Journal of Genetics v. 16, p.983-988, 1993.

NOVOA, A. D. \& RUSSELL, W. A. Harvest Index Analyses in Three Improved Maize Synthetics. Rev. Brasil. Genet., v.11, n.2, p.355-367. 1988.

NYHUS, K. A.; RUSSELL, W. A. \& GUTHRIE, W. D. Changes in Agronomic Traits Associated with Recurrent Selection in Two Maize Synthetics. Crop Science, v.29, n. 2, p.269-275. 1989.

OLIVEIRA. E.; WAQUIL, J. M.; FERNANDES, F. T.; PAIVA E. RESENDE R. O; ELLIOTE, W.; KITAIMA, W. "Enfezamento p'lido e "Efezamento Vermelho" na cultura do milho no Brasil Central. Fitopatologia Brasileira. v. 23, n. 1, p. 45-47, 1998

PASCHOLATI, S. F. \& LEITE, B. Mecanismos de Resistência. In: FIlHO, A.B.; KIMATI, H., AMORIM, L Manual de Fitopatologia. São Paulo: Ceres, 1995. cap. 22, p. 417-453: Mecanismos de Resistência.

PATAKY, J.K.; EASTBURN, D.M. Comparing partial resistance to P. sorghi and applications of fungicides for controlling common rust on sweet corn. Phytopathology, v.83, p. 1046-1051, 1993. 
PEGORARO, D.G.; BARBOSA NETO, J.; VACARO, E.; NUSS, C. N. ; DAL SOGLIO, F.K. Incidência da mancha foliar causada pelo fungo Phaeosphaeria maydis em milho: efeito de épocas de semeadura e doses de nitrogênio. In: CONGRESSO NACIONAL DE MILHO E SORGO, 22., Recife, 1998. Globalização e segurança alimentar; resumos. Recife: ABMS / EMBRAPA / IPA, 1998. p. 132.

PEREIRA, O.A.P. Situação atual de Doenças da cultura do milho no Brasil e estratégias de controle. In: ENCONTRO SOBRE TEMAS DE GENÉTICA E MELHORAMENTO, 12., Piracicaba, 1995. Anais. Piracicaba: Departamento de Genética/ ESALQ, 1995. p. 25-30.

PEREIRA, O.A.P.; BALMER, E.; MIRANDA FILHO, J.B. Inheritance of the resistance to stalk rot in maize (Zea may's L.) caused by Colletotrichum graminicola (CES).Wils. Revista Brasileira Genética, v. 12, p.53-65, 1989.

PIMENTEL GOMES, F .Curso de Estatística Experimental. 13 ed. Piracicaba, POTAFOS, 1990. 468p.

RAMALHO, M.; SANTOS, J. B. \& PINTO, C. B. Genética na Agropecuária. São Paulo: Globo Rural, 1989. 359p.

RANDLE, W.M.; DAVIS, D.W.; GROTH, J.V. Improvement and genetic control of partial resistance in Sweet corn to corn leaf rust. Journal of American Society Horticultural Science, v. 109, p.777-781, 1984.

REGITANO NETO, A. Avaliação quantitativa da estrutura genética de uma população de milho pipoca. Piracicaba, 1993, 106 p. Dissertação (Mestrado) -Escola Superior de Agricultura "Luiz de Queiroz", Universidade de São Paulo.

REGITANO NETO, A. Incorporação de germoplasma exótico de milho (Zea mays L.). Piracicaba, 1998, 133p. Tese (Doutorado) - Escola Superior de Agricultura "Luiz de Queiroz", Universidade de São Paulo. 
RICHTER, T.E. New rust resistance specificities associated with recombination in the Rpl complex in maize. Genetics, v. 141, p.373-381, 1995

ROBBINS, W. A. Jr.; WARREN, H. L . Inheritance of resistance to Exserohilum turcicum in PI 209135, 'Mayorbela' variety of maize. Maydica, v.38, n. 3, p.209$213,1993$.

RODRIGUEZ-ARODON, R.; SCOTT, G.E.; KING, S.B. Maize yield losses caused by southern corn rust. Crop Science, v.20, p.812-814, 1980.

SALHUANA, W.. Strategies for increasing the use of germplasm. In: Plant Breeding Research Forum, Caracas, Report. p. 141-172, 1987.

SANZ-ALFEREZ, S.; RICHTER, T.E.; HULBERT, S.H.; BENNETZEN, J.L. The Rp3 disease resistance gene of maize: mapping and characterization of introgressed alleles. Theoretical and Applied Genetics, v.91, p.25-32, 1995.

SAWAZAKI, E.; DUDIENAS, C.; PATERNIANI, M.E.A.G.Z. et al. Reação de cultivares de milho a mancha de Phaeosphaeria no Estado de São Paulo. Pesquisa Agropecuaria Brasileira, v.32, p.585-589, 1997.

SCAPIM, C. A.; CARVALHO, C. G. P.; CRUZ, C. D. Uma Proposta de Classificação dos Coeficientes de Variação para a Cultura do Milho. Pesq. agropec bras., Brasilia, v.30, n.5, p.683-686, maio, 1995.

SCOTT, G.E.; KING, S.B.; ARMOUR, J.W. Inheritance of resistance to southern corn rust in maize populations, Crop Science, v.24, p.265-267, 1984.

SCOTT, G.E.; ROSENKRANZ, E. E. Effctiveness of recurrent selection to corn stunt resitance in a variety. Crop Science. V.14, p. 758-760, 1974.

SCOTT, G.E.; ROSENKRANZ, E. E. Location of genes conditioning resistance to the corn stunting disease complex in maize. Crop. Science, v. 17 p. 923-925, 1977. 
SILVA, H. P. Incidência de Doenças Fúngicas na "Safrinha". In: SEMINÁRIO SOBRE A CULTURA DO MILHO SAFRINHA, 4, Assis, 1997

SMITH, D.R.; WHITE, D.G. Disease of corn In: SPRAGUE, G.F.; DUDLEY, J.W. (Ed.) Corn and corn improvement. Madison: American Society of Agronomy, 1988. cap. 12, p.687-766.

SMITH, J.C.S.; DUVICK, D.N. Germplasm collections and the private plant breeder. In: A.D.H. Brown, O.H. Frankel, D.R. Marshall, J.T. Williams,. The Use of Plant Genetic Resources. Cambrigde University Press, London, p. 17-31, 1989.

SOTCHENKO, V.S. Evaluation of combining ability of maize lines in top-crosses and diallel crosses. Selektsiya i Semenovodstvo Kukuruzy, p.298-303, 1971. /Resumo em CAB Abstracts on CD-ROM, 1972-75/

SPRAGUE, G.F., TATUM, L.A. General vs. especific combining ability in single crosses of corn. Journal American Society Agronomic, v.34, p.923-932, 1942.

TABA, S., F.E. PINEDA, AND J. CROSSA.. Forming core subsets from the Tuxpeno race complex. In: TABA, S. The CIMMYT Maize Germplasm Bank: Genetic Resouce Preservation, Regeneration, Maintenance, and Use. Maize Program Special Report. Mexico. D.F.1994, p. 60-81.

TROYER, A.F.. A retrospective view of corn genetic resources. Jouirnal of Heredity, v.81, p. 17-24, 1990.

URBINA, R. Incidencia y efectos del achaparramiento en la produccion de maiz en Nicaragua. CNIGB-MIDNRA. Separata. 1991, p.25.

VAN DER PLANK, J.E., 1963. Plant diseases: Epidemics and control. Academic Press, New York.

VENCOVSKY, R.; BARRIGA, P. Genética biométrica no fitomelhoramento. Ribeirão Preto: SBG, 1992. 496p. 
VENCOVSKY, R.; MIRANDA FILHO, J. B. Determinação do número de possiveis compostos e pares de compostos. Rel.Cient.Inst.Genética (ESALQ/USP), v.6, p. 120 123, 1972.

VON PINHO, R. G. V.; RAMALHO, M. P.; REZENDE, I.C.; OLIVATTO, A. V. Controle genético da resistência do milho às ferrugens polysora ( Puccinia polysora) e tropical (Physopella Zeae). In: CONGRESSO NACIONAL DE MILHO E SORGO, 22., Recife, 1998. Globalização e segurança alimentar; resumos. Recife: ABMS / EMBRAPA / IPA, 1998b. p. 101.

VON PINHO, R. G. V.; RAMALHO, M. P.; REZENDE, I.C.; SILVA, H. P.; OLIVATTO, A. V. Danos causados pelas ferrugens polysora e tropical do milho. In: CONGRESSO NACIONAL DE MILHO E SORGO, 22., Recife, 1998. Globalização e segurança alimentar; resumos. Recife: ABMS / EMBRAPA / IPA, 1998a. p. 254.

WALLIN, J.R. An epiphytotic of com rust in the north central regions of the USAPlant Disease Report, v.35, p.207-11, 1951.

WELDEKIDAN, T. \& HAWK, J. A. Inheritance of Anthracnose Stalk Rot Resistance in Maize. Maydica, v.38, n.3, p.189-192, 1993.

WRIGHT, S. The effects of inbeeding and crossbreeding on guinea pigs. III. Crosses between highly inbred families. USDA, Bull 1121, 1922.

ZOCCOLI, T.T. Componentes de heterose e depressão endogâmica quanto à reação a Puccinia polysora, Physopella zeae e Phaeosphaeria maydis em quatro populações de milho. Goiânia, 96p. 1998. Dissertação (Mestrado) - Escola de Agronomia, Universidade Federal de Goiás. 
Tabela 8. Médias dos tratamentos do experimento 1 para mancha de turcicum, mancha de Phaeosphaeria. ferrugem comum, porcentagem de plantas com podridão de colmo (PODR), porcentagem de plantas com enfezamento (ENFE), altura de planta (AP), altura da espiga (AE), comprimento de espiga (CE), diâmetro de espiga (DE), e peso de grãos por parcela (PG).

\begin{tabular}{|c|c|c|c|c|c|c|c|c|c|c|}
\hline Acessos & TURC & PHAE & SORG & PODR & ENFE & AP & $\mathbf{A E}$ & CE & \multicolumn{2}{|c|}{ DE PG } \\
\hline 1 & 2,00 & 2,00 & 3,75 & 0,00 & 0,00 & 214,0 & 139,5 & 13,8 & 4,1 & 2,764 \\
\hline 2 & 2.00 & 2.25 & 5.00 & 0,00 & 2,94 & 205.8 & 126,5 & 11,8 & 4,0 & 3,217 \\
\hline 3 & 2.00 & 2.00 & 3.50 & 0.00 & 1,52 & 216.5 & 149.8 & 12.9 & 3.9 & 2.906 \\
\hline 4 & 2.25 & 2.50 & 3.75 & 0.00 & 2.50 & 230.0 & 155.5 & 13.3 & 3.9 & 3.382 \\
\hline 5 & 2,00 & 2.25 & 4,25 & 1,52 & 2,73 & 200.5 & 120,3 & 14.2 & 5.1 & 2.899 \\
\hline 6 & 2.25 & 2,00 & 5,00 & 0,00 & 1,47 & 221.8 & 131,5 & 13,3 & 4.2 & 2,621 \\
\hline 9 & 2.00 & 2,00 & 5.50 & 0,00 & 1,61 & 171.8 & 109,3 & 13.0 & 4.0 & 2,399 \\
\hline 11 & 2,00 & 2,00 & 4,50 & 0,00 & 3,78 & 214.5 & 133,0 & 14,3 & 4.1 & 3,708 \\
\hline 12 & 2.00 & 2.00 & 5.25 & 0.00 & 2,44 & 231.0 & 147.8 & 13.0 & 4.2 & 2.584 \\
\hline 13 & 2.00 & 2.00 & 5.00 & 0.00 & 7.72 & 204.8 & 126.0 & 13.3 & 3.6 & 2.503 \\
\hline 14 & 2.00 & 2,00 & 4.00 & 0.00 & 1.28 & 232.0 & 150.0 & 14.3 & 4.1 & 3.433 \\
\hline 15 & 2.00 & 2,00 & 4,50 & 0,00 & 2.56 & 235.3 & 154.5 & 12.6 & 4.0 & 2.793 \\
\hline 16 & 2,00 & 2,00 & 5,25 & 0,00 & 0,00 & 242.5 & 156,0 & 14,0 & 3.9 & 3,085 \\
\hline 17 & 2,00 & 2,00 & 5,75 & 0,00 & 0,00 & 252.8 & 163,8 & 14,4 & 4,0 & 2,828 \\
\hline 18 & 2.00 & 2,00 & 4,25 & 0,00 & 29,54 & 197,8 & 123,0 & 13.9 & 4,0 & 2.250 \\
\hline 19 & 2,00 & 2,00 & 5,00 & 0,00 & 0,00 & 219,3 & 137,3 & 15.0 & 3.9 & 3.224 \\
\hline 20 & 2.00 & 2,00 & 4,75 & 0,00 & 6,60 & 207.8 & 130.0 & 12,1 & 3,9 & 2.871 \\
\hline 21 & 2.00 & 2,00 & 4,00 & 0,00 & 1,52 & 221.8 & 134.0 & 14.1 & 4.1 & 2,723 \\
\hline 22 & 2.25 & 2,00 & 4,75 & 0,00 & 7,07 & 209.5 & 129,8 & 13.2 & 3,8 & 1,963 \\
\hline 23 & 2,00 & 2,00 & 4,50 & 0,00 & 11,07 & 42.5 & 168,5 & 13,6 & 4,0 & 2.798 \\
\hline 24 & 2.00 & 2,00 & 3.50 & 0.00 & 3,33 & 244.0 & 170,0 & 12.9 & 3.6 & 2.650 \\
\hline 26 & 2.50 & 2,00 & 4.00 & 0.00 & 1,39 & 214.3 & 134.3 & 12.2 & 4.0 & 2.696 \\
\hline 27 & 2.00 & 2.00 & 4.00 & 0.00 & 10.29 & 216.0 & 140.3 & 12.7 & 3,9 & 2.381 \\
\hline 29 & 2,00 & 2.00 & 3.25 & 1.28 & 9.85 & 247.8 & 174.5 & 12.1 & 4.0 & 2.672 \\
\hline 30 & 2.00 & 2.00 & 4.50 & 2,08 & 0.00 & $24+.8$ & 167.0 & 11.0 & 3.1 & 2.525 \\
\hline Híbridos & TURC & PHAE & SORG & PODR & ENFE & AP & $\mathbf{A E}$ & CE & $\mathrm{DE}$ & PG \\
\hline H3 & 2.00 & 2,00 & 3.50 & 0,00 & 4,41 & 161.8 & 90,0 & 12.3 & 4.0 & 3.032 \\
\hline $\mathrm{H4}$ & 2.00 & 2.50 & 4.50 & 0.00 & 0.00 & 177.5 & 85.8 & 12.0 & 4.4 & 3.407 \\
\hline Cruzamentos & TURC & PHAE & SORG & PODR & ENFE & $\mathbf{A P}$ & $\mathbf{A E}$ & $\mathrm{CE}$ & $\mathrm{DE}$ & PG \\
\hline $1 \times \mathrm{H3}$ & 2.25 & 2.00 & 4.00 & 0,00 & 2,74 & 211.0 & 128.8 & 14.4 & 4,6 & 4.829 \\
\hline $1 \times \mathrm{H4}$ & 2.00 & 2.00 & 3.50 & 0.00 & 2.63 & $2 \geq 4.0$ & 136.3 & 13.7 & 4.3 & 3.478 \\
\hline $2 \times \mathrm{H3}$ & 3.00 & 2.00 & 5.75 & 0.00 & 5.36 & 211.8 & 119.3 & 14.0 & 4.3 & 3.729 \\
\hline $2 \times \mathrm{H4}$ & 2.00 & 2.25 & 4.75 & 0,00 & 2.63 & 219.0 & 130.5 & 13.5 & 4.3 & 3.720 \\
\hline $3 \times \mathrm{H3}$ & 2.00 & 2,00 & 4.50 & 0.00 & 1.35 & 210.5 & 125.5 & 13.3 & 4.1 & 3.692 \\
\hline $3 \times \mathrm{H4}$ & 2.25 & 2.00 & 5.50 & 0.00 & 3.03 & 197.0 & 115.3 & 13.8 & 4.3 & 3.899 \\
\hline $4 \times 43$ & 2.00 & 2,75 & 4.00 & 0,00 & 6.06 & 207.3 & 124.0 & 12.4 & 4.2 & 3.341 \\
\hline $4 \times \mathrm{H4}$ & 2.25 & 2.00 & 3,75 & 0.00 & 0.00 & 221.5 & 142.5 & 13.8 & 4.3 & 4.022 \\
\hline $5 \times \mathrm{H3}$ & 2.00 & 2.50 & 4.75 & 0.00 & 0.00 & 200.5 & 119.3 & 13.9 & 4.3 & 3.338 \\
\hline $5 \times \mathrm{H4}$ & 2.00 & 2.00 & 4.00 & 0.00 & 0.00 & 210.0 & 119.3 & 13.7 & 4.5 & 4.006 \\
\hline $6 \times \mathrm{H3}$ & 2.25 & 2.00 & 3.75 & 0.00 & 0.00 & 204.5 & 126.0 & 13.4 & 4.2 & 4.322 \\
\hline $6 \times \mathrm{H4}$ & 2.25 & 2.00 & 4.00 & 2.67 & 2.70 & 193.8 & 109.0 & 13.4 & 4.3 & 3.266 \\
\hline $9 \times \mathrm{H3}$ & 2.00 & 2.75 & 4.75 & 0.00 & 2.56 & 199.0 & 123.3 & 15.1 & 4.3 & 3.199 \\
\hline $9 \times \mathrm{H4}$ & 2.00 & 2.25 & 4.25 & 0.00 & 6.25 & $21+.0$ & 122.5 & 12.8 & 3.9 & 3.787 \\
\hline
\end{tabular}




\begin{tabular}{|c|c|c|c|c|c|c|c|c|c|c|}
\hline Cruzamentos & TURC & PHAE & SORG & PODR & ENFE & AP & $\mathrm{AE}$ & $\mathrm{CE}$ & $\mathbf{D E}$ & PG \\
\hline $11 \times \mathrm{H3}$ & 2,00 & 2,00 & 4,00 & 0,00 & 1.28 & 198,8 & 119,3 & 14,2 & 4.6 & $\overline{4,198}$ \\
\hline $11 \times \mathrm{H4}$ & 2,00 & 2,25 & 3,50 & 0.00 & 5,77 & 191,8 & 108,8 & 14,5 & 4,4 & 3,955 \\
\hline $12 \times \mathrm{H} 3$ & 2.25 & 2.00 & 5.00 & 0,00 & 2.56 & 210.8 & 132.8 & 13,9 & 4,5 & 3.851 \\
\hline $12 \times \mathrm{H4}$ & 2.00 & 2,00 & 5.50 & 0.00 & 4.41 & 194.5 & 107.8 & 14,3 & 4,3 & 3.461 \\
\hline $13 \times \mathrm{H} 3$ & 2.00 & 2.25 & 4.25 & 0.00 & 0.00 & 204,0 & 131.3 & 13,0 & 4.1 & 3.889 \\
\hline $13 \times \mathbf{H 4}$ & 2.50 & 2,00 & 4.25 & 0,00 & 0,00 & 221.3 & 136,8 & 15,1 & 4.4 & 4,443 \\
\hline $14 \times \mathrm{H} 3$ & 2.00 & 2.00 & 3.75 & 0.00 & 0.00 & 208.3 & 128,0 & 14,4 & 4.3 & 3,409 \\
\hline $14 \times \mathrm{H4}$ & 2.25 & 2.25 & 4.00 & 0.00 & 3.85 & 217.3 & 124.8 & 13.6 & 4.1 & 3.815 \\
\hline $15 \times \mathrm{H3}$ & 2.00 & 2.00 & 4.00 & 0.00 & 4.05 & 213.5 & 133.8 & 13.1 & 4.4 & 3.587 \\
\hline $15 \times \mathrm{H4}$ & 2,00 & 2,50 & 3,50 & 0,00 & 3.85 & 219.8 & 130,3 & 13,9 & 4,0 & 4,013 \\
\hline $16 \times \mathrm{H3}$ & 2.50 & 2.00 & 4.50 & 0,00 & 2,70 & 213.5 & 142.0 & 13,9 & 4.1 & 3.536 \\
\hline $16 \times \mathrm{H4}$ & 2.00 & 2.00 & 4.50 & 0.00 & 1.47 & 223.0 & 139.0 & 13.9 & 4.1 & 3.632 \\
\hline $17 \times \mathbf{H 3}$ & 2.50 & 2.00 & 5,00 & 0.00 & 0,00 & 220.8 & 143,5 & 13,6 & 3,8 & 3,179 \\
\hline $17 \times \mathrm{H4}$ & 2,00 & 2,00 & 4,00 & 0,00 & 2.56 & 212.8 & 131,3 & 14,2 & 4,6 & 4,378 \\
\hline $18 \times \mathrm{H3}$ & 2.00 & 2,00 & 4,50 & 0.00 & 2.56 & 216.8 & 137.5 & 13,8 & 4,4 & 3.293 \\
\hline $18 \times \mathrm{H4}$ & 2,00 & 2,00 & 3,75 & 0,00 & 0,00 & 214.5 & 140,8 & 15,4 & 4,3 & 3,669 \\
\hline $19 \times$ Н3 & 2,25 & 2,00 & 4,25 & 0.00 & 5.56 & 193,3 & 121,0 & 14,6 & 4,2 & 3.053 \\
\hline $19 \times \mathrm{H4}$ & 2.00 & 2.25 & 3.75 & 0,00 & 1.43 & 189.3 & 107.8 & 14.5 & 7.1 & 4.393 \\
\hline $20 \times \mathrm{H3}$ & 2.25 & 2,00 & 4,25 & 0,00 & 0,00 & 206,8 & 126,3 & 13,1 & 5,3 & 3,779 \\
\hline $20 \times \mathrm{H4}$ & 2,00 & 2,00 & 5,50 & 0,00 & 0,00 & 215,3 & 131,0 & 14,0 & 4.2 & 4,407 \\
\hline $21 \times \mathrm{H3}$ & 2,25 & 2,25 & 3,50 & 0,00 & 3,23 & 204,5 & 126,0 & 14,0 & 4,6 & 4,341 \\
\hline $21 \times \mathrm{H4}$ & 2,00 & 2,00 & 4,50 & 0,00 & 0,00 & 216.0 & 131,0 & 14,3 & 4.3 & 3,653 \\
\hline $22 \times \mathrm{H} 3$ & 2.00 & 2.00 & 4,75 & 0.00 & 0.00 & 199.0 & 109.8 & 13.5 & 4.2 & 3.529 \\
\hline $22 \times \mathrm{H4}$ & 2.00 & 2.25 & 4.75 & 0.00 & 1.25 & 206.0 & 126.0 & 12.3 & 3,8 & 3.845 \\
\hline $23 \times \mathrm{H3}$ & 2.00 & 2.00 & 4.75 & 0.00 & 5.36 & 218.8 & 135.8 & 14.8 & 4.5 & 3.489 \\
\hline $23 \times \mathbf{H 4}$ & 2.00 & 2.00 & 3.75 & 0.00 & 2.86 & 211.0 & 126.3 & 14.7 & 4.6 & 3.724 \\
\hline $24 \times \mathrm{H3}$ & 2.00 & 2,00 & 4.50 & 0,00 & 6.06 & 206.5 & 130.5 & 13.3 & 4.1 & 3.180 \\
\hline $24 \times \mathrm{H4}$ & 2.50 & 2.00 & 3.75 & 0.00 & 4,05 & 216.3 & 142.8 & 13.4 & 4.0 & 2.607 \\
\hline $26 \times \mathrm{H3}$ & 2.00 & 2,00 & 4.50 & 0,00 & 0.00 & 217.3 & 135.5 & 13.7 & 3,9 & 3.548 \\
\hline $26 \times \mathrm{H4}$ & 2.00 & 2.00 & 4.75 & 0,00 & 1,47 & 217.0 & 127.8 & 14.4 & 4.3 & 3.348 \\
\hline $27 \times$ H3 & 2.50 & 2.00 & 4,00 & 0.00 & 0,00 & 211.3 & 135.8 & 13.5 & 4.0 & 3.244 \\
\hline $27 \times \mathbf{H 4}$ & 2.50 & 2,00 & 4,00 & 0.00 & 0.00 & 229.0 & 149,3 & 12.8 & 3.9 & 3.625 \\
\hline $29 \times \mathrm{H3}$ & 2.00 & 2.00 & 4.75 & 0,00 & 2.77 & 221.5 & 138.8 & 13.5 & 4.5 & 3.174 \\
\hline $29 \times \mathrm{H4}$ & 2.00 & 2.00 & 3.75 & 0.00 & 5.00 & 223.5 & 137,8 & 30.2 & 4.2 & 3.994 \\
\hline $30 \times \mathrm{H} 3$ & 2.00 & 2.00 & 4,00 & 0.00 & 4,00 & 208,3 & 127.0 & 14.3 & 4.4 & 3.885 \\
\hline $30 \times \mathrm{H4}$ & 2.00 & 2.00 & 3.00 & 0.00 & 1.61 & 211.3 & 130.1 & 14.3 & 4.4 & 4.180 \\
\hline Testemunhas. & TURC & PHAE & SORG & PODR & ENFE & AP & $\mathrm{AE}$ & $\mathrm{CE}$ & $\mathrm{DE}$ & PG \\
\hline $\mathrm{T} 1$ & 2.05 & 2.00 & 3.50 & 0.00 & 1.94 & 173.9 & 98.4 & 13.3 & 4.6 & 3.189 \\
\hline $\mathrm{T} 2$ & 2.00 & 2.00 & 4.85 & 0.00 & 1.89 & 229.9 & 134.2 & 13.8 & 4.4 & 2.897 \\
\hline
\end{tabular}


Tabela 9. Resumo das análises de variância do experimento 1 de safrinha para mancha de turcicum. mancha de Phaeosphaeria. ferrugem comum, porcentagem de plantas com podridão de colmo (PODR) e porcentagem de plantas com enfezamento (ENFE).

\begin{tabular}{|c|c|c|c|c|c|c|}
\hline & & & QM & & & \\
\hline FV & GL & TURC & PHAE & SORG & $\begin{array}{l}\text { PODR } \\
\times 10^{4}\end{array}$ & $\begin{array}{l}\text { ENFE } \\
\times 10^{3}\end{array}$ \\
\hline Repetição & 1 & 0.092 & 0.000 & 17.070 & 0.038 & 1.384 \\
\hline Tratamentos & 78 & 0.073 & $0.060 * *$ & 0.861 & $1.285^{* *}$ & 4.777 \\
\hline Dialelo & 76 & 0,073 & $0.060 * *$ & 0.758 & $1.312 * *$ & 4.855 \\
\hline Acessos & $\overline{24}$ & $0.04 \overline{2}$ & $\overline{0}, \overline{0} \overline{3}^{*}-$ & $1,1 \overline{4} 6^{*}$ & $\overline{1} . \overline{88} 6^{* *}$ & $6,97 \overline{1}$ \\
\hline Hibridos & 1 & 0,078 & 0,009 & 0,422 & $0.604^{*}$ & 0.619 \\
\hline Entre grupos & 1 & 0.113 & $0.166^{*}$ & 1,498 & $2,661^{* *}$ & $21.966 *$ \\
\hline Heterose & 50 & 0.087 & $0.057 * *$ & 0,564 & $1.023 * *$ & 3.582 \\
\hline H. média & 1 & 0.142 & 0.039 & 0.032 & 0.128 & 1.908 \\
\hline H. Acessos & 24 & 0.075 & 0.035 & 0.649 & $1.422 * *$ & 5.810 \\
\hline H. Hibridos & 1 & 0.012 & $0,251 * *$ & 1.788 & 0,097 & 3.417 \\
\hline H. especifica & 24 & 0.100 & $0.073 *$ & 0,450 & $0,701 * *$ & 1,430 \\
\hline Testemunhas & -- & $0.01 \overline{3}$ & $\overline{0.000}-$ & $9,113^{* *}$ & $\overline{0}, \overline{0} 00^{--}$ & $0.03 \overline{3}$ \\
\hline Dialelo vs Testemunha & 1 & 0,101 & 0,107 & 0,432 & $0.532 *$ & 3,615 \\
\hline Residuo & 94 & 0.067 & 0.032 & 0.712 & 0.103 & 5.138 \\
\hline Dentro test./rep. & 16 & 0,013 & 0,025 & 0,788 & 0,000 & 2.312 \\
\hline Erro & 78 & 0,078 & 0,033 & 0,697 & 0,124 & 5.718 \\
\hline CV\% & & 12,33 & 8,63 & 19,57 & 0,99 & 19.77 \\
\hline Média geral & & 2,09 & 2,07 & 4.31 & 0,10 & 2.97 \\
\hline
\end{tabular}

** e * indicam. respectivamente, significância ao nível de $1 \%$ e de $5 \%$ de probabilidade. 
Tabela 10. Resumo das análises de variância do experimento 1 de safrinha para altura de planta (AP), altura da espiga (AE), comprimento de espiga (CE), diâmetro de espiga (DE), e peso de grãos por parcela $(P G)$.

\begin{tabular}{|c|c|c|c|c|c|c|}
\hline \multicolumn{7}{|c|}{$\mathrm{QM}$} \\
\hline FV & GL & $\mathbf{A P}$ & $\mathbf{A E}$ & CE & DE & PG \\
\hline Repetição & 1 & 9379.35 & 8656.70 & 8.341 & 1,063 & 0.037 \\
\hline Tratamentos & 78 & $716.01 * *$ & $643.09 * *$ & 8,377 & $0.421^{*}$ & $0.731 * *$ \\
\hline Dialelo & 76 & $499.66^{* *}$ & $517.53 * *$ & 8.563 & $0.408^{*}$ & $0.714^{* *}$ \\
\hline Ácessos & $\overline{24}$ & $6 \overline{76} . \overline{40 *}$ & $\overline{668.62 * *}$ & $\overline{4} . \overline{2} \overline{45}$ & $\overline{0.296^{-}}$ & $0, \overline{364} *$ \\
\hline Hibridos & 1 & 515.35 & 21.04 & 12.975 & 0.099 & $1,027^{*}$ \\
\hline Entre grupos & 1 & $8893,03 * *$ & $12712.75^{* *}$ & 12.156 & $3.654^{* *}$ & $22,050 * *$ \\
\hline Heterose & 50 & 246.64 & $211.04^{*}$ & $10.475^{*}$ & $0.404^{*}$ & $0.450 * *$ \\
\hline H. média & 1 & $2882.94 * *$ & $2218.55 * *$ & $29.005^{*}$ & 0.802 & $6,531 * *$ \\
\hline H. Acessos & 24 & $293.16^{*}$ & $228,28^{*}$ & 8,684 & 0.342 & 0.252 \\
\hline H. Hibridos & 1 & 62.14 & 7,52 & 3,038 & 0,066 & 0,000 \\
\hline H. especifica & 24 & 97.96 & 118.64 & $11,805^{*}$ & $0,463^{*}$ & $0,412^{*}$ \\
\hline Testemunhas & $\overline{1}$ & $15 \overline{5} 80,00 * \bar{*}$ & $6408 . \overline{2} 0^{* *}$ & $1, \overline{456}$ & $0, \overline{189}$ & 0,427 \\
\hline Dialelo vs Testemunha & 1 & $2195,02 * *$ & $4420.00 * *$ & 1.149 & $1.630^{*}$ & $2,328 * *$ \\
\hline Resíduo & 94 & 175.85 & 135.67 & 6.670 & 0.262 & 0,223 \\
\hline Dentro test./rep. & 16 & 198,83 & 134.43 & 1,307 & 0,087 & 0,168 \\
\hline Erro & 78 & 171.14 & 135.92 & 7,771 & 0.298 & 0.234 \\
\hline CV\% & & 6.26 & 8.94 & 18,73 & 12.05 & 14.03 \\
\hline Média geral & & 211.76 & 130.29 & 13.79 & 4.25 & 3.36 \\
\hline
\end{tabular}

** e * indicam, respectivamente. significância ao nível de $1 \%$ e de $5 \%$ de probabilidade. 
Tabela 11. Efeitos de variedade $v_{i}$ no experimento 1 para mancha de turcicum, mancha de Phaeosphaeria. ferrugem comum, porcentagem de plantas com podridão de colmo (PODR), porcentagem de plantas com enfezamento (ENFE), altura de planta (AP), altura da espiga (AE), comprimento de espiga (CE), diâmetro de espiga (DE), e peso de grãos por parcela (PG).

\begin{tabular}{|c|c|c|c|c|c|c|c|c|c|c|}
\hline Acessos & TURC & PHAE & SORG & PODR & ENFE & AP & $\mathbf{A E}$ & CE & DE & PG \\
\hline 1 & $-0,050$ & $-0,040$ & $-0,710$ & $-0,004$ & $-0,060$ & $-7,530$ & $-3,372$ & 0.516 & 0,128 & $-0,031$ \\
\hline 2 & -0.050 & 0,210 & 0,540 & $-0,004$ & $-0,016$ & $-15,780$ & -16.372 & $-1,416$ & -0.002 & 0.422 \\
\hline 3 & -0.050 & -0.040 & $-0,960$ & $-0,004$ & $-0,037$ & $-5,030$ & 6.878 & -0.377 & -0.102 & 0,111 \\
\hline 4 & 0.200 & 0,460 & $-0,710$ & $-0,004$ & $-0,022$ & 8,470 & 12,628 & 0,085 & $-0,061$ & 0.587 \\
\hline 5 & -0.050 & 0.210 & -0.210 & 0,009 & $-0,017$ & -21.030 & -22.622 & 0.975 & 1.095 & 0.104 \\
\hline 6 & 0.200 & -0.040 & 0.540 & $-0,004$ & $-0,037$ & 0.220 & $-11,372$ & 0,034 & 0.201 & -0.174 \\
\hline 9 & -0.050 & -0.040 & 1.040 & $-0,004$ & $-0,035$ & $-49,780$ & -33.622 & -0.217 & 0.061 & -0.396 \\
\hline 11 & $-0,050$ & $-0,040$ & 0,040 & $-0,004$ & $-0,002$ & $-7,030$ & $-9,872$ & 1,022 & 0,115 & 0.913 \\
\hline 12 & -0.050 & $-0,040$ & 0,790 & $-0,004$ & $-0,022$ & 9.470 & 4,928 & -0.220 & 0,207 & -0.210 \\
\hline 13 & -0.050 & -0.040 & 0.540 & $-0,004$ & 0,049 & $-16,780$ & $-16,872$ & 0.087 & -0.410 & -0.292 \\
\hline 14 & -0.050 & -0.040 & -0.460 & $-0,004$ & -0.040 & 10.470 & 7.128 & 1.081 & 0.153 & 0.638 \\
\hline 15 & -0.050 & $-0,040$ & 0.040 & -0.004 & $-0,020$ & 13,720 & 11.628 & -0.637 & 0,027 & -0.002 \\
\hline 16 & -0.050 & -0.040 & 0.790 & -0.004 & -0.060 & 20.970 & 13.128 & 0.752 & $-0,029$ & 0.290 \\
\hline 17 & -0.050 & -0.040 & 1.290 & $-0,004$ & $-0,060$ & 31.220 & 20,878 & 1.113 & 0,008 & 0.033 \\
\hline 18 & -0.050 & $-0,040$ & -0.210 & $-0,004$ & 0.276 & -23.780 & $-19,872$ & 0.696 & $-0,018$ & $-0,545$ \\
\hline 19 & -0.050 & $-0,040$ & 0,540 & $-0,004$ & $-0,060$ & -2.280 & -5.622 & 1.733 & $-0,087$ & 0,429 \\
\hline 20 & -0.050 & -0.040 & 0.290 & $-0,004$ & 0,037 & $-13,780$ & -12.872 & -1.155 & -0.114 & 0.076 \\
\hline 21 & -0.050 & $-0,040$ & -0.460 & $-0,004$ & $-0,037$ & 0.220 & -8.872 & 0.846 & 0.165 & -0.072 \\
\hline 22 & 0.200 & $-0,040$ & 0.290 & $-0,004$ & 0,044 & $-12,030$ & $-13,122$ & -0.051 & -0.147 & -0.832 \\
\hline 23 & -0.050 & $-0,040$ & 0.040 & $-0,004$ & 0.087 & 20,970 & 25,628 & 0.383 & 0,034 & 0,003 \\
\hline 24 & -0.050 & -0.040 & -0.960 & -0.004 & -0.011 & 22.470 & 27.128 & -0.342 & $-0,359$ & -0.145 \\
\hline 26 & 0.450 & $-0,040$ & -0.460 & -0.004 & -0.039 & -7.280 & -8.622 & -1.039 & -0.015 & -0.099 \\
\hline 27 & -0.050 & -0.040 & -0.460 & $-0,004$ & 0,072 & -5.530 & $-2,622$ & -0.498 & $-0,044$ & -0.414 \\
\hline 29 & -0.050 & $-0,040$ & $-1,210$ & 0,027 & 0.073 & 26,220 & 31,628 & $-1,140$ & 0,034 & $-0,123$ \\
\hline 30 & -0.050 & $-0,040$ & 0.040 & 0,045 & $-0,060$ & 23.220 & 24,128 & -2.236 & $-0,836$ & -0.270 \\
\hline Híbridos & TURC & PHAE & SORG & PODR & ENFE & $\mathbf{A P}$ & AE & CE & $\mathrm{DE}$ & PG \\
\hline H3 & 0.000 & -0.250 & -0.500 & 0.000 & 0.032 & -7.875 & 2,125 & 0.141 & -0.177 & -0.188 \\
\hline H4 & 0.000 & 0.250 & 0.500 & 0.000 & -0.032 & 7.875 & $-2,125$ & -0.140 & 0,177 & 0.188 \\
\hline
\end{tabular}


Tabela 12. Efeitos de heterose de variedade $h_{i}$ no experimento 1 para mancha de turcicum, mancha de Phaeosphaeria, ferrugem comum, porcentagem de plantas com podridão de colmo (PODR), porcentagem de plantas com enfezamento (ENFE), altura de planta (AP), altura da espiga (AE), comprimento de espiga (CE), diâmetro de espiga (DE), e peso de grãos por parcela (PG).

\begin{tabular}{|c|c|c|c|c|c|c|c|c|c|c|}
\hline Acessos & TURC & PHAE & SORG & PODR & ENFE & AP & AE & CE & $\mathbf{D E}$ & PG \\
\hline 1 & 0.020 & -0.070 & -0.175 & 0,001 & 0.039 & 10.740 & 5,700 & -0.380 & 0,069 & 0.451 \\
\hline 2 & 0.395 & $-0,070$ & 0.700 & 0.001 & 0.032 & 12.740 & 4.575 & 0,272 & $-0,043$ & -0.205 \\
\hline 3 & 0.020 & $-0,070$ & 1,200 & 0.001 & 0,018 & $-4,260$ & -11.550 & $-0,440$ & $-0,102$ & 0,021 \\
\hline 4 & -0.105 & 0,055 & -0.050 & 0,001 & 0,019 & -0.385 & $-1,550$ & $-1,164$ & -0.029 & $-0,331$ \\
\hline 5 & -0.105 & 0,055 & 0,200 & $-0,005$ & $-0,025$ & 5,240 & 2,075 & $-0,865$ & $-0,485$ & $-0,099$ \\
\hline 6 & 0.020 & $-0,070$ & -0.675 & 0.022 & 0,005 & -11.510 & -5.300 & -0.781 & -0.165 & 0.162 \\
\hline 9 & -0.105 & 0,430 & $-0,300$ & 0,001 & 0,049 & 20,865 & 11.200 & $-0,162$ & $-0,282$ & $-0,028$ \\
\hline 11 & $-0,105$ & 0,055 & $-0,550$ & 0,001 & 0,018 & $-11,760$ & $-9,550$ & $-0,373$ & 0,105 & -0.099 \\
\hline 12 & 0,020 & $-0,070$ & 0,575 & 0,001 & 0,028 & $-12,635$ & $-10,700$ & 0,031 & -0.044 & 0.042 \\
\hline 13 & 0,145 & 0,055 & $-0,300$ & 0,001 & $-0,058$ & 10,490 & 13,950 & $-0,184$ & 0,120 & 0,593 \\
\hline 14 & 0,020 & 0,055 & -0.175 & 0,001 & 0,014 & $-3,010$ & $-5,675$ & $-0,713$ & $-0,207$ & $-0,426$ \\
\hline 15 & $-0,105$ & 0,180 & $-0,550$ & 0,001 & 0,034 & $-0,760$ & $-2,300$ & $-0,367$ & $-0,152$ & 0.082 \\
\hline 16 & 0,145 & $-0,070$ & -0.175 & 0.001 & 0.028 & $-2,760$ & 5,450 & $-0,687$ & -0.220 & -0.280 \\
\hline 17 & 0.145 & $-0,070$ & $-0,425$ & 0,001 & 0,016 & $-9,385$ & $-1,550$ & $-0,840$ & $-0,141$ & 0.044 \\
\hline 18 & $-0,105$ & $-0,070$ & -0.050 & 0,001 & $-0,152$ & 16,990 & 20,575 & 0,111 & $-0,008$ & 0,035 \\
\hline 19 & 0.020 & 0,055 & $-0,550$ & 0,001 & 0,046 & $-18,135$ & $-11,300$ & $-0,483$ & 1,334 & $-0,210$ \\
\hline 20 & 0.020 & $-0,070$ & 0,450 & 0,001 & $-0,053$ & 7.365 & 6,575 & $-0,048$ & 0,482 & 0.336 \\
\hline 21 & 0.020 & 0,055 & -0.050 & 0,001 & 0,008 & $-0,385$ & 4,450 & -0.491 & 0.070 & 0.314 \\
\hline 22 & -0.230 & 0,055 & 0.325 & 0.001 & -0.046 & -2.010 & -4.050 & -1.245 & -0.238 & 0.385 \\
\hline 23 & -0.105 & -0.070 & -0.050 & 0.001 & -0.018 & -6.135 & -10.300 & 0.381 & 0.223 & -0.114 \\
\hline 24 & 0.145 & -0.070 & 0.325 & 0.001 & 0.045 & -10.385 & -5.425 & $-0,641$ & -0.081 & -0.753 \\
\hline 26 & -0.355 & $-0,070$ & 0.575 & 0,001 & $-0,003$ & 10,240 & 7,450 & 0.371 & -0.256 & -0.221 \\
\hline 27 & 0.395 & -0.070 & $-0,050$ & 0,001 & $-0,070$ & 12,365 & 15,325 & $-0,777$ & $-0,407$ & $-0,077$ \\
\hline 29 & $-0,105$ & $-0,070$ & 0,575 & $-0,014$ & $-0,011$ & $-1,135$ & $-6,050$ & 8.257 & 0.021 & -0.073 \\
\hline 30 & $-0,105$ & $-0,070$ & $-0,800$ & -0.023 & 0,038 & -12.385 & -12.025 & 1,221 & 0.437 & 0.449 \\
\hline Híbridos & TURC & PHAE & SORG & PODR & ENFE & AP & $\mathbf{A E}$ & CE & DE & PG \\
\hline H3 & 0,030 & 0,135 & 0,360 & $-0,001$ & $-0,016$ & 2,123 & $-0,738$ & $-0,470$ & 0.069 & 0.000 \\
\hline H4 & $-0,030$ & $-0,135$ & -0.360 & 0.001 & 0.016 & $-2,123$ & 0,739 & 0,469 & $-0,069$ & 0.000 \\
\hline
\end{tabular}


Tabela 13. Efeitos de capacidade geral de combinação $g_{\text {ı }}$ no experimento 1 para mancha de turcicum. mancha de Phaeosphaeria, ferrugem comum, porcentagem de plantas com podridão de colmo (PODR), porcentagem de plantas com enfezamento (ENFE), altura de planta (AP), altura da espiga (AE), comprimento de espiga (CE), diâmetro de espiga (DE), e peso de grãos por parcela (PG).

\begin{tabular}{|c|c|c|c|c|c|c|c|c|c|c|}
\hline Acessos & TURC & PHAE & SORG $\mathrm{F}$ & $\mathrm{DR} \times 10^{2}$ & ENFE & AP & $\mathbf{A E}$ & $\mathrm{CE}$ & $\mathrm{DE}$ & PG \\
\hline 1 & $-0,005$ & $-0,090$ & $-0,530$ & $-0,084$ & 0,009 & 6,975 & 4,014 & $-0,121$ & 0.133 & 0.435 \\
\hline 2 & 0,370 & 0.035 & & -0.084 & 0.024 & 4.850 & $-3,611$ & -0.436 & -0.044 & 0.006 \\
\hline 3 & -0.005 & & 0,720 & -0.084 & $-0,001$ & $-6,775$ & $-8,111$ & -0.628 & -0.153 & 0.077 \\
\hline 4 & -0.005 & & -0.4 & & 0,008 & & & -1.121 & -0.060 & -0.037 \\
\hline 5 & & & & & & -5.275 & $-9,236$ & -0.378 & 0.062 & -0.047 \\
\hline 6 & 120 & & $-0,405$ & & $-0,014$ & & $-10,986$ & -0.764 & -0.064 & 0.075 \\
\hline 9 & $-0,130$ & & 0,220 & & 0,031 & & $-5,611$ & -0.270 & -0.251 & -0.226 \\
\hline 11 & -0.130 & 0,035 & $-0,530$ & & 0,016 & -15.275 & $-14,486$ & 0.138 & 0.162 & 0.358 \\
\hline 12 & -0.005 & -0.090 & 0.970 & $-0,084$ & 0,017 & -7.900 & $-8,236$ & -0.079 & 0.059 & -0.063 \\
\hline 13 & & & $-0,0$ & & & & & & & 0.447 \\
\hline 14 & $-0,005$ & & -0.405 & & $-0,0$ & & $-2,1$ & $-0,1$ & $-0,130$ & $-0,107$ \\
\hline 15 & -0.1 & & -0.5 & & 0,0 & & & -0.686 & & 0,081 \\
\hline 16 & & $-0,090$ & 0,220 & & $-0,002$ & 725 & 12,014 & $-0,311$ & -0.235 & -0.135 \\
\hline 17 & & & 0,220 & & $-0,0$ & 25 & & -0.283 & $-0,137$ & 0,060 \\
\hline 18 & $-0,130$ & $-0,090$ & $-0,155$ & & $-0,0$ & 100 & 10 & 0,459 & $-0,017$ & -0.237 \\
\hline 19 & -0.005 & & $-0,280$ & & & & & 0.383 & & 0.004 \\
\hline 20 & $-0,005$ & $-0,090$ & & & -0.0 & & & $-0,626$ & & 0.374 \\
\hline 21 & $-0,005$ & & $-0,280$ & $-0,084$ & $-0,010$ & $-0,275$ & 0,014 & -0.069 & 0.153 & 0.278 \\
\hline 22 & $-0,130$ & & 0,470 & $-0,084$ & $-0,024$ & $-8,025$ & $-10,611$ & -1.270 & -0.311 & -0.032 \\
\hline 23 & $-0,130$ & $-0,090$ & $-0,030$ & $-0,084$ & 0.025 & 4.350 & 2,514 & 0.573 & 0.240 & -0.112 \\
\hline 24 & 0,120 & -0.090 & -0.1 & -0.084 & 0.040 & & & -0.812 & -0.260 & -0.826 \\
\hline 26 & $-0,130$ & -0.090 & & -0.084 & -0.022 & 6.600 & 39 & -0.149 & -0.264 & -0.271 \\
\hline 27 & & & -0.280 & & $-0,0$ & & 14,014 & $-1,026$ & $-0,428$ & $-0,284$ \\
\hline 29 & $-0,130$ & $-0,090$ & -0.030 & $-0,084$ & 0.025 & 11,975 & 9,764 & 7,687 & 0,038 & $-0,134$ \\
\hline 30 & $-0,130$ & -0.090 & $-0,780$ & $-0,084$ & 0,008 & -0.775 & 0,039 & 0,104 & 0.019 & 0.314 \\
\hline Híbrido & TURC & PHAE & SORG & PODR & ENFE & AP & $\mathbf{A E}$ & $\mathrm{CE}$ & DE & PG \\
\hline H3 & 0,030 & & & $-0,084$ & & & 0.324 & $-0,399$ & -0.020 & -0.094 \\
\hline H4 & -0.030 & -0.010 & -0.110 & 0.084 & 0.000 & 1.815 & -0.324 & 0.399 & 0.020 & 0.094 \\
\hline
\end{tabular}


Tabela 14. Médias dos tratamentos do experimento 2 para mancha de turcicum, mancha de Phaeosphaeria. ferrugem comum, porcentagem de plantas com enfezamento (ENFE), altura de planta (AP), altura da espiga (AE), comprimento de espiga (CE), diâmetro de espiga (DE), e peso de grãos por parcela (PG).

\begin{tabular}{|c|c|c|c|c|c|c|c|c|c|}
\hline Acessos & TURC & PHAE & SORG & ENFE & AP & $\mathrm{AE}$ & $\mathrm{CE}$ & DE & $\mathbf{P G}$ \\
\hline $1 \mathrm{~s}$ & 2.50 & 2,25 & 5.25 & 15,98 & 128,3 & 54,5 & 9,4 & 3,4 & 1.126 \\
\hline $2 s$ & 3,50 & 2.50 & 4.50 & 2.08 & 150,0 & 66.5 & 12.4 & 4,3 & 2.288 \\
\hline $5 s$ & 2.50 & 2.50 & 3.00 & 7.63 & 197.3 & 110.5 & 12.9 & 3.9 & 2.650 \\
\hline $6 s$ & 2.63 & 3.38 & 3.00 & 3.33 & 175.0 & 93.8 & 12.1 & 4.1 & 2.287 \\
\hline $7 s$ & 2.25 & 3,00 & 3.50 & 0.00 & 203.3 & 105.3 & 13.2 & 4,4 & 3.903 \\
\hline $8 s$ & 2.75 & 2,00 & 5.25 & 1,92 & 157.3 & 72.5 & 11.5 & 4,0 & 1.264 \\
\hline $9 s$ & 2.00 & 2.50 & 4.25 & 1.22 & 168,0 & 80.5 & 11.1 & 4.0 & 2.777 \\
\hline $10 \mathrm{~s}$ & 2.50 & 2.50 & 4.25 & 4,09 & 190,3 & 99.0 & 13,5 & 4.1 & 3.580 \\
\hline $12 \mathrm{~s}$ & 2.00 & 2,25 & 3.00 & 5.30 & 187,3 & 98,5 & 13,1 & 4.2 & 3.034 \\
\hline $13 \mathrm{~s}$ & 2.50 & 2.75 & 2.75 & 5,56 & 192,0 & 96.8 & 13,7 & 4.4 & 3.580 \\
\hline $14 \mathrm{~s}$ & 2.00 & 2,75 & 3.25 & 5,22 & 191.0 & 96,5 & 13,4 & 4.1 & 3.335 \\
\hline $15 \mathrm{~s}$ & 2.00 & 2.50 & 4.00 & 13.33 & 189.8 & 98,3 & 13.3 & 4,0 & 3,356 \\
\hline $16 s$ & 3.25 & 2,00 & 3.50 & 0,00 & 164.3 & 77,8 & 13.2 & 4,4 & 3,098 \\
\hline $17 \mathrm{~s}$ & 2,50 & 2,00 & 3,75 & 0.00 & 187.3 & 87,0 & 12.9 & 4.4 & 3.332 \\
\hline $18 \mathrm{~s}$ & 3.00 & 2.00 & 3.50 & 0.00 & 173.5 & 84.8 & 12.2 & 4.1 & 3,008 \\
\hline $19 \mathrm{~s}$ & 2,00 & 2.00 & 2,00 & 0,00 & 239,5 & 144,0 & 13,5 & 3,9 & 3,635 \\
\hline $20 \mathrm{~s}$ & 2.50 & 2.00 & 3.25 & 10,94 & 199.5 & 110,0 & 12.9 & 3.6 & 2,231 \\
\hline $21 \mathrm{~s}$ & 3.00 & 2,00 & 2.00 & 2,86 & 175.3 & 81.5 & 13.0 & 4.2 & 3.423 \\
\hline $22 \mathrm{~s}$ & 2.00 & 2.00 & 3.50 & 9,35 & 189.5 & 113.5 & 13.0 & 3.4 & 2.844 \\
\hline $23 \mathrm{~s}$ & 2.50 & 2.00 & 3.00 & 4,17 & 169.5 & 85.0 & 13,0 & 4.0 & 3.100 \\
\hline $24 s$ & 2.50 & 2.75 & 2.50 & 4,96 & 169.8 & 84.5 & 11.8 & 4.0 & 2.750 \\
\hline $25 \mathrm{~s}$ & 3.25 & 2.00 & 1.25 & 0.00 & 216.5 & 132.0 & 12.4 & 3.6 & 2.654 \\
\hline $26 s$ & 2.00 & 2.50 & 4.50 & 0,00 & 185,3 & 102.0 & 12.9 & 3.6 & 2.306 \\
\hline $30 \mathrm{~s}$ & 2.25 & 2,00 & 2.50 & 2,56 & 208,3 & 119.0 & 12.5 & 4,0 & 3,371 \\
\hline Hibridos & TURC & PHAE & SORG & ENFE & $\mathbf{A P}$ & $\mathbf{A E}$ & $\mathrm{CE}$ & DE & PG \\
\hline H3 & 2.00 & 2.00 & 2.00 & 6,72 & 160.5 & 90.0 & 12.0 & 4.2 & 2.502 \\
\hline H4 & 2.25 & 2.25 & 3.75 & 1,43 & 168.8 & 79.3 & 12.9 & 4.3 & 3.084 \\
\hline Cruzamentos & TURC & PHAE & SORG & ENFE & AP & $\mathbf{A E}$ & $\mathrm{CE}$ & $\mathbf{D E}$ & PG \\
\hline $1 \mathrm{~s}, 3$ & 2,25 & 2.00 & 5.25 & 3.23 & 152,8 & 70,0 & 12.0 & 3.8 & 2.992 \\
\hline $1 \mathrm{~s}, 4$ & 3.00 & 2,38 & 5.25 & 1.39 & 163.0 & 78.3 & 12.3 & 4.1 & 2.332 \\
\hline $2 s, 3$ & 2.75 & 2.00 & 2.00 & 0.00 & 201.5 & 96.5 & 14.4 & 4.7 & 4.391 \\
\hline $2 s, 4$ & 3.00 & 2.25 & 3.50 & 0.00 & 177.0 & 87.5 & 12.7 & 4.4 & 3.189 \\
\hline $5 s, 3$ & 2.00 & 2.00 & 3.00 & 0.00 & 191.0 & 106.0 & 12,9 & 4.4 & 3.311 \\
\hline $5 s, 4$ & 2.00 & 2.75 & 2.00 & 0.00 & 205.3 & 117.8 & 14.1 & 4,3 & 3.444 \\
\hline $6 s, 3$ & 2.00 & 2.25 & 2.50 & 4.17 & 175.5 & 100.5 & 12.8 & 4.3 & 3.392 \\
\hline $6 s .4$ & 2.00 & 2.00 & 2.50 & 0.00 & 193.8 & 105.8 & 12.9 & 4.2 & 3.687 \\
\hline $7 s, 3$ & 2.00 & 2.25 & 3.50 & 0.00 & 181.5 & 93.8 & 14.1 & 4.2 & 3.726 \\
\hline $7 \mathrm{~s}, 4$ & 2.00 & 2.00 & 3.00 & 0.00 & 201.8 & 102.8 & 13.8 & 4.4 & 3.271 \\
\hline $8 s, 3$ & 2.00 & 2.25 & 4.00 & $1 .+7$ & 169.5 & 77.8 & 13.6 & 4.0 & 3.002 \\
\hline $8 s, 4$ & 2.00 & 3.00 & 5.00 & 2.78 & 178.5 & 88.0 & 12.8 & 4.4 & 3.094 \\
\hline $9 \mathrm{~s}, 3$ & 2.50 & 2.00 & 2.25 & 2.56 & 174.0 & 87.5 & 12.6 & 4.4 & 3.257 \\
\hline $9 s, 4$ & 2.50 & 3.00 & 2.50 & 4.06 & 177.5 & 81.8 & 12.8 & 4.5 & $3 .+60$ \\
\hline $10 \mathrm{~s}, 3$ & 2.00 & 2.00 & 2.00 & 1.35 & 187.0 & 97.8 & 13.3 & 4.6 & 3.825 \\
\hline
\end{tabular}




\begin{tabular}{|c|c|c|c|c|c|c|c|c|c|}
\hline Cruzamentos & TURC & PHAE & SORG & ENFE & $\mathbf{A P}$ & $\mathbf{A E}$ & $\mathrm{CE}$ & DE & PG \\
\hline $10 \mathrm{~s}, 4$ & 2.50 & 2,50 & 2.00 & 0,00 & 204,3 & 101,0 & 14.5 & 4,4 & 4,605 \\
\hline $12 s, 3$ & 2,00 & 2,50 & 2.00 & 0,00 & 185.8 & 96.8 & 13,6 & 4,3 & 4,707 \\
\hline $12 \mathrm{~s}, 4$ & 2.25 & 2,50 & 2,50 & 1,25 & 186.5 & 93,3 & 12,8 & 4,4 & 3,867 \\
\hline $13 s, 3$ & 2.25 & 2,00 & 2,50 & 14,29 & 192,0 & 104.5 & 14.2 & 4.5 & 4,312 \\
\hline $13 s, 4$ & 2.00 & 2.25 & 3.25 & 1,32 & 196,3 & 104.0 & 13,2 & 4.1 & 3,765 \\
\hline $14 s, 3$ & 2,00 & 2,50 & 2,00 & 0,00 & 190,0 & 102,9 & 14,4 & 4,6 & 4,110 \\
\hline $14 s, 4$ & 2.25 & 2.50 & 2.50 & 6,27 & 203,0 & 100,0 & 14.5 & 4.1 & 3.980 \\
\hline $15 s, 3$ & 2.00 & 2.00 & 2.00 & 1.67 & 191.0 & 100.8 & 13.7 & 4.2 & 4.403 \\
\hline $15 s, 4$ & 2,50 & 2,75 & 2.50 & 1.56 & 182.3 & 95.3 & 12.9 & 4.4 & 3.584 \\
\hline $16 \mathrm{~s}, 3$ & 2.00 & 2.00 & 3.50 & 4.13 & 179.5 & 95,0 & 13.3 & 4.5 & 4.237 \\
\hline $16 s, 4$ & 2.00 & 2,00 & 2.50 & 2.94 & 184.0 & 88.8 & 13.1 & 4.5 & 3.965 \\
\hline $17 \mathrm{~s}, 3$ & 2.25 & 2.00 & 3.00 & 8.06 & 185.5 & 95.8 & 14,3 & 4.7 & 4.003 \\
\hline $17 \mathrm{~s}, 4$ & 2.50 & 2,50 & 3.00 & 1.22 & 200,8 & 98,3 & 13,6 & 4.6 & 4,429 \\
\hline $18 \mathrm{~s}, 3$ & 3.00 & 2,50 & 2.00 & 1,32 & 181.0 & 89.5 & 13.2 & 4.1 & 3.818 \\
\hline $18 \mathrm{~s}, 4$ & 2.75 & 2.75 & 2.50 & 0,00 & 186.0 & 88.5 & 12.9 & 4.5 & 3.984 \\
\hline $19 s, 3$ & 2.25 & 2,00 & 2.50 & 3.88 & 195,8 & 114.8 & 14.3 & 4,4 & 4.036 \\
\hline $19 s, 4$ & 2.00 & 2.00 & 3.00 & 0.00 & 202.8 & 112.8 & 14.8 & 4.1 & 3.836 \\
\hline $20 \mathrm{~s}, 3$ & 2.50 & 2,00 & 3.00 & 4,59 & 208.3 & 121.0 & 15.1 & 3.9 & 4.298 \\
\hline $20 s, 4$ & 2.50 & 2.50 & 2.75 & 0.00 & 206.5 & 113.3 & 13.8 & 4.2 & 3.808 \\
\hline $21 \mathrm{~s}, 3$ & 2.25 & 2,00 & 2.50 & 4,05 & 189,5 & 106,0 & 13,6 & 4,3 & 3,889 \\
\hline $21 \mathrm{~s}, 4$ & 2,00 & 2,50 & 2,00 & 5,26 & 186,5 & 86,0 & 14,2 & 4,4 & 3,726 \\
\hline $22 s, 3$ & 2.50 & 2,00 & 3,25 & 2,67 & 207,0 & 124,3 & 14,2 & 4,4 & 4.629 \\
\hline $22 s, 4$ & 2.00 & 2,00 & 3.50 & 2.94 & 196.5 & 110.5 & 11.5 & 4.1 & 3.497 \\
\hline $23 s, 3$ & 2.00 & 2,00 & 3.50 & 1.67 & 162.8 & 84.8 & 13.7 & 4.1 & 3.490 \\
\hline $23 s, 4$ & 2.00 & 2.50 & 2.50 & 4,17 & 187.8 & 91.5 & 14.2 & 4.4 & 3.692 \\
\hline $24 s, 3$ & 2.50 & 2.25 & 2.00 & 8.93 & 189.5 & 103.0 & 13.8 & 4.5 & 3.755 \\
\hline $24 s, 4$ & 2.50 & 2.00 & 3.00 & 7.14 & 182.5 & 86.0 & 13.5 & 4.5 & 3.748 \\
\hline $25 s, 3$ & 2.00 & 2.00 & $2.50^{\circ}$ & 0.00 & 212.5 & 114.8 & 13.0 & 4.6 & 3.777 \\
\hline $25 s, 4$ & 2,00 & 2,00 & 3.00 & 0,00 & 212.8 & 119.8 & 13.2 & 4.2 & 4.021 \\
\hline $26 s, 3$ & 2.00 & 2,00 & 3.25 & 1,61 & 194.8 & 103,3 & 14,2 & 4,1 & 4,290 \\
\hline $26 s, 4$ & 2.00 & 2.25 & 3.00 & 0.00 & 185.3 & 102.8 & 13.2 & 4.1 & 3.384 \\
\hline $30 \mathrm{~s}, 3$ & 2.00 & 2.00 & 2.00 & 2.63 & 190.8 & 108.5 & 13.8 & 4.6 & 3.811 \\
\hline $30 s, 4$ & 2.00 & 2.00 & 4.75 & 5.26 & 208.0 & 111.0 & 14.3 & 4.3 & 4.117 \\
\hline Testemunhas & TURC & PHAE & SORG & ENFE & AP & $\mathbf{A E}$ & $\mathrm{CE}$ & DE & PG \\
\hline $\mathrm{T} 1$ & 2.19 & 1.75 & 2.00 & 3.33 & 177.3 & 101.1 & 14.3 & 4,9 & 3.160 \\
\hline $\mathrm{T} 2$ & 2.25 & 2.00 & 3.13 & 1.47 & 237.9 & 138.3 & 14.6 & 4.3 & 3.164 \\
\hline
\end{tabular}


Tabela 15. Resumo das análises de variância do experimento 2 de safrinha para mancha de turcicum, mancha de Phaeosphaeria, ferrugem comum e porcentagem de plantas com enfezamento (ENFE).

\begin{tabular}{|c|c|c|c|c|c|}
\hline \multirow[b]{2}{*}{ FV } & \multirow[b]{2}{*}{ GL } & \multicolumn{3}{|c|}{ QM } & \multirow[b]{2}{*}{ STUNT } \\
\hline & & TURC & PHAE & SORGHI & \\
\hline Repetição & 1 & 0,321 & 0.098 & 0.390 & 64,438 \\
\hline Tratamentos & 75 & 0.274 & $0.240^{*}$ & $1.723 * *$ & 4.267 \\
\hline Dialelo & 73 & 0.279 & $0.213^{*}$ & $1.648^{* *}$ & 4.326 \\
\hline Acessos & $\overline{2} 3^{-}$ & $0 . \overline{45} 0^{* *}$ & $\overline{0.250 *}-$ & $2.6 \overline{5} 4^{*} \bar{*}$ & $\overline{6}, 06 \overline{2}^{--}$ \\
\hline Hibridos & 1 & 0,109 & $1.688 * *$ & 3.223 & 7,950 \\
\hline Entre grupos & 1 & $2.247 * *$ & 0,413 & $11.803^{* *}$ & 10,451 \\
\hline Heterose & 48 & 0.160 & 0,160 & 0.921 & 3.292 \\
\hline H. média & 1 & 0,073 & 0,000 & 1.292 & 6.875 \\
\hline H. Acessos & 23 & 0.254 & 0.207 & 1.107 & 4,124 \\
\hline H. Hibridos & 1 & 0,018 & 0,068 & 1.339 & 1,922 \\
\hline H. especifica & 23 & 0,076 & 0,123 & 0,701 & 2,363 \\
\hline Testemunhas & $\bar{l}$ & $0, \overline{0} \overline{1} \overline{6}$ & $0, \overline{25} 0^{-}$ & $5,063 *$ & 2,529 \\
\hline Dialelo vs Testemunha & 1 & 0,136 & $2,218 * *$ & $3.883^{*}$ & 1,681 \\
\hline Residuos & 87 & 0.216 & 0,143 & 0,905 & 4,302 \\
\hline Dentro test./rep. & 12 & 0.432 & 0.250 & 0,729 & 4,445 \\
\hline Erro & 75 & 0.182 & 0,126 & 0,933 & 4,279 \\
\hline $\mathrm{CV} \%$ & & 20,16 & 16.98 & 31,39 & 17,99 \\
\hline Média geral & & 2.31 & 2.23 & 3.03 & 3.07 \\
\hline
\end{tabular}

** $\mathrm{e}^{*}$ indicam, respectivamente, signifi cânciaao nivel de $1 \%$ e de $5 \%$ de probabilidade. 
Tabela 16. Resumo das análises de variância do experimento 2 de safrinha para altura de planta (AP), altura da espiga ( $\mathrm{AE}$ ), comprimento de espiga (CE), diâmetro de espiga (DE), e peso de grãos por parcela (PG).

\begin{tabular}{|c|c|c|c|c|c|c|}
\hline \multirow[b]{2}{*}{ FV } & \multirow[b]{2}{*}{ GL } & \multicolumn{5}{|c|}{$\mathbf{Q M}$} \\
\hline & & $\mathbf{A P}$ & $\mathbf{A E}$ & $\mathrm{CE}$ & $\mathbf{D E}$ & PG \\
\hline Repetição & 1 & 24.98 & 56,49 & 5.206 & 1,012 & 198.964 \\
\hline Tratamentos & 75 & $862.97 * *$ & $616.83 * *$ & $1.973 * *$ & $0.195 * *$ & $98.900 * *$ \\
\hline Dialelo & 73 & $601.04 * *$ & $461.68 * *$ & $1.700 * *$ & $0.158 *$ & $99.785^{* *}$ \\
\hline Ácessos & $\overline{2} \overline{3}$ & $\overline{1} \overline{7} \overline{1}, \overline{8} 8^{*} \bar{*}$ & $\overline{1} \overline{26} \overline{2} . \overline{5} 8^{*} \bar{*}$ & $2 . \overline{6}+8^{* *}$ & $\overline{0} \overline{2} \overline{4} \overline{6}^{*} \bar{*}$ & $\overline{132.864^{* *}-}$ \\
\hline Hibridos & 1 & 665.44 & 97.97 & 0.946 & 0,008 & 51.898 \\
\hline Entre grupos & 1 & 122.43 & 53,75 & $16,425 * *$ & $2.871^{* *}$ & $1710.557 * *$ \\
\hline Heterose & 48 & 192.39* & 93.98 & 0.954 & 0.062 & $51.375 * *$ \\
\hline H. média & 1 & $3027.85 * *$ & $1050.65 * *$ & $12.728 * *$ & 0,420 & $1174,800 * *$ \\
\hline H. Acessos & 23 & $129.85^{*}$ & 77.48 & 0.513 & 0,042 & 24.597 \\
\hline H. Hibridos & 1 & 2.63 & 57.31 & 1.982 & 0,015 & 85.229 \\
\hline H. especifica & 23 & 139.89 & 70.49 & 0.839 & 0.068 & 27.837 \\
\hline Testemunhas & $\overline{1}$ & 14701.56 & $\overline{55} \overline{13} .06^{*} \bar{*}$ & $\overline{0} \overline{3} 4 \overline{6}$ & $\overline{1.15} \overline{6^{* *}}$ & $\overline{0} . \overline{005}$ \\
\hline Dialelo v's Testemunha & 1 & $6145.24 * *$ & $7046.56 * *$ & $23.573 * *$ & $1,993^{* *}$ & $133.129 *$ \\
\hline Residuo & 87 & 188.01 & 85.85 & 0,984 & 0,106 & 25,773 \\
\hline Dentro test./rep. & 12 & 180.85 & 116,35 & 1,355 & 0,268 & 13,687 \\
\hline Erro & 75 & 189.16 & 80,97 & 0,924 & 0,081 & 27.706 \\
\hline CV\% & & 7.26 & 9.29 & 7.44 & 7.66 & 14.77 \\
\hline Média geral & & 188.95 & 99.75 & 13.34 & 4.26 & 3.44 \\
\hline
\end{tabular}

** e * indicam, respectivamente, significância ao nivel de $1 \%$ e de $5 \%$ de probabilidade. 
Tabela 17. Efeitos de variedade $v_{i}$ no experimento 2 para mancha de turcicum, mancha de Phaeosphaeria, ferrugem comum, porcentagem de plantas com enfezamento (ENFE), altura de planta (AP), altura da espiga (AE), comprimento de espiga (CE), diâmetro de espiga (DE), e peso de grãos por parcela (PG).

\begin{tabular}{|c|c|c|c|c|c|c|c|c|c|}
\hline Acessos & TURC & PHAE & SORG & ENFE & AP & $\mathbf{A E}$ & CE & DE & PG \\
\hline $1 \mathrm{~s}$ & 0,005 & $-0,089$ & 1,740 & 0,152 & -55.385 & $-41,063$ & $-3,190$ & $-0,613$ & $-1,746$ \\
\hline $2 \mathrm{~s}$ & 1.005 & 0.161 & 0.990 & -0.026 & -33.635 & -29.063 & -0.190 & 0.289 & -0.585 \\
\hline $5 \mathrm{~s}$ & 005 & 161 & -0.510 & 0.052 & 13.615 & 938 & 0.308 & -0.065 & -0.222 \\
\hline $6 s$ & 0.130 & 1.036 & -0.510 & -0.009 & -8.635 & 813 & -0.531 & 0.052 & $-0,585$ \\
\hline $7 \mathrm{~s}$ & -0.245 & 0.661 & -0.010 & -0.058 & 19.615 & 9.688 & 0.612 & 0.402 & 1.031 \\
\hline $8 s$ & 0.255 & -0.339 & 1.740 & -0.029 & -26.385 & -23.063 & -1.103 & 0.018 & -1.608 \\
\hline $9 s$ & -0.495 & 0.161 & 0,740 & -0.039 & $-15,635$ & -15.063 & $-1,509$ & -0.015 & $-0,095$ \\
\hline $10 \mathrm{~s}$ & 05 & & 40 & & 6,615 & & & 0.112 & 0,708 \\
\hline $12 \mathrm{~s}$ & -0.495 & $-0,089$ & $-0,510$ & 0,020 & 615 & 38 & & 0.227 & 0.162 \\
\hline $13 \mathrm{~s}$ & 0.005 & 0,411 & $-0,760$ & 0.019 & 365 & 88 & 25 & 0.432 & 0,708 \\
\hline $14 \mathrm{~s}$ & -0.495 & 0,411 & $-0,260$ & 0,020 & 7.365 & 0.938 & 0,815 & 0.062 & 0,462 \\
\hline $15 \mathrm{~s}$ & $-0,495$ & 0,161 & 490 & 0,106 & 6,115 & 2,688 & 0,699 & 0.024 & 0,484 \\
\hline $16 s$ & 0,755 & $-0,339$ & $-0,010$ & $-0,058$ & -19.385 & -17.813 & & 0.401 & 0.226 \\
\hline $17 \mathrm{~s}$ & 0.005 & $-0,339$ & 240 & -0.058 & 615 & & 0,2 & 0.435 & 0,459 \\
\hline $18 \mathrm{~s}$ & 0.505 & $-0,3$ & -0.010 & -0.058 & $-10,135$ & -10 . & -0 & 0.047 & 0.136 \\
\hline $19 \mathrm{~s}$ & $-0,495$ & $-0,339$ & $-1,510$ & $-0,058$ & 55,865 & 48,438 & 0,828 & $-0,158$ & 0,763 \\
\hline $20 \mathrm{~s}$ & 0,005 & $-0,339$ & $-0,260$ & 0,081 & 15,865 & 14,438 & 0,258 & $-0,420$ & $-0,641$ \\
\hline $21 \mathrm{~s}$ & 0.505 & -0.339 & -1.510 & -0.015 & -8.385 & -14.063 & 0,363 & 0.178 & 0.551 \\
\hline $22 \mathrm{~s}$ & -0.495 & $-0,3$ & -0.010 & 0.072 & 5.865 & .938 & 0,7 & -0.609 & -0.028 \\
\hline $23 \mathrm{~s}$ & 0.005 & -0.339 & -0.510 & 0.005 & -14.135 & -10.563 & 0.362 & -0.023 & 0.228 \\
\hline $24 s$ & 0.005 & 0.411 & -1.010 & 0.015 & -13.885 & -11.063 & -0.782 & 0.026 & -0.122 \\
\hline $25 \mathrm{~s}$ & 0.755 & -0.339 & 0,740 & -0.058 & 32.865 & 36.438 & -0.261 & -0.368 & $-0,218$ \\
\hline $26 s$ & -0.495 & 0,161 & 0,990 & -0.058 & 1,615 & 6,438 & 0.252 & -0.377 & -0.566 \\
\hline $30 \mathrm{~s}$ & -0.245 & $-0,339$ & $-1,010$ & $-0,020$ & 24,615 & 23,438 & $-0,101$ & -0.056 & 0,499 \\
\hline Híbridos & TURC & PHAE & SORG & ENFE & AP & $\mathrm{AE}$ & CE & $\mathrm{DE}$ & PG \\
\hline $\mathrm{H3}$ & -0.125 & -0.125 & $-0,875$ & 0.037 & -4.125 & 5.375 & $-0,468$ & -0.040 & -0.291 \\
\hline H4 & 0.125 & 0.125 & 0.875 & -0.037 & 4.125 & -5.375 & 0,468 & 0.040 & 0.291 \\
\hline
\end{tabular}


Tabela 18. Efeitos de heterose de variedade $h_{i}$ no experimento 2 para mancha de turcicum. mancha de Phaeosphaeria. ferrugem comum, porcentagem de plantas com enfezamento (ENFE), altura de planta (AP), altura da espiga (AE), comprimento de espiga (CE), diâmetro de espiga (DE), e peso de grãos por parcela (PG).

\begin{tabular}{|c|c|c|c|c|c|c|c|c|c|}
\hline Acessos & TURC & PHAE & SORG & ENFE & AP & AE & CE & $\mathbf{D E}$ & PG \\
\hline $1 \mathrm{~s}$ & 0.388 & $-0,005$ & 1.505 & -0.077 & -3.943 & $-4,497$ & 0,229 & $-0,065$ & $-0,256$ \\
\hline $2 s$ & .138 & -0.193 & -0.620 & -0.023 & 16.557 & 7,378 & 0.132 & 0.082 & 0.292 \\
\hline $5 s$ & -0.237 & 0,057 & -0.120 & -0.062 & 1.807 & 5.253 & $-0,196$ & 0,074 & -0.302 \\
\hline $6 s$ & -0.299 & -0.630 & -0.120 & -0.001 & -0.568 & 4.878 & -0.411 & -0.063 & 0.041 \\
\hline $7 \mathrm{~s}$ & $-0,112$ & $-0,443$ & 0,380 & -0.007 & $-7,693$ & $-5,747$ & 0,092 & $-0,227$ & $-0,807$ \\
\hline $8 s$ & -0.362 & 0,557 & 0.755 & 0.011 & -2.318 & -4.747 & 0.216 & -0.146 & 0,062 \\
\hline $9 s$ & 0.513 & 0,182 & -0.870 & 0.034 & -5.943 & -6.997 & $-0,074$ & 0,095 & -0.384 \\
\hline $10 \mathrm{~s}$ & 0.013 & -0.068 & -1.245 & -0.027 & 2.807 & $-1,497$ & $-0,081$ & 0,105 & 0,071 \\
\hline $12 \mathrm{~s}$ & 0.138 & 0,307 & $-0,370$ & -0.036 & -5.1 & $-5,622$ & $-0,558$ & $-0,088$ & 0,415 \\
\hline $13 \mathrm{~s}$ & -0.112 & -0.318 & 0.380 & 0.052 & 0.4 & 4,503 & $-0,358$ & -0.227 & $-0,106$ \\
\hline $14 \mathrm{~s}$ & 0.138 & 0,057 & $-0,495$ & 0.001 & 3,3 & 1.815 & 0,488 & -0.029 & 0,023 \\
\hline $15 \mathrm{~s}$ & 0,263 & 0,057 & $-0,870$ & -0.064 & $-5,943$ & $-2,497$ & $-0,585$ & $-0,037$ & $-0,039$ \\
\hline $16 \mathrm{~s}$ & -0.612 & -0.068 & 0.130 & 0.048 & 1,932 & 1.628 & $-0,644$ & -0.001 & 0.197 \\
\hline $17 \mathrm{~s}$ & 0,138 & 0,182 & 0,005 & 0.057 & 1.807 & 2.128 & 0.286 & 0,097 & 0,196 \\
\hline $18 \mathrm{~s}$ & 0.388 & 0.557 & $-0,620$ & 0.004 & $-0,943$ & $-4,747$ & -0.311 & $-0,089$ & 0,043 \\
\hline $19 \mathrm{~s}$ & 0,138 & $-0,068$ & 0,630 & 0,023 & $-18,193$ & $-9,622$ & 0,601 & 0,035 & $-0,236$ \\
\hline $20 \mathrm{~s}$ & 0,263 & 0,182 & 0,130 & $-0,041$ & 9,932 & 10,753 & 0,794 & $-0,073$ & 0,583 \\
\hline $21 \mathrm{~s}$ & -0.362 & 0,182 & 0,130 & 0.038 & 2,682 & 3.878 & 0.195 & -0.059 & -0.258 \\
\hline $22 \mathrm{~s}$ & 0.263 & -0.068 & 0.505 & -0.029 & 9.307 & 9.253 & -0.870 & 0.201 & 0.286 \\
\hline $23 s$ & -0.237 & 0,182 & 0,380 & 0.005 & -7.193 & -5.747 & 0.215 & -0.076 & -0.313 \\
\hline $24 s$ & 0.263 & -0.318 & 0,130 & 0.063 & 3.432 & 0,878 & 0.497 & 0.136 & 0.022 \\
\hline $25 \mathrm{~s}$ & -0.612 & -0.068 & -0.495 & -0.007 & 6.682 & -0.122 & -0.280 & 0.268 & 0.218 \\
\hline $26 \mathrm{~s}$ & 0.013 & -0.193 & -0.245 & 0.006 & -0.318 & 0.628 & 0.069 & -0.056 & 0.330 \\
\hline $30 \mathrm{~s}$ & -0.112 & -0.068 & 1.005 & 0.031 & -2.443 & -1.122 & 0.554 & 0.144 & $-0,076$ \\
\hline Híbridos & TURC & PHAE & SORG & ENFE & $\mathbf{A P}$ & $\mathbf{A E}$ & $\mathrm{CE}$ & DE & PG \\
\hline H3 & 0.036 & $-0,070$ & 0,313 & -0.012 & $-0,438$ & -2.044 & 0,380 & 0.033 & 0.249 \\
\hline H4 & -0.036 & 0,070 & $-0,313$ & 0.012 & 0,438 & 2.044 & $-0,380$ & $-0,033$ & -0.249 \\
\hline
\end{tabular}


Tabela 19. Efeitos de capacidade geral de combinação $\mathrm{g}_{\mathrm{i}}$ no experimento 2 para mancha de turcicum. mancha de Phaeosphaeria, ferrugem comum, porcentagem de plantas com enfezamento (ENFE), altura de planta (AP), altura da espiga (AE), comprimento de espiga (CE), diâmetro de espiga (DE), e peso de grãos por parcela (PG).

\begin{tabular}{|c|c|c|c|c|c|c|c|c|c|}
\hline Acessos & TURC & PHAE & SORG & ENFE & AP & $\mathbf{A E}$ & CE & DE & PG \\
\hline $1 \mathrm{~s}$ & 0.391 & $\begin{array}{l}-0.049 \\
\end{array}$ & 2.375 & $-0,001$ & $-31,635$ & $-25,029$ & $-1,367$ & -0.372 & -1.129 \\
\hline $2 s$ & 0.641 & -0.112 & $-0,125$ & -0.036 & $-0,260$ & $-7,154$ & 0,036 & 0.227 & $-0,001$ \\
\hline $5 \mathrm{~s}$ & -0.234 & 0.138 & -0.375 & -0.036 & 8.615 & 12.721 & -0.042 & 0.042 & -0.413 \\
\hline $6 s$ & -0.234 & -0.112 & -0.375 & -0.006 & -4.885 & 3.971 & -0.676 & -0.037 & -0.251 \\
\hline $7 s$ & -0.234 & -0.112 & 0.375 & -0.036 & 2.115 & -0.904 & 0.398 & -0.026 & -0.292 \\
\hline $8 s$ & -0.234 & 0.388 & 1,625 & $-0,003$ & $-15,510$ & $-16,279$ & -0.335 & -0.137 & $-0,742$ \\
\hline $9 s$ & 0.266 & 0.263 & -0.500 & 0,015 & $-13,760$ & -14.529 & $-0,828$ & 0.087 & -0.432 \\
\hline $10 \mathrm{~s}$ & & 0.013 & $-0,875$ & $-0,025$ & 6,115 & 0,221 & 0,376 & 0,161 & 0,425 \\
\hline $12 \mathrm{~s}$ & -0.109 & 0.263 & $-0,625$ & $-0,026$ & -3.385 & -4.154 & -0.339 & 0.026 & 0,496 \\
\hline $13 \mathrm{~s}$ & -0.109 & -0.112 & 0.000 & 0.062 & 4.615 & 5.096 & 0.154 & -0.011 & 0.248 \\
\hline $14 \mathrm{~s}$ & -0.109 & 0,263 & $-0,625$ & 0,010 & 6,990 & 2,284 & 0,896 & 0,002 & 0,255 \\
\hline $15 \mathrm{~s}$ & 016 & 0.138 & $-0,625$ & $-0,011$ & -2.885 & -1.154 & $-0,235$ & -0.025 & 0.203 \\
\hline $16 s$ & -0.234 & $-0,237$ & 0,125 & & $-7,760$ & $-7,279$ & $-0,366$ & 0,199 & 0.310 \\
\hline $17 \mathrm{~s}$ & 141 & 13 & 0,125 & 0,028 & 3,615 & -2 & 0,419 & 15 & 0,426 \\
\hline $18 \mathrm{~s}$ & 0,641 & 0.388 & -0.625 & -0.025 & $-6,010$ & & 504 & 66 & 0.111 \\
\hline $19 \mathrm{~s}$ & -0.109 & -0.237 & $-0,125$ & $-0,006$ & 9,740 & 14,596 & 1,015 & $-0,044$ & 0,146 \\
\hline $20 \mathrm{~s}$ & 0,266 & 0,013 & 0,000 & $-0,001$ & 17,865 & 17,971 & 0,922 & $-0,283$ & 0,263 \\
\hline $21 \mathrm{~s}$ & -0.109 & 0.013 & -0.625 & 0.031 & -1.510 & -3.154 & 0,377 & 0,030 & 0,017 \\
\hline $22 \mathrm{~s}$ & 0.016 & -0.237 & 0,500 & 0.007 & 12.240 & 18.221 & -0.693 & -0.104 & 0,272 \\
\hline $23 \mathrm{~s}$ & -0.234 & 0,013 & 0,125 & 0,007 & $-14,260$ & $-11,029$ & 0.396 & $-0,088$ & -0.200 \\
\hline $24 s$ & 0.266 & -0.112 & -0.375 & 0.071 & $-3,510$ & -4.654 & 0.106 & 0.149 & -0.039 \\
\hline $25 \mathrm{~s}$ & -0.234 & -0.237 & -0.125 & -0.036 & 23.115 & 18.096 & -0.411 & 0.084 & 0.109 \\
\hline $26 s$ & -0.234 & -0.112 & 0.250 & -0.023 & 0.490 & 3.846 & 0,196 & -0.245 & 0.046 \\
\hline $30 \mathrm{~s}$ & -0.234 & -0.237 & 0.500 & 0,021 & 9.865 & 10,596 & 0.504 & 0.116 & 0,173 \\
\hline Híbridos & TURC & PHAE & SORG & ENFE & AP & $\mathbf{A E}$ & $\mathrm{CE}$ & DE & PG \\
\hline H3 & -0.026 & $-0,133$ & $-0,125$ & 0,007 & $-2,500$ & 0,643 & 0.146 & 0,013 & 0.104 \\
\hline H4 & 0.026 & 0.133 & 0.125 & $-0,007$ & 2,500 & -0.643 & $-0,146$ & $-0,013$ & $-0,104$ \\
\hline
\end{tabular}


Tabela 20. . Médias dos tratamentos do experimento 3 para mancha de turcicum. mancha de Phaeosphaeria, ferrugem comum, porcentagem de plantas com podridão do colmo (PODR). porcentagem de plantas com enfezamento (ENFE), altura de planta (AP), altura da espiga (AE). comprimento de espiga $(C E)$, diâmetro de espiga $(D E)$, e peso de grãos por parcela $(P G)$.

\begin{tabular}{|c|c|c|c|c|c|c|c|c|c|c|}
\hline Acessos & TURC & PHAE & SORG & PODR & ENFE & AP & $\overline{\mathrm{AE}}$ & $\mathrm{CE}$ & DE & PG \\
\hline 1 & 3.25 & 2,78 & 4,75 & 1,48 & 18,19 & 188,3 & 102,8 & 10,8 & 3.3 & 1.165 \\
\hline 2 & 3.50 & 2.94 & 6,00 & 3,61 & 14,18 & 182,5 & 94.8 & 11,6 & 3.1 & 0.998 \\
\hline 3 & 4.38 & 2.24 & 5.75 & 4.19 & 10.39 & 204.3 & 116.5 & 10.5 & 3.4 & 0.843 \\
\hline 4 & 4.32 & 2.65 & 4.50 & 1.44 & 8.34 & 216.0 & 127.3 & 10.8 & 3.3 & 0.887 \\
\hline 5 & 4.00 & 2.23 & 6.00 & 8.37 & 17.02 & 185.8 & 94.3 & 10.5 & 3.3 & 0.798 \\
\hline 6 & 3.75 & 2,30 & 5.50 & 0.00 & 14.58 & 172.3 & 85,0 & 10,1 & 2.8 & 0.997 \\
\hline 8 & 3.00 & 2.31 & 5.50 & 7.38 & 15.44 & 195.3 & 113.3 & 10.4 & 3.5 & 0.471 \\
\hline 9 & 4,25 & 2.19 & 6,25 & 10,04 & 23,68 & 180,0 & 94,0 & 10,0 & 3.8 & 0.539 \\
\hline 10 & 3.50 & 2,22 & 6,00 & 1,33 & 20,89 & 172.3 & 88,3 & 11.8 & 3.3 & 1,339 \\
\hline 11 & 4.00 & 2.09 & 5,50 & 1,30 & 8.91 & 187.8 & 102.3 & 11.3 & 3.4 & 1.556 \\
\hline 12 & 4.00 & 2,86 & 6.25 & 0,03 & 20.64 & 196.3 & 109.8 & 10,0 & 3.2 & 0.700 \\
\hline 13 & 3.75 & 2.45 & 5.00 & 3,05 & 10.52 & 210.0 & 119.5 & 10.3 & 3.1 & 0.868 \\
\hline 14 & 4.50 & 2.21 & 5.50 & 0.00 & 3.83 & 201.5 & 165.0 & 11.1 & 3.3 & 1.099 \\
\hline 15 & 3.50 & 2,02 & 6,00 & 2,72 & 9.85 & 213.5 & 120.5 & 11.5 & 3.3 & 0.852 \\
\hline 16 & 4.00 & 2,24 & 6.25 & 3.68 & 20,36 & 209.3 & 118.8 & 10,7 & 3.2 & 0.866 \\
\hline 17 & 4,50 & 2,56 & 5,25 & 4,44 & 13,39 & 216,0 & 126,0 & 10,5 & 3,3 & 0,812 \\
\hline 18 & 4,00 & 2,37 & 5,00 & 10,36 & 54,13 & 197.8 & 111,8 & 11,6 & 3.6 & 0,885 \\
\hline 19 & 3.50 & 2.68 & 4.50 & 1.35 & 10.46 & 186,0 & 99.8 & 11.1 & 3.2 & 1.062 \\
\hline 20 & 3.50 & 2.45 & 5.00 & 1.76 & 48.38 & 173.8 & 87.0 & 9.8 & 2.8 & 0.679 \\
\hline 21 & 4.00 & 2.10 & 6.50 & 7,61 & 23.67 & 196.0 & 105.3 & 9.7 & 3.2 & 0.841 \\
\hline 22 & 3.88 & 2.22 & 5.75 & 4,31 & 26.93 & 189,5 & 96.5 & 10.5 & 3.1 & 0.861 \\
\hline 23 & 5.00 & 2,00 & 4.25 & 1.26 & 25.42 & 200.5 & 115.3 & 10.0 & 3.2 & 0.568 \\
\hline 25 & 3.83 & 2.06 & 5.25 & 7.16 & 14.36 & 190.8 & 106.8 & 11.3 & 3.1 & 0.994 \\
\hline 26 & 4.25 & 2,22 & 5.75 & 5.56 & 8,11 & 200,8 & 117,3 & 11,0 & 3.5 & 1,061 \\
\hline 27 & 3.75 & 2.14 & 6.00 & 3.23 & 21.84 & 220.5 & 122.8 & 11.9 & 3.1 & 0.803 \\
\hline 29 & 3.50 & 2,40 & 4.25 & 4,57 & 17.17 & 218.8 & 131.5 & 10,9 & 3.4 & 1.039 \\
\hline 30 & 3.50 & 2.19 & 5.00 & 2.52 & 7.38 & 238.8 & 146.3 & 10,4 & 3.2 & 0.669 \\
\hline Topcrosses & TURC & PHAE & SORG & PODR & ENFE & AP & AE & CE & DE & PG \\
\hline$t 1$ & 4.00 & 2.43 & 4.50 & 1.33 & 22.11 & 202.8 & 115.0 & 9.9 & 3.3 & 0.941 \\
\hline $\mathrm{t} 2$ & 2.94 & 2.28 & 5.25 & 4.31 & 6.43 & 192.8 & 100.5 & 10.6 & 3.2 & 1.074 \\
\hline $\mathrm{t} 3$ & 3.50 & 2.04 & 6.50 & 2.88 & 11.96 & 206.8 & 114.8 & 11.4 & 3.6 & 1.008 \\
\hline t4 & 3.75 & 2.33 & 5.75 & 2.88 & 17.81 & 209.3 & 123.3 & 11.9 & 3.5 & 1.033 \\
\hline t5 & 4.00 & 2.46 & 5.75 & 4.18 & 15.20 & 194.8 & 104.3 & 11.2 & 3.7 & 1.037 \\
\hline t6 & 3.25 & 2.08 & 5.25 & 1.41 & 12.50 & 198.0 & 111.5 & 11.8 & 3.8 & 1.092 \\
\hline t8 & 4.00 & 2.48 & 5.50 & 2.11 & 8.61 & 180.3 & 94.8 & 10.8 & 3.3 & 0.997 \\
\hline t9 & 3.00 & 2.46 & 5.00 & 0.02 & 8.97 & 192.3 & 103.3 & 11.2 & 3.4 & 0.999 \\
\hline $\mathrm{t} 10$ & 3.66 & 2.75 & 5.25 & 1.28 & 7.69 & 213.8 & 121.0 & 11.4 & 3.2 & 1.601 \\
\hline t11 & 3.50 & 2.42 & 5,50 & 3.86 & 10.70 & 202.0 & 116.5 & 10.3 & 3.4 & 1.106 \\
\hline $\mathrm{t} 12$ & 3.25 & 2.71 & 5.50 & 0.02 & 10.95 & 208.5 & 120.0 & 11.7 & 3.1 & 1.381 \\
\hline $\mathrm{t} 13$ & 4.00 & 2.11 & 6.50 & 4.30 & 11.53 & 204.3 & 115.5 & 9.0 & 3.2 & 1.024 \\
\hline t1t & 3.63 & 2.54 & 6.25 & 2.51 & 6.61 & 215.3 & 74.0 & 10.4 & 3.3 & 1.043 \\
\hline t15 & 3.75 & 2.40 & 5.00 & 2.97 & 22.16 & 193.8 & 103.8 & 10.5 & 3.3 & 0.967 \\
\hline$t 16$ & 4.00 & 2.09 & 5.50 & 3.05 & 16.56 & 206.0 & 120.0 & 9.1 & 2.9 & 0.863 \\
\hline
\end{tabular}




\begin{tabular}{crrrrrrrrrr}
\hline Topcrosses & TURC & PHAE & SORG & PODR & ENFE & AP & AE & CE & DE & PG \\
\hline t17 & 3,75 & 2,20 & 5.25 & 2.80 & 19,64 & 188.8 & 108,8 & 10.6 & 3.4 & 0,799 \\
t18 & 4,00 & 2,10 & 6,00 & 3.49 & 11.99 & 200,0 & 114.0 & 11.3 & 3,6 & 0.924 \\
t19 & 3,75 & 2,21 & 6.00 & 3,16 & 25,51 & 183.0 & 102.5 & 11.5 & 3.3 & 1,197 \\
t20 & 3.25 & 2.46 & 5.50 & 0.00 & 12,23 & 193,0 & 102,0 & 11.3 & 3.4 & 1.078 \\
t21 & 4.50 & 2,31 & 5.50 & 5.44 & 17.04 & 191.3 & 54,0 & 10.0 & 3.3 & 0.839 \\
t22 & 3,50 & 2,19 & 6.25 & 0,00 & 12,31 & 205.3 & 115,0 & 10.4 & 3,0 & 1,022 \\
t23 & 4,06 & 2,18 & 6,25 & 6,09 & 13.83 & 215.8 & 124,8 & 11.4 & 3.5 & 0,864 \\
t25 & 3,50 & 2.17 & 5.75 & 3.13 & 17.19 & 197.5 & 110.8 & 12.0 & 3.4 & 1.060 \\
t26 & 4.75 & 2.24 & 5.00 & 3.05 & 11.12 & 214.0 & 124.8 & 9.7 & 3.4 & 0.700 \\
t27 & 4.25 & 2.18 & 4.75 & 0.00 & 3.03 & 220.5 & 123.5 & 11.8 & 3.4 & 1,254 \\
t29 & 3.75 & 2.05 & 5.50 & 0.03 & 24.77 & 198.3 & 113.0 & 11.8 & 3.6 & 1,238 \\
t30 & 4.38 & 2.40 & 6.00 & 4.19 & 10.58 & 210.3 & 116.0 & 10.3 & 3.3 & 0.888 \\
\hline Testemunhas & TURC & PHAE & SORG & PODR & ENFE & AP & AE & CE & DE & PG \\
\hline T1 & 2.92 & 2,13 & 3.33 & 0,00 & 12.26 & 155.5 & 71,8 & 12,7 & 4.2 & 1.624 \\
T2 & 4.00 & 2.06 & 6.33 & 0.00 & 3.76 & 206.2 & 108.7 & 10.7 & 3.8 & 1.236 \\
\hline
\end{tabular}


Tabela 21. Resumo das análises de variância do experimento 3 para mancha de turcicum. mancha de Phaeosphaeria, ferrugem comum, porcentagem de plantas com podridão do colmo (PODR) e porcentagem de plantas com enfezamento (ENFE).

\begin{tabular}{|c|c|c|c|c|c|c|}
\hline \multirow[b]{2}{*}{ FV } & \multirow[b]{2}{*}{ GL } & \multicolumn{4}{|c|}{ QM } & \multirow[b]{2}{*}{$\begin{array}{l}\text { STUNT } \\
\times 10^{3}\end{array}$} \\
\hline & & TURC & PHAE & SORG & $\begin{array}{l}\text { PODRI } \\
\times 10^{3}\end{array}$ & \\
\hline Repetição & 1 & 3.429 & 0.218 & 10.800 & 0.090 & 0.571 \\
\hline Tratamentos & 55 & $0,460 * *$ & $0.108^{*}$ & $1.2+2 * *$ & $7.906 * *$ & $22.151^{*}$ \\
\hline Topcross & 53 & $0.383^{*}$ & $0.102^{*}$ & 0.683 & $6.586^{* *}$ & $20.413^{* *}$ \\
\hline$\overline{\mathrm{A}} \overline{\mathrm{cess}} \overline{\mathrm{s}} \mathrm{s} \mathrm{s}^{-\cdots-\cdots}$ & $2 \overline{6}$ & $\overline{0}, \overline{401} \overline{1}^{*}$ & $0, \overline{13} 0^{*}$ & $\overline{0.614}$ & $\overline{8}, \overline{159 * *}$ & $25,09 \overline{1}$ \\
\hline Heterose média & 1 & 0,388 & 0.026 & 0,454 & 7,904 & $61.690 *$ \\
\hline Heterose acessos & 26 & 0.366 & 0.076 & 0.761 & $4.962 * *$ & 14.146 \\
\hline Testemunha & $\overline{1}$ & $\overline{3} . \overline{5} 21^{* *}$ & $0.016^{-1}$ & $\overline{2} \overline{7} . \overline{0} 00^{* *}$ & $\overline{0}, \overline{0} 00^{---}$ & $3 \overline{5} . \overline{9} 8$ \\
\hline Topcross rs Testemunha & 1 & $1,453^{*}$ & $0.561^{* *}$ & $5.070 * *$ & $85,790 * *$ & $100.948 * *$ \\
\hline Residuo & 63 & 0.231 & 0,065 & 0.518 & 2.287 & 11.025 \\
\hline Dentro test./rep. & 8 & 0,208 & 0,021 & 0.667 & 0,000 & 6.359 \\
\hline Erro & 55 & 0.234 & 0,071 & 0.496 & 2,619 & 11,703 \\
\hline $\mathrm{CV} \%$ & & 12.68 & 11,08 & 13.20 & 11,90 & 20.28 \\
\hline Média geral & & 3.79 & 2,30 & 5.45 & 3,06 & 15.59 \\
\hline
\end{tabular}

** e * indicam. respectivamente, significância ao nivel de $1 \%$ e de $5 \%$ de probabilidade.

Tabela 22. Resumo das análises de variância do experimento 3 de safrinha para altura da espiga $(\mathrm{AE})$, comprimento de espiga (CE), diâmetro de espiga (DE), e peso de grãos por parcela (PG).

\begin{tabular}{|c|c|c|c|c|c|c|}
\hline \multirow[b]{2}{*}{ FV } & \multirow[b]{2}{*}{ GL } & \multicolumn{5}{|c|}{ QM } \\
\hline & & AP & $\mathrm{AE}$ & $\mathrm{CE}$ & $\mathrm{DE}$ & PG \\
\hline Repetição & 1 & 5300,05 & 3735.25 & 10.609 & 0,138 & 1.517 \\
\hline Tratamentos & 55 & $900,83^{* *}$ & $700.85 * *$ & 1.407 & $0,189 * *$ & $0,144^{* *}$ \\
\hline Topcross & 53 & $870,83^{* *}$ & 567.29 & 1.084 & 0.087 & $0.098^{* *}$ \\
\hline Ácessos & $\overline{2} \overline{6}$ & $6 \overline{8} 2.24^{*} *$ & $\overline{592.1 \overline{2}}$ & $1.00 \overline{2}$ & $0.0 \overline{9}$ & $\overline{0.1} \overline{124 * *}$ \\
\hline Heterose média & 1 & $7301.33 * *$ & 185.39 & 0.479 & $0.265^{*}$ & $0.528 * *$ \\
\hline Heterose acessos & 26 & $812.09 * *$ & 557.14 & 1.190 & 0.075 & 0.055 \\
\hline Testemunha & $i$ & $2 \overline{75} .52$ & $\overline{4070} . \overline{0} 8^{*} * \bar{*}$ & $11.367 * \bar{*}$ & $0.385^{*}$ & $0 . \overline{4} \overline{1} \overline{1}^{* *}$ \\
\hline Topcross vs Testemunha & 1 & $3116.10 * *$ & $4+10.47 * *$ & $8.532 * *$ & $5.391 * *$ & $2.301^{* *}$ \\
\hline Residuo & 63 & 158,01 & 374.74 & 0.980 & 0,063 & $0.0+3$ \\
\hline Dentro test./rep. & 8 & 100.13 & 55.42 & 0.464 & 0.067 & 0.070 \\
\hline Erro & 55 & 166.43 & 421.19 & 1.056 & 0.062 & 0.039 \\
\hline $\mathrm{CV} \%$ & & 6.01 & 17.85 & 9.09 & 7.41 & 20.38 \\
\hline Média geral & & 209.16 & 108.44 & 10.89 & 3.38 & 1.01 \\
\hline
\end{tabular}

** e * indicam. respectivamente. significância ao ní el de $1 \%$ e de $5 \%$ de probabilidade 
Tabela 23. Efeitos de variedade $v_{i}$ no experimento 3 para para mancha de turcicum. mancha de Phaeosphaeria. ferrugem comum, porcentagem de plantas com podridão do colmo (PODR), porcentagem de plantas com enfezamento (ENFE), altura de planta (AP), altura da espiga (AE), comprimento de espiga $(\mathrm{CE})$, diâmetro de espiga $(\mathrm{DE})$, e peso de grãos por parcela $(\mathrm{PG})$.

\begin{tabular}{|c|c|c|c|c|c|c|c|c|c|c|}
\hline Acessos & TURC & PHAE & SORG & PODR & STUN & AP & $\mathbf{A E}$ & $\mathrm{CE}$ & DE & PG \\
\hline 1 & -0.640 & 0,443 & $-0,704$ & $-0,054$ & 0,008 & $-5,083$ & $-9,019$ & 0,022 & 0,037 & 0,267 \\
\hline 2 & -0.390 & 0.601 & 0.546 & 0.087 & -0.038 & -13.333 & -17.019 & 0.862 & -0.138 & 0.100 \\
\hline 3 & 0.490 & -0.102 & 0.296 & 0.011 & -0.083 & -2.583 & 4.731 & -0.209 & 0.140 & -0.055 \\
\hline 4 & 0.430 & 0.317 & -0.954 & -0.054 & -0.109 & 10.917 & 15.481 & 0.041 & 0.046 & -0.011 \\
\hline 5 & 0.110 & -0.108 & 0.546 & 0.110 & -0.010 & -18.583 & -17.519 & -0.198 & 0.021 & -0.100 \\
\hline 6 & -0.140 & -0.039 & 0.046 & -0.098 & -0.036 & 2.667 & -26.769 & -0.671 & -0.430 & 0.099 \\
\hline 8 & -0.890 & -0.032 & 0.046 & 0.069 & -0.030 & -19.083 & 1.481 & -0.379 & 0.267 & -0.427 \\
\hline 9 & 0.360 & -0.148 & 0,796 & 0.163 & 0,065 & $-47,333$ & -17.769 & -0.738 & 0.496 & -0.360 \\
\hline 10 & -0.390 & $-0,113$ & 0,546 & $-0,052$ & 0,033 & $-24,833$ & -23.519 & 1.050 & $-0,014$ & 0,440 \\
\hline 11 & 0.110 & -0.249 & 0.046 & -0.039 & -0.103 & -4.583 & 519 & 0.563 & 0.103 & 0.657 \\
\hline 12 & 0.110 & 0.523 & 0.796 & -0.036 & 0,035 & 11.917 & -2.019 & -0.750 & -0.086 & -0.199 \\
\hline 13 & -0.140 & 0.110 & $-0,454$ & -0.029 & $-0,084$ & $-14,333$ & 7.731 & -0.464 & -0.207 & -0.030 \\
\hline 14 & 0.610 & $-0,131$ & 0.046 & $-0,098$ & $-0,171$ & 12,917 & 53.231 & 0.320 & 0.035 & 0.201 \\
\hline 15 & -0.390 & -0.318 & 0,546 & $-0,014$ & $-0,092$ & 16.167 & 8,731 & 0,750 & 0.080 & -0.046 \\
\hline 16 & 0.110 & -0.101 & 0,796 & 0,001 & 0,032 & 23,417 & 6,981 & -0.003 & -0.037 & $-0,032$ \\
\hline 17 & 0,610 & 0.221 & $-0,204$ & 0,022 & $-0,048$ & 33,667 & 14,231 & -0.264 & 0.020 & -0.087 \\
\hline 18 & 0.110 & 0.032 & -0.454 & 0.063 & 0,385 & -21.333 & -0.019 & 0.839 & 0.314 & -0.013 \\
\hline 19 & -0.390 & 0.343 & $-0,954$ & -0.076 & $-0,082$ & 0.167 & $-12,019$ & 0.379 & -0.059 & 0.164 \\
\hline 20 & -0.390 & 0.115 & -0.454 & 0.015 & 0.324 & -11.333 & -24.769 & -0.977 & -0.449 & -0.219 \\
\hline 21 & 0.110 & -0.238 & 1,046 & 0.090 & 0.067 & 2.667 & -6.519 & -1.019 & -0.018 & -0.057 \\
\hline 22 & -0.010 & -0.119 & 0.296 & 0.019 & 0.086 & -9.583 & -15.269 & -0.228 & -0.186 & -0.03 \\
\hline 23 & 1.110 & -0.337 & -1.204 & -0.058 & 0,084 & 23.417 & 3.481 & -0.711 & $-0.0+7$ & -0.330 \\
\hline 25 & -0.060 & -0.274 & -0.204 & 0.024 & $-0,037$ & 24.917 & -5.019 & 0.545 & -0.140 & 0.096 \\
\hline 26 & 0.360 & -0.120 & 0.296 & -0.020 & -0.112 & 8.417 & 5.481 & 0.240 & 0.281 & 0.163 \\
\hline 27 & -0.140 & -0.194 & 0.546 & -0.050 & 0,043 & -4.833 & 10.981 & 1.128 & -0.135 & -0.095 \\
\hline 29 & -0.390 & 0.059 & -1.204 & 0,009 & $-0,005$ & -3.083 & 19.731 & 0.210 & 0.164 & 0.14 \\
\hline 30 & -0.390 & -0.143 & -0.454 & -0.006 & $-0,122$ & 28.667 & 34,481 & -0.340 & -0.058 & -0.22 \\
\hline
\end{tabular}


Tabela 24. Efeitos de heterose de variedade $\mathbf{h}_{\mathbf{i}}$ no experimento 3 para para mancha de turcicum. mancha de Phaeosphaeria, ferrugem comum, porcentagem de plantas com podridão do colmo (PODR) porcentagem de plantas com enfezamento (ENFE), altura de planta (AP), altura da espiga (AE), comprimento de espiga (CE), diâmetro de espiga (DE), e peso de grãos por parcela (PG).

\begin{tabular}{|c|c|c|c|c|c|c|c|c|c|c|}
\hline Acessos & TURC & PHAE & SORG & PODR & STUN & AP & $\overline{\mathrm{AE}}$ & $\mathrm{CE}$ & DE & PG \\
\hline 1 & 0.597 & -0.102 & -0.790 & -0.014 & 0.095 & 48.225 & 11.190 & -1.094 & -0.137 & -0.249 \\
\hline 2 & -0.681 & -0.354 & -0.655 & 0.009 & -0.075 & -41.010 & -0.150 & -0.794 & -0.074 & -0.015 \\
\hline 3 & -0.551 & -0.234 & 0.830 & -0.005 & 0.028 & -46.545 & 3.495 & 0.739 & 0.226 & -0.003 \\
\hline 4 & -0.251 & -0.140 & 0.695 & 0.039 & 0.115 & -50.055 & 6.870 & 1.143 & 0.162 & 0.000 \\
\hline 5 & 0.192 & 0,226 & -0.115 & -0.058 & 0.021 & -17.115 & 4.170 & 0.516 & 0,342 & 0.053 \\
\hline 6 & -0.483 & -0.220 & -0.385 & 0.055 & 0.009 & 1.650 & 16.995 & 1.372 & 0.680 & 0.005 \\
\hline 8 & 0.732 & 0.204 & -0.115 & 0,007 & -0.049 & 19.335 & $-16,350$ & 0.177 & $-0,168$ & 0.187 \\
\hline 9 & -1.023 & 0,248 & $-1,060$ & $-0,128$ & $-0,097$ & 48,630 & 3,225 & 0,712 & $-0,192$ & 0,152 \\
\hline 10 & 0,089 & 0.541 & $-0,655$ & $-0,037$ & $-0,094$ & 18,390 & 25,500 & 0,059 & $-0,158$ & 0,370 \\
\hline 11 & -0.348 & 0,257 & $-0,115$ & 0.019 & 0.022 & 12,315 & 13,080 & -0.863 & $-0,015$ & -0.281 \\
\hline 12 & -0.618 & 0.152 & $-0,520$ & -0.024 & -0.050 & 11,235 & 12,810 & 1.288 & -0.275 & 0.478 \\
\hline 13 & 0.327 & -0.275 & 1.235 & 0.034 & 0.022 & 16.230 & 2.685 & $-1,771$ & -0.052 & 0.001 \\
\hline 14 & -0.483 & 0.328 & 0.695 & 0.031 & 0.001 & -13.065 & -66.705 & -0.623 & -0.045 & -0.103 \\
\hline 15 & 0.192 & 0.269 & -0.925 & 0.067 & 0.156 & -6.990 & -10.545 & -0.786 & -0.091 & -0.052 \\
\hline 16 & 0.192 & $-0,183$ & $-0,520$ & 0,018 & 0.022 & 8,535 & 7,950 & -1.862 & $-0,523$ & -0.172 \\
\hline 17 & -0.348 & $-0,239$ & -0.250 & 0,003 & 0.102 & $-13,200$ & $-8,115$ & $-0,184$ & $-0,018$ & $-0,212$ \\
\hline 18 & 0.192 & $-0,243$ & 0,695 & $-0,065$ & -0.227 & 31,890 & 5,250 & 0,012 & 0.063 & -0.116 \\
\hline 19 & 0.192 & -0.292 & 0.965 & 0.104 & 0.185 & -2.400 & -0.690 & 0.429 & -0.056 & 0,083 \\
\hline 20 & -0.348 & 0.102 & 0.155 & -0.095 & -0.190 & 14,070 & 5,655 & 0.976 & 0.312 & 0.161 \\
\hline 21 & 0.732 & 0.133 & -0.655 & 0.073 & 0.011 & -2.130 & -56.040 & -0.439 & -0.071 & -0.184 \\
\hline 22 & -0.281 & -0.058 & 0.560 & $-0,097$ & -0.059 & 7.185 & 14.565 & -0.339 & -0.298 & 0.003 \\
\hline 23 & -0.281 & 0.050 & 1,370 & 0,107 & -0.039 & -22.245 & 14.970 & 0.966 & 0.152 & -0.010 \\
\hline 25 & -0.255 & -0.003 & 0.290 & -0.050 & 0,064 & $-22,515$ & 4,440 & 0,899 & 0.148 & -0.029 \\
\hline 26 & 0.867 & $-0,002$ & -0.790 & 0.016 & 0.032 & 6,105 & 13,890 & $-1,339$ & -0.155 & -0.453 \\
\hline 27 & 0.597 & -0.036 & -1.195 & -0.060 & -0.171 & -1.050 & 9.570 & 0.394 & 0.098 & 0.285 \\
\hline 29 & 0.192 & $-0,305$ & 0.560 & $-0,008$ & 0.134 & $-2,265$ & $-6,495$ & 0,882 & 0,135 & 0,139 \\
\hline 30 & 0.867 & 0.179 & 0.695 & 0.060 & 0.030 & -3.210 & -11.220 & $-0,470$ & 0.010 & -0.038 \\
\hline
\end{tabular}


Tabela 25. Efeitos de capacidade geral de combinação $g_{i}$ no experimento 3 para para mancha de turcicum, mancha de Phaeosphaeria. ferrugem comum, porcentagem de plantas com podridão do colmo (PODR)porcentagem de plantas com enfezamento (ENFE), altura de planta (AP), altura da espiga (AE), comprimento de espiga $(\mathrm{CE})$, diâmetro de espiga (DE), e peso de grãos por parcela $(P G)$.

\begin{tabular}{|c|c|c|c|c|c|c|c|c|c|c|}
\hline Acessos & TURC & PHAE & SORG & PODR & STUN & AP & $\mathbf{A E}$ & $\mathrm{CE}$ & $\overline{D E}$ & $P G$ \\
\hline 1 & 0.277 & 0.119 & -1.142 & -0.041 & 0.099 & 45.683 & 6,681 & $-1,083$ & $-0,118$ & -0.115 \\
\hline 2 & -0.876 & -0.053 & -0.382 & 0.053 & -0.094 & -47.677 & -8.659 & -0.363 & -0.142 & 0.035 \\
\hline 3 & -0.306 & -0.285 & 0.978 & 0.000 & -0.014 & -47.837 & 5.861 & 0.634 & 0.296 & -0.030 \\
\hline 4 & -0.036 & 0.018 & 0.218 & 0.012 & 0.060 & -44.597 & 14.611 & 1.163 & 0.185 & -0.005 \\
\hline 5 & 0.247 & 0,172 & 0.158 & -0.003 & 0,016 & -26.407 & -4.589 & 0.417 & 0.353 & 0.003 \\
\hline 6 & -0.553 & -0.239 & -0.362 & 0.006 & -0.009 & 2.983 & 3.611 & 1.036 & 0.465 & 0.055 \\
\hline 8 & 0,287 & 0,188 & $-0,092$ & 0.042 & $-0,064$ & 9,793 & $-15,609$ & $-0,012$ & $-0,035$ & $-0,027$ \\
\hline 9 & -0.843 & 0,174 & $-0,662$ & -0.046 & $-0,064$ & 24,963 & $-5,659$ & 0.343 & 0,057 & $-0,028$ \\
\hline 10 & -0.106 & 0,484 & -0.382 & -0.063 & -0.077 & 5,973 & 13.741 & 0.584 & $-0,165$ & 0,591 \\
\hline 11 & -0.293 & 0.133 & $-0,092$ & 0.000 & $-0,030$ & 10,023 & 8,321 & -0.582 & 0,036 & 0,047 \\
\hline 12 & -0.563 & 0,413 & -0.122 & $-0,042$ & $-0,033$ & 17,193 & 11,801 & 0,914 & -0.319 & 0.378 \\
\hline 13 & 0.257 & $-0,220$ & 1.008 & 0,019 & $-0,019$ & 9,063 & 6,551 & $-2,003$ & $-0,155$ & $-0,014$ \\
\hline 14 & $-0,178$ & 0,262 & 0,718 & -0.018 & $-0,084$ & $-6,607$ & $-40,089$ & $-0,463$ & $-0,028$ & $-0,003$ \\
\hline 15 & $-0,003$ & 0,110 & -0.652 & 0.060 & 0,110 & 1,093 & $-6,179$ & $-0,411$ & -0.051 & $-0,075$ \\
\hline 16 & 0.247 & $-0,234$ & $-0,122$ & 0,019 & 0.038 & 20,243 & 11,441 & $-1,863$ & $-0,542$ & $-0,188$ \\
\hline 17 & -0.043 & -0.128 & -0.352 & 0.014 & 0.078 & 3,633 & $-0,999$ & $-0,317$ & $-0,008$ & $-0,255$ \\
\hline 18 & 0.247 & -0.227 & 0,468 & -0.034 & -0.034 & 21,223 & 5,241 & 0,432 & 0,220 & -0.123 \\
\hline 19 & -0.003 & $-0,121$ & 0,488 & 0,066 & 0,144 & $-2,317$ & $-6,699$ & 0,619 & -0.085 & 0.165 \\
\hline 20 & $-0,543$ & 0,160 & -0.072 & $-0,088$ & $-0,028$ & 8,403 & $-6,729$ & 0,488 & 0.087 & 0,051 \\
\hline 21 & 0.787 & 0.014 & -0.132 & 0.118 & 0.044 & -0.797 & -59.299 & -0.948 & -0.080 & -0.213 \\
\hline 22 & -0.286 & -0.117 & 0.708 & -0.088 & -0.016 & 2.393 & 6.931 & -0.453 & -0.391 & -0.016 \\
\hline 23 & 0.274 & -0.119 & 0.768 & 0.078 & 0.003 & -10.537 & 16.711 & 0.610 & 0.128 & -0.175 \\
\hline 25 & -0.285 & -0.140 & 0.188 & -0.038 & 0,046 & -10.057 & 1.931 & 1.172 & 0.078 & 0.019 \\
\hline 26 & 1.047 & $-0,062$ & -0.642 & 0,006 & $-0,024$ & 10.313 & 16.631 & $-1,219$ & -0.014 & $-0,371$ \\
\hline 27 & 0.527 & $-0,133$ & $-0,922$ & -0.085 & $-0,149$ & $-3,467$ & 15,061 & 0,958 & 0.031 & 0,237 \\
\hline 29 & -0.003 & -0.275 & $-0,042$ & $-0,003$ & 0,131 & $-3,807$ & 3,371 & 0,987 & 0,217 & 0.210 \\
\hline 30 & 0.672 & 0.107 & 0,468 & 0.057 & -0.031 & 11.123 & 6.021 & -0.641 & -0.019 & -0.153 \\
\hline
\end{tabular}


Tabela 26. . Médias dos tratamentos do experimento 4 para mancha de turcicum. mancha de Phaeosphaeria. ferrugem comum, porcentagem de plantas com podridão do colmo (PODR), porcentagem de plantas com enfezamento (ENFE), altura de planta (AP), altura da espiga (AE), comprimento de espiga (CE), diâmetro de espiga (DE), e peso de grãos por parcela (PG).

\begin{tabular}{|c|c|c|c|c|c|c|c|c|c|c|}
\hline Acessos & TURC & PHAE & SORG & PODR & ENFE & $\mathbf{A P}$ & $\mathbf{A E}$ & CE & DE & PG \\
\hline $2 \mathrm{~s}$ & 3,49 & 2,86 & 5,48 & 9,77 & 13,95 & 135,8 & 56,3 & 9,5 & 3,7 & 0,838 \\
\hline $3 s$ & 3,54 & 2.65 & 5,00 & 3,33 & 9,68 & 133,8 & 58,8 & 9.6 & 3,6 & 0,766 \\
\hline $4 s$ & 4.15 & 2.60 & 6.13 & 7.45 & 15.91 & 130.8 & 54.0 & 8.0 & 3.2 & 0.378 \\
\hline $5 s$ & 3.50 & 2.27 & 4.75 & 10.00 & 19.00 & 154.8 & 76.5 & 10.3 & 4.0 & 0.662 \\
\hline $6 \mathrm{~s}$ & 3,00 & 2.90 & 5.75 & 6.17 & 6.45 & 154.3 & 74.5 & 8.7 & 3,4 & 0,576 \\
\hline $7 \mathrm{~s}$ & 3.50 & 2.32 & 5.75 & 10,80 & 15.34 & 169.0 & 83.0 & 10.2 & 3.3 & 0.826 \\
\hline $8 s$ & 4.59 & 1,72 & 6,50 & 10.71 & 11.98 & 107.8 & 42.8 & 5.3 & 1.9 & 0,220 \\
\hline $9 \mathrm{~s}$ & 3,87 & 2,04 & 5.85 & 4.29 & 18.12 & 132.3 & 55,0 & 7.6 & 3.5 & 0.392 \\
\hline $10 \mathrm{~s}$ & 3.50 & 2.86 & 4.75 & 4.25 & 20.03 & 168.8 & 85,0 & 11.6 & 3.8 & 1,065 \\
\hline $11 \mathrm{~s}$ & 3.25 & 2.41 & 5.25 & 0.00 & 6,76 & 150.5 & 72.5 & 11,7 & 3,7 & 1.215 \\
\hline $12 \mathrm{~s}$ & 3.48 & 2,38 & 4,75 & 2.70 & 7.03 & 163.0 & 81,8 & 11.8 & 3,7 & 1,386 \\
\hline $13 \mathrm{~s}$ & 3.88 & 2.34 & 5.38 & 0,00 & 9,63 & 163.3 & 80.0 & 10.1 & 3.5 & 0.767 \\
\hline $14 \mathrm{~s}$ & 4.08 & 2,20 & 5.75 & 13.29 & 8,93 & 173.8 & 83.8 & 9.6 & 3.2 & 0,537 \\
\hline $15 \mathrm{~s}$ & 3,50 & 2,64 & 4.50 & 1,32 & 11,92 & 159,8 & 79.8 & 11,2 & 3.7 & 1,182 \\
\hline $16 \mathrm{~s}$ & 3.00 & 2,48 & 5,54 & 0.00 & 13.33 & 139.5 & 63.5 & 10.2 & 3.7 & 1,066 \\
\hline $17 \mathrm{~s}$ & 3.50 & 2,45 & 6.13 & 1.28 & 10,99 & 157.5 & 71,0 & 9,2 & 3,5 & 0,831 \\
\hline $18 \mathrm{~s}$ & 3,75 & 2.46 & 6,44 & 1,79 & 12,88 & 142.3 & 61.3 & 9.0 & 3,5 & 0,947 \\
\hline $19 \mathrm{~s}$ & 3.88 & 2,62 & 4.00 & 0,00 & 9,52 & 196.0 & 109.5 & 11,2 & 3.3 & 1,550 \\
\hline $20 \mathrm{~s}$ & 4.00 & 2.81 & 5.25 & 3,23 & 9.95 & 178.0 & 92,8 & 11,4 & 3.3 & 0,618 \\
\hline $21 \mathrm{~s}$ & 3.75 & 2.88 & 5,00 & 1,47 & 17.61 & 157.5 & 69.3 & 10.4 & 3.6 & 1.121 \\
\hline $22 \mathrm{~s}$ & 4.00 & 2.75 & 4.00 & 2.63 & 25,43 & 172.3 & 90.5 & 10,8 & 2.8 & 0.899 \\
\hline $23 \mathrm{~s}$ & 4.38 & 2.94 & 6.50 & 10.61 & 12.12 & 136.8 & 57.3 & 9.8 & 3.1 & 0.699 \\
\hline $24 \mathrm{~s}$ & 3.65 & 2,81 & 5.84 & 17.10 & 16.27 & 139.0 & 62.5 & 8.8 & 3.4 & 0,737 \\
\hline $25 \mathrm{~s}$ & 4,50 & 2,88 & 5.50 & 5.17 & 3,75 & 213.0 & 123.3 & 9.7 & 3.2 & 0.746 \\
\hline $26 s$ & 3.50 & 2.24 & 6.88 & 6.40 & 11.95 & 155.8 & 77.5 & 10.5 & 3.0 & 0.624 \\
\hline $27 \mathrm{~s}$ & 4.50 & 2.75 & 4.75 & 0.00 & 6.00 & 186.3 & 95.0 & 11.2 & 3.3 & 1,124 \\
\hline $28 \mathrm{~s}$ & 3.25 & 2.63 & 5.00 & 1,39 & 4,17 & 180,8 & 99.3 & 8.9 & 3,2 & 0,471 \\
\hline $30 \mathrm{~s}$ & 3.25 & 2.89 & 4.25 & 0.00 & 11.50 & 175.5 & 88.8 & 12.0 & 3.4 & 1.522 \\
\hline Cruzamentos & TURC & PHAE & SORG & PODR & ENFE & $\mathbf{A P}$ & $\mathbf{A E}$ & $\mathrm{CE}$ & DE & PG \\
\hline $2 \mathrm{~s} \times \mathrm{Tsp}$ & 2.75 & 2.08 & 4.83 & 5,71 & 10.00 & 152.0 & 66.8 & 10,1 & 3.7 & 0.935 \\
\hline $3 s \times$ Tsp & 3.00 & 2.29 & 4.85 & 5.27 & 11.14 & 155.3 & 68.8 & 9.5 & 2.8 & 0.922 \\
\hline $4 \mathrm{~s} \times \mathrm{Tsp}$ & 4.81 & 2.64 & 6.06 & 6.20 & 6.11 & 156.5 & 66.0 & 9.3 & 3.4 & 0.768 \\
\hline $5 s \times$ Tsp & 3.20 & 2.55 & 5.00 & 5.20 & 9.26 & 185.0 & 95.5 & 10.4 & 3.5 & 1.067 \\
\hline $6 s \times T s p$ & 3.25 & 2.86 & 5.50 & 4.68 & 9.05 & 164.3 & 84.3 & 10.8 & 3.6 & 1.206 \\
\hline 7 s $x$ Tsp & 3.63 & 2.24 & 4.25 & 1,72 & 8.58 & 177.3 & 80.8 & 11.0 & 3.7 & 1.035 \\
\hline $8 s \times T s p$ & 5.22 & 2.22 & 6.15 & 8.02 & 5.72 & 151.3 & 71.5 & 9.3 & 3.4 & 0.483 \\
\hline $9 \mathrm{~s} \times \mathrm{Tsp}$ & 4.00 & 2.11 & 5.30 & 4.80 & 11.22 & 156.3 & 72.8 & 9.4 & 3.5 & 0.672 \\
\hline $10 s \times T s p$ & 3.75 & 2.55 & 4.60 & 2.50 & 6.52 & 176.8 & 96.0 & 11.4 & 3.8 & 1.105 \\
\hline $11 \mathrm{~s} \times \mathrm{Tsp}$ & 3.38 & 2.61 & 5.50 & 0.00 & 5.22 & 178.0 & 88.0 & 11.5 & 3.6 & $1.27 t$ \\
\hline $12 \mathrm{~s} \times \mathrm{Tsp}$ & 3.38 & 3.55 & 4.75 & 4.93 & 8.78 & 179.8 & 86.0 & 9.6 & 3.3 & 1.305 \\
\hline $13 \mathrm{~s} \times \mathrm{Tsp}$ & 3.38 & 2.48 & 5.25 & 0.00 & 7.69 & 185.0 & 90.0 & 10.9 & 3.7 & 1.345 \\
\hline $14 \mathrm{~s} \times \mathrm{Tsp}$ & 3.25 & 2.67 & 5.75 & 1.25 & 5.20 & 171.0 & 84.5 & 9.9 & 3.5 & 0.821 \\
\hline $15 \mathrm{~s} \times \mathrm{Tsp}$ & 4.00 & 2.43 & 5.88 & 6.23 & 10.15 & 165.5 & 84.0 & 10.3 & 3.5 & 0.985 \\
\hline
\end{tabular}




\begin{tabular}{|c|c|c|c|c|c|c|c|c|c|c|}
\hline Cruzamentos & TURC & PHAE & SORG & PODR & ENFE & AP & $\mathrm{AE}$ & CE & $\overline{D E}$ & PG \\
\hline $16 \mathrm{~s} \times \mathrm{Tsp}$ & 3.52 & 2.68 & 5,01 & 5,56 & 18,33 & 158,8 & 72.5 & 9,9 & 3,5 & 1.121 \\
\hline $17 \mathrm{~s} \times \mathrm{Tsp}$ & 3.38 & 2,41 & 5,50 & 3,95 & 7,63 & 162,3 & 77.5 & 10,5 & 3.7 & 1.110 \\
\hline $18 \mathrm{~s} \times \mathrm{Tsp}$ & 3,13 & 2.28 & 5,51 & 5.80 & 17,39 & 160,0 & 73.5 & 9,7 & 3,6 & 0,931 \\
\hline 19 s. Tsp & 4.00 & 2.26 & 5.50 & 2,50 & 10,13 & 194,0 & 108,0 & 11,4 & 3,7 & 1,415 \\
\hline $20 \mathrm{~s} \times \mathrm{Tsp}$ & 4.13 & 3,00 & 6.00 & 5,00 & 9.37 & 184,3 & 94,3 & 11.6 & 3.5 & 1,151 \\
\hline $21 s \times T s p$ & 3.50 & 2,20 & 4,50 & 1,72 & 2,94 & 162,5 & 80,0 & 10,8 & 3,6 & 1,232 \\
\hline $22 s \times T s p$ & 3,50 & 2,64 & 5,00 & 3,49 & 15,56 & 167,0 & 88.0 & 11.0 & 3,3 & 0,938 \\
\hline $23 \mathrm{~s} \times \mathrm{Tsp}$ & 3.75 & 2.43 & 3,72 & 11,24 & 14,81 & 167.3 & 80.5 & 8.2 & 3.8 & 0,969 \\
\hline $24 \mathrm{~s} \times \mathrm{Tsp}$ & 3.50 & 2.33 & 5.91 & 7.54 & 11.29 & 146.5 & 61.5 & 9.9 & 3.7 & 0.887 \\
\hline $25 \mathrm{~s} \times \mathrm{Tsp}$ & 3.75 & 2.32 & 5.25 & 2.27 & 0,00 & 188.3 & 101.8 & 10.0 & 3.3 & 1.009 \\
\hline $26 s \times T s p$ & 3.38 & 2.69 & 6.00 & 1,19 & 6.55 & 170.8 & 90,8 & 10.3 & 3.3 & 1,012 \\
\hline $27 \mathrm{~s} \times \mathrm{Tsp}$ & 4.00 & 2.54 & 5.88 & 2,70 & 5.41 & 188.0 & 103.3 & 10.7 & 3.2 & 0.747 \\
\hline $28 s \times$ Tsp & 4.00 & 3,13 & 6.25 & 2,90 & 11.55 & 173.5 & 92.5 & 10.3 & 3,7 & 0.886 \\
\hline $30 \mathrm{~s} \times \mathrm{Tsp}$ & 3,74 & 2,56 & 4,50 & 0,00 & 16,67 & 171,0 & 88,3 & 11.1 & 3.0 & 1,500 \\
\hline Testemunhas & TURC & PHAE & SORG & PODR & ENFE & AP & $\mathrm{AE}$ & $\mathrm{CE}$ & DE & $\mathbf{P G}$ \\
\hline $\mathrm{T} 1$ & 3.17 & 2.77 & 3,67 & 0.00 & 2.77 & 151.3 & 73.5 & 13.2 & 4,0 & 1,515 \\
\hline $\mathrm{T} 2$ & 4.17 & 3.00 & 5.67 & 0.00 & 5.96 & 207.0 & 115.0 & 10.0 & 3.5 & 1.178 \\
\hline
\end{tabular}


Tabela 27. Resumo das análises de variância do experimento 4 para mancha de turcicum. mancha de Phaeosphaeria. ferrugem comum, porcentagem de plantas com podridão do colmo (PODR), porcentagem de plantas com enfezamento (ENFE).

\begin{tabular}{|c|c|c|c|c|c|c|}
\hline \multirow[b]{2}{*}{ FV } & \multirow[b]{2}{*}{ GL } & \multicolumn{4}{|c|}{$\mathbf{Q M}$} & \multirow[b]{2}{*}{$\begin{array}{l}\text { ENFE } \\
\times 10^{3} \\
\end{array}$} \\
\hline & & TURC & PHAE & SORG & $\begin{array}{l}\text { PODRI } \\
\times 10^{3}\end{array}$ & \\
\hline Repetição & 1 & 1,317 & 0,010 & 0,325 & 28,255 & 50,069 \\
\hline Tratamentos & 57 & $0.486^{* *}$ & $0.211^{*}$ & $1.238^{* *}$ & $3.316^{* *}$ & $5.948 *$ \\
\hline Topcross & 55 & $0.449 * *$ & 0.192 & $0.977^{*}$ & $3.043^{*}$ & 5.252 \\
\hline Acessos & $27^{-}$ & $0 . \overline{59} \overline{3} * \bar{*}$ & $\overline{0}, \overline{196}$ & $1.236^{* *}$ & $4.9 \overline{4} 1 * \bar{*}$ & $6.555 *-$ \\
\hline Heterose média & 1 & 0,139 & 0,036 & 0.217 & 2.108 & $24,003^{*}$ \\
\hline Heterose acessos & 27 & 0,316 & 0.194 & 0.745 & 1.180 & 3.255 \\
\hline Testemunha & 1 & $3.000 * \bar{*}$ & $0, \overline{154}$ & $12.000 * *$ & 0,000 & $3.08 \overline{1}$ \\
\hline Topcross vs Testemunha & 1 & 0.004 & $1.275^{* *}$ & $4.859 * *$ & $21.627 * *$ & $47.054 * *$ \\
\hline Resíduo & 65 & 0,226 & 0.137 & 0.605 & 1.751 & 3.851 \\
\hline Dentro test./rep. & 8 & 0,125 & 0,047 & 1.417 & 0.000 & 1.292 \\
\hline Erro & 57 & 0,240 & 0,150 & 0,491 & 1,997 & 4.210 \\
\hline $\mathrm{CV} \%$ & & 12.90 & 14,38 & 14.75 & 5.07 & 6.98 \\
\hline Média geral & & 3.68 & 2.58 & 5.27 & 4.27 & 10.54 \\
\hline
\end{tabular}

** e * indicam. respectivamente. significância ao nivel de $1 \%$ e de $5 \%$ de probabilidade.

Tabela 28. Resumo das análises de variância do experimento 4 para altura de planta (AP), al tura da espiga (AE), comprimento de espiga (CE), diâmetro de espiga (DE), e peso de grãos por parcela (PG).

\begin{tabular}{|c|c|c|c|c|c|c|}
\hline \multirow[b]{2}{*}{ FV } & \multirow[b]{2}{*}{ GL } & \multicolumn{5}{|c|}{$\mathbf{Q M}$} \\
\hline & & AP & $\mathbf{A E}$ & $\mathrm{CE}$ & $\mathrm{DE}$ & PG \\
\hline Repetição & 1 & 1766,32 & 1571,95 & 1.195 & 0,014 & 0.352 \\
\hline Tratamentos & 57 & $907,89 * *$ & $598,79 * *$ & $3,730 * *$ & $0,247 *$ & $0.211 * *$ \\
\hline Topcross & 55 & $725.58^{* *}$ & $487,77^{* *}$ & $2,836^{* *}$ & 0,210 & $0.180^{* *}$ \\
\hline Acessos & $2 \overline{7}$ & $\overline{1250}, \overline{18 * *}$ & $\overline{878,15 * *}$ & $4,8 \overline{4} \overline{9}^{-1 *}$ & $\overline{0.29} \overline{1}^{*} \bar{*}$ & $-\overline{0.291 * \bar{*}}-$ \\
\hline Heterose média & 1 & $3668,58 * *$ & $1460.90 * *$ & 3,789 & $0.361 *$ & $0.916 * *$ \\
\hline Heterose acessos & 27 & 91.97 & 61.36 & 0.788 & 0.124 & 0.041 \\
\hline Testemunha & 1 & $9296.33^{* *}$ & $\overline{5166.75 * *}$ & $1 \overline{7} . \overline{1} \overline{1} 3^{* *}$ & $0 . \overline{134}$ & $0 . \overline{3+1} * \overline{1}$ \\
\hline Topcross is Testemunha & 1 & $25+6.32 * *$ & $2136.60 * *$ & $39.049 * *$ & $2.392 * *$ & $1.797 * *$ \\
\hline Resíduo & 65 & 156.00 & 93.18 & 0.971 & 0.139 & 0.031 \\
\hline Dentro test./rep. & 8 & 282.00 & 196.67 & 0.786 & 0.131 & 0.043 \\
\hline Erro & 57 & 138.31 & 78.66 & 0.997 & 0.140 & 0.030 \\
\hline $\mathrm{CV} \%$ & & 7.55 & 11.83 & 9.55 & 10.72 & 18.07 \\
\hline Média geral & & 165.32 & 81.57 & 10.31 & 3.48 & 0.98 \\
\hline
\end{tabular}

** $\mathrm{e}^{*}$ indicam. respectivamente. significância ao nível de $1 \%$ e de $5 \%$ de probabilidade. 
Tabela 29. Efeitos de variedade $v$, no experimento 4 para mancha de turcicum. mancha de Phaeosphaeria. ferrugem comum, porcentagem de plantas com podridão do colmo (PODR), porcentagem de plantas com enfezamento (ENFE), altura de planta (AP), altura da espiga (AE), comprimento de espiga (CE), diâmetro de espiga (DE), e peso de grãos por parcela (PG).

\begin{tabular}{|c|c|c|c|c|c|c|c|c|c|c|}
\hline Acesso & TURC & PHAE & SORG & PODR & STUN & AP & $\mathbf{A E}$ & CE & DE & PG \\
\hline $2 s$ & -0.236 & 0,293 & 0,102 & 0,050 & 0,018 & -22.366 & -20.348 & $-0,417$ & 0,343 & -0.010 \\
\hline $3 s$ & -0.186 & 083 & -0.380 & $-0,016$ & 0,026 & 24.366 & & 0,332 & 0.183 & $-0,083$ \\
\hline 45 & & & & 026 & & & & & & 470 \\
\hline $5 s$ & -0.221 & -0.294 & -0.630 & 0.054 & 0.071 & & & 0.380 & & -0.187 \\
\hline $6 s$ & -0.721 & 0.336 & 0.370 & 0.013 & -0.059 & -3.866 & & -1.232 & & -0.273 \\
\hline $7 s$ & 221 & $-0,247$ & 0,370 & & & & & & & -0.023 \\
\hline $8 s$ & & $-0,8$ & 1.117 & 0.062 & -0.0 & -50 & & & & 0.628 \\
\hline $9 s$ & & & & .006 & & & & & & 0.456 \\
\hline $10 \mathrm{~s}$ & $-0,221$ & 0.2 & -0.630 & -0.006 & 0.0 & & & & & 0.216 \\
\hline $11 \mathrm{~s}$ & .471 & -0.1 & $-0,130$ & -0.049 & -0.0 & & & & & .366 \\
\hline $12 \mathrm{~s}$ & -0.246 & -0.187 & -0.630 & $-0,022$ & $-0,054$ & 4.884 & & & & 0.537 \\
\hline $13 \mathrm{~s}$ & & -0.219 & $-0,005$ & -0.049 & -0.0 & 5.134 & & & & $-0,082$ \\
\hline $14 s$ & & -0.364 & 370 & 087 & $-0,0$ & & & & & -0.311 \\
\hline $15 s$ & -0.221 & 0,0 & $-0,880$ & $-0,036$ & $-0,0$ & & & & & 0,333 \\
\hline $16 s$ & .721 & $-0,082$ & 0,160 & -0.049 & 0.011 & $-18,616$ & & & & 0.217 \\
\hline $17 \mathrm{~s}$ & & $-0,117$ &, 745 & $-0,036$ & $-0,013$ & $-0,616$ & & -0 , & & $-0,018$ \\
\hline $18 \mathrm{~s}$ & & $-0,107$ & 1.060 & -0.031 & 0.007 & -15.866 & & & & 0.098 \\
\hline $19 s$ & & & $-1,380$ & -0.049 & -0.0 & & & & & 0.701 \\
\hline $20 \mathrm{~s}$ & 279 & 0,246 & $-0,130$ & $-0,017$ & $-0,023$ & 19,884 & & 1,4 & & -0.231 \\
\hline $21 \mathrm{~s}$ & & 0,318 & -0.380 & $-0,034$ & 0,056 & $-0,616$ & & & & 0,27 \\
\hline $22 \mathrm{~s}$ & & 0.188 & -1.380 & $-0,023$ & 0.146 & 14.134 & & & & 0.050 \\
\hline $23 s$ & 654 & 0.381 & 1,120 & 0.058 & $-0,001$ & -21.366 & -19.348 & $-0,178$ & -0 & -0.149 \\
\hline $24 s$ & -0.076 & 0.248 & 0.455 & 0.129 & 0,043 & -19.116 & -14.098 & -1.152 & 037 & -0.112 \\
\hline $25 s$ & & 0.313 & 20 & 0.003 & -0.0 & 54.884 & 46.652 & -0.226 & & -0.10 \\
\hline $26 s$ & & -0.319 & 1.495 & 0.015 & -0.003 & -2.366 & 0.902 & 0.533 & -0.355 & -0.225 \\
\hline $27 \mathrm{~s}$ & & 0,188 & -0.630 & $-0,049$ & $-0,064$ & 28.134 & 18,402 & & & 0.27 \\
\hline $28 \mathrm{~s}$ & $-0,471$ & 0,063 & $-0,380$ & $-0,035$ & $-0,083$ & 22,634 & 22,652 & $-1,018$ & $-0,187$ & $-0,37\}$ \\
\hline $30 \mathrm{~s}$ & -0.471 & 0,331 & $-1,130$ & $-0,049$ & $-0,008$ & 17.384 & 12,152 & 2,062 & 0.052 & 0.67 \\
\hline
\end{tabular}


Tabela 30. Efeitos de heterose de variedade $h_{i}$ no experimento 4 para mancha de turcicum. mancha de Phaeosphaeria, ferrugem comum, porcentagem de plantas com podridão do colmo (PODR), porcentagem de plantas com enfezamento (ENFE), altura de planta (AP), altura da espiga (AE), comprimento de espiga $(\mathrm{CE})$, diâmetro de espiga $(\mathrm{DE})$, e peso de grãos por parcela (PG).

\begin{tabular}{|c|c|c|c|c|c|c|c|c|c|c|}
\hline Acessos & TURC & PHAE & SORG & PODR & STUN & AP & AE & CE & DE & PG \\
\hline $2 \mathrm{~s}$ & -0.843 & $-0,635$ & $-0,553$ & -0.008 & $-0,003$ & $-6,870$ & -7.428 & $-0,030$ & 0,008 & -0.097 \\
\hline $3 \mathrm{~s}$ & -0.601 & -0.304 & -0.277 & 0.022 & 0.033 & -2.293 & -6.620 & -0.705 & -0.883 & -0.071 \\
\hline $4 s$ & 1.017 & 0,102 & 0,419 & 0.010 & $-0,057$ & 0,668 & $-7,024$ & $-0,024$ & -0.036 & -0.028 \\
\hline $5 \mathrm{~s}$ & -0.367 & 0.179 & 0.025 & -0.016 & -0.040 & 18,438 & 12.630 & -0.066 & -0.354 & 0.141 \\
\hline $6 s$ & -0.043 & 0,176 & 0,025 & 0.000 & 0.027 & -3.639 & 1.591 & 1,142 & 0.119 & 0.337 \\
\hline $7 \mathrm{~s}$ & 0.091 & -0.175 & -1.321 & -0.057 & -0.027 & 2.418 & -6.755 & 0.579 & 0.262 & 0.018 \\
\hline $8 s$ & 1.222 & 0,129 & 0,317 & 0,011 & $-0,039$ & 7,399 & 4,957 & 1.457 & 0,654 & -0.250 \\
\hline $9 s$ & 0.290 & $-0,168$ & $-0,244$ & 0,012 & $-0,015$ & $-0,409$ & 293 & 0.250 & -0.047 & -0.139 \\
\hline $10 s$ & 0.226 & -0.132 & -0.403 & -0.013 & $-0,079$ & 2.014 & 8.591 & 0,291 & 0,083 & -0.035 \\
\hline $11 \mathrm{~s}$ & -0.043 & 0.172 & 0,294 & -0.017 & $-0,016$ & 13.188 & 6.707 & 0,352 & $-0,046$ & 0.066 \\
\hline $12 \mathrm{~s}$ & -0.165 & 1,206 & -0.244 & 0,022 & 0,022 & 8.341 & $-0,428$ & $-1,702$ & $-0,395$ & 0,007 \\
\hline $13 \mathrm{~s}$ & -0.380 & 0,071 & -0.043 & -0.017 & $-0,004$ & 13.861 & 4.822 & 0.582 & 0.172 & 0.383 \\
\hline $14 \mathrm{~s}$ & -0.622 & 0.354 & 0.294 & -0.077 & -0.028 & -6.870 & -3.120 & $-0,284$ & 0,129 & -0.057 \\
\hline $15 \mathrm{~s}$ & 0.495 & $-0,144$ & 1.102 & 0,043 & 0,009 & -5.255 & -1.505 & -0.749 & -0.174 & -0.228 \\
\hline $16 \mathrm{~s}$ & 0.242 & 0,205 & $-0,387$ & 0,043 & 0,094 & $-1,620$ & -5.139 & -0.646 & $-0,133$ & -0.019 \\
\hline $17 \mathrm{~s}$ & $-0,178$ & $-0,065$ & $-0,177$ & 0,019 & $-0,013$ & -7.543 & $-3,793$ & 0.590 & 0,150 & 0.096 \\
\hline $18 \mathrm{~s}$ & -0.582 & $-0,207$ & $-0,339$ & 0,036 & 0,085 & $-1,755$ & $-2,851$ & $-0,104$ & 0,054 & -0.159 \\
\hline $19 \mathrm{~s}$ & 293 & $-0,320$ & 0,967 & 0,010 & 0,023 & 5.918 & 8,322 & 0,462 & 0,225 & 0.038 \\
\hline $20 \mathrm{~s}$ & 0.360 & 0,378 & 0,832 & 0,020 & 0,012 & 5.111 & 2.534 & 0,643 & 0,009 & 0.255 \\
\hline $21 \mathrm{~s}$ & -0.178 & $-0,520$ & -0.648 & -0.006 & -0.101 & -7.274 & -0.159 & 0.255 & 0.001 & 0.071 \\
\hline $22 \mathrm{~s}$ & -0.313 & 0,022 & 0.429 & 0.006 & -0.006 & -10.370 & -2.986 & 0.252 & 0,110 & -0.125 \\
\hline $23 \mathrm{~s}$ & -0.245 & $-0,314$ & -2.293 & 0.047 & 0,060 & 9.014 & 6.841 & -2.218 & 0.433 & 0.015 \\
\hline $24 \mathrm{~s}$ & -0.122 & $-0,350$ & 0,421 & $-0,031$ & 0,001 & $-14,543$ & $-16,447$ & 0.140 & 0.189 & -0.093 \\
\hline $25 \mathrm{~s}$ & -0.313 & $-0,393$ & -0.110 & $-0,020$ & -0.056 & -9.428 & $-5,812$ & $-0,185$ & -0.049 & 0.033 \\
\hline $26 s$ & -0.178 & 0.351 & $-0,043$ & -0.039 & $-0,030$ & 2.553 & 6,976 & -0.248 & 0.036 & 0.102 \\
\hline $27 \mathrm{~s}$ & -0.043 & -0.091 & 0.967 & 0,012 & -0.010 & 4.707 & 11,014 & -0.255 & -0.272 & -0.452 \\
\hline $28 s$ & 0.630 & 0.611 & 1.236 & 0.007 & 0,068 & -7.947 & -2.851 & 0.529 & 0.289 & 0.049 \\
\hline $30 s$ & 0.350 & -0.141 & $-0,244$ & $-0,017$ & 0,085 & -7.813 & $-1,774$ & -0.306 & -0.534 & 0.144 \\
\hline
\end{tabular}


Tabela 31. Efeitos de capacidade geral de combinação $g_{3}$ no experimento 4 para mancha de turcicum. mancha de Phaeosphaeria. ferrugem comum, porcentagem de plantas com podridão do colmo (PODR), porcentagem de plantas com enfezamento (ENFE), altura de planta (AP), altura da espiga (AE), comprimento de espiga (CE), diâmetro de espiga (DE), e peso de grãos por parcela (PG).

\begin{tabular}{|c|c|c|c|c|c|c|c|c|c|c|}
\hline Acessos & TURC & PHAE & SORG & PODR & ENFE & AP & $\mathrm{AE}$ & CE & $\mathrm{DE}$ & PG \\
\hline $2 s$ & -0.961 & -0.489 & -0.502 & 0,017 & 0.007 & -18.053 & $-17,602$ & $-0,239$ & 0,179 & $-0,102$ \\
\hline $3 s$ & -0.694 & -0.262 & -0.467 & 0,014 & 0,020 & $-14,476$ & -15.544 & $-0,871$ & $-0,792$ & -0.113 \\
\hline 45 & 1.232 & 0.119 & 0,795 & 0.023 & -0.038 & -13.015 & -18.323 & -0.990 & -0.107 & -0.264 \\
\hline $5 s$ & -0.477 & 0.032 & -0.290 & 0.011 & $-0,005$ & 16.754 & 12.581 & 0.125 & -0.033 & 0.047 \\
\hline $6 s$ & -0.404 & 0.344 & 0.210 & 0.007 & -0.002 & -5.572 & 0.542 & 0.526 & 0,120 & 0.200 \\
\hline $7 \mathrm{~s}$ & -0.020 & -0.298 & -1.137 & -0.027 & -0.011 & 7.860 & -3.554 & 0.692 & 0.228 & 0.006 \\
\hline $8 s$ & 1.656 & $-0,294$ & 0.875 & 0.041 & -0.040 & -17.784 & -11.967 & $-0,861$ & -0.089 & $-0,564$ \\
\hline $9 s$ & 0,365 & $-0,428$ & $-0,012$ & 0,009 & 0,017 & -13.342 & $-11,092$ & $-0,907$ & $-0,002$ & $-0,367$ \\
\hline $10 \mathrm{~s}$ & 0.115 & 0.017 & $-0,718$ & $-0,016$ & $-0,035$ & 7,331 & 12,792 & 1,137 & 0,316 & 0,073 \\
\hline $11 \mathrm{~s}$ & -0.279 & 0,094 & 0,229 & $-0,042$ & $-0,044$ & 9,379 & 4,658 & 1,241 & 0,135 & 0,249 \\
\hline $12 \mathrm{~s}$ & $-0,288$ & 1.113 & -0.560 & 0,011 & $-0,004$ & 10,783 & 2,148 & $-0,800$ & -0.237 & 0,275 \\
\hline $13 \mathrm{~s}$ & -0.303 & -0.038 & -0.045 & -0.042 & -0.018 & 16.428 & 6.523 & 0.664 & 0,232 & 0,343 \\
\hline $14 \mathrm{~s}$ & -0.446 & 0.172 & 0.479 & $-0,033$ & $-0,045$ & 0.947 & 0.456 & $-0,461$ & 0.045 & $-0,213$ \\
\hline $15 \mathrm{~s}$ & 0,384 & $-0,106$ & 0.662 & 0.025 & 0.008 & -4.438 & 0,071 & $-0,097$ & -0.035 & -0.061 \\
\hline $16 \mathrm{~s}$ & $-0,119$ & 0,164 & $-0,307$ & 0,019 & 0,099 & $-10,928$ & $-11,689$ & $-0,510$ & 0,007 & 0,090 \\
\hline $17 \mathrm{~s}$ & $-0,289$ & $-0,123$ & 0,195 & 0,001 & $-0,019$ & $-7,851$ & $-6,592$ & 0,219 & 0,214 & 0.087 \\
\hline $18 \mathrm{~s}$ & $-0,568$ & $-0,261$ & 0.191 & 0,020 & 0,089 & $-9,688$ & $-10,525$ & $-0,591$ & 0.114 & -0.110 \\
\hline $19 \mathrm{~s}$ & 0,370 & -0.291 & 0,277 & $-0,015$ & 0,009 & 24,860 & 24,773 & 1,096 & 0,178 & 0,388 \\
\hline $20 \mathrm{~s}$ & 0.500 & 0,501 & 0,767 & 0,011 & 0,000 & 15,053 & 10,610 & 1,357 & $-0,038$ & 0,139 \\
\hline $21 \mathrm{~s}$ & -0.164 & -0.360 & -0.838 & -0.024 & $-0,073$ & -7.582 & -3.833 & 0.479 & 0,108 & 0.208 \\
\hline $22 \mathrm{~s}$ & $-0,173$ & 0.116 & -0.262 & -0.005 & 0.067 & -3.303 & 3.965 & 0.679 & -0.177 & -0.101 \\
\hline $23 \mathrm{~s}$ & 0.081 & -0.123 & -1.733 & 0.076 & 0.060 & -1.669 & -2.833 & -2.307 & 0.314 & -0.059 \\
\hline $24 \mathrm{~s}$ & -0.160 & -0.226 & 0.648 & 0,033 & 0,022 & -24.101 & -23.496 & -0.436 & 0.208 & -0.179 \\
\hline $25 \mathrm{~s}$ & 0,077 & -0.236 & $-0,050$ & $-0,019$ & $-0,099$ & 18.014 & 17,513 & $-0,298$ & -0.148 & -0.019 \\
\hline $26 s$ & $-0,289$ & 0,192 & 0,705 & $-0,031$ & $-0,031$ & 1.370 & 7.427 & 0.018 & $-0,141$ & -0.010 \\
\hline $27 \mathrm{~s}$ & 0,346 & 0,003 & 0.652 & $-0,012$ & $-0,042$ & 18,774 & 20,215 & 0,389 & -0.289 & $-0,315$ \\
\hline $28 s$ & 0.394 & 0.643 & 1.046 & -0.011 & 0,027 & 3,370 & 8.475 & 0,020 & 0,196 & $-0,140$ \\
\hline $30 \mathrm{~s}$ & 0.114 & 0.024 & -0.810 & $-0,042$ & 0.081 & 0.879 & 4.302 & 0,725 & -0.508 & 0.481 \\
\hline
\end{tabular}


Tabela 32. Médias dos tratamentos do experimento 1A para mancha de Phaeosphaeria (PHAE), altura de planta (AP), altura da espiga (AE), comprimento de espiga (CE), diâmetro de espiga $(D E)$, e peso de grãos por parcela (PG).

\begin{tabular}{|c|c|c|c|c|c|c|}
\hline Acessos & PHAE & AP & $\mathbf{A E}$ & CE & $\mathrm{DE}$ & PG \\
\hline 1 & 3,4 & 241,5 & 135,9 & 14,3 & 3,7 & 2.276 \\
\hline 2 & 4.5 & 230.1 & 130,6 & 13,8 & 3,8 & 2,009 \\
\hline 3 & 4,4 & 257,6 & 161,4 & 13,1 & 3,7 & 2,267 \\
\hline 4 & 3,8 & 257,6 & 148.6 & 13.6 & 3,4 & 1,840 \\
\hline 5 & 4.5 & 231.2 & 133.4 & 13.9 & 3.8 & 1.828 \\
\hline 6 & 4,5 & 239,8 & 135,9 & 13,9 & 3,7 & 2,343 \\
\hline 8 & 3.8 & 233,8 & 136,6 & 13,0 & 3,7 & 1,530 \\
\hline 9 & 3.8 & 222,6 & 133.1 & 13.6 & 3.9 & 1,902 \\
\hline 10 & 5.3 & 225.8 & 132,1 & 14.7 & 3,5 & 2,108 \\
\hline 11 & 4.8 & 221,4 & 130.0 & 15,3 & 3,8 & 2,765 \\
\hline 12 & 3.8 & 255,1 & 149,8 & 13,7 & 3.8 & 2,451 \\
\hline 13 & 3.4 & 263,1 & 168,5 & 13,8 & 3,4 & 2,222 \\
\hline 14 & 4,3 & 259,6 & 155,9 & $13,7$. & 3,7 & 2,567 \\
\hline 15 & 3,3 & 264,5 & 163,3 & 13,8 & 3.8 & 2,670 \\
\hline 16 & 3,5 & 258,0 & 155,4 & 13,8 & 3,5 & 2,390 \\
\hline 17 & 4,3 & 280,3 & 176,1 & 14,9 & 3,8 & 2,503 \\
\hline 18 & 3,4 & 251,4 & 162,0 & 12,9 & 3,5 & 1,730 \\
\hline 19 & 3,8 & 225,4 & 130,4 & 14,6 & 3,6 & 2,213 \\
\hline 20 & 3.4 & 245,4 & 145,6 & 14,8 & 3,8 & 2,566 \\
\hline 21 & 4,5 & 263,1 & 155,5 & 14,4 & 3,9 & 2,068 \\
\hline 22 & 3,8 & 241,3 & 140,8 & 13,8 & 3,5 & 2,141 \\
\hline 23 & 3,4 & 275,4 & 167,5 & 13,3 & 3,6 & 2,136 \\
\hline 24 & 3.1 & 290.7 & 191.8 & 14.3 & 3.5 & 1.582 \\
\hline 25 & 3.8 & 266.4 & 166.4 & 13.9 & 3.7 & 2.441 \\
\hline 26 & 3.5 & 255.8 & 156.5 & 13,7 & 3.9 & 2,775 \\
\hline 27 & 4,4 & 267.1 & 164,4 & 14.0 & 3,6 & 2,178 \\
\hline 29 & 3.1 & 285.6 & 181,5 & 13,5 & 3.8 & 2.395 \\
\hline 30 & 4.8 & 263,3 & 163,5 & 13.1 & 3.4 & 1.855 \\
\hline Híbridos & PHAE & $\mathbf{A P}$ & $\mathbf{A E}$ & $\mathrm{CE}$ & $\mathrm{DE}$ & PG \\
\hline H1 & 4.5 & 173,6 & 98.4 & 11.4 & 4.0 & 1.864 \\
\hline $\mathrm{H} 2$ & 4.3 & 195.8 & 100.3 & 12.9 & 3.9 & 2.486 \\
\hline H3 & 3,5 & 193,0 & 98,6 & 13,1 & 3,9 & 2,043 \\
\hline H4 & 4.0 & 207.0 & 100.9 & 12.2 & 3.6 & 1.663 \\
\hline Cruzamentos & PHAE & AP & $\mathbf{A E}$ & $\mathrm{CE}$ & $\mathrm{DE}$ & PG \\
\hline 1.1 & 5.0 & 225.4 & 129,1 & 14,8 & 3.9 & 3.119 \\
\hline 1.2 & 4.8 & 232.3 & 130.0 & 14.3 & 4.0 & 3.370 \\
\hline 1.3 & 4.3 & 234.1 & 137.6 & 13.9 & 4.0 & 2.973 \\
\hline 1.4 & 5.3 & 240.1 & 129.1 & 14.3 & 3.9 & 2.670 \\
\hline 2.1 & 3.8 & 227.6 & 124.9 & 14.1 & 3.9 & 2.561 \\
\hline 2.2 & 4.5 & 219.2 & 118.5 & 14.0 & 3.9 & 3.108 \\
\hline 2.3 & 3.7 & 223.3 & 128.3 & 14.5 & 3.9 & 2.823 \\
\hline 2.4 & 5.3 & 239.3 & 136.6 & 12.7 & 3.7 & 2.099 \\
\hline 3.1 & 3,7 & 218,0 & 127,4 & 12,4 & 4,0 & 2,936 \\
\hline 3.2 & 3,5 & 230,0 & 132,3 & 14,2 & 3,9 & 3,300 \\
\hline
\end{tabular}




\begin{tabular}{|c|c|c|c|c|c|c|}
\hline Cruzamentos & PHAE & AP & $\mathbf{A E}$ & CE & DE & PG \\
\hline 3.3 & 4,1 & 232,7 & 137,4 & 14,7 & 4,1 & 3,360 \\
\hline 3.4 & 4,2 & 252,3 & 149,4 & 13,9 & 3,9 & 2,954 \\
\hline 4.1 & 4.5 & 228.6 & 129.4 & 14,8 & 4,4 & 2,938 \\
\hline 4.2 & 5,0 & 227.2 & 127,4 & 14,0 & 3,8 & 2,829 \\
\hline 4.3 & 4.0 & 227,9 & 130,8 & 13,6 & 4,1 & 2,749 \\
\hline 4.4 & 4,6 & 238,2 & 140,8 & 13,6 & 3,9 & 2.589 \\
\hline 5.1 & 4.5 & 204.9 & 115,5 & 15,0 & 4,2 & 1,907 \\
\hline 5.2 & 3.7 & 221.1 & 119.5 & 14.3 & 3.9 & 2.953 \\
\hline 5.3 & 4.4 & 214.7 & 120.0 & 13.6 & 4.1 & 2.774 \\
\hline 5.4 & 3.8 & 224.4 & 121,4 & 14.2 & 3.9 & 2.624 \\
\hline 6.1 & 4.9 & 211,5 & 120,0 & 12,8 & 4,0 & 2.964 \\
\hline 6.2 & 5.0 & 216,5 & 117,1 & 14,6 & 4.1 & 2,841 \\
\hline 6.3 & 4.5 & 226,0 & 132,0 & 14,7 & 4.2 & 2,742 \\
\hline 6.4 & 4.8 & 226.7 & 123,5 & 13,2 & 3,9 & 2,497 \\
\hline 8.1 & 3.4 & 214,9 & 127,4 & 13,0 & 3.8 & 2.509 \\
\hline 8.2 & 3.8 & 228,3 & 127.8 & 13,1 & 4,0 & 2.998 \\
\hline 8.3 & 3,8 & 234.0 & 140,6 & 14,4 & 4,0 & 2.223 \\
\hline 8.4 & 4,4 & 230.8 & 127,9 & 14,5 & 4,0 & 2,472 \\
\hline 9.1 & 3.6 & 230,4 & 126,8 & 13,9 & 4,0 & 2,190 \\
\hline 9.2 & 3,8 & 227.5 & 135,6 & 13,3 & 3,8 & 2,662 \\
\hline 9.3 & 4.1 & 224,1 & 127,9 & 13,8 & 3,8 & 1,941 \\
\hline 9.4 & 3.5 & 231,5 & 130,9 & 13,4 & 3.8 & 2.261 \\
\hline 10.1 & 3.9 & 195.6 & 111,1 & 14.7 & 3.8 & 3.100 \\
\hline 10.2 & 3.7 & 206,8 & 115.4 & 15,0 & 3.7 & 2,790 \\
\hline 10.3 & 3.5 & 213.6 & 122,9 & 14.5 & 3,9 & 3,290 \\
\hline 10.4 & 4.8 & 235.5 & 131.6 & 15.1 & 3.7 & 2.838 \\
\hline 11.1 & 3.1 & 210,7 & 113,9 & 14.8 & 4.0 & 2.685 \\
\hline 11.2 & 4.1 & 205.6 & 107.5 & 15.0 & 3.9 & 2,798 \\
\hline 11.3 & 4.1 & 217,6 & 119,3 & 15,0 & 4.1 & 2.980 \\
\hline 11.4 & 4.8 & 219.3 & 121.8 & 14.6 & 3.9 & 2.912 \\
\hline 12.1 & 3.4 & 224.9 & 132.5 & 13.8 & 3.9 & 2.628 \\
\hline 12.2 & 3.6 & 239,9 & 136.5 & 13,1 & 3.9 & 2.675 \\
\hline 12.3 & 3.8 & 238.2 & 134,1 & 14,0 & 4.1 & 2.881 \\
\hline 12.4 & 3.9 & 241,5 & 140,1 & 13,7 & 3.8 & 2,774 \\
\hline 13.1 & 4.0 & 234,2 & 133,6 & 13.9 & 4.0 & 3,072 \\
\hline 13.2 & 3.6 & 230.2 & 128.5 & 14.7 & 3.9 & 3.267 \\
\hline 13.3 & +.3 & $2+1.4$ & 136.5 & 14.0 & 4.0 & 3.218 \\
\hline 13.4 & 3.5 & $2+2.1$ & 139.8 & 14,3 & 3,9 & 2,936 \\
\hline 14.1 & 4.3 & 233.4 & 131,4 & 14.1 & 4,0 & 3.241 \\
\hline 14.2 & 3.6 & 234.9 & 129.8 & 14.3 & 3.9 & 3.174 \\
\hline 14.3 & 4.1 & 249.0 & 146.9 & 14.6 & 4.0 & 3.179 \\
\hline 14.4 & 3.5 & 236.2 & 131.4 & 14.0 & 3.8 & 2.764 \\
\hline 15.1 & 3.9 & 251.5 & 149.6 & 12.4 & 3.5 & 2.664 \\
\hline 15.2 & 3.8 & 232.4 & 133.8 & 14.8 & 4.1 & 2.833 \\
\hline 15.3 & 3.1 & 236.0 & $1+2.1$ & $1+.1$ & 3.9 & 2.800 \\
\hline 15.4 & 3.9 & 249.7 & 137.3 & 14.7 & 4.0 & 2.518 \\
\hline 16.1 & 3.8 & 236.6 & 139.0 & 14.2 & 4.1 & 3.059 \\
\hline 16.2 & 4.0 & 253.5 & 153.0 & 14.4 & 3.8 & 2.581 \\
\hline
\end{tabular}




\begin{tabular}{|c|c|c|c|c|c|c|}
\hline Cruzamentos & PHAE & $\mathbf{A P}$ & $\mathbf{A E}$ & $\mathbf{C E}$ & $\overline{D E}$ & PG \\
\hline 16.3 & 3.6 & 243.8 & 144.0 & 14.5 & 3.9 & 3,157 \\
\hline 16.4 & 3.5 & 252.5 & 143,0 & 14.1 & 3,9 & 2,747 \\
\hline 17.1 & 3,8 & 243,0 & 143,3 & 14,8 & 4,0 & 3,282 \\
\hline 17.2 & 4,0 & 247,1 & 141,8 & 13,4 & 3,9 & 3,208 \\
\hline 17.3 & 3,8 & 252,0 & 151,6 & 14,8 & 4,1 & 2,866 \\
\hline 17.4 & 3,4 & 254,5 & 147,1 & 14,3 & 3,9 & 3,128 \\
\hline 18.1 & 4,3 & 219,6 & 125.8 & 14,6 & 4,2 & 2,572 \\
\hline 18.2 & 4.3 & 212,3 & 127.1 & 14,4 & 3.8 & 2.902 \\
\hline 18.3 & 3.3 & 231.6 & 134.8 & 14.8 & 4,0 & 2.825 \\
\hline 18.4 & 3.8 & 243,6 & 137,5 & 14.0 & 3.7 & 2,732 \\
\hline 19.1 & 4,1 & 207.0 & 121.1 & 14.4 & 3.9 & 3.039 \\
\hline 19.2 & 3.8 & 210.6 & 115.1 & 14.5 & 3.9 & 2,864 \\
\hline 19.3 & 4.3 & 227.6 & 131,1 & 14,5 & 3,9 & 3,083 \\
\hline 19.4 & 3.8 & 221,3 & 120,9 & 14,6 & 3,9 & 2,876 \\
\hline 20.1 & 4.1 & 226.8 & 130,9 & 14,3 & 3.9 & 2,875 \\
\hline 20.2 & 4.0 & 222.3 & 124.9 & 14,2 & 4,2 & 3,095 \\
\hline 20.3 & 4.2 & 232.8 & 129.4 & 13.5 & 3.8 & 2.824 \\
\hline 20.4 & 4,0 & 230.3 & 132,0 & 13,8 & 3.9 & 3.264 \\
\hline 21.1 & 3.5 & 228,6 & 132,9 & 14.5 & 4.1 & 2,594 \\
\hline 21.2 & 4,3 & 239,4 & 133,0 & 14,0 & 3,9 & 2,873 \\
\hline 21.3 & 3,4 & 246,5 & 140,9 & 14,0 & 3,9 & 2,887 \\
\hline 21.4 & 4.2 & 239,1 & 133,6 & 14,3 & 4,0 & 2,496 \\
\hline 22.1 & 3.6 & 241.5 & 138.4 & 13,3 & 3.5 & 2.349 \\
\hline 22.2 & 3,6 & 235.3 & 133.5 & 14.7 & 4,0 & 2.759 \\
\hline 22.3 & 3.9 & 236.8 & 139.1 & 13.8 & 3.9 & 2.666 \\
\hline 22.4 & 4,4 & 238,2 & 134.3 & 13,8 & 3.8 & 2,763 \\
\hline 23.1 & 4,1 & 225,9 & 129,6 & 13,0 & 4,0 & 2,841 \\
\hline 23.2 & 3,8 & 233,5 & 130,0 & 13,8 & 4,1 & 3,647 \\
\hline 23.3 & 3,5 & 227,9 & 133,4 & 15,3 & 4,1 & 3,081 \\
\hline 23.4 & 4,9 & 243,5 & 137,3 & 14,9 & 4,1 & 2,571 \\
\hline 24.1 & 4.1 & 221.3 & 131,6 & 13,9 & 4.2 & 3,492 \\
\hline 24.2 & 4.9 & 254.3 & 151.8 & 13.8 & 3.9 & 3.085 \\
\hline 24.3 & 3.8 & 248.0 & 150.1 & 14.4 & 3.9 & 2.925 \\
\hline 24.4 & 3.5 & 254.8 & 155.1 & 13.5 & 3.7 & 2.303 \\
\hline 25.1 & 3,4 & 234.7 & 133.0 & 14.3 & 3.9 & 2.561 \\
\hline 25.2 & 3.6 & 240.7 & 141.9 & 13.8 & 3.9 & 3.146 \\
\hline 25.3 & 4.2 & 245.9 & 141.8 & 13.5 & 3.8 & 3.521 \\
\hline 25.4 & 3.4 & 241.5 & $1+2.3$ & 14,3 & 3.9 & 3.153 \\
\hline 26.1 & 3.9 & 245.9 & $1+1.9$ & 14.7 & 4.1 & 3.035 \\
\hline 26.2 & 3.8 & 230.0 & 130.1 & 14.6 & 4.7 & 3.054 \\
\hline 26.3 & 4.3 & 238.8 & 142.9 & 13.8 & 4.0 & 2.912 \\
\hline 26.4 & 3.8 & 252.2 & 140.5 & 14.3 & 4.2 & 3.406 \\
\hline 27.1 & 3.2 & 243.2 & 143.6 & 13.8 & 3.7 & 3.066 \\
\hline 27.2 & 3.3 & 252.3 & 146.5 & 15.1 & 3.6 & 3.447 \\
\hline 27.3 & 4.0 & 257.9 & 157.0 & 14.4 & 3.9 & 3.263 \\
\hline 27.4 & 4.6 & 242.3 & 141.8 & 14.5 & 3.7 & 2.981 \\
\hline 29.1 & 4.6 & 245.5 & $1+2.9$ & $1+.2$ & 4.0 & 2.878 \\
\hline 29.2 & 4.4 & 240.5 & 137.3 & 14.1 & 3.9 & 2.956 \\
\hline
\end{tabular}




\begin{tabular}{|c|c|c|c|c|c|c|}
\hline Cruzamentos & PHAE & AP & $\mathbf{A E}$ & CE & DE & PG \\
\hline 29.3 & 4,2 & 246,7 & 144.6 & 14,3 & 4.2 & 2,982 \\
\hline 29.4 & 4,4 & 248,0 & 140,9 & 13.8 & 4,1 & 2,911 \\
\hline 30.1 & 4.0 & 236,4 & 131,0 & 13.3 & 4,1 & 2,925 \\
\hline 30.2 & 4,0 & 259,0 & 154,8 & 14,7 & 3,8 & 2,749 \\
\hline 30.3 & 3.9 & 253.5 & 154,3 & 15,0 & 3,9 & 2,708 \\
\hline 30.4 & 4,6 & 257.3 & 150,9 & 14,6 & 4,2 & 3,132 \\
\hline Testemunhas & PHAE & AP & $\mathrm{AE}$ & $\mathrm{CE}$ & DE & PG \\
\hline $\mathrm{T} 1$ & 3,3 & 215.5 & 113,1 & 14,9 & 4,6 & 4,6 \\
\hline T2 & 3,9 & 248.0 & 129,9 & 14,2 & 4,4 & 4,4 \\
\hline
\end{tabular}

Tabela 33. Resumo das análises de variância do experimento 1A para mancha de Phaeosphaeria (PHAE), altura de planta (AP), altura da espiga (AE), comprimento de espiga (CE), diâmetro de espiga (DE), e peso de grãos por parcela (PG).

\begin{tabular}{|c|c|c|c|c|c|c|c|}
\hline \multirow[b]{2}{*}{ FV } & \multirow[b]{2}{*}{ GL } & \multicolumn{5}{|c|}{ QM } & \multirow[b]{2}{*}{ PG } \\
\hline & & PHAE & AP & $\overline{\mathrm{AE}}$ & CE & DE & \\
\hline Repetição & 3 & 182.893 & 1728,14 & 93,75 & 0.673 & 0,103 & 0.342 \\
\hline Tratamentos & 145 & 1,047 & $1398,11^{* *}$ & $1030,73 * *$ & $1,885 * *$ & $0,303 * *$ & $1,980 * *$ \\
\hline Dialelo & 143 & 0,970 & $1291,02 * *$ & $920,83^{* *}$ & $1,758^{* *}$ & $0,151^{* *}$ & $0.748^{* *}$ \\
\hline Acessos & 27 & $\overline{1.472}$ & $\overline{3097.53 * *}$ & $2166.91^{* *}-$ & $2.110^{* *}$ & $0 . \overline{159 * *}$ & $0 . \overline{888 * *-}$ \\
\hline Híbridos & 3 & 1.085 & $4049.77 * *$ & $1191.56 * *$ & $3,190^{*}$ & $0.230^{*}$ & $1.602 * *$ \\
\hline Entre grupos & 1 & 0.717 & $57261.20 * *$ & $50500.65 * *$ & 1.091 & $5.141^{* *}$ & $19.269 * *$ \\
\hline Heterose & 112 & 0.848 & $281.90 * *$ & $170.50 * *$ & $1.641 * *$ & $0.103^{* *}$ & $0.526 * *$ \\
\hline H. média & 1 & 0.006 & $6338.81 * *$ & $3134.43 * *$ & $50.989 * *$ & $1,752^{* *}$ & $29.178 * *$ \\
\hline H. Acessos & 27 & 1.395 & $339.28 * *$ & $234.80 * *$ & 0.893 & 0.097 & $0.357 * *$ \\
\hline H. Hibridos & 3 & 0,743 & 132,99 & 164,47 & 0,954 & 0,043 & 0,084 \\
\hline H. especifica & 81 & 0.680 & $193,51 * *$ & $112,70 * *$ & 1,307 & 0,086 & $0.245 * *$ \\
\hline Testemunhas & 1 & $5,790^{*}$ & $16916,25^{* *}$ & $4505,77^{* *}$ & $8, \overline{146^{* *}-}$ & $0 . \overline{595 * *}$ & $\overline{0.820 *}$ \\
\hline Dialelo rs Testem. & 1 & $7.367 *$ & $1193.10 * *$ & $13272.36^{* *}$ & $13.695 * *$ & $21.700 * *$ & $179.277 * *$ \\
\hline Residuo & 491 & 1.257 & 100.39 & 77.06 & 1.017 & 0.069 & 0.144 \\
\hline Dentro test./rep. & 56 & 0.235 & 78.61 & 60.21 & 1.154 & 0,073 & 0.153 \\
\hline Erro & 435 & 1.388 & 103.19 & 79.23 & 1.000 & 0.069 & 0.143 \\
\hline$C V \%$ & & 28.37 & 4.25 & 6.50 & 7.15 & 6.65 & 13.09 \\
\hline Média geral & & 3.95 & 235.81 & 135.13 & 14.10 & 3.95 & 2.90 \\
\hline
\end{tabular}

** e * indicam, respectivamente. significância ao nivel de $1 \%$ e de $5 \%$ de probabilidade. 
Tabela 34. Efeitos de variedade $v_{1}$ no experimento 1A para mancha de Phaeosphaeria (PHAE), altura de planta (AP), altura da espiga (AE), comprimento de espiga (CE), diâmetro de espiga $(D E)$, e peso de grãos por parcela (PG).

\begin{tabular}{|c|c|c|c|c|c|c|}
\hline Acessos & PEAE & AP & $\overline{\mathbf{A E}}$ & $\overline{C E}$ & $\mathrm{DE}$ & $\overline{P G}$ \\
\hline 1 & $-0,543$ & $-11,131$ & $-16,705$ & 0,383 & 0,078 & 0,071 \\
\hline 2 & 0,557 & $-22,489$ & $-21,955$ & $-0,124$ & 0,168 & $-0,196$ \\
\hline 3 & 0,457 & 5.002 & 8.795 & $-0,799$ & 0.023 & 0.062 \\
\hline 4 & -0.143 & 5.017 & -3.955 & $-0,264$ & -0.292 & -0.365 \\
\hline 5 & 0.557 & $-21,422$ & $-19,205$ & 0,001 & 0,098 & $-0,377$ \\
\hline 6 & 0,557 & $-12,819$ & $-16,705$ & 0,018 & $-0,006$ & 0.138 \\
\hline 8 & $-0,143$ & $-18,803$ & $-15,955$ & $-0,892$ & 0,069 & $-0,675$ \\
\hline 9 & -0.143 & $-30,026$ & -19.455 & $-0,279$ & 0,211 & -0.303 \\
\hline 10 & 1.357 & $-26,802$ & $-20,455$ & 0,784 & $-0,142$ & $-0,097$ \\
\hline 11 & 0,857 & $-31,176$ & -22.580 & 1,392 & 0.129 & 0.560 \\
\hline 12 & $-0,143$ & 2.468 & -2.830 & -0.213 & 0.107 & 0.246 \\
\hline 13 & $-0,543$ & 10.485 & 15.920 & $-0,085$ & $-0,260$ & 0.017 \\
\hline 14 & 0.357 & 6,976 & 3.295 & $-0,209$ & 0.023 & 0.362 \\
\hline 15 & $-0,643$ & 11.948 & 10.670 & $-0,069$ & 0.172 & 0.465 \\
\hline 16 & $-0,443$ & 5,393 & 2.795 & $-0,115$ & $-0,155$ & 0,185 \\
\hline 17 & 0.357 & 27,734 & 23.545 & 1.034 & 0.089 & 0,298 \\
\hline 18 & $-0,543$ & -1.224 & 9,420 & $-1,027$ & $-0,178$ & $-0,475$ \\
\hline 19 & -0.143 & -27.213 & -22.205 & 0,660 & $-0,103$ & 0.008 \\
\hline 20 & -0.543 & -7.210 & -6.955 & 0.842 & 0,149 & 0,361 \\
\hline 21 & 0.557 & 10,548 & 2,920 & 0,492 & 0,213 & $-0,137$ \\
\hline 22 & $-0,143$ & $-11,253$ & $-11,830$ & $-0,067$ & $-0,203$ & -0.064 \\
\hline 23 & $-0,543$ & 22,770 & 14,920 & $-0,614$ & $-0,045$ & $-0,069$ \\
\hline 24 & -0.843 & 38,121 & 39,170 & 0,427 & $-0,201$ & $-0,623$ \\
\hline 25 & -0.143 & 13.780 & 13,795 & 0.016 & $-0,020$ & 0.236 \\
\hline 26 & -0.443 & 3.161 & 3.920 & $-0,174$ & 0.265 & 0,570 \\
\hline 27 & 0,457 & 14.492 & 11.795 & 0,048 & $-0,103$ & $-0,027$ \\
\hline 29 & $-0,843$ & 32.983 & 28.920 & $-0,386$ & 0.148 & 0.190 \\
\hline 30 & 0,857 & 10.692 & 10.920 & $-0,779$ & -0.234 & -0.350 \\
\hline Hibridos & PHAE & AP & $\mathbf{A E}$ & CE & DE & PG \\
\hline H1 & 0.425 & -18.751 & -1.156 & $-0,996$ & 0.128 & -0.150 \\
\hline $\mathrm{H} 2$ & 0.225 & 3.444 & 0.719 & 0.510 & 0.056 & 0.472 \\
\hline H3 & -0.575 & 0.673 & -0.906 & 0.698 & 0.060 & 0.029 \\
\hline H4 & -0.075 & 14.634 & 1.344 & -0.212 & -0.244 & -0.351 \\
\hline
\end{tabular}


Tabela 35. Efeitos de heterose de variedade $h_{j}$ no experimento $1 A$ para mancha de Phaeosphaeria (PHAE), altura de planta (AP), altura da espiga (AE), comprimento de espiga (CE), diâmetro de espiga (DE), e peso de grãos por parcela (PG).

\begin{tabular}{crrrrrr}
\hline Acessos & PHAE & AP & AE & CE & DE & PG \\
\hline $\mathbf{1}$ & 1,107 & 4,791 & 5,830 & $-0,002$ & $-0,042$ & 0,122 \\
$\mathbf{2}$ & 0,032 & 4,828 & 4,049 & $-0,263$ & $-0,195$ & $-0,130$ \\
$\mathbf{3}$ & $-0,368$ & $-2,991$ & $-1,795$ & 0,061 & 0,007 & 0,231 \\
$\mathbf{4}$ & 0.582 & -5.760 & 0.049 & -0.006 & 0.226 & 0.084 \\
$\mathbf{5}$ & $-0,193$ & $-6,736$ & -5.295 & 0.115 & 0,020 & $-0,122$ \\
$\mathbf{6}$ & 0,507 & $-7,173$ & $-2,482$ & $-0,330$ & 0.091 & -0.183 \\
$\mathbf{8}$ & $-0,093$ & 2,648 & 4,893 & 0,053 & -0.016 & 0,013 \\
$\mathbf{9}$ & $-0,193$ & 9,652 & 6.018 & $-0,418$ & -0.171 & $-0,460$ \\
$\mathbf{1 0}$ & $-0,718$ & $-7,478$ & $-3,513$ & 0,279 & $-0,080$ & 0,178 \\
$\mathbf{1 1}$ & $-0,418$ & $-4,856$ & $-7,107$ & $-0,018$ & $-0,012$ & $-0,312$ \\
$\mathbf{1 2}$ & -0.268 & 1.131 & 3.237 & -0.386 & -0.052 & $-0,259$ \\
$\mathbf{1 3}$ & 0.107 & $-2,021$ & -7.357 & 0,121 & 0,143 & 0,240 \\
$\mathbf{1 4}$ & $-0,318$ & 1,157 & $-0,795$ & 0,184 & $-0,035$ & 0,033 \\
$\mathbf{1 5}$ & $-0,018$ & 2,687 & 1,362 & $-0,144$ & $-0,164$ & $-0,404$ \\
$\mathbf{1 6}$ & $-0,068$ & 10,165 & 9,362 & 0,204 & 0,068 & $-0,082$ \\
$\mathbf{1 7}$ & $-0,443$ & 1,545 & 0,174 & $-0,350$ & $-0,020$ & 0,097 \\
$\mathbf{1 8}$ & 0,182 & $-6,327$ & $-7,420$ & 0,814 & 0,101 & 0,120 \\
$\mathbf{1 9}$ & 0.057 & $-3,519$ & -0.826 & 0,013 & $-0,016$ & 0,086 \\
$\mathbf{2 0}$ & 0.332 & $-2,095$ & $-1,232$ & $-0,625$ & $-0,093$ & $-0,041$ \\
$\mathbf{2 1}$ & $-0,443$ & $-0,641$ & $-0,357$ & -0.192 & $-0,076$ & $-0,094$ \\
$\mathbf{2 2}$ & $-0,068$ & 9,842 & 8.237 & $-0,232$ & $-0,064$ & $-0,209$ \\
$\mathbf{2 3}$ & 0.332 & -12.425 & $-8,888$ & 0,394 & 0.141 & 0.194 \\
$\mathbf{2 4}$ & 0,482 & -8.206 & $-6,420$ & -0.450 & 0.087 & 0.388 \\
$\mathbf{2 5}$ & -0.293 & 0.063 & -1.170 & $-0,199$ & -0.049 & 0,102 \\
$\mathbf{2 6}$ & 0,157 & 6,402 & 2.893 & 0,272 & 0,143 & $-0,059$ \\
$\mathbf{2 7}$ & $-0,468$ & 7,935 & 7,330 & 0,297 & $-0,156$ & 0,328 \\
$\mathbf{2 9}$ & 0.807 & $-5,069$ & $-7,045$ & 0.132 & 0,034 & -0.039 \\
$\mathbf{3 0}$ & -0.318 & 12.454 & 8.268 & 0,677 & 0,178 & 0,178 \\
\hline $\mathbf{H i b r i d o s}$ & $\mathbf{P H A E}$ & $\mathbf{A P}$ & $\mathbf{A E}$ & $\mathbf{C E}$ & $\mathbf{D E}$ & $\mathbf{P G}$ \\
\hline $\mathbf{H 1}$ & $-0,2804$ & 3,050 & $-2,792$ & 0,344 & $-0,041$ & 0,024 \\
$\mathbf{H 2}$ & $-0,1161$ & $-3,947$ & $-2,917$ & $-0,184$ & $-0,042$ & $-0,113$ \\
$\mathbf{H 3}$ & 0.2089 & 1.718 & 4.002 & -0.220 & 0.008 & 0.026 \\
$\mathbf{H 4}$ & 0.1875 & -0.821 & 1.708 & 0.061 & 0.075 & 0,063 \\
\hline & & & & & & \\
& & & & &
\end{tabular}


Tabela 36. Efeitos de capacidade geral de combinação $g_{1}$ no experimento $1 \mathrm{~A}$ para mancha de Phaeosphaeria (PHAE), altura de planta (AP), altura da espiga (AE), comprimento de espiga $(C E)$, diâmetro de espiga (DE), e peso de grãos por parcela $(P G)$.

\begin{tabular}{|c|c|c|c|c|c|c|}
\hline Acessos & PHAE & AP & $\mathbf{A E}$ & CE & DE & $\mathrm{PG}$ \\
\hline 1 & 0.836 & -0.774 & $-2,522$ & 0,189 & -0.003 & 0,158 \\
\hline 2 & 0.311 & $-6,417$ & -6.929 & $-0,325$ & $-0,111$ & -0.228 \\
\hline 3 & -0.139 & -0.490 & 2.603 & -0.338 & 0.019 & 0.262 \\
\hline 4 & 0,511 & -3.251 & -1.929 & -0.138 & 0,080 & -0.099 \\
\hline 5 & 0.086 & $-17,447$ & $-14,897$ & 0,115 & 0,069 & -0.311 \\
\hline 6 & 0,786 & -13.582 & -10.835 & -0.321 & 0.088 & -0.114 \\
\hline 8 & $-0,164$ & -6.753 & $-3,085$ & $-0,392$ & 0.019 & -0.325 \\
\hline 9 & -0.264 & -5.361 & -3.710 & -0.558 & -0.066 & -0.612 \\
\hline 10 & -0.039 & -20.879 & $-13,741$ & 0,671 & $-0,151$ & 0,129 \\
\hline 11 & 0,011 & $-20,444$ & $-18,397$ & 0,678 & 0,053 & $-0,032$ \\
\hline 12 & $-0,339$ & 2.365 & 1,821 & $-0,493$ & 0,001 & $-0,136$ \\
\hline 13 & -0.164 & 3.221 & 0,603 & 0,078 & 0,013 & 0.248 \\
\hline 14 & -0.139 & 4.645 & 0,853 & 0,079 & -0.023 & 0.214 \\
\hline 15 & -0.339 & 8.661 & 6.696 & -0.179 & -0.078 & -0.172 \\
\hline 16 & -0.289 & 12.861 & 10,759 & 0,146 & -0.009 & 0.011 \\
\hline 17 & -0.264 & 15,412 & 11,946 & 0.167 & 0.025 & 0.246 \\
\hline 18 & $-0,089$ & $-6,939$ & $-2,710$ & 0,301 & 0,011 & $-0,118$ \\
\hline 19 & $-0,014$ & $-17,126$ & $-11,929$ & 0,343 & $-0,068$ & 0.090 \\
\hline 20 & 0.061 & $-5,700$ & $-4,710$ & $-0,204$ & $-0,018$ & 0,139 \\
\hline 21 & $-0,164$ & 4,633 & 1,103 & 0,055 & 0,030 & -0.163 \\
\hline 22 & $-0,139$ & 4.215 & 2.321 & $-0,266$ & $-0,165$ & -0.241 \\
\hline 23 & 0,061 & $-1,040$ & $-1,429$ & 0,088 & 0.118 & 0.160 \\
\hline 24 & 0,061 & 10,854 & 13,165 & -0.236 & -0.013 & 0.076 \\
\hline 25 & $-0,364$ & 6.953 & 5.728 & $-0,191$ & -0.059 & 0.220 \\
\hline 26 & $-0,064$ & 7.983 & 4,853 & 0,185 & 0.276 & 0.226 \\
\hline 27 & -0.239 & 15,180 & 13,228 & 0,321 & $-0,208$ & 0,314 \\
\hline 29 & 0,386 & 11,422 & 7,415 & $-0,061$ & 0,109 & 0,056 \\
\hline 30 & 0.111 & 17.800 & 13,728 & 0.287 & 0.061 & 0.003 \\
\hline Hibridos & PHAE & AP & $\mathbf{A E}$ & $\mathrm{CE}$ & DE & PG \\
\hline H1 & -0.0679 & -6.326 & -3.371 & $-0,154$ & 0.023 & -0.051 \\
\hline $\mathrm{H} 2$ & -0.0036 & -2.225 & -2.558 & 0.071 & -0.014 & 0.123 \\
\hline $\mathrm{H3}$ & -0.0786 & 2.054 & 3.549 & 0.128 & 0.038 & 0.040 \\
\hline $\mathrm{H4}$ & 0.1500 & 6.496 & 2.379 & -0.045 & -0.047 & -0.112 \\
\hline
\end{tabular}


Tabela 37. Médias dos tratamentos do experimento 1C para mancha de Phaeosphaeria, ferrugem tropical, porcentagem de plantas com colmos quebrados (QUEB), porcentagem de plantas acamadas (ACAM), altura de planta (AP), altura da espiga (AE), comprimento de espiga $(C E)$, diâmetro de espiga (DE), e peso de grãos por parcela (PG).

\begin{tabular}{|c|c|c|c|c|c|c|c|c|c|}
\hline Acessos & PHAE & PHYS & QUEB & ACAM & AP & $\mathbf{A E}$ & $\mathrm{CE}$ & DE & PG \\
\hline 1 & 3,4 & 3,3 & 7,11 & 2,15 & 245,8 & 152,4 & 16,6 & 4.4 & 4,126 \\
\hline 2 & 3.5 & 3.5 & 11.40 & 5.80 & 253.2 & 153.6 & 16.7 & 4.5 & 4.272 \\
\hline 3 & 2.5 & 3.5 & 10.25 & 1.54 & 267.7 & 179.6 & 15.8 & 4.4 & 4.064 \\
\hline 4 & 3,5 & 3.5 & 8.45 & 5,60 & 272.8 & 173,1 & 17.2 & 4.4 & 3.863 \\
\hline 5 & 4,4 & 3.8 & 8.73 & 3,41 & 246.1 & 151.6 & 16.9 & 4.5 & 4.575 \\
\hline 6 & 3,9 & 3,4 & 13.60 & 3,59 & 259.1 & 157,8 & 16.6 & 4.8 & 4.924 \\
\hline 8 & 4.3 & 3.8 & 22.04 & 18,59 & 256.3 & 154,3 & 16.2 & 4.5 & 3.156 \\
\hline 9 & 4,4 & 3,1 & 14,09 & 10,71 & 250,3 & 156,0 & 15,6 & 4,6 & 3,913 \\
\hline 10 & 3.7 & 3.6 & 8,30 & 5.37 & 247.8 & 147,1 & 16.6 & 4.1 & 4.303 \\
\hline 11 & 4,1 & 3,4 & 11.99 & 4,41 & 247.0 & 142,9 & 17.3 & 4.3 & 4.694 \\
\hline 12 & 3,9 & 3.3 & 11,45 & 5,65 & 265.5 & 159,2 & 16.0 & 4,7 & 4.034 \\
\hline 13 & 2,9 & 4,1 & 6,42 & 3,54 & 284,7 & 197,5 & 16,7 & 4,2 & 3.931 \\
\hline 14 & 3,0 & 4.0 & 3.39 & 2,72 & 267.1 & 180,7 & 16,5 & 4,4 & 3.822 \\
\hline 15 & 3,5 & 3.5 & 3.21 & 3,21 & 276.2 & 165,8 & 16.5 & 4.6 & 4.648 \\
\hline 16 & 3.4 & 3,5 & 7.50 & 0.89 & 268,5 & 170,5 & 15,8 & 4.3 & 4.350 \\
\hline 17 & 3,5 & 3,4 & 5,98 & 6,33 & 275.1 & 179,5 & 17,0 & 4.5 & 4.445 \\
\hline 18 & 4.2 & 3,8 & 9,76 & 16,01 & 254,8 & 160,7 & 17,0 & 4.4 & 3.494 \\
\hline 19 & 4.5 & 3,3 & 8.39 & 1,52 & 250.4 & 154,6 & 17.0 & 4.2 & 4.500 \\
\hline 20 & 3.4 & 3.5 & 12,46 & 5,15 & 251.4 & 151,4 & 16.4 & 4.4 & 4.027 \\
\hline 21 & 3,4 & 3.5 & 12,71 & 12,91 & 272.7 & 172,8 & 16,9 & 4.2 & +.006 \\
\hline 22 & 3.8 & 3.5 & 9.87 & 3.74 & 269.8 & 162.5 & 16.7 & 4.3 & 4.524 \\
\hline 23 & 2.9 & 3.1 & 4.17 & 5.97 & 281.8 & 178.4 & 16.6 & 4.9 & 4.395 \\
\hline 24 & 2.9 & 3.9 & 12.22 & 1.52 & 280.7 & 193.1 & 15.2 & 4.2 & 2.843 \\
\hline 25 & 3,4 & 3.7 & 11.35 & 3.23 & 251.0 & 171,3 & 16,5 & 4,2 & 4.223 \\
\hline 26 & 3,1 & 3.8 & 9,02 & 2,32 & 269,9 & 163,8 & 16,1 & 4,5 & 4,325 \\
\hline 27 & 2.9 & 3.5 & 7.26 & 4,46 & 276.2 & 181,3 & 16,3 & 4.5 & 3.390 \\
\hline 29 & 2.8 & 3,6 & 6.88 & 2.09 & 282.1 & 185,3 & 15.9 & 4,6 & 3,877 \\
\hline 30 & 3.5 & 3.3 & 1.83 & 3,03 & 272.0 & 174,6 & 15.7 & 4.6 & 3.794 \\
\hline Híbridos & PHAE & PHYS & QUEB & ACAM & AP & $\mathbf{A E}$ & $\mathrm{CE}$ & $\mathrm{DE}$ & PG \\
\hline H1 & 3.7 & 3.5 & 7.11 & 1.61 & 210.5 & 115.6 & 12.7 & 4.5 & 3.132 \\
\hline $\mathrm{H} 2$ & 3.6 & 3.9 & 0.61 & 0.00 & 231.7 & 127.9 & 15.0 & 4.6 & +.377 \\
\hline H3 & 3.9 & 3.5 & 5.99 & 5.88 & 220.4 & 125.2 & 13.2 & 4.4 & 2.965 \\
\hline H4 & 5.1 & 3.5 & 0.00 & 0.00 & 241.8 & 127.3 & 15.6 & 4.5 & 4.121 \\
\hline Cruzamentos & PHAE & PHYS & QUEB & ACAM & AP & $\mathbf{A E}$ & $\mathrm{CE}$ & DE & PG \\
\hline 1.1 & 4.0 & 3.5 & 5.45 & 4.17 & 260.4 & 163,0 & 16.5 & 4.8 & 4.963 \\
\hline 1.2 & 3.6 & 3.5 & 2.55 & 1.93 & 251.3 & 135.5 & 16.6 & 4.6 & 5.123 \\
\hline 1.3 & 2.9 & 3.4 & 2.90 & 0.00 & 256.1 & 161.5 & 16.0 & +6 & 5.447 \\
\hline 1.4 & 3.3 & 3.6 & 1.35 & 4.11 & 261.8 & 154.2 & 16.9 & 4.6 & 5.136 \\
\hline 2.1 & 3.7 & 3.6 & 9.08 & 0.68 & 264.6 & 156.3 & 16.7 & 4.9 & $5.08 t$ \\
\hline 2.2 & 3.5 & 4.3 & 9.85 & 2.10 & 260.2 & 155.9 & 16.5 & 4.7 & 5.746 \\
\hline 2.3 & 3.1 & 3.4 & 8.33 & 0.68 & 253.8 & $1+1.6$ & 16.0 & 4.7 & 5.418 \\
\hline 2.4 & 3.8 & 3.8 & 3.10 & 2.61 & 252.5 & 141.5 & 16.8 & 4.9 & 4.822 \\
\hline 3.1 & 2.8 & 3.5 & 6.17 & 2.87 & 257.3 & 150.3 & 15.1 & 4.7 & 5.068 \\
\hline
\end{tabular}




\begin{tabular}{|c|c|c|c|c|c|c|c|c|c|}
\hline Cruzamentos & PHAE & PHYS & QUEB & $\overline{\text { ACAM }}$ & $\mathbf{A P}$ & $\mathbf{A E}$ & $\overline{C E}$ & $\overline{D E}$ & $\mathbf{P G}$ \\
\hline 3.2 & 2.9 & 3.8 & 4.79 & 5.30 & 257.7 & 159.9 & 16.2 & 4.5 & 5.573 \\
\hline 3.3 & 3.5 & 3.5 & 2.27 & 3.13 & 269.7 & 161.5 & 16.1 & 4.7 & 5,013 \\
\hline 3.4 & 3.4 & 3.4 & 6,98 & 1,61 & 265.9 & 156.0 & 17.2 & 4,7 & 6,047 \\
\hline 4.1 & 3,5 & 3,4 & 9,81 & 0,00 & 249,7 & 151,7 & 16,4 & 4,8 & 4,372 \\
\hline 4.2 & 3,8 & 4,0 & 4.59 & 2,08 & 262.9 & 153,3 & 16,8 & 4,6 & 4,952 \\
\hline 4.3 & 3,6 & 3,4 & 1,35 & 0,00 & 262,8 & 156,4 & 16,8 & 4,9 & 5,513 \\
\hline 4.4 & 3.5 & 3.6 & 0.00 & 0.00 & 263.9 & 165.2 & 16.5 & 4,7 & 5,156 \\
\hline 5.1 & 3.1 & 3.1 & 4.18 & 2.09 & 243.6 & 137.6 & 15.9 & 4.8 & 4.546 \\
\hline 5.2 & 4.3 & 4.4 & 5.00 & 1.52 & 254.6 & 135.3 & 17.6 & 4.5 & 5.015 \\
\hline 5.3 & 3,2 & 3,1 & 7,92 & 3,15 & 242,0 & 139.9 & 16,1 & 4.8 & 5.254 \\
\hline 5.4 & 4,5 & 3,6 & 4.01 & 0,00 & 257,7 & 144,3 & 16,6 & 4,8 & 4,906 \\
\hline 6.1 & 3.9 & 3.1 & 8,11 & 2.34 & 257.9 & 150,8 & 15.7 & 4.8 & 5.108 \\
\hline 6.2 & 3.6 & 3,4 & 6,74 & 0,78 & 261,5 & 145,4 & 16,7 & 4,7 & 5,638 \\
\hline 6.3 & 2.8 & 3,4 & 3,14 & 4,88 & 259.6 & 148,0 & 16,2 & 4,8 & 4,978 \\
\hline 6.4 & 3,8 & 3,5 & 3.64 & 1,61 & 251,8 & 140,2 & 16,8 & 4,7 & 6,122 \\
\hline 8.1 & 3.3 & 3,5 & 11.20 & 5,99 & 258.0 & 158.4 & 15,8 & 4,9 & 4,446 \\
\hline 8.2 & 3.7 & 3.6 & 7,08 & 1.63 & 254.4 & 146,5 & 16,6 & 4.8 & 5.118 \\
\hline 8.3 & 3.5 & 3.3 & 12.43 & 4.21 & 266.6 & 163.0 & 16,7 & 4,9 & 4,160 \\
\hline 8.4 & 4,8 & 3,5 & 7,95 & 0,83 & 248,8 & 143,7 & 16,6 & 4,8 & 5,159 \\
\hline 9.1 & 4,1 & 3,1 & 0,69 & 0,00 & 246,1 & 147.2 & 15,7 & 4,9 & 5,118 \\
\hline 9.2 & 4,3 & 3,5 & 7,61 & 2,35 & 262,0 & 170,0 & 15,8 & 4,6 & 5,157 \\
\hline 9.3 & 3,5 & 3,5 & 3,59 & 6,42 & 256,3 & 155,2 & 16,3 & 4,8 & 4,162 \\
\hline 9.4 & 3.9 & 3,6 & 7,35 & 8,89 & 265.2 & 147,5 & 16.6 & 4.8 & 5,026 \\
\hline 10.1 & 3.8 & 3,8 & 7.05 & 2.38 & 241.2 & 136.1 & 16.7 & 4.6 & 5.151 \\
\hline 10.2 & 3,7 & 3,8 & 4,52 & 2.58 & 247.0 & 148.8 & 17.4 & 4,5 & 5.936 \\
\hline 10.3 & 3,0 & 3,6 & 2.28 & 0.00 & 252.6 & 146.9 & 17.3 & 4.5 & 5.264 \\
\hline 10.4 & 4,4 & 3,3 & 2,70 & 0.68 & 266,0 & 163.7 & 17.1 & 4,4 & 5.457 \\
\hline 11.1 & 3.1 & 3,6 & 6.17 & 0.00 & 252,4 & 153,7 & 16.8 & 4.7 & 4.725 \\
\hline 11.2 & 4,0 & 3,8 & 1.99 & 0,00 & 253,1 & 137,6 & 17,3 & 4,6 & 5.916 \\
\hline 11.3 & 2.8 & 3,4 & 3.67 & 0.00 & 254,8 & 150,8 & 16.4 & 4.8 & 5,411 \\
\hline 11.4 & 3.6 & 3.4 & 5,72 & 0,71 & 256.1 & 152,9 & 16,9 & 4,5 & 5,498 \\
\hline 12.1 & 4,0 & 3,1 & 10.48 & 4.35 & 257,8 & 149.5 & 16,5 & 4,7 & 5,057 \\
\hline 12.2 & 3.9 & 3.4 & 6.98 & 6,43 & 270.2 & 159,3 & 17.3 & 4.8 & 5.987 \\
\hline 12.3 & 2.8 & 3,4 & 5.66 & 0,00 & 260.9 & 161.0 & 16.3 & 4,8 & 5.361 \\
\hline 12.4 & 3.9 & 3.5 & 1.92 & 1,91 & 268.4 & 161.9 & 16.8 & 4,7 & 5.837 \\
\hline 13.1 & 2.9 & 3.6 & 5.49 & 4.03 & 263.6 & 145.4 & 16.0 & 4.7 & 5.619 \\
\hline 13.2 & 2.9 & 3.8 & 2.53 & 2.50 & 263.3 & 159.0 & 16.9 & 4.6 & 6.190 \\
\hline 13.3 & 2.9 & 3.4 & 6,34 & 1.52 & 269.9 & 168,3 & 16.1 & 4.6 & 4,698 \\
\hline 13.4 & 3.1 & 3.5 & 9,96 & 5,71 & 261.2 & 159.6 & 17.0 & 4,6 & 5.867 \\
\hline 14.1 & 2.9 & 3,0 & 0.71 & 2.14 & 258.4 & 167.9 & 16.9 & 4.7 & 5.219 \\
\hline 14.2 & 3.5 & 3.8 & 3.34 & 3.26 & 271.1 & 162.2 & 16.4 & 4.7 & 6.570 \\
\hline 14.3 & 2.5 & 3.8 & 6.88 & 0,00 & 269.2 & 162.3 & 15.9 & 4.6 & 5.110 \\
\hline 14.4 & 3.8 & 3.4 & 6.98 & 1.97 & 264.7 & 164.7 & 17.0 & 4.6 & 5.501 \\
\hline 15.1 & 3.5 & 3.5 & 6.15 & 0.71 & 262.5 & 152.6 & 16.0 & 4.8 & 4.992 \\
\hline 15.2 & 4.1 & 3.5 & 4.90 & 2.10 & 263.9 & 163.9 & 16.8 & 4.9 & 6.208 \\
\hline 15.3 & 3.1 & 3.5 & 2.21 & 0.00 & 260.0 & 158.8 & 16.8 & 4.7 & 5.416 \\
\hline 15.4 & 4.0 & 4.1 & 4.21 & 4.81 & 271.6 & 153.9 & 17.1 & 4.7 & 5.999 \\
\hline 16.1 & 2.9 & 3.3 & 5.17 & 1.88 & 256.8 & 151.1 & 16.6 & 4.3 & 4.976 \\
\hline
\end{tabular}




\begin{tabular}{|c|c|c|c|c|c|c|c|c|c|}
\hline Cruzamentos & PHAE & PHYS & QUEB & ACAM & $\mathbf{A P}$ & $\mathbf{A E}$ & $\mathbf{C E}$ & DE & PG \\
\hline 16.2 & 3,4 & 4.3 & 8,15 & 2,68 & 263,6 & 158.2 & 16,9 & 4,5 & 4,754 \\
\hline 16.3 & 2,4 & 3,0 & 7,48 & 1,35 & 255,8 & 166,7 & 16.1 & 4,8 & 5,481 \\
\hline 16.4 & 3.3 & 3,8 & 0.00 & 0.00 & 268.1 & 153,7 & 16.8 & 4.5 & 5.523 \\
\hline 17.1 & 3.4 & 3,5 & 10.26 & 2,63 & 266.0 & 158,8 & 16,4 & 4.8 & 4.881 \\
\hline 17.2 & 3.8 & 3.6 & 1,98 & 3,31 & 269.6 & 168,1 & 16,9 & 4,7 & 5,511 \\
\hline 17.3 & 2,8 & 3,5 & 2,10 & 0,71 & 271,1 & 159,2 & 16,2 & 4,8 & 4,886 \\
\hline 17.4 & 3,8 & 3,5 & 2,16 & 1,41 & 263,5 & 158,1 & 17,0 & 4,8 & 6,192 \\
\hline 18.1 & 3.3 & 3.4 & 8.48 & 0.61 & 252.8 & 145,9 & 17.2 & 4.7 & 4.660 \\
\hline 18.2 & 3.1 & 3.9 & 7.65 & 0,00 & 258.3 & 160.5 & 17.2 & 4.6 & 5.928 \\
\hline 18.3 & 3.0 & 3,8 & 4.20 & 3.08 & 260.6 & 151,4 & 16.5 & 4.6 & 4.703 \\
\hline 18.4 & 3.5 & 3.5 & 8.12 & 0,00 & 265.0 & 148,9 & 17.8 & 4.6 & 4.803 \\
\hline 19.1 & 2.8 & 3.9 & 6.80 & 0,58 & 248.4 & 146.7 & 16.6 & 6.2 & 5.417 \\
\hline 19.2 & 4,8 & 3,8 & 2,84 & 1,43 & 252,5 & 143,8 & 16.5 & 4,4 & 5,325 \\
\hline 19.3 & 2,4 & 3,4 & 4,75 & 2,33 & 248,6 & 150,9 & 16,3 & 4,6 & 5,388 \\
\hline 19.4 & 4.1 & 3,9 & 1.39 & 0,69 & 259,5 & 159,9 & 17.6 & 4.5 & 5.623 \\
\hline 20.1 & 4.2 & 3,8 & 4,38 & 0,00 & 231.0 & 124,4 & 15.4 & 4,6 & 4.233 \\
\hline 20.2 & 2.9 . & 3.8 & 3,31 & 0.00 & 255.2 & 150,8 & 17.1 & 4.8 & 5,459 \\
\hline 20.3 & 2,9 & 3,4 & 5,27 & 0,00 & 248,2 & 135,1 & 16,2 & 4.7 & 5,058 \\
\hline 20.4 & 2,9 & 4,0 & 4,15 & 3,40 & 254,1 & 155,4 & 15.6 & 4,7 & 5,309 \\
\hline 21.1 & 3.5 & 3,6 & 6,96 & 2,64 & 250,6 & 149,2 & 16.5 & 4.8 & 4.905 \\
\hline 21.2 & 2,9 & 3,9 & 7,86 & 2,24 & 263,7 & 157,6 & 17.2 & 4.8 & 5.540 \\
\hline 21.3 & 2,5 & 3.2 & 4,73 & 0.71 & 252,4 & 149,6 & 16.6 & 4,9 & 5,511 \\
\hline 21.4 & 4,4 & 3,6 & 5.96 & 0,68 & 267,1 & 160,0 & 17.1 & 4,6 & 5.229 \\
\hline 22.1 & 3.9 & 3.1 & 10,42 & 0,83 & 255,9 & 158,9 & 15,6 & 4,7 & 4.676 \\
\hline 22.2 & 3.3 & 3.4 & 11.20 & 6.90 & 269.1 & 162.2 & 16.7 & 4.6 & 5.772 \\
\hline 22.3 & 2.4 & 3.0 & 4.05 & 0.68 & 254.7 & 157.2 & 16.5 & 4.7 & 5.354 \\
\hline 22.4 & 3.9 & 3.6 & 8.91 & 2.54 & 256.9 & 151.8 & 16.4 & 4.6 & 5.060 \\
\hline 23.1 & 3.1 & 3.6 & 8.54 & 3.66 & 275.5 & 177.3 & 16.6 & 4.9 & 5.258 \\
\hline 23.2 & 2,7 & 3,6 & 6.82 & 4,59 & 259.3 & 150.4 & 17.2 & 4.8 & 6,993 \\
\hline 23.3 & 2.6 & 3.3 & 2,60 & 1,35 & 260.9 & 142.5 & 16.6 & 5.1 & 5,316 \\
\hline 23.4 & 3,3 & 3,4 & 4,45 & 1.35 & 272.9 & 170,5 & 16,7 & 5,0 & 5,407 \\
\hline 24.1 & 3.8 & 3.5 & 3,55 & 0,00 & 243.0 & 161.0 & 14.9 & 4,7 & 4,461 \\
\hline 24.2 & 3.0 & 3.8 & 2.63 & 3,31 & 276.5 & 173.1 & 16.3 & 4.8 & 5.259 \\
\hline 24.3 & 2.6 & 3,3 & 4.68 & 4,69 & 270.4 & 176,3 & 16.1 & 4.7 & 4,677 \\
\hline 24.4 & 2.3 & 3,5 & 5,78 & 2,50 & 283,4 & 182,3 & 16.3 & 4.6 & 4.198 \\
\hline 25.1 & 2.9 & 3.3 & 3.78 & 9.04 & 254.1 & 144.6 & 16.3 & 4.5 & 4.833 \\
\hline 25.2 & 3.1 & 3.9 & 4.77 & 2,02 & 269.2 & 161.2 & 16.5 & 4.6 & 4.823 \\
\hline 25.3 & 2.5 & 3.4 & 2.64 & 0.00 & 253.1 & 153,6 & 16.1 & 4.6 & 5.321 \\
\hline 25.4 & 3.1 & 3.4 & 0.00 & 2.94 & 272.3 & 164.4 & 15.9 & 4.5 & 5.643 \\
\hline 26.1 & 2.6 & 3.0 & 10.99 & 2.42 & 272.3 & 170.3 & 15.7 & 4.7 & 4.616 \\
\hline 26.2 & 3.3 & 3.8 & 7.63 & 1.72 & 261.3 & 146.8 & 16.2 & 4.8 & 5.364 \\
\hline 26.3 & 2.4 & 3.9 & 7.11 & 2.77 & 265.1 & 156.8 & 16.4 & 4.8 & 5.213 \\
\hline 26.4 & 4.1 & 4.0 & 3.82 & 0.00 & 263.6 & 156.3 & 16.4 & 4.8 & 5.594 \\
\hline 27.1 & 3.1 & 3.5 & 9.48 & 2.86 & 256.1 & 141.8 & 16.7 & 4.7 & 5.052 \\
\hline 27.2 & 3.0 & 3.7 & 7.36 & 5.26 & 279.1 & 179.2 & 17.2 & 4.5 & 4.359 \\
\hline 27.3 & 2.8 & 3.8 & 9.60 & $1 .+3$ & 266.4 & 167.6 & 16.9 & 4.8 & 5.196 \\
\hline 27.4 & 2.8 & 3.3 & 2.03 & 0.00 & 256.1 & 150.2 & 17.5 & +.5 & $5.34 t$ \\
\hline 29.1 & +.0 & 3.5 & 7.79 & 2.17 & 264.1 & 161.9 & 16.1 & 4.8 & 4.981 \\
\hline
\end{tabular}




\begin{tabular}{cccccccccc}
\hline Cruzamentos & PHAE & PHYS & QUEB & ACAM & AP & AE & CE & DE & PG \\
\hline $\mathbf{2 9 . 2}$ & 3,8 & 3.5 & 2.03 & 0,74 & 267,4 & 160,7 & 16.6 & 4.7 & 5.709 \\
$\mathbf{2 9 . 3}$ & 2.8 & 3.4 & 2,21 & 0.00 & 266.8 & 156,7 & 16,0 & 5.1 & 4.337 \\
$\mathbf{2 9 . 4}$ & 3,6 & 3,6 & 5.16 & 1,43 & 260,3 & 154.5 & 16.4 & 4,7 & 5.106 \\
$\mathbf{3 0 . 1}$ & 2,9 & 3,5 & 3,26 & 3,95 & 265,0 & 153,3 & 15,6 & 4,8 & 5,255 \\
$\mathbf{3 0 . 2}$ & 3,4 & 3,5 & 4,04 & 0,00 & 280,4 & 172,5 & 16,2 & 4,5 & 5,232 \\
$\mathbf{3 0 . 3}$ & 3,0 & 3,3 & 6,97 & 4,63 & 261,4 & 175,4 & 16,5 & 4,8 & 5,097 \\
$\mathbf{3 0 . 4}$ & 3.7 & 3.3 & 3.33 & 0.66 & 266.7 & 163.3 & 16.5 & 4.6 & 5.355 \\
\hline Testemunhas & PHAE & PHYS & QUEB & ACAM & AP & AE & CE & DE & PG \\
\hline T1 & 2,1 & 3,0 & 1,75 & 0.50 & 247,2 & 138,0 & 16,0 & 5,1 & 6,491 \\
T2 & 2,5 & 3,9 & 6,09 & 7,10 & 272,2 & 153,4 & 16,2 & 4,9 & 5,539 \\
\hline
\end{tabular}

Tabela 38. Resumo das análises de variância do experimento $1 \mathrm{C}$ para mancha de Phaeosphaeria. ferrugem tropical, porcentagem de plantas com colmos quebrados (QUEB) e porcentagem de plantas acamadas (ACAM).

\begin{tabular}{|c|c|c|c|c|c|}
\hline \multirow[b]{2}{*}{ FV } & \multicolumn{2}{|r|}{ QM } & \multirow[b]{2}{*}{ PHYSO } & \multirow[b]{2}{*}{ QUEB $\times 10^{3}$} & \multirow[b]{2}{*}{ ACAM $\times 10^{3}$} \\
\hline & GL & PHAE & & & \\
\hline Repetição & 3 & 25,754 & 7.505 & 102,889 & 7,287 \\
\hline Tratamentos & 145 & $1.791^{* *}$ & $0.360^{* *}$ & $5,603 * *$ & $4.103 * *$ \\
\hline Dialelo & 143 & $1,319^{* *}$ & 0.269 & $5.270^{* *}$ & $3.562^{* *}$ \\
\hline Acessos & 27 & $2,251^{* *}$ & 0.276 & $155,623^{* *}$ & $83.411^{* *}$ \\
\hline Hibridos & 3 & $13,458^{* *}$ & $2.649^{* *}$ & $8.508^{* *}$ & $5.383^{* *}$ \\
\hline Entre grupos & 1 & 0.040 & 0.052 & $15,913^{* *}$ & 0.721 \\
\hline Heterose & 112 & $0,780 * *$ & 0,206 & 2,862 & 2.487 \\
\hline H. média & 1 & $10.095^{* *}$ & 0.030 & 5,866 & $11.286^{*}$ \\
\hline H. Acessos & 27 & 0,433 & 0,180 & 3,516 & $4,794^{* *}$ \\
\hline H. Híbridos & 3 & $1,830 * *$ & 0.102 & 2,762 & 3,829 \\
\hline H. especifica & 81 & $0.742 * *$ & 0.220 & 2.610 & 1.559 \\
\hline Testemunhas & 1 & $3.063^{* *}$ & $13.598^{* *}$ & $31,484^{* *}$ & $76,739^{* *}$ \\
\hline Dialelo rs Testemunha & 1 & $68.088^{* *}$ & 0.122 & $27.355^{* *}$ & 8.751 \\
\hline Resíduo & 491 & 0.443 & $0.2+0$ & 2.971 & 2.538 \\
\hline Dentro test./rep. & 56 & 0.085 & 0.106 & 2.474 & 5.802 \\
\hline Erro & 435 & 0.489 & 0.257 & 3.035 & 2.118 \\
\hline $\mathrm{CV} \%$ & & 20.23 & 13.90 & 6,45 & 6.19 \\
\hline Média geral & & 3.29 & 3.53 & 6,04 & 2.71 \\
\hline
\end{tabular}

** e * indicam. respectivamente. significância ao nivel de $1 \%$ e de $5 \%$ de probabilidade. 
Tabela 39. Resumo das análises de variância do experimento $1 \mathrm{C}$ para altura de planta (AP), altura da espiga (AE), comprimento de espiga (CE), diâmetro de espiga (DE), e peso de grãos por parcela $(P G)$.

\begin{tabular}{|c|c|c|c|c|c|c|}
\hline \multirow[b]{2}{*}{ FV } & \multirow[b]{2}{*}{ GL } & \multicolumn{3}{|c|}{$\mathbf{Q M}$} & \multirow[b]{2}{*}{ DE } & \multirow[b]{2}{*}{ PG } \\
\hline & & $\overline{\mathbf{A P}}$ & $\mathbf{A E}$ & CE & & \\
\hline Repetição & 3 & 11667,71 & 6329,59 & 0,894 & 0,062 & 0,905 \\
\hline Tratamentos & 145 & $574,98 * *$ & $760,50 * *$ & $1,866 * *$ & $0,255 * *$ & $2.524 * *$ \\
\hline Dialelo & 143 & $513.02 * *$ & $696.31^{* *}$ & $1.853 * *$ & $0.200 * *$ & $2.018 * *$ \\
\hline Acessos & 27 & $1047.67 * *$ & $1415.23 * *$ & $2.251 * *$ & $0.271 * *$ & $1.720 * *$ \\
\hline Hibridos & 3 & $1793,49 * *$ & $559.77 *$ & $15,867 * *$ & $0.370 * *$ & $10.618^{* *}$ \\
\hline Entre grupos & 1 & $8827,98 * *$ & $24568.45^{* *}$ & $12,019 * *$ & $3.994^{* *}$ & $53.511 * *$ \\
\hline Heterose & 112 & $275.59 * *$ & $313.51 * *$ & $1.291 * *$ & $0.144 * *$ & $1.400 * *$ \\
\hline H. média & 1 & $11516,45^{* *}$ & $4878,94 * *$ & $76,910 * *$ & $2.893 * *$ & $93.102 * *$ \\
\hline H. Acessos & 27 & 120,62 & 192,33 & 0,571 & 0,076 & 0,432 \\
\hline H. Hibridos & 3 & 199,75 & 13,10 & $2.310^{*}$ & 0.183 & 0.260 \\
\hline H. especifica & 81 & 191.27 & $308.67^{*}$ & 0,559 & $0.132 * *$ & $0.632 *$ \\
\hline Testemunhas & 1 & $10000,00^{* *}$ & $3789,94 * *$ & 0.766 & $0,473^{* *}$ & $14.496^{* *}$ \\
\hline Dialelo is Testemunha & 1 & 11,21 & $6910,51 * *$ & $4,869 * *$ & $7,966 * *$ & $62.923 * *$ \\
\hline Residuo & 491 & 174.25 & 212.36 & 0.793 & 0.085 & 0.484 \\
\hline Dentro test./rep. & 56 & 141,13 & 113,37 & 0,704 & 0,016 & 0,589 \\
\hline Erro & 435 & 178,52 & 225,10 & 0,805 & 0.094 & 0.471 \\
\hline $\mathrm{CV} \%$ & & 5.08 & 9,37 & 5,43 & 6.23 & 13.72 \\
\hline Média geral & & 260,08 & 155.60 & 16,40 & 4.68 & 5.07 \\
\hline
\end{tabular}

** e * indicanı respectivamente. significância ao nivel de $1 \%$ e de $5 \%$ de probabilidade. 
Tabela 40. Efeitos de variedade $v_{i}$ no experimento $1 \mathrm{C}$ para mancha de Phaeosphaeria, ferrugem tropical. porcentagem de plantas com colmos quebrados (QUEB), porcentagem de plantas acamadas (ACAM), altura de planta (AP), altura da espiga (AE), comprimento de espiga (CE), diâmetro de espiga $(\mathrm{DE})$, e peso de grãos por parcela $(\mathrm{PG})$.

\begin{tabular}{|c|c|c|c|c|c|c|c|c|c|}
\hline Acessos & PHAE & PHYS & QUEB & ACAM & $\mathbf{A P}$ & $\mathbf{A E}$ & $\mathrm{CE}$ & DE & PG \\
\hline 1 & $-0,078$ & $-0,270$ & $-0,023$ & $-0,032$ & $-15,848$ & $-12,813$ & 0,161 & $-0,036$ & 0,036 \\
\hline 2 & $-0,018$ & $-0,020$ & 0,023 & 0,006 & $-9,598$ & $-10,313$ & 0,261 & 0,064 & 0,182 \\
\hline 3 & -1.018 & -0.020 & 0.011 & $-0,038$ & 2,902 & 12.188 & -0.639 & -0.036 & -0.026 \\
\hline 4 & -0.018 & -0.020 & -0.009 & 0.003 & 6.652 & 5.938 & 0.761 & -0.036 & -0.227 \\
\hline 5 & 0,922 & 0,230 & -0.007 & -0.019 & -17.098 & -14.063 & 0.461 & 0.064 & 0.485 \\
\hline 6 & 0.362 & -0.140 & 0.046 & -0.017 & -4.598 & -7.813 & 0.161 & 0.364 & 0.834 \\
\hline 8 & 0,792 & 0.230 & 0.138 & 0.146 & $-17,098$ & -19.063 & -0.239 & 0.064 & -0.934 \\
\hline 9 & 0,862 & $-0,390$ & 0,051 & 0,057 & -13.348 & $-14,063$ & $-0,839$ & $0,16 t$ & -0.177 \\
\hline 10 & & 0,110 & $-0,011$ & & $-17,098$ & $-16,563$ & 0,161 & $-0,336$ & 0.213 \\
\hline 11 & 0,542 & $-0,140$ & 0,028 & $-0,009$ & $-15,848$ & $-24,063$ & 0,861 & $-0,136$ & 0,604 \\
\hline 12 & 0.362 & -0.270 & 0,022 & 0,005 & 2,902 & $-5,313$ & $-0,439$ & 0,264 & $-0,056$ \\
\hline 13 & $-0,638$ & 0,610 & $-0,030$ & $-0,018$ & 16,652 & 25.938 & 0,261 & $-0,236$ & -0.159 \\
\hline 14 & -0.518 & 0.480 & -0.061 & $-0,026$ & 2.902 & 10.938 & 0.061 & -0.036 & -0.268 \\
\hline 15 & & -0.020 & -0.063 & $-0,0$ & 14.152 & 0.938 & 0.061 & 0.164 & 0.558 \\
\hline 16 & & $-0,020$ & -0.018 & $-0,044$ & 5.402 & 2.188 & -0.639 & -0.136 & 0,260 \\
\hline 17 & $-0,018$ & $-0,140$ & $-0,035$ & 0,011 & 10,402 & 12,188 & 0,561 & 0,064 & 0,355 \\
\hline 18 & 0 & 0.230 & 0,003 & 0,115 & $-10,848$ & $-6,563$ & 0,561 & $-0,036$ & $-0,596$ \\
\hline 19 & & $-0,270$ & $-0,010$ & $-0,038$ & $-9,598$ & -5.313 & 0,561 & $-0,236$ & 0,410 \\
\hline 20 & -0.138 & $-0,020$ & 0,034 & $-0,002$ & $-10,848$ & $-11,563$ & $-0,039$ & $-0,036$ & -0.063 \\
\hline 21 & -0.138 & $-0,020$ & 0.034 & 0,083 & 6,652 & 2.188 & 0.461 & -0.236 & -0.084 \\
\hline 22 & 0.232 & -0.020 & 0.005 & -0.016 & 4.152 & -4.063 & 0,261 & -0.136 & 0.434 \\
\hline 23 & -0.638 & -0.390 & -0.053 & 0,007 & 12,902 & 9.688 & 0.161 & 0.464 & 0.305 \\
\hline 24 & $-0,638$ & 0.360 & 0.029 & $-0,038$ & 19,152 & 30.938 & -1.239 & -0.236 & -1.247 \\
\hline 25 & $-0,138$ & $-0,140$ & 0.021 & $-0,021$ & -8.348 & 5.938 & 0.061 & $-0,236$ & 0,133 \\
\hline 26 & $-0,388$ & 0,230 & -0.002 & -0.030 & 9,152 & -1.563 & $-0,339$ & 0.064 & 0.235 \\
\hline 27 & -0.638 & $-0,020$ & -0.022 & -0.009 & 14.152 & 13,438 & -0.139 & 0.064 & -0.700 \\
\hline 29 & $-0,768$ & 0.110 & -0.026 & $-0,032$ & 10.402 & 10,938 & $-0,539$ & 0,164 & -0.213 \\
\hline 30 & -0.018 & -0.270 & -0.077 & -0.023 & 11.652 & 9.688 & $-0,739$ & 0.164 & -0.296 \\
\hline Híbridos & PHAE & PHYS & QUEB & ACAM & AP & $\mathrm{AE}$ & $\mathrm{CE}$ & $\mathrm{DE}$ & PG \\
\hline H1 & & -0.095 & 0.038 & -0.003 & -20.625 & -13.750 & -1.425 & 0.000 & -0.517 \\
\hline $\mathbf{H} 2$ & -0.453 & 0.285 & -0.029 & -0.019 & 1.875 & -1.250 & 0.875 & 0.100 & 0.728 \\
\hline H3 & -0.203 & -0.095 & 0.026 & 0.040 & -0.625 & 5.000 & -0.925 & -0.100 & -0.684 \\
\hline $\mathrm{HA}$ & 1.048 & -0.095 & -0.035 & -0.019 & 19.375 & 10.000 & $1 .+75$ & 0.000 & 0.472 \\
\hline
\end{tabular}


Tabela 41 Efeitos de heterose de variedade $h_{i}$ no experimento $1 C$ para mancha de Phaeosphaeria. ferrugem tropical. porcentagem de plantas com colmos quebrados (QUEB), porcentagem de plantas acamadas (ACAM), altura de planta (AP), altura da espiga (AE), comprimento de espiga (CE), diâmetro de espiga (DE), e peso de grãos por parcela (PG).

\begin{tabular}{|c|c|c|c|c|c|c|c|c|c|}
\hline Acessos & PHAE & PHYS & QUEB & ACAM & $\mathbf{A P}$ & $\mathbf{A E}$ & $\mathrm{CE}$ & DE & PG \\
\hline 1 & 0,113 & 0,104 & $-0,012$ & 0,020 & 4,810 & 5,809 & $-0,102$ & $-0,046$ & $-0,088$ \\
\hline 2 & 0.193 & 0.229 & 0,011 & $-0,009$ & 2,310 & $-1,691$ & $-0,152$ & 0,054 & $-0,061$ \\
\hline 3 & 0.288 & 0.009 & -0.009 & 0,030 & 2.935 & -2.003 & -0.052 & -0.046 & 0.201 \\
\hline 4 & 0.255 & 0.074 & -0.010 & $-0,017$ & -2.065 & 0.184 & $-0,277$ & 0.054 & $-0,125$ \\
\hline 5 & $-0,042$ & -0.099 & 0.002 & 0,005 & -4.877 & -7.941 & -0.202 & -0.021 & -0.549 \\
\hline 6 & -0.012 & -0.116 & -0.023 & 0.012 & -0.815 & -5.441 & -0.252 & $-0.1+6$ & -0.193 \\
\hline 8 & 0.053 & -0.179 & -0.025 & -0.062 & 5.748 & 7.684 & 0,023 & 0.104 & -0.049 \\
\hline 9 & 0.190 & 0.101 & -0.031 & -0.005 & 4.498 & 6.434 & -0.002 & -0.021 & -0.283 \\
\hline 10 & 0,285 & 0,021 & $-0,007$ & $-0,007$ & -0.502 & 0,184 & 0,523 & $-0,046$ & 0,108 \\
\hline 11 & -0.242 & 0,071 & -0.024 & $-0,015$ & $-0,502$ & 3.934 & $-0,102$ & 0,004 & $-0,137$ \\
\hline 12 & 0,098 & $-0,051$ & $-0,001$ & 0,008 & 1,373 & 4.872 & 0,423 & $-0,096$ & 0.351 \\
\hline 13 & -0.072 & $-0,274$ & 0,022 & 0,022 & $-3,627$ & -9.816 & $-0,152$ & 0.029 & 0.436 \\
\hline 14 & 0,068 & $-0,304$ & 0,022 & 0.010 & 4.498 & 4.247 & -0.002 & -0.046 & 0,497 \\
\hline 15 & 0.333 & 0,134 & 0,021 & 0,009 & $-3,940$ & $-0,441$ & 0,123 & $-0,021$ & 0,138 \\
\hline 16 & $-0,307$ & 0,039 & 0.007 & 0,016 & -1.440 & 2.997 & 0,398 & -0.121 & -0.184 \\
\hline 17 & 0,068 & 0,069 & 0.005 & $-0,006$ & 2,310 & 0,184 & $-0,177$ & 0,029 & $-0,047$ \\
\hline 18 & $-0,450$ & $-0,021$ & 0,016 & $-0,069$ & 5,748 & $-0,753$ & 0,373 & $-0,071$ & 0,084 \\
\hline 19 & -0.337 & 0.324 & -0.010 & 0,011 & $-4,877$ & $-4,191$ & $-0,052$ & 0.329 & $-0,004$ \\
\hline 20 & $-0,072$ & 0,196 & $-0,028$ & $-0,012$ & $-7,065$ & $-7,941$ & $-0,427$ & 0,004 & $-0,191$ \\
\hline 21 & 0,035 & 0,059 & -0.007 & $-0,047$ & -3.940 & -2.628 & 0,098 & 0,179 & 0.101 \\
\hline 22 & -0.117 & -0.239 & 0.032 & 0.014 & -3.315 & 3.934 & $-0,352$ & 0.004 & -0.239 \\
\hline 23 & -0.105 & 0.134 & 0.029 & 0.003 & 1.373 & -0.128 & 0.173 & 0.004 & 0.354 \\
\hline 24 & -0.122 & -0.214 & -0.027 & 0.024 & -2.690 & -1.691 & -0.002 & 0.104 & 0.035 \\
\hline 25 & -0.370 & 0.009 & -0.036 & 0,025 & 6.998 & 0.184 & -0.352 & -0.046 & -0.149 \\
\hline 26 & -0.075 & 0.009 & 0.022 & 0,011 & -1.440 & 1.434 & -0.177 & 0,029 & -0.158 \\
\hline 27 & $-0,122$ & 0,024 & 0.029 & 0,007 & $-3,002$ & -1.691 & 0,623 & $-0,121$ & 0,101 \\
\hline 29 & 0,565 & $-0,086$ & 0,002 & 0,006 & $-1,440$ & -3.253 & 0,023 & 0,029 & $-0,097$ \\
\hline 30 & -0.102 & -0.024 & 0.029 & 0,014 & 2,935 & 7.529 & 0,048 & -0.121 & 0.146 \\
\hline Hibridos & PHAE & PHYS & QUEB & ACAM & AP & $\mathbf{A E}$ & CE & DE & PG \\
\hline H1 & 0.232 & $-0,060$ & -0.004 & & 6.306 & 4.537 & 0,366 & 0.072 & -0.062 \\
\hline $\mathrm{H} 2$ & 0.375 & 0.056 & 0.015 & 0.013 & 1.395 & 0.809 & -0.188 & -0.113 & -0.059 \\
\hline H3 & -0.388 & -0.084 & -0.018 & $-0,024$ & 0.100 & -1.133 & 0.298 & 0.094 & 0.204 \\
\hline $\mathrm{H4}$ & -0.219 & 0.088 & 0,007 & 0,007 & -7.801 & +.213 & -0.477 & -0.053 & -0.083 \\
\hline
\end{tabular}


Tabela 42. Efeitos de capacidade geral de combinação $\mathrm{g}_{\mathrm{i}}$ no experimento $1 \mathrm{C}$ para mancha de Phaeosphaeria. ferrugem tropical, porcentagem de plantas com colmos quebrados (QUEB), porcentagem de plantas acamadas (ACAM), altura de planta (AP), altura da espiga (AE), comprimento de espiga (CE), diâmetro de espiga (DE), e peso de grãos por parcela (PG).

\begin{tabular}{|c|c|c|c|c|c|c|c|c|c|}
\hline Híbridos & PHAE & PHYS & QUEB & ACAM & AP & $\mathbf{A E}$ & $\mathrm{CE}$ & DE & $P G$ \\
\hline 1 & 0,074 & $-0,031$ & $-0,023$ & 0,005 & $-3,114$ & $-0,597$ & $-0,021$ & $-0,063$ & $-0,070$ \\
\hline 2 & 0,184 & 0,219 & 0,023 & $-0,006$ & $-2,489$ & $-6,847$ & $-0,021$ & 0,087 & 0,030 \\
\hline 3 & -0.221 & -0.001 & -0.003 & 0.011 & 4.386 & 4.090 & -0.371 & -0.063 & 0.188 \\
\hline 4 & 0.246 & 0.064 & -0.014 & -0.016 & 1.261 & 3.153 & 0.104 & 0.037 & -0.239 \\
\hline 5 & 419 & 0.017 & -0.001 & $-0,004$ & -13.426 & -14.972 & 0,029 & 0,012 & $-0,307$ \\
\hline 6 & 0,169 & $-0,186$ & 0,001 & 0,003 & $-3,114$ & $-9,347$ & $-0,171$ & 0,037 & 0.224 \\
\hline 8 & 0,449 & $-0,063$ & 0,044 & 0.011 & $-2,801$ & $-1,847$ & $-0,096$ & 0,137 & $-0,516$ \\
\hline 9 & 0,621 & $-0,093$ & $-0,006$ & 0.024 & $-2,176$ & $-0,597$ & $-0,421$ & 0,062 & $-0,371$ \\
\hline 10 & 0.371 & 0,077 & -0.012 & -0.007 & $-9,051$ & $-8,097$ & 0,604 & $-0,213$ & 0,215 \\
\hline 11 & 0 & 0.002 & -0.010 & -0.019 & $-8,426$ & -8.097 & 0,329 & $-0,063$ & 0.165 \\
\hline 12 & 0,279 & $-0,186$ & 0,009 & 0,011 & 2,824 & 2.215 & 0,204 & 0,037 & 0,323 \\
\hline 13 & $-0,391$ & 0,032 & 0.007 & 0,013 & 4,699 & 3,153 & $-0,021$ & $-0,088$ & 0,356 \\
\hline 14 & $-0,191$ & -0.063 & -0.009 & $-0,003$ & 5.949 & 9.715 & 0.029 & -0.063 & 0,363 \\
\hline 15 & & 0,124 & $-0,010$ & -0.0 & 3,136 & 0,028 & 0,154 & 0.062 & 0,417 \\
\hline 16 & -0.346 & 0,029 & $-0,002$ & $-0,006$ & 1.261 & 4.090 & 0,079 & -0.188 & $-0,054$ \\
\hline 17 & 0,059 & $-0,001$ & $-0,012$ & $-0,001$ & 7.511 & 6,278 & 0,104 & 0,062 & 0,130 \\
\hline 18 & $-0,114$ & 0,094 & 0.018 & $-0,012$ & 0.324 & -4.035 & 0.654 & -0.088 & $-0,214$ \\
\hline 19 & & 189 & $-0,015$ & $-0,008$ & -9.676 & -6.847 & 0.229 & 0,212 & 0,201 \\
\hline 20 & -0.141 & 0.187 & $-0,011$ & $-0,013$ & $-12,489$ & -13.722 & $-0,446$ & $-0,013$ & $-0,222$ \\
\hline 21 & -0.034 & 0.049 & 0,010 & -0.005 & -0.614 & -1.535 & 0,329 & 0,062 & 0.059 \\
\hline 22 & -0.001 & -0.248 & 0.034 & 0.006 & $-1,239$ & 1.903 & -0.221 & -0.063 & -0.022 \\
\hline 23 & $-0,424$ & -0.061 & 0.002 & 0.006 & 7,824 & 4.715 & 0.254 & 0.237 & 0.506 \\
\hline 24 & -0.441 & $-0,033$ & -0.012 & 0.005 & 6.886 & 13.778 & $-0,621$ & -0.013 & -0.588 \\
\hline 25 & $-0,439$ & $-0,061$ & -0.026 & 0.014 & 2.824 & 3.153 & $-0,321$ & -0.163 & -0.082 \\
\hline 26 & -0.269 & 0.124 & 0.021 & -0.004 & 3.136 & 0.653 & -0.346 & 0,062 & $-0,040$ \\
\hline 27 & -0.441 & 0.014 & 0.018 & 0,003 & 4.074 & 5.028 & 0,554 & -0.088 & $-0,249$ \\
\hline 29 & 0,181 & -0.031 & -0.011 & $-0,010$ & 3.761 & 2.215 & $-0,246$ & 0,112 & $-0,204$ \\
\hline 30 & $-0,111$ & $-0,158$ & $-0,010$ & 0.002 & 8.761 & 12.373 & $-0,321$ & $-0,038$ & $-0,002$ \\
\hline Híbridos & PHAE & PHYS & QUEB & ACAM & $\mathbf{A P}$ & $\mathrm{AE}$ & CE & DE & PG \\
\hline H1 & & -0.107 & 0.002 & 0.001 & -4.007 & -2.338 & $-0,346$ & 0,072 & $-0,320$ \\
\hline $\mathrm{H} 2$ & 0.149 & 0.198 & 0.004 & 0.002 & 2.333 & 0.184 & 0.250 & -0.063 & 0.305 \\
\hline H3 & -0.489 & -0.131 & -() .004 & -0.002 & -0.212 & 1.367 & -0.164 & 0.044 & -0.138 \\
\hline $\mathrm{HA}$ & 0.305 & $0.0+0$ & $-(0.002$ & 0.000 & 1.886 & 0.787 & 0.261 & -0.053 & 0.153 \\
\hline
\end{tabular}


Tabela 43. Médias dos tratamentos do experimento $1 \mathrm{R}$ para mancha de Phaeosphaeria (PHAE). porcentagem de plantas com enfezamento (ENFE), porcentagem de plantas acamadas (ACAM), altura de planta (AP), altura da espiga (AE) e peso de grãos por parcela (PG)

\begin{tabular}{|c|c|c|c|c|c|c|}
\hline Acessos & PHAE & ENFE & ACAM & AP & $\mathbf{A E}$ & PG \\
\hline 1 & 2,6 & 0,0 & 8,95 & 240,6 & 140,0 & 2,285 \\
\hline 2 & 3.4 & 0,0 & 10,98 & 238,8 & 120,0 & 3,155 \\
\hline 3 & 2.7 & 2.4 & 9,56 & 260,0 & 160.6 & 2,791 \\
\hline 4 & 3.4 & 0.0 & 10,61 & 258.1 & 158,1 & 2.597 \\
\hline 5 & 4.5 & 0.0 & 8.83 & 241.3 & 133,8 & 2.893 \\
\hline 6 & 4.3 & 1.0 & 6,95 & 238.3 & 127.5 & 3.370 \\
\hline 8 & 3.8 & 0.7 & 14,40 & 231.3 & 131.9 & 2.114 \\
\hline 9 & 4.1 & 0.0 & 13,49 & 236.3 & 128.8 & 2.728 \\
\hline 10 & 3.9 & 1,4 & 6,54 & 230,6 & 128,8 & 2,410 \\
\hline 11 & 3.3 & 0,7 & 7,14 & 240.0 & 135,0 & 2,980 \\
\hline 12 & 3.0 & 0,0 & 10,67 & 266,3 & 160,0 & 3.004 \\
\hline 13 & 3.2 & 0.9 & 7,02 & 265.6 & 156.9 & 2.435 \\
\hline 14 & 3.3 & 1,0 & 8,32 & 248.1 & 151,9 & 2.849 \\
\hline 15 & 2.6 & 0.7 & 8,44 & 273.1 & 172.5 & 2.96 \\
\hline 16 & 3.5 & 0,0 & 5,95 & 273,1 & 173,1 & 2,583 \\
\hline 17 & 2,6 & 0,0 & 9,24 & 275,0 & 164,4 & 2,745 \\
\hline 18 & 3,2 & 0,0 & 14,43 & 253,8 & 149,4 & 2,271 \\
\hline 19 & 3.6 & 0,7 & 7,66 & 248,5 & 139,4 & 3,143 \\
\hline 20 & 2.9 & 0.0 & 6.22 & 255.0 & 146,3 & 3.056 \\
\hline 21 & 3.0 & 0.0 & 14.27 & 259,4 & 152,5 & 2.828 \\
\hline 22 & 3.6 & 0.0 & 13,19 & 236.9 & 140,0 & 2.921 \\
\hline 23 & 2.5 & 0.7 & 8,57 & 261,9 & 160.6 & 2.691 \\
\hline 24 & 2.3 & 0.0 & 6,56 & 286.9 & 194.4 & 1.341 \\
\hline 25 & 2.8 & 2.0 & 10.98 & 275.6 & 148.4 & 2.254 \\
\hline 26 & 3.1 & 0,0 & 9,07 & 260.6 & 153.8 & 2,975 \\
\hline 27 & 2.3 & 0.7 & 6,46 & 280.6 & 172.5 & 2.285 \\
\hline 29 & 2.3 & 1.4 & 6,75 & 286.9 & 184,4 & 2,790 \\
\hline 30 & 2.6 & 1,5 & 6,16 & 276,9 & 173,1 & 2.601 \\
\hline Híbridos & PHAE & STUNT & ACAM & AP & $\mathrm{AE}$ & PG \\
\hline H1 & 2.8 & 7,3 & 6,09 & 201.3 & 108,1 & 1,848 \\
\hline H2 & 3.8 & 0.0 & 6,68 & 201.3 & 105.6 & 2.585 \\
\hline H3 & 3.3 & 0.8 & 6.86 & 198.8 & 106,3 & 2.270 \\
\hline H4 & 3.9 & 0.0 & 6.07 & 203.8 & 106.9 & 2.243 \\
\hline Cruzamentos & PHAE & STUNT & ACAM & AP & $\mathrm{AE}$ & PG \\
\hline 1.1 & 3.6 & 0.0 & 7.72 & 236.3 & 125.6 & 3.261 \\
\hline 1.2 & 2.9 & 0.0 & 8.04 & 243.1 & 136.9 & 3.926 \\
\hline 1.3 & 2.2 & 0.7 & 6,25 & 245.0 & 140.0 & 4.405 \\
\hline 1.4 & 3.1 & 1.4 & 6.95 & 237.5 & 130.6 & 3.606 \\
\hline 2.1 & 3.1 & 0.0 & 8.22 & 246.3 & 133.1 & 3.214 \\
\hline 2.2 & 3.1 & 1.0 & 10.72 & 223.8 & 120.6 & 2.919 \\
\hline 2.3 & 2.9 & 0.0 & 7.29 & 235.6 & 135.6 & 3.80 \\
\hline 2.4 & 3.6 & 1.6 & 6.22 & 229.4 & 130.0 & 3.153 \\
\hline 3.1 & 2.7 & 0.0 & 7.22 & 233.8 & 126.9 & 3.20 \\
\hline 3.2 & 3.0 & 2.2 & 8.72 & 249.4 & 142.5 & 3.49 \\
\hline
\end{tabular}




\begin{tabular}{|c|c|c|c|c|c|c|}
\hline Cruzamentos & PHAE & STUNT & ACAM & AP & $\mathbf{A E}$ & PG \\
\hline 3.3 & 2,6 & 0.8 & 6,11 & 246,9 & 141,3 & 4,016 \\
\hline 3.4 & 3.3 & 0,0 & 6,40 & 256,3 & 149.4 & 3.561 \\
\hline 4.1 & 2.8 & 0,0 & 5.66 & 234,4 & 131,9 & 3.635 \\
\hline 4.2 & 3.5 & 0,0 & 6.49 & 237.5 & 137.5 & 3.581 \\
\hline 4.3 & 2.6 & 0,7 & 5,57 & 221.3 & 120.0 & 3,906 \\
\hline 4.4 & 2,8 & 0,7 & 7,52 & 255,6 & 150,0 & 3,395 \\
\hline 5.1 & 3.9 & 0,8 & 7,00 & 233,1 & 125,6 & 3,125 \\
\hline 5.2 & 4.2 & 0,0 & 9,21 & 232.5 & 130.0 & 3,418 \\
\hline 5.3 & 2.9 & 0.7 & 7,74 & 236,3 & 133.1 & 3,039 \\
\hline 5.4 & 3.6 & 0.0 & 7,79 & 223.8 & 122,5 & 3.178 \\
\hline 6.1 & 3,5 & 0,8 & 7.22 & 223,1 & 123.1 & 3,381 \\
\hline 6.2 & 3.5 & 0,0 & 7.71 & 235.0 & 128.8 & 3.198 \\
\hline 6.3 & 2.6 & 0,0 & 6,75 & 254,4 & 136.9 & 3,910 \\
\hline 6.4 & 3,4 & 0.0 & 5,69 & 245,6 & 142.5 & 3.756 \\
\hline 8.1 & 3.1 & 0,7 & 12,20 & 239.4 & 129.4 & 2.869 \\
\hline 8.2 & 3,6 & 0,0 & 6,32 & 241,9 & 137.5 & 3.274 \\
\hline 8.3 & 2.9 & 0,0 & 9,13 & 253,1 & 144,4 & 3,559 \\
\hline 8.4 & 3.7 & 0,7 & 12,04 & 243,8 & 135.6 & 2,449 \\
\hline 9.1 & 3.8 & 0,7 & 8,98 & 229,4 & 127.5 & 2.707 \\
\hline 9.2 & 3.2 & 0.7 & 5.60 & 241.3 & 136.9 & 3.435 \\
\hline 9.3 & 3.2 & 0,0 & 8,29 & 242.5 & 141.9 & 3,341 \\
\hline 9.4 & 3,3 & 2,8 & 7,34 & 243.1 & 136,9 & 3,425 \\
\hline 10.1 & 3,8 & 0,0 & 7,91 & 225,6 & 125.0 & 3.023 \\
\hline 10.2 & 3,5 & 0,0 & 5,67 & 228,1 & 115,0 & 3,435 \\
\hline 10.3 & 2.9 & 0,0 & 5,57 & 224.4 & 128.8 & 4.289 \\
\hline 10.4 & 3.6 & 0.0 & 6.10 & 229.4 & 131.3 & 3.764 \\
\hline 11.1 & 3.2 & 0.0 & 6.95 & 226.9 & 121.3 & 3.478 \\
\hline 11.2 & 4.0 & 0.0 & 7.46 & 231.9 & 128.8 & 3.383 \\
\hline 11.3 & 3.5 & 0,0 & 7,21 & 232,5 & 128,8 & 3.851 \\
\hline 11.4 & 3,6 & 0,0 & 5,69 & 225.6 & 121,3 & 3,556 \\
\hline 12.1 & 3.1 & 0,0 & 6,92 & 241.9 & 131,9 & 3,339 \\
\hline 12.2 & 3,1 & 0,0 & 8,05 & 238,8 & 136,3 & 3.468 \\
\hline 12.3 & 3.4 & 0.0 & 7,16 & 237.5 & 135,8 & 3.367 \\
\hline 12.4 & 3.7 & 0,0 & 7,80 & 240,6 & 140,0 & 4,033 \\
\hline 13.1 & 2.4 & 0.0 & 7.23 & 244.4 & 135,6 & 3.338 \\
\hline 13.2 & 3.4 & 1,4 & 5.69 & 260.0 & 142.5 & 3.499 \\
\hline 13.3 & 2.6 & 0.0 & 6,75 & 241.3 & 143.8 & 3.461 \\
\hline 13.4 & 4.0 & 0.0 & 3.78 & 247.5 & 142.5 & 3.763 \\
\hline 14.1 & 3.0 & 0.0 & 7.77 & 254.4 & 147.5 & 3.574 \\
\hline 14.2 & 3.3 & 0.0 & 7.40 & 244.4 & 135.6 & 3.835 \\
\hline 14.3 & 2.6 & 0.0 & 4,91 & 256.3 & 148.8 & 3.436 \\
\hline 14.4 & 3,1 & 1.4 & 5.52 & 247.5 & 142,5 & 3.206 \\
\hline 15.1 & 2.4 & 1.5 & 11,12 & 259.4 & 148.8 & 2.926 \\
\hline 15.2 & 3.5 & 0.0 & 6.71 & 240.6 & 140.0 & 2.990 \\
\hline 15.3 & 2.4 & 0.0 & 7.39 & 251.9 & 143.8 & 4.016 \\
\hline 15.4 & 3.1 & 1.7 & 7.54 & 245.6 & 138.8 & 3.386 \\
\hline 16.1 & 3.2 & 0.6 & 7.15 & 256.3 & 145.0 & 3.511 \\
\hline 16.2 & 2.6 & 0.8 & 7.12 & 265.0 & 145.0 & 3.233 \\
\hline
\end{tabular}




\begin{tabular}{|c|c|c|c|c|c|c|}
\hline Cruzamentos & PHAE & STUNT & ACAM & AP & $\mathbf{A E}$ & PG \\
\hline 16.3 & 2.8 & 0.0 & 5,50 & 245.0 & 145.0 & 3.998 \\
\hline 16.4 & 3,3 & 0.0 & 7,80 & 242.5 & 136.3 & 3.020 \\
\hline 17.1 & 2.6 & 0,0 & 8,81 & 238,8 & 145.0 & 3,435 \\
\hline 17.2 & 2,7 & 0,0 & 6,45 & 238,1 & 137,5 & 3,296 \\
\hline 17.3 & 2,6 & 0.0 & 6,45 & 255,6 & 146,3 & 3,525 \\
\hline 17.4 & 3,2 & 1,4 & 7,12 & 253,8 & 151,3 & 4,093 \\
\hline 18.1 & 3,1 & 0.9 & 7,67 & 245,6 & 142,5 & 3,356 \\
\hline 18.2 & 3.1 & 0.9 & 6.27 & 238.8 & 138,8 & 3.546 \\
\hline 18.3 & 2.3 & 0.0 & 8,67 & 244.4 & 141.9 & 4,025 \\
\hline 18.4 & 3.3 & 0.7 & 6,62 & 245.0 & 144.4 & 3,760 \\
\hline 19.1 & 2.8 & 2.2 & 8.38 & 230.6 & 126,3 & 3,385 \\
\hline 19.2 & 3.9 & 0.0 & 6,72 & 226.9 & 121.9 & 3.564 \\
\hline 19.3 & 2.9 & 0.7 & 8.61 & 228.1 & 131.3 & 3.613 \\
\hline 19.4 & 3.3 & 0,7 & 6,31 & 245.6 & 136,9 & 3.541 \\
\hline 20.1 & 3,3 & 0.0 & 6,00 & 226,9 & 124.4 & 3.086 \\
\hline 20.2 & 3,1 & 0.0 & 8,96 & 243,8 & 138,1 & 3,656 \\
\hline 20.3 & 2,4 & 0.6 & 7,14 & 238.8 & 140.0 & 3.959 \\
\hline 20.4 & 3,0 & 0.0 & 6,64 & 243.1 & 130.6 & 3,756 \\
\hline 21.1 & 2,8 & 0,0 & 8,48 & 229,4 & 141,3 & 2,961 \\
\hline 21.2 & 3.1 & 0.6 & 7,22 & 248.8 & 136.3 & 3.445 \\
\hline 21.3 & 2,8 & 0,7 & 6,99 & 256,3 & 146,3 & 3.423 \\
\hline 21.4 & 3,0 & 0.0 & 7.35 & 260,6 & 145,0 & 3.279 \\
\hline 22.1 & 3,3 & 0.0 & 7.25 & 247.5 & 138,1 & 3.256 \\
\hline 22.2 & 3,6 & 0.0 & 8,65 & 238,8 & 126,9 & 3.343 \\
\hline 22.3 & 2,9 & 0.8 & 8,15 & 245.6 & 138,1 & 3,136 \\
\hline 22.4 & 3.4 & 0,0 & 8,23 & 240.0 & 136,9 & 3,121 \\
\hline 23.1 & 2.5 & 1.4 & 7.50 & 259.4 & 151,9 & 3.813 \\
\hline 23.2 & 3.3 & 0.6 & 9.12 & 237.5 & 131.3 & 4.289 \\
\hline 23.3 & 2.4 & 0.0 & 7.73 & 255.0 & 148.8 & 4.554 \\
\hline 23.4 & 2.6 & 0.0 & 7.34 & 263.8 & 139.4 & 3,799 \\
\hline 24.1 & 2,0 & 2.0 & 5,37 & 245.6 & 146,9 & 3,640 \\
\hline 24.2 & 2.3 & 0,0 & 7,18 & 250.6 & 148,8 & 3,419 \\
\hline 24.3 & 2.6 & 0.0 & 5,60 & 258,8 & 151,9 & 4,028 \\
\hline 24.4 & 2,2 & 1.6 & 6,26 & 260,6 & 158,1 & 3,735 \\
\hline 25.1 & 2.1 & 0.0 & 8.36 & 249,4 & 140.6 & 3.425 \\
\hline 25.2 & 2.8 & 2.2 & 8.21 & 255.6 & 143.1 & 3.207 \\
\hline 25.3 & 2.3 & 0.0 & 5.55 & 253.1 & 148.1 & 3.713 \\
\hline 25.4 & 2.6 & 0.0 & 5,82 & 267.5 & 158.8 & 3.934 \\
\hline 26.1 & 2.9 & 2.3 & 10.00 & 240.6 & 147.5 & 2.896 \\
\hline 26.2 & 2.9 & 0.0 & 8.10 & 244.4 & 138.1 & 3.253 \\
\hline 26.3 & 2.3 & 1.4 & 7.84 & 237.5 & 140,0 & 3.664 \\
\hline 26.4 & 2.4 & 0.7 & 6.38 & 254.4 & 148.8 & 3.515 \\
\hline 27.1 & 2.4 & 0.0 & 5.41 & 260.8 & 150.0 & 3.957 \\
\hline 27.2 & 2.5 & 0.0 & 5.66 & 258.1 & 150.0 & 3.911 \\
\hline 27.3 & 2.0 & 0.0 & 5.66 & 256.7 & 145.8 & 4.228 \\
\hline 27.4 & 2.6 & 0.0 & 5.85 & 261.3 & 150.0 & 4.005 \\
\hline 29.1 & 2.8 & 0.7 & 10.06 & 261.3 & 150.0 & 2.983 \\
\hline 29.2 & 3.0 & 0.0 & 6.87 & 266.3 & 154.4 & 4.410 \\
\hline
\end{tabular}




\begin{tabular}{crrrrrr}
\hline Cruzamentos & PHAE & STUNT & ACAM & AP & AE & PG \\
\hline $\mathbf{2 9 . 3}$ & 2.8 & 0.7 & 5.87 & 253.8 & 146,3 & 3.653 \\
$\mathbf{2 9 . 4}$ & 2,7 & 0.0 & 7.29 & 260.6 & 157.5 & 4.010 \\
$\mathbf{3 0 . 1}$ & 3.0 & 0.0 & 6,46 & 249,4 & 150,0 & 3.234 \\
$\mathbf{3 0 . 2}$ & 2,8 & 0,0 & 7,18 & 266,3 & 154,4 & 2,926 \\
$\mathbf{3 0 . 3}$ & 3.1 & 0.0 & 5,65 & 278.1 & 161,3 & 3,723 \\
$\mathbf{3 0 . 4}$ & 3,1 & 0,0 & 7,15 & 253,8 & 145,6 & 3,571 \\
\hline Testemunhas & PHAE & STUNT & ACAM & AP & AE & PG \\
\hline T1 & 1.8 & 0.2 & 5.57 & 221.5 & 120,2 & 4,391 \\
T2 & 2.1 & 0.7 & 5.89 & 245.9 & 133.4 & 4.400 \\
\hline
\end{tabular}

Tabela 44. Resumo das análises de variância do experimento $1 R$ para mancha de Phaeosphaeria, porcentagem de plantas com enfezamento (ENFE), porcentagem de plantas acamadas (ACAM), altura de planta (AP), altura da espiga (AE) e peso de grãos por parcela (PG)

\begin{tabular}{|c|c|c|c|c|c|c|c|}
\hline \multirow[b]{2}{*}{ FV } & \multirow[b]{2}{*}{ GL } & \multirow[b]{2}{*}{ PHAE } & \multicolumn{3}{|c|}{ QM } & \multirow[b]{2}{*}{$\mathbf{A E}$} & \multirow[b]{2}{*}{ PG } \\
\hline & & & $\begin{array}{l}\text { ENFE } x \\
10^{3}\end{array}$ & $\begin{array}{l}\mathrm{X} \text { ACAM } \mathrm{x} \\
10^{3}\end{array}$ & AP & & \\
\hline Repetição & 3 & 2.186 & 0.345 & 4,617 & 652.39 & 235.84 & 0.284 \\
\hline Tratamentos & 145 & $1,495 * *$ & $0.306 * *$ & $1.618 * *$ & $1092.85 * *$ & $866.50 * *$ & $1,612^{* *}$ \\
\hline Dialelo & 143 & $1,035 * *$ & $0.307 * *$ & $1.495^{* *}$ & $981,36^{* *}$ & $781,79 * *$ & $1,171^{* *}$ \\
\hline Acessos & 27 & $2,948 * *$ & $0, \overline{158}$ & $3 . \overline{3} 27^{*} *$ & $\overline{2} \overline{2} \overline{6} . \overline{3} \overline{2} * \bar{*}$ & $2151.79^{* *}$ & $0.609 * *$ \\
\hline Hibridos & 3 & $6.490 * *$ & $1.058 * *$ & $2.146^{*}$ & $588.35^{*}$ & $599.37 * *$ & $4.401 * *$ \\
\hline Entre grupos & 1 & 0.204 & 0.264 & $36,772 * *$ & $34675.33 * *$ & $29538,90 * *$ & $26,494 * *$ \\
\hline Heterose & 112 & $0,435 * *$ & $0.323 * *$ & $0,720^{*}$ & $366.82^{* *}$ & $199,64^{* *}$ & $0,994 * *$ \\
\hline H. média & 1 & $4.365 * *$ & $3.838^{* *}$ & 1.729 & $11972.32 * *$ & $4633,22 * *$ & $56.228 * *$ \\
\hline H. Aces & 27 & 0,383 & 0.201 & $1.078 *$ & $286.16^{*}$ & $221,89^{*}$ & $1.007 * *$ \\
\hline H. Hibridos & 3 & 0.775 & $4.254 * *$ & 0.469 & 80,08 & 96,88 & 0,491 \\
\hline H. especifica & 81 & 0.391 & 0.175 & 0.598 & 261.05 & $141.30^{*}$ & $0,326^{*}$ \\
\hline Testemunhas & 1 & $1,410^{*}$ & $\overline{0}, \overline{3} \overline{79}$ & $0, \overline{16} \overline{3}$ & $\overline{9} \overline{567} . \overline{28} \overline{5}^{* *}$ & $27 \overline{5} 6,250^{* *}$ & $0,00 \overline{1}$ \\
\hline Dialelo rs Testem. & 1 & $67.347 * *$ & 0,033 & $20.683 * *$ & 8561.31 & $11090,75^{* *}$ & $66.332 * *$ \\
\hline Resíduo & 491 & 0.308 & 0.167 & 0.582 & 176.85 & 125.41 & 0.231 \\
\hline Dentro test./rep. & 56 & 0.187 & 0.130 & 0.068 & 172.06 & 108.73 & 0.336 \\
\hline Erro & +35 & 0.323 & 0.171 & $0.6+9$ & 177.47 & 127.56 & 0.218 \\
\hline $\mathrm{CV} \%$ & & 18.90 & 49.99 & 15.10 & 5.44 & 8.04 & 14.03 \\
\hline Média geral & & 2.93 & 0.50 & 7.57 & 244.68 & 139.29 & 3.43 \\
\hline
\end{tabular}

** e * indicam. respectivamente, significância ao nivel de $1 \%$ e de $5 \%$ de probabilidade. 
Tabela 45. Efeitos de variedade $v_{i}$ no experimento 1R para mancha de Phaeosphaeria, porcentagem de plantas com enfezamento (ENFE), porcentagem de plantas acamadas (ACAM), altura de planta (AP), altura da espiga (AE) e peso de grãos por parcela (PG)

\begin{tabular}{|c|c|c|c|c|c|c|}
\hline Acessos & PHAE & ENFE & ACAM & $\mathbf{A P}$ & $\mathbf{A E}$ & $\mathbf{P G}$ \\
\hline 1 & $-0,581$ & $-0,006$ & $-0,003$ & $-16,494$ & $-12,063$ & $-0,396$ \\
\hline 2 & 0.231 & $-0,006$ & 0,018 & $-18,369$ & -32.063 & 0,474 \\
\hline 3 & -0.456 & 0.019 & 0.003 & 2,881 & 8.563 & 0.111 \\
\hline 4 & 0.231 & -0.006 & 0.014 & 1,006 & 6,063 & -0.083 \\
\hline 5 & 1.356 & -0.006 & $-0,004$ & -15.869 & $-18,313$ & 0.212 \\
\hline 6 & 1.190 & 0.005 & $-0,023$ & $-18,786$ & -24.563 & 0.689 \\
\hline 8 & 0.606 & 0.002 & 0,053 & $-25,869$ & -20.188 & -0.567 \\
\hline 9 & 0.919 & -0.006 & 0.045 & -20.869 & -23.313 & 0.047 \\
\hline 10 & 0.731 & 0.008 & $-0,027$ & $-26,494$ & $-23,313$ & $-0,271$ \\
\hline 11 & 0.106 & 0.001 & $-0,021$ & $-17,119$ & -17.063 & 0,299 \\
\hline 12 & -0.144 & $-0,006$ & 0,015 & 9,131 & 7,938 & 0.323 \\
\hline 13 & 0.044 & 0,003 & $-0,022$ & 8,506 & 4,813 & $-0,246$ \\
\hline 14 & 0.106 & 0,004 & $-0,009$ & $-8,994$ & $-0,188$ & 0,168 \\
\hline 15 & -0.519 & 0.001 & $-0,008$ & 16,006 & 20,438 & 0.283 \\
\hline 16 & 0.356 & -0.006 & $-0,033$ & 16,006 & 21,063 & -0.098 \\
\hline 17 & -0.519 & -0.006 & 0,000 & 17,881 & 12,313 & 0,064 \\
\hline 18 & 0,044 & $-0,006$ & 0,055 & $-3,369$ & $-2,688$ & $-0,409$ \\
\hline 19 & 0,419 & 0,002 & $-0,016$ & $-8,619$ & $-12,688$ & 0.462 \\
\hline 20 & $-0,206$ & $-0,006$ & $-0,030$ & $-2,119$ & $-5,813$ & 0,376 \\
\hline 21 & -0.144 & -0.006 & 0,052 & 2,256 & 0.438 & 0.147 \\
\hline 22 & 0,481 & -0.006 & 0,041 & $-20,244$ & $-12,063$ & 0.241 \\
\hline 23 & -0.644 & 0.002 & -0.006 & 4,756 & 8.563 & 0.011 \\
\hline 24 & -0.831 & -0.006 & -0.027 & 29,756 & 42.313 & -1.339 \\
\hline 25 & -0.394 & 0.014 & 0,019 & 18,506 & -3.688 & -0.427 \\
\hline 26 & -0.081 & -0.006 & -0.001 & 3,506 & 1.688 & 0,294 \\
\hline 27 & -0.894 & 0,001 & $-0,028$ & 23,506 & 20.438 & -0.396 \\
\hline 29 & -0.894 & 0.009 & $-0,025$ & 29.756 & 32.313 & 0.109 \\
\hline 30 & -0.519 & 0,009 & $-0,031$ & 19,756 & 21.063 & $-0,079$ \\
\hline Híbridos & PHAE & ENFE & ACAM & AP & $\mathbf{A E}$ & PG \\
\hline H1 & $-0,703$ & 0,053 & -0.003 & 0,000 & 1,406 & $-0,389$ \\
\hline $\mathbf{H} 2$ & 0.359 & -0.020 & 0.003 & 0,000 & -1.094 & 0.349 \\
\hline H3 & -0.141 & -0.012 & 0.004 & -2.500 & -0.469 & 0.034 \\
\hline H4 & 0.484 & -0.020 & -0.004 & 2.500 & 0.156 & 0.006 \\
\hline
\end{tabular}


Tabela 46. Efeitos de heterose de variedade $h_{i}$ no experimento $1 R$ para mancha de Phaeosphaeria, porcentagem de plantas com enfezamento (ENFE), porcentagem de plantas acamadas (ACAM), altura de planta (AP), altura da espiga (AE) e peso de grãos por parcela (PG)

\begin{tabular}{|c|c|c|c|c|c|c|}
\hline Acessos & PHAE & STUNT & ACAM & $\mathbf{A P}$ & $\mathbf{A E}$ & PG \\
\hline 1 & 0,226 & 0,004 & 0,001 & 4,023 & 0,274 & 0,477 \\
\hline 2 & 0.070 & 0.005 & 0.000 & $-1,759$ & 6.837 & $-0,486$ \\
\hline 3 & 0.101 & -0.006 & $-0,003$ & 0,429 & $-3,320$ & $-0,006$ \\
\hline 4 & -0.212 & 0.002 & -0.017 & $-8,009$ & -7.226 & 0.150 \\
\hline 5 & $-0,029$ & 0.002 & 0,009 & -5.352 & $-2,070$ & $-0,437$ \\
\hline 6 & -0.363 & $-0,005$ & 0,007 & 4,231 & 6,055 & $-0,305$ \\
\hline 8 & 0.007 & -0.001 & 0,001 & 12,773 & 7,774 & -0.200 \\
\hline 9 & $-0,102$ & 0,009 & $-0,019$ & 4,804 & 8.399 & -0.318 \\
\hline 10 & 0.054 & -0.008 & 0,004 & $-4,571$ & $-2,382$ & 0,242 \\
\hline 11 & 0.523 & $-0,005$ & 0.006 & $-6,915$ & -5.507 & $-0,104$ \\
\hline 12 & 0,392 & $-0,001$ & -0.005 & $-9,571$ & -7.017 & $-0,131$ \\
\hline 13 & 0,101 & $-0,002$ & $-0,003$ & $-0,665$ & $-0,351$ & 0,117 \\
\hline 14 & -0.071 & $-0,003$ & $-0,004$ & 10,429 & 4,649 & $-0,093$ \\
\hline 15 & 0,116 & 0,003 & 0,014 & $-3,321$ & $-6,445$ & $-0,333$ \\
\hline 16 & -0.212 & 0.002 & 0.013 & $-0,509$ & $-6,757$ & $-0,032$ \\
\hline 17 & 0.038 & 0,002 & $-0,001$ & $-7,071$ & $-0,195$ & 0,034 \\
\hline 18 & $-0,071$ & 0,005 & -0.027 & 0.429 & 4.180 & 0.355 \\
\hline 19 & 0.007 & 0,004 & 0,011 & $-7,571$ & $-3,632$ & -0.227 \\
\hline 20 & 0,038 & 0,000 & 0,015 & $-5,509$ & -2.851 & $-0,095$ \\
\hline 21 & 0,007 & 0.002 & $-0,023$ & 2,929 & 2,930 & $-0,318$ \\
\hline 22 & 0.038 & 0.001 & $-0,012$ & 8,398 & 1.993 & $-0,428$ \\
\hline 23 & 0.023 & 0.000 & 0.010 & 6.835 & -0.507 & 0.587 \\
\hline 24 & -0.337 & 0.008 & 0.002 & -5.665 & -8.788 & 0.854 \\
\hline 25 & $-0,352$ & $-0,006$ & -0.012 & 2,460 & 10,462 & 0.262 \\
\hline 26 & -0.337 & 0,010 & 0.009 & -2.227 & 3.712 & -0.337 \\
\hline 27 & $-0,186$ & $-0,005$ & -0.002 & 2,773 & -0.299 & 0,702 \\
\hline 29 & 0,257 & $-0,005$ & 0.016 & 0,898 & $-3,163$ & 0,188 \\
\hline 30 & 0.273 & -0.009 & 0.009 & 7,304 & 3.243 & -0.118 \\
\hline Híbridos & PHAE & STUNT & ACAM & AP & $\mathbf{A E}$ & $P G$ \\
\hline H1 & 0.315 & -0.026 & 0.008 & $-2,922$ & -2.866 & $-0,041$ \\
\hline $\mathrm{H} 2$ & 0.012 & 0.010 & 0.000 & -0.876 & -1.594 & -0.219 \\
\hline H3 & -0.245 & 0.005 & -0.006 & 2.465 & 2.394 & 0.235 \\
\hline $\mathrm{H4}$ & -0.081 & 0.011 & -0.002 & 1.334 & 2.067 & 0.025 \\
\hline
\end{tabular}


Tabela 47. Efeitos de capacidade geral de combinação $g_{i}$ no experimento $1 R$ para mancha de Phaeosphaeria. porcentagem de plantas com enfezamento (ENFE), porcentagem de plantas acamadas (ACAM), altura de planta (AP), altura da espiga (AE) e peso de grãos por parcela (PG)

\begin{tabular}{|c|c|c|c|c|c|c|}
\hline Acessos & PHAE & STUNT & ACAM & AP & $\mathbf{A E}$ & PG \\
\hline 1 & $-0,065$ & 0,001 & 0,000 & $-4,224$ & $-5,757$ & 0,279 \\
\hline 2 & 0.185 & 0.002 & 0,009 & $-10,943$ & -9.195 & -0.249 \\
\hline 3 & -0.127 & 0.003 & -0.001 & 1.869 & 0.962 & 0.049 \\
\hline 4 & -0.096 & -0.001 & -0.009 & -7.506 & -4.195 & 0.108 \\
\hline 5 & 0.649 & -0.001 & 0,007 & $-13,287$ & -11.226 & -0.331 \\
\hline 6 & 0.232 & -0.002 & -0.004 & $-5,162$ & -6.226 & 0.040 \\
\hline 8 & 0.310 & -0.001 & 0.027 & -0.162 & -2.320 & -0.484 \\
\hline 9 & 0.357 & 0.006 & 0.003 & -5.631 & $-3,257$ & -0.294 \\
\hline 10 & 0.420 & $-0,004$ & $-0,009$ & $-17,818$ & $-14,038$ & 0.106 \\
\hline 11 & 0.576 & -0.004 & -0.004 & -15.474 & -14.038 & 0.046 \\
\hline 12 & 0,321 & $-0,004$ & 0,002 & $-5,006$ & $-3,049$ & 0,030 \\
\hline 13 & 0.123 & $-0,001$ & $-0,014$ & 3,588 & 2,055 & $-0,006$ \\
\hline 14 & -0.018 & -0.001 & $-0,008$ & 5,932 & 4,555 & $-0,008$ \\
\hline 15 & -0.143 & 0,004 & 0,010 & 4,682 & 3,774 & $-0,192$ \\
\hline 16 & -0.033 & $-0,001$ & $-0,004$ & 7,494 & 3,774 & $-0,081$ \\
\hline 17 & $-0,221$ & $-0,001$ & 0,000 & 1,869 & 5,962 & 0,066 \\
\hline 18 & $-0,049$ & 0,002 & 0,001 & -1.256 & 2,837 & 0.151 \\
\hline 19 & 0,217 & 0,005 & 0,003 & $-11,881$ & -9.976 & 0.004 \\
\hline 20 & $-0,065$ & -0.003 & -0.001 & $-6,568$ & -5.757 & 0.093 \\
\hline 21 & -0.065 & $-0,001$ & 0.003 & 4.057 & 3,149 & $-0,244$ \\
\hline 22 & 0.279 & -0.002 & 0,008 & $-1,724$ & $-4,038$ & -0.307 \\
\hline 23 & -0.299 & 0.001 & 0.007 & 9.213 & 3.774 & 0.592 \\
\hline 24 & -0.752 & 0.005 & -0.012 & 9.213 & 12.368 & 0.184 \\
\hline 25 & -0.549 & 0.001 & -0.003 & 11.713 & 8.618 & 0.048 \\
\hline 26 & -0.377 & 0.007 & 0.009 & $-0,474$ & 4.555 & -0.189 \\
\hline 27 & -0.632 & -0.004 & -0.016 & 14.526 & 9.920 & 0.504 \\
\hline 29 & -0.190 & $-0,001$ & 0.003 & 15.776 & 12.993 & 0.242 \\
\hline 30 & 0.013 & -0.004 & -0.006 & 17,182 & 13.774 & -0.158 \\
\hline Hibridos & PHAE & STUNT & ACAM & AP & $\mathbf{A E}$ & PG \\
\hline H1 & -0.036 & 0,001 & 0,006 & $-2,922$ & -2.163 & -0.235 \\
\hline $\mathrm{H} 2$ & 0.191 & -0.001 & 0.002 & $-0,876$ & -2.141 & -0.044 \\
\hline $\mathrm{H} 3$ & -0.315 & -0.002 & -0.004 & 1.215 & 2.160 & 0.252 \\
\hline $\mathrm{H4}$ & 0.161 & 0.001 & -0.004 & 2.584 & 2.145 & 0.028 \\
\hline
\end{tabular}


Tabela 48. Resumo das análises de variância conjuntas dos dialelos intergrupos dos experimentos 1A, 1C e 1R para mancha de Phaeosphaeria e peso de grãos por parcela (PG).

\begin{tabular}{lcll}
\hline FV & & PHAE & PG \\
\hline Local (L) & 2 & 133.417 & $780.725^{* *}$ \\
Dialelo & 143 & $1,791^{* *}$ & $2.971^{* *}$ \\
\hline Acessos & 27 & $4,326^{* *}$ & $2,110^{* *}$ \\
Hibridos & 3 & $16,676^{* *}$ & $7.921^{* *}$ \\
Grupos & 1 & 0,000 & $94,672^{* *}$ \\
Heterose & 112 & 0,797 & $2,228^{* *}$ \\
$\quad$ H. média & 1 & $8,894^{* *}$ & $169.506^{* *}$ \\
H. acessos(I) & 27 & 0.859 & $1,140^{* *}$ \\
H. hibridos(II) & 3 & 0.511 & 0.582 \\
H. especifica & 81 & 0,687 & $0.586^{* *}$ \\
\hline Interação local $\times$ dialelo & 286 & 0,768 & $0,483^{* *}$ \\
\hline L $\times$ Acessos & 54 & $1,162^{* *}$ & $0,553^{* *}$ \\
L $\times$ Híbridos & 6 & $2,107^{* *}$ & $4,349 * *$ \\
L $\times$ Grupo & 2 & 0,439 & $2,305^{* *}$ \\
L $\times$ Heterose & 224 & 0,640 & $0.346^{* *}$ \\
L $\times$ H. média & 2 & $2,583^{*}$ & $4,510^{* *}$ \\
L $\times$ H. acessos(I) & 54 & 0.702 & 0.329 \\
L $\times$ H. hibridos(II) & 6 & $1,427 *$ & 0,127 \\
L x. H. especifica & 162 & 0.565 & $0.309^{*}$ \\
\hline Residuo combinado & 1473 & 0.669 & 0.287
\end{tabular}

** e * indicam, respectivamente, significância ao nivel de $1 \%$ e de $5 \%$ de probabilidade. 
Tabela 49. Médias dos tratamentos do experimento 2A para mancha de Phaeosphaeria, altura de planta (AP), altura da espiga (AE), comprimento de espiga (CE), diâmetro de espiga (DE), e peso de grãos por parcela $(\mathrm{PG}) \mathrm{em} \mathrm{kg}$.

\begin{tabular}{|c|c|c|c|c|c|c|}
\hline Acessos & PHAE & AP & $\mathrm{AE}$ & $\mathrm{CE}$ & DE & PG \\
\hline Is & 4,9 & 166.4 & 91,9 & 12,5 & 3,4 & 2,275 \\
\hline $2 s$ & 4,7 & 165,7 & 87,9 & 12,7 & 3,8 & 2,018 \\
\hline $3 s$ & 4,8 & 170.2 & 92.0 & 12.8 & 3,6 & 2.046 \\
\hline $4 s$ & 5,1 & 171.0 & 88.1 & 12.7 & 3,8 & 2,089 \\
\hline $5 s$ & 5,0 & 207,6 & 123.5 & 12.9 & 3.3 & 1.834 \\
\hline $6 s$ & 4,9 & 202,2 & 118.8 & 12,6 & 3.7 & 1,560 \\
\hline $7 \mathrm{~s}$ & 5,3 & 218.2 & 121.9 & 13,7 & 3.9 & 2,418 \\
\hline $8 s$ & 5.1 & 162.5 & 80.5 & 12.2 & 3.3 & 1.268 \\
\hline $9 s$ & 5,1 & 170.2 & 90,2 & 12,6 & 4,0 & 1,880 \\
\hline $10 \mathrm{~s}$ & 5.5 & 194.4 & 105,0 & 12,6 & 3,8 & 2,230 \\
\hline $11 \mathrm{~s}$ & 5,3 & 213.3 & 113.5 & 14,0 & 3,9 & 2,709 \\
\hline $12 \mathrm{~s}$ & 5,3 & 195,2 & 104,2 & 13.4 & 4,0 & 2,670 \\
\hline $13 \mathrm{~s}$ & 5,1 & 210,3 & 117,6 & 13,8 & 3,8 & 2,402 \\
\hline $14 \mathrm{~s}$ & 5,0 & 211.4 & 122.5 & 14,5 & 3,8 & 2.370 \\
\hline $15 \mathrm{~s}$ & 5,3 & 194,9 & 104,1 & 13,1 & 3,7 & 2,465 \\
\hline $16 s$ & 4,7 & 174,1 & 89.9 & 12,6 & 3,8 & 3,080 \\
\hline $17 \mathrm{~s}$ & 4,9 & 189,1 & 100,1 & 13,5 & 4,3 & 2,357 \\
\hline $18 \mathrm{~s}$ & 5,0 & 181,0 & 97,1 & 12,6 & 3,9 & 2,485 \\
\hline $19 \mathrm{~s}$ & 5,3 & 242,0 & 147,9 & 13,7 & 3,8 & 2,333 \\
\hline $20 \mathrm{~s}$ & 5,5 & 228.8 & 132.0 & 13,9 & 3,5 & 2,545 \\
\hline $21 \mathrm{~s}$ & 5.2 & 195.5 & 102,9 & 13,9 & 3,9 & 2,841 \\
\hline $22 s$ & 4.9 & 216.1 & 125.7 & 13.3 & 3,3 & 2.037 \\
\hline $23 \mathrm{~s}$ & 4.9 & 184.9 & 97.7 & 13.5 & 3.8 & 2,719 \\
\hline $24 \mathrm{~s}$ & 5.0 & 187.2 & 104,6 & 13.0 & 4.0 & 2.607 \\
\hline $25 \mathrm{~s}$ & 4,3 & 249,2 & 159,7 & 13,4 & 3,7 & 2,950 \\
\hline $26 s$ & 5,3 & 189,4 & 112,0 & 13,2 & 3,4 & 1,972 \\
\hline $27 \mathrm{~s}$ & 5,1 & 246.4 & 152.3 & 12,8 & 3.6 & 2.280 \\
\hline $28 \mathrm{~s}$ & 4.9 & 232,9 & 145,1 & 12,9 & 3,8 & 1.575 \\
\hline $30 \mathrm{~s}$ & 5.0 & 223.3 & 124.2 & 14.9 & 3.8 & 2.515 \\
\hline Híbridos & PHAE & AP & $\mathrm{AE}$ & $\mathrm{CE}$ & $\mathrm{DE}$ & PG \\
\hline H1 & 4,4 & 188.5 & 102,6 & 11,7 & 3.9 & 2,328 \\
\hline $\mathrm{H} 2$ & 5.1 & 197.9 & 102.8 & 12.5 & 3.8 & 2.570 \\
\hline H3 & 4.3 & 186.1 & 102.1 & 12,0 & 3.6 & 1.902 \\
\hline H4 & 5.5 & 193.0 & 99.1 & 12.8 & 3,7 & 2.008 \\
\hline Cruzamentos & PHAE & AP & $\mathrm{AE}$ & $\mathrm{CE}$ & $\mathrm{DE}$ & PG \\
\hline $1 \mathrm{~s} .1$ & 4.8 & 192.7 & 104.5 & 13.4 & 4.0 & 2.702 \\
\hline $1 \mathrm{~s} .2$ & 4.9 & 180.8 & 94.9 & 12.8 & 3,7 & 2.609 \\
\hline $1 \mathrm{~s} .3$ & 4.9 & 180.1 & 101.5 & 13.7 & 3.8 & 2.827 \\
\hline $1 \mathrm{s.4}$ & 4.8 & 189.2 & 106.6 & 12.4 & 3.7 & 2.530 \\
\hline $2 \mathrm{s.1}$ & 5.0 & 176.4 & 96.9 & 13.7 & 4.1 & 2.548 \\
\hline $2 \mathrm{~s} .2$ & 4.9 & 174.1 & 88.1 & 14.2 & 4.1 & 3.098 \\
\hline $2 s .3$ & 4.8 & 188.5 & 98.8 & 14.1 & 4.3 & 3.494 \\
\hline $2 s .4$ & 5.1 & 187.1 & 98.8 & $1+.0$ & 4.0 & 3.128 \\
\hline
\end{tabular}




\begin{tabular}{|c|c|c|c|c|c|c|}
\hline Cruzamentos & PHAE & AP & $\mathbf{A E}$ & CE & DE & PG \\
\hline $3 \mathrm{~s} .1$ & 5.3 & 196,0 & 106.5 & 13.2 & 4.0 & 2.775 \\
\hline $3 \mathrm{~s} .2$ & 5.1 & 193,3 & 103.5 & 14.4 & 3,7 & 3,425 \\
\hline $3 s .3$ & 4.7 & 188,6 & 103.9 & 14,3 & 4,1 & 2,491 \\
\hline $3 s .4$ & 5.4 & 192,3 & 97,9 & 13,0 & 3,9 & 2,302 \\
\hline $4 \mathrm{s.} 1$ & 4.9 & 181,1 & 97,3 & 13,9 & 4,2 & 2,459 \\
\hline 45.2 & 5,6 & 185,8 & 102,9 & 13,4 & 3,9 & 3,250 \\
\hline $4 s .3$ & 5.1 & 194.5 & 104,3 & 13,7 & 4,1 & 3,005 \\
\hline 45.4 & 5.3 & 188.8 & 97.6 & 13.8 & 3,9 & 2.438 \\
\hline $5 \mathrm{~s} .1$ & 5.3 & 211,1 & 117.1 & 12,9 & 3,8 & 2,786 \\
\hline $5 \mathrm{~s} .2$ & 5.4 & 216,2 & 121.2 & 13,3 & 3,6 & 2,723 \\
\hline $5 s .3$ & 4.6 & 208,7 & 117,7 & 13,3 & 4,1 & 2,904 \\
\hline $5 s .4$ & 4.8 & 223.1 & 131.1 & 13,7 & 3,9 & 2.729 \\
\hline $6 s .1$ & 4.9 & 203.3 & 114.8 & 13.9 & 4.1 & 2.859 \\
\hline $6 s .2$ & 4.9 & 209.2 & 116,0 & 13,8 & 4,0 & 3,041 \\
\hline $6 s .3$ & 4.9 & 201.4 & 113.1 & 15.0 & 4,1 & 2.996 \\
\hline $6 s .4$ & 5.5 & 212,8 & 118.5 & 13,4 & 3,9 & 2.465 \\
\hline $7 \mathrm{~s} .1$ & 4.8 & 200,2 & 111.1 & 14.4 & 4,0 & 2,832 \\
\hline $7 s .2$ & 5.1 & 212.7 & 115,6 & 14,1 & 4,0 & 3.357 \\
\hline $7 s .3$ & 4.8 & 212,8 & 117,3 & 15,1 & 4,0 & 2,978 \\
\hline $7 \mathrm{s.4}$ & 5.4 & 214,1 & 118.4 & 13,8 & 3,9 & 2.770 \\
\hline $8 s .1$ & 5.0 & 180,0 & 99,5 & 13,8 & 3,9 & 2,318 \\
\hline $8 \mathrm{~s} .2$ & 5,1 & 188,1 & 98,4 & 13,2 & 3,7 & 2.649 \\
\hline $8 s .3$ & 4.0 & 192,1 & 106,3 & 14,4 & 3.9 & 2,417 \\
\hline $8 s .4$ & 5.0 & 193.2 & 102,7 & 13,8 & 3.8 & 2.697 \\
\hline 9s. 1 & 5.3 & 186.3 & 106.2 & 13,7 & 4,1 & 2.545 \\
\hline $9 \mathrm{~s} .2$ & 5.1 & 196.9 & 106,7 & 14.7 & 4,4 & 2.800 \\
\hline $9 \mathrm{~s} .3$ & 4.7 & 185.7 & 99.6 & 13.1 & 4.2 & 2.738 \\
\hline $9 \mathrm{s.4}$ & 5.1 & 200.8 & 104.6 & 13.3 & 4.2 & 2.981 \\
\hline $10 \mathrm{~s} .1$ & 5.4 & 202,9 & 101.3 & 14.1 & 4.3 & 2.737 \\
\hline $10 \mathrm{~s} .2$ & 5.0 & 199.8 & 109,9 & 14,1 & 4.1 & 2.885 \\
\hline $10 \mathrm{~s} .3$ & 5.1 & 200,9 & 108,3 & 14.2 & 4,2 & 3,189 \\
\hline $10 \mathrm{s.4}$ & 5.4 & 206,6 & 106,9 & 13,8 & 3,9 & 2,738 \\
\hline $11 \mathrm{~s} .1$ & 5,5 & 201,8 & 108,3 & 14.6 & 3.9 & 3.212 \\
\hline $11 \mathrm{~s} .2$ & 4.8 & 205.2 & 114.6 & 13.7 & 4,0 & 3.435 \\
\hline $11 \mathrm{~s} .3$ & 4.6 & 209.9 & 115.6 & 15.0 & 4.2 & 3.486 \\
\hline $11 \mathrm{s.4}$ & 4.9 & 205.5 & 110.4 & 14.2 & 4.0 & 2.526 \\
\hline $12 \mathrm{~s} .1$ & 5.1 & 197.2 & 104.4 & 13.9 & 4.0 & 2.870 \\
\hline $12 \mathrm{~s} .2$ & 5.0 & 202.6 & 111.0 & 13.8 & 4.1 & 3.328 \\
\hline $12 \mathrm{~s} .3$ & 4.7 & 203.4 & 114,8 & 15,5 & 4,1 & 3.320 \\
\hline $12 \mathrm{~s} .4$ & 5.0 & 208.7 & 109.7 & 13.5 & 3.9 & 2,658 \\
\hline $13 \mathrm{~s} .1$ & 5.1 & 213.4 & 117.8 & 13.5 & 3.7 & 2.850 \\
\hline $13 \mathrm{~s} .2$ & 4.9 & 213.9 & 117.1 & 13.6 & 3.8 & 2.954 \\
\hline $13 \mathrm{~s} .3$ & 4.8 & 206.7 & 116.6 & 14.3 & 4.2 & 3.043 \\
\hline $13 \mathrm{s.4}$ & 5.1 & 218.5 & 120.8 & 13.9 & 4.1 & 2.965 \\
\hline $14 \mathrm{~s} .1$ & 5.1 & 205.9 & 114.3 & 14.0 & 4.0 & 3.101 \\
\hline $14 \mathrm{~s} .2$ & 5.1 & 219.1 & 120.1 & 13.9 & 4.0 & 2.874 \\
\hline $14 \mathrm{~s} .3$ & 4.8 & 219.3 & 126.0 & 13.7 & 4.1 & 3.365 \\
\hline $14 s .4$ & 5.3 & 198.7 & 104.9 & 13.9 & 3.8 & 2.506 \\
\hline
\end{tabular}




\begin{tabular}{|c|c|c|c|c|c|c|}
\hline Cruzamentos & PHAE & $\mathbf{A P}$ & $\mathbf{A E}$ & CE & DE & PG \\
\hline $15 \mathrm{~s} .1$ & 4,8 & 192.5 & 105,0 & 14,6 & 4,2 & 3,100 \\
\hline $15 \mathrm{~s} .2$ & 5.2 & 207.2 & 116,0 & 13,8 & 4,1 & 3,203 \\
\hline $15 \mathrm{~s} .3$ & 4,9 & 205,0 & 113,4 & 14,3 & 4,4 & 3,916 \\
\hline $15 \mathrm{~s} .4$ & 5,0 & 210.5 & 110,9 & 13,6 & 4,2 & 2,984 \\
\hline $16 \mathrm{~s} .1$ & 4,4 & 188,5 & 103,2 & 14.1 & 4,2 & 3,280 \\
\hline $16 \mathrm{~s} .2$ & 5,1 & 189,0 & 102,3 & 13,8 & 4,2 & 3,181 \\
\hline $16 \mathrm{~s} .3$ & 4,3 & 193,1 & 107,0 & 13.5 & 4,4 & 3,952 \\
\hline $16 \mathrm{~s} .4$ & 4.9 & 205.2 & 108.8 & 13.8 & 4.3 & 3.636 \\
\hline $17 \mathrm{~s} .1$ & 5.1 & 196.9 & 107.5 & 14.1 & 4.2 & 3.159 \\
\hline $17 \mathrm{~s} .2$ & 5.0 & 198.6 & 101.4 & 13.7 & 4.1 & 3.448 \\
\hline $17 \mathrm{~s} .3$ & 5.1 & 196.3 & 104.1 & 14.5 & 4.5 & 3.032 \\
\hline $17 \mathrm{~s} .4$ & 5.8 & 207.3 & 104.8 & 14.1 & 4.1 & 3.185 \\
\hline $18 \mathrm{~s} .1$ & 4,9 & 193,3 & 98,5 & 13.3 & 4,0 & 2,857 \\
\hline $18 \mathrm{~s} .2$ & 5,1 & 203,6 & 106,6 & 13,7 & 4,1 & 2,842 \\
\hline $18 \mathrm{~s} .3$ & 4.8 & 194,8 & 105,3 & 13.4 & 4.1 & 3,058 \\
\hline $18 \mathrm{~s} .4$ & 5,4 & 198,7 & 98,1 & 12.4 & 3,8 & 2,797 \\
\hline $19 \mathrm{~s} .1$ & 5,0 & 219,8 & 125,4 & 13,7 & 3,9 & 3.295 \\
\hline $19 \mathrm{~s} .2$ & 4,9 & 228.2 & 136.5 & 14.5 & 3.9 & 2,974 \\
\hline $19 \mathrm{~s} .3$ & 4,7 & 219,0 & 123,8 & 13,9 & 4,0 & 2,913 \\
\hline $19 \mathrm{~s} .4$ & 5,4 & 234,4 & 140,1 & 15,2 & 4,2 & 3,340 \\
\hline $20 \mathrm{~s} .1$ & 4,6 & 225,8 & 127,0 & 15,3 & 4,1 & 3,465 \\
\hline $20 \mathrm{~s} .2$ & 5,5 & 223,3 & 119,3 & 14,7 & 3,8 & 3.220 \\
\hline $20 \mathrm{~s} .3$ & 4.5 & 224.4 & 128,4 & 14,4 & 4,0 & 3,567 \\
\hline 20 s. 4 & 4.8 & 223.4 & 121,3 & 15.1 & 3,9 & 3,417 \\
\hline $21 \mathrm{~s} .1$ & 4,9 & 193.8 & 105.1 & 14.4 & 4.3 & 2.873 \\
\hline $21 \mathrm{~s} .2$ & 5,3 & 207.6 & 107.4 & 14.8 & 4,1 & 3.483 \\
\hline $21 \mathrm{~s} .3$ & 4.8 & 200.1 & 103.8 & 14.7 & 4.3 & 3.895 \\
\hline $21 \mathrm{s.4}$ & 5.8 & 206.9 & 105,9 & 14.5 & 4.0 & 2,934 \\
\hline $22 \mathrm{~s} .1$ & 4,4 & 205,5 & 114,3 & 14.9 & 4,1 & 3.446 \\
\hline $22 \mathrm{~s} .2$ & 5.3 & 224.2 & 132,1 & 14,7 & 3.6 & 3,370 \\
\hline $22 \mathrm{~s} .3$ & 4,4 & 215,1 & 122,2 & 15,1 & 4,0 & 3.377 \\
\hline $22 s .4$ & 5.0 & 221.9 & 121,0 & 14,5 & 3.5 & 3.470 \\
\hline $23 \mathrm{~s} .1$ & 5.1 & 201.2 & 105,2 & 12.6 & 4,0 & 3.237 \\
\hline $23 \mathrm{~s} .2$ & 4,9 & 187,7 & 94,9 & 14.0 & 4.0 & 3.436 \\
\hline $23 \mathrm{~s} .3$ & 4.8 & 198.1 & 103,0 & 13.3 & 4.2 & 3.152 \\
\hline $23 \mathrm{~s} .4$ & 5.5 & 198.7 & 103.4 & 13.9 & 3.9 & 3.083 \\
\hline $24 \mathrm{s.1}$ & 5.1 & 188.7 & 104.8 & 12.9 & 4.1 & 3.038 \\
\hline $24 \mathrm{~s} .2$ & 5.5 & 200.2 & 103.5 & 13.4 & 4.1 & 3.315 \\
\hline $24 s .3$ & 4.8 & 201.7 & 115.8 & 14.2 & 4.3 & 3.906 \\
\hline $24 s .4$ & 5.5 & 198.3 & 104.5 & 13.2 & 3,9 & 2,934 \\
\hline $25 \mathrm{~s} .1$ & 4.1 & 211.6 & 119,7 & 14.0 & 3.8 & 3.281 \\
\hline $25 s .2$ & 4.6 & 222.6 & 128,5 & 14.1 & 4.0 & 3.251 \\
\hline $25 \mathrm{~s} .3$ & 3.6 & 239.5 & 137.6 & 13.1 & 4.0 & 3.670 \\
\hline $25 s .4$ & 4.8 & 226.2 & 134.7 & 14.3 & 3.9 & 3.625 \\
\hline $26 s .1$ & 4.9 & 218.4 & 128.8 & 13.4 & 3.9 & 2.601 \\
\hline $26 \mathrm{~s} .2$ & 4.9 & 208.6 & 119.8 & 13.2 & 3.9 & 2.758 \\
\hline $26 \mathrm{~s} .3$ & 4.7 & 200.3 & 116.2 & 13.5 & 3.9 & 2.916 \\
\hline $26 \mathrm{~s} .4$ & 5.4 & 219.9 & 121.3 & 14.5 & 3,7 & 2.885 \\
\hline
\end{tabular}




\begin{tabular}{ccrrrrr}
\hline Cruzamentos & PHAE & AP & AE & CE & DE & PG \\
\hline $\mathbf{2 7 s . 1}$ & 5.2 & 225,2 & 130,7 & 13,7 & 3,9 & 3.530 \\
$\mathbf{2 7 s . 2}$ & 4,7 & 223,4 & 125,3 & 14.6 & 3,8 & 3,580 \\
$\mathbf{2 7 s . 3}$ & 4.3 & 232,7 & 134,0 & 14,7 & 4,3 & 3.834 \\
$\mathbf{2 7 s . 4}$ & 4,7 & 233.1 & 136,7 & 13.4 & 4,0 & 2.551 \\
$\mathbf{2 8 s . 1}$ & 5,3 & 215.1 & 121,0 & 14,4 & 4,0 & 2,799 \\
$\mathbf{2 8 s . 2}$ & 5,3 & 219,5 & 122,6 & 12,9 & 4,0 & 3,382 \\
$\mathbf{2 8 s . 3}$ & 4.9 & 217.8 & 128,6 & 14,2 & 4,0 & 3,143 \\
$\mathbf{2 8 s . 4}$ & 5.8 & 227.3 & 130.0 & 13.3 & 3.9 & 2.947 \\
$\mathbf{3 0 s . 1}$ & 4.9 & 220.2 & 119.3 & 13,7 & 3.9 & 3.415 \\
$\mathbf{3 0 s . 2}$ & 4,8 & 224,5 & 122,8 & 14,8 & 3,8 & 3.917 \\
$\mathbf{3 0 s . 3}$ & 4.8 & 209,2 & 116.8 & 14.6 & 4,1 & 3,890 \\
$\mathbf{3 0 s . 4}$ & 5,3 & 219.9 & 114.8 & 14.2 & 3,9 & 3.114 \\
\hline Testemunhas & PHAE & AP & AE & CE & DE & PG \\
\hline T1 & 3.3 & 214,0 & 113,8 & 15,0 & 4,6 & 5,1 \\
T2 & 3.8 & 240.9 & 128,9 & 14,1 & 4.2 & 4,5 \\
\hline
\end{tabular}

Tabela 50. Resumo das análises de variância do experimento $2 \mathrm{~A}$ para mancha de Phaeosphaeria, altura de planta (AP), altura da espiga (AE), comprimento de espiga (CE), diâmetro de espiga (DE), e peso de grãos por parcela $(\mathrm{PG}) \mathrm{em} \mathrm{kg}$.

\begin{tabular}{|c|c|c|c|c|c|c|c|}
\hline \multirow[b]{2}{*}{ FV } & \multirow[b]{2}{*}{ GL } & \multicolumn{5}{|c|}{ QM } & \multirow[b]{2}{*}{ PG } \\
\hline & & PHAE & AP & $\mathbf{A E}$ & $C E$ & DE & \\
\hline Repetição & 3 & 1.009 & 4886.71 & 1519.41 & 3.019 & 0.059 & 0.863 \\
\hline Tratamentos & 150 & $1.275^{* *}$ & $1409.45 * *$ & $768,41^{* *}$ & $2.387^{* *}$ & $0,291 * *$ & $2,405 * *$ \\
\hline Dialelo & 148 & $0.469^{* *}$ & $1133,86^{* *}$ & $721,74^{* *}$ & $2,111 * *$ & $0,193 * *$ & $1.039 * *$ \\
\hline Acessos & $\overline{28}$ & $\overline{0.65} \overline{5} 0^{*} \bar{*}$ & $\overline{5149,93 * *}$ & $3368,16^{* *}$ & $3.5 \overline{5} 0 * \bar{*}$ & $\overline{0,4 \overline{2} \overline{1}^{*} \bar{*}}$ & $\overline{1}, 6 \overline{2} 3^{* *}-$ \\
\hline Híbridos & 3 & $6,820 * *$ & $1168,99 * *$ & 164,54 & 2,110 & $0,795 * *$ & $2,803 * *$ \\
\hline Entre grupos & 1 & 0.771 & $672.91 *$ & 230.20 & $12.549 * *$ & $3.738 * *$ & $30.199 * *$ \\
\hline Heterose & 116 & $0,259 *$ & $167,52 * *$ & $101.59 * *$ & $1.673 * *$ & $0.092 * *$ & $0.601 * *$ \\
\hline H. média & 1 & 0.178 & $4811.03 * *$ & $1630.96 * *$ & $72.585 * *$ & $3.625 * *$ & $34.208 * *$ \\
\hline H. Acessos & 28 & 0.300 & 110.66 & 84.11 & 1.208 & 0.056 & $0.352 * *$ \\
\hline H. Hibridos & 3 & 0.266 & 133.63 & 49.24 & 1.663 & $0.225^{* *}$ & $0.724 * *$ \\
\hline H. especifica & 84 & 0.246 & 132.41 & $91.08 *$ & 0.985 & 0.057 & $0.279 * *$ \\
\hline Testemunhas & $1-$ & $\overline{4} \overline{1} \overline{2} 6^{* *}-$ & $\overline{11} \overline{15} \overline{15}, \overline{9} \overline{7}^{* *}$ & $\overline{3} 6 \overline{2} 2 . \overline{5} 4^{*} *$ & $1 \overline{3} . \overline{3} 8^{* *}$ & $2.0 \overline{3} \overline{2}^{-1 \bar{*}}-$ & $\overline{5}, 462^{*} *-$ \\
\hline Dialelo vs Test. & 1 & $117,711^{* *}$ & $32091.05^{* *}$ & $4821.50 * *$ & $32.453^{* *}$ & $13.044 * *$ & $201.498 * *$ \\
\hline Resíduo & 506 & 0.202 & 101,63 & 67.80 & 0.954 & 0.052 & 0.160 \\
\hline Dentro test./rep. & 56 & 0.145 & 93.16 & 47.86 & 1.424 & 0.044 & 0.224 \\
\hline Erro & 450 & 0.209 & 102.68 & 70.29 & 0.896 & 0.053 & 0.152 \\
\hline $\mathrm{CV} \%$ & & 9.28 & 4.89 & 7.28 & 7.06 & 5.72 & 13.00 \\
\hline Média geral & & 4.85 & 206.18 & 113.12 & 13.83 & 4.00 & 3.08 \\
\hline
\end{tabular}

** e * indicam. respectivamente. significância ao nivel de $1 \%$ e de $5 \%$ de probabilidade. 
Tabela 51 . Efeitos de variedade $\mathrm{v}_{1}$ no experimento $2 \mathrm{~A}$ para mancha de Phaeosphaeria, altura de planta (AP), altura da espiga (AE), comprimento de espiga (CE), diâmetro de espiga (DE), e peso de grãos por parcela (PG) e m kg.

\begin{tabular}{|c|c|c|c|c|c|c|}
\hline Acessos & PHAE & AP & $\mathbf{A E}$ & CE & DE & PG \\
\hline $1 \mathrm{~s}$ & -0.148 & $-33,398$ & $-20,262$ & $-0,717$ & $-0,338$ & $-0,019$ \\
\hline $2 s$ & -0.348 & -34.048 & -24.229 & $-0,517$ & 0.062 & -0.276 \\
\hline $3 \mathrm{~s}$ & -0.248 & -29.532 & -20.149 & -0.417 & -0.138 & -0.248 \\
\hline $4 s$ & 0,052 & $-28,747$ & $-24,078$ & $-0,517$ & 0.062 & $-0,205$ \\
\hline $5 s$ & $-0,048$ & 7.798 & 11,335 & -0.317 & $-0,438$ & -0.460 \\
\hline $6 s$ & -0.148 & 2.397 & 6,669 & $-0,617$ & $-0,038$ & $-0,734$ \\
\hline $7 \mathrm{~s}$ & 0.252 & 18.441 & 9,726 & 0.483 & 0.162 & 0.124 \\
\hline $8 s$ & 0.052 & -37.238 & $-31,666$ & -1.017 & -0.438 & $-1,026$ \\
\hline $9 s$ & 0,052 & -29.609 & $-21,979$ & $-0,617$ & 0,262 & -0.414 \\
\hline $10 \mathrm{~s}$ & 0.452 & -5.332 & $-7,223$ & $-0,617$ & 0,062 & $-0,064$ \\
\hline $11 \mathrm{~s}$ & 0.252 & 13,521 & 1,346 & 0,783 & 0,162 & 0,415 \\
\hline $12 \mathrm{~s}$ & 0.252 & $-4,612$ & $-7,942$ & 0,183 & 0,262 & 0,376 \\
\hline $13 \mathrm{~s}$ & 0,052 & 10,568 & 5,394 & 0,583 & 0,062 & 0,108 \\
\hline $14 \mathrm{~s}$ & $-0,048$ & 11,644 & 10,355 & 1,283 & 0,062 & 0,076 \\
\hline $15 \mathrm{~s}$ & 0,252 & $-4,854$ & $-8,103$ & $-0,117$ & -0.038 & 0.171 \\
\hline $16 s$ & -0.348 & $-25,685$ & $-22,253$ & $-0,617$ & 0.062 & 0,786 \\
\hline $17 \mathrm{~s}$ & -0.148 & -10.715 & -12.118 & 0.283 & 0.562 & 0.063 \\
\hline $18 \mathrm{~s}$ & -0.048 & -18.745 & $-15,077$ & -0.617 & 0.162 & 0.191 \\
\hline $19 \mathrm{~s}$ & 0.252 & 42.260 & 35,695 & 0,483 & 0,062 & 0,039 \\
\hline $20 \mathrm{~s}$ & 0.452 & 29,065 & 19,792 & 0,683 & $-0,238$ & 0.251 \\
\hline $21 \mathrm{~s}$ & 0.152 & -4.286 & -9.272 & 0.683 & 0.162 & 0.547 \\
\hline $22 \mathrm{~s}$ & -0.148 & 16,315 & 13.557 & 0.083 & -0.438 & -0.257 \\
\hline $23 \mathrm{~s}$ & -0.148 & -14.872 & -14.468 & 0.283 & 0.062 & 0.425 \\
\hline $24 s$ & -0.048 & -12.595 & -7.612 & -0.217 & 0.262 & 0.313 \\
\hline $25 s$ & -0.748 & 49.386 & 47.562 & 0,183 & -0.038 & 0,656 \\
\hline $26 s$ & 0.252 & $-10,355$ & $-0,191$ & $-0,017$ & $-0,338$ & -0.322 \\
\hline $27 \mathrm{~s}$ & 0,052 & 46,633 & 40,165 & $-0,417$ & $-0,138$ & $-0,014$ \\
\hline $28 s$ & -0.148 & 33.096 & 32,972 & $-0,317$ & 0,062 & -0.719 \\
\hline $30 \mathrm{~s}$ & -0.048 & 23.504 & 12,050 & 1,683 & 0,062 & 0.221 \\
\hline Hibridos & PHAE & AP & $\mathbf{A E}$ & $\mathrm{CE}$ & DE & PG \\
\hline H1 & -0.425 & -2.880 & 0.953 & -0.550 & 0.150 & 0.126 \\
\hline $\mathrm{H} 2$ & 0.275 & 6.539 & 1.144 & 0.250 & 0.050 & 0.368 \\
\hline H3 & -0.525 & -5.259 & 0,495 & -0.250 & -0.150 & -0.300 \\
\hline H4 & 0.675 & 1.601 & -2.591 & 0.550 & -0.050 & -0.194 \\
\hline
\end{tabular}


Tabela 52. Efeitos de heterose de variedade $h_{1}$ no experimento $2 \mathrm{~A}$ para mancha de Phaeosphaeria, altura de planta (AP), altura da espiga (AE), comprimento de espiga (CE), diâmetro de espiga $(\mathrm{DE})$, e peso de grãos por parcela $(\mathrm{PG}) \mathrm{em} \mathrm{kg}$.

\begin{tabular}{crrrrrr}
\hline Acessos & PHAE & AP & AE & CE & DE & PG \\
\hline $\mathbf{1 s}$ & $-0,061$ & $-2,953$ & $-0,605$ & $-0,507$ & $-0,042$ & $-0,397$ \\
$\mathbf{2 s}$ & 0.139 & $-6,807$ & $-4,849$ & 0,318 & 0.083 & 0.131 \\
$\mathbf{3 s}$ & 0.264 & 1.963 & 0.424 & -0.007 & -0.017 & -0.202 \\
$\mathbf{4 s}$ & 0.214 & -3.436 & $-0,062$ & 0,018 & -0.017 & -0.183 \\
$\mathbf{5 s}$ & 0.064 & 5.549 & 3.488 & -0.482 & 0.058 & $-0,058$ \\
$\mathbf{6 s}$ & 0.139 & 0.147 & $-0,370$ & 0,393 & 0.033 & 0,133 \\
$\mathbf{7 s}$ & $-0,086$ & $-4,634$ & $-1,880$ & 0,168 & -0.117 & -0.152 \\
$\mathbf{8 s}$ & -0.236 & 1,621 & 4,954 & 0.368 & 0,033 & $-0,041$ \\
$\mathbf{9 s}$ & 0.039 & 1.851 & 2.635 & 0.068 & 0.083 & $-0,101$ \\
$\mathbf{1 0 s}$ & 0.014 & -0.159 & -2.400 & 0,418 & 0,083 & $-0,155$ \\
$\mathbf{1 1 s}$ & $-0,161$ & $-6,523$ & -1.058 & 0,043 & $-0,067$ & $-0,117$ \\
$\mathbf{1 2 s}$ & -0.161 & -0.088 & 1.331 & 0,143 & $-0,117$ & $-0,218$ \\
$\mathbf{1 3 s}$ & $-0,036$ & 2,509 & 2,743 & $-0,407$ & -0.092 & -0.175 \\
$\mathbf{1 4 s}$ & 0,114 & $-0,441$ & $-1,473$ & $-0,707$ & -0.067 & $-0,150$ \\
$\mathbf{1 5 s}$ & -0.136 & 0,862 & 2,772 & 0,193 & 0,233 & 0.141 \\
$\mathbf{1 6 s}$ & $-0,136$ & 1,442 & 3,824 & 0,168 & 0,233 & 0.045 \\
$\mathbf{1 7 s}$ & 0,339 & $-0,254$ & -2.120 & 0,018 & -0.067 & 0.101 \\
$\mathbf{1 8 s}$ & 0,089 & 1,620 & $-2,960$ & $-0,432$ & -0.092 & $-0,281$ \\
$\mathbf{1 9 s}$ & -0.111 & $-1,139$ & 0,995 & 0.143 & -0.042 & 0,037 \\
$\mathbf{2 0 s}$ & -0.361 & 4.344 & 1,471 & 0.593 & 0.058 & 0,218 \\
$\mathbf{2 1 s}$ & 0.139 & -1.136 & $-2,443$ & 0.318 & 0.083 & -0.051 \\
$\mathbf{2 2 s}$ & -0.136 & 3.175 & 3,007 & 0.818 & 0.008 & 0,470 \\
$\mathbf{2 3 s}$ & 0.164 & -1.485 & $-3,734$ & -0.632 & -0.017 & $-0,059$ \\
$\mathbf{2 4 s}$ & 0.264 & $-1,840$ & $-1,660$ & -0.407 & -0.042 & 0,068 \\
$\mathbf{2 5 s}$ & $-0,336$ & $-5,079$ & $-6,262$ & $-0,157$ & $-0,067$ & 0,055 \\
$\mathbf{2 6 s}$ & -0.136 & 11.617 & 9.020 & -0.282 & 0.008 & $-0,123$ \\
$\mathbf{2 7 s}$ & -0.286 & -0.084 & $-1,008$ & 0,368 & 0.058 & 0,307 \\
$\mathbf{2 8 s}$ & 0.414 & -1.984 & -3.549 & $-0,082$ & -0.067 & 0,353 \\
$\mathbf{3 0 s}$ & $-0,011$ & 1,343 & -0.233 & $-0,457$ & $-0,117$ & 0,400 \\
\hline Hibridos & $\mathbf{P H A E}$ & $\mathbf{A P}$ & $\mathbf{A E}$ & $\mathbf{C E}$ & $\mathbf{D E}$ & $\mathbf{P G}$ \\
\hline $\mathbf{H 1}$ & 0.200 & -2.368 & -2.209 & 0.200 & -0.062 & -0.172 \\
$\mathbf{H 2}$ & -0.054 & -2.899 & -0.812 & -0.145 & -0.084 & -0.093 \\
$\mathbf{H 3}$ & -0.037 & 2.076 & 1.061 & 0.350 & 0.198 & 0.334 \\
$\mathbf{H 4}$ & -0.109 & 3.192 & 1.960 & -0.405 & -0.052 & -0.069 \\
\hline & & & & & & \\
& & & & &
\end{tabular}


Tabela 53. Efeitos de capacidade geral de combinação $\mathrm{g}_{1}$ no experimento $2 \mathrm{~A}$ para mancha de Phaeosphaeria, altura de planta (AP), altura da espiga (AE), comprimento de espiga (CE), diâmetro de espiga (DE), e peso de grãos por parcela (PG) em kg.

\begin{tabular}{|c|c|c|c|c|c|c|}
\hline Acessos & PHAE & AP & $\mathbf{A E}$ & CE & DE & PG \\
\hline $1 \mathrm{~s}$ & $-0,135$ & $-19,652$ & $-10,736$ & $-0,865$ & $-0,2 \mathrm{ll}$ & -0.407 \\
\hline $2 s$ & $-0,035$ & $-23,831$ & $-16,964$ & 0,060 & 0,114 & $-0,007$ \\
\hline $3 s$ & 0.140 & -12.804 & $-9,650$ & $-0,215$ & $-0,086$ & $-0,326$ \\
\hline $4 s$ & 0.240 & -17.809 & $-12,100$ & -0.240 & 0,014 & $-0,286$ \\
\hline $5 \mathrm{~s}$ & 0,040 & 9.448 & 9.156 & -0.640 & -0.161 & -0.288 \\
\hline $6 s$ & 0.065 & 1.346 & 2.965 & 0.085 & 0.014 & -0.234 \\
\hline $7 s$ & 0.040 & 4.586 & 2.983 & 0.410 & -0.036 & -0.090 \\
\hline $8 s$ & -0.210 & -16.999 & -10.879 & -0.140 & -0.186 & -0.554 \\
\hline $9 s$ & 0.065 & $-12,953$ & $-8,354$ & $-0,240$ & 0,214 & -0.308 \\
\hline $10 \mathrm{~s}$ & 0.240 & -2.825 & $-6,011$ & 0,110 & 0,114 & $-0,187$ \\
\hline $11 \mathrm{~s}$ & $-0,035$ & 0.237 & $-0,384$ & 0,434 & 0,014 & 0,091 \\
\hline $12 \mathrm{~s}$ & -0.035 & $-2,394$ & $-2,640$ & 0,235 & 0,014 & $-0,030$ \\
\hline $13 s$ & -0.010 & 7.79 .3 & 5,440 & $-0,115$ & $-0,061$ & $-0,121$ \\
\hline $14 s$ & 090 & 5.381 & 3,705 & $-0,065$ & -0.036 & -0.112 \\
\hline $15 \mathrm{~s}$ & $-0,010$ & -1.565 & -1.279 & 0,135 & 0,214 & 0.227 \\
\hline $16 s$ & $-0,310$ & -11.401 & -7.303 & $-0,140$ & 0,264 & 0,438 \\
\hline $17 \mathrm{~s}$ & 0,265 & $-5,612$ & $-8,178$ & 0,160 & 0.214 & 0,132 \\
\hline $18 s$ & 0,065 & $-7,752$ & $-10,498$ & $-0,740$ & $-0,011$ & $-0,185$ \\
\hline $19 \mathrm{~s}$ & 0,015 & 19.990 & 18,843 & 0,385 & $-0,011$ & 0.057 \\
\hline $20 \mathrm{~s}$ & -0.135 & 18,877 & 11,368 & 0,935 & -0.061 & 0,343 \\
\hline $21 \mathrm{~s}$ & 0,215 & $-3,279$ & -7.079 & 0,660 & 0,164 & 0,222 \\
\hline $22 \mathrm{~s}$ & -0.210 & 11.332 & 9.785 & 0.860 & -0.211 & 0.342 \\
\hline $23 \mathrm{~s}$ & 0.090 & -8.922 & -10.967 & -0.490 & 0.014 & 0.153 \\
\hline $24 s$ & 0.240 & -8.138 & -5.466 & -0.516 & 0.089 & 0.224 \\
\hline $25 \mathrm{~s}$ & $-0,710$ & 19.614 & 17.519 & $-0,065$ & -0.086 & 0.383 \\
\hline $26 s$ & -0.010 & 6,440 & 8.924 & -0.290 & -0.161 & -0.284 \\
\hline $27 \mathrm{~s}$ & -0.260 & 23.233 & 19,075 & 0,160 & $-0,011$ & 0.300 \\
\hline $28 \mathrm{~s}$ & 0.340 & 14,563 & 12.938 & $-0,240$ & $-0,036$ & $-0,006$ \\
\hline $30 \mathrm{~s}$ & -0.035 & 13.095 & 5.792 & 0.385 & $-0,086$ & 0.510 \\
\hline Hibridos & PHAE & $\mathbf{A P}$ & $\mathbf{A E}$ & CE & DE & PG \\
\hline H1 & -0.013 & -3.808 & $-1,732$ & -0.075 & 0.013 & -0.109 \\
\hline H 2 & 0.084 & 0.370 & -0.240 & -0.020 & -0.059 & 0,091 \\
\hline H3 & -0.299 & -0.554 & 1.308 & 0.225 & 0.123 & 0.184 \\
\hline H4 & 0.228 & 3.992 & 0.665 & -0.130 & -0.077 & -0.166 \\
\hline
\end{tabular}


Tabela 54. Médias dos tratamentos do experimento 2C para mancha de Phaeosphaeria. ferrugem tropical, porcentagem de colmos quebrados (QUEB), porcentagem de plantas acamadas (ACAM), altura de planta (AP), altura da espiga (AE), comprimento de espiga (CE), diâmetro de espiga (DE) e peso de grãos por parcela (PG)

\begin{tabular}{|c|c|c|c|c|c|c|c|c|c|}
\hline Acessos & PHAE & PHYSO & QUEB & ACAM & AP & $\mathbf{A E}$ & $\mathrm{CE}$ & DE & PG \\
\hline $1 \mathrm{~s}$ & 4.3 & 3.5 & 17.27 & 11.66 & 185.0 & 95,0 & 15.6 & 4.2 & 3,212 \\
\hline $2 s$ & 3.9 & 3.5 & 14.51 & 13,15 & 212.5 & 97.5 & 16.1 & 4.5 & 3.836 \\
\hline $3 \mathrm{~s}$ & 4.3 & 4.0 & 3.88 & 11.64 & 215.0 & 120.0 & 15.0 & 4.5 & 3.339 \\
\hline $4 s$ & 5.0 & 4,0 & 9.27 & 2,86 & 210.0 & 102.5 & 14.7 & 4.4 & 3,692 \\
\hline $5 s$ & 4,0 & 3,5 & 13.29 & 42,99 & 220,0 & 125.0 & 15.4 & 3.4 & 1.885 \\
\hline $6 s$ & 3.1 & 3,5 & 25.66 & 16.37 & 237.5 & 135,0 & 15.7 & 4.5 & 3,460 \\
\hline $7 \mathrm{~s}$ & 3,3 & 3,8 & 2.78 & 23,11 & 227,5 & 130,0 & 17.3 & 4.6 & 4,074 \\
\hline $8 s$ & 3.8 & 3,8 & 31.00 & 46,00 & 210,0 & 112,5 & 13,0 & 3.8 & 1.828 \\
\hline $9 s$ & 3.3 & 4.0 & 13.98 & 18,19 & 227.5 & 120,0 & 14,4 & 4.9 & 2,526 \\
\hline $10 \mathrm{~s}$ & 4,0 & 4,3 & 8,45 & 29,00 & 208,8 & 110,0 & 15,8 & 4,8 & 4,258 \\
\hline $11 \mathrm{~s}$ & 4,8 & 3,3 & 8,84 & 4,42 & 222,5 & 125,0 & 17,0 & 4.6 & 4,299 \\
\hline $12 \mathrm{~s}$ & 4,5 & 3,0 & 11.19 & 6,45 & 231,3 & 117,5 & 17.9 & 4.8 & 4.499 \\
\hline $13 \mathrm{~s}$ & 3.5 & 3.8 & 9.97 & 26,72 & 222,5 & 127,5 & 16.6 & 4.6 & 4.309 \\
\hline $14 s$ & 4.0 & 3.5 & 17.92 & 16.87 & 227,5 & 130,0 & 16,8 & 4.5 & 4.194 \\
\hline $15 \mathrm{~s}$ & 3.9 & 4,0 & 2.86 & 5,27 & 228.8 & 133,8 & 16,2 & 4.8 & 4.780 \\
\hline $16 \mathrm{~s}$ & 3.5 & 3.3 & 8.82 & 8,95 & 217.5 & 117,5 & 14,7 & 4.6 & 4,493 \\
\hline $17 \mathrm{~s}$ & 4.0 & 3,3 & 3,57 & 15.26 & 227.5 & 107,5 & 15,7 & 4.8 & 4.583 \\
\hline $18 \mathrm{~s}$ & 4,0 & 3,5 & 3,23 & 8,06 & 220,0 & 115,0 & 15,1 & 4.5 & 4,006 \\
\hline $19 s$ & 4,3 & 3,3 & 16.67 & 25,64 & 260.0 & 152,5 & 17,7 & 4.7 & 5.321 \\
\hline $20 \mathrm{~s}$ & 3.0 & 3.0 & 10.82 & 43.33 & 235.0 & 145.0 & 16.2 & 4.4 & 3.533 \\
\hline $21 \mathrm{~s}$ & 3.8 & 4.0 & 8.66 & 5.20 & 225.0 & 122.5 & 16.6 & 4.9 & 5.385 \\
\hline $22 \mathrm{~s}$ & 2.5 & 3.5 & 5.73 & 10.31 & 242.5 & 147.5 & 16.8 & 4.3 & 3.350 \\
\hline $23 \mathrm{~s}$ & 3.9 & 3,8 & 12.41 & 20,12 & 220,0 & 120,0 & 16,0 & 4.6 & 4.466 \\
\hline $24 s$ & 3.1 & 3,5 & 6.39 & 11.31 & 217.5 & 115,0 & 16.0 & 4.3 & 4.369 \\
\hline $25 s$ & 3.0 & 3,3 & 11.46 & 5.57 & 220.0 & 132.5 & 15.1 & 4.2 & 2.696 \\
\hline $26 s$ & 3.5 & 3,5 & 17.19 & 47,40 & 215,0 & 117,5 & 16.8 & 4.2 & 3.342 \\
\hline $27 s$ & 4,3 & 3.8 & 13.16 & 27,95 & 232.5 & 135,0 & 16.6 & 4.5 & 3,892 \\
\hline $28 \mathrm{~s}$ & 3.0 & 3,3 & 14.50 & 16,48 & 247.5 & 165,0 & 15,3 & 4,8 & 3,264 \\
\hline $30 \mathrm{~s}$ & 3.0 & 3.6 & 5.03 & 3,78 & 240.0 & 132.5 & 17.9 & 4.5 & 4.630 \\
\hline Hibridos & PHAE & PHYSO & QUEB & ACAM & AP & $\mathrm{AE}$ & CE & $\mathrm{DE}$ & PG \\
\hline $\mathrm{H} 1$ & 3.5 & 3.3 & 1.35 & 2.70 & 212.5 & 107.5 & 13.9 & 4.8 & 3.952 \\
\hline $\mathrm{H} 2$ & 4.6 & 3.8 & 0.00 & 3.75 & 210.0 & 110.0 & 16.2 & 4.9 & 5.308 \\
\hline H3 & 3.8 & 3.3 & 3.27 & 1.92 & 202.5 & 107.5 & 15.3 & 4.8 & 3.777 \\
\hline $\mathrm{H4}$ & 4.9 & 3,0 & 0.00 & 2,63 & 225.0 & 110.0 & 16.0 & 4.7 & 3.886 \\
\hline Cruzamentos & PHAE & PHYSO & QUEB & ACAM & AP & $\mathrm{AE}$ & $\mathrm{CE}$ & $\mathrm{DE}$ & PG \\
\hline $1 \mathrm{s.} .1$ & 3.5 & 4.0 & 17.14 & 5,71 & 230.0 & 120.0 & 14.6 & 4.9 & 4.434 \\
\hline $1 \mathrm{s.} 2$ & 3.5 & 3.0 & 11.67 & 5.00 & 212.5 & 115.0 & 15.1 & 4.6 & 4.434 \\
\hline $1 \mathrm{s.} 3$ & 3.5 & 3.8 & 12.27 & 3.57 & 216.3 & 114.2 & 15.2 & 4.7 & 4.393 \\
\hline $1 s .4$ & 3.5 & 4.3 & 8.01 & 0.00 & 206.3 & 107.5 & 16.1 & 4.5 & 4.310 \\
\hline $2 \mathrm{s.} 1$ & 3.0 & 3.0 & 12.04 & 2.78 & 207.5 & 112.5 & 15.7 & 4.8 & 4.447 \\
\hline $2 \mathrm{~s} .2$ & 3.3 & 4.3 & 6.39 & 2.78 & 222.5 & 120.0 & 16.0 & 4.8 & 5.649 \\
\hline $2 s .3$ & 2.5 & 3.0 & 4.69 & 10.65 & 227.5 & 120.0 & 16.4 & 5.0 & 5.394 \\
\hline
\end{tabular}




\begin{tabular}{|c|c|c|c|c|c|c|c|c|c|}
\hline Cruzamentos & PHAE & PHYSO & QUEB & ACAM & AP & $\mathbf{A E}$ & CE & DE & PG \\
\hline $2 \mathrm{~s} .4$ & 4.3 & 4.0 & 4.29 & 4.06 & 226.3 & 112,5 & 16.9 & 4.9 & 4,800 \\
\hline $3 s .1$ & 4.3 & 3.5 & 5.48 & 4,02 & 217.5 & 110,0 & 15.2 & 4.7 & 4.625 \\
\hline $3 s .2$ & 4.0 & 4,0 & 11,05 & 0,00 & 225,0 & 120,0 & 16,7 & 4,8 & 5,491 \\
\hline $3 s .3$ & 2.8 & 3,4 & 4,55 & 8,68 & 235,0 & 127,5 & 15,7 & 4,9 & 4,819 \\
\hline $3 s .4$ & 4.5 & 3,5 & 1,32 & 1,28 & 215,0 & 115,0 & 17,7 & 4,7 & 5,056 \\
\hline 45.1 & 3,9 & 3,1 & 6,65 & 6,87 & 215,0 & 112,5 & 15,0 & 4,8 & 3,777 \\
\hline 45.2 & 3.6 & 3,8 & 4.41 & 1,47 & 232,5 & 115,0 & 16,1 & 4,7 & 4.885 \\
\hline $4 s .3$ & 3.6 & 3.5 & 5.16 & 3.57 & 237.5 & 132.5 & 14.8 & 4.8 & 4,756 \\
\hline 45.4 & 4.4 & 3.0 & 7.11 & 5.64 & 230,0 & 132,5 & 16.3 & 4,7 & 4.952 \\
\hline $5 \mathrm{~s} .1$ & 3.8 & 3.0 & 13.78 & 14.78 & 230.0 & 117,5 & 16.0 & 4.6 & 3,908 \\
\hline $5 s .2$ & 3.3 & 3.3 & 10.60 & 30.65 & 235.0 & 137.5 & 15.5 & 4.6 & 4.547 \\
\hline $5 s .3$ & 3.0 & 3.3 & 17.87 & 12.28 & 213.8 & 117,5 & 16.9 & 4.8 & 5.222 \\
\hline $5 s .4$ & 3.4 & 3,9 & 20.45 & 16,29 & 230,0 & 127,5 & 16.6 & 4,8 & 4.032 \\
\hline $6 s .1$ & 2.8 & 3.3 & 13.66 & 8,70 & 232.5 & 137,5 & 16,5 & 4,7 & 4,503 \\
\hline $6 s .2$ & 3.5 & 3.5 & 12.11 & 12,75 & 220.0 & 112.5 & 16,3 & 4,8 & 4,898 \\
\hline $6 s .3$ & 2.3 & 3,9 & 18,82 & 6,51 & 222.5 & 137,5 & 16,8 & 5.2 & 4,816 \\
\hline $6 s .4$ & 3.5 & 3.0 & 7,91 & 19,35 & 247,5 & 137.5 & 17,1 & 4.8 & 5,067 \\
\hline $7 s .1$ & 2.8 & 3.5 & 10.76 & 12,98 & 235,0 & 135.0 & 15.5 & 4.6 & 4,571 \\
\hline $7 \mathrm{~s} .2$ & 4.8 & 3.5 & 4,38 & 1,52 & 237.5 & 140,0 & 17,5 & 4.7 & 5,797 \\
\hline $7 \mathrm{~s} .3$ & 2,5 & 3,3 & 6,90 & 0,00 & 232.5 & 132,5 & 16,8 & 5,0 & 5,576 \\
\hline $7 \mathrm{~s} .4$ & 4.3 & 3,0 & 1,43 & 6,41 & 238,8 & 142,5 & 17,1 & 4,9 & 5,545 \\
\hline $8 s .1$ & 2.8 & 3,3 & 23.96 & 7,35 & 215,0 & 117,5 & 16,9 & 4.5 & 4,321 \\
\hline $8 s .2$ & 2.8 & 3,0 & 17.63 & 4.26 & 222.5 & 115.0 & 16.1 & 4.1 & 4.465 \\
\hline $8 s .3$ & 3.0 & 3.0 & 50.00 & 31.43 & 242.5 & 130,0 & 16.5 & 4.8 & 4.527 \\
\hline $8 s .4$ & 4.5 & 3.0 & 20.51 & 6,41 & 235,0 & 120,0 & 16,0 & 4.6 & 4.123 \\
\hline 9s. 1 & 3.0 & 3.5 & 9.21 & 6,58 & 220.0 & 117,5 & 16,1 & 5.0 & 5.297 \\
\hline $9 \mathrm{~s} .2$ & 3.1 & 3.6 & 4.88 & 6.25 & 230.0 & 120,0 & 15.9 & 5.0 & 4.649 \\
\hline $9 s .3$ & 2.8 & 3.3 & 4.79 & 7.92 & 227.5 & 120,0 & 16.8 & 5.1 & 4.605 \\
\hline $9 \mathrm{s.4}$ & 4.5 & 3.8 & 3.13 & 12,50 & 227.5 & 117.5 & 16.4 & 4.9 & 5.085 \\
\hline 10s.1 & 3.3 & 3.5 & 4.05 & 5,41 & 227.5 & 125.0 & 16.4 & 4.8 & 4.632 \\
\hline $10 \mathrm{~s} .2$ & 2.5 & 4.5 & 3.98 & 10.67 & 232.5 & 125.0 & 17.8 & 4.9 & 5.585 \\
\hline $10 \mathrm{~s} .3$ & 2.3 & 3.0 & 15.80 & 8.51 & 220.0 & 126,3 & 17.2 & 5,2 & 5,805 \\
\hline $10 \mathrm{~s} .4$ & 4,8 & 3,0 & 2,78 & 4,13 & 237,5 & 120,0 & 17,1 & 4,9 & 5,270 \\
\hline $11 \mathrm{~s} .1$ & 2.8 & 3,5 & 7,07 & 1,56 & 232.5 & 118,8 & 16,9 & 5,0 & 5,379 \\
\hline $11 \mathrm{~s} .2$ & 3.9 & 4.0 & 5.48 & 0,00 & 240,0 & 125,0 & 16,5 & 4.7 & 6,013 \\
\hline $11 \mathrm{~s} .3$ & 2.0 & 3.9 & 8.50 & 0.00 & 237.5 & 120,0 & 16.3 & 4.9 & 5.805 \\
\hline $11 \mathrm{s.4}$ & 5.3 & 3.3 & 0.00 & 0.00 & 240.0 & 132,5 & 16.5 & 5.0 & 5.129 \\
\hline $12 \mathrm{~s} .1$ & 4.5 & 3.0 & 7.35 & 10.13 & 232.5 & 120.0 & 17.7 & 5.0 & 5.397 \\
\hline $12 \mathrm{~s} .2$ & 3.3 & 4.0 & 6.79 & 0.00 & 228.8 & 121.3 & 16.8 & 4.9 & 5.455 \\
\hline $12 \mathrm{~s} .3$ & 2.0 & 3.5 & 11.90 & 0.00 & 225.0 & 122.5 & 16.5 & 5.2 & 5.726 \\
\hline $12 \mathrm{~s} .4$ & 4.5 & 3.0 & 2.94 & 4.19 & 240.0 & 127.5 & 16.6 & 4.7 & 5.602 \\
\hline $13 \mathrm{~s} .1$ & 2.5 & 3.3 & 9.98 & 1.35 & 237.5 & 140.0 & 16,2 & 4.9 & 4.800 \\
\hline $13 \mathrm{~s} .2$ & 3.8 & 3.0 & 9.11 & 13.06 & 250.0 & 132,5 & 16,2 & 4.8 & 5.534 \\
\hline $13 s .3$ & 2.8 & 3.3 & 5.16 & 3.95 & 242.5 & 135.0 & 17.3 & 5.1 & 5.634 \\
\hline $13 \mathrm{~s} .4$ & 4.0 & 3.3 & 7.94 & 1.47 & 227.5 & 127.5 & 17.0 & 4.8 & 4.891 \\
\hline $14 s .1$ & 3.3 & 3.3 & 4.05 & 4.09 & 230.0 & 140.0 & 17.1 & +6 & 5.273 \\
\hline $14 \mathrm{~s} .2$ & 3.5 & 3.5 & 10.81 & 12.16 & 237.5 & 132.5 & 16.3 & 4.8 & 5.407 \\
\hline $14 \mathrm{~s} .3$ & 2.3 & 4.0 & 13.43 & 18.53 & 217.5 & 135.0 & 16.3 & 5.0 & 3.067 \\
\hline
\end{tabular}




\begin{tabular}{|c|c|c|c|c|c|c|c|c|c|}
\hline Cruzamentos & PHAE & PHYSO & QUEB & ACAM & $\mathbf{A P}$ & $\mathbf{A E}$ & $\mathrm{CE}$ & DE & PG \\
\hline $14 \mathrm{~s} .4$ & 4,0 & 3,0 & 3.04 & 13,41 & 237,5 & 135,0 & 17,3 & 4,6 & 5,071 \\
\hline $15 \mathrm{~s} .1$ & 3,4 & 3.0 & 8.39 & 2,56 & 227.5 & 127.5 & 16.3 & 4.9 & 4,676 \\
\hline $15 \mathrm{~s} .2$ & 3.6 & 3.5 & 1.35 & 1,22 & 235,0 & 122.5 & 16.4 & 4,9 & 5.518 \\
\hline $15 \mathrm{~s} .3$ & 2.3 & 3,8 & 12.09 & 0.00 & 225.0 & 125,0 & 16,9 & 4,9 & 5,039 \\
\hline $15 \mathrm{~s} .4$ & 4.5 & 3,0 & 1.47 & 2,78 & 237.5 & 135.0 & 16,7 & 4,6 & 5,962 \\
\hline $16 s .1$ & 3,0 & 3,0 & 8.11 & 0,00 & 240,0 & 127,5 & 16.2 & 5,0 & 3,947 \\
\hline $16 \mathrm{~s} .2$ & 3,3 & 3,1 & 0,00 & 5,34 & 217,5 & 107,5 & 16,0 & 5,0 & 5,729 \\
\hline $16 \mathrm{~s} .3$ & 2.8 & 3.5 & 3,73 & 6,41 & 215,0 & 125,0 & 16.5 & 5.1 & 5,699 \\
\hline $16 s .4$ & 4.0 & 3.3 & 0.00 & 1.61 & 225.0 & 120.0 & 15.9 & 5.0 & 5.951 \\
\hline $17 \mathrm{~s} .1$ & 4.1 & 3.0 & 14.58 & 4,90 & 235.0 & 127.5 & 16.1 & 4.9 & 5,262 \\
\hline $17 \mathrm{~s} .2$ & 4,0 & 3.0 & 2.63 & 9.21 & 232.5 & 122,5 & 17.4 & 4,8 & 6.027 \\
\hline $17 \mathrm{~s} .3$ & 2.8 & 3.3 & 2.63 & 6.58 & 220,0 & 122,5 & 16.0 & 5,1 & 5,467 \\
\hline $17 \mathrm{s.4}$ & 2,8 & 3,5 & 0,00 & 9.35 & 237.5 & 135,0 & 17,2 & 4.9 & 5.250 \\
\hline $18 s .1$ & 3,0 & 3,5 & 3.23 & 7,80 & 222.5 & 120,0 & 16,4 & 4.8 & 4.835 \\
\hline $18 \mathrm{~s} .2$ & 2.8 & 4.3 & 4.35 & 11.65 & 230.0 & 117.5 & 16,0 & 4.7 & 4.593 \\
\hline $18 \mathrm{~s} .3$ & 3.3 & 3,0 & 6,41 & 1.28 & 225.0 & 122.5 & 16,7 & 4,9 & 5,186 \\
\hline $18 \mathrm{~s} .4$ & 4,9 & 3.8 & 1,92 & 0,00 & 225,0 & 112,5 & 17,1 & 4,9 & 4,960 \\
\hline $19 \mathrm{~s} .1$ & 3,4 & 3,0 & 4,41 & 7,18 & 240.0 & 135,0 & 16.4 & 4,8 & 5,319 \\
\hline $19 s .2$ & 3.5 & 4.0 & 8.89 & 5.03 & 237,5 & 130,0 & 17,4 & 4,6 & 5.825 \\
\hline $19 \mathrm{~s} .3$ & 2,9 & 3,5 & 3.95 & 5.26 & 242.5 & 142.5 & 13.7 & 8,3 & 6,114 \\
\hline $19 \mathrm{s.4}$ & 4,1 & 3,3 & 2,78 & 11,36 & 222.5 & 120,0 & 18,2 & 4,9 & 4,542 \\
\hline $20 \mathrm{~s} .1$ & 2,0 & 3,0 & 1,72 & 0,00 & 250,0 & 142.5 & 17.1 & 5,0 & 5.244 \\
\hline $20 \mathrm{~s} .2$ & 2,4 & 3,8 & 2.94 & 10.29 & 232.5 & 137.5 & 16.8 & 4,6 & 5.397 \\
\hline $20 \mathrm{~s} .3$ & 2.0 & 3,0 & 11,89 & 5,32 & 230.0 & 131.3 & 17.1 & 5,0 & 4.739 \\
\hline $20 \mathrm{s.4}$ & 4,1 & 3,4 & 7,89 & 9.00 & 250.0 & 130,0 & 17.1 & 4,7 & 5,295 \\
\hline $21 \mathrm{~s} .1$ & 3.5 & 3.8 & 0.00 & 2.63 & 242.5 & 145.0 & 16.5 & 5.0 & 5.668 \\
\hline $21 \mathrm{~s} .2$ & 3.1 & 4.3 & 4.05 & 1.35 & 240.0 & 132.5 & 16.9 & 5.0 & 6.443 \\
\hline $21 \mathrm{s.} 3$ & 2.3 & 3.5 & 1.22 & 8.57 & 220.0 & 120.0 & 16.6 & 4.9 & 5.787 \\
\hline $21 \mathrm{s.4}$ & 4,3 & 3,3 & 1,47 & 7.86 & 232.5 & 125,0 & 17.6 & 4.9 & 5.674 \\
\hline $22 s .1$ & 2,6 & 3,0 & 2.70 & 8,11 & 228,8 & 120,0 & 17.7 & 4,8 & 5.487 \\
\hline $22 \mathrm{~s} .2$ & 2,0 & 3,1 & 5.97 & 3.55 & 237.5 & 147,5 & 17.7 & 4.6 & 5.111 \\
\hline $22 s .3$ & 2,8 & 3.0 & 5.13 & 10.39 & 222.5 & 130,0 & 16,6 & 4.7 & 5.798 \\
\hline $22 s .4$ & 3.0 & 3.0 & 1.35 & 2.44 & 247,5 & 138,8 & 17.0 & 4.7 & 5.763 \\
\hline $23 s .1$ & 4,5 & 3,5 & 8,22 & 8,33 & 232,5 & 122,5 & 16,6 & 4.8 & 4,665 \\
\hline $23 \mathrm{~s} .2$ & 2.5 & 3.5 & 1.39 & 5,56 & 235,0 & 120,0 & 17.0 & 4.9 & 5,464 \\
\hline $23 s .3$ & 2.5 & 3.0 & 0.00 & 6.70 & 222.5 & 122.5 & 16.3 & 5.0 & 4.593 \\
\hline $23 s .4$ & 4.0 & 3.8 & 0.00 & 7.64 & 215.0 & 120.0 & 16.7 & 4.8 & 5.770 \\
\hline $24 s .1$ & 3.4 & 3.8 & 5.17 & 9.12 & 210.0 & 110.0 & 14.5 & 4.9 & +.610 \\
\hline $24 s .2$ & 4.6 & 3.5 & 3.23 & 4.84 & 227.5 & 112.5 & 16.8 & 4.9 & 5.444 \\
\hline $24 s .3$ & 2.6 & 3.0 & 9.89 & 1.61 & 222.5 & 120.0 & 16.2 & 5.0 & 4.869 \\
\hline $24 s .4$ & 5.0 & 3.5 & 6.22 & 0.00 & 225.0 & 115.0 & 16.3 & 4.6 & 5.268 \\
\hline $25 \mathrm{~s} .1$ & 2.1 & 3,0 & 6.64 & 2.48 & 235.0 & 142.5 & 15.7 & 4.7 & 5.274 \\
\hline $25 \mathrm{s.} 2$ & 2.3 & 3.5 & 8.23 & 2,74 & 242.5 & 142.5 & 16.7 & 4.8 & 4.753 \\
\hline $25 \mathrm{~s} .3$ & 2.5 & 3.3 & 11.32 & 1.32 & 233.8 & 152.5 & 16.8 & 5.1 & 4.789 \\
\hline $25 \mathrm{s.4}$ & 2.3 & 3.0 & 2.60 & 5.26 & 237.5 & 140.0 & 16.3 & 4.5 & 5.294 \\
\hline $26 s .1$ & 3.3 & 3.5 & 17.59 & 16.47 & 220.0 & 127.5 & 16.3 & 4.6 & +.198 \\
\hline $26 \mathrm{~s} .2$ & 3.1 & 4.3 & 3.75 & 8.81 & 235.0 & 135.0 & 15.4 & 4.5 & 5.118 \\
\hline $26 s .3$ & 2.5 & 3.0 & 11.11 & 13.89 & 215.0 & 125.0 & 17.7 & 4.9 & 5.393 \\
\hline
\end{tabular}




\begin{tabular}{cccrrrrrrr}
\hline Cruzamentos & PHAE & PHYSO QUEB & ACAM & AP & AE & CE & DE & PG \\
\hline $\mathbf{2 6 s . 4}$ & 3.5 & 3.8 & 6,67 & 2.38 & 232,5 & 127.5 & 17.8 & 4.6 & 5.224 \\
$\mathbf{2 7 s . 1}$ & 2.5 & 3,8 & 17,29 & 5,89 & 242,5 & 147,5 & 16.3 & 4.7 & 4.854 \\
$\mathbf{2 7 s . 2}$ & 2.8 & 3,5 & 5,00 & 6,66 & 248,8 & 157,5 & 16,3 & 4,3 & 5.531 \\
$\mathbf{2 7 s . 3}$ & 2.8 & 3,2 & 11,91 & 0,00 & 237,5 & 142,5 & 16,4 & 4,9 & 5,475 \\
$\mathbf{2 7 s . 4}$ & 3,5 & 4,0 & 2,90 & 4,29 & 255,0 & 147,5 & 17,2 & 4,9 & 5,179 \\
$\mathbf{2 8 s . 1}$ & 2.9 & 3,5 & 4,17 & 1,39 & 235,0 & 130,0 & 15,8 & 4,9 & 4,873 \\
$\mathbf{2 8 s . 2}$ & 3.5 & 3,8 & 13,83 & 5.26 & 245,0 & 150,0 & 16.0 & 4.9 & 5.020 \\
$\mathbf{2 8 s . 3}$ & 2.3 & 3.5 & 6.06 & 5.97 & 220.0 & 137.5 & 16,9 & 5.0 & 4.907 \\
$\mathbf{2 8 s . 4}$ & 4.6 & 3.8 & 4.17 & 5,71 & 237.5 & 140,0 & 15,9 & 5.0 & 4,918 \\
$\mathbf{3 0 s . 1}$ & 3.0 & 3.0 & 6,76 & 14,86 & 240,0 & 137.5 & 17,5 & 5.1 & 3,967 \\
30s.2 & 3.8 & 3,5 & 6.78 & 3,03 & 252.5 & 137.5 & 17.1 & 4.8 & 5.359 \\
30s.3 & 2.5 & 3.0 & 4.55 & 0.00 & 232.5 & 135.0 & 17.2 & 4.7 & 5.401 \\
30s.4 & 3.6 & 3,5 & 6.91 & 0.00 & 242.5 & 137.5 & 17.1 & 4.7 & 5.270 \\
\hline Testemunhas & PHAE & PHYSO QUEB & ACAM & AP & AE & CE & DE & PG \\
\hline T1 & 2,0 & 3,1 & 2,10 & 0.84 & 229.8 & 123.8 & 16,7 & 5.2 & 6.585 \\
T2 & 2.2 & 3,8 & $\mathbf{4}, 60$ & 27,17 & 250,9 & 140.0 & 16.7 & 5,0 & 5,136 \\
\hline
\end{tabular}

Tabela 55. Resumo das análises de variância do experimento $2 \mathrm{C}$ para mancha de Phaeosphaeria, ferrugem tropical, porcentagem de colmos quebrados (QUEB) e porcentagem de plantas acamadas (ACAM).

\begin{tabular}{|c|c|c|c|c|c|}
\hline \multirow[b]{2}{*}{ FV } & \multicolumn{2}{|r|}{ QM } & \multirow[b]{2}{*}{ PHYSO } & \multirow[b]{2}{*}{ QUEB $\times 10^{4}$} & \multirow[b]{2}{*}{ ACAM $\times 10^{3}$} \\
\hline & GL & PHAE & & & \\
\hline Repetição & 1 & 0.436 & 9.300 & 7.863 & 78,968 \\
\hline Tratamentos & 150 & $1.505 * *$ & $0.295 * *$ & $7.680 * *$ & $27.827 * *$ \\
\hline Dialelo & 148 & $1.211^{* *}$ & $0.275^{* *}$ & $7.251 * *$ & $22.293 * *$ \\
\hline Acessos & 28 & $1.348^{* *}$ & $0.286^{* *}$ & $106.238^{* *}$ & $902.820^{* *}$ \\
\hline Hibridos & 3 & $20,028 * *$ & $1,462 * *$ & $16.388 * *$ & $49.355^{* *}$ \\
\hline Entre grupos & 1 & $2,893 * *$ & $1,292 * *$ & $29.721^{* *}$ & 1,368 \\
\hline Heterose & 116 & $0,677 * *$ & $0.232 * *$ & 3,611 & 8.711 \\
\hline H. média & 1 & $11,304 * *$ & 0,021 & 9,435 & $58.047 *$ \\
\hline H. Acessos & 28 & 0,396 & 0.213 & 4.259 & 11.888 \\
\hline H. Hibridos & 3 & $1,144^{*}$ & 0.068 & 1.238 & 0.358 \\
\hline H. especifica & 84 & $0.627^{* *}$ & $0.247 * *$ & $3 .+10$ & 7.363 \\
\hline Testemunhas & 1 & 0,330 & $3.611^{* *}$ & 7.950 & $780 .+89^{* *}$ \\
\hline Dialelo rs Testemunha & 1 & $46.169 * *$ & 0.023 & $70.929 * *$ & $94.137 * *$ \\
\hline Resíduo & 178 & 0.398 & 0.157 & 3.283 & 9.851 \\
\hline Dentro test./rep. & 28 & 0.077 & 0.089 & 2.906 & 19.344 \\
\hline Erro & 150 & 0.457 & 0.170 & 3.353 & 8.079 \\
\hline$\overline{C V \%}$ & & 19.26 & 11.52 & 41,16 & 22.59 \\
\hline Média geral & & 3.27 & 3.44 & 7.98 & 8.52 \\
\hline
\end{tabular}

** e * indicam. respectivamente, significância ao nível de $1 \%$ e de $5 \%$ de probabilidade. 
Tabela 56. Resumo das análises de variância do experimento 2C para altura de planta (AP), altura da espiga (AE), comprimento de espiga (CE), diâmetro de espiga (DE) e peso de grãos por parcela (PG)

\begin{tabular}{|c|c|c|c|c|c|c|}
\hline \multirow[b]{2}{*}{ FV } & \multirow[b]{2}{*}{ GL } & \multicolumn{4}{|c|}{$\mathbf{Q M}$} & \multirow[b]{2}{*}{ PG } \\
\hline & & $\overline{\mathbf{A P}}$ & $\mathbf{A E}$ & CE & $\mathrm{DE}$ & \\
\hline Repetição & 1 & 486,87 & 1183,71 & 8,909 & 0,431 & 2,818 \\
\hline Tratamentos & 150 & $312.00 * *$ & $308.23 * *$ & $1.506 * *$ & $0.315^{* *}$ & $1,621 * *$ \\
\hline Dialelo & 148 & $267.33^{* *}$ & $292.56 * *$ & $1.507 * *$ & $0,292^{* *}$ & $1.322^{* *}$ \\
\hline Acessos & 28 & $631,44^{* *}$ & $977,58^{* *}$ & $3,038^{* *}$ & $0,376^{* *}$ & $2.276^{* *}$ \\
\hline Hibridos & 3 & $662.97 * *$ & 14,80 & $4.892 * *$ & $1.131^{* *}$ & $3.545 * *$ \\
\hline Entre grupos & 1 & 355,13 & 4.22 & $3,422^{*}$ & $4,958^{* *}$ & $47,370 * *$ \\
\hline Heterose & 116 & $168,45^{* *}$ & $136.88^{*}$ & $1.033 * *$ & 0.209 & $0,637 * *$ \\
\hline H. média & 1 & $3885,21^{* *}$ & $3115,81^{* *}$ & $17.790 * *$ & $0.985^{*}$ & $28,023 * *$ \\
\hline H. Acessos & 28 & 138,03 & $168,04^{*}$ & $1,012 *$ & 0,120 & 0.395 \\
\hline H. Hibridos & 3 & 79.95 & 6.54 & 0,930 & 0.205 & 0.627 \\
\hline H. especifica & 84 & $137.50 *$ & 95,68 & 0.844 & 0,230 & 0,392 \\
\hline Testemunhas & 1 & $3559,57^{* *}$ & $2112.50^{* *}$ & 0,008 & 0,451 & $16.805 * *$ \\
\hline Dialelo vs Testemunha & 1 & $3676,73 * *$ & $823.08 * *$ & $2,914^{* *}$ & $3,681^{* *}$ & $30,771 * *$ \\
\hline Resíduo & 178 & 105.30 & 107.01 & 0.666 & 0,173 & 0.377 \\
\hline Dentro test./rep. & 28 & 84.85 & 47,99 & 0.726 & 0,016 & 0.381 \\
\hline Erro & 150 & 109,12 & 118,03 & 0.655 & 0.202 & 0.376 \\
\hline CV\% & & 4,46 & 8.14 & 4.98 & 8,68 & 12,46 \\
\hline Média geral & & 230,20 & 127.06 & 16.39 & 4.79 & 4.93 \\
\hline
\end{tabular}

** e * indicam, respectivamente, significância ao nivel de $1 \%$ e de $5 \%$ de probabilidade. 
Tabela 57. Efeitos de variedade $v_{i}$ no experimento $2 \mathrm{C}$ para mancha de Phaeosphaeria, ferrugem tropical, porcentagem de colmos quebrados (QUEB), porcentagem de plantas acamadas (ACAM), altura de planta (AP), altura da espiga (AE), comprimento de espiga (CE), diâmetro de espiga (DE) e peso de grãos por parcela (PG)

\begin{tabular}{|c|c|c|c|c|c|c|c|c|c|}
\hline Acessos & PHA & PHY & QUE & $\mathbf{A C A}$ & AP & $\mathbf{A E}$ & CE & $\mathrm{DE}$ & PG \\
\hline $1 \mathrm{~s}$ & 0.521 & -0.073 & 0,076 & $-0,064$ & $-39,353$ & $-29,353$ & $-0,400$ & $-0,290$ & $-0,636$ \\
\hline $2 s$ & 151 & -0.073 & 0.042 & -0.047 & -11.853 & -26.853 & 0.100 & 0,010 & -0.006 \\
\hline $3 s$ & 0.521 & 0.427 & -0.092 & -0.066 & $-9,353$ & -4.353 & $-1,000$ & 0.010 & -0.506 \\
\hline $4 s$ & 1.271 & 0,427 & $-0,020$ & $-0,184$ & -14.353 & -21.853 & -1.300 & -0.090 & -0.156 \\
\hline $5 s$ & 0.271 & -0.073 & 0.030 & 0,268 & $-4,353$ & 0.647 & $-0,600$ & $-1,090$ & $-1,966$ \\
\hline $6 s$ & -0.599 & -0.073 & 0.167 & $-0,012$ & 13.147 & 10,647 & -0.300 & 0.010 & $-0,386$ \\
\hline $7 \mathrm{~s}$ & -0.479 & 0.177 & -0.109 & 0,064 & 3.147 & 5.647 & 1.300 & 0.110 & 0.225 \\
\hline $8 s$ & 0.021 & 0.177 & 0.222 & 0.298 & -14.353 & $-11,853$ & $-3,000$ & -0.690 & $-2,016$ \\
\hline $9 s$ & -0.479 & 0.427 & 0,038 & 0,010 & 3,147 & $-4,353$ & $-1,600$ & 0.410 & $-1,316$ \\
\hline $10 \mathrm{~s}$ & 0.271 & 0.677 & -0.031 & 0,126 & $-15,603$ & $-14,353$ & -0.200 & 0,310 & 0,415 \\
\hline $11 \mathrm{~s}$ & 1.021 & -0.323 & $-0,026$ & $-0,159$ & $-1,853$ & 0,647 & 1,000 & 0,110 & 0,455 \\
\hline $12 \mathrm{~s}$ & 0.771 & $-0,573$ & 0,003 & $-0,138$ & 6,897 & $-6,853$ & 1,900 & 0,310 & 0,655 \\
\hline $13 \mathrm{~s}$ & -0.229 & 0.177 & $-0,010$ & 0,100 & -1.853 & 3.147 & 0.600 & 0.110 & 0,465 \\
\hline $14 \mathrm{~s}$ & 0.271 & -0.073 & 0.083 & $-0,004$ & 3,147 & 5,647 & 0,800 & 0.010 & 0,345 \\
\hline $15 \mathrm{~s}$ & 0.151 & 0,427 & $-0,108$ & $-0,148$ & 4,397 & 9.397 & 0.200 & 0,310 & 0,935 \\
\hline $16 s$ & $-0,229$ & $-0,323$ & $-0,030$ & $-0,098$ & $-6,853$ & $-6,853$ & $-1,300$ & 0,110 & 0,645 \\
\hline $17 \mathrm{~s}$ & 0.27 & -0.323 & $-0,099$ & $-0,025$ & 3,147 & $-16,853$ & $-0,300$ & 0,310 & 0,735 \\
\hline $18 \mathrm{~s}$ & 0.271 & -0.073 & $-0,103$ & $-0,119$ & $-4,353$ & -9.353 & $-0,900$ & 0,010 & 0,165 \\
\hline $19 \mathrm{~s}$ & 0.521 & -0.323 & 0,069 & 0.088 & 35,647 & 28,147 & 1,700 & 0.210 & 1.475 \\
\hline $20 s$ & -0.729 & -0.573 & 0.000 & 0.271 & 10,647 & 20,647 & 0,200 & $-0,090$ & $-0,316$ \\
\hline $21 \mathrm{~s}$ & 0.021 & 0.427 & -0.032 & -0.148 & 0.647 & -1.853 & 0.600 & 0.410 & 1,545 \\
\hline $22 \mathrm{~s}$ & -1.229 & -0.073 & -0.065 & $-0,082$ & 18.147 & 23.147 & 0.800 & $-0,190$ & -0.496 \\
\hline $23 \mathrm{~s}$ & 0.151 & 0.177 & 0,016 & 0.029 & $-4,353$ & -4.353 & 0.000 & 0.110 & 0.625 \\
\hline $24 \mathrm{~s}$ & -0.599 & -0.073 & $-0,056$ & -0.069 & $-6,853$ & -9.353 & 0,000 & $-0,190$ & 0,525 \\
\hline $25 \mathrm{~s}$ & -0.729 & -0.323 & 0.004 & -0.143 & -4.353 & 8.147 & -0.900 & $-0,290$ & $-1,1+6$ \\
\hline $26 s$ & -0.229 & -0.073 & 0.052 & 0.318 & -9.353 & -6.853 & 0.800 & -0.290 & -0.506 \\
\hline $27 \mathrm{~s}$ & 0.521 & 0.177 & 0.011 & 0.115 & 8.147 & 10.647 & 0.600 & 0.010 & 0.045 \\
\hline $28 s$ & -0.729 & -0.323 & 0,044 & $-0,012$ & 23.147 & +0.647 & $-0,700$ & 0.310 & $-0,586$ \\
\hline $30 \mathrm{~s}$ & -0.729 & 0,057 & $-0,076$ & $-0,168$ & 15,647 & 8,147 & 1,900 & 0,010 & 0,785 \\
\hline Híbridos & PHA & PHY & QUE & ACA & $\mathbf{A P}$ & $\mathrm{AE}$ & CE & DE & PG \\
\hline $\mathrm{H} 1$ & -0.690 & -0.063 & 0.003 & -0.001 & 0.000 & -1.250 & -1.450 & 0.000 & -0.283 \\
\hline $\mathrm{H} 2$ & 0.440 & $0 .+38$ & -0.018 & 0.014 & -2.500 & 1.250 & 0.850 & 0.100 & 1.078 \\
\hline $\mathrm{H} 3$ & $-0.4+0$ & -0.063 & 0.033 & -0.012 & -10.000 & -1.250 & -0.050 & 0.000 & $-0 .+53$ \\
\hline $\mathrm{H4}$ & 0.690 & -0.313 & -0.018 & -0.002 & 12.500 & 1.250 & 0.650 & -0.100 & -0.343 \\
\hline
\end{tabular}


Tabela 58. Efeitos de heterose de variedade $h_{i}$ no experimento $2 \mathrm{C}$ para mancha de Phaeosphaeria. ferrugem tropical, porcentagem de colmos quebrados (QUEB), porcentagem de plantas acamadas (ACAM), altura de planta (AP), altura da espiga (AE), comprimento de espiga $(\mathrm{CE})$, diâmetro de espiga (DE) e peso de grãos por parcela $(\mathrm{PG})$

\begin{tabular}{|c|c|c|c|c|c|c|c|c|c|}
\hline Acessos & PHA & PHY & QUE & ACA & AP & $\mathbf{A E}$ & CE & DE & PG \\
\hline $1 \mathrm{~s}$ & -0.048 & 0.372 & 0,027 & $-0,001$ & 5.054 & 1.147 & -1.058 & $-0,046$ & $-0,387$ \\
\hline $2 \mathrm{~s}$ & -0.113 & 0.185 & $-0,028$ & 0,010 & -4.009 & 1.979 & $-0,316$ & 0,017 & $-0,020$ \\
\hline $3 s$ & 0.327 & -0.033 & 0,022 & $-0,001$ & $-3,071$ & -7.396 & 0.309 & $-0,083$ & 0,155 \\
\hline 45 & $-0,043$ & $-0,283$ & $-0,007$ & 0,070 & 5.054 & 6.354 & -0.316 & -0.058 & -0.425 \\
\hline $5 \mathrm{~s}$ & -0.078 & -0.033 & 0,089 & 0,016 & -1.509 & -3.021 & 0.034 & 0,392 & 0,315 \\
\hline $6 s$ & 0.012 & 0.030 & $-0,009$ & 0,075 & -6.821 & -1.771 & 0,309 & 0,017 & -0.080 \\
\hline $7 \mathrm{~s}$ & 0.514 & -0.190 & 0,035 & $-0,046$ & 3.491 & 6.979 & -0.441 & -0.108 & 0,165 \\
\hline $8 s$ & -0.048 & $-0,440$ & 0,129 & $-0,080$ & 5,054 & -1.146 & 1.359 & $-0,008$ & 0,270 \\
\hline $9 s$ & 297 & -0.095 & $-0,041$ & 0,020 & $-6,196$ & $-6,771$ & 0,584 & $-0,058$ & 0,473 \\
\hline $10 \mathrm{~s}$ & -0.236 & -0.253 & 0,005 & $-0,045$ & 6,304 & 3,542 & 0,709 & $-0,058$ & 0.018 \\
\hline $11 \mathrm{~s}$ & -0.328 & 0,405 & $-0,014$ & 0,000 & 7.554 & -3.958 & $-0,466$ & $-0,008$ & 0,258 \\
\hline $12 \mathrm{~s}$ & $-0,111$ & 0,247 & $-0,002$ & 0,034 & $-2,759$ & $-1,458$ & $-0,566$ & $-0,058$ & 0,125 \\
\hline $13 \mathrm{~s}$ & 0,077 & $-0,315$ & 0,017 & $-0,066$ & 9,429 & 4,479 & $-0,141$ & $-0,008$ & $-0,115$ \\
\hline $14 \mathrm{~s}$ & $-0,173$ & 0,060 & $-0,035$ & 077 & $-1,821$ & 5.104 & $-0,166$ & $-0,108$ & $-0,562$ \\
\hline $15 \mathrm{~s}$ & 0.077 & -0.315 & 0,032 & 0,013 & -1.821 & -4.896 & -0.041 & $-0,183$ & $-0,262$ \\
\hline $16 \mathrm{~s}$ & 0,077 & $-0,033$ & $-0,046$ & 0,011 & -3.071 & -4.271 & 0.284 & 0,117 & -0.085 \\
\hline $17 \mathrm{~s}$ & -0.016 & $-0,065$ & 0,016 & 0,035 & -1.19 & 7.604 & 0.309 & $-0,083$ & 0,040 \\
\hline $18 \mathrm{~s}$ & 0.047 & 0.2 & 0,007 & 0,047 & -3.071 & -4.896 & 0,484 & -0.033 & $-0,285$ \\
\hline $19 \mathrm{~s}$ & $-0,076$ & 0,185 & $-0,065$ & $-0,027$ & $-13,071$ & $-9,896$ & $-0,941$ & 0,692 & $-0,382$ \\
\hline $20 \mathrm{~s}$ & -0.296 & 0,155 & $-0,016$ & $-0,135$ & 4,429 & $-2,708$ & 0,409 & 0.017 & 0.230 \\
\hline $21 \mathrm{~s}$ & -0.016 & 0.060 & $-0,062$ & 0,062 & 2.554 & 3.854 & 0.084 & -0.108 & 0.025 \\
\hline $22 \mathrm{~s}$ & -0.078 & -0.345 & $-0,013$ & 0,041 & -5.884 & -5.208 & 0.334 & -0.058 & 0.693 \\
\hline $23 \mathrm{~s}$ & 0.012 & -0.065 & $-0,076$ & $-0,002$ & -2.446 & -4.271 & 0.134 & -0.033 & -0.285 \\
\hline $24 \mathrm{~s}$ & 0.922 & 0.060 & 0,013 & 0,005 & -6.196 & $-8,646$ & -0.566 & 0.092 & $-0,310$ \\
\hline $25 \mathrm{~s}$ & -0.641 & $-0,065$ & $-0,002$ & 0,030 & 8.491 & 12,604 & 0,309 & 0,067 & 0,503 \\
\hline $26 s$ & -0.078 & 0,247 & 0,004 & $-0,104$ & -0.571 & 4,479 & $-0,116$ & -0.058 & 0,140 \\
\hline $27 \mathrm{~s}$ & -0.673 & 0,105 & 0,018 & $-0,081$ & 10.991 & 15,729 & -0.266 & -0.158 & 0,140 \\
\hline $28 \mathrm{~s}$ & 0,392 & 0.372 & $-0,026$ & $-0,014$ & -8.071 & $-8,646$ & -0.016 & -0.058 & 0.128 \\
\hline $30 \mathrm{~s}$ & 0.297 & -0.193 & 0,026 & 0,057 & 3.179 & 5,104 & $-0,241$ & $-0,033$ & $-0,487$ \\
\hline Híbridos & PHA & PHY & QUE & ACA & AP & $\mathbf{A E}$ & $\mathrm{CE}$ & $\mathrm{DE}$ & PG \\
\hline H1 & 0.248 & -0.077 & 0,016 & 0,003 & -1.088 & 0.039 & 0.458 & -0.032 & -0.187 \\
\hline $\mathrm{H} 2$ & -0.205 & 0.001 & 0,000 & $-0,005$ & 3.998 & -0.607 & -0.434 & -0.162 & -0.319 \\
\hline H3 & -0.459 & -0.062 & 0,011 & 0,009 & 1.067 & 1.347 & -0.038 & 0.221 & 0.283 \\
\hline $\mathrm{H4}$ & 0.416 & 0.138 & $-0,027$ & $-0,007$ & -3.976 & -0.779 & 0.014 & -0.027 & 0.222 \\
\hline
\end{tabular}


Tabela 59. Efeitos de capacidade geral de combinação $\mathrm{g}_{\mathrm{i}}$ no experimento $2 \mathrm{C}$ para mancha de Phaeosphaeria. ferrugem tropical, porcentagem de colmos quebrados (QUEB), porcentagem de plantas acamadas (ACAM), altura de planta (AP), altura da espiga (AE), comprimento de espiga $(\mathrm{CE})$, diâmetro de espiga (DE) e peso de grãos por parcela (PG).

\begin{tabular}{|c|c|c|c|c|c|c|c|c|c|}
\hline Acessos & PHA & PHY & QUE & ACA & AP & $\mathbf{A E}$ & $\mathrm{CE}$ & DE & PG \\
\hline $1 \mathrm{~s}$ & 0,212 & 0.335 & 0,065 & $-0,034$ & $-14,623$ & $-13,530$ & $-1,258$ & -0.191 & $-0,705$ \\
\hline $2 s$ & -0.038 & 0.148 & $-0,007$ & $-0,014$ & -9.935 & -11.448 & $-0,266$ & 0.022 & -0.022 \\
\hline $3 s$ & 0.587 & 0.180 & -0.023 & -0.034 & -7.748 & -9.573 & $-0,191$ & -0.078 & -0.097 \\
\hline $4 s$ & 0,592 & -0.070 & $-0,018$ & $-0,021$ & -2.123 & -4.573 & -0.966 & -0.103 & -0.502 \\
\hline $5 s$ & 0,057 & -0.070 & 0.104 & 0,150 & -3.685 & $-2,698$ & $-0,266$ & -0.153 & -0.667 \\
\hline $6 s$ & -0.288 & -0.007 & 0,075 & 0,069 & -0.248 & 3.552 & 0,159 & 0.022 & -0.272 \\
\hline $7 \mathrm{~s}$ & 0.275 & -0.102 & -0.020 & -0.014 & 5.065 & 9.802 & 0.209 & -0.053 & 0.278 \\
\hline $8 \mathrm{~s}$ & -0.038 & -0.352 & 0.240 & 0,069 & $-2,123$ & $-7,073$ & -0.141 & -0.353 & -0.737 \\
\hline $9 s$ & 0.057 & 0.118 & -0.022 & 0,025 & -4.623 & -8.948 & $-0,216$ & 0.147 & -0.185 \\
\hline $10 \mathrm{~s}$ & -0.100 & 0.085 & -0.010 & 0,018 & -1.498 & -3.635 & 0.609 & 0,097 & 0.225 \\
\hline $11 \mathrm{~s}$ & 0.182 & 0.243 & $-0,027$ & $-0,080$ & 6.627 & $-3,635$ & 0,034 & 0,047 & 0,485 \\
\hline $12 \mathrm{~s}$ & 0,275 & $-0,040$ & $-0,001$ & $-0,035$ & 0,690 & & 0,384 & 0,0 & 0,453 \\
\hline $13 \mathrm{~s}$ & -0.038 & -0.227 & 0,013 & $-0,016$ & 8,502 & & 0,159 & 0.047 & 0,118 \\
\hline $14 \mathrm{~s}$ & $-0,038$ & 0.023 & 0,007 & 0,075 & $-0,248$ & 7,927 & 0,234 & -0.103 & -0.390 \\
\hline $15 \mathrm{~s}$ & 0.152 & -0.102 & $-0,022$ & $-0,061$ & 0,377 & $-0,198$ & 0.059 & $-0,028$ & 0.205 \\
\hline $16 \mathrm{~s}$ & -0.038 & $-0,195$ & $-0,060$ & $-0,038$ & $-6,498$ & $-7,698$ & $-0,366$ & 0,172 & 0,238 \\
\hline $17 \mathrm{~s}$ & 0.120 & -0.227 & -0.034 & 0,023 & 0.377 & $-0,823$ & 0.159 & 0.072 & 0,408 \\
\hline $18 \mathrm{~s}$ & 0,182 & 0,210 & $-0,045$ & $-0,013$ & -5.248 & -9.573 & 0,034 & -0.028 & -0.202 \\
\hline $19 \mathrm{~s}$ & 0.185 & 0.023 & $-0,031$ & 0,017 & 4.752 & 4.177 & $-0,091$ & 0,797 & 0.355 \\
\hline $20 \mathrm{~s}$ & $-0,660$ & -0.132 & $-0,016$ & 0.001 & 9.752 & 7,615 & 0.509 & $-0,028$ & 0.073 \\
\hline $21 \mathrm{~s}$ & -0.005 & 0.273 & $-0,078$ & -0.012 & 2.877 & 2.927 & 0,384 & 0,097 & 0,798 \\
\hline $22 \mathrm{~s}$ & -0.693 & -0.382 & $-0,046$ & 0,000 & 3.190 & 6.365 & 0.734 & -0.153 & 0.445 \\
\hline $23 \mathrm{~s}$ & 0.087 & 0.023 & -0.068 & 0.013 & -4.623 & -6.448 & 0.134 & 0.022 & 0.028 \\
\hline $24 \mathrm{~s}$ & 0.622 & 0.023 & -0.015 & -0.030 & -9.623 & -13.323 & -0.566 & -0.003 & -0.047 \\
\hline $25 \mathrm{~s}$ & -1.005 & -0.227 & 0.000 & $-0,042$ & 6.315 & 16.677 & -0.141 & -0.078 & -0.070 \\
\hline $26 \mathrm{~s}$ & -0.193 & 0.210 & 0.030 & 0.055 & -5.248 & 1.052 & 0.284 & -0.203 & -0.112 \\
\hline $27 \mathrm{~s}$ & -0.413 & 0.193 & 0,024 & $-0,024$ & 15.065 & 21.052 & 0,034 & $-0,153$ & 0.163 \\
\hline $28 \mathrm{~s}$ & 0.027 & 0.210 & $-0,003$ & $-0,020$ & 3,502 & 11.677 & -0.366 & 0,097 & $-0,165$ \\
\hline $30 \mathrm{~s}$ & -0.068 & -0.165 & $-0,012$ & $-0,028$ & 11,002 & 9.177 & 0,709 & $-0,028$ & $-0,095$ \\
\hline Hibridos & PHA & PHY & QUE & ACA & AP & $\mathbf{A E}$ & $\mathrm{CE}$ & $\mathrm{DE}$ & PG \\
\hline H1 & -0.097 & -0.108 & 0.017 & 0.003 & -1.088 & -0.586 & -0.268 & -0.032 & -0.328 \\
\hline $\mathrm{H} 2$ & 0.015 & 0.219 & -0.009 & 0.002 & 2.748 & 0.018 & -0.009 & -0.112 & 0.220 \\
\hline H3 & -0.679 & -0.093 & 0.028 & 0.003 & -3.933 & 0.722 & -0.063 & 0.221 & 0.057 \\
\hline $\mathrm{H} 4$ & 0.761 & -0.018 & -0.036 & $-0,008$ & 2,274 & -0.154 & 0,339 & -0.077 & 0.051 \\
\hline
\end{tabular}


Tabela 60. Médias dos tratamentos do experimento 2R para mancha de Phaeosphaeria. porcentagem de plantas com enfezamento (ENFE), porcentagem de plantas acamadas (ACAM), altura de planta (AP), altura da espiga (AE) e peso de grãos por parcela (PG).

\begin{tabular}{|c|c|c|c|c|c|c|}
\hline Acessos & PHAE & ENFE & ACAM & AP & $\mathbf{A E}$ & PG \\
\hline $1 \mathrm{~s}$ & 5.1 & 0,0 & 16,11 & 177.2 & 83,1 & 1,881 \\
\hline $2 s$ & 4,8 & 0,0 & 10,67 & 180,4 & 88,1 & 2,301 \\
\hline $3 s$ & 4,8 & 0,0 & 9,95 & 188,5 & 94,4 & 2,321 \\
\hline $4 s$ & 4.9 & 0.0 & 11.20 & 198.1 & 98,8 & 2.358 \\
\hline $5 \mathrm{~s}$ & 4.4 & 0.0 & 18,42 & 206.0 & 103.8 & 2.096 \\
\hline $6 s$ & 5.0 & 0.0 & 11.38 & 212.7 & 118.1 & 2.225 \\
\hline $7 \mathrm{~s}$ & 3.6 & 0.0 & 12,69 & 233.6 & 121.3 & 3.871 \\
\hline $8 s$ & 4.9 & 0,0 & 29.47 & 168.0 & 81.9 & 1.391 \\
\hline $9 s$ & 4.9 & 0,9 & 11,00 & 184.4 & 93,1 & 1,740 \\
\hline $10 \mathrm{~s}$ & 4,4 & 0,0 & 8,12 & 211,2 & 111,9 & 2,658 \\
\hline $11 \mathrm{~s}$ & 4.5 & 0,0 & 6,44 & 223,3 & 120,0 & 3.694 \\
\hline $12 \mathrm{~s}$ & 4.6 & 0,7 & 6,67 & 220,6 & 119,4 & 3,486 \\
\hline $13 \mathrm{~s}$ & 3.8 & 1,5 & 9.29 & 218,0 & 115,6 & 3,451 \\
\hline $14 \mathrm{~s}$ & 4,4 & 0,0 & 9,65 & 219,4 & 120,0 & 3,381 \\
\hline $15 \mathrm{~s}$ & 4,3 & 0,0 & 5,60 & 216,4 & 116,9 & 3,026 \\
\hline $16 s$ & 3.2 & 0,0 & 7,40 & 199,4 & 105,0 & 3.103 \\
\hline $17 \mathrm{~s}$ & 4,5 & 0,0 & 10,85 & 213,1 & 108,1 & 3,006 \\
\hline $18 \mathrm{~s}$ & 4.4 & 0.8 & 8,89 & 201,7 & 104.4 & 3,089 \\
\hline $19 \mathrm{~s}$ & 3.4 & 0.0 & 9,37 & 242,3 & 141,9 & 3.280 \\
\hline $20 \mathrm{~s}$ & 4.0 & 0,8 & 16.12 & 230.8 & 126,9 & 2.014 \\
\hline $21 \mathrm{~s}$ & 4.1 & 0.0 & 7,95 & 212.3 & 110,0 & 3,479 \\
\hline $22 \mathrm{~s}$ & 2,9 & 1,6 & 7,75 & 229.1 & 133.1 & 2,901 \\
\hline $23 \mathrm{~s}$ & 4.1 & 1,7 & 11,88 & 213.5 & 106.9 & 3.061 \\
\hline $24 \mathrm{~s}$ & 4.1 & 1.0 & 8.98 & 200.4 & 100.6 & 2.816 \\
\hline $25 \mathrm{~s}$ & 2.3 & 0.0 & 11,12 & 239.1 & 136.3 & 2.680 \\
\hline $26 s$ & 4,1 & 0,0 & 13,08 & 212,8 & 117.5 & 2.978 \\
\hline $27 \mathrm{~s}$ & 3,4 & 0,8 & 8,14 & 250,8 & 138.1 & 3,089 \\
\hline $28 s$ & 3.5 & 0,0 & 17,93 & 223,7 & 130,6 & 2,306 \\
\hline $30 \mathrm{~s}$ & 3,6 & 0,0 & 6.47 & 225.9 & 121,9 & 3,449 \\
\hline Híbridos & PHAE & ENFE & ACAM & AP & $\mathbf{A E}$ & PG \\
\hline H1 & 3.5 & 1,5 & 7,03 & 208,1 & 106,9 & 2,340 \\
\hline $\mathrm{H} 2$ & 4.0 & 0.0 & 9.41 & 208.1 & 106.3 & 2.889 \\
\hline H3 & 3.7 & 2.1 & 6.10 & 210.2 & 106.3 & 2.691 \\
\hline $\mathrm{H4}$ & 4.1 & 0.0 & 6.66 & 211.1 & 112.5 & 2.804 \\
\hline Cruzamentos & PHAE & ENFE & ACAM & AP & $\mathbf{A E}$ & PG \\
\hline $1 \mathrm{~s} .1$ & 5.1 & 0.0 & 7.69 & 192.6 & 103.8 & 2.528 \\
\hline $1 \mathrm{~s} .2$ & 5.1 & 0,0 & 7,24 & 184.2 & 93.8 & 2.505 \\
\hline $1 \mathrm{~s} .3$ & 3.9 & 0,0 & 9,37 & 194.2 & 98.8 & 3.604 \\
\hline $1 \mathrm{s.4}$ & 5.0 & 0.0 & 6.45 & 200.9 & 101.3 & 5.280 \\
\hline $2 \mathrm{s.} 1$ & 4.3 & 0.0 & 7.87 & 195.5 & 98.1 & 2.726 \\
\hline $2 \mathrm{s.} 2$ & 3.9 & 0.0 & 7.94 & 209.8 & 103.8 & 3.603 \\
\hline $2 \mathrm{~s} .3$ & 3.7 & 0.7 & 7.03 & 196.6 & 102.5 & 3.881 \\
\hline $2 s .4$ & 4.3 & 1.5 & 8.46 & 204.6 & 105.6 & 3.696 \\
\hline $3 \mathrm{~s} .1$ & 4.1 & 0.8 & 7.67 & 193.7 & 99.4 & 2.833 \\
\hline
\end{tabular}




\begin{tabular}{|c|c|c|c|c|c|c|}
\hline Cruzamentos & PHAE & ENFE & ACAM & AP & AE & PG \\
\hline $3 \mathrm{~s} .2$ & 4.6 & 0,0 & 7,26 & 212,4 & 113.8 & 3,425 \\
\hline $3 \mathrm{~s} .3$ & 3,9 & 0,0 & 6,45 & 201,3 & 108.8 & 3.571 \\
\hline $3 s .4$ & 4.4 & 0,0 & 9,83 & 199.0 & 95.6 & 3.239 \\
\hline $4 \mathrm{~s} .1$ & 4,1 & 1,5 & 5,91 & 174,8 & 99,4 & 3.134 \\
\hline $4 s .2$ & 4.0 & 0,0 & 7,36 & 191,7 & 98.8 & 3,170 \\
\hline $4 s .3$ & 4,0 & 0,0 & 6,44 & 226,1 & 113,8 & 3,418 \\
\hline $4 s .4$ & 4,3 & 3,2 & 6,83 & 199,1 & 95.0 & 3,101 \\
\hline $5 s .1$ & 4.1 & 0,0 & 15,85 & 215,4 & 116.3 & 2,891 \\
\hline $5 s .2$ & 4.2 & 0,0 & 8,73 & 223.9 & 120,6 & 3,449 \\
\hline $5 s .3$ & 3.9 & 0,0 & 10,87 & 212.4 & 115.0 & 3.270 \\
\hline $5 s .4$ & 4.0 & 0.9 & 10.08 & 212.7 & 113.1 & 3.244 \\
\hline $6 s .1$ & 4.9 & 0.0 & 8.22 & 218.9 & 119.4 & 3.363 \\
\hline $6 s .2$ & 4.5 & 0.0 & 8.29 & 219.6 & 120.6 & 3.980 \\
\hline $6 s .3$ & 3.8 & 0,0 & 6,84 & 216.5 & 118.1 & 4.339 \\
\hline $6 s .4$ & 4.4 & 0.0 & 6,24 & 217.3 & 118.1 & 3.666 \\
\hline $7 \mathrm{s.} 1$ & 3.6 & 0,0 & 7,88 & 234,5 & 126,9 & 3,868 \\
\hline $7 \mathrm{~s} .2$ & 3.5 & 0.0 & 6,79 & 229.3 & 128,8 & 4,195 \\
\hline $7 s .3$ & 3.6 & 1.3 & 5,58 & 232,3 & 118.1 & 4,001 \\
\hline $7 \mathrm{s.} 4$ & 3.9 & 0.0 & 9.67 & 236.1 & 130.0 & 4.000 \\
\hline $8 s .1$ & 3.9 & 0.7 & 12.04 & 192.9 & 100.0 & 2.473 \\
\hline $8 s .2$ & 4,3 & 0,0 & 14,28 & 196,7 & 98.8 & 2,743 \\
\hline $8 s .3$ & 2,6 & 0,0 & 10,18 & 213,5 & 106,3 & 3,103 \\
\hline $8 s .4$ & 4,9 & 0,8 & 9,32 & 213.8 & 110,0 & 3.040 \\
\hline 9s.1 & 3.9 & 0,0 & 7.21 & 209.0 & 108,8 & 3.311 \\
\hline $9 \mathrm{~s} .2$ & 4.1 & 0,0 & 6.40 & 210.2 & 110,0 & 3.330 \\
\hline $9 \mathrm{~s} .3$ & 3.0 & 0.0 & 8.20 & 204.5 & 108.1 & 3,605 \\
\hline $9 s .4$ & 4.8 & 0.0 & 6.14 & 203.9 & 105.6 & 3,165 \\
\hline $10 \mathrm{~s} .1$ & 3.8 & 0,0 & 9.62 & 212.6 & 111.3 & 3.128 \\
\hline $10 \mathrm{~s} .2$ & 3.7 & 0,0 & 9,88 & 212.2 & 109,4 & 3.554 \\
\hline $10 \mathrm{~s} .3$ & 3.4 & 0.0 & 6,94 & 214.7 & 120,0 & 3.509 \\
\hline $10 \mathrm{~s} .4$ & 4.9 & 0,7 & 6,13 & 215.5 & 112.5 & 3.301 \\
\hline $11 \mathrm{~s} .1$ & 3.8 & 0.0 & 7,80 & 217.7 & 116.3 & 3.819 \\
\hline $11 \mathrm{~s} .2$ & 3.9 & 0.0 & 7.56 & 228.2 & 120.6 & 4,194 \\
\hline $11 \mathrm{~s} .3$ & 3.4 & 0,0 & 5,57 & 218.5 & 116.9 & 4,644 \\
\hline $11 \mathrm{~s} .4$ & 4.1 & 0,7 & 6,94 & 221.0 & 121.9 & 3.658 \\
\hline $12 \mathrm{~s} .1$ & 4.0 & 0.0 & 7.36 & 215.7 & 112.5 & 3.636 \\
\hline $12 \mathrm{~s} .2$ & 4.5 & 0.7 & 10.40 & 214.2 & 113.1 & 4.239 \\
\hline $12 \mathrm{~s} .3$ & 3.3 & 0.7 & 7.01 & 220.6 & 123.1 & 4.894 \\
\hline $12 \mathrm{~s} .4$ & 4.3 & 0.0 & 6.55 & 225.4 & 121.9 & 3.869 \\
\hline $13 \mathrm{~s} .1$ & 3.6 & 0.0 & 6.28 & 210.1 & 117.5 & 3,736 \\
\hline $13 \mathrm{~s} .2$ & 3.8 & 0.0 & 8.36 & 227.5 & 123.8 & 4.128 \\
\hline $13 \mathrm{~s} .3$ & 3.1 & 0.7 & 6.51 & 224.7 & 126.3 & 4.245 \\
\hline $13 \mathrm{~s} .4$ & 3.8 & 0.8 & 7.15 & 228.3 & 123.8 & 4.191 \\
\hline $14 \mathrm{~s} .1$ & 4.2 & 0.0 & 8.45 & 234.5 & 129.4 & 4.100 \\
\hline $14 \mathrm{~s} .2$ & 3.8 & 0.0 & 8.91 & 234.2 & 120.6 & 3.844 \\
\hline $14 s .3$ & 2.9 & 0.0 & 6.30 & 230.3 & 124.4 & 4.225 \\
\hline $14 \mathrm{s.4}$ & 4.1 & 0.0 & 8.28 & 221.4 & 120.6 & 3.830 \\
\hline $15 \mathrm{~s} .1$ & 3.3 & 0.0 & 6.88 & 232.9 & 120.6 & 3.425 \\
\hline
\end{tabular}




\begin{tabular}{|c|c|c|c|c|c|c|}
\hline Cruzamentos & PHAE & ENFE & ACAM & AP & $\mathbf{A E}$ & PG \\
\hline $15 \mathrm{~s} .2$ & 3.6 & 0.0 & 7,12 & 211,1 & 116,3 & 3.698 \\
\hline $15 \mathrm{~s} .3$ & 3.7 & 0,0 & 5,64 & 227,3 & 122,5 & 4.848 \\
\hline $15 \mathrm{~s} .4$ & 3.8 & 0.8 & 6,69 & 221,7 & 116,3 & 3,858 \\
\hline $16 \mathrm{~s} .1$ & 3.5 & 0.0 & 7.40 & 223.0 & 115,0 & 3,465 \\
\hline $16 \mathrm{~s} .2$ & 3.4 & 3.5 & 6.59 & 203.3 & 108.1 & 3.665 \\
\hline $16 \mathrm{~s} .3$ & 2.8 & 0,6 & 6.24 & 214.3 & 116,9 & 4,291 \\
\hline $16 \mathrm{s.t}$ & 3.8 & 0.7 & 7,16 & 206,8 & 109.4 & 4,391 \\
\hline $17 \mathrm{~s} .1$ & 3.6 & 0.0 & 8.67 & 213.9 & 111.3 & 3.571 \\
\hline $17 \mathrm{~s} .2$ & 4.4 & 0.0 & 8,54 & 206.8 & 106.3 & 3.819 \\
\hline $17 \mathrm{~s} .3$ & 3.3 & 0.8 & 9,07 & 202.4 & 103.8 & 4.229 \\
\hline $17 \mathrm{~s} .4$ & 4.1 & 0.6 & 6,38 & 210.6 & 107.5 & 3,834 \\
\hline $18 \mathrm{~s} .1$ & 3.8 & 0.8 & 8.54 & 214.5 & 110.0 & 3.390 \\
\hline $18 \mathrm{~s} .2$ & 3.9 & 0.7 & 6,40 & 216,7 & 115,0 & 3.501 \\
\hline $18 \mathrm{~s} .3$ & 4,0 & 0.7 & 5,60 & 219,9 & 112.5 & 4,196 \\
\hline $18 s .4$ & 4.3 & 0.0 & 7,46 & 206,1 & 106.9 & 3.190 \\
\hline 19s. 1 & 4.3 & 0,0 & 7,23 & 229,3 & 124.4 & 3,744 \\
\hline $19 \mathrm{~s} .2$ & 3,9 & 0,0 & 8,44 & 231,1 & 128,1 & 4.060 \\
\hline $19 \mathrm{~s} .3$ & 2,9 & 0,0 & 6,21 & 229,7 & 121,9 & 3,891 \\
\hline 19s.4 & 3,8 & 0,0 & 6,32 & 226,3 & 123,8 & 4,155 \\
\hline $20 \mathrm{~s} .1$ & 3.2 & 0.7 & 7.25 & 231,3 & 128.8 & 4.186 \\
\hline $20 \mathrm{~s} .2$ & 3.4 & 0.0 & 9.97 & 229.9 & 128.1 & 4.210 \\
\hline $20 \mathrm{~s} .3$ & 2.9 & 0.0 & 6.64 & 235.0 & 134,4 & 4.520 \\
\hline $20 \mathrm{~s} .4$ & 3.0 & 0.0 & 6.68 & 238.0 & 260.1 & 3.651 \\
\hline $21 \mathrm{~s} .1$ & 3.8 & 2.1 & 6,19 & 212,6 & 111,3 & 3,260 \\
\hline $21 \mathrm{~s} .2$ & 4.0 & 0,7 & 6.67 & 218,1 & 113,8 & 3,633 \\
\hline $21 \mathrm{~s} .3$ & 3.3 & 0.8 & 5,83 & 217.6 & 115.6 & 4,598 \\
\hline $21 \mathrm{s.4}$ & 3.8 & 1.4 & 7.38 & 217.4 & 113.1 & 3.839 \\
\hline $22 \mathrm{s.} .1$ & 2.6 & 0.0 & 6.06 & 234.1 & 134.4 & 3.778 \\
\hline $22 \mathrm{~s} .2$ & 3.1 & 0.7 & 5.82 & 231.0 & 126.3 & 4.171 \\
\hline $22 s .3$ & 2.6 & 0.0 & 5.95 & 237.9 & 138.1 & 4.655 \\
\hline $22 \mathrm{s.} .4$ & 3.3 & 0,0 & 5.43 & 231,9 & 125,6 & 4.179 \\
\hline $23 \mathrm{~s} .1$ & 3.5 & 0,0 & 9.17 & 214,8 & 109,4 & 3.229 \\
\hline $23 \mathrm{~s} .2$ & 3.7 & 0.0 & 8.83 & 221,4 & 118.8 & 3.669 \\
\hline $23 \mathrm{~s} .3$ & 3.7 & 0,0 & 7.25 & 213,6 & 115.6 & 4.248 \\
\hline $23 \mathrm{s.4}$ & 3.9 & 0.0 & 6.75 & 210,7 & 111,9 & 4,044 \\
\hline $24 s .1$ & 3.9 & 1.5 & 7.36 & 217.6 & 114.4 & 2.928 \\
\hline $24 s .2$ & 4.1 & 0.0 & 8.25 & 206.5 & 103.8 & 3.544 \\
\hline $24 s .3$ & 2.9 & 0.0 & 7.09 & 215.3 & 113,8 & 3.785 \\
\hline $24 s .4$ & 3.7 & 0.0 & 6.82 & 222.5 & 115.0 & 3.965 \\
\hline $25 \mathrm{~s} .1$ & 2.4 & 0.6 & 7.84 & $2+9.2$ & 140.0 & 3.739 \\
\hline $25 \mathrm{~s} .2$ & 2.6 & 0.0 & 7.29 & 239.3 & 136.3 & 3.893 \\
\hline $25 \mathrm{~s} .3$ & 2.0 & 0.0 & 5.55 & 235.6 & 130.6 & 4.474 \\
\hline 255.4 & 2.5 & 0.0 & 6.29 & 236.5 & 136.3 & 3.919 \\
\hline $26 s .1$ & 4.1 & 0.8 & 7.77 & 221.4 & 123.8 & 3.526 \\
\hline $26 s .2$ & 4.3 & 0.0 & 9.11 & 217.1 & 119.4 & 3.359 \\
\hline $26 \mathrm{~s} .3$ & 3.5 & 0.0 & 6.59 & 218.9 & 120.0 & 4.429 \\
\hline $26 s .4$ & 4.0 & 0.0 & 8.94 & 238.1 & 128.8 & 4.084 \\
\hline $27 \mathrm{~s} .1$ & 3.5 & 0.0 & 9.45 & 237.7 & 130.6 & 3.956 \\
\hline
\end{tabular}




\begin{tabular}{cccrrrr}
\hline Cruzamentos & PHAE & ENFE & ACAM & AP & AE & PG \\
\hline $\mathbf{2 7 s . 2}$ & 3.4 & 0,0 & 6,63 & 240,8 & 140,6 & 4.274 \\
$\mathbf{2 7 s . 3}$ & 2.6 & 0.0 & 5.49 & 238.5 & 135,6 & 4.245 \\
$\mathbf{2 7 s . 4}$ & 3.4 & 0,0 & 6,62 & 239,0 & 139.4 & 3.704 \\
$\mathbf{2 8 s . 1}$ & 3,7 & 0,8 & 7,82 & 222.2 & 115,6 & 3.613 \\
$\mathbf{2 8 s . 2}$ & 2.9 & 0,7 & 8,32 & 239,7 & 135,6 & 4.266 \\
$\mathbf{2 8 s . 3}$ & 2,8 & 1,5 & 6,45 & 226,4 & 126,9 & 4,253 \\
$\mathbf{2 8 s . 4}$ & 3.8 & 0,0 & 6,82 & 240,2 & 135,6 & 4.028 \\
$\mathbf{3 0 s . 1}$ & 3.7 & 1.5 & 7.35 & 228,7 & 120.0 & 3.970 \\
$\mathbf{3 0 s . 2}$ & 3.3 & 1.4 & 6.50 & 232.7 & 126,9 & 4.045 \\
$\mathbf{3 0 s . 3}$ & 3.1 & 0,7 & 7,03 & 215,5 & 121,9 & 4,605 \\
$\mathbf{3 0 s . 4}$ & 3.3 & 0,0 & $\mathbf{5 , 7 2}$ & 225,3 & 123,8 & 4,129 \\
\hline Testemunhas & PHAE & ENFE & ACAM & AP & AE & PG \\
\hline T1 & 1.9 & 0,0 & $\mathbf{5 , 6 3}$ & 218,4 & 118,6 & $\mathbf{5 , 1 7 1}$ \\
T2 & 2.1 & 0.0 & $\mathbf{5 , 7 7}$ & $\mathbf{2 4 2 , 3}$ & 132.7 & $\mathbf{5 , 0 7 1}$ \\
\hline
\end{tabular}

Tabela 61. Resumo das análises de variância do experimento $2 \mathrm{R}$ para mancha de Phaeosphaeria. porcentagem de plantas com enfezamento (ENFE), porcentagem de plantas acamadas (ACAM), altura de planta (AP), altura da espiga (AE) e peso de grãos por parcela (PG).

\begin{tabular}{|c|c|c|c|c|c|c|c|}
\hline & & & & $\mathbf{Q M}$ & & & \\
\hline FV & GL & $\begin{array}{l}\text { PHAE } \\
10^{3}\end{array}$ & $\begin{array}{l}\text { STUNT } \\
10^{4}\end{array}$ & ACAM & AP & $\mathbf{A E}$ & PG \\
\hline Repetição & 3 & 3,222 & 3.267 & 4.848 & 1206,89 & 491,61 & 2,787 \\
\hline Tratamentos & 150 & $2,815^{* *}$ & $1,596 * *$ & $4.291 * *$ & $1037,55 * *$ & $1169.70 * *$ & $2.749 * *$ \\
\hline Dialelo & 148 & $1.589 * *$ & $1.566^{* *}$ & $4,079 * *$ & $922.11^{* *}$ & $1134.21^{* *}$ & $1.823^{* *}$ \\
\hline Acessos & 28 & $\overline{5.015 * *}$ & $\overline{1.326}-$ & $\overline{1} 1 . \overline{3} 79^{* *}$ & $\overline{3} \overline{79} \overline{2}, \overline{5} \overline{5 *}-$ & $\overline{3} 22 \overline{5}, \overline{78 * \bar{*}}$ & $3.07 \overline{1}^{* *}$ \\
\hline Hibridos & 3 & $10,805^{* *}$ & 0,900 & $4.934^{* *}$ & 124,79 & 678.13 & $8.950 * *$ \\
\hline Entre grupos & 1 & $13.155^{* *}$ & 1.288 & $118.901 * *$ & $1787,63^{* *}$ & 1076.67 & $46.901 * *$ \\
\hline Heterose & 116 & $0.424^{*}$ & $1.644 * *$ & $1.306 * *$ & $2+2.40 * *$ & $641,64 * *$ & $0.949 * *$ \\
\hline H. média & 1 & $3.194 * *$ & 3,865 & $15.364 * *$ & $3134,53 * *$ & $3214.27 * *$ & $53.277 * *$ \\
\hline H. Acessos & 28 & 0.394 & $2.109 * *$ & $3.061 * *$ & $246,65^{* *}$ & 538,04 & $0.582 *$ \\
\hline H. Húbridos & 3 & $0,995^{*}$ & $4,494 * *$ & 0,369 & 4,27 & 21,30 & 0,812 \\
\hline H. especifica & 84 & 0,381 & 1.360 & 0.586 & $215.05^{* *}$ & $667,70 * *$ & 0,453 \\
\hline Téstemunhas & $\overline{1}$ & $\overline{1.000}$ & 0.000 & $-\overline{0.031}$ & $\overline{9} \overline{1} \overline{4}, \overline{1} \overline{4 * \bar{*}}-$ & $\overline{3} \overline{199} . \overline{3} \overline{2}^{*} \bar{*}$ & $0 . \overline{16} \overline{1}^{-\cdots}$ \\
\hline Dialelo is Testem. & 1 & $186.083^{* *}$ & $7.651 * *$ & $39.828 * *$ & $10016.76^{* *}$ & $+391.45 * *$ & $142.401 * *$ \\
\hline Resíduo & 506 & 0.317 & 1.110 & 0.860 & 123.12 & $4+9.77$ & 0.360 \\
\hline Dentro test./rep. & 56 & 0.157 & 0,000 & 0.061 & 71,80 & 51.69 & $0.2+1$ \\
\hline Erro & 450 & 0.337 & 1.248 & 0.959 & 129.51 & 499.31 & 0.375 \\
\hline $\mathrm{CV} \%$ & & 15.52 & 1.34 & 3.39 & 5.08 & 18.00 & 16.21 \\
\hline Média geral & & 3.63 & 0.36 & 8.22 & 218.42 & 117.79 & 3.70 \\
\hline
\end{tabular}

** $\mathrm{e}^{*}$ indicam. respectivamente. significância ao nivel de $1 \%$ e de $5 \%$ de probabilidade. 
Tabela 62. Efeitos de variedade $v_{i}$ no experimento $2 \mathbf{R}$ para mancha de Phaeosphaeria. porcentagem de plantas com enfezamento (ENFE), porcentagem de plantas acamadas (ACAM), altura de planta (AP), altura da espiga (AE) e peso de grãos por parcela (PG).

\begin{tabular}{|c|c|c|c|c|c|c|}
\hline Acessos & PHAE & ENFE & ACAM & AP & $\mathbf{A E}$ & PG \\
\hline $1 \mathrm{~s}$ & 0,925 & -0.003 & 0,051 & $-34,991$ & -29.547 & $-0,916$ \\
\hline $2 s$ & 0,612 & $-0,003$ & $-0,005$ & $-31,791$ & $-24,547$ & $-0,496$ \\
\hline $3 s$ & 0.675 & -0.003 & -0.013 & $-23,651$ & $-18,297$ & -0.476 \\
\hline $4 s$ & 0.800 & $-0,003$ & $-0,001$ & $-14,031$ & -13.922 & -0.440 \\
\hline $5 s$ & 0.237 & -0.003 & 0,075 & $-6,201$ & $-8,922$ & $-0,701$ \\
\hline $6 s$ & 0.862 & $-0,003$ & 0,001 & 0,579 & 5,453 & $-0,573$ \\
\hline $7 s$ & -0.513 & -0.003 & 0.015 & 21.489 & 8.578 & 1.074 \\
\hline $8 s$ & 0.800 & -0.003 & 0.220 & -44.131 & -30.797 & $-1,406$ \\
\hline $9 s$ & 0,800 & 0.005 & $-0,002$ & $-27,741$ & -19.547 & $-1,058$ \\
\hline $10 \mathrm{~s}$ & 0.237 & $-0,003$ & $-0,032$ & $-0,981$ & $-0,797$ & $-0,140$ \\
\hline $11 \mathrm{~s}$ & 0.362 & $-0,003$ & $-0,049$ & 11,099 & 7,328 & 0,896 \\
\hline $12 \mathrm{~s}$ & 0,487 & 0,003 & $-0,047$ & 8,479 & 6.703 & 0,689 \\
\hline $13 \mathrm{~s}$ & $-0,388$ & 0.012 & $-0,020$ & 5,889 & 2.953 & 0,654 \\
\hline $14 s$ & 0.237 & -0.003 & $-0,017$ & 7,219 & 7,328 & 0,584 \\
\hline $15 \mathrm{~s}$ & 0.175 & $-0,003$ & $-0,058$ & 4,289 & 4,203 & 0,228 \\
\hline $16 s$ & $-0,950$ & $-0,003$ & -0.040 & $-12,781$ & -7.672 & 0,305 \\
\hline $17 \mathrm{~s}$ & 0,362 & $-0,003$ & $-0,004$ & 0,969 & $-4,547$ & 0,209 \\
\hline $18 \mathrm{~s}$ & 300 & 0,005 & $-0,024$ & $-10,441$ & $-8,297$ & 0.291 \\
\hline $19 \mathrm{~s}$ & -0.700 & $-0,003$ & $-0,020$ & 30.099 & 29.203 & 0.482 \\
\hline $20 s$ & -0.138 & 0,004 & 0,050 & 18.639 & 14.203 & $-0,784$ \\
\hline $21 \mathrm{~s}$ & -0.013 & $-0,003$ & $-0,034$ & 0,109 & -2.672 & 0.681 \\
\hline $22 \mathrm{~s}$ & -1.263 & 0.013 & -0.036 & 16,899 & 20.453 & 0.104 \\
\hline $23 \mathrm{~s}$ & $-0,013$ & 0,013 & 0,006 & 1,369 & $-5,797$ & 0.264 \\
\hline $24 s$ & -0.075 & 0.007 & -0.024 & $-11,771$ & -12.047 & 0.019 \\
\hline $25 \mathrm{~s}$ & -1.888 & $-0,003$ & -0.002 & 26,919 & 23.578 & -0.118 \\
\hline $26 s$ & -0.013 & $-0,003$ & 0,019 & 0,629 & 4.828 & 0,180 \\
\hline $27 \mathrm{~s}$ & $-0,700$ & 0,004 & $-0,032$ & 38,599 & 25,453 & 0.291 \\
\hline $28 s$ & $-0,638$ & $-0,003$ & 0,071 & 11.519 & 17,953 & $-0,491$ \\
\hline $30 \mathrm{~s}$ & -0.575 & -0.003 & -0.049 & 13,719 & 9.203 & 0.651 \\
\hline Hibridos & PHAE & ENFE & ACAM & AP & $\mathbf{A E}$ & PG \\
\hline H1 & $-0,303$ & 0.006 & -0.003 & -1.278 & -1.094 & -0.341 \\
\hline $\mathbf{H} 2$ & 0.197 & -0.009 & 0.021 & -1.288 & $-1,719$ & 0.208 \\
\hline H3 & -0.153 & 0.012 & -0.012 & 0.853 & -1.719 & 0.010 \\
\hline $\mathrm{H4}$ & 0.259 & -0.009 & -0.006 & 1.713 & 4.531 & 0.123 \\
\hline
\end{tabular}


Tabela 63. Efeitos de heterose de variedade $h_{i}$ no experimento $2 R$ para mancha de Phaeosphaeria, porcentagem de plantas com enfezamento (ENFE), porcentagem de plantas acamadas (ACAM), altura de planta (AP), altura da espiga (AE) e peso de grãos por parcela (PG).

\begin{tabular}{|c|c|c|c|c|c|c|}
\hline Acessos & PHAE & ENFE & ACAM & AP & AE & PG \\
\hline $1 \mathrm{~s}$ & 0.601 & $-0,002$ & $-0,024$ & $-8,172$ & $-4,177$ & 0,167 \\
\hline $2 s$ & 0.023 & 0,004 & 0.005 & -1.167 & -3.552 & $-0,045$ \\
\hline $3 s$ & 0.163 & 0.000 & 0.009 & -5.239 & -4.802 & $-0,265$ \\
\hline $4 s$ & -0.018 & 0.010 & -0.009 & -13.737 & -9.645 & -0.344 \\
\hline $5 s$ & 0.195 & 0,000 & 0,002 & 0,523 & 2.386 & $-0,206$ \\
\hline $6 s$ & 0.216 & $-0,002$ & $-0,002$ & $-0,887$ & -1.989 & 0,353 \\
\hline $7 \mathrm{~s}$ & 0.195 & 0.001 & -0.008 & 3.648 & 3.323 & -0.291 \\
\hline $8 s$ & -0.212 & 0.002 & -0.070 & 7.608 & 0.823 & -0.227 \\
\hline $9 s$ & -0.165 & -0.006 & -0.005 & 2.123 & -0.427 & 0.112 \\
\hline $10 \mathrm{~s}$ & 0.107 & 0.000 & 0.022 & -4.422 & -4.645 & $-0,327$ \\
\hline $11 \mathrm{~s}$ & -0.118 & 0,000 & 0,019 & -2.839 & -3.083 & $-0,139$ \\
\hline $12 \mathrm{~s}$ & 0,070 & $-0,002$ & 0,026 & -3.902 & -4.020 & 0,045 \\
\hline $13 \mathrm{~s}$ & 0,038 & $-0,006$ & 0,005 & 1,056 & 3,011 & $-0,022$ \\
\hline $14 \mathrm{~s}$ & $-0,087$ & $-0,002$ & 0,012 & 7,798 & 1,761 & $-0,062$ \\
\hline $15 \mathrm{~s}$ & -0.212 & 0.000 & 0.019 & 2.463 & $-1,520$ & 0,073 \\
\hline $16 \mathrm{~s}$ & 0.101 & 0,010 & 0.012 & $-0,414$ & -2.145 & 0,031 \\
\hline $17 \mathrm{~s}$ & $-0,055$ & 0.002 & 0,008 & $-10,732$ & $-8,864$ & $-0,011$ \\
\hline $18 \mathrm{~s}$ & 0,101 & $-0,001$ & 0,006 & 0.848 & $-3,083$ & -0.346 \\
\hline $19 \mathrm{~s}$ & 0.320 & $-0,002$ & 0,004 & $-4,607$ & $-8,395$ & $-0,049$ \\
\hline $20 \mathrm{~s}$ & -0.534 & $-0,004$ & $-0,025$ & 5,581 & 37,417 & 0,764 \\
\hline $21 \mathrm{~s}$ & -0.009 & 0.011 & 0.006 & -2.289 & -3.552 & -0.278 \\
\hline $22 \mathrm{~s}$ & -0.180 & -0.008 & 0.000 & 6.628 & 2.542 & 0.374 \\
\hline $23 \mathrm{~s}$ & -0.024 & $-0,010$ & 0.001 & -4.219 & -1.520 & -0.104 \\
\hline $24 \mathrm{~s}$ & -0.024 & -0.003 & 0.010 & 2.696 & -0.583 & $-0,224$ \\
\hline $25 \mathrm{~s}$ & -0.399 & 0.000 & -0.008 & 8.028 & 5.667 & 0.295 \\
\hline $26 \mathrm{~s}$ & 0.257 & 0,000 & $-0,004$ & 4.886 & 2.230 & -0.010 \\
\hline $27 \mathrm{~s}$ & -0.143 & $-0,006$ & 0,011 & 1.031 & 5.511 & 0.129 \\
\hline $28 \mathrm{~s}$ & $-0,102$ & 0.006 & -0.038 & 7.688 & 1.136 & 0.516 \\
\hline $30 \mathrm{~s}$ & -0.102 & 0,007 & 0,015 & 0,023 & 0.198 & 0.092 \\
\hline Hibridos & PHAE & ENFE & ACAM & AP & $\mathbf{A E}$ & PG \\
\hline H1 & 0.223 & -0.003 & 0.007 & -0.742 & -1.636 & -0.174 \\
\hline $\mathrm{H} 2$ & 0.029 & 0.004 & -0.006 & 0.584 & -0.246 & -0.144 \\
\hline H3 & -0.381 & -0.007 & $-0,001$ & 0.016 & 0.810 & 0,348 \\
\hline H4 & 0.129 & 0.005 & 0.000 & 0.141 & 1.073 & -0.030 \\
\hline
\end{tabular}


Tabela 64. Efeitos de capacidade geral de combinação $g_{i}$ no experimento $2 \mathbf{R}$ para mancha de Phaeosphaeria. porcentagem de plantas com enfezamento (ENFE), porcentagem de plantas acamadas (ACAM), altura de planta (AP), altura da espiga (AE) e peso de grãos por parcela (PG).

\begin{tabular}{|c|c|c|c|c|c|c|}
\hline Acessos & PHAE & ENFE & ACAM & AP & $\mathrm{AE}$ & PG \\
\hline $1 \mathrm{~s}$ & 1.063 & -0.004 & 0.001 & $-25,667$ & $-18,950$ & $-0,291$ \\
\hline $2 s$ & 0.329 & 0,002 & .003 & -17.062 & -15.825 & -0.293 \\
\hline $3 \mathrm{~s}$ & 0.501 & -0.001 & 0.002 & -17.065 & -13.950 & -0.503 \\
\hline $4 s$ & 0.382 & 0.008 & -0.010 & $-20,752$ & -16.607 & -0.564 \\
\hline $5 s$ & 0.313 & $-0,001$ & 0,039 & $-2,577$ & $-2,075$ & $-0,556$ \\
\hline $6 s$ & 0.647 & $-0,004$ & $-0,002$ & -0.597 & 0,737 & 0.067 \\
\hline $7 s$ & -0.062 & 0.000 & $-0,001$ & 14.393 & 7.612 & 0.246 \\
\hline $8 s$ & 0.188 & 0,000 & 0,040 & $-14,457$ & $-14,575$ & -0.930 \\
\hline $9 s$ & 0.235 & $-0,004$ & -0.006 & $-11,747$ & -10.200 & $-0,417$ \\
\hline $10 \mathrm{~s}$ & 0.226 & -0.002 & 0.006 & -4.912 & -5.044 & $-0,397$ \\
\hline $11 \mathrm{~s}$ & 0.063 & -0.002 & -0.006 & 2,710 & 0.581 & 0.309 \\
\hline $12 \mathrm{~s}$ & 0.313 & 0,000 & 0,003 & 0,338 & $-0,669$ & 0,390 \\
\hline $13 \mathrm{~s}$ & -0.156 & 0,000 & $-0,005$ & 4,000 & 4,487 & 0,305 \\
\hline $14 \mathrm{~s}$ & 0.032 & $-0,004$ & 0,004 & 11,408 & 5,425 & 0,230 \\
\hline $15 \mathrm{~s}$ & -0.124 & $-0,001$ & $-0,010$ & 4,608 & 0,581 & 0.187 \\
\hline $16 \mathrm{~s}$ & -0.374 & 0,009 & $-0,007$ & $-6,805$ & -5.982 & 0,183 \\
\hline $17 \mathrm{~s}$ & 0.126 & 0,000 & 0,006 & $-10,247$ & -11.138 & 0,093 \\
\hline $18 \mathrm{~s}$ & 0.251 & 0.002 & -0.006 & -4.372 & -7.232 & -0.200 \\
\hline $19 \mathrm{~s}$ & -0.031 & -0.004 & -0.005 & 10,443 & 6.206 & 0.193 \\
\hline $20 \mathrm{~s}$ & -0.603 & $-0,002$ & 0,001 & 14,900 & 44.518 & 0.372 \\
\hline $21 \mathrm{~s}$ & -0.015 & 0.009 & -0.011 & -2.235 & -4.888 & 0.062 \\
\hline $22 \mathrm{~s}$ & -0.812 & $-0,002$ & $-0,018$ & 15,078 & 12,768 & 0,426 \\
\hline $23 \mathrm{~s}$ & -0.031 & -0.004 & 0.004 & -3.535 & -4.419 & 0.027 \\
\hline $24 \mathrm{~s}$ & -0.062 & 0.000 & $-0,002$ & -3.190 & -6.607 & -0.215 \\
\hline $25 \mathrm{~s}$ & -1.343 & -0.002 & -0.008 & 21,488 & 17.456 & 0.236 \\
\hline $26 s$ & 0.251 & $-0,001$ & 0,005 & 5,200 & 4,643 & 0.080 \\
\hline $27 \mathrm{~s}$ & $-0,493$ & $-0,004$ & $-0,005$ & 20,330 & 18.237 & 0,275 \\
\hline $28 \mathrm{~s}$ & -0.421 & 0,004 & -0.002 & 13,448 & 10.112 & 0,270 \\
\hline $30 \mathrm{~s}$ & -0.390 & 0,006 & -0.009 & 6,883 & 4,800 & 0,417 \\
\hline Híbridos & PHAE & ENFE & ACAM & AP & $\mathbf{A E}$ & PG \\
\hline H1 & 0.071 & 0.001 & 0.005 & -1.380 & -2.183 & -0.345 \\
\hline $\mathrm{H} 2$ & 0.127 & -0.001 & 0.005 & -0.059 & -1.106 & -0.040 \\
\hline H3 & -0.457 & -0.001 & -0.007 & 0.442 & -0.050 & 0.353 \\
\hline $\mathrm{H4}$ & 0.259 & 0.001 & -0.004 & 0,997 & 3.338 & 0.032 \\
\hline
\end{tabular}


Tabela 65. Resumo das análises conjuntas de variância dos dialelos intergrupos dos experimentos 2A, 2C e 2R para mancha de Phaeosphaeria (PHAE) e peso dos grãos por parcela $(\mathrm{PG})$.

\begin{tabular}{|c|c|c|c|}
\hline FV & GL & PHAE & PG \\
\hline Local (L) & 2 & $100,631^{* *}$ & $143,601^{* *}$ \\
\hline Dialelo & 148 & $0,691 * *$ & $1,065^{* *}$ \\
\hline Acessos & 28 & $1,380^{* *}$ & $1.815^{* *}$ \\
\hline Hibridos & 3 & $11.969 * *$ & $3,176 * *$ \\
\hline Grupos & 1 & $3,818^{* *}$ & $40,619^{* *}$ \\
\hline Heterose & 116 & $0.206 * *$ & $0,488^{* *}$ \\
\hline H. média & 1 & $3,188^{* *}$ & $35,482 * *$ \\
\hline H. acessos $(\mathrm{I})$ & 28 & $0.214 * *$ & $0.242 * *$ \\
\hline H. lúbridos(II) & 3 & $0,596 * *$ & $0,603 * *$ \\
\hline H. especifica & 84 & $0,154^{*}$ & $0,149^{*}$ \\
\hline Interação local $\mathrm{x}$ dialelo & 296 & $0,214^{* *}$ & $0.156^{* *}$ \\
\hline L $\times$ Acessos & 56 & $0.359 * *$ & $0.248 * *$ \\
\hline$L \times$ Hibridos & 6 & $1,175^{* *}$ & $0,767 * *$ \\
\hline L $x$ Grupo & 2 & $0,450 *$ & $1,172 * *$ \\
\hline L $x$ Heterose & 232 & $0,153 * *$ & 0,109 \\
\hline L $x$ H. média & 2 & $1,628^{* *}$ & 0,201 \\
\hline L $\times$ H. acessos $(\mathrm{I})$ & 56 & 0,082 & 0,094 \\
\hline L $\times$ H. lúbridos(II) & 6 & 0,158 & 0,047 \\
\hline L $x$ H. especifica & 168 & 0,158 & 0,115 \\
\hline Residuo combinado & 1190 & 0.110 & 0,106 \\
\hline
\end{tabular}

** e * indicam, respectivamente, significância ao nível de $1 \%$ e de $5 \%$ de probabilidade. 
Tabela 66. Médias dos tratamentos do experimento 3A para mancha de Phaeosphaeria (PHAE), altura de planta (AP), altura da espiga (AE), comprimento de espiga (CE), diâmetro de espiga $(\mathrm{DE})$, e peso de grãos por parcela (PG) em kg.

\begin{tabular}{|c|c|c|c|c|c|c|}
\hline Acessos & PHAE & $\mathbf{A P}$ & $\mathbf{A E}$ & CE & DE & PG \\
\hline 1 & 5,0 & 243,4 & 132,6 & 12,5 & 3,7 & 2,269 \\
\hline 2 & 4,9 & 237.5 & 139,1 & 13,6 & 3,7 & 2,293 \\
\hline 3 & 5,0 & 265,4 & 171,4 & 12,3 & 3,5 & 2,625 \\
\hline 4 & 4,9 & 259.9 & 159.8 & 14.1 & 3,5 & 2.035 \\
\hline 5 & 4,3 & 238.8 & 138,9 & 13.4 & 3,4 & 1,909 \\
\hline 6 & 4,8 & 244.6 & 140,5 & 14,0 & 3,7 & 2,833 \\
\hline 8 & 4,9 & 239.8 & 143,4 & 13,4 & 3,9 & 1,869 \\
\hline 9 & 5,3 & 230.0 & 137,1 & 12,7 & 3,6 & 2.383 \\
\hline 10 & 5,0 & 235,8 & 135,5 & 13,8 & 3,4 & 1,980 \\
\hline 11 & 4,9 & 231,4 & 130,0 & 14,6 & 3,7 & 2,850 \\
\hline 12 & 5,0 & 260,9 & 162.5 & 13.8 & 3,7 & 2,616 \\
\hline 13 & 5.0 & 271.9 & 165,8 & 13.7 & 3,2 & 2,304 \\
\hline 14 & 4,6 & 250.8 & 150,9 & 13.6 & 3,8 & 2.656 \\
\hline 15 & 4.9 & 258.1 & 158,9 & 12.7 & 3.5 & 2.345 \\
\hline 16 & 4,8 & 278,8 & 170,6 & 13,5 & 3,7 & 2,373 \\
\hline 17 & 4,7 & 278,4 & 178,3 & 14,5 & 3,8 & 2,545 \\
\hline 18 & 4,7 & 254,3 & 161,0 & 13,7 & 3,7 & 2,086 \\
\hline 19 & 4,5 & 236,5 & 143,1 & 15,2 & 3,7 & 2,878 \\
\hline 20 & 4,7 & 238,9 & 139,5 & 14,0 & 3,9 & 2,768 \\
\hline 21 & 4,8 & 262.5 & 162,1 & 14,9 & 3,7 & 2.235 \\
\hline 22 & 4.9 & 252,6 & 149,3 & 12.2 & 3,4 & 2.424 \\
\hline 23 & 4.9 & 267,6 & 162,6 & 13,7 & 3,8 & 2.239 \\
\hline 24 & 4,6 & 291.6 & 197,6 & 12,8 & 3,2 & 1.545 \\
\hline 25 & 4,4 & 267,9 & 170,3 & 13.5 & 3,6 & 2,290 \\
\hline 26 & 4,7 & 255,3 & 154,3 & 12,4 & 3,8 & 2,440 \\
\hline 27 & 4.5 & 271.8 & 171.6 & 13,6 & 3.5 & 1.954 \\
\hline 29 & 4,8 & 276,3 & 175,5 & 12,7 & 3,4 & 1,923 \\
\hline 30 & 4,9 & 280.8 & 183,9 & 12.9 & 3,4 & 2.460 \\
\hline Topcrosses & PHAE & $\mathbf{A P}$ & $\mathbf{A E}$ & $\mathrm{CE}$ & $\mathbf{D E}$ & PG \\
\hline $1 t$ & 4.9 & 242.0 & 140.5 & 12.8 & 3,4 & 2.248 \\
\hline $2 t$ & 5,0 & 246.1 & 148,6 & 13.0 & 3,5 & 2.134 \\
\hline $3 t$ & 4.9 & 258.6 & 155,8 & 13.6 & 3.7 & 2.588 \\
\hline $4 t$ & 5.1 & 251.6 & 157.9 & 13.3 & 3.3 & 2.198 \\
\hline $5 t$ & 4.9 & 237.8 & 144,0 & 13.3 & 3.6 & 1.915 \\
\hline $6 t$ & 4.9 & 250.9 & 147,0 & 13.4 & 3.7 & 2.299 \\
\hline $8 t$ & 5.0 & 252.4 & 149.1 & 13.1 & 3.8 & 2.143 \\
\hline $9 t$ & 5.0 & 257.1 & 154.5 & 14.2 & 3.9 & 2.160 \\
\hline $10 t$ & 4.9 & 248.1 & 148.8 & 14.0 & 3.4 & 2.245 \\
\hline $11 t$ & 4.8 & 252.9 & 154.0 & 14.6 & 3.8 & 3.221 \\
\hline $12 \mathrm{t}$ & 4.9 & 263.6 & 161.8 & 14.0 & 3.6 & 2.654 \\
\hline $13 t$ & 4.8 & 256.9 & 156.6 & 13.4 & 3.5 & 2.275 \\
\hline $14 \mathrm{t}$ & 4.9 & 257.3 & 155.9 & 13.4 & 3.7 & 2.344 \\
\hline $15 t$ & 5.0 & 252.3 & 151.3 & 13.8 & 3.9 & 2.624 \\
\hline $16 t$ & 4.5 & 271.6 & 168.0 & 14.2 & 3.8 & 2.650 \\
\hline
\end{tabular}




\begin{tabular}{ccrrrrr}
\hline Topcrosses & PHAE & AP & AE & CE & DE & PG \\
\hline $\mathbf{1 7 t}$ & 4,6 & 267,4 & 160,6 & 13,8 & 3,4 & 2,326 \\
$\mathbf{1 8 t}$ & 4,8 & 250,4 & 153,8 & 13,3 & 3,5 & 2,284 \\
$\mathbf{1 9 t}$ & 4,9 & 240,3 & 146,4 & 13,6 & 3,6 & 2,701 \\
$\mathbf{2 0 t}$ & 4,5 & 254,8 & 155,1 & 13,9 & 3,6 & 2.536 \\
$\mathbf{2 1 t}$ & 4,9 & 264,5 & 165,8 & 13,0 & 3,6 & 2,505 \\
$\mathbf{2 2 t}$ & 4.9 & 240,4 & 148,3 & 14,0 & 4,1 & 2,571 \\
$\mathbf{2 3 t}$ & 4,9 & 272,4 & 167,0 & 13,5 & 3,8 & 3,239 \\
$\mathbf{2 4 t}$ & 4.5 & 289.1 & 185.4 & 12.5 & 3.5 & 2.244 \\
$\mathbf{2 5 t}$ & 4.6 & 265.5 & 170.3 & 13.9 & 3.6 & 2.986 \\
$\mathbf{2 6 t}$ & 4.8 & 249.3 & 156.5 & 12.8 & 3,7 & 2.348 \\
$\mathbf{2 7 t}$ & 4.9 & 269.3 & 166,5 & 13.6 & 3.5 & 2.705 \\
$\mathbf{2 9 t}$ & 4.4 & 270.3 & 173.0 & 13.4 & 3.6 & 2.450 \\
$\mathbf{3 0 t}$ & 4.9 & 271.5 & 172,4 & 13,5 & 3.7 & 2.301 \\
\hline Testemunhas & PHAE & AP & AE & CE & DE & PG \\
\hline T1 & 3.3 & 213,04 & 108,04 & 14,71 & 4,54 & 4,83 \\
T2 & 4,0 & 247,50 & 128,00 & 14,16 & 4,33 & 4,39 \\
\hline
\end{tabular}

Tabela 67. Resumo das análises de variância do experimento 3A para mancha de Phaeosphaeria (PHAE), altura de planta (AP), altura da espiga (AE), comprimento de espiga (CE), diâmetro de espiga (DE), e peso de grãos por parcela $(\mathrm{PG}) \mathrm{em} \mathrm{kg}$.

\begin{tabular}{|c|c|c|c|c|c|c|c|}
\hline \multirow[b]{2}{*}{ FV } & \multirow[b]{2}{*}{ GL } & \multicolumn{5}{|c|}{ QM } & \multirow[b]{2}{*}{ PG } \\
\hline & & PHAE & AP & $\overline{\mathbf{A E}}$ & CE & DE & \\
\hline Repetição & 3 & 0.047 & 178.79 & 304.18 & 1.217 & 0.063 & 0.752 \\
\hline Tratamentos & 57 & $0.707 * *$ & $1218,65^{* *}$ & $1390,72 * *$ & $1,922 * *$ & $0,384 * *$ & $2.305 * *$ \\
\hline- Topcross & 55 & 0,159 & $854,49 * *$ & $794,39 * *$ & $1,625^{* *}$ & $0,131^{* *}$ & $0.430^{* *}$ \\
\hline Acessos & 27 & $\overline{0.218}$ & $\overline{1573,79 * *}$ & $\overline{152} \overline{4}, \overline{84} * *$ & $\overline{2}, \overline{3} \overline{5} \overline{1}^{* *}$ & $\overline{0.154^{* *}}$ & $\overline{0 . \overline{5} 60 * *}$ \\
\hline Heterose média & 1 & 0.081 & 37.95 & 58.53 & 0,082 & 0.073 & $1.015 * *$ \\
\hline Heterose acessos & 27 & 0.103 & 165,44 & 91.20 & 0.957 & 0,110 & $0.280 * *$ \\
\hline Testemunha & 1 & $\overline{3} . \overline{3} 75^{* *}-$ & $\overline{7} \overline{2} \overline{4}, 26^{* *}$ & $2390,01^{* *}$ & $\overline{1,822}$ & $\overline{0}, \overline{2} 66^{--}$ & $\overline{1} 16^{*} * *$ \\
\hline Topcross vs Test. & 1 & $28.184^{* *}$ & $15341.85^{* *}$ & $33189.36^{* *}$ & $18.364^{* *}$ & $14.398 * *$ & $106.552 * *$ \\
\hline Resíduo & 187 & 0,144 & 119.66 & 73.15 & 0.749 & 0.072 & 0.138 \\
\hline Dentro test./rep. & 16 & & & & & & \\
\hline Erro & 171 & & & & & & \\
\hline CV\% & & 8.08 & 4.30 & 5.58 & 6.36 & 7.22 & 14.25 \\
\hline Média geral & & 4.70 & 254.30 & 153.36 & 13.60 & 3.70 & 2.61 \\
\hline
\end{tabular}

** e $*$ indicam. respectivamente. significância ao nir el de $1 \%$ e de $5 \%$ de probabilidade. 
Tabela 68. Efeitos de variedade $v_{1}$ no experimento 3A para mancha de Phaeosphaeria (PHAE), altura de planta (AP), altura da espiga (AE), comprimento de espiga (CE), diâmetro de espiga $(D E)$, e peso de grãos por parcela (PG) em kg.

\begin{tabular}{crrrrrrr}
\hline Acessos & PHAE & AP & AE & CE & DE & P100G & PG \\
\hline $\mathbf{1}$ & 0,212 & $-13,088$ & $-24,013$ & $-0,967$ & 0,129 & $-0,915$ & $-0,057$ \\
$\mathbf{2}$ & 0.087 & $-18,963$ & $-17,513$ & 0,091 & 0,140 & $-1,540$ & $-0,033$ \\
$\mathbf{3}$ & 0.212 & 8.913 & 14,737 & -1.158 & -0.153 & -0.915 & 0.299 \\
$\mathbf{4}$ & 0.087 & 3.413 & 3.112 & 0.557 & -0.067 & -1.540 & -0.291 \\
$\mathbf{5}$ & -0.538 & -17.713 & -17.763 & -0.071 & $-0,192$ & 0.335 & -0.417 \\
$\mathbf{6}$ & 0.025 & $-11,838$ & $-16,138$ & 0,480 & 0,142 & -3.415 & 0,507 \\
$\mathbf{8}$ & 0,087 & $-16,713$ & $-13,263$ & $-0,090$ & 0,250 & $-0,290$ & $-0,457$ \\
$\mathbf{9}$ & 0.462 & $-26,463$ & $-19,513$ & $-0,756$ & 0,031 & $-1,540$ & 0,057 \\
$\mathbf{1 0}$ & 0.212 & $-20,713$ & $-21,138$ & 0.263 & $-0,240$ & $-2,165$ & $-0,346$ \\
$\mathbf{1 1}$ & 0,150 & $-25,088$ & $-26,638$ & 1,117 & 0,085 & $-2,165$ & 0,524 \\
$\mathbf{1 2}$ & 0,212 & 4,413 & 5.862 & 0,324 & 0.128 & 0,960 & 0,290 \\
$\mathbf{1 3}$ & 0.212 & 15,413 & 9,112 & 0,240 & $-0,383$ & $-0,915$ & $-0,022$ \\
$\mathbf{1 4}$ & $-0,225$ & $-5,712$ & $-5,763$ & 0,077 & 0,152 & 0,335 & 0,330 \\
$\mathbf{1 5}$ & 0.150 & 1,663 & 2.237 & $-0,800$ & -0.068 & 0,335 & 0,019 \\
$\mathbf{1 6}$ & 0,025 & 22,288 & 13,987 & 0,008 & 0,107 & $-1,540$ & 0,047 \\
$\mathbf{1 7}$ & $-0,100$ & 21.913 & 21.612 & 1.041 & 0.155 & 2.210 & 0.219 \\
$\mathbf{1 8}$ & $-0,100$ & $-2,212$ & 4.362 & 0,222 & 0,131 & $-0,915$ & $-0,240$ \\
$\mathbf{1 9}$ & -0.288 & $-19,963$ & -13.513 & 1,657 & 0.063 & $-0,915$ & 0,552 \\
$\mathbf{2 0}$ & -0.100 & $-17,588$ & -17.138 & 0,534 & 0,266 & -1.540 & 0,442 \\
$\mathbf{2 1}$ & $-0,038$ & 6.038 & $\mathbf{5 , 4 8 7}$ & 1,393 & 0,072 & -1.540 & $-0,091$ \\
$\mathbf{2 2}$ & 0.087 & $-3,887$ & -7.388 & $-1,310$ & -0.217 & -0.915 & 0.098 \\
$\mathbf{2 3}$ & 0.087 & 11,163 & 5.987 & 0,157 & 0.194 & 4,710 & $-0,087$ \\
$\mathbf{2 4}$ & -0.225 & 35.163 & 40,987 & -0.710 & -0.432 & 2.210 & -0.781 \\
$\mathbf{2 5}$ & -0.350 & 11,413 & 13.612 & 0.051 & 0,015 & 1,585 & -0.036 \\
$\mathbf{2 6}$ & -0.100 & -1.212 & $-2,388$ & $-1,081$ & 0.206 & 2,210 & 0,114 \\
$\mathbf{2 7}$ & -0.288 & 15.288 & 14,987 & 0,132 & $-0,138$ & 2,210 & $-0,372$ \\
$\mathbf{2 9}$ & -0.038 & 19,788 & 18.862 & $-0,821$ & -0.200 & 4,710 & $-0,403$ \\
$\mathbf{3 0}$ & 0,087 & 24,288 & 27,237 & $-0,578$ & $-0,176$ & 0,960 & 0,134 \\
\hline & & & & & & &
\end{tabular}


Tabela 69. Efeitos de heterose de variedade $h_{i}$ no experimento $3 A$ para mancha de Phaeosphaeria (PHAE), altura de planta (AP), altura da espiga (AE), comprimento de espiga $(\mathrm{CE})$, diâmetro de espiga (DE), e peso de grãos por parcela (PG) em kg.

\begin{tabular}{crrrrrrr}
\hline Acessos & PHAE & \multicolumn{1}{c}{ AP } & \multicolumn{1}{l}{ AE } & \multicolumn{1}{l}{ CE } & \multicolumn{1}{c}{ DE } & P100G & \multicolumn{1}{l}{ PG } \\
\hline $\mathbf{1}$ & $-0,061$ & $-9,414$ & $-5,550$ & $-0,227$ & $-0,283$ & 2,536 & $-0,199$ \\
$\mathbf{2}$ & 0,141 & $-1,809$ & $-0,300$ & $-0,652$ & $-0,242$ & 2,200 & $-0,334$ \\
$\mathbf{3}$ & 0.006 & $-3,357$ & -9.993 & 0.726 & 0,190 & 1,190 & $-0,024$ \\
$\mathbf{4}$ & 0.208 & -7.934 & -1.445 & -0.521 & -0.320 & -1.839 & -0.127 \\
$\mathbf{5}$ & 0.343 & -11.501 & $-5,147$ & -0.236 & 0.089 & -2.175 & -0.363 \\
$\mathbf{6}$ & 0.107 & -0.530 & -2.791 & -0.374 & -0.034 & -2.849 & -0.447 \\
$\mathbf{8}$ & 0.141 & 3,711 & -2.050 & $-0,460$ & 0.052 & 0.853 & -0.096 \\
$\mathbf{9}$ & -0.061 & 14.076 & 7,103 & 1.119 & 0.242 & 2.873 & -0.354 \\
$\mathbf{1 0}$ & -0.061 & 1,288 & 1,786 & 0,349 & $-0,118$ & -0.156 & $-0,046$ \\
$\mathbf{1 1}$ & $-0,162$ & 8,759 & 10,401 & 0,568 & 0,075 & 2,536 & 0,537 \\
$\mathbf{1 2}$ & 0.006 & 4.451 & 1.248 & 0.311 & $-0,101$ & -1.166 & 0,052 \\
$\mathbf{1 3}$ & -0.196 & $-8,741$ & -6.022 & $-0,235$ & 0.082 & 0,517 & -0.188 \\
$\mathbf{1 4}$ & 0.242 & 3.038 & 1,180 & $-0,142$ & -0.046 & -0.829 & $-0,304$ \\
$\mathbf{1 5}$ & 0,107 & $-6,318$ & $-8,108$ & 0,668 & 0,316 & 2.536 & 0,166 \\
$\mathbf{1 6}$ & $-0,364$ & 3,441 & 3,603 & 0,682 & 0,155 & $-1,839$ & 0,179 \\
$\mathbf{1 7}$ & -0.230 & $-0,934$ & $-8,445$ & $-0,233$ & $-0,302$ & 0,853 & $-0,263$ \\
$\mathbf{1 8}$ & 0,040 & $-6,251$ & $-6,560$ & $-0,373$ & $-0,171$ & $-2,175$ & $-0,061$ \\
$\mathbf{1 9}$ & 0.275 & $-7,597$ & -4.877 & $-0,776$ & $-0,033$ & 0.517 & $-0,038$ \\
$\mathbf{2 0}$ & -0.297 & 6.739 & 6,498 & 0,079 & $-0,146$ & $-2,512$ & $-0,156$ \\
$\mathbf{2 1}$ & 0.141 & 4.518 & $\mathbf{5 , 7 5 7}$ & $-1,331$ & -0.137 & 0.853 & 0,097 \\
$\mathbf{2 2}$ & 0,073 & $-16,118$ & -6.156 & 1.188 & 0.607 & -2.849 & 0,067 \\
$\mathbf{2 3}$ & 0.073 & 10.239 & 6.834 & -0.131 & 0.034 & -0.493 & 0.885 \\
$\mathbf{2 4}$ & -0.230 & 15.355 & 7,776 & -0.754 & 0.040 & 1.526 & 0.187 \\
$\mathbf{2 5}$ & -0.095 & 2,701 & 6.228 & 0.394 & -0.091 & -0.156 & 0,585 \\
$\mathbf{2 6}$ & 0.040 & -8.001 & 0.036 & -0.198 & -0.010 & -1.839 & $-0,183$ \\
$\mathbf{2 7}$ & 0.208 & 4,653 & 1,450 & 0,043 & $-0,036$ & 0,180 & 0,464 \\
$\mathbf{2 9}$ & -0.398 & 3.307 & 6.363 & 0,247 & 0,027 & 0.180 & 0,206 \\
$\mathbf{3 0}$ & 0,006 & 2.230 & 1,180 & 0,267 & 0,162 & 1,526 & $-0,244$ \\
\hline & & & & & & & \\
\end{tabular}


Tabela 70. Efeitos de capacidade geral de combinação $g_{i}$ no experimento $3 \mathrm{~A}$ para mancha de Phaeosphaeria (PHAE), altura de planta (AP), altura da espiga (AE), comprimento de espiga $(\mathrm{CE})$, diâmetro de espiga (DE), e peso de grãos por parcela $(\mathrm{PG}) \mathrm{em} \mathrm{kg}$.

\begin{tabular}{crrrrrrr}
\hline Acessos & PHAE & AP & AE & CE & DE & P100G & PG \\
\hline $\mathbf{1}$ & 0,045 & $-15,958$ & $-17,557$ & $-0,711$ & $-0,218$ & 2,078 & $-0,227$ \\
$\mathbf{2}$ & 0,184 & $-11,290$ & $-9,057$ & $-0,607$ & $-0,172$ & 1,429 & -0.350 \\
$\mathbf{3}$ & 0.112 & 1.100 & $-2,624$ & 0,148 & 0,114 & 0.732 & 0.125 \\
$\mathbf{4}$ & 0.251 & -6.227 & 0.111 & $-0,242$ & $-0,353$ & -2.609 & -0.272 \\
$\mathbf{5}$ & 0.074 & $-20,357$ & $-14,028$ & $-0,272$ & $-0,006$ & $-2,008$ & -0.571 \\
$\mathbf{6}$ & 0.119 & $-6,449$ & $-10,860$ & $-0,134$ & 0,038 & $-4,556$ & $-0,194$ \\
$\mathbf{8}$ & 0,184 & $-4,646$ & $-8,682$ & $-0,504$ & 0,177 & 0,708 & $-0,325$ \\
$\mathbf{9}$ & 0.170 & 0.845 & -2.653 & 0.741 & 0,257 & 2.103 & -0.326 \\
$\mathbf{1 0}$ & 0.045 & $-9,069$ & $-8,783$ & 0,480 & -0.238 & $-1,239$ & $-0,219$ \\
$\mathbf{1 1}$ & -0.087 & -3.785 & -2.918 & 1,126 & 0,117 & 1,453 & 0,799 \\
$\mathbf{1 2}$ & 0,112 & 6,657 & 4.178 & 0,473 & $-0,037$ & $-0,686$ & 0,197 \\
$\mathbf{1 3}$ & $-0,090$ & $-1,035$ & $-1,466$ & $-0,115$ & $-0,110$ & 0,059 & $-0,199$ \\
$\mathbf{1 4}$ & 0,129 & 0,181 & $-1,701$ & $-0,104$ & 0,030 & -0.662 & -0.138 \\
$\mathbf{1 5}$ & 0.182 & $-5,487$ & -6.990 & 0,268 & 0,283 & 2,703 & 0,175 \\
$\mathbf{1 6}$ & -0.352 & 14.585 & 10.597 & 0,686 & 0.208 & -2.609 & 0,202 \\
$\mathbf{1 7}$ & -0.280 & 10.023 & 2.361 & 0,288 & -0.225 & 1,958 & $-0,153$ \\
$\mathbf{1 8}$ & -0.011 & $-7,357$ & $-4,379$ & $-0,262$ & -0.106 & $-2,633$ & $-0,181$ \\
$\mathbf{1 9}$ & 0,131 & $-17,578$ & $-11,634$ & 0,053 & $-0,001$ & 0,059 & 0,238 \\
$\mathbf{2 0}$ & $-0,347$ & $-2,054$ & $-2,072$ & 0,346 & $-0,013$ & -3.282 & 0,065 \\
$\mathbf{2 1}$ & 0.122 & 7.537 & 8.501 & $-0,635$ & -0.102 & 0.083 & 0.052 \\
$\mathbf{2 2}$ & 0.117 & -18.062 & -9.850 & 0,533 & 0.498 & -3.306 & 0.116 \\
$\mathbf{2 3}$ & 0.117 & 15.821 & 9.827 & -0.053 & 0.131 & 1.862 & 0.842 \\
$\mathbf{2 4}$ & -0.342 & 32.936 & 28.270 & $-1,109$ & -0.176 & 2.631 & -0.203 \\
$\mathbf{2 5}$ & $-0,270$ & 8,407 & 13,034 & 0,420 & $-0,083$ & 0,636 & 0.568 \\
$\mathbf{2 6}$ & $-0,011$ & $-8,607$ & -1.158 & $-0,738$ & 0,093 & $-0,734$ & -0.126 \\
$\mathbf{2 7}$ & 0.064 & 12,297 & 8,943 & 0,109 & $-0,106$ & 1,285 & 0,278 \\
$\mathbf{2 9}$ & $-0,417$ & 13.200 & 15,794 & $-0,163$ & $-0,073$ & 2.535 & 0,004 \\
$\mathbf{3 0}$ & 0.050 & 14.374 & 14,799 & $-0,023$ & 0,073 & 2,006 & $-0,177$ \\
\hline & & & & & & &
\end{tabular}


Tabela 71. Médias dos tratamentos do experimento 3C para mancha de Phaeosphaeria (PHAE), ferrugem tropical (PHYS), ferrugem polysora (POLY), porcentagem de colmos quebrados (QUEB), porcentagem de plantas acamadas (ACAM), altura de planta (AP), altura da espiga (AE), comprimento de espiga (CE), diâmetro de espiga (DE), e peso de grãos por parcela (PG)

\begin{tabular}{|c|c|c|c|c|c|c|c|c|c|c|}
\hline Acessos & PHAE & PHYS & POLY & QUEB & ACAM & AP & $\mathbf{A E}$ & $\mathrm{CE}$ & $\mathrm{DE}$ & $\mathrm{PG}$ \\
\hline 1 & 5.4 & 4,31 & 3.1 & 0.60 & 0.00 & 241.3 & 126.3 & 16.1 & 4.2 & 3.648 \\
\hline 2 & 4.9 & 3,77 & 3,0 & 2,63 & 0.00 & 235.0 & 131.3 & 17,1 & 4,3 & 3.808 \\
\hline 3 & 5.3 & 4,15 & 3,0 & 8,62 & 3.22 & 251,3 & 147.5 & 15.1 & 4.3 & 3.786 \\
\hline 4 & 4,7 & 3,76 & 2.8 & 5,20 & 0,00 & 252.5 & 147.5 & 17,6 & 4.5 & 4.222 \\
\hline 5 & 5,1 & 3,96 & 3.0 & 3,26 & 0,00 & 240,0 & 131,3 & 17,1 & 4.4 & 3.848 \\
\hline 6 & 5.2 & 3,94 & 2.9 & 5.92 & 0.00 & 235.0 & 118.8 & 15.7 & 4.4 & 3.991 \\
\hline 8 & 4,4 & 3,67 & 2,9 & 11,13 & 1,39 & 231.3 & 125.0 & 16.0 & 4.5 & 2,908 \\
\hline 9 & 5,5 & 3,96 & 3,0 & 6,82 & 0,00 & 225,0 & 123,8 & 14,8 & 4,5 & 3,069 \\
\hline 10 & 5,1 & 4,10 & 3,4 & 1,88 & 0,00 & 223,8 & 127.5 & 16,4 & 4.0 & 3,790 \\
\hline 11 & 4,6 & 3,89 & 3,0 & 2,52 & 0,00 & 233,8 & 121.3 & 16.1 & 4,1 & 3,907 \\
\hline 12 & 4,8 & 4,16 & 3,3 & 6,34 & 0,61 & 245,0 & 133,8 & 16,6 & 4,5 & 4,080 \\
\hline 13 & 4,8 & 3,94 & 2,9 & 7,55 & 0,00 & 253,8 & 150,0 & 15,2 & 4.2 & 3,490 \\
\hline 14 & 5.1 & 4,07 & 2,8 & 4,84 & 0,00 & 247,5 & 141,3 & 15,8 & 4,4 & 3,991 \\
\hline 15 & 4,4 & 4,22 & 2,7 & 3,70 & 0,71 & 250,0 & 147,5 & 15.5 & 4,4 & 3,841 \\
\hline 16 & 4.9 & 3,96 & 3,0 & 5,62 & 0,00 & 250,0 & 141,3 & 16,6 & 4.3 & 4,131 \\
\hline 17 & 4.0 & 3,99 & 2.9 & 7.24 & 0.00 & 262.5 & 161,3 & 16.1 & 4.5 & 3,726 \\
\hline 18 & 4.8 & 3,48 & 2,8 & 6,00 & 0.00 & 237,5 & 141.3 & 16,1 & 4.4 & 3,308 \\
\hline 19 & 5,3 & 4,29 & 3,0 & 5,32 & 0,00 & 235,0 & 138,8 & 16,3 & 4,1 & 3,668 \\
\hline 20 & 4,9 & 4,02 & 2,8 & 4,22 & 0,00 & 248,8 & 128,8 & 15,1 & 4,4 & 3,961 \\
\hline 21 & 4.6 & 3,86 & 3.1 & 10.51 & 0.00 & 253,8 & 137,5 & 16,0 & 4.5 & 3.706 \\
\hline 22 & 4.8 & 3,67 & 2.5 & 3.35 & 1.28 & 246.3 & 135,0 & 16,4 & +.3 & 4.380 \\
\hline 23 & 4.3 & 4,24 & 3.1 & 4,07 & 1.39 & 247.5 & 146.3 & 14.8 & 4.8 & 3.361 \\
\hline 24 & 3.3 & 3,92 & 2.6 & 3,63 & 0.66 & 275.0 & 171,3 & 14.4 & 4.2 & 2.366 \\
\hline 25 & 3.9 & 3,90 & 2,9 & 5,98 & 0,00 & 251,3 & 146.3 & 16,5 & 4,3 & 3,607 \\
\hline 26 & 4,0 & 3,74 & 2,9 & 5,20 & 0,00 & 250,0 & 147,5 & 15,5 & 4,4 & 3,734 \\
\hline 27 & 3,5 & 3,85 & 2,5 & 5,20 & 0,00 & 258,8 & 155,0 & 16,1 & 4,3 & 3,616 \\
\hline 29 & 4.4 & 4,18 & 2.8 & 2.52 & 1,27 & 260,0 & 157.5 & 15.5 & 4.5 & 3.566 \\
\hline 30 & 4,9 & 4,14 & 2,6 & 4.66 & 0,00 & 261,3 & 156,3 & 15.8 & 4.5 & 3.609 \\
\hline Topcrosses & PHAE & PHYS & POLY & QUEB & ACAM & AP & $\mathrm{AE}$ & $\mathrm{CE}$ & DE & PG \\
\hline $1 \mathrm{t}$ & 3.9 & 4,46 & 2.8 & 2.05 & 1.35 & 251.3 & $1+5.0$ & 16.2 & 4.5 & 4.093 \\
\hline $2 t$ & 4.8 & 4,02 & 2.5 & 3.90 & 0.00 & 242.5 & 130.0 & 16.0 & 4.5 & 4.026 \\
\hline $3 t$ & 5.3 & 4,06 & 3.0 & 7,12 & 0,00 & 253,8 & 138.8 & 16.2 & 4.4 & 3.998 \\
\hline $4 t$ & 5.3 & 3,88 & 3.1 & 9.05 & 0.71 & 251.3 & 141.3 & 16.9 & 4.4 & 4.145 \\
\hline $5 t$ & 5.4 & 3,64 & 3.0 & 4.17 & 2.12 & 231.3 & 126,3 & 16.2 & 4.4 & 3.788 \\
\hline $6 t$ & 4.5 & 4,10 & 3.0 & 2,98 & 0,00 & 242.5 & 132.5 & 15.6 & 4.4 & 4.245 \\
\hline $8 t$ & 5.4 & 4,02 & 2.8 & 11.17 & 0.63 & 236.3 & 140.0 & 15.9 & 4.5 & 3.817 \\
\hline $9 t$ & 5.1 & 4,08 & 3.0 & 6.96 & 0.60 & 251.3 & 135.0 & 15.7 & +.6 & 3.492 \\
\hline $10 t$ & 5.4 & 4,20 & 3.0 & 2.78 & 0.00 & 237.5 & 128.8 & 16.6 & 4.1 & 3.899 \\
\hline $11 t$ & 5.4 & 3,87 & 2.8 & 4.66 & 0.00 & 228.8 & 130.0 & 16.7 & 4.3 & +.000 \\
\hline $12 t$ & 5.4 & 4,17 & 3.0 & 6.71 & 0.00 & 251.3 & 137.5 & 16.9 & 4.5 & 4.735 \\
\hline $13 t$ & 4.1 & 3,58 & 2.8 & 8.02 & 0.00 & 252.5 & 143.8 & 15.6 & 4.5 & 4.028 \\
\hline
\end{tabular}




\begin{tabular}{ccccrrrrrrr}
\hline Topcrosses & PHAE & PHYS & POLY & QUEB & ACAM & AP & AE & CE & DE & PG \\
\hline $\mathbf{1 4 t}$ & 4.8 & 4,25 & 2.9 & 5,61 & 0,00 & 240,0 & 131.3 & 16,2 & 4.4 & 4,021 \\
$\mathbf{1 5 t}$ & 5.2 & 3,88 & 2.5 & 2.86 & 0.00 & 258.8 & 136.3 & 17.6 & 4.5 & 4.246 \\
$\mathbf{1 6 t}$ & 4.3 & 3,80 & 2.9 & 4.94 & 0,00 & 248,8 & 141,3 & 17.2 & 4,4 & 4.592 \\
$\mathbf{1 7 t}$ & 4,3 & 3,86 & 2.8 & 6,28 & 0,00 & 260.0 & 160,0 & 17,2 & 4,5 & 3,957 \\
$\mathbf{1 8 t}$ & 5,0 & 4,11 & 3,0 & 7.91 & 0,00 & 241,3 & 140,0 & 16,2 & 4,3 & 3.682 \\
$\mathbf{1 9 t}$ & 5,4 & $\mathbf{4 , 0 8}$ & 3,0 & 5,52 & 0,00 & 240,0 & 132,5 & 17,6 & 4,3 & 4,077 \\
$\mathbf{2 0 t}$ & 4.2 & 3,74 & 2,8 & 2,55 & 0,00 & 246,3 & 146,3 & 16,5 & 4,5 & 4,830 \\
$\mathbf{2 1 t}$ & 4.3 & 3,96 & 2.8 & 7.36 & 0,00 & 247.5 & 137.5 & 16.4 & 4.6 & 4.446 \\
$\mathbf{2 2 t}$ & 4.9 & 3,93 & 2.9 & 5.33 & 0.00 & 245.0 & 140.0 & 16.1 & 4.4 & 4.020 \\
$\mathbf{2 3 t}$ & 4,4 & 3,83 & 2.9 & 5.71 & 0.00 & 258.8 & 148.8 & 17.5 & 4.7 & 4,200 \\
$\mathbf{2 4 t}$ & 4,1 & 3,71 & 3.1 & 4,30 & 0,00 & 256,3 & 152,5 & 16,0 & 4.4 & 3.886 \\
$\mathbf{2 5 t}$ & 4,1 & 3,86 & 2.9 & 5.64 & 0,00 & 251.3 & 142,5 & 15,6 & 4.3 & 4.048 \\
$\mathbf{2 6 t}$ & 4,2 & 3,72 & 3.3 & 6,55 & 0,00 & 241,3 & 147,5 & 15,4 & 4.5 & 3.886 \\
$\mathbf{2 7 t}$ & 4.9 & $\mathbf{4 , 0 2}$ & 2.9 & $\mathbf{7 , 9 2}$ & 0,00 & 262,5 & 152,5 & 15,7 & 4,4 & 4.396 \\
$\mathbf{2 9 t}$ & $\mathbf{5 , 4}$ & 3,84 & 3.0 & 6,72 & 0,00 & 256.3 & 147,5 & 16,6 & 4,6 & 4.261 \\
$\mathbf{3 0 t}$ & $\mathbf{5 . 4}$ & $\mathbf{4}, 12$ & 3.0 & 8,29 & 0,56 & 261,3 & 155,0 & 16,3 & 4,5 & 4,009 \\
\hline Testemunhas & PHAE & PHYS & POLY & QUEB & ACAM & AP & AE & CE & DE & PG \\
\hline T1 & 2.7 & 3.2 & 2.0 & 2.03 & 0,00 & 219.2 & 109.6 & 15,3 & 5.0 & 5,309 \\
T2 & 3.0 & 4,1 & 2.4 & 4,72 & 0,00 & 241,7 & 125,0 & 15,7 & 4,9 & 5.208 \\
\hline
\end{tabular}


Tabela 72. Resumo das análises de variância do experimento 3C para mancha de Phaeosphaeria (PHAE), ferrugem tropical (PHYS), ferrugem polysora (POLY), porcentagem de colmos quebrados (QUEB)e porcentagem de plantas acamadas (ACAM).

\begin{tabular}{|c|c|c|c|c|c|c|}
\hline FV & GL & $\begin{array}{l}\text { QM } \\
\text { PHAE }\end{array}$ & PHYSO & POLY & $\begin{array}{l}\text { QUEB } \\
10^{3}\end{array}$ & $\begin{array}{l}\text { ACAM X } \\
10^{4}\end{array}$ \\
\hline Repetição & 3 & 2,263 & 0,422 & 0,244 & 7,718 & $8 \quad 0,385$ \\
\hline Tratamentos & 57 & $2.507 * *$ & $0,277 * *$ & $0,323 * *$ & $2,381^{*}$ & $1.573 * *$ \\
\hline Topcross & 55 & $1.182^{* *}$ & 0.160 & 0.146 & 2.189 & $1.596^{* *}$ \\
\hline Ácessos & $\overline{2} 7$ & $1.479 * *$ & $\overline{0.196}$ & $0 . \overline{165}$ & $3.5 \overline{1} 2 * *$ & $*^{-1} \overline{1.802 *}$ \\
\hline Heterose média & 1 & 1.143 & 0.008 & 0.000 & 2.518 & $8 \quad 1.498$ \\
\hline Heterose acessos & 27 & $0.886^{* *}$ & 0.128 & 0.132 & 0.853 & 1.393 \\
\hline Testemunha & 1 & $0 . \overline{75} \overline{3}$ & $4.5 \overline{28} * \bar{*}$ & $\overline{0} \overline{8} \overline{4} 4^{*} *$ & $-\overline{2}, \overline{9} 07$ & 0,000 \\
\hline Topcross is Testemunha & 1 & $77,120 * *$ & $2,500 * *$ & $9,549 * *$ & $12,416 * *$ & 1,887 \\
\hline Residuo & 187 & 0,405 & 0,130 & 0,124 & 1,639 & 0,985 \\
\hline Dentro test./rep. & 16 & 0,107 & 0.064 & 0,083 & 1,042 & 0,000 \\
\hline Erro & 171 & 0,433 & 0,136 & 0,128 & 1.695 & $5 \quad 1.077$ \\
\hline $\mathrm{CV} \%$ & & 13.99 & 9.16 & 12.45 & 4.83 & 1.26 \\
\hline Média geral & & 4.55 & 3.93 & 2.83 & 5,42 & 0,28 \\
\hline
\end{tabular}

** $\mathrm{e}^{*}$ indicam, respectivamente, significância ao nível de $1 \%$ e de $5 \%$ de probabilidade.

Tabela 73. Resumo das análises de variância do experimento $3 \mathrm{C}$ para altura de planta (AP), altura da espiga (AE), comprimento de espiga (CE), diâmetro de espiga (DE), e peso de grãos por parcela $(\mathrm{PG})$.

\begin{tabular}{|c|c|c|c|c|c|c|}
\hline \multirow[b]{2}{*}{ FV } & \multirow[b]{2}{*}{ GL } & \multirow[b]{2}{*}{ AP } & \multicolumn{2}{|l|}{$\mathbf{Q M}$} & \multirow[b]{2}{*}{$\mathrm{DE}$} & \multirow[b]{2}{*}{ PG } \\
\hline & & & $\mathrm{AE}$ & $\mathbf{C E}$ & & \\
\hline Repetição & 3 & 681,99 & 543.82 & 1.087 & 0.023 & 1,016 \\
\hline Tratamentos & 57 & $582,47 * *$ & $693.43 * *$ & $2.218^{* *}$ & $0.198 * *$ & $1.372 * *$ \\
\hline Topcross & 55 & $436,39 * *$ & $477,73^{* *}$ & $2,087 * *$ & $0.088^{* *}$ & $0.685^{* *}$ \\
\hline $\bar{A}$ cessos & $\overline{2} 7$ & $746 . \overline{3} * \bar{*}$ & $860.69^{* *}$ & $2 . \overline{3} \overline{8} * \bar{*}-$ & $\overline{0.176^{* *}}$ & $0 . \overline{796 * *}$ \\
\hline Heterose média & 1 & 129.02 & 1,00 & $10,850 * *$ & $0.403 * *$ & $9,787 * *$ \\
\hline Heterose acessos & 27 & 137,43 & 112,41 & $1.511^{* *}$ & 0.017 & 0.236 \\
\hline Testemunha & -1 & $\overline{30} \overline{3} \overline{50} . \bar{*} *$ & $\overline{1} \overline{4} \overline{6} . \overline{0} \overline{4} * \bar{*}-$ & $0.673^{---}$ & $\overline{0.027}--$ & 0.062 \\
\hline Topcross is Testem. & 1 & $6162.10 * *$ & $11824.74^{* *}$ & $10.985 * *$ & $6.448 * *$ & $40.488 * *$ \\
\hline Resíduo & 187 & 136.10 & 114,16 & 0,757 & 0,019 & 0.299 \\
\hline Dentro test./rep. & 16 & 109.37 & 58.33 & 0.640 & 0.012 & 0.471 \\
\hline Erro & 171 & 138.60 & 119.38 & 0.768 & 0.019 & 0.283 \\
\hline $\mathrm{CV} \%$ & & 4.75 & 7.72 & 5.41 & 3.06 & 13.60 \\
\hline Média geral & & 245.65 & 138.39 & 16.10 & 4.44 & 4.02 \\
\hline
\end{tabular}

** e * indicam. respectivamente. significância ao nível de $1 \%$ e de $5 \%$ de probabilidade. 
Tabela 74. Efeitos de variedade $v_{i}$ no experimento 3C para mancha de Phaeosphaeria (PHAE), ferrugem tropical (PHYS), ferrugem polysora (POLY), porcentagem de colmos quebrados (QUEB), porcentagem de plantas acamadas (ACAM), altura de planta (AP), altura da espiga $(\mathrm{AE})$, comprimento de espiga $(\mathrm{CE})$, diâmetro de espiga $(\mathrm{DE})$, e peso de grãos por parcela $(\mathrm{PG})$

\begin{tabular}{|c|c|c|c|c|c|c|c|c|c|c|}
\hline Acessos & PHAE & PHYS & POLY & QUEB & ACAM & AP & $\mathbf{A E}$ & CE & $\overline{D E}$ & $\overline{\mathrm{PG}}$ \\
\hline 1 & 0.717 & 0,344 & 0,232 & $-0,046$ & $-0,004$ & -5.268 & $-14,330$ & 0.148 & $-0,121$ & $-0,035$ \\
\hline 2 & 0.217 & -0.156 & 0.107 & $-0,026$ & $-0,004$ & -11.518 & $-9,330$ & 1.150 & -0.046 & 0.126 \\
\hline 3 & 0.592 & 0.219 & 0.107 & 0,035 & 0.029 & 4.732 & 6.920 & -0.831 & -0.021 & 0.104 \\
\hline 4 & 0,029 & -0.281 & -0.143 & 0.000 & $-0,004$ & 5.982 & 6.920 & 1.699 & 0.154 & 0.539 \\
\hline 5 & 0.404 & -0.094 & 0,107 & $-0,019$ & $-0,004$ & $-6,518$ & -9.330 & 1.122 & 0.004 & 0,166 \\
\hline 6 & 0.529 & 0,031 & -0.018 & 0.008 & $-0,004$ & $-11,518$ & -21.830 & -0.259 & 0,079 & 0,308 \\
\hline 8 & $-0,283$ & $-0,344$ & -0.018 & 0.061 & 0.010 & -15.268 & $-15,580$ & 0.074 & 0.154 & -0.775 \\
\hline 9 & 0,842 & $-0,031$ & 0.107 & 0.017 & -0.004 & $-21,518$ & $-16,830$ & -1.176 & 0.129 & $-0,613$ \\
\hline 10 & 0,404 & 0,281 & 0.482 & $-0,033$ & $-0,004$ & $-22,768$ & $-13,080$ & 0.456 & $-0,371$ & 0.107 \\
\hline 11 & $-0,033$ & -0.094 & 0,107 & $-0,027$ & $-0,004$ & $-12,768$ & $-19,330$ & 0.137 & -0.271 & 0,224 \\
\hline 12 & 0.154 & 0,156 & 0,357 & 0,012 & 0,002 & $-1,518$ & $-6,830$ & 0,685 & 0,179 & 0,397 \\
\hline 13 & 0,092 & 0,031 & $-0,018$ & 0,024 & $-0,004$ & 7,232 & 9,420 . & $-0,704$ & $-0,171$ & $-0,193$ \\
\hline 14 & 0.467 & 0,031 & $-0,143$ & -0.003 & $-0,004$ & 0.982 & 0,670 & -0.099 & 0.004 & 0.308 \\
\hline 15 & -0.283 & 0.219 & -0.205 & -0.015 & 0,003 & 3.482 & 6,920 & -0.446 & 0.079 & 0.158 \\
\hline 16 & 0.217 & 0.031 & 0.107 & 0.005 & -0.004 & 3.482 & 0,670 & 0.698 & -0.096 & 0,448 \\
\hline 17 & $-0,658$ & 0.031 & -0.018 & 0.021 & $-0,004$ & 15.982 & 20.670 & 0.183 & 0,104 & 0.043 \\
\hline 18 & 0.092 & -0.406 & $-0,143$ & 0,009 & -0.004 & -9.018 & 0.670 & 0.127 & 0,004 & -0.374 \\
\hline 19 & 0.592 & 0.281 & 0.107 & 0,001 & $-0,004$ & -11.518 & $-1,830$ & 0.384 & $-0,271$ & $-0,015$ \\
\hline 20 & 0,279 & $-0,031$ & $-0,143$ & $-0,009$ & $-0,004$ & 2,232 & $-11,830$ & $-0,818$ & 0,004 & 0,279 \\
\hline 21 & -0.033 & -0.031 & 0,232 & 0,054 & $-0,004$ & 7.232 & $-3,080$ & 0.023 & 0.104 & 0.023 \\
\hline 22 & 0.092 & -0.406 & -0.393 & -0.018 & 0.009 & -0.268 & -5.580 & 0.496 & -0.096 & 0.697 \\
\hline 23 & -0.408 & 0.281 & 0.232 & -0.011 & 0.010 & 0.982 & 5.670 & -1.118 & 0.429 & -0.322 \\
\hline 24 & -1.408 & $-0,094$ & -0.268 & -0.015 & 0,003 & 28.482 & 30.670 & -1.578 & -0.146 & -1.317 \\
\hline 25 & $-0,783$ & $-0,094$ & -0.018 & 0,008 & $-0,004$ & 4,732 & 5,670 & 0.505 & $-0,071$ & $-0,076$ \\
\hline 26 & $-0,658$ & $-0,156$ & 0,045 & 0,000 & $-0,004$ & 3,482 & 6,920 & $-0,408$ & 0,004 & 0,051 \\
\hline 27 & -1.158 & $-0,094$ & $-0,393$ & 0,000 & $-0,004$ & 12,232 & 14,420 & 0.154 & $-0,021$ & -0.067 \\
\hline 29 & $-0,221$ & 0,219 & $-0,143$ & $-0,027$ & 0,009 & 13,482 & 16,920 & $-0,422$ & 0,154 & -0.116 \\
\hline 30 & 0,217 & 0.156 & -0.268 & -0.005 & -0.004 & 14.732 & 15.670 & -0.182 & 0.104 & -0.073 \\
\hline
\end{tabular}


Tabela 75. Efeitos de heterose de variedade $h_{\mathrm{i}}$ no experimento $3 \mathrm{C}$ para mancha de Phaeosphaeria (PHAE), ferrugem tropical (PHYS), ferrugem polysora (POLY), porcentagem de colmos quebrados (QUEB), porcentagem de plantas acamadas (ACAM), altura de planta (AP), altura da espiga (AE), comprimento de espiga (CE), diâmetro de espiga (DE), e peso de grãos por parcela $(\mathrm{PG})$

\begin{tabular}{|c|c|c|c|c|c|c|c|c|c|c|}
\hline Acessos & PHAE & PHYS & POLY & QUEB & ACAM & $\mathbf{A P}$ & $\mathbf{A E}$ & CE & $\mathrm{DE}$ & PG \\
\hline 1 & -1.383 & 0,397 & -0.279 & -0.016 & & 6.298 & 12,332 & 0.270 & 0,086 & \\
\hline 2 & -0.172 & 0.060 & -0.481 & -0.007 & & 0.240 & -6.514 & -1.053 & 0.046 & 0,148 \\
\hline 3 & 0.165 & $-0,007$ & 0,058 & -0.005 & -0.018 & 3.606 & -5.841 & 0.281 & -0.049 & $-0,166$ \\
\hline 4 & .468 & -0.007 & 0.327 & 0.035 & 0.007 & 0.240 & -3.149 & -0.330 & -0.089 & -0.243 \\
\hline 5 & 400 & $-0,310$ & 0.058 & -0.008 & & -14.567 & -10.553 & 0.755 & 0.089 & .426 \\
\hline 6 & -0.609 & 094 & 125 & -0.035 & & 0.240 & & .738 & 0.049 & 0.010 \\
\hline 8 & 838 & 0,228 & $-0,144$ & 0,027 & $-0,001$ & -4.471 & 7,620 & $-0,572$ & $-0,035$ & 0,111 \\
\hline 9 & 105 & 0,127 & 0,058 & 0.003 & & 15,048 & 2.909 & -0.157 & 0,086 & -0.326 \\
\hline 10 & 400 & 0,026 & $-0,144$ & $-0,015$ & 0,000 & 0,913 & $-5,841$ & $-0,036$ & $-0,156$ & $-0,275$ \\
\hline 11 & & & $-0,2$ & & & 894 & & 0.287 & $-0,022$ & 0.229 \\
\hline 12 & & 094 & $-0,0$ & & & 4.279 & & 0,190 & $-0,049$ &, 46 \\
\hline 13 & .778 & $-0,243$ & $-0,144$ & & & 0.913 & -1.803 & $-0,441$ & 0.113 & 0.025 \\
\hline 1. & 306 & 228 & 0,058 & $-0,001$ & & -9.183 & & $-0,132$ & -0.089 & -0.252 \\
\hline 15 & & 209 & $-0,3$ & & & 9.663 & & 1.578 & 032 & .07 \\
\hline 16 & $-0,710$ & $-0,108$ & $-0,077$ & $-0,012$ & & -1.106 & 0,216 & 0,448 & 0,046 & 0,288 \\
\hline 17 & -0.239 & $-0,108$ & $-0,144$ & -0. & & 4.279 & & 0.779 & 0,046 & -0.178 \\
\hline 18 & 165 & 0.397 & 0.192 & & & -2.452 & $-1,130$ & -0.220 & -0.170 & -0.25 \\
\hline 19 & 299 & -0.041 & 0.058 & -0.004 & & -2.452 & -7 & 1.067 & 0.032 & $-0,01$ \\
\hline 20 & .811 & $-0,344$ & $-0,077$ & -0.031 & & -3.125 & & 0.548 & 0.046 & .63 \\
\hline 21 & -0.576 & & -0.279 & -0.012 & & -4.471 & -1.803 & 0.036 & 0,073 & 0,360 \\
\hline 22 & .097 & 0,195 & 0,192 & 0.004 & -0.007 & -3.125 & 2.236 & -0.528 & 0,046 & -0.463 \\
\hline 23 & .239 & -0.310 & $-0,144$ & 0.005 & -0.008 & 11.010 & 5.601 & 1.851 & 0.086 & 0.28 \\
\hline 24 & 0.030 & -0.175 & 0.394 & -0.008 & -0.004 & -6.490 & -3.822 & 0.421 & 0.073 & 0.478 \\
\hline 25 & -0.374 & -0.108 & -0.010 & -0.007 & & 0.913 & -1.130 & -1.145 & -0.129 & -0.017 \\
\hline 26 & -0.306 & $-0,007$ & 0.361 & 0.008 & 0.000 & -9.183 & 3.582 & -0.826 & 0.019 & -0.259 \\
\hline 27 & & & 0.192 & & & 8.990 & 4.928 & $-0,835$ & 0.005 & 0,35 \\
\hline 29 & .804 & -0.075 & 0,192 & 0.024 & $-0,007$ & 1.587 & -1.803 & 0.507 & 0.073 & 0.235 \\
\hline 30 & 0.501 & 0.026 & 0,260 & 0,029 & 0.006 & 6.298 & 6.947 & 0.047 & 0.019 & -0.06 \\
\hline
\end{tabular}


Tabela 76. Efeitos de capacidade geral de combinação $g_{i}$ no experimento $3 C$ para mancha de Phaeosphaeria (PHAE), ferrugem tropical (PHYS), ferrugem polysora (POLY), porcentagem de colmos quebrados (QUEB), porcentagem de plantas acamadas (ACAM), altura de planta (AP), altura da espiga (AE), comprimento de espiga (CE), diâmetro de espiga (DE), e peso de grãos por parcela (PG)

\begin{tabular}{|c|c|c|c|c|c|c|c|c|c|c|}
\hline Acessos & PHAE & PHYS & POLY & QUEB & ACAM & AP & $\mathbf{A E}$ & CE & DE & $\overline{P G}$ \\
\hline 1 & -1.025 & 0.569 & $-0,163$ & -0.039 & 0,012 & 3.664 & 5.167 & -0.197 & 0,026 & -0.007 \\
\hline 2 & -0.064 & -0.018 & -0.427 & $-0,020$ & $-0,002$ & -5.519 & $-11,180$ & $-0,478$ & 0,023 & $-0,085$ \\
\hline 3 & 0.460 & 0.102 & 0.111 & 0,012 & $-0,003$ & 5.972 & $-2,382$ & -0.135 & $-0,059$ & -0.114 \\
\hline 4 & 0.482 & -0.148 & 0.255 & 0.035 & 0,006 & 3,231 & 0.311 & 0.519 & -0.012 & 0.027 \\
\hline 5 & 0,602 & -0.357 & 0.111 & -0.017 & 0,021 & -17.826 & $-15,218$ & -0.194 & $-0,087$ & $-0,343$ \\
\hline 6 & -0.345 & 0.109 & 0.116 & -0.031 & -0.002 & -5.519 & -8.007 & -0.868 & -0.009 & 0.144 \\
\hline 8 & 0,696 & 0,056 & $-0,153$ & 0,057 & 0,004 & $-12,105$ & $-0,170$ & $-0,535$ & 0,042 & $-0,276$ \\
\hline 9 & 0,316 & 0,112 & 0,111 & 0,012 & 0,004 & 4,289 & $-5,507$ & $-0,745$ & 0,151 & $-0,632$ \\
\hline 10 & 0,602 & 0,167 & 0,097 & $-0,032$ & $-0,002$ & $-10,470$ & $-12,382$ & 0,192 & $-0,342$ & -0.221 \\
\hline 11 & 0.619 & $-0,020$ & $-0,158$ & $-0,012$ & $-0,002$ & $-20,278$ & $-10,795$ & 0,356 & $-0,157$ & $-0,117$ \\
\hline 12 & 0,612 & 0,172 & 0,102 & 0,010 & $-0,002$ & 3,520 & $-3,199$ & 0,532 & 0,041 & 0,667 \\
\hline 13 & -0.732 & -0.227 & $-0,153$ & 0.023 & -0.002 & 4,530 & 2,907 & -0.793 & 0.028 & $-0,071$ \\
\hline 14 & -0.073 & 0.244 & $-0,014$ & $-0,002$ & $-0,002$ & $-8,692$ & $-10,218$ & $-0,182$ & -0.087 & $-0,097$ \\
\hline 15 & 0.427 & $-0,100$ & $-0,415$ & $-0,032$ & $-0,002$ & 11.405 & $-5,074$ & 1.355 & 0.072 & 0.150 \\
\hline 16 & -0.602 & $-0,093$ & $-0,023$ & $-0,010$ & $-0,002$ & 0.635 & 0,551 & 0,797 & -0.002 & 0,512 \\
\hline 17 & -0.568 & -0.093 & $-0,153$ & 0,004 & $-0,002$ & 12.270 & 19,974 & 0,870 & 0,098 & -0.156 \\
\hline 18 & 0.210 & 0.194 & 0,121 & 0.023 & $-0,002$ & $-6,961$ & $-0,795$ & -0.157 & $-0,167$ & $-0,437$ \\
\hline 19 & 0,595 & 0,100 & 0,111 & $-0,004$ & $-0,002$ & $-8,211$ & $-8,776$ & 1.259 & $-0,103$ & $-0,025$ \\
\hline 20 & -0.672 & $-0,359$ & $-0,148$ & -0.035 & $-0,002$ & -2.009 & 6,417 & 0.139 & 0,048 & 0.774 \\
\hline 21 & -0.592 & 0.044 & $-0,163$ & 0.015 & -0.002 & -0.855 & -3.343 & 0.047 & 0.125 & 0.371 \\
\hline 22 & 0.143 & -0.008 & -0.004 & $-0,005$ & $-0,003$ & -3.259 & -0.555 & -0.280 & $-0,002$ & -0.114 \\
\hline 23 & $-0,443$ & $-0,169$ & $-0,028$ & $-0,001$ & $-0,003$ & 11,501 & 8.436 & 1.292 & 0.301 & 0.119 \\
\hline 24 & $-0,674$ & $-0,222$ & 0,260 & -0.016 & $-0,002$ & 7,751 & 11.513 & $-0,368$ & 0,000 & $-0,180$ \\
\hline 25 & $-0,766$ & $-0,155$ & $-0,019$ & $-0,003$ & -0.002 & 3.280 & 1,705 & $-0,892$ & $-0,165$ & $-0,054$ \\
\hline 26 & $-0,636$ & -0.085 & 0.383 & 0.008 & $-0,002$ & -7.442 & 7,042 & -1.030 & 0.021 & -0.234 \\
\hline 27 & 0.124 & 0.047 & $-0,004$ & 0.023 & $-0,002$ & 15.106 & 12,138 & $-0,758$ & $-0,005$ & 0.320 \\
\hline 29 & 0.694 & 0,035 & 0.121 & 0,011 & $-0,003$ & 8.328 & 6,657 & 0.296 & 0.150 & 0.177 \\
\hline 30 & 0,609 & 0,105 & 0,126 & 0,027 & 0,004 & 13,664 & 14,782 & $-0,044$ & 0,071 & $-0,096$ \\
\hline
\end{tabular}


Tabela 77. Médias dos tratamentos do experimento 3R para mancha de Phaeosphaeria (PHAE). porcentagem de plantas com enfezamento (ENFE), porcentagem de plantas acamadas $(\mathrm{ACAM})$, altura de planta (AP), altura da espiga (AE) e peso de grãos por parcela (PG).

\begin{tabular}{|c|c|c|c|c|c|c|}
\hline Acessos & PHAE & ENFE & ACAM & $\mathbf{A P}$ & $\mathbf{A E}$ & PG \\
\hline 1 & 2,4 & 0,0 & 5,99 & 256,9 & 150,6 & 2,542 \\
\hline 2 & 3,2 & 0,0 & 8,93 & 245,6 & 145,6 & 2,739 \\
\hline 3 & 3.0 & 0.0 & 8.28 & 263,8 & 161,3 & 3,063 \\
\hline 4 & 2.9 & 0.6 & 9.38 & 250,6 & 148.8 & 2,398 \\
\hline 5 & 3,5 & 0,0 & 7,78 & 242,5 & 140,6 & 2,631 \\
\hline 6 & 3,1 & 0,0 & 5,98 & 247.5 & 145,6 & 3,293 \\
\hline 8 & 3.3 & 0.0 & 15,75 & 245.6 & 138.1 & 1.970 \\
\hline 9 & 3.3 & 0.0 & 10.31 & 236.3 & 136.9 & 1,904 \\
\hline 10 & 2.8 & 0.7 & 5,78 & 234.4 & 140.6 & 2.440 \\
\hline 11 & 2.9 & 0.0 & 8,94 & 236.3 & 132.5 & 2,763 \\
\hline 12 & 3,1 & 0.0 & 10,47 & 261,9 & 160,6 & 2,695 \\
\hline 13 & 2.8 & 0,0 & 8,39 & 264,4 & 161,3 & 2,412 \\
\hline 14 & 2,8 & 0,0 & 6,26 & 265,6 & 159,4 & 2,787 \\
\hline 15 & 2.9 & 0.0 & 8,39 & 273.1 & 166.3 & 2.862 \\
\hline 16 & 2.6 & 0.0 & 5,89 & 264,4 & 163.8 & 2,606 \\
\hline 17 & 2.5 & 0.0 & 5,97 & 268.8 & 165.6 & 2,249 \\
\hline 18 & 3,3 & 0.0 & 7,04 & 258,8 & 153,1 & 2,379 \\
\hline 19 & 2,8 & 0,0 & 7,44 & 235,6 & 139,4 & 2,346 \\
\hline 20 & 2,8 & 0.8 & 8,34 & 236.3 & 124,4 & 2,693 \\
\hline 21 & 2,8 & 0.0 & 11,77 & 265,0 & 163.1 & 2.427 \\
\hline 22 & 3,0 & 0.7 & 6.06 & 255,0 & 148,8 & 2,877 \\
\hline 23 & 2.3 & 0.0 & 8,27 & 279.4 & 171.3 & 2.944 \\
\hline 24 & 2.1 & 0.0 & 6,39 & 294.4 & 188.8 & 1.273 \\
\hline 25 & 2.6 & 0.0 & 8.67 & 259.4 & 159.4 & 2.062 \\
\hline 26 & 2.5 & 0.0 & 8.22 & 257.5 & 166.3 & 2.831 \\
\hline 27 & 2.4 & 0.0 & 5,84 & 273,8 & 175,6 & 2,673 \\
\hline 29 & 2.4 & 0,0 & 5,99 & 270.6 & 166.9 & 2.650 \\
\hline 30 & 2.4 & 0.0 & 7.52 & 275.0 & 174.4 & 2,171 \\
\hline Topcrosses & PHAE & ENFE & ACAM & $\mathbf{A P}$ & $\mathbf{A E}$ & PG \\
\hline $1 t$ & 2.9 & 0.0 & 7,51 & 276,9 & 168.1 & 2.754 \\
\hline $2 t$ & 2.9 & 0.0 & 7.45 & 248.8 & 150.0 & 2.824 \\
\hline $3 t$ & 2.3 & 1.4 & 7.38 & 263.1 & 160.6 & 2.952 \\
\hline $4 t$ & 2.5 & 0.0 & 8,28 & 253.8 & 156.3 & 2.739 \\
\hline $5 t$ & 2.9 & 0.0 & 9,43 & 247,5 & 153.1 & 2,428 \\
\hline $6 t$ & 2.7 & 0.0 & 9.27 & 249.4 & 146.3 & 2,863 \\
\hline $8 \mathrm{t}$ & 3.3 & 0.0 & 12.71 & 249.4 & 146.9 & 2.534 \\
\hline $9 t$ & 3.3 & 0.0 & 10.09 & $2+8.1$ & 150.6 & 2.338 \\
\hline $10 t$ & 2.8 & 0.0 & 9.10 & $2+8.8$ & 141,9 & 2.982 \\
\hline $11 t$ & 2.8 & 0.8 & 6.65 & 238.1 & 138.8 & 3.102 \\
\hline $12 \mathrm{t}$ & 2.4 & 0.0 & 8.50 & 263.8 & 161.3 & 3.109 \\
\hline $13 t$ & 2.8 & 0.0 & 6.06 & 271.9 & 162.5 & 3.154 \\
\hline $14 t$ & 2.8 & 0.0 & 7.00 & 265.6 & 163.8 & 2.939 \\
\hline $15 t$ & 2.8 & 0.7 & 7.29 & $2+7.5$ & 146.9 & 2.954 \\
\hline $16 t$ & 2.8 & 0.0 & 7.02 & 264.4 & 160.6 & 2.772 \\
\hline
\end{tabular}




\begin{tabular}{cccrrrr}
\hline Topcrosses & PHAE & ENFE & ACAM & AP & AE & PG \\
\hline $\mathbf{1 7 t}$ & 2.4 & 0.7 & 8,87 & 256,9 & 153.8 & 2,703 \\
$\mathbf{1 8 t}$ & 2.5 & 0,0 & 8.50 & 262,5 & 158.8 & 2.832 \\
$\mathbf{1 9 t}$ & 2.9 & 0.0 & 6,32 & 241,9 & 143.1 & 2,766 \\
$\mathbf{2 0 t}$ & 3.1 & 0,0 & 5,85 & 263,8 & 157,5 & 3.160 \\
$\mathbf{2 1 t}$ & 2.8 & 0,0 & 9,86 & 240,6 & 141.9 & 3,227 \\
$\mathbf{2 2 t}$ & 2,9 & 0,0 & 5,60 & 266,3 & 159,4 & 3,312 \\
$\mathbf{2 3 t}$ & 2,6 & 0,0 & 6,99 & 257,5 & 160.0 & 3,538 \\
$\mathbf{2 4 t}$ & 2.3 & 0,0 & 6.14 & 270.6 & 167.5 & 2.534 \\
$\mathbf{2 5 t}$ & 2.3 & 0,0 & 8.61 & 264.4 & 161.9 & 2.762 \\
$\mathbf{2 6 t}$ & 2.8 & 0.0 & 8.93 & 263.1 & 163.1 & 2.923 \\
$\mathbf{2 7 t}$ & 2.3 & 0,0 & 5,64 & 273.8 & 165,0 & 3.235 \\
$\mathbf{2 9 t}$ & 2.6 & 0,9 & 6,77 & 276.9 & 163.8 & 2,422 \\
$\mathbf{3 0 t}$ & 2,6 & 0,0 & 7,76 & 267.5 & 167,5 & 2.433 \\
\hline Testemunhas & PHAE & $\mathbf{E N F E}$ & $\mathbf{A C A M}$ & $\mathbf{A P}$ & $\mathbf{A E}$ & $\mathbf{P G}$ \\
\hline T1 & 2.0 & 0.0 & 5,43 & 227.3 & 128.8 & 4.126 \\
T2 & $\mathbf{2 . 1}$ & 0,0 & 6.13 & 247.7 & 137.5 & 4,237 \\
\hline
\end{tabular}

Tabela 78. Resumo das análises de variância do experimento 3R para mancha de Phaeosphaeria (PHAE), porcentagem de plantas com enfezamento (ENFE), porcentagem de plantas acamadas $(\mathrm{ACAM})$, altura de planta (AP), altura da espiga (AE) e peso de grãos por parcela (PG).

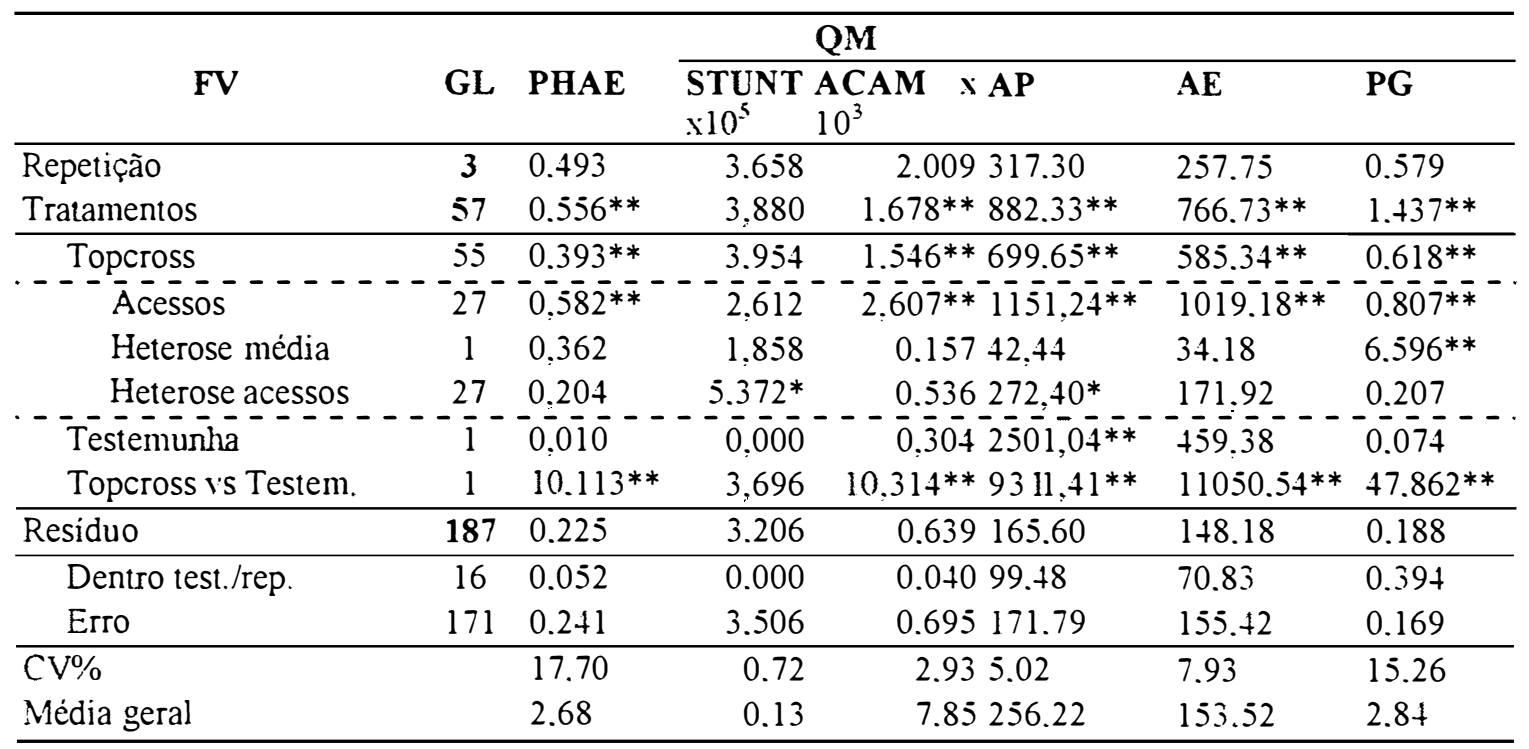

** e * indicam. respectivamente, significância ao nivel de $1 \%$ e de $5 \%$ de probabilidade. 
Tabela 79. Efeitos de variedade $v_{i}$ no experimento $3 R$ para mancha de Phaeosphaeria (PHAE). porcentagem de plantas com enfezamento (ENFE), porcentagem de plantas acamadas (ACAM), altura de planta (AP), altura da espiga (AE) e peso de grãos por parcela (PG).

\begin{tabular}{crrrrrr}
\hline Acessos & PHAE & ENFE & ACAM & AP & AE & PG \\
\hline $\mathbf{1}$ & -0.411 & -0.001 & $-0,021$ & -0.915 & $-4,688$ & 0,017 \\
$\mathbf{2}$ & 0.402 & -0.001 & 0,009 & $-12,165$ & $-9,688$ & 0,214 \\
$\mathbf{3}$ & 0.214 & -0.001 & 0.003 & 5.960 & 5.938 & 0,539 \\
$\mathbf{4}$ & 0.089 & 0.005 & 0.014 & -7.165 & -6.563 & -0.127 \\
$\mathbf{5}$ & 0.714 & -0.001 & $-0,002$ & -15.290 & $-14,688$ & 0.106 \\
$\mathbf{6}$ & 0.277 & -0.001 & -0.021 & -10.290 & -9.688 & 0.769 \\
$\mathbf{8}$ & 0.464 & -0.001 & 0.080 & -12.165 & $-17,188$ & -0.554 \\
$\mathbf{9}$ & 0.464 & -0.001 & 0.023 & -21.540 & $-18,438$ & -0.620 \\
$\mathbf{1 0}$ & -0.036 & 0.006 & $-0,023$ & $-23,415$ & -14.688 & $-0,084$ \\
$\mathbf{1 1}$ & 0.152 & $-0,001$ & 0,009 & $-21,540$ & $-22,813$ & 0.239 \\
$\mathbf{1 2}$ & 0.277 & -0.001 & 0,025 & 4,085 & 5.313 & 0.170 \\
$\mathbf{1 3}$ & -0.036 & -0.001 & 0,004 & 6,585 & 5,938 & $-0,112$ \\
$\mathbf{1 4}$ & 0.027 & -0.001 & $-0,018$ & 7,835 & 4.063 & 0.263 \\
$\mathbf{1 5}$ & 0.089 & -0.001 & 0,004 & 15,335 & 10.938 & 0.338 \\
$\mathbf{1 6}$ & -0.161 & -0.001 & $-0,022$ & 6,585 & 8,438 & 0.082 \\
$\mathbf{1 7}$ & -0.286 & $-0,001$ & $-0,021$ & 10,960 & 10,313 & $-0,275$ \\
$\mathbf{1 8}$ & 0,464 & $-0,001$ & $-0,010$ & 0,960 & $-2,188$ & $-0,145$ \\
$\mathbf{1 9}$ & -0.036 & $-0,001$ & $-0,006$ & $-22,165$ & -15.938 & -0.178 \\
$\mathbf{2 0}$ & 0.027 & 0.007 & 0.004 & -21.540 & -30.938 & 0.169 \\
$\mathbf{2 1}$ & -0.036 & -0.001 & 0.039 & 7.210 & 7.813 & -0.097 \\
$\mathbf{2 2}$ & 0.214 & 0.006 & -0.020 & $-2,790$ & -6.563 & 0,353 \\
$\mathbf{2 3}$ & -0.536 & -0.001 & 0.003 & 21,585 & 15.938 & 0.420 \\
$\mathbf{2 4}$ & -0.661 & -0.001 & -0.016 & 36.585 & 33.438 & -1.251 \\
$\mathbf{2 5}$ & -0.223 & -0.001 & 0.007 & 1.585 & 4.063 & -0.463 \\
$\mathbf{2 6}$ & -0.286 & -0.001 & 0.002 & -0.290 & 10.938 & 0.307 \\
$\mathbf{2 7}$ & -0.411 & -0.001 & -0.022 & 15.960 & 20.313 & 0.149 \\
$\mathbf{2 9}$ & -0.411 & -0.001 & -0.021 & 12.835 & 11.563 & 0.126 \\
$\mathbf{3 0}$ & -0.348 & -0.001 & -0.005 & 17.210 & 19.063 & -0.354 \\
\hline & & & & & & \\
& & & & &
\end{tabular}


Tabela 80. Efeitos de heterose de variedade $h_{i}$ no experimento $3 R$ para mancha de Phaeosphaeria (PHAE), porcentagem de plantas com enfezamento (ENFE), porcentagem de plantas acamadas (ACAM), altura de planta (AP), altura da espiga (AE) e peso de grãos por parcela (PG).

\begin{tabular}{crrrrrr}
\hline Acessos & PHAE & ENFE & ACAM & AP & AE & PG \\
\hline $\mathbf{1}$ & 0,404 & $-0,001$ & 0,007 & 20,108 & 15,481 & -0.131 \\
$\mathbf{2}$ & 0,034 & $-0,001$ & $-0,009$ & $-4,123$ & $-1,346$ & $-0,162$ \\
$\mathbf{3}$ & -0.606 & 0.014 & $-0,007$ & 1.599 & 1.683 & $-0,200$ \\
$\mathbf{4}$ & $-0,269$ & $-0,005$ & $-0,003$ & $-1,430$ & 3,702 & -0.071 \\
$\mathbf{5}$ & -0.202 & $-0,001$ & 0,019 & $-3,786$ & 4.712 & -0.530 \\
$\mathbf{6}$ & $-0,168$ & $-0,001$ & 0,027 & $-4,459$ & $-5,385$ & -0.419 \\
$\mathbf{8}$ & 0.337 & -0.001 & 0.011 & $-3,450$ & -0.673 & -0.060 \\
$\mathbf{9}$ & 0,337 & $-0,001$ & 0,012 & 0.252 & 4,038 & $-0,236$ \\
$\mathbf{1 0}$ & 0,067 & $-0,005$ & 0,027 & 1,935 & $-7,404$ & 0,168 \\
$\mathbf{1 1}$ & $-0,034$ & 0,007 & $-0,018$ & $-10,517$ & $-6,394$ & 0,124 \\
$\mathbf{1 2}$ & $-0,438$ & -0.001 & $-0,006$ & 3,281 & 2,692 & 0,169 \\
$\mathbf{1 3}$ & 0.135 & -0.001 & $-0,022$ & 10,685 & 3,702 & 0,369 \\
$\mathbf{1 4}$ & 0,101 & -0.001 & 0.000 & 3.281 & 6,058 & $-0,065$ \\
$\mathbf{1 5}$ & 0.067 & 0.006 & $-0,008$ & -20.276 & $-15,817$ & $-0,089$ \\
$\mathbf{1 6}$ & 0.135 & $-0,001$ & 0.003 & 2.608 & 0.337 & -0.147 \\
$\mathbf{1 7}$ & -0.135 & 0,006 & 0,022 & $-7,825$ & -8.077 & -0.029 \\
$\mathbf{1 8}$ & -0.471 & -0.001 & 0,012 & 3,618 & 4.038 & 0.039 \\
$\mathbf{1 9}$ & 0.202 & $-0,001$ & $-0,014$ & -6.142 & -5.385 & -0.013 \\
$\mathbf{2 0}$ & 0,438 & $-0,005$ & $-0,024$ & 17,079 & 18,173 & 0,224 \\
$\mathbf{2 1}$ & 0.067 & $-0,001$ & 0,001 & $-23,305$ & $-19,519$ & 0,439 \\
$\mathbf{2 2}$ & 0.135 & -0.005 & $-0,014$ & 9,675 & 7.067 & 0.289 \\
$\mathbf{2 3}$ & 0.202 & -0.001 & -0.011 & $-12,873$ & -4.375 & 0.496 \\
$\mathbf{2 4}$ & -0.135 & -0.001 & $-0,010$ & $-6,815$ & -5.721 & 0.314 \\
$\mathbf{2 5}$ & $-0,370$ & $-0,001$ & 0,005 & 5,300 & 4,038 & 0.136 \\
$\mathbf{2 6}$ & 0,269 & $-0,001$ & 0,011 & $\mathbf{4}, 964$ & 1,683 & -0.106 \\
$\mathbf{2 7}$ & $-0,269$ & $-0,001$ & $-0,012$ & 7,656 & $-1,346$ & 0.315 \\
$\mathbf{2 9}$ & 0.067 & 0,009 & -0.001 & 12,704 & 2,019 & $-0,548$ \\
$\mathbf{3 0}$ & 0.101 & -0.001 & 0.002 & 0.252 & 2.019 & -0.277 \\
\hline & & & & & & \\
& & & & &
\end{tabular}


Tabela 81. Efeitos de capacidade geral de combinação $\mathrm{g}_{\mathrm{i}}$ no experimento $3 \mathrm{R}$ para mancha de Phaeosphaeria (PHAE), porcentagem de plantas com enfezamento (ENFE), porcentagem de plantas acamadas (ACAM), altura de planta (AP), altura da espiga (AE) e peso de grãos por parcela $(P G)$.

\begin{tabular}{crrrrrr}
\hline AcessoS & PHAE & STUNT & ACAM & AP & AE & PG \\
\hline $\mathbf{1}$ & 0,198 & $-0,002$ & $-0,003$ & 19,651 & 13,137 & $-0,123$ \\
$\mathbf{2}$ & 0,235 & $-0,002$ & -0.005 & -10.205 & $-6,190$ & $-0,055$ \\
$\mathbf{3}$ & $-0,499$ & 0.013 & $-0,005$ & 4.578 & 4.651 & 0,070 \\
$\mathbf{4}$ & -0.225 & $-0,002$ & 0,004 & -5.013 & 0,421 & $-0,134$ \\
$\mathbf{5}$ & 0,155 & $-0,002$ & 0,018 & $-11,431$ & $-2,632$ & $-0,477$ \\
$\mathbf{6}$ & $-0,030$ & $-0,002$ & 0,016 & -9.604 & -10.228 & $-0,035$ \\
$\mathbf{8}$ & 0.569 & $-0,002$ & 0,051 & -9.532 & -9.267 & -0.337 \\
$\mathbf{9}$ & 0.569 & -0.002 & 0.024 & -10.518 & -5.180 & $-0,546$ \\
$\mathbf{1 0}$ & 0,049 & -0.002 & 0.015 & -9.772 & $-14,748$ & 0.126 \\
$\mathbf{1 1}$ & 0,042 & 0.006 & -0.014 & -21.287 & -17.800 & 0.244 \\
$\mathbf{1 2}$ & $-0,299$ & -0.002 & 0,006 & 5.324 & 5,349 & 0,254 \\
$\mathbf{1 3}$ & 0,117 & $-0,002$ & $-0,020$ & 13,978 & 6,671 & 0,313 \\
$\mathbf{1 4}$ & 0.114 & $-0,002$ & $-0,009$ & 7,199 & 8,089 & 0,066 \\
$\mathbf{1 5}$ & 0,112 & 0,006 & $-0,006$ & $-12,609$ & $-10,349$ & 0,080 \\
$\mathbf{1 6}$ & 0.054 & -0.002 & -0.008 & 5.901 & 4.555 & -0.106 \\
$\mathbf{1 7}$ & $-0,277$ & 0,006 & 0,012 & $-2,345$ & $-2,921$ & $-0,166$ \\
$\mathbf{1 8}$ & $-0,239$ & $-0,002$ & 0,007 & 4,098 & 2.945 & $-0,033$ \\
$\mathbf{1 9}$ & 0,184 & $-0,002$ & $-0,017$ & -17.224 & $-13,353$ & $-0,103$ \\
$\mathbf{2 0}$ & 0,451 & $-0,002$ & $-0,022$ & 6,309 & 2,704 & 0,309 \\
$\mathbf{2 1}$ & 0.049 & $-0,002$ & 0,020 & $-19,700$ & $-15,613$ & 0,391 \\
$\mathbf{2 2}$ & 0.242 & $-0,002$ & $-0,024$ & 8.280 & 3,786 & 0,465 \\
$\mathbf{2 3}$ & -0.066 & $-0,002$ & $-0,010$ & $-2,080$ & 3,594 & 0,706 \\
$\mathbf{2 4}$ & $-0,465$ & -0.002 & -0.018 & 11,478 & 10.998 & -0.312 \\
$\mathbf{2 5}$ & -0.482 & $-0,002$ & 0.008 & 6.093 & 6.070 & -0.096 \\
$\mathbf{2 6}$ & 0,126 & $-0,002$ & 0,012 & 4.819 & 7.151 & 0,047 \\
$\mathbf{2 7}$ & -0.475 & -0.002 & $-0,023$ & 15,636 & 8.810 & 0,390 \\
$\mathbf{2 9}$ & $-0,138$ & 0.008 & $-0,011$ & 19,122 & 7.800 & -0.485 \\
$\mathbf{3 0}$ & -0.073 & -0.002 & $-0,001$ & 8.857 & 11.550 & -0.454 \\
\hline & & & & & &
\end{tabular}


Tabela 82. Resumo das análises conjuntas de variância dos top-crosses dos experimentos $3 \mathrm{~A}, 3 \mathrm{C}$ e 3R para mancha de Phaeosphaeria (PHAE) e peso dos grãos por parcela (PG).

\begin{tabular}{|c|c|c|c|}
\hline & & PHAE & PG \\
\hline FV & GL & $\mathrm{QM}$ & QM \\
\hline Repetição/Local & 9 & 0.934 & 0,782 \\
\hline Local (L) & 2 & $313.320 * *$ & $143,087 * *$ \\
\hline Topcross & 55 & $0.878 * *$ & $1,270 * *$ \\
\hline Acessos & 27 & $1.441 * *$ & $1,583 * *$ \\
\hline Heterose média & 1 & 0.188 & $14,981 * *$ \\
\hline Heterose dos acessos & 27 & 0.340 & $0,450 * *$ \\
\hline Local $\times$ Topcross & 110 & $0.428 * *$ & 0.231 \\
\hline Local $\times$ Acessos & 54 & $0.419 * *$ & $0.290^{*}$ \\
\hline L $x$ Heterose média & 2 & 0,698 & $1,208^{* *}$ \\
\hline L $x$ Heterose dos acessos & 54 & $0,426 * *$ & 0,137 \\
\hline Resíduo combinado & 561 & 0,258 & 0,208 \\
\hline
\end{tabular}


Tabela 83. Médias dos tratamentos do experimento 4A para mancha de Phaeosphaeria (PHAE), altura de planta (AP), altura da espiga (AE), comprimento de espiga (CE), diâmetro de espiga (DE), e peso de grãos por parcela (PG) em kg.

\begin{tabular}{|c|c|c|c|c|c|c|}
\hline Acessos & PHAE & $\mathbf{A P}$ & $\mathbf{A E}$ & $\mathrm{CE}$ & $\mathbf{D E}$ & PG \\
\hline $1 \mathrm{~s}$ & 5.3 & 157,9 & 88.5 & 12,3 & 3.5 & 1.784 \\
\hline $2 s$ & 5,6 & 162.9 & 86.9 & 12,7 & 3,7 & 2.208 \\
\hline $3 s$ & 5.3 & 171,2 & 93,0 & 12,4 & 3,7 & 2,001 \\
\hline $4 s$ & 5,4 & 163,0 & 83,4 & 12,4 & 3,6 & 2,213 \\
\hline $5 s$ & 5,1 & 207,6 & 121,0 & 13,0 & 3,3 & 1,742 \\
\hline $6 s$ & 5.1 & 190,5 & 112.4 & 12.4 & 3.4 & 1.554 \\
\hline $7 \mathrm{~s}$ & 5.0 & 205,0 & 119.3 & 14.1 & 3,8 & 2,663 \\
\hline $8 s$ & 5.1 & 166,9 & 88.8 & 11,7 & 3,3 & 1,178 \\
\hline $9 \mathbf{s}$ & 5.3 & 165,0 & 90.1 & 13.0 & 4.2 & 2,166 \\
\hline $10 \mathrm{~s}$ & 5.0 & 185.5 & 107.2 & 13,6 & 3.9 & 2.024 \\
\hline $11 \mathrm{~s}$ & 5.2 & 205.7 & 117.6 & 13.3 & 3.9 & 2.653 \\
\hline $12 \mathrm{~s}$ & 5.1 & 198,3 & 109,1 & 14,0 & 4.1 & 2,661 \\
\hline $13 \mathrm{~s}$ & 5.0 & 213,1 & 127.0 & 14.2 & 4.0 & 2.443 \\
\hline $14 \mathrm{~s}$ & 5,1 & 201,4 & 115,8 & 14,2 & 3.7 & 2.427 \\
\hline $15 \mathrm{~s}$ & 5,1 & 199,7 & 114,7 & 13,5 & 3.8 & 2.260 \\
\hline $16 s$ & 4,8 & 173,4 & 92,4 & 12,8 & 3,8 & 2,707 \\
\hline $17 \mathrm{~s}$ & 5,5 & 176,6 & 94,7 & 13,6 & 3,9 & 2,194 \\
\hline $18 \mathrm{~s}$ & 5,1 & 171,2 & 89,8 & 12,8 & 4.0 & 2,052 \\
\hline $19 \mathrm{~s}$ & 4.9 & 240,2 & 146,3 & 13,1 & 3,7 & 2,575 \\
\hline $20 \mathrm{~s}$ & 4.9 & 215,3 & 125,4 & 14,0 & 3,5 & 2,346 \\
\hline $21 \mathrm{~s}$ & 5.2 & 193,3 & 100.3 & 14,2 & 4,0 & 2,683 \\
\hline $22 \mathrm{~s}$ & 4,8 & 205,8 & 120,8 & 14,1 & 3,4 & 1,890 \\
\hline $23 \mathrm{~s}$ & 4.9 & 186,5 & 103.6 & 13.8 & 3,7 & 3,146 \\
\hline $24 \mathrm{~s}$ & 5,3 & 177,8 & 95.9 & 12.9 & 3.8 & 2.458 \\
\hline $25 \mathrm{~s}$ & 4.3 & 232,6 & 146.4 & 13.5 & 3.6 & 2,864 \\
\hline $26 s$ & 5.0 & 182.6 & 111.6 & 14.2 & 3.5 & 1.916 \\
\hline $27 \mathrm{~s}$ & 4,8 & 235,4 & 139.9 & 13,3 & 3.5 & 2,038 \\
\hline $28 s$ & 4,9 & 232.1 & 151,1 & 12,6 & 3,6 & 1,796 \\
\hline $30 \mathrm{~s}$ & 4.8 & 208,9 & 119.0 & 14,6 & 3.7 & 2,763 \\
\hline Topcrosses & PHAE & $\mathbf{A P}$ & $\mathbf{A E}$ & $\mathrm{CE}$ & $\mathrm{DE}$ & PG \\
\hline $1 \mathrm{st}$ & 5.4 & 166.4 & 93.3 & 12.4 & 3.7 & 2.076 \\
\hline 2 st & 5.2 & 177,5 & 96.6 & 12.3 & 3.8 & 2.375 \\
\hline $3 s t$ & 5.4 & 188.5 & 101,6 & 13.7 & 3,8 & 2.441 \\
\hline $4 s t$ & 5.3 & 177.3 & 97.9 & 12.9 & 3.8 & 2.481 \\
\hline $5 s t$ & 5.3 & 199.5 & 116.9 & 14.7 & 4.0 & 1.990 \\
\hline $6 s t$ & 5.4 & 214.0 & 133.5 & 13.6 & 4.0 & 2.064 \\
\hline $7 \mathrm{st}$ & 5.0 & 202.6 & 111.2 & 13.6 & 3.9 & 2.738 \\
\hline $8 s t$ & 5.3 & 177.2 & 101.7 & 12.7 & 3.5 & 2.284 \\
\hline 9 st & 5,0 & 177.9 & 100.6 & 16.3 & 4.9 & 2.374 \\
\hline $10 \mathrm{st}$ & 4.9 & 198.0 & 106.3 & 14.3 & 4.1 & 2,408 \\
\hline $11 s t$ & 5.1 & 209,7 & 114.9 & 13.7 & 3.7 & 2.545 \\
\hline $12 \mathrm{st}$ & 5.0 & 199,5 & 117.9 & 13.5 & 3.9 & 2.313 \\
\hline $13 \mathrm{st}$ & 5.0 & 196.1 & 108.8 & 13.5 & 4.0 & 2.513 \\
\hline $14 \mathrm{st}$ & 5.0 & 207.6 & 117.5 & 14.7 & 3.9 & 2.355 \\
\hline $15 \mathrm{st}$ & 5.3 & 193.6 & 112.8 & 14.0 & +.0 & 2.501 \\
\hline $16 s t$ & 4.8 & 184.9 & 101.5 & 13.5 & 4.0 & 2.764 \\
\hline
\end{tabular}




\begin{tabular}{cccccccc}
\cline { 7 - 8 } Topcrosses & PHAE & AP & AE & CE & DE & PG \\
17st & 5,1 & 189,3 & 103.0 & 13,6 & 3.9 & 2.758 \\
18st & 5.0 & 185,0 & 103.6 & 13,8 & 4.1 & 2,643 \\
19st & 5.1 & 220.7 & 130.6 & 13,9 & 3.9 & 2.311 \\
20st & 5.2 & 216.7 & 125.4 & 14,8 & 3,8 & 2,815 \\
21st & 5,3 & 189,1 & 101,6 & 14,2 & 3,9 & 3,187 \\
22st & 4,9 & 223.2 & 124,8 & 15,2 & 3,8 & 2,714 \\
23st & 4,9 & 182,9 & 101.2 & 13.2 & 3,6 & 2.688 \\
24st & 5,1 & 191,6 & 101.5 & 13,6 & 4.2 & 2,581 \\
25st & 5.1 & 225,0 & 138.1 & 13.6 & 3.5 & 2.841 \\
26st & 5.0 & 196.6 & 116.8 & 13.1 & 3.6 & 1.939 \\
27st & 4.9 & 226.3 & 137.4 & 13,8 & 3,7 & 2,716 \\
28st & 5,1 & 213,4 & 130,6 & 12,9 & 4,0 & 2,415 \\
30st & $\mathbf{5 . 1}$ & 210.9 & 113,5 & 14,8 & 3,9 & 3,148 \\
\hline Testemunhas & PHAE & AP & AE & CE & DE & PG \\
\hline T1 & 3.5 & 207,0 & 108.8 & 15,2 & 4,5 & 4,933 \\
T2 & $\mathbf{4 . 1}$ & 236,2 & 129.6 & 14,4 & 4.3 & 4,643
\end{tabular}

Tabela 84. Resumo das análises de variância do experimento $4 \mathrm{~A}$ para mancha de Phaeosphaeria (PHAE), altura de planta (AP), altura da espiga (AE), comprimento de espiga (CE), diâmetro de espiga (DE), e peso đe grâos por parcela $(\mathrm{PG})$.

\begin{tabular}{|c|c|c|c|c|c|c|c|}
\hline \multirow[b]{2}{*}{ FV } & \multirow[b]{2}{*}{ GL } & \multirow[b]{2}{*}{ PHAE } & \multirow[b]{2}{*}{$\mathbf{A P}$} & \multicolumn{3}{|l|}{$\mathbf{Q M}$} & \multirow[b]{2}{*}{ PG } \\
\hline & & & & $\overline{\mathbf{A E}}$ & CE & $\mathbf{D E}$ & \\
\hline Repetição & 3 & 0,211 & 1026,17 & 660,86 & 1.231 & 0.015 & 1,604 \\
\hline Tratamentos & 59 & $0.835 * *$ & $1913,10^{* *}$ & $1091,69 * *$ & $3.328 * *$ & $0.414^{* *}$ & $2,740 * *$ \\
\hline Topcross & 57 & $0.185^{*}$ & $1639.11^{* *}$ & $1062,55^{* *}$ & $2,759 * *$ & $0.285^{* *}$ & $0.625^{* *}$ \\
\hline Acessos & $2 \overline{8}$ & $0,29 \overline{4}^{* *}$ & $\overline{3} \overline{10} \overline{1}, \overline{8} \overline{1}^{* *}$ & $20 \overline{8} 8,1 \overline{7}^{* *}$ & $3,2 \overline{3} * \bar{*}$ & $0,349^{* *}$ & $0 . \overline{93} \overline{9}^{* *}$ \\
\hline Heterose média & 1 & 0,093 & $920,74^{* *}$ & 165,19 & $13.425^{* *}$ & $1,990^{* *}$ & $3.955 * *$ \\
\hline Heterose acessos & 28 & 0.079 & $202,06 * *$ & $128,98 * *$ & 1,914 & 0.160 & $0.193^{*}$ \\
\hline Testemunha & 1 & $2,7 \overline{3} 4^{* *}$ & $5 \overline{110}, \overline{73 * \bar{*}}$ & $2593,24^{* *}$ & $3,8 \overline{58}$ & $0.490^{*}$ & $0,504^{*}$ \\
\hline Topcross vs Test. & 1 & $36,010 * *$ & $14333,09 * *$ & $1250,93^{* *}$ & $35.229 * *$ & $7,699 * *$ & $125,534^{* *}$ \\
\hline Resíduo & 193 & 0,116 & 99.53 & 51.66 & 1,259 & 0.116 & 0,110 \\
\hline Dentro test./rep. & 16 & 0,089 & 82,93 & 27,54 & 0,684 & 0,049 & 0,266 \\
\hline Erro & 177 & 0,118 & 101,03 & 53.84 & 1,311 & 0,122 & 0.096 \\
\hline $\mathrm{CV} \%$ & & 6.86 & 5.03 & 6.40 & 8.21 & 8.84 & 12,72 \\
\hline Média geral & & 4.96 & 198.38 & 112.32 & 13.67 & 3,86 & 2.61 \\
\hline
\end{tabular}

** e * indicam, respectivamente. significância ao nivel de $1 \%$ e de $5 \%$ de probabilidade. 
Tabela 85. Efeitos de variedade $v_{i}$ no experimento 4A para mancha de Phaeosphaeria (PHAE), altura de planta (AP), altura da espiga (AE), comprimento de espiga (CE), diâmetro de espiga (DE), e peso de grãos por parcela (PG).

\begin{tabular}{|c|c|c|c|c|c|c|}
\hline Acessoss & PHAE & AP & $\mathbf{A E}$ & CE & $\mathbf{D E}$ & $\overline{P G}$ \\
\hline $1 \mathrm{~s}$ & 0.188 & -36.115 & -22.213 & $-1,014$ & $-0,209$ & $-0,472$ \\
\hline $2 s$ & 0.563 & $-31,050$ & -23.910 & $-0,599$ & 0,020 & $-0,047$ \\
\hline $3 \mathrm{~s}$ & 0,188 & $-22,770$ & $-17,727$ & $-0,882$ & $-0,009$ & $-0,254$ \\
\hline $4 s$ & 0.313 & $-31,014$ & $-27,385$ & $-0,959$ & $-0,111$ & $-0,042$ \\
\hline $5 s$ & 0.063 & 13,583 & 10.220 & $-0,312$ & $-0,455$ & -0.514 \\
\hline $6 s$ & 0.063 & -3.470 & 1.675 & $-0,914$ & $-0,328$ & $-0,701$ \\
\hline $7 \mathrm{~s}$ & -0.063 & 11.053 & 8.529 & 0.759 & 0.085 & 0,408 \\
\hline $8 \mathrm{~s}$ & 0.063 & -27.080 & -21.932 & -1.622 & -0.386 & -1.078 \\
\hline $9 s$ & 0.188 & -28.993 & -20.678 & $-0,311$ & 0,486 & $-0,089$ \\
\hline $10 \mathrm{~s}$ & -0.063 & $-8,479$ & -3.597 & 0.255 & 0,148 & -0.231 \\
\hline $11 \mathrm{~s}$ & 0.125 & 11.697 & 6,873 & -0.054 & 0,172 & 0,398 \\
\hline $12 \mathrm{~s}$ & 0.063 & 4,339 & $-1,699$ & 0.666 & 0,402 & 0,406 \\
\hline $13 \mathrm{~s}$ & -0.063 & 19.140 & 16.239 & 0.902 & 0.307 & 0.187 \\
\hline $14 \mathrm{~s}$ & 0,063 & 7.399 & 5.048 & 0.898 & 0,007 & 0.171 \\
\hline $15 s$ & 0.063 & 5.768 & 3,969 & 0.189 & 0,083 & 0.005 \\
\hline $16 s$ & -0.313 & -20.565 & $-18,408$ & $-0,500$ & 0.094 & 0.452 \\
\hline $17 \mathrm{~s}$ & 0.438 & $-17,374$ & $-16,041$ & 0,266 & 0,236 & $-0,061$ \\
\hline $18 \mathrm{~s}$ & 0.063 & $-22,736$ & $-20,954$ & $-0,556$ & 0,320 & $-0,203$ \\
\hline $19 \mathrm{~s}$ & -0.125 & 46,270 & 35,514 & $-0,170$ & $-0,045$ & 0,319 \\
\hline $20 \mathrm{~s}$ & -0.188 & 21.289 & 14,647 & 0.684 & $-0,244$ & 0,091 \\
\hline $21 \mathrm{~s}$ & 0.125 & $-0,700$ & -10.443 & 0.855 & 0.295 & 0,427 \\
\hline $22 \mathrm{~s}$ & -0.250 & 11,774 & 10,048 & 0,766 & $-0,288$ & $-0,365$ \\
\hline $23 \mathrm{~s}$ & -0.125 & $-7,502$ & $-7,126$ & 0.513 & 0,013 & 0.891 \\
\hline $24 \mathrm{~s}$ & 0.188 & $-16,146$ & -14.832 & $-0,447$ & 0.083 & 0.203 \\
\hline $25 \mathrm{~s}$ & -0.813 & 38.580 & 35.589 & 0.186 & $-0,083$ & 0.609 \\
\hline $26 s$ & -0.063 & -11.392 & 0.862 & 0.893 & -0.247 & $-0,339$ \\
\hline $27 s$ & -0.313 & 41.392 & 29,152 & $-0,056$ & $-0,196$ & -0.218 \\
\hline $28 \mathrm{~s}$ & -0.125 & 38,152 & 40,299 & -0.737 & $-0,098$ & $-0,459$ \\
\hline $30 \mathrm{~s}$ & -0.250 & 14.949 & 8,282 & 1.300 & -0.052 & 0.508 \\
\hline
\end{tabular}




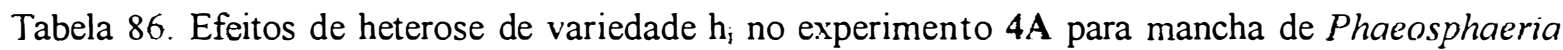
(PHAE), altura de planta (AP), altura da espiga (AE), comprimento de espiga (CE), diâmetro de espiga (DE), e peso de grãos por parcela (PG).

\begin{tabular}{crrrrrr}
\hline Acessos & PHAE & AP & AE & CE & DE & PG \\
\hline $\mathbf{1 s}$ & 0.192 & -14.455 & -8.644 & -0.966 & $-0,095$ & $-0,220$ \\
$\mathbf{2 s}$ & $-0,211$ & -5.343 & $-4,180$ & -1.227 & $-0,121$ & $-0,127$ \\
$\mathbf{3 s}$ & 0,192 & 2.064 & -2.173 & 0.407 & $-0,110$ & 0.056 \\
$\mathbf{4 s}$ & $-0,009$ & -5.505 & -0.875 & -0.414 & $-0,013$ & $-0,016$ \\
$\mathbf{5 s}$ & 0.192 & -5.686 & -0.723 & 1.122 & 0.347 & -0.290 \\
$\mathbf{6 s}$ & 0.259 & 19.088 & 21.709 & 0.307 & 0,302 & -0.110 \\
$\mathbf{7 s}$ & -0.077 & -0.924 & -5.879 & -0.583 & -0.064 & 0.019 \\
$\mathbf{8 s}$ & 0.125 & -7.771 & 0.233 & -0.269 & $-0,238$ & 0,329 \\
$\mathbf{9 s}$ & -0.211 & -5.959 & -1.650 & 2.914 & 0,858 & $-0,105$ \\
$\mathbf{1 0 s}$ & -0.144 & 4.591 & -4.701 & 0.433 & 0,135 & 0.008 \\
$\mathbf{1 1 s}$ & -0.110 & 6.317 & -1.108 & -0.108 & $-0,314$ & $-0,183$ \\
$\mathbf{1 2 s}$ & $-0,144$ & -0.677 & 6,762 & $-0,692$ & $-0,214$ & $-0,437$ \\
$\mathbf{1 3 s}$ & -0.077 & -12.231 & $-12,640$ & -0.816 & $-0,042$ & $-0,104$ \\
$\mathbf{1 4 s}$ & $-0,144$ & 6,340 & 2,724 & 0,445 & $-0,024$ & $-0,265$ \\
$\mathbf{1 5 s}$ & 0,192 & $-7,760$ & $-1,803$ & 0.079 & 0,125 & $-0,019$ \\
$\mathbf{1 6 s}$ & $-0,211$ & -3.028 & $-1,887$ & -0.079 & 0,017 & 0,023 \\
$\mathbf{1 7 s}$ & $-0,211$ & 0.015 & $-1,567$ & -0.301 & $-0,159$ & 0,293 \\
$\mathbf{1 8 s}$ & $-0,144$ & -1.659 & 1,757 & 0,315 & 0,014 & 0,245 \\
$\mathbf{1 9 s}$ & 0,091 & $-0,460$ & 0,438 & 0,170 & 0,019 & $-0,393$ \\
$\mathbf{2 0 s}$ & 0.192 & 8.654 & 6.035 & 0,678 & $-0,016$ & 0,272 \\
$\mathbf{2 1 s}$ & 0.091 & -9.189 & $-6,046$ & 0.011 & $-0,100$ & 0,491 \\
$\mathbf{2 2 s}$ & -0.043 & 20.762 & 7,854 & 1.078 & 0.005 & 0.409 \\
$\mathbf{2 3 s}$ & -0.110 & -12.167 & -8.277 & -0.870 & -0.271 & -0.294 \\
$\mathbf{2 4 s}$ & -0.077 & 1.820 & -3.747 & 0.069 & 0.336 & -0.040 \\
$\mathbf{2 5 s}$ & 0.434 & 8.326 & 8.466 & -0.308 & $-0,328$ & 0.022 \\
$\mathbf{2 6 s}$ & -0.077 & 4.694 & 4,251 & -1.257 & $-0,151$ & -0.438 \\
$\mathbf{2 7 s}$ & -0.077 & 8.229 & 11,129 & $-0,001$ & $-0,081$ & 0,331 \\
$\mathbf{2 8 s}$ & 0.024 & -3.942 & $-2,155$ & -0.543 & 0,179 & 0,137 \\
$\mathbf{3 0 s}$ & 0.091 & $\mathbf{5 . 8 5 5}$ & $-3,301$ & 0,407 & 0,003 & 0.406 \\
\hline & & & & & &
\end{tabular}


Tabela 87. Efeitos de capacidade geral de combinação $\mathbf{g}_{\mathbf{i}}$ no experimento $4 \mathbf{A}$ para mancha de Phaeosphaeria (PHAE), altura de planta (AP), altura da espiga (AE), comprimento de espiga (CE), diâmetro de espiga (DE), e peso de grãos por parcela (PG).

\begin{tabular}{crrrrrr}
\hline Acessos & PHAE & AP & AE & CE & DE & PG \\
\hline $\mathbf{1 s}$ & 0.286 & $-32,512$ & $-19,751$ & -1.473 & $-0,200$ & $-0,456$ \\
$\mathbf{2 s}$ & 0.070 & $-20,868$ & $-16,135$ & $-1,527$ & $-0,111$ & $-0,150$ \\
$\mathbf{3 s}$ & 0.286 & -9.321 & -11.037 & -0.033 & $-0,115$ & -0.071 \\
$\mathbf{4 s}$ & 0,147 & $-21,012$ & $-14,568$ & $-0,893$ & $-0,069$ & $-0,037$ \\
$\mathbf{5 s}$ & 0.223 & 1.105 & 4.387 & 0.966 & 0,119 & $-0,547$ \\
$\mathbf{6 s}$ & 0.290 & 17.353 & 22.547 & -0.150 & 0,138 & -0.460 \\
$\mathbf{7 s}$ & -0.108 & 4.602 & $-1,615$ & -0.204 & -0.022 & 0.223 \\
$\mathbf{8 s}$ & 0.156 & $-21,311$ & $-10,733$ & -1.080 & $-0,430$ & -0.210 \\
$\mathbf{9 s}$ & $-0,117$ & -20.455 & $-11,989$ & 2,759 & 1,101 & $-0,150$ \\
$\mathbf{1 0 s}$ & $-0,175$ & 0.352 & $-6,499$ & 0.561 & 0.209 & -0.108 \\
$\mathbf{1 1 s}$ & $-0,048$ & 12,166 & 2,329 & -0.135 & $-0,228$ & 0,016 \\
$\mathbf{1 2 s}$ & -0.113 & 1,493 & 5,912 & -0.359 & $-0,013$ & $-0,234$ \\
$\mathbf{1 3 s}$ & -0.108 & -2.661 & -4.521 & -0.365 & 0,112 & $-0,010$ \\
$\mathbf{1 4 s}$ & $-0,113$ & 10,040 & 5,247 & 0.894 & $-0,020$ & $-0,180$ \\
$\mathbf{1 5 s}$ & 0,223 & $-4,876$ & 0,182 & 0,173 & 0,167 & $-0,017$ \\
$\mathbf{1 6 s}$ & -0.367 & -13.310 & $-11,091$ & -0.329 & 0,064 & 0,249 \\
$\mathbf{1 7 s}$ & 0,008 & $-8,672$ & $-9,587$ & $-0,167$ & $-0,041$ & 0,262 \\
$\mathbf{1 8 s}$ & $-0,113$ & $-13,027$ & $-8,720$ & 0.037 & 0,174 & 0,144 \\
$\mathbf{1 9 s}$ & 0,029 & 22,675 & 18,195 & 0,085 & $-0,003$ & $-0,233$ \\
$\mathbf{2 0 s}$ & 0,098 & 19.298 & 13.358 & 1,020 & $-0,137$ & 0,317 \\
$\mathbf{2 1 s}$ & 0,154 & -9.539 & -11.268 & 0,438 & 0,047 & 0,704 \\
$\mathbf{2 2 s}$ & $-0,168$ & 26,649 & 12,878 & 1,461 & $-0,139$ & 0.226 \\
$\mathbf{2 3 s}$ & $-0,173$ & $-15,918$ & $-11,840$ & -0.614 & $-0,265$ & 0,151 \\
$\mathbf{2 4 s}$ & 0.017 & $-6,252$ & $-11,163$ & -0.155 & 0,377 & 0.062 \\
$\mathbf{2 5 s}$ & 0.027 & 27.616 & 26.260 & -0.215 & -0.369 & 0.326 \\
$\mathbf{2 6 s}$ & -0.108 & -1.002 & 4.682 & -0.811 & -0.275 & -0.607 \\
$\mathbf{2 7 s}$ & $-0,233$ & 28.925 & 25,705 & $-0,029$ & $-0,179$ & 0,223 \\
$\mathbf{2 8 s}$ & $-0,038$ & 15,134 & 17,994 & -0.912 & 0,130 & -0.092 \\
$\mathbf{3 0 s}$ & -0.034 & 13,330 & 0,840 & 1.057 & -0.023 & 0.660 \\
\hline & & & & & &
\end{tabular}


Tabela 88. Médias dos tratamentos do experimento 4C para mancha de Phaeosphaeria (PHAE), ferrugem tropical (PHYS), ferrugem polysora (POLY), porcentagem de colmos quebrados (QUEB), porcentagem de plantas acamadas (ACAM), altura de planta (AP), altura da espiga (AE), comprimento de espiga (CE), diâmetro de espiga (DE), e peso de grãos por parcela (PG).

\begin{tabular}{|c|c|c|c|c|c|c|c|c|c|c|}
\hline Acessos & PHAE & PHYS & POLY & QUEB & ACAM & AP & $\mathbf{A E}$ & CE & $\mathrm{DE}$ & PG \\
\hline $1 \mathrm{~s}$ & 4,88 & 4,00 & 3,00 & 7,87 & 0,00 & 180,0 & 73,8 & 15.3 & 4,2 & 2,532 \\
\hline $2 s$ & 5.19 & 3,38 & 2,75 & 4,23 & 0,69 & 175,0 & 71,3 & 15,7 & 4,4 & 3,196 \\
\hline $3 \mathrm{~s}$ & 4,19 & 3,38 & 2,75 & 2,48 & 0,71 & 177,5 & 76,3 & 14,2 & 4,1 & 2.552 \\
\hline $4 s$ & 5.25 & 3.63 & 3.00 & 0,63 & 0.00 & 188.8 & 88.8 & 14.3 & 4.3 & 3.097 \\
\hline $5 s$ & 5.06 & 3.44 & 2.88 & 12.02 & 1.33 & 211.3 & 111.3 & 15.5 & 4.1 & 2.895 \\
\hline $6 s$ & 5,31 & 3.38 & 2.88 & 11.74 & 0.00 & 198.8 & 107.5 & 15.5 & 4.3 & 3.076 \\
\hline $7 \mathrm{~s}$ & 5.38 & 3,19 & 2.75 & 1.85 & 0.63 & 225.0 & 125,0 & 15.9 & 4,6 & 3,880 \\
\hline $8 s$ & 4.00 & 3,63 & 3,00 & 22,85 & 0.00 & 170,0 & 77.5 & 13,2 & 3,7 & 1.326 \\
\hline $9 s$ & 5,00 & 3,69 & 3,13 & 2.55 & 1.28 & 181,3 & 73.8 & 15,4 & 4,7 & 3,254 \\
\hline $10 \mathrm{~s}$ & 5.81 & 4,00 & 3,25 & 1,30 & 0,00 & 205,0 & 102,5 & 16,4 & 4.5 & 3.284 \\
\hline $11 \mathrm{~s}$ & 4,94 & 4,00 & 2,75 & 3,31 & 0.64 & 213,8 & 113,8 & 16.2 & 4,5 & 3.780 \\
\hline $12 \mathrm{~s}$ & 5,50 & 4.06 & 2,75 & 1.88 & 0,00 & 196.3 & 101,3 & 16.3 & 4.4 & 3.774 \\
\hline $13 \mathrm{~s}$ & 5,56 & 3,88 & 2,88 & 1,88 & 0.64 & 217.5 & 115,0 & 16,5 & 4,4 & 3,908 \\
\hline $14 \mathrm{~s}$ & 5,81 & 3,56 & 2,88 & 2,62 & 1.32 & 218.8 & 110,0 & 16.2 & 4.2 & 3,435 \\
\hline $15 \mathrm{~s}$ & 4.81 & 3,38 & 3.06 & 3,05 & 0.00 & 201.3 & 106.3 & 15,6 & 4.5 & 3.865 \\
\hline $16 \mathrm{~s}$ & 4,69 & 3,63 & 3,13 & 1.27 & 0,64 & 192,5 & 82,5 & 14,8 & 4,4 & 3,915 \\
\hline $17 \mathrm{~s}$ & 5,25 & 3,31 & 2,75 & 2,55 & 1,28 & 206,3 & 93,8 & 15,5 & 4.7 & 3,912 \\
\hline $18 \mathrm{~s}$ & 4,88 & 3,56 & 2,88 & 1,35 & 0,00 & 197,5 & 86,3 & 14,4 & 4,1 & 3,101 \\
\hline $19 \mathrm{~s}$ & 5,88 & 4.25 & 2,75 & 6,96 & 0.64 & 228,8 & 132,5 & 17,7 & 4,4 & 4,096 \\
\hline $20 \mathrm{~s}$ & 5.50 & 4.25 & 3.00 & 5,63 & 0.00 & 223.8 & 122,5 & 15.8 & 4.2 & 3,718 \\
\hline $21 \mathrm{~s}$ & 5.31 & 4.00 & 2,75 & 0.63 & 0.00 & 206.3 & 111.3 & 16,1 & 4.5 & 4.510 \\
\hline $22 \mathrm{~s}$ & 3.50 & 4,00 & 2.88 & 1.35 & 0.00 & 217.5 & 122,5 & 16.6 & 4.2 & 3.619 \\
\hline $23 \mathrm{~s}$ & 4.88 & 3.81 & 3.00 & 0.63 & 0.00 & 197.5 & 91,3 & 15,2 & 4.2 & 3,597 \\
\hline $24 s$ & 4.50 & 4.13 & 2.88 & 0.68 & 0,00 & 182,5 & 81.3 & 14.8 & 4.3 & 3.307 \\
\hline $25 \mathrm{~s}$ & 3,63 & 3.13 & 2.50 & 9,23 & 0,00 & 231,3 & 131,3 & 14,5 & 4,1 & 2.462 \\
\hline $26 s$ & 5,00 & 3,38 & 2,75 & 5,07 & 0,63 & 193.8 & 105,0 & 16,4 & 4,0 & 2,994 \\
\hline $27 \mathrm{~s}$ & 4.81 & 3.75 & 2.75 & 3.78 & 0,58 & 243.8 & 143.8 & 16.4 & 4,4 & 3.641 \\
\hline $28 \mathrm{~s}$ & 5.44 & 3.44 & 2.88 & 6,50 & 0.00 & 231,3 & 127.5 & 15,1 & 4.6 & 3.483 \\
\hline $30 \mathrm{~s}$ & 4,38 & 3.75 & 2.75 & 2,52 & 0.00 & 220.0 & 107,5 & 16,5 & 4.2 & 3.615 \\
\hline Topcrosses & PHAE & PHYS & POLY & QUEB & ACAM & AP & $\mathbf{A E}$ & CE & DE & PG \\
\hline $1 \mathrm{st}$ & 5,00 & 3,81 & 2.50 & 4,12 & 2,78 & 186,3 & 76,3 & 13,7 & 4,1 & 2,571 \\
\hline $2 s t$ & 5,56 & 4.13 & 3.00 & 2.55 & 0.68 & 198.8 & 100,0 & 15,5 & 4.4 & 4.020 \\
\hline $3 s t$ & 5.19 & 3.75 & 3.25 & 3.05 & 0.00 & 202.5 & 103.8 & 15.5 & 4.3 & 3.482 \\
\hline 4 st & 5.00 & 3.56 & 2.50 & 2.49 & 0.00 & 186.3 & 85.0 & 15.3 & +.3 & 3.334 \\
\hline 5st & 5.00 & 3.56 & 2.75 & 6.88 & 1,22 & 216.3 & 111,3 & 16,8 & 4.4 & 3.520 \\
\hline $6 \mathrm{st}$ & 4.56 & 3.63 & 2.75 & 4.36 & 0.64 & 213.8 & 112.5 & 16.3 & 4.5 & 3.911 \\
\hline $7 s t$ & 6.25 & 3.94 & 3.00 & 3.13 & 0.00 & 218.8 & 113.8 & 16.2 & 4.4 & 3.862 \\
\hline $8 s t$ & 4.56 & 3.63 & 3.00 & 10.06 & 1.83 & 195.0 & 81.3 & 16.0 & 4.1 & $3.2+6$ \\
\hline 9st & 5.25 & 3.50 & 3.00 & 1.90 & 0.00 & 190.0 & 93.8 & 16.2 & 4.5 & 3.565 \\
\hline $10 \mathrm{st}$ & 5.44 & 3.63 & 3.00 & 4.00 & 0.00 & 220.0 & 116.3 & 16.6 & 4.5 & $3.8+7$ \\
\hline $11 \mathrm{st}$ & 5.44 & 3.75 & 3.00 & $7 .+2$ & 0.00 & 206.3 & 111.3 & 16.0 & +.5 & 4.010 \\
\hline $12 \mathrm{st}$ & 6.31 & 3.75 & 2.75 & 1.30 & 0.00 & 207.5 & 108.8 & 15.7 & 4.4 & 4.112 \\
\hline $13 \mathrm{st}$ & 5.94 & 3.63 & 3.00 & 3.24 & 0.00 & 223.8 & 117.5 & 16.3 & 4.5 & 3.772 \\
\hline $1+s t$ & 5.25 & 3.63 & 2.56 & 3.48 & 0.00 & 216.3 & 117.5 & 16.3 & t.t & $+.16 t$ \\
\hline $15 \mathrm{st}$ & 4.75 & 3.56 & 2.75 & 6.28 & 0.00 & 217.5 & 115.0 & 16.3 & +.5 & +.031 \\
\hline
\end{tabular}




\begin{tabular}{ccccccccccc}
\hline Topcrosses & PHAE & PHYS & POLY & QUEB & ACAM & AP & AE & CE & DE & PG \\
\hline 16st & 5.25 & 3,44 & 3,00 & 1.88 & 0,00 & 202,5 & 98,8 & 15,5 & 4.7 & 4.189 \\
17st & 4,88 & 3,63 & 2.81 & 4.36 & 0.00 & 211,3 & 106.3 & 15,7 & 4,4 & 4.303 \\
18st & 5.56 & 3,88 & 2,88 & 0,61 & 1,89 & 211,3 & 111.3 & 16,0 & 4,4 & 3,768 \\
19st & 5.31 & 3.75 & 3,00 & 5,97 & 0,00 & 222.5 & 116,3 & 16,4 & 4,4 & 4,240 \\
20st & 5,56 & 3,75 & 2,75 & 6.12 & 0,00 & 218,8 & 118,8 & 16,6 & 4,4 & 4,001 \\
21st & $\mathbf{5 . 0 0}$ & 3,75 & 3,00 & 1,78 & 0,00 & 203,8 & 102,5 & 15.7 & 4,5 & 4,108 \\
22st & 4.63 & 3.38 & 3.25 & 0,60 & 0.00 & 230,0 & 126,3 & 16,9 & 4.5 & 4,454 \\
23st & $\mathbf{5 , 1 9}$ & 3,69 & 3,25 & 1,83 & 0,61 & 206,3 & 105,0 & 16,0 & 4,4 & 3,888 \\
24st & $\mathbf{5 . 0 6}$ & 3,63 & 2,88 & 1,32 & 0,69 & 201,3 & 93,8 & 15,7 & 4,4 & 3.636 \\
25st & 4,44 & 3.88 & 2,50 & 4.34 & 1,88 & 211,3 & 116,3 & 14,6 & 4,0 & 3.510 \\
26st & $\mathbf{5 . 4 4}$ & 3,75 & 2,88 & 8,19 & 0,00 & 210,0 & 110,0 & 16.0 & 4.2 & 3.435 \\
27st & $\mathbf{5 . 3 8}$ & 4.00 & 3.00 & 2.42 & 0.00 & 227,5 & 123,8 & 16.0 & 4.3 & 3.972 \\
28st & $\mathbf{5 . 1 3}$ & 3,75 & 3.00 & 4,47 & 0,63 & 233,8 & 132,5 & 15.3 & 4.6 & 4.205 \\
30st & $\mathbf{5 . 0 0}$ & 4.38 & 3,00 & 1,88 & 0.00 & 222,5 & 120,0 & 17,3 & 4.5 & $\mathbf{5 , 1 1 0}$ \\
\hline Testemunhas & PHAE & PHYS & POLY & QUEB & ACAM & AP & AE & CE & DE & PG \\
\hline T1 & 3,54 & 3,25 & 2,17 & 1,48 & 0,00 & 210,0 & 107,1 & 15,9 & 5,0 & 5.579 \\
T2 & 4.00 & 4,08 & 2.58 & 3,64 & 0,63 & 234,6 & 125,0 & 16,0 & 4.9 & 5.215 \\
\hline
\end{tabular}


Tabela 89. Resumo das análises de variância do experimento 4C para mancha de Phaeosphaeria (PHAE), ferrugem tropical (PH'S), ferrugem polysora (POLY), porcentagem de colmos quebrados (QUEB) e porcentagem de plantas acamadas (ACAM).

\begin{tabular}{|c|c|c|c|c|c|c|}
\hline \multirow[b]{2}{*}{ FV } & \multirow[b]{2}{*}{ GL } & \multirow[b]{2}{*}{ PHAE } & \multicolumn{2}{|c|}{ QM } & \multirow[b]{2}{*}{$\begin{array}{c}\text { QUEB } x \\
10^{3} \\
\end{array}$} & \multirow[b]{2}{*}{$\begin{array}{c}\text { ACAM } x \\
10^{4} \\
\end{array}$} \\
\hline & & & PHYSO & POLY & & \\
\hline Repetição & 3 & 4,692 & 6,313 & 0,637 & 1,966 & 7,566 \\
\hline Tratamentos & 59 & $1,811 * *$ & $0,347 *$ & $0.243 * *$ & $5,954 * *$ & 1.580 \\
\hline Topcross & 57 & $1.181^{* *}$ & 0.285 & 0,134 & $6,017^{* *}$ & 1,591 \\
\hline Acessos & $\overline{28}$ & $\overline{1.8 \overline{2} 3 * \bar{*}}$ & $0.3 \overline{3} \overline{7}$ & $0.1 \overline{19}$ & $11.051^{* *}$ & $0.8 \overline{7}$ \\
\hline Heterose média & 1 & $3.379 *$ & 0.087 & 0.033 & 2.694 & 0.238 \\
\hline Heterose acessos & 28 & 0.461 & 0.241 & 0,153 & 1,102 & 2.357 \\
\hline Testemunha & $\overline{1}$ & 1.260 & $4, \overline{16} \overline{7 *}$ & $1,0 \overline{4} 2^{-* *}$ & $2,8 \overline{3} \overline{4}$ & $2, \overline{3} \overline{5} \overline{6}$ \\
\hline Topcross is Testemunha & 1 & $38.251 * *$ & 0.035 & $5.650 * *$ & $5.458 *$ & 0.213 \\
\hline Residuo & 193 & 0.688 & 0,224 & 0.146 & 1,207 & 1.641 \\
\hline Dentro test./rep. & 16 & 0,969 & 0,281 & 0.208 & 1,061 & 1.336 \\
\hline Erro & 177 & 0,663 & 0,219 & 0,140 & 1,220 & 1.669 \\
\hline $\mathrm{CV} \%$ & & 16,68 & 12,79 & 13,46 & 4,21 & 1,62 \\
\hline Média geral & & 4,97 & 3,70 & 2,84 & 4,06 & 0,41 \\
\hline
\end{tabular}

** e * indicam. respectivamente, significância ao nível de $1 \%$ e de $5 \%$ de probabilidade.

Tabela 90. Resumo das análises de variância do experimento 4C para altura de planta (AP), altura da espiga (AE), comprimento de espiga (CE), diâmetro de espiga (DE), e peso de grãos por parcela $(\mathrm{PG})$.

\begin{tabular}{lclllll}
\hline & & \multicolumn{5}{c}{$\mathbf{Q M}$} \\
\cline { 3 - 7 } \multicolumn{1}{c}{ FV } & GL & AP & AE & CE & DE & PG \\
\hline Repetição & $\mathbf{3}$ & 910,55 & 1121,71 & 1,125 & 0,011 & 0,286 \\
Tratamentos & $\mathbf{5 9}$ & $1174,82^{* *}$ & $1195,86^{* *}$ & $2,751^{* *}$ & $0,268^{* *}$ & $2.557^{* *}$ \\
\hline Topcross & $\mathbf{5 7}$ & $1070,63^{* *}$ & $1164,16^{* *}$ & $2,832^{* *}$ & $0.139^{* *}$ & $1.431^{* *}$ \\
$\quad$ Acessos & 28 & $1937,71^{* *}$ & $2112,92^{* *}$ & $4,163^{* *}$ & $0,224^{* *}$ & $2.017^{* *}$ \\
$\quad$ Heterose média & 1 & $2203,56^{* *}$ & $1603,88^{* *}$ & $8,307^{* *}$ & $0,385^{* *}$ & $14.378^{* *}$ \\
$\quad$ Heterose acessos & 28 & 163.09 & $199,69^{*}$ & $1,305^{*}$ & $0,044^{*}$ & $0,382^{* *}$ \\
Testemunha & 1 & $3626.04^{* *}$ & $1926,04^{* *}$ & 0.034 & $0,167^{*}$ & $0,792^{*}$ \\
Topcross vs Testemunha & 1 & $4662.18^{* *}$ & $2272,95^{* *}$ & 0.895 & $7.738^{* *}$ & $68.510^{* *}$ \\
\hline Residuo & $\mathbf{1 9 3}$ & 150.05 & 124.85 & 0.817 & 0.027 & 0.203 \\
$\quad$ Dentro test./rep. & 16 & 192,71 & 139,58 & 1.043 & 0,020 & 0.415 \\
Erro & 177 & 146.20 & 123.51 & 0.797 & 0.027 & 0.184 \\
\hline CV\% & & 5.866 & 10.46 & 5.73 & 3.71 & 11.89 \\
Média geral & & 209.0202 & 106.78 & 15.77 & 4.42 & 3.79 \\
\hline
\end{tabular}

** e * indicam. respectivamente. significância ao nivel de $1 \%$ e de $5 \%$ de probabilidade 
Tabela 91. Efeitos de variedade $v_{i}$ no experimento 4C para mancha de Phaeosphaeria (PHAE), ferrugem tropical (PHYS), ferrugem polysora (POLY), porcentagem de colmos quebrados (QUEB), porcentagem de plantas acamadas ( $A C A M$ ), altura de planta (AP), altura da espiga (AE), comprimento de espiga (CE), diâmetro de espiga (DE), e peso de grãos por parcela (PG).

\begin{tabular}{|c|c|c|c|c|c|c|c|c|c|c|}
\hline Acessos & PHAE & PHYS & POLY & QUEB & ACAM & AP & $\mathbf{A E}$ & CE & DE & $\overline{P G}$ \\
\hline $1 \mathrm{~s}$ & $-0,101$ & 0,313 & 0,127 & 0,034 & $-0,004$ & $-24,569$ & $-29,440$ & $-0,312$ & $-0,114$ & $-0,842$ \\
\hline $2 s$ & 0.211 & $-0,313$ & $-0,123$ & $-0,003$ & 0,003 & $-29,569$ & $-31,940$ & 0,088 & 0,060 & $-0,177$ \\
\hline $3 \mathrm{~s}$ & $-0,789$ & $-0,313$ & $-0,123$ & $-0,020$ & 0,003 & $-27,069$ & $-26,940$ & $-1,412$ & $-0,208$ & $-0,821$ \\
\hline $4 s$ & 0,274 & $-0,063$ & 0,127 & $-0,039$ & $-0,004$ & $-15,819$ & $-14,440$ & $-1,287$ & $-0,024$ & $-0,276$ \\
\hline $5 s$ & 0,086 & -0.250 & 0.002 & 0.077 & 0.010 & 6,681 & 8.060 & -0.087 & -0.201 & $-0,478$ \\
\hline $6 s$ & 0.336 & $-0,313$ & 0.002 & 0.074 & $-0,004$ & $-5,819$ & 4,310 & -0.112 & $-0,054$ & -0.297 \\
\hline $7 \mathrm{~s}$ & 0.399 & -0.500 & $-0,123$ & -0.026 & 0,002 & 20.431 & 21,810 & 0.338 & 0,271 & 0,507 \\
\hline $8 s$ & $-0,976$ & $-0,063$ & 0,127 & 0,196 & -0.004 & $-34,569$ & $-25,690$ & $-2,412$ & $-0,635$ & -2.047 \\
\hline $9 s$ & 0,024 & 0.000 & 0.252 & -0.019 & 0,009 & -23.319 & -29.440 & $-0,187$ & 0,372 & $-0,119$ \\
\hline $10 \mathrm{~s}$ & 0,836 & 0,313 & 0,377 & $-0,032$ & $-0,004$ & 0,431 & $-0,690$ & 0,813 & 0,216 & $-0,089$ \\
\hline $11 \mathrm{~s}$ & -0.039 & 0,313 & $-0,123$ & $-0,012$ & 0,003 & 9,181 & 10,560 & 0,588 & 0,177 & 0,407 \\
\hline $12 \mathrm{~s}$ & 0.524 & 0,375 & -0.123 & -0.026 & -0.004 & -8.319 & $-1,940$ & 0.738 & 0,087 & 0.401 \\
\hline $13 \mathrm{~s}$ & 0.586 & 0,188 & 0.002 & -0.026 & 0.003 & 12.931 & 11,810 & 0.913 & 0.085 & 0,535 \\
\hline $14 \mathrm{~s}$ & 0.836 & -0.125 & 0.002 & -0.019 & 0,009 & 14,181 & 6.810 & 0,663 & $-0,098$ & 0,061 \\
\hline $15 \mathrm{~s}$ & -0.164 & $-0,313$ & 0,190 & -0.014 & $-0,004$ & $-3,319$ & 3.060 & $-0,012$ & 0.162 & 0.492 \\
\hline $16 \mathrm{~s}$ & $-0,289$ & $-0,063$ & 0,252 & $-0,032$ & 0,003 & $-12,069$ & $-20,690$ & $-0,762$ & 0,088 & 0,542 \\
\hline $17 \mathrm{~s}$ & 0,274 & $-0,375$ & $-0,123$ & $-0,019$ & 0,009 & 1,681 & $-9,440$ & $-0,112$ & 0,366 & 0.539 \\
\hline $18 \mathrm{~s}$ & $-0,101$ & $-0,125$ & 0,002 & $-0,031$ & $-0,004$ & $-7,069$ & $-16,940$ & $-1,187$ & $-0,180$ & $-0,272$ \\
\hline $19 \mathrm{~s}$ & 0.899 & 0.563 & $-0,123$ & 0.025 & 0,003 & 24,181 & 29,310 & 2,088 & 0,074 & 0,722 \\
\hline $20 \mathrm{~s}$ & 0.524 & 0.563 & 0,127 & 0.012 & $-0,004$ & 19.181 & 19.310 & 0.213 & -0.157 & 0,344 \\
\hline $21 \mathrm{~s}$ & 0.336 & 0,313 & -0.123 & $-0,039$ & $-0,004$ & 1,681 & 8,060 & 0,563 & 0,215 & 1,137 \\
\hline $22 \mathrm{~s}$ & $-1,476$ & 0,313 & 0,002 & $-0,031$ & $-0,004$ & 12,931 & 19,310 & 1,013 & -0.145 & 0,245 \\
\hline $23 s$ & -0.101 & 0,125 & 0,127 & $-0,039$ & $-0,004$ & $-7,069$ & $-11,940$ & $-0,387$ & $-0,101$ & 0.224 \\
\hline $24 \mathrm{~s}$ & -0.476 & 0.438 & 0,002 & $-0,038$ & $-0,004$ & -22.069 & $-21,940$ & $-0,762$ & 0,028 & -0.067 \\
\hline $25 \mathrm{~s}$ & -1.351 & -0.563 & $-0,373$ & 0.048 & -0.004 & 26.681 & 28.060 & -1.112 & -0.211 & -0.911 \\
\hline $26 s$ & 0,024 & -0.313 & -0.123 & 0.006 & 0.002 & $-10,819$ & 1,810 & 0,863 & $-0,278$ & $-0,379$ \\
\hline $27 \mathrm{~s}$ & -0.164 & 0,063 & $-0,123$ & $-0,007$ & 0,002 & 39,181 & 40.560 & 0,863 & 0,072 & 0,268 \\
\hline $28 s$ & 0,461 & -0.250 & 0,002 & 0,020 & $-0,004$ & 26,681 & 24,310 & $-0,512$ & 0,230 & 0,110 \\
\hline $30 \mathrm{~s}$ & -0.601 & 0.063 & -0.123 & -0.020 & -0.004 & 15,431 & 4.310 & 0,913 & $-0,098$ & 0.241 \\
\hline
\end{tabular}


Tabela 92. Efeitos de heterose de variedade $\mathrm{h}_{\mathrm{i}}$ no experimento $4 \mathrm{C}$ para mancha de Phaeosphaeria (PHAE), ferrugem tropical (PHYS), ferrugem polysora (POLY), porcentagem de colmos quebrados (QUEB), porcentagem de plantas acamadas (ACAM), altura de planta (AP), altura da espiga (AE), comprimento de espiga (CE), diâmetro de espiga (DE), e peso de grãos por parcela (PG).

mancha de Phaeosphaeria, ferrugem tropical, ferrugem polysora, porcentagem de colmos quebrados (QUEB), porcentagem de plantas acamadas (ACAM), altura de planta (AP), altura da espiga (AE), comprimento de espiga (CE), diâmetro de espiga (DE), e peso de grãos por parcela $(\mathrm{PG})$.

\begin{tabular}{|c|c|c|c|c|c|c|c|c|c|c|}
\hline Acessos & PHAE & PHYS & POLY & QUEB & ACAM & AP & $\mathbf{A E}$ & CE & $\mathrm{DE}$ & PG \\
\hline $1 \mathrm{~s}$ & -0.179 & -0.075 & -0.494 & -0.015 & 0.027 & -13.102 & -18.773 & -2.212 & $-0,230$ & -0.944 \\
\hline $2 s$ & 0.257 & 0.596 & 0.177 & -0.012 & 0.001 & 3.009 & 8.079 & -0.494 & -0.013 & 0.254 \\
\hline $3 \mathrm{~s}$ & 0.391 & 0.193 & 0.446 & 0.003 & $-0,007$ & 5.694 & 9.421 & 0,312 & 0.035 & 0.023 \\
\hline $4 s$ & $-0,381$ & -0.142 & -0.494 & 0.007 & -0.003 & -17.801 & -17.431 & $-0,050$ & $-0,081$ & -0.428 \\
\hline $5 s$ & -0.280 & -0.042 & -0.159 & -0.008 & 0.003 & 2.338 & $-1,319$ & 0,916 & 0.116 & $-0,120$ \\
\hline $6 s$ & $-0,884$ & 0.059 & -0.159 & -0.034 & 0,004 & 6,366 & 2.037 & 0,473 & 0,133 & 0,202 \\
\hline $7 \mathrm{~s}$ & 0,895 & 0,495 & 0.177 & 0.007 & $-0,006$ & $-2,361$ & $-6,019$ & 0,097 & $-0,111$ & $-0,282$ \\
\hline $8 s$ & -0.179 & -0.075 & 0.043 & -0.037 & 0.017 & 1.667 & $-15,417$ & 1,386 & 0.056 & 0.427 \\
\hline $9 s$ & 0.022 & -0.243 & -0.024 & -0.010 & -0.010 & -9.745 & 0,023 & 0,406 & -0.147 & -0.265 \\
\hline $10 \mathrm{~s}$ & $-0,213$ & -0.277 & -0.091 & 0,019 & $-0,003$ & 9.722 & 8,750 & 0,218 & 0.033 & 0.022 \\
\hline $11 \mathrm{~s}$ & 0.257 & -0.142 & 0.177 & 0.046 & -0.006 & -9.745 & $-2,662$ & $-0,225$ & 0,025 & $-0,069$ \\
\hline $12 \mathrm{~s}$ & 0,895 & -0.176 & $-0,091$ & -0.013 & -0.003 & 0.995 & 1,366 & $-0,655$ & $-0,074$ & 0,043 \\
\hline $13 \mathrm{~s}$ & 0,458 & -0.209 & 0,110 & 0,008 & $-0,006$ & 7,037 & 3,380 & $-0,131$ & 0,100 & $-0,394$ \\
\hline $14 \mathrm{~s}$ & $-0,414$ & $-0,042$ & $-0,360$ & 0,007 & $-0,010$ & $-1,690$ & 6,065 & 0,030 & 0,067 & 0,281 \\
\hline $15 \mathrm{~s}$ & $-0,414$ & -0.008 & -0.259 & 0,034 & $-0,003$ & 9,051 & 5,394 & 0,366 & $-0,029$ & $-0,092$ \\
\hline $16 s$ & 0.190 & -0.277 & -0.024 & -0.003 & -0.006 & $-2,361$ & 0.694 & $-0,091$ & 0.222 & 0,050 \\
\hline $17 \mathrm{~s}$ & -0.515 & 0.093 & -0.024 & 0,016 & -0.010 & -0.347 & 2.708 & -0.198 & -0.172 & 0.174 \\
\hline $18 \mathrm{~s}$ & 0,425 & 0.227 & -0.024 & -0.018 & 0.018 & 4.352 & 12.106 & 0.675 & 0.123 & 0.035 \\
\hline $19 \mathrm{~s}$ & -0.381 & -0.277 & 0.177 & 0.010 & -0.006 & -0.347 & -7.361 & -0.655 & -0.094 & 0.008 \\
\hline $20 \mathrm{~s}$ & 0.089 & -0.277 & -0.226 & 0.019 & -0.003 & -1.690 & 0.694 & 0.621 & 0.097 & -0.045 \\
\hline $21 \mathrm{~s}$ & -0.414 & -0.142 & 0.177 & -0.001 & -0.003 & $-8,403$ & $-10,718$ & $-0,534$ & 0.001 & -0.356 \\
\hline $22 \mathrm{~s}$ & 0,156 & -0.545 & 0,378 & $-0,018$ & $-0,003$ & 13,750 & 8,750 & 0,433 & 0,130 & 0,495 \\
\hline $23 \mathrm{~s}$ & 0.022 & -0.109 & 0.311 & -0.001 & 0,004 & $-1,019$ & 2,708 & 0,272 & 0,051 & $-0,102$ \\
\hline $24 s$ & 0.089 & -0.344 & -0.024 & -0.006 & 0.005 & 1.667 & $-4,005$ & 0,151 & -0.021 & -0.216 \\
\hline $25 \mathrm{~s}$ & -0.112 & 0.462 & -0.226 & -0.020 & 0.017 & -13.773 & -6.690 & -0.816 & -0.326 & 0,101 \\
\hline $26 s$ & 0.223 & 0.193 & 0.043 & 0.045 & -0.006 & 5.023 & 0.694 & $-0,453$ & -0.043 & -0.265 \\
\hline $27 \mathrm{~s}$ & 0,257 & 0.260 & 0.177 & -0.011 & -0.006 & -3.032 & -5.347 & $-0,426$ & -0.116 & $-0,036$ \\
\hline $28 \mathrm{~s}$ & $-0,347$ & 0.160 & 0.110 & -0.004 & 0,004 & 10.394 & 12,778 & $-0,413$ & 0,083 & 0.299 \\
\hline $30 \mathrm{~s}$ & 0.089 & 0.663 & 0.177 & -0.010 & -0.003 & 4.352 & 10.093 & 0,997 & 0.185 & 1.201 \\
\hline
\end{tabular}


Tabela 93. Efeitos de capacidade geral de combinação $g_{i}$ no experimento $4 \mathrm{C}$ para mancha de Phaeosphaeria (PHAE), ferrugem tropical (PHYS), ferrugem polysora (POLY), porcentagem de colmos quebrados (QUEB), porcentagem de plantas acamadas (ACAM), altura de planta (AP), altura da espiga (AE), comprimento de espiga (CE), diâmetro de espiga (DE), e peso de grãos por parcela (PG).

\begin{tabular}{|c|c|c|c|c|c|c|c|c|c|c|}
\hline Acessos & PHAE & PHYS & POLY & QUEB & ACAM & AP & $\mathbf{A E}$ & CE & DE & PG \\
\hline $1 \mathrm{~s}$ & -0.230 & 0,081 & $-0,431$ & 0,002 & 0,025 & $-25,386$ & $-33,493$ & $-2,368$ & $-0,287$ & -1.365 \\
\hline $2 s$ & 0.363 & 0.440 & 0,116 & $-0,013$ & 0.002 & -11.775 & $-7,891$ & $-0,450$ & 0,017 & 0,166 \\
\hline $3 \mathrm{~s}$ & -0.003 & 0.037 & 0.384 & -0.007 & -0.005 & -7.840 & -4.049 & -0.394 & -0.069 & $-0,387$ \\
\hline $4 s$ & -0.244 & -0.174 & -0.431 & -0.013 & -0.005 & -25.710 & -24.650 & $-0,694$ & -0.094 & -0.566 \\
\hline $5 s$ & $-0,237$ & $-0,167$ & $-0,157$ & 0.031 & 0.008 & 5.678 & 2,711 & 0,873 & 0.015 & $-0,359$ \\
\hline $6 s$ & $-0,716$ & $-0,097$ & $-0,157$ & 0,003 & 0.002 & 3.456 & 4,192 & 0,417 & 0,106 & 0,054 \\
\hline $7 \mathrm{~s}$ & 1.094 & 0.245 & 0,116 & $-0,006$ & -0.005 & 7.854 & 4.887 & 0,266 & 0,025 & $-0,029$ \\
\hline $8 s$ & -0.668 & -0.106 & 0.106 & 0.061 & 0.015 & -15.618 & -28.261 & 0.180 & -0.262 & -0.596 \\
\hline $9 s$ & 0,034 & -0.243 & 0.102 & $-0,020$ & $-0,005$ & -21.405 & $-14,697$ & 0,312 & 0,038 & $-0,325$ \\
\hline $10 \mathrm{~s}$ & 0.205 & $-0,120$ & 0,097 & 0,003 & -0.005 & 9,938 & 8,405 & 0,625 & 0,141 & $-0,022$ \\
\hline $11 \mathrm{~s}$ & 0.238 & 0.014 & 0.116 & 0.040 & -0.005 & -5.155 & 2,618 & 0,069 & 0,113 & 0.134 \\
\hline $12 \mathrm{~s}$ & 1.157 & 0.012 & -0.153 & -0.026 & -0.005 & -3.164 & 0,396 & $-0,286$ & $-0,031$ & 0,244 \\
\hline $13 \mathrm{~s}$ & 0,751 & -0.116 & 0,111 & -0.005 & -0.005 & 13.503 & 9.285 & 0,325 & 0,143 & -0.127 \\
\hline $14 \mathrm{~s}$ & 0.004 & -0.104 & $-0,359$ & -0.003 & -0.005 & 5.401 & 9.470 & 0,362 & 0.018 & 0.312 \\
\hline $15 \mathrm{~s}$ & $-0,496$ & $-0,164$ & $-0,164$ & 0,027 & -0.005 & 7.391 & 6,924 & 0,360 & 0,051 & 0,154 \\
\hline $16 s$ & 0.045 & -0.308 & 0,102 & -0.020 & -0.005 & $-8,396$ & $-9,650$ & $-0,472$ & 0,266 & 0,321 \\
\hline $17 \mathrm{~s}$ & $-0,378$ & $-0,095$ & $-0,086$ & 0,007 & $-0,005$ & 0,493 & $-2,011$ & $-0,254$ & 0,011 & 0,444 \\
\hline $18 \mathrm{~s}$ & 0,374 & 0.164 & $-0,023$ & $-0,033$ & 0,016 & 0,817 & 3,637 & 0,081 & 0,033 & $-0,101$ \\
\hline $19 \mathrm{~s}$ & 0.069 & 0.005 & 0,116 & 0,023 & $-0,005$ & 11,743 & 7,294 & 0,389 & $-0,058$ & 0,369 \\
\hline $20 \mathrm{~s}$ & 0.351 & 0,005 & $-0,162$ & 0,025 & -0.005 & 7,901 & 10,350 & 0,727 & 0,019 & 0,127 \\
\hline $21 \mathrm{~s}$ & -0.246 & 0.014 & 0,116 & $-0,020$ & $-0,005$ & $-7,562$ & $-6,687$ & $-0,252$ & 0,109 & 0,212 \\
\hline $22 \mathrm{~s}$ & $-0,582$ & -0.389 & 0,380 & $-0,033$ & -0.005 & 20.216 & 18,405 & 0,939 & 0.058 & 0.617 \\
\hline $23 s$ & $-0,029$ & $-0,046$ & 0,375 & -0.020 & 0.002 & -4.553 & $-3,261$ & 0,078 & 0.000 & 0.010 \\
\hline $24 s$ & $-0,149$ & -0.125 & -0.023 & -0.025 & 0.003 & -9.368 & $-14,974$ & -0.230 & -0.007 & -0.250 \\
\hline $25 \mathrm{~s}$ & $-0,788$ & 0,181 & -0.412 & 0,004 & 0.016 & $-0,433$ & 7,340 & $-1,372$ & -0.431 & -0.354 \\
\hline $26 s$ & 0,235 & 0,037 & $-0,019$ & 0,048 & -0.005 & $-0,386$ & 1,600 & $-0,022$ & $-0,182$ & $-0,455$ \\
\hline $27 \mathrm{~s}$ & 0.175 & 0,292 & 0,116 & $-0,015$ & -0.005 & 16,558 & 14,933 & 0,005 & $-0,080$ & 0,098 \\
\hline $28 s$ & -0.117 & 0.035 & 0,111 & 0,006 & 0.002 & 23,734 & 24,933 & -0.669 & 0.199 & 0.354 \\
\hline $30 \mathrm{~s}$ & -0.212 & 0.694 & 0.116 & -0.020 & -0.005 & 12.067 & 12.248 & 1.453 & 0.137 & 1.321 \\
\hline
\end{tabular}


Tabela 94. Médias dos tratamentos do experimento 4R para mancha de Phaeosphaeria (PHAE). porcentagem de plantas com enfezamento (ENFE), porcentagem de plantas acamadas (ACAM), altura de planta (AP), altura da espiga (AE) e peso de grãos por parcela (PG)

\begin{tabular}{|c|c|c|c|c|c|c|}
\hline Acessos & PHAE & ENFE & ACAM & AP & AE & PG \\
\hline $1 \mathrm{~s}$ & 4.6 & 2,08 & 18,55 & 176,7 & 86,9 & 1,447 \\
\hline $2 \mathrm{~s}$ & 4,8 & 0,00 & 8,61 & 192,0 & 97,8 & 1,772 \\
\hline $3 s$ & 5.0 & 0,00 & 6,90 & 203,0 & 100,9 & 1,948 \\
\hline $4 s$ & 4,9 & 0,00 & 7,15 & 186,9 & 91,3 & 1,948 \\
\hline $5 \mathrm{~s}$ & 4.4 & 0,00 & 11,48 & 216,7 & 119,0 & 2,140 \\
\hline $6 s$ & 4.8 & 0.00 & 10.10 & 217.0 & 119.2 & 2.273 \\
\hline $7 \mathrm{~s}$ & 3.6 & 0.83 & 7.85 & 224.1 & 123.1 & 3.286 \\
\hline $8 s$ & 4.8 & 0.00 & 17.25 & 199.3 & 93.0 & 1.058 \\
\hline $9 s$ & 4.8 & 0,00 & 6,62 & 201,4 & 109.2 & 1.643 \\
\hline $10 \mathrm{~s}$ & 4,9 & 0.00 & 7,30 & 220,0 & 115,7 & 2,596 \\
\hline $11 \mathrm{~s}$ & 4,2 & 0,00 & 5,61 & 226,7 & 124,8 & 3,355 \\
\hline $12 \mathrm{~s}$ & 4,4 & 0,00 & 5,90 & 226,3 & 121,3 & 3.278 \\
\hline $13 \mathrm{~s}$ & 3.6 & 0.76 & 7,74 & 230.1 & 127.6 & 3.628 \\
\hline $14 \mathrm{~s}$ & 4.4 & 0,00 & 7,52 & 221,5 & 123,5 & 2,937 \\
\hline $15 \mathrm{~s}$ & 4,1 & 0,00 & 6,05 & 211,1 & 110,8 & 3,333 \\
\hline $16 s$ & 3,3 & 0,00 & 7,37 & 207,6 & 109,3 & 3,441 \\
\hline $17 \mathrm{~s}$ & 4,4 & 0,00 & 8,31 & 213,3 & 105,5 & 3,208 \\
\hline $18 \mathrm{~s}$ & 4.6 & 0,74 & 5,96 & 192.2 & 97,5 & 2,783 \\
\hline $19 \mathrm{~s}$ & 3,6 & 0,00 & 9,55 & 247,2 & 143,1 & 3,352 \\
\hline $20 \mathrm{~s}$ & 3.5 & 0,00 & 9,78 & 224,2 & 118,9 & 2,419 \\
\hline $21 \mathrm{~s}$ & 4.0 & 0,00 & 6.48 & 208,4 & 111,6 & 3,606 \\
\hline $22 \mathrm{~s}$ & 2,9 & 0,00 & 6,62 & 226,9 & 126,5 & 2,678 \\
\hline $23 \mathrm{~s}$ & 3.9 & 0,00 & 7,69 & 208.4 & 111,3 & 3,156 \\
\hline $24 \mathrm{~s}$ & 4.6 & 0.81 & 6,89 & 193.9 & 103.7 & 2,735 \\
\hline $25 \mathrm{~s}$ & 2.1 & 0.00 & 5,93 & 253.9 & 152,7 & 2.400 \\
\hline $26 \mathrm{~s}$ & 4.9 & 0.00 & 12.14 & 216.2 & 115.1 & 3.045 \\
\hline $27 \mathrm{~s}$ & 3.4 & 0,00 & 5,98 & 250,7 & 135.1 & 2,751 \\
\hline $28 \mathrm{~s}$ & 3,8 & 0,00 & 12,15 & 248,9 & 145,5 & 2,232 \\
\hline $30 \mathrm{~s}$ & 3.8 & 0.00 & 5,66 & 230,0 & 126,6 & 3,179 \\
\hline Topcross & PHAE & ENFE & ACAM & AP & $\mathbf{A E}$ & PG \\
\hline $1 \mathrm{st}$ & 4.9 & 0,00 & 10,08 & 186,6 & 94,4 & 1,963 \\
\hline $2 s t$ & 4,5 & 0,00 & 7,92 & 202,7 & 109,7 & 2.814 \\
\hline $3 s t$ & 4.6 & 0,00 & 6.13 & 203.8 & 106,3 & 2.540 \\
\hline $4 s t$ & 4.4 & 0.00 & 8.05 & 199.2 & 99.9 & 2.510 \\
\hline 5st & 4.4 & 0.00 & 9.09 & 229.8 & 131,4 & 3.073 \\
\hline $6 \mathrm{st}$ & 4.6 & 0.39 & 5.26 & 226.8 & 130.4 & 3.245 \\
\hline $7 \mathrm{st}$ & 4.3 & 0.00 & 7.32 & 225,8 & 132,4 & 3.395 \\
\hline $8 s t$ & 4.8 & 1.85 & 9.57 & 194.9 & 100,6 & 2.005 \\
\hline 9st & 4.1 & 0,00 & 6.27 & 208.2 & 108,7 & 2.982 \\
\hline $10 \mathrm{st}$ & 4.4 & 0.00 & 7.16 & 231.2 & 125.5 & 2.981 \\
\hline $11 \mathrm{st}$ & 4.1 & 0.00 & 8.37 & 226.3 & 126.2 & 3.379 \\
\hline $12 \mathrm{st}$ & 4.3 & 0.0() & 9.03 & 233.1 & 124.7 & 3.392 \\
\hline $13 \mathrm{st}$ & 3.9 & 0.00 & 6.67 & 233.5 & 129.7 & 3.471 \\
\hline $14 s t$ & 3.8 & 0,00 & 6.98 & 227.7 & 127.5 & 3.423 \\
\hline $15 s t$ & 4.1 & 0.86 & 7.49 & 231.9 & 125.4 & $3.5(0) 8$ \\
\hline $16 \mathrm{st}$ & 3.8 & 0.81 & 6.96 & 209.0 & 110.2 & 3.231 \\
\hline
\end{tabular}




\begin{tabular}{ccrrrrr}
\hline Topcross & PHAE & ENFE & ACAM & AP & AE & PG \\
\hline 17st & 4,1 & 0,68 & 6,15 & 221,8 & 117.8 & 3,379 \\
18st & 4,3 & 0,00 & 9,20 & 214,1 & 113,9 & 3,085 \\
19st & 3.6 & 0,68 & 7,11 & 238.4 & 135,5 & 3,778 \\
20st & 3.8 & 0,00 & 7,30 & 219.9 & 118,0 & 3,214 \\
21st & 3.9 & 0,00 & 6,03 & 220,1 & 121,4 & 3,462 \\
22st & 3,6 & 0,00 & 7,62 & 237,2 & 134,1 & 3,592 \\
23st & 4,2 & 0,00 & 6,67 & 213,7 & 119,4 & 3,605 \\
24st & 4,6 & 0,00 & 23,14 & 211,3 & 109,5 & 3,176 \\
25st & 2.9 & 0,00 & 7,06 & 250,1 & 146,6 & 3,533 \\
26st & 4.4 & 0.68 & 7,78 & 221.5 & 122.3 & 3.148 \\
27st & 3.5 & 0.00 & 7,76 & 230.9 & 138.9 & 3.081 \\
28st & 4.3 & 0,00 & 8,81 & 239.0 & 138,4 & 3.286 \\
30st & 3.8 & 0,00 & 6,31 & 227.5 & 123,4 & 4.132 \\
\hline Testemunhas & PHAE & ENFE & ACAM & AP & AE & PG \\
\hline T1 & 2,0 & 0,00 & 5,56 & 219,4 & 122,5 & 4,932 \\
T2 & 2.2 & 0,00 & $\mathbf{5 , 8 2}$ & 251,5 & 141,5 & $\mathbf{5 , 1 7 0}$ \\
\hline
\end{tabular}

Tabela 95. Resumo das análises de variância do experimento $4 \mathrm{R}$ para mancha de Phaeosphaeria (PHAE), porcentagem de plantas com enfezamento (ENFE), porcentagem de plantas acamadas $(\mathrm{ACAM})$, altura de planta (AP), altura da espiga (AE) e peso de grãos por parcela (PG)

\begin{tabular}{|c|c|c|c|c|c|c|c|}
\hline \multirow[b]{2}{*}{ FV } & \multirow[b]{2}{*}{ GL } & \multirow[b]{2}{*}{ PHAE } & \multirow[b]{2}{*}{$\begin{array}{l}\text { STUNT } \\
\times 10^{4} \\
\end{array}$} & \multicolumn{3}{|l|}{ QM } & \multirow[b]{2}{*}{ PG } \\
\hline & & & & $\begin{array}{l}\text { ACAM } \\
10^{3}\end{array}$ & $\therefore \mathbf{A P}$ & $\mathbf{A E}$ & \\
\hline Repetição & 3 & 0,417 & 1.362 & 4.191 & 173,81 & 382,99 & 0.756 \\
\hline Tratamentos & 59 & $3,928 * *$ & 1,706 & $5.428 *$ & $1354,69 * *$ & $928,98 * *$ & $3.241 * *$ \\
\hline Topcross & 57 & $2,357 * *$ & 1.733 & $5.225^{*}$ & $1188,60 * *$ & $857,16^{* *}$ & $1.634^{* *}$ \\
\hline Acessos & 28 & $3,206 * *$ & $\overline{1}, \overline{53} \overline{1}$ & $6.069^{-}$ & $2 \overline{184,40 * *}$ & $\overline{156} \overline{5,2} \overline{1}^{* * *}$ & $2.520 * *$ \\
\hline Heterose média & 1 & 1.002 & 0,104 & 1.469 & $1385.30 * *$ & $1685,57 * *$ & $15,013^{* *}$ \\
\hline Heterose acessos & 28 & 1.557 & 1.993 & 4.514 & 185.77 & 119.52 & 0.269 \\
\hline Testemunha & $\overline{1}$ & 0,167 & 0,000 & $0,07 \overline{5}$ & $6 \overline{176,04 * *}$ & $2156,51 * *$ & 0.339 \\
\hline Topcross vs Testemunha & 1 & $97,188^{* *}$ & 1,885 & $22.381^{*}$ & $6000,51^{* *}$ & $3795,17^{* *}$ & $97.752 * *$ \\
\hline Resíduo & 193 & 1.054 & 1.827 & 3.454 & $1+2.46$ & 90.30 & 0.188 \\
\hline Dentro test./rep. & 16 & 0.063 & 0.000 & 0.062 & 40.61 & 43.75 & 0.161 \\
\hline Erro & 177 & 1,143 & 1.992 & 3.761 & 151.67 & $9+.50$ & 0.191 \\
\hline$\overline{C V \%}$ & & 25.67 & 4,47 & 13.47 & 5.42 & 7.92 & 13.86 \\
\hline Média geral & & 4.00 & 0.19 & 8.16 & 220.36 & 120.01 & 3.13 \\
\hline
\end{tabular}

** e * indicam. respectivamente, significância ao nivel de $1 \%$ e de $5 \%$ de probabilidade. 
Tabela 96. Efeitos de variedade $\mathrm{v}$, no experimento 4R para mancha de Phaeosphaeria (PHAE), porcentagem de plantas com enfezamento (ENFE), porcentagem de plantas acamadas (ACAM), altura de planta (AP), altura da espiga (AE) e peso de grãos por parcela (PG)

\begin{tabular}{crrrrrr}
\hline Acessos & PHAE & ENFE & ACAM & AP & AE & PG \\
\hline $\mathbf{1 s}$ & 0,431 & 0,027 & 0,109 & $-39,686$ & $-29,183$ & $-1,230$ \\
$\mathbf{2 s}$ & 0,619 & $-0,003$ & 0,004 & -24.366 & $-18,229$ & $-0,905$ \\
$\mathbf{3 s}$ & 0,869 & $-0,003$ & $-0,018$ & $-13,406$ & $-15,144$ & $-0,729$ \\
$\mathbf{4 s}$ & 0,744 & $-0,003$ & $-0,015$ & $-29,497$ & $-24,778$ & $-0,729$ \\
$\mathbf{5 s}$ & 0.306 & -0.003 & 0.038 & 0,362 & 2,920 & $-0,537$ \\
$\mathbf{6 s}$ & 0.619 & -0.003 & 0.022 & 0.669 & 3.148 & -0.404 \\
$\mathbf{7 s}$ & -0.506 & 0.010 & -0.006 & 7.731 & 7.057 & 0.609 \\
$\mathbf{8 s}$ & 0.619 & -0.003 & 0.104 & -17.030 & -23.088 & -1.619 \\
$\mathbf{9 s}$ & 0.619 & -0.003 & -0.022 & -14.915 & -6.871 & -1.033 \\
$\mathbf{1 0 s}$ & 0.806 & -0.003 & $-0,013$ & 3.671 & -0.423 & -0.081 \\
$\mathbf{1 1 s}$ & 0.056 & -0.003 & -0.036 & 10.323 & 8,717 & 0,678 \\
$\mathbf{1 2 s}$ & 0,306 & $-0,003$ & $-0,032$ & 9.898 & 5,182 & 0,602 \\
$\mathbf{1 3 s}$ & -0.506 & 0.009 & -0.008 & 13.776 & 11,478 & 0,951 \\
$\mathbf{1 4 s}$ & 0,306 & $-0,003$ & $-0,010$ & $\mathbf{5 . 1 4 7}$ & 7,457 & 0,260 \\
$\mathbf{1 5 s}$ & $-0,006$ & $-0,003$ & $-0,030$ & -5.305 & $-5,310$ & 0,656 \\
$\mathbf{1 6 s}$ & $-0,881$ & $-0,003$ & -0.013 & $-8,780$ & $-6,824$ & 0,764 \\
$\mathbf{1 7 s}$ & 0,244 & $-0,003$ & 0,000 & $-3,042$ & $-10,623$ & 0,531 \\
$\mathbf{1 8 s}$ & 0,494 & 0,009 & $-0,031$ & $-24,181$ & -18.581 & 0,106 \\
$\mathbf{1 9 s}$ & $-0,569$ & $-0,003$ & 0,014 & 30,882 & 27,026 & 0,675 \\
$\mathbf{2 0 s}$ & $-0,631$ & $-0,003$ & 0,018 & 7.794 & 2,790 & $-0,258$ \\
$\mathbf{2 1 s}$ & $-0,131$ & $-0,003$ & $-0,024$ & -7.973 & $-4,505$ & 0,930 \\
$\mathbf{2 2 s}$ & $-1,256$ & $-0,003$ & $-0,022$ & 10.501 & 10,443 & 0,002 \\
$\mathbf{2 3 s}$ & -0.256 & -0.003 & -0.009 & -7.949 & $-4,801$ & 0.479 \\
$\mathbf{2 4 s}$ & 0.431 & 0.010 & -0.019 & -22.480 & -12.366 & 0.058 \\
$\mathbf{2 5 s}$ & -2.006 & -0.003 & -0.031 & 37.491 & 36.607 & -0.277 \\
$\mathbf{2 6 s}$ & 0.744 & -0.003 & 0.047 & -0.163 & $-1,008$ & 0.368 \\
$\mathbf{2 7 s}$ & $-0,756$ & -0.003 & $-0,031$ & 34,293 & 18.989 & 0.074 \\
$\mathbf{2 8 s}$ & -0.319 & $-0,003$ & 0,048 & 32,575 & 29,438 & $-0,444$ \\
$\mathbf{3 0 s}$ & $-0,381$ & -0.003 & $-0,035$ & 13,659 & 10,482 & 0,503 \\
\hline & & & & & &
\end{tabular}


Tabela 97. Efeitos de heterose de variedade $\mathrm{h}_{\mathrm{i}}$ no experimento $4 \mathrm{R}$ para mancha de Phaeosphaeria (PHAE), porcentagem de plantas com enfezamento (ENFE), porcentagem de plantas acamadas $(\mathrm{ACAM})$, altura de planta (AP), altura da espiga (AE) e peso de grãos por parcela (PG)

\begin{tabular}{crrrrrr}
\hline Acessos & PHAE & ENFE & ACAM & AP & AE & PG \\
\hline $\mathbf{1 s}$ & 0,426 & $-0,018$ & $-0,029$ & $-15,910$ & $-13,384$ & $-0,653$ \\
$\mathbf{2 s}$ & $-0,078$ & $-0,002$ & $-0,002$ & $-6,796$ & $-2,803$ & 0,087 \\
$\mathbf{3 s}$ & $-0,078$ & $-0,002$ & $-0,015$ & $-11,541$ & $-8,111$ & $-0,302$ \\
$\mathbf{4 s}$ & $-0,279$ & $-0,002$ & 0,010 & $-7,807$ & $-9,886$ & $-0,334$ \\
$\mathbf{5 s}$ & 0.023 & -0.002 & -0.005 & 8.940 & 9.099 & 0.168 \\
$\mathbf{6 s}$ & -0.010 & 0.005 & -0.050 & 5.618 & 7.920 & 0.280 \\
$\mathbf{7 s}$ & 0.258 & $-0,009$ & -0.006 & 0.751 & 7.975 & $-0,102$ \\
$\mathbf{8 s}$ & 0.258 & 0,027 & $-0,033$ & $-19,113$ & $-9,983$ & $-0,399$ \\
$\mathbf{9 s}$ & 3.682 & $-0,002$ & $-0,011$ & $-5,988$ & $-10,069$ & 0,336 \\
$\mathbf{1 0 s}$ & -0.313 & -0.002 & -0.004 & 8.759 & 4.570 & -0.177 \\
$\mathbf{1 1 s}$ & -0.178 & $-0,002$ & 0.025 & -0.133 & 0,404 & $-0,156$ \\
$\mathbf{1 2 s}$ & $-0,111$ & $-0,002$ & 0,029 & 7.453 & 0,716 & $-0,101$ \\
$\mathbf{1 3 s}$ & $-0,145$ & $-0,008$ & $-0,014$ & 5,778 & 2,691 & $-0,205$ \\
$\mathbf{1 4 s}$ & $-0,715$ & $-0,002$ & $-0,008$ & 4.173 & 2.505 & 0.116 \\
$\mathbf{1 5 s}$ & $-0,145$ & 0.013 & 0,009 & 14,314 & 7,093 & $-0,006$ \\
$\mathbf{1 6 s}$ & -0.010 & 0,012 & $-0,006$ & -8.426 & $-8,426$ & -0.362 \\
$\mathbf{1 7 s}$ & $-0,279$ & 0,010 & $-0,025$ & 2.240 & 1,787 & $-0,078$ \\
$\mathbf{1 8 s}$ & -0.279 & -0.008 & 0,034 & $\mathbf{5 . 3 2 1}$ & 1,894 & $-0,166$ \\
$\mathbf{1 9 s}$ & $-0,447$ & 0,010 & $-0,019$ & 1.821 & 0,589 & 0,274 \\
$\mathbf{2 0 s}$ & -0.145 & $-0,002$ & $-0,019$ & -5.588 & $-5,235$ & 0,169 \\
$\mathbf{2 1 s}$ & -0.279 & $-0,002$ & $-0,014$ & 3.000 & 2,358 & $-0,203$ \\
$\mathbf{2 2 s}$ & -0.078 & -0.002 & 0,007 & 11.448 & 8.014 & 0.435 \\
$\mathbf{2 3 s}$ & 0.057 & -0.002 & $-0,013$ & -3.843 & 0,374 & 0.193 \\
$\mathbf{2 4 s}$ & 0.090 & -0.009 & 0,186 & 1.368 & -6.245 & -0.041 \\
$\mathbf{2 5 s}$ & $-0,413$ & $-0,002$ & 0,004 & 10.846 & 7.291 & 0.522 \\
$\mathbf{2 6 s}$ & $-0,279$ & 0,010 & $-0,028$ & 0.335 & 1,440 & -0.238 \\
$\mathbf{2 7 s}$ & $-0,413$ & $-0,002$ & 0.014 & -8.012 & 8,512 & -0.152 \\
$\mathbf{2 8 s}$ & 0,225 & -0.002 & -0.014 & 1.616 & 2,426 & 0.347 \\
$\mathbf{3 0 s}$ & -0.346 & $-0,002$ & $-0,004$ & $-0,628$ & -3.517 & 0.747 \\
\hline & & & & & &
\end{tabular}


Tabela 98. Efeitos de capacidade geral de combinação $g_{\imath}$ no experimento $4 R$ para mancha de Phaeosphaeria (PHAE), porcentagem de plantas com enfezamento (ENFE), porcentagem de plantas acamadas (ACAM), altura de planta (AP), altura da espiga (AE) e peso de grãos por parcela (PG)

\begin{tabular}{crrrrrr}
\hline Acessos & PHAE & STUNT & ACAM & AP & AE & PG \\
\hline $\mathbf{1 s}$ & 0,641 & $-0,004$ & 0,025 & -35.753 & $-27,976$ & -1.268 \\
$\mathbf{2 s}$ & 0,232 & $-0,003$ & 0,000 & $-18,979$ & $-11,918$ & $-0,365$ \\
$\mathbf{3 s}$ & 0,357 & -0.003 & $-0,025$ & $-18,244$ & $-15,683$ & $-0,666$ \\
$\mathbf{4 s}$ & 0,093 & -0.003 & 0,002 & -22.555 & $-22,275$ & $-0,698$ \\
$\mathbf{5 s}$ & 0.176 & -0.003 & 0.015 & 9.121 & 10,559 & -0.101 \\
$\mathbf{6 s}$ & 0.299 & 0.003 & -0.039 & 5.953 & 9.494 & 0.078 \\
$\mathbf{7 s}$ & 0.005 & -0.004 & -0.009 & 4.617 & 11.504 & 0.202 \\
$\mathbf{8 s}$ & 0.567 & 0.026 & 0.019 & -27.628 & $-21,527$ & -1.208 \\
$\mathbf{9 s}$ & 3,991 & -0.003 & -0.022 & -13.446 & -13.504 & -0.180 \\
$\mathbf{1 0 s}$ & 0.091 & $-0,003$ & $-0,010$ & 10,595 & 4,359 & -0.217 \\
$\mathbf{1 1 s}$ & -0.150 & $-0,003$ & 0,007 & 5.029 & 4,762 & 0.183 \\
$\mathbf{1 2 s}$ & 0,042 & -0.003 & 0,013 & 12.402 & 3,307 & 0,200 \\
$\mathbf{1 3 s}$ & -0.398 & -0.004 & $-0,018$ & 12.665 & 8,430 & 0.271 \\
$\mathbf{1 4 s}$ & -0.562 & -0.003 & -0.013 & 6.747 & 6,234 & 0,246 \\
$\mathbf{1 5 s}$ & $-0,148$ & 0,011 & $-0,005$ & 11.662 & 4,438 & 0.322 \\
$\mathbf{1 6 s}$ & $-0,451$ & 0.010 & $-0,013$ & -12.816 & $-11,838$ & 0,020 \\
$\mathbf{1 7 s}$ & $-0,157$ & 0,008 & $-0,025$ & 0,720 & $-3,524$ & 0,188 \\
$\mathbf{1 8 s}$ & $-0,032$ & $-0,004$ & 0,019 & $-6,769$ & $-7,397$ & $-0,112$ \\
$\mathbf{1 9 s}$ & $-0,731$ & 0.008 & -0.013 & 17.261 & 14,102 & 0.611 \\
$\mathbf{2 0 s}$ & $-0,460$ & -0.003 & -0.010 & -1.690 & $-3,840$ & 0.040 \\
$\mathbf{2 1 s}$ & $-0,345$ & -0.003 & -0.026 & -0.987 & 0,105 & 0.262 \\
$\mathbf{2 2 s}$ & $-0,706$ & -0.003 & -0.004 & 16.699 & 13.236 & 0,436 \\
$\mathbf{2 3 s}$ & -0.072 & -0.003 & $-0,017$ & -7.818 & -2.027 & 0.432 \\
$\mathbf{2 4 s}$ & 0.306 & -0.004 & 0,177 & -9.872 & $-12,428$ & -0.012 \\
$\mathbf{2 5 s}$ & -1.416 & -0.003 & $-0,011$ & 29.592 & 25,595 & 0.383 \\
$\mathbf{2 6 s}$ & 0.093 & 0.008 & $-0,005$ & 0.254 & 0.936 & -0.054 \\
$\mathbf{2 7 s}$ & $-0,791$ & -0.003 & $-0,001$ & 9.134 & 18,007 & -0.115 \\
$\mathbf{2 8 s}$ & 0,065 & $-0,003$ & 0,010 & 17,904 & 17,145 & 0.125 \\
$\mathbf{3 0 s}$ & $-0,537$ & $-0,003$ & $-0,022$ & 6.202 & 1,724 & 0,998 \\
\hline & & & & & &
\end{tabular}


Tabela 99. Quadrados médios das análises conjuntas de variância dos topcrosses dos experimentos 4A, 4C e 4R para mancha de Phaeosphaeria (PHAE) e peso dos grãos por parcela (PG).

\begin{tabular}{lcll}
\hline FV & GL & PHAE & PG \\
\hline Repetição/Local & $\mathbf{9}$ & 1,867 & 0.882 \\
Local (L) & $\mathbf{2}$ & $90.328^{* *}$ & $89.162^{* *}$ \\
Topcross & 57 & $1,371^{* *}$ & $2,951^{* *}$ \\
\hline Acessos & 28 & $2.502^{* *}$ & $4.395^{* *}$ \\
Heterose média & 1 & $1,508^{*}$ & $31,074^{* *}$ \\
Heterose dos acessos & 28 & 0,234 & $0,503^{* *}$ \\
\hline Local x Topcross & 114 & $0,660^{* *}$ & $0.369^{* *}$ \\
\hline Local x Acessos & 56 & $1,067^{* *}$ & $0.541^{* *}$ \\
Lx Heterose média & 2 & 0,982 & $1.136^{* *}$ \\
Lx Heterose dos acessos & 56 & 0,242 & 0.170 \\
\hline Resíduo combinado & $\mathbf{5 7 9}$ & 0,340 & 0.167 \\
\hline
\end{tabular}

** $\mathrm{e}^{*}$ indicam, respectivamente, significância ao nível de $1 \%$ e de $5 \%$ de probabilidade. 
Tabela 100. Predição das médias de produção de grãos (kg/parcela) dos compostos de tamanho $\mathrm{k}$ formados pelos acessos selecionados com base na capacidade geral de combinação. A letras $\mathrm{A}, \mathrm{B}, \ldots$ em ordem alfabética correspondem, respectivamente, aos acessos 10, 12, e 27 no experimento 3: $21 \mathrm{~s}, 13 \mathrm{~s}$ e 30 s no experimento 4; 20 e 23 nos experimentos 3A, 3C e 3R; e 30s, 21 s e $22 \mathrm{~s}$ nos experimentos $4 \mathrm{~A}, 4 \mathrm{C}$ e $4 \mathrm{R}$.

\begin{tabular}{|c|c|c|}
\hline \multirow[b]{2}{*}{ Compostos } & \multicolumn{2}{|c|}{ Produção de grāos em kg/parcela } \\
\hline & Experimento 3 & Experimento 4 \\
\hline \multicolumn{3}{|l|}{$k=3$} \\
\hline $\mathrm{ABC}$ & 1.547 & 1.528 \\
\hline \multicolumn{3}{|l|}{$k=2$} \\
\hline $\mathrm{AB}$ & 1.516 & 1.265 \\
\hline$A C$ & 1.471 & 1.523 \\
\hline \multirow[t]{2}{*}{$\mathrm{BC}$} & 1.205 & 1.502 \\
\hline & $1.038=$ & $1.030 \#$ \\
\hline Compostos & Experimento $3 \mathbf{A}$ & Experimento 4.A \\
\hline \multicolumn{3}{|l|}{$k=3$} \\
\hline$\triangle \mathrm{ABC}$ & & 3,206 \\
\hline \multicolumn{3}{|l|}{$k=2$} \\
\hline$A B$ & 2,937 & 3.307 \\
\hline$A C$ & & 2,869 \\
\hline \multirow[t]{2}{*}{$\mathrm{BC}$} & & 2,871 \\
\hline & $2,461 \#$ & $2,516 \#$ \\
\hline Compostos & Experimento 3C & Experimento 4C \\
\hline \multicolumn{3}{|l|}{$k=3$} \\
\hline$A B C$ & & 4,853 \\
\hline \multicolumn{3}{|l|}{$k=2$} \\
\hline $\mathrm{AB}$ & 4.335 & 4.743 \\
\hline$A C$ & & 4.722 \\
\hline \multirow[t]{2}{*}{$\mathrm{BC}$} & & 4.392 \\
\hline & $4.101 \nRightarrow$ & $3.871 \%$ \\
\hline Compostos & Experimento 3R & Experimento $4 \mathbf{R}$ \\
\hline \multicolumn{3}{|l|}{$k=3$} \\
\hline$A B C$ & & 3.941 \\
\hline \multicolumn{3}{|l|}{$k=2$} \\
\hline$A B$ & 3.357 & 3.928 \\
\hline$A C$ & & 3.787 \\
\hline \multirow[t]{2}{*}{$\mathrm{BC}$} & & 3.522 \\
\hline & $2.868 \#$ & $3.186 \%$ \\
\hline
\end{tabular}

$\#$ Média do cruzamento de rodos os acessos. antes da seleção ( $\overline{\mathrm{T}}$ ) 